Supporting information for

\title{
Live-Cell Protein Modification Using Boronate-Assisted Hydroxamic Acid Catalysis
}

Christopher Adamson, Hidetoshi Kajino, Shigehiro A. Kawashima, ${ }^{*}$ Kenzo Yamatsugu,* and Motomu Kanai*

Graduate School of Pharmaceutical Sciences, The University of Tokyo

7-3-1 Hongo, Bunkyo-ku, Tokyo, JAPAN 113-0033

Correspondence to:

skawashima@mol.f.u-tokyo.ac.jp (S.A.K.)

yamatsugu@mol.f.u-tokyo.ac.jp (K.Y.)

kanai@mol.f.u-tokyo.ac.jp (M.K.), 


\section{Table of contents}

\section{Supporting figures}

Figure S1: Screening of acetyl donor strucutures

Figure S2: Spectroscopic analyses supporting $\mathrm{sp}^{2}$-hybridization of boronate species

Figure S3: Quantification of intracellular concentration of eDHFR-GFP

Figure S4: Screening of catalyst structures for in-cell acetylation of eDHFR-GFP

Figure S5: Computational studies to rationalize the catalyst design

Figure S6: Investigations about in-vitro reactivity and membrane permeability of catalysts $\mathbf{6 , 7}$, and $\mathbf{8}$.

Figure S7: Evaluation of the stability of acetyl donor D4.

SI-10

Figure S8: Protein selectivity of 4-azidobuterylation reaction in living cells

Figure S9: Effect of D4 on membrane protein acetylation

Figure S10: Comparison of catalytic activity of mBAHA-TMP to DSH-TMP

SI-13

Figure S11: Cytotoxicity of catalyst and acyl donors

SI-14

Figure S12: Dihydrofolate reductase assay of eDHFR-GFP before and after the lysine acetylation by BAHA

\section{Experimental methods and data}

Procedure for Figure S6 
Procedure for Figure $4 \mathrm{c}$ and Figure S8

Data for Figure S10

Data for Figure 5

SI-40

General synthetic procedures

SI-41

Synthesis of starting materials

SI-42

Synthesis of acyl donors

SI-73

Synthesis of model catalysts for Figure 2

SI-111

Synthesis of catalysts for in-cell reactions

SI-149

References

SI-185

NMR spectra

SI-186 


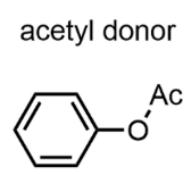

SI-1<smiles>[CH]N1C(=O)OC[C@H]1c1ccccc1</smiles><smiles>O=C(c1nn(C2CCCCC2)c2ccccc12)N1CCCCC1</smiles>

SI-3<smiles>Cn1ncc2ncccc21</smiles><smiles>CC1(n2c(=O)[nH]c3ccc([18OH])cc32)CCCC1</smiles><smiles>CC(=O)Cn1c(=O)n(C)c2cc([18OH])ccc21</smiles><smiles>CCn1c(=O)n(C)c2cc([18OH])ccc21</smiles>
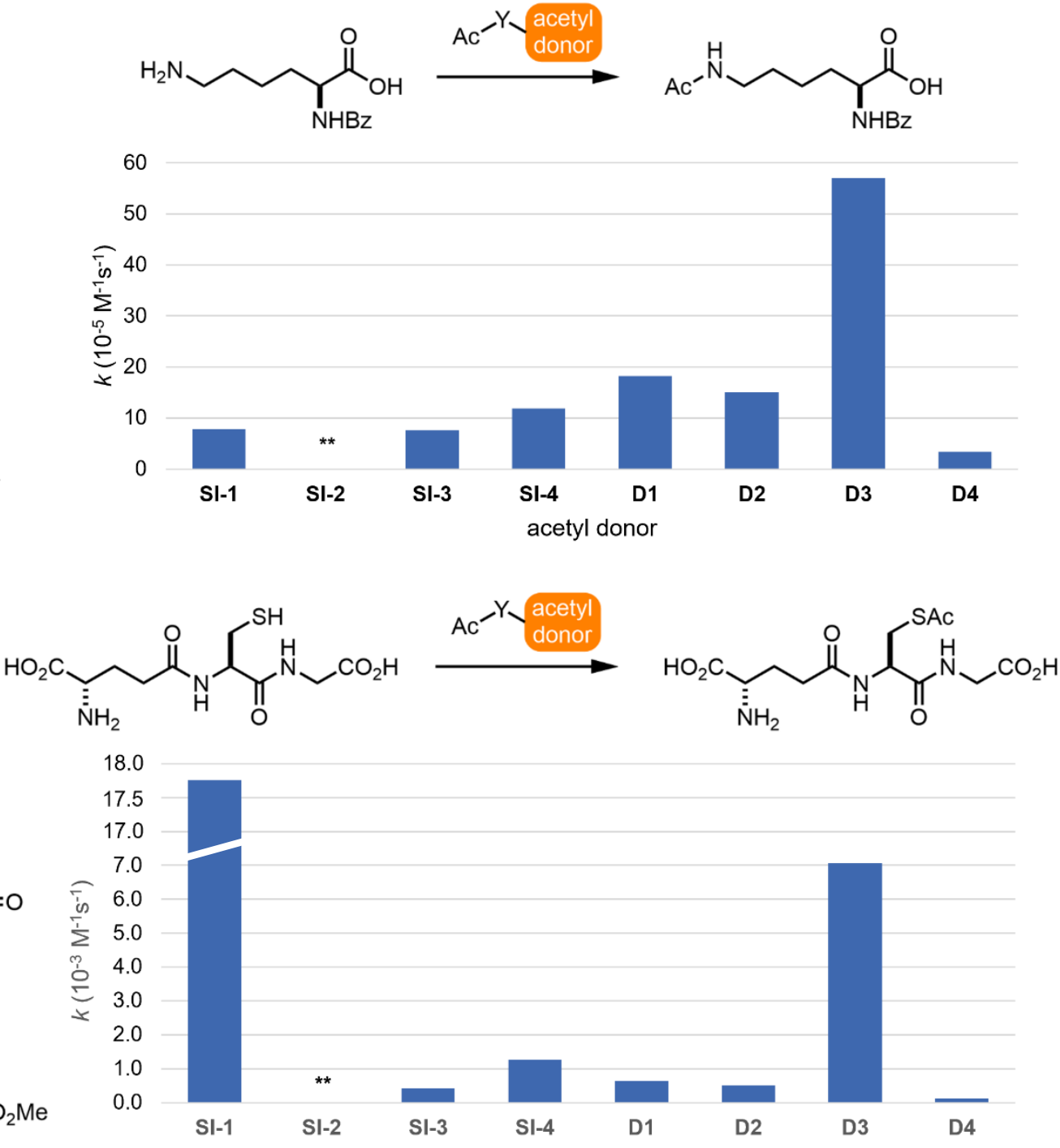

Figure S1. Screening of acetyl donor structures. Reaction conditions: $40 \mathrm{mM} N^{\alpha}$-benzoyl lysine or $5 \mathrm{mM} \mathrm{GSH}, 1.5$ $\mathrm{mM}$ acetyl donor, $50 \mathrm{mM}$ phosphate, $5 \% \mathrm{v} / \mathrm{v}$ DMSO, $\mathrm{pH} 7.5,37^{\circ} \mathrm{C}$. ** denotes no reaction. Data is average of duplicate trials. See page SI-23 for procedure and data. 
a)

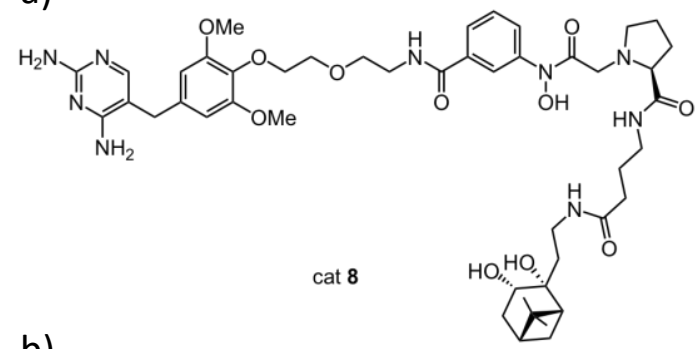

b)
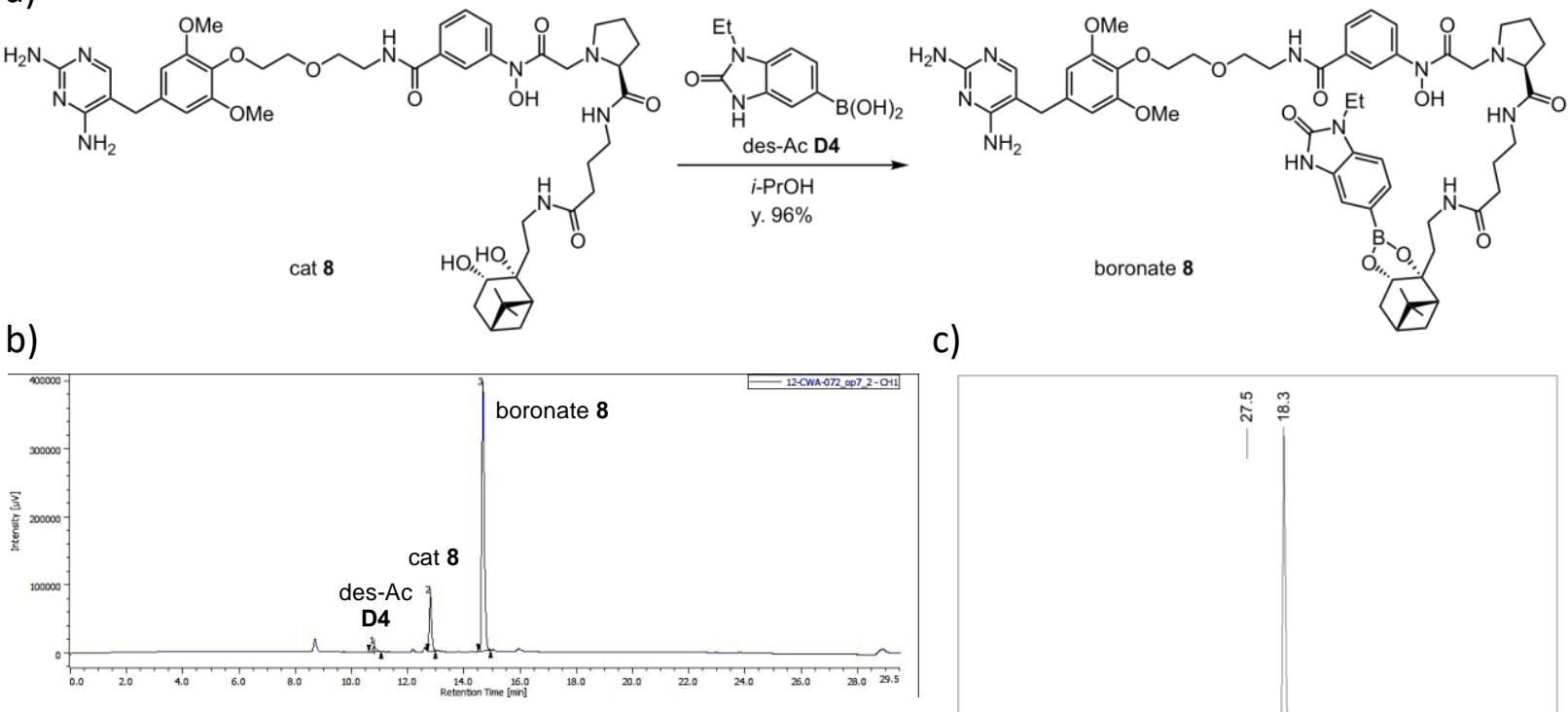

c)

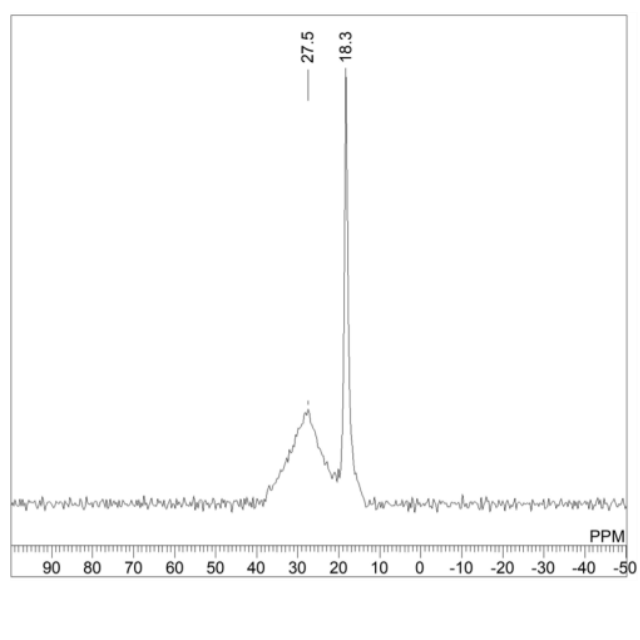

Figure S2. Spectroscopic analyses supporting $\mathrm{sp}^{2}$-hybridization of boronate species. a) Synthesis of boronate $\mathbf{8}$ for ${ }^{11}$ B NMR study. Cat 8 (5 $\mu \mathrm{mol}, 3.3 \mathrm{mM}$ final) and des-Ac D4 (5 $\mu \mathrm{mol}, 3.3 \mathrm{mM}$ final) in isopropanol, room temperature, 2 hours. b) HPLC (upper) and mass spectrometry (lower) analyses of the NMR sample of boronate 8 . c) ${ }^{11} \mathrm{~B}$ NMR spectra of isolated boronate $\mathbf{8}$. The peak at $28 \mathrm{ppm}$ is assigned as des-Ac D4, which resulted from partial hydrolysis of boronate $\mathbf{8}$. The peak at $18 \mathrm{ppm}$ would be an $\mathrm{sp}^{2}$-hybridized boronate, since $\mathrm{sp}^{3}$-hybridized boronates generally appear at around $0 \mathrm{ppm} .{ }^{11} \mathrm{~B}$ NMR spectra were calibrated with respect to external $\mathrm{BF}_{3} \cdot \mathrm{OEt}_{2}$ in $\mathrm{CD}_{3} \mathrm{CN}(\delta 0)$. 

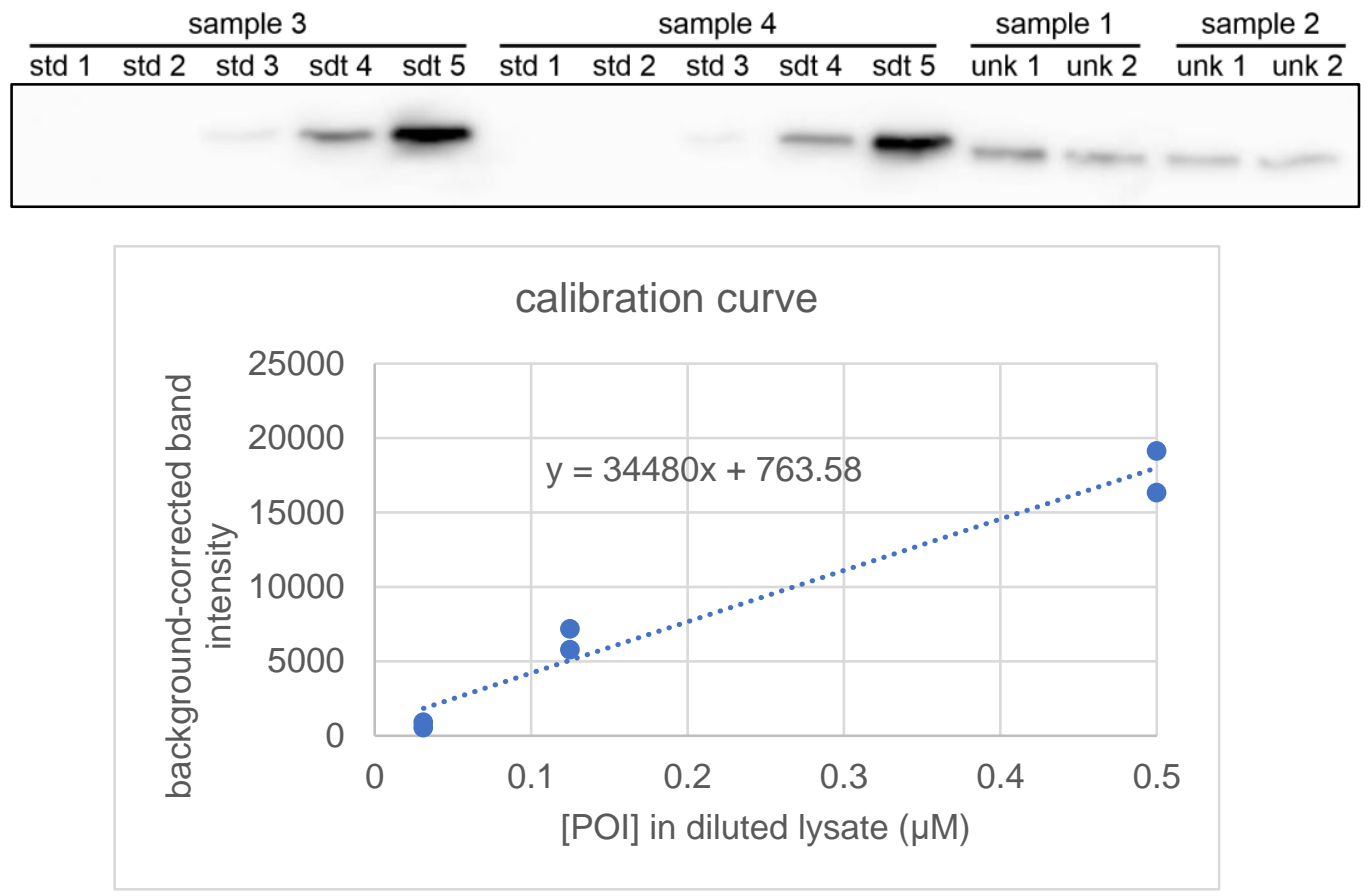

Figure S3. Quantification of intracellular concentration of eDHFR-GFP. HEK293T lysates were analyzed by western blotting ( $\alpha$-GFP). Lysates from untransfected HEK293T cells (samples 3 and 4) were spiked with recombinant eDHFR-GFP at various concentrations. Lysates transfected cells (samples 1 and 2) were analyzed in duplicate. The band intensity from spiked lysates was used to generate a calibration curve. As the band from 'std 2' $(0.07825 \mu \mathrm{M}$ eDHFR-GFP) was not detected, it was omitted from the calibration. See SI- 26 for procedure. 

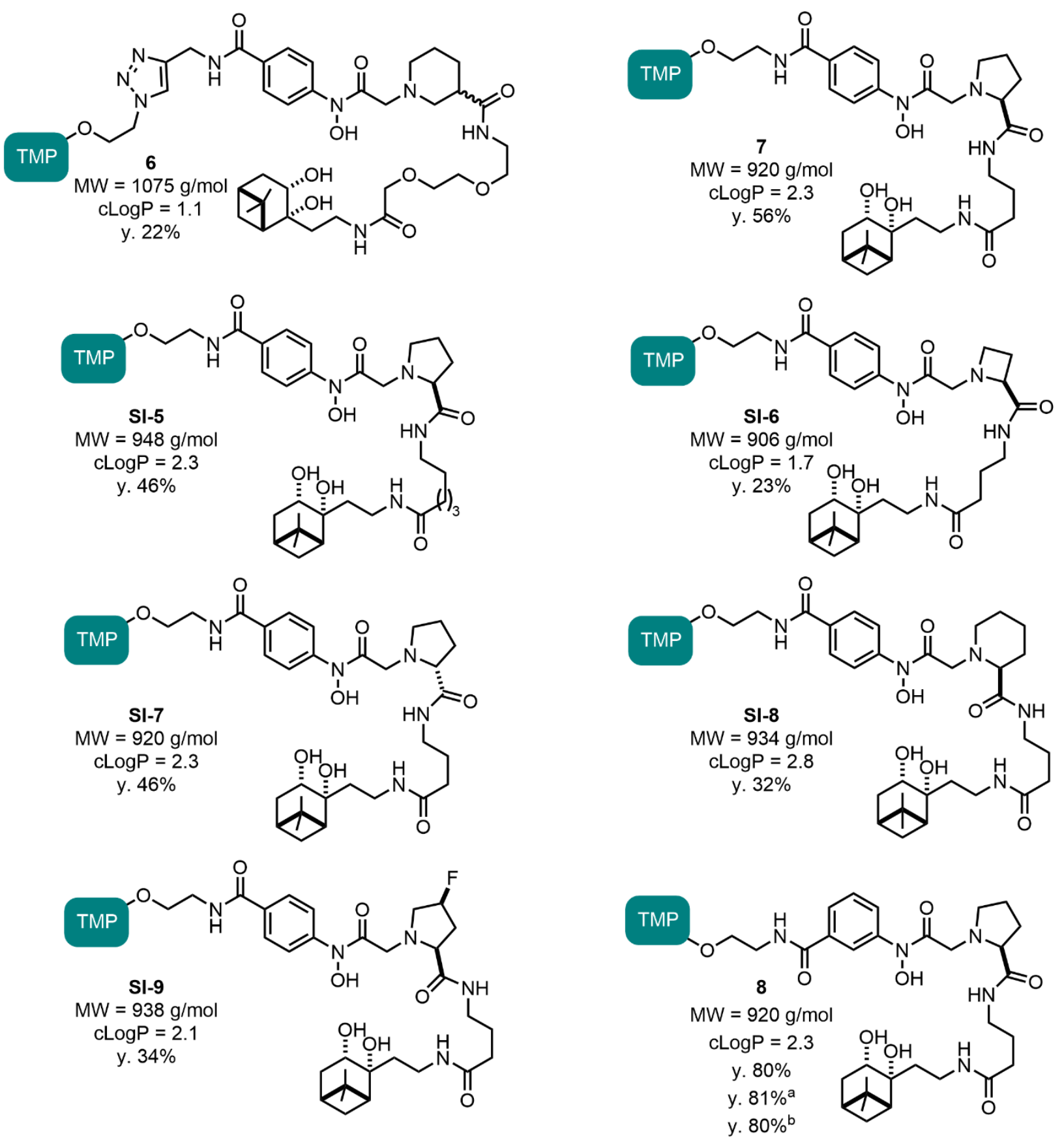

Figure S4. Screening of catalyst structures for in-cell acetylation of eDHFR-GFP K32. Reaction conditions: $5 \mu \mathrm{M}$ catalyst, $100 \mu \mathrm{M} \mathrm{D2}, 5$ hours. Yield data is average of duplicate trials. cLogP values were calculated using ChemDraw 20.0. a) Using D3 instead of D2. b) Using D4 instead of D2. See SI-16 for procedure and SI-37 for data. 
a)
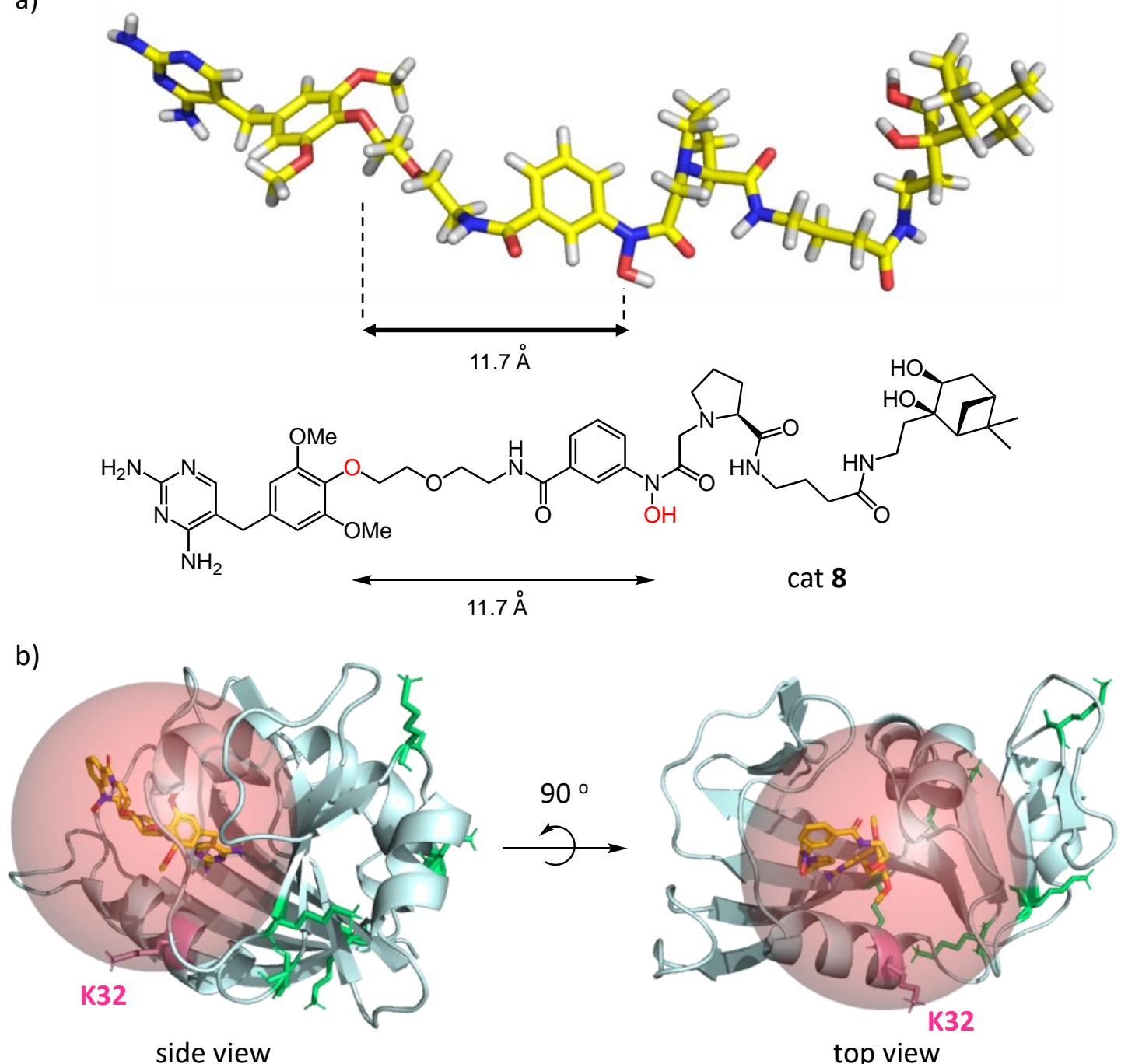<smiles>COc1cc(Cc2cnc(N)nc2N)cc(OC)c1OCCOCCNC(=O)c1cccc(N(O)C(=O)CN2CCCC2)c1</smiles>

Figure S5. Computational studies to rationalize the catalyst design. a) Energy-minimized structure of catalyst 8 calculated at B3LYP/6-31G*. Distance between the edge of the trimethoprim ligand and the hydroxamic acid, both of which are colored red, is shown. b) Docking structures of eDHFR (PDB: 3DAU) and the catalyst, calculated with Auto-Dock Vina. A structure with trimethoprim and hydroxamic acid catalyst, lacking the diol moiety (shown at the bottom), was used for docking because catalyst $\mathbf{8}$ itself could not be docked with eDHFR in an energetically favored form probably due to its large size. The pale red sphere shows the region of $11.7 \AA$ distance from the trimethoprim ligand oxygen, which is colored red in a). Target $\mathrm{K} 32$ is colored pink, while the other lysines are colored green. 
a)

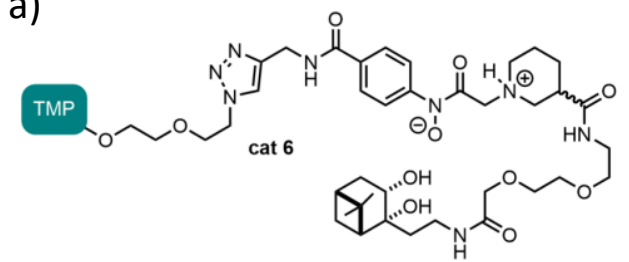

b)

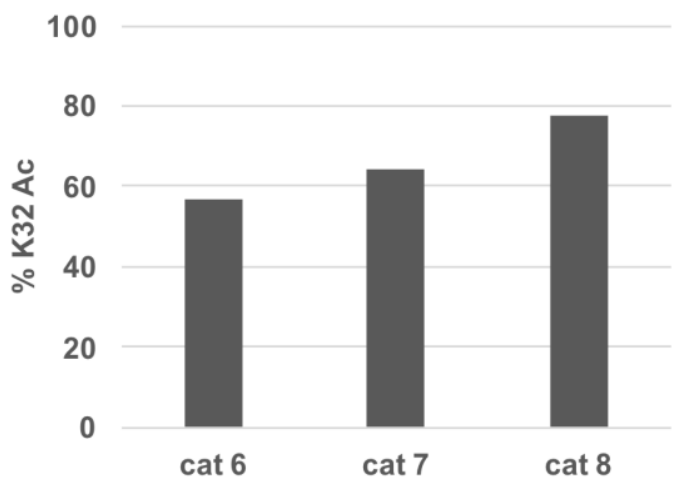

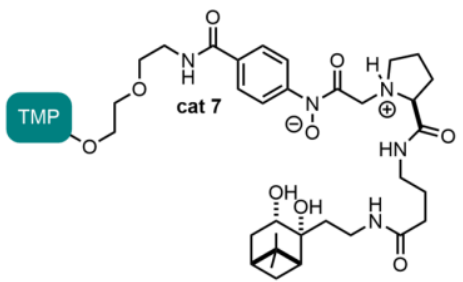

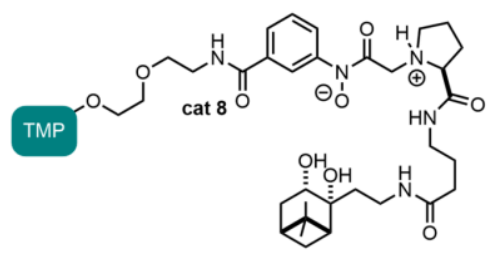

c)

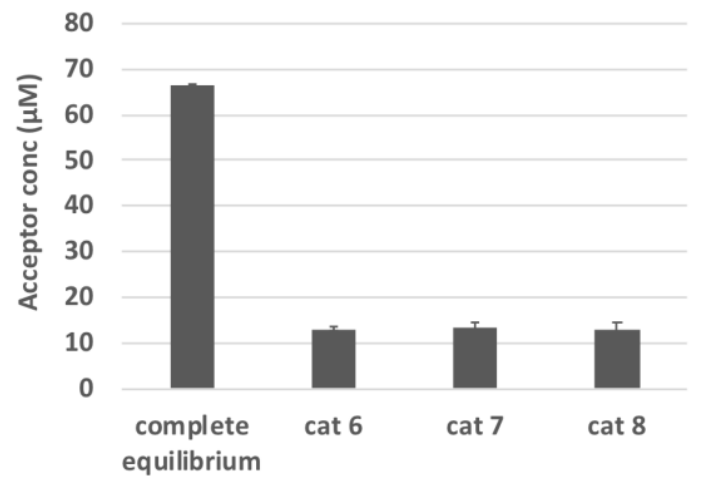

Figure S6. Investigations about in-vitro reactivity and membrane permeability of catalyst $\mathbf{6}, \mathbf{7}$, and $\mathbf{8}$. a) Structures of catalysts 6, 7, and 8. b) Acetylation of eDHFR-GFP with catalyst 6/7/8 and D4 in test-tubes. eDHFR-GFP (10 $\mu \mathrm{M})$, catalyst $(2 \mu \mathrm{M}), \mathbf{D 4}(200 \mu \mathrm{M})$, tris(2-carboxyethyl)phosphine hydrochloride $(200 \mu \mathrm{M})$, phosphate $(50 \mathrm{mM}, \mathrm{pH}$ 7.5), $37{ }^{\circ} \mathrm{C}, 4$ hours. c) PAMPA of catalyst $6 / 7 / 8$. Starting concentration of the catalysts in donor plates $(150 \mu \mathrm{L})$ are $200 \mu \mathrm{M}$. Acceptor plate volume is $300 \mu \mathrm{L}$. Incubation was conducted at room temperature for 5 hours. Error bars denote standard deviations $(n=3)$. 
a)

\section{Serum}

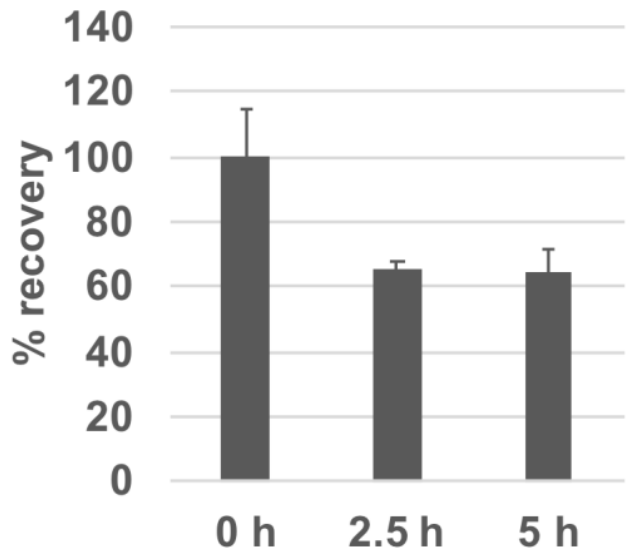

c)

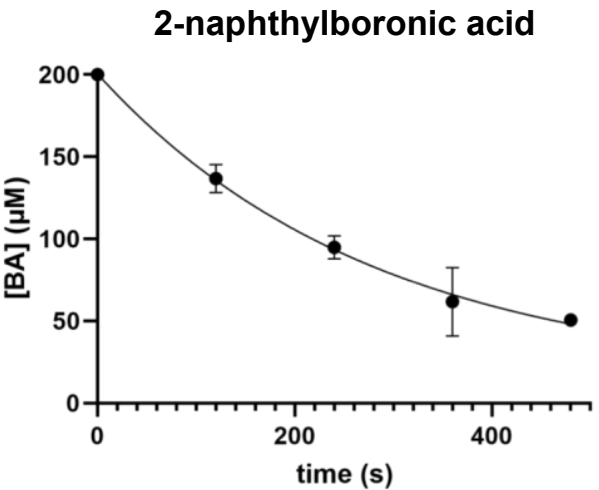

b)

\section{OptiMem}
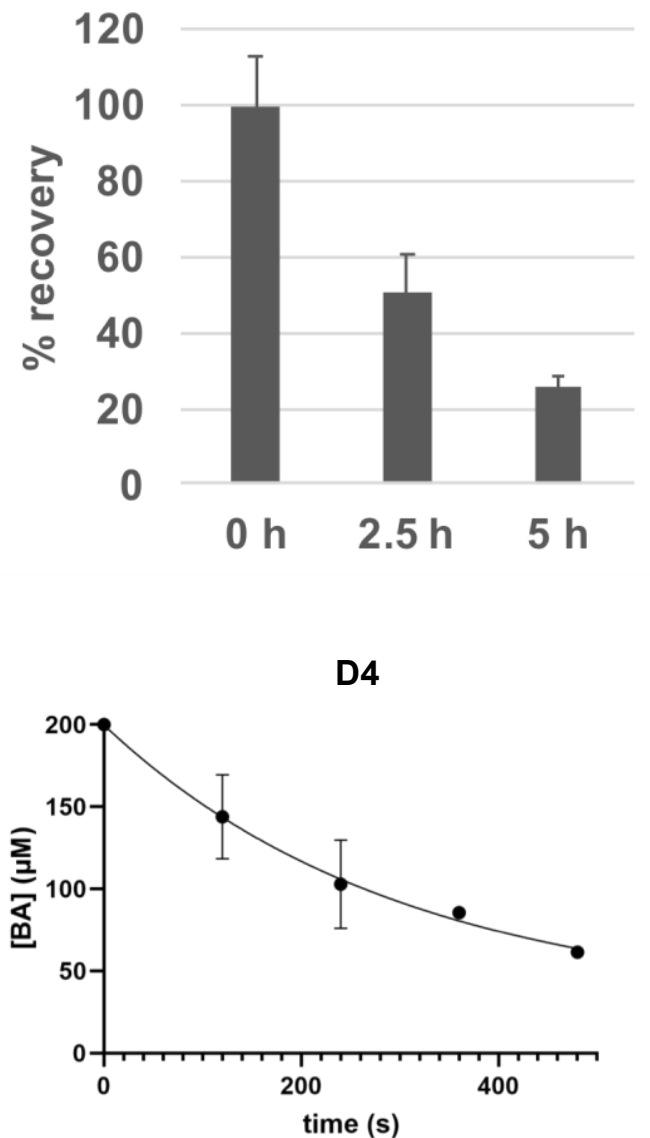

Figure S7. Evaluation of the stability of acetyl donor D4. a) Stability in human serum. D4 (100 $\mu$ M), $37^{\circ} \mathrm{C}, 5$ hours.

b) Stability in OptiMem. D4 $(100 \mu \mathrm{M}), 37^{\circ} \mathrm{C}, 5$ hours. c) Stability to hydrogen peroxide. Stability of 2naphthylboronic acid is shown at left as a reference. Boronic acid (BA, $200 \mu \mathrm{M})$, hydrogen peroxide $(800 \mu \mathrm{M})$, DMSO $(3.5 \% \mathrm{v} / \mathrm{v})$, phosphate $(50 \mathrm{mM}, \mathrm{pH} 7.5), 25^{\circ} \mathrm{C}$. Error bars denote range $(\mathrm{n}=2)$. 


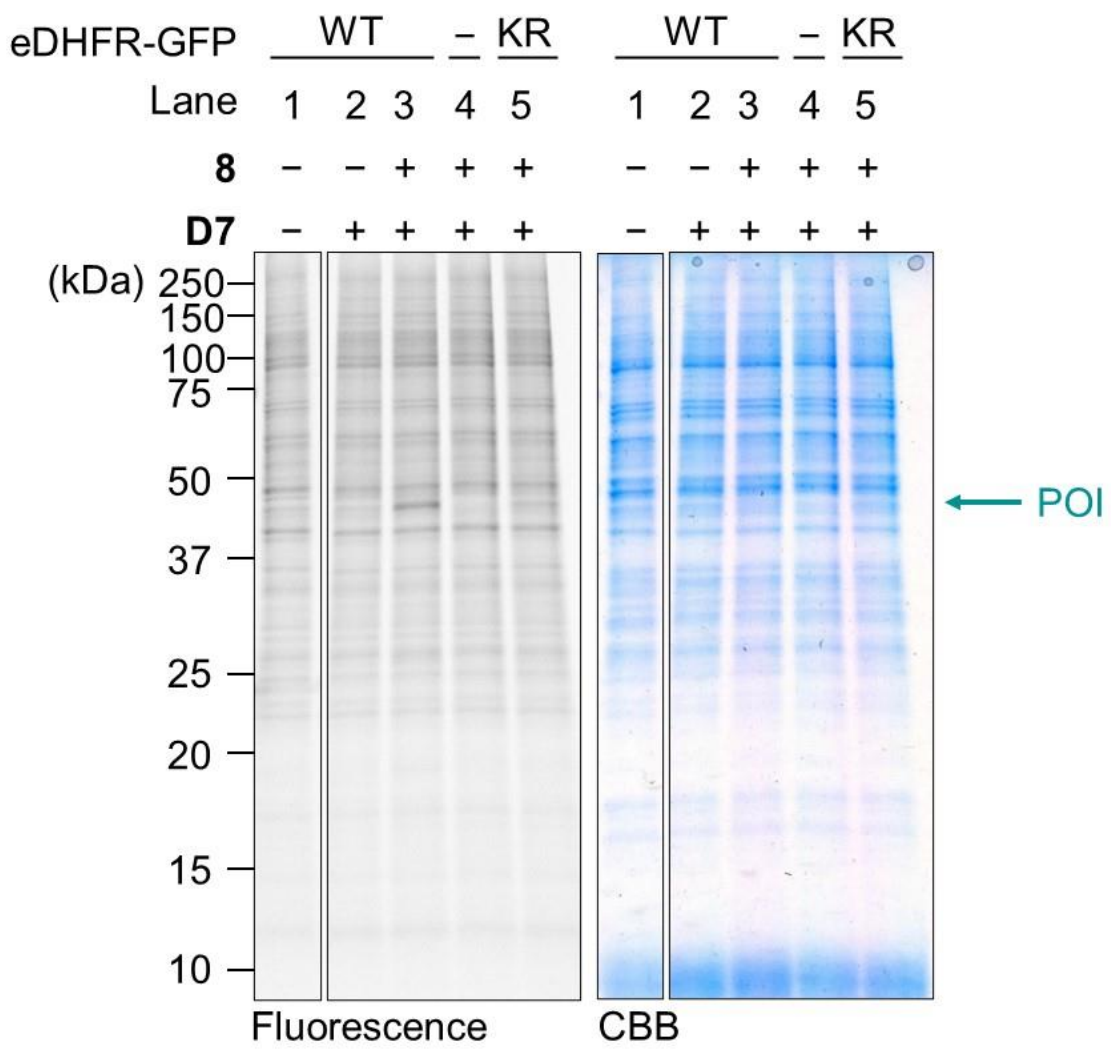

Figure S8. Protein selectivity of 4-azidobuterylation reaction in living cells. WT or K32R mutant eDHFR-GFPtransfected HEK293T cells were incubated with azide-containing acyl donor D7 $(100 \mu \mathrm{M})$ with or without catalyst 8 $(1 \mu \mathrm{M})$ for $5 \mathrm{~h}$. Acylated lysines were labeled with ADIBO-PEG4-TAMRA by strain-promoted azide-alkyne cycloaddition reaction. The fluorescence detection is shown. Proteins were visualized by CBB staining. Lane 1, which is without the catalyst and the acyl donor, showed background reaction derived from the click reagent, ADIBO-PEG4-TAMRA. In lane 3, treatment of the cells with 8 and D7 promoted the catalysis-dependent selective acylation of eDHFR-GFP. The grouping of images from different parts of the same gel is indicated by dividing lines. See SI-39 for procedure. 


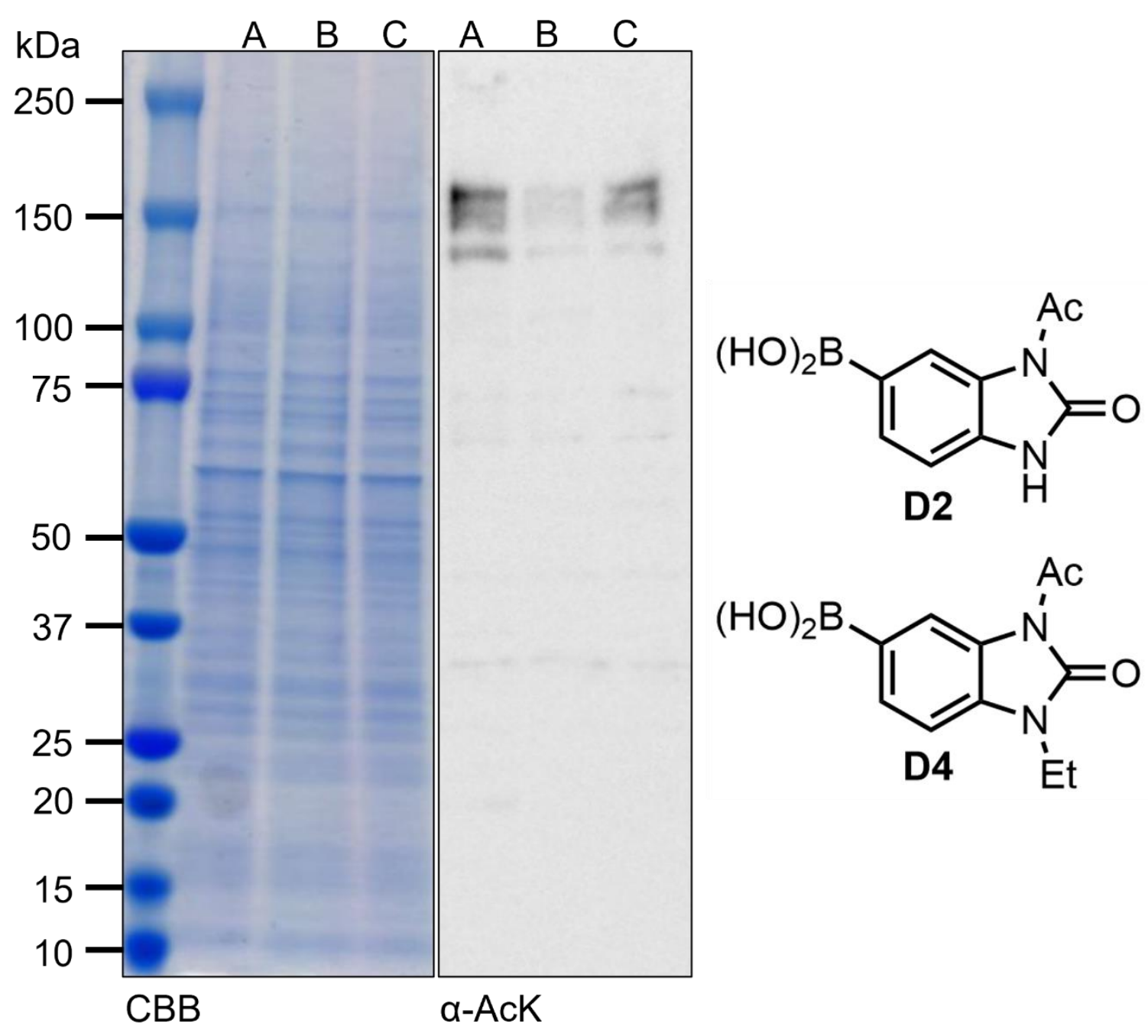

Figure S9. Effect of acetyl donors on membrane protein acetylation. HEK293T cells were incubated for 5 hours with A) DMSO control, B) $100 \mu \mathrm{M}$ D4, or C) $100 \mu \mathrm{M}$ D2. Membrane proteins were isolated and analyzed by CBB and western blotting $(\alpha-\mathrm{AcK})$. See SI-29 for procedure. 


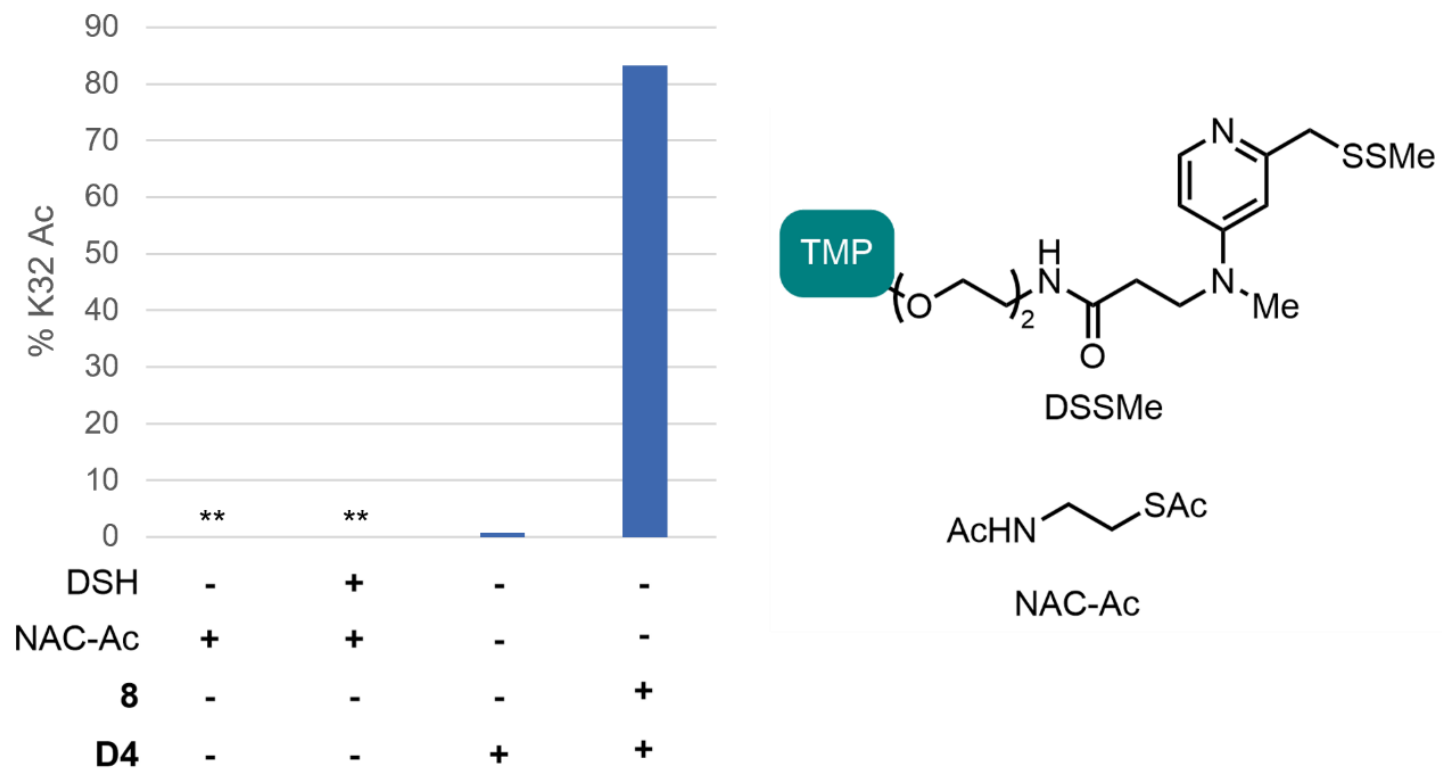

Figure S10. Comparison of catalytic activity of BAHA and DSSMe catalyst systems. eDHFR-GFP-transfected HEK293T cells were incubated with or without a catalyst (1 $\mu \mathrm{M}$, DSSMe or 8) and an acetyl donor (100 $\mu \mathrm{M}, \mathrm{NAC}$ Ac or D4) at $37{ }^{\circ} \mathrm{C}$ for $5 \mathrm{~h}$. Acetylation yield of K32 in eDHFR is shown. Yield data is average of duplicate trials. DSSMe is a prodrug of DSH, and liberates the DSH catalyst under in-cell reducing conditions. See SI-16 for procedure. $* *$ denotes that acetylation was not detected. 

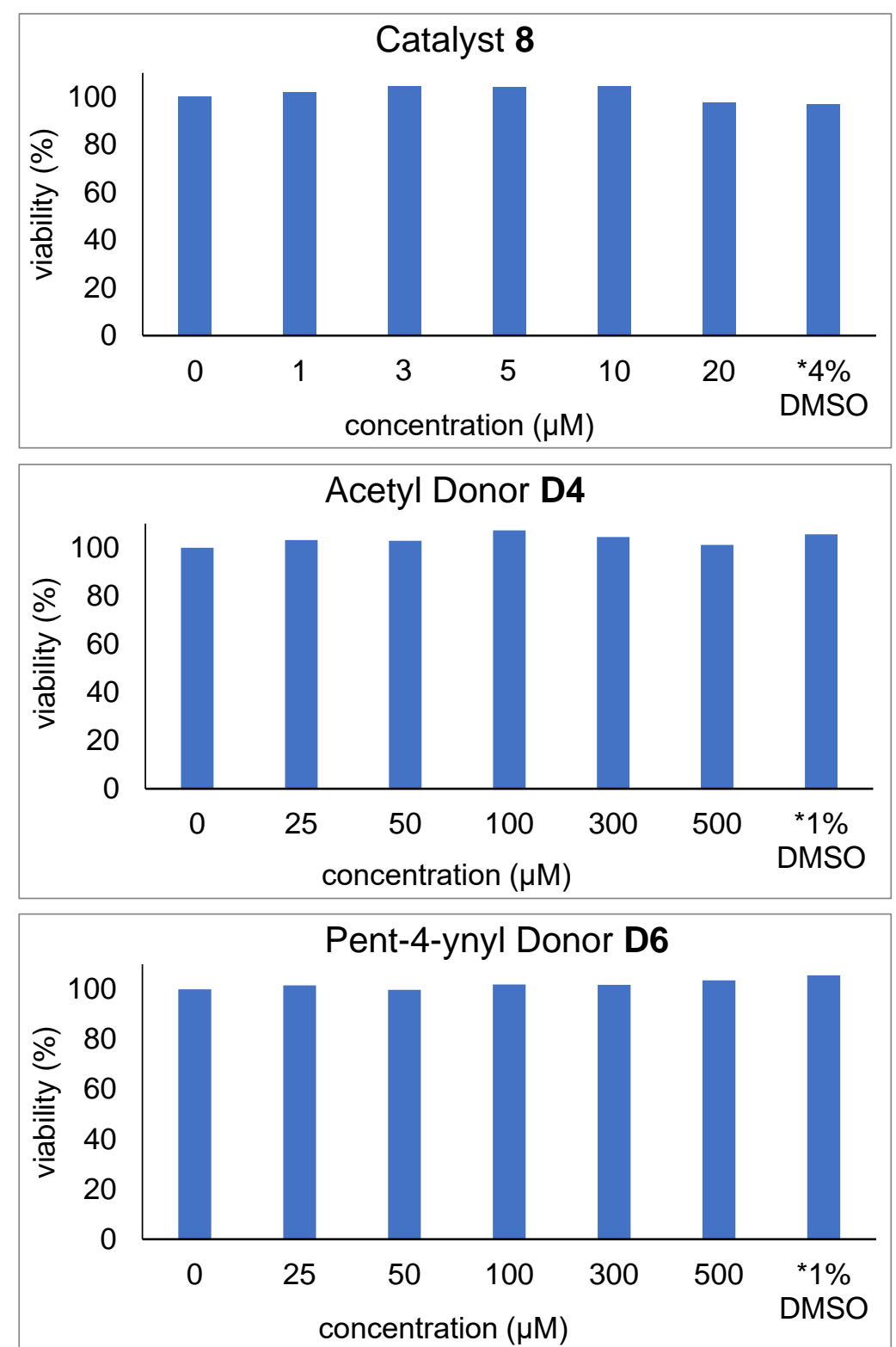

Figure S11. Cytotoxicity of catalyst and acyl donors. HEK293T cells were incubated with indicated concentrations of a catalyst or an acyl donor at $37{ }^{\circ} \mathrm{C}$ for $5 \mathrm{~h}$ (the final sample solutions contain $4 \%$ (v/v) DMSO for the catalyst and $1 \%(\mathrm{v} / \mathrm{v})$ DMSO for the acyl donors). After incubation, the cell viability assay was performed using CellTiterGlo 2.0 and cell viabilities were calculated. See SI-29 for procedure. 
a)

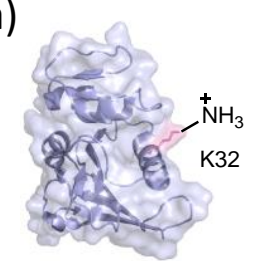

eDHFR-GFP

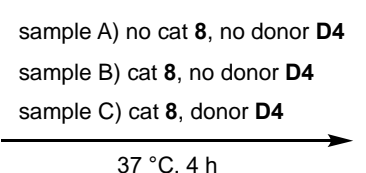

$37^{\circ} \mathrm{C}, 4 \mathrm{~h}$

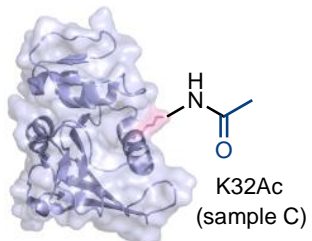

(sample C)

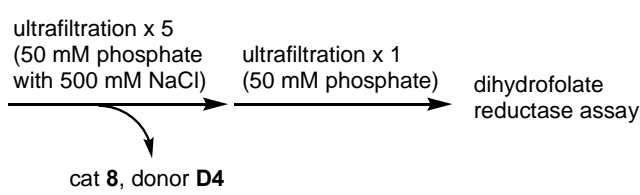

b)

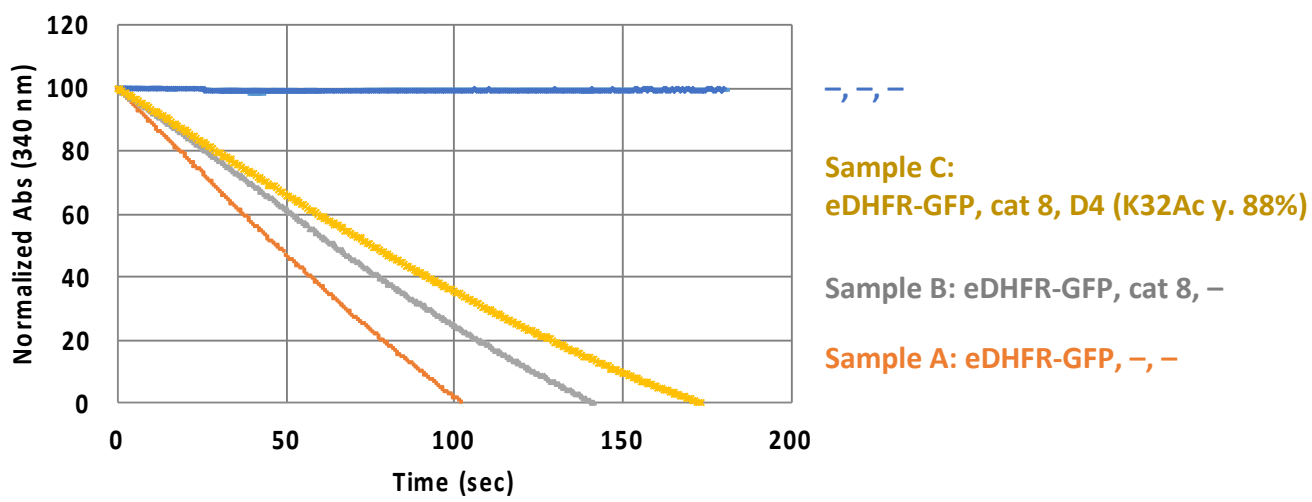

Figure S12. Dihydrofolate reductase assay of eDHFR-GFP before and after the lysine acetylation by BAHA. a) Sample preparation for eDHFR-GFP dihydrofolate reductase activity assay. b) eDHFR-GFP dihydrofolate reductase activity. The activity was assessed by monitoring the consumption of NADPH cofactor (UV, $340 \mathrm{~nm}$ ) upon reduction of the dihydrofolate substrate to tetrahydrofolate product. The K32 acetylation by BAHA catalysis did not significantly affect the enzymatic activity. The assay mixture contains eDHFR-GFP ( $25 \mathrm{nM}$ ), dihydrofolate (50 $\mu \mathrm{M})$, NADPH $(60 \mu \mathrm{M}), 1 \mathrm{mM}$ EDTA, $10 \mathrm{mM}$ 2-mercaptoethanol, and $50 \mathrm{mM}$ phosphate buffer (pH 7.0). See SI-30 for procedure. The averages of triplicate experiments are shown. 


\section{List of antibodies used}

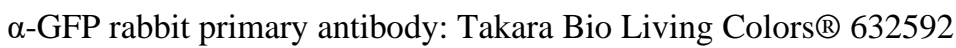

$\alpha$-Acetyl lysine rabbit primary antibody: Cell Signaling technology 9441

Horseradish peroxidase-linked goat $\alpha$-rabbit secondary antibody: Cell Signaling technology 7074

\section{General methods for in-cell experiments}

HEK293T cells (kindly provided by the Toru Hirota laboratory) were incubated at $37{ }^{\circ} \mathrm{C}$ and $5 \% \mathrm{CO}_{2}$. DMEM ${ }^{++}$ refers to Dulbecco's Modified Eagle Medium (DMEM) supplemented with 10\% fetal bovine serum (FBS) and GlutaMAX. DMEM ${ }^{+++}$refers to $\mathrm{DMEM}^{++}$supplemented with penicillin and streptomycin. CRB buffer refers to 50 $\mathrm{mM}$ Tris- $\mathrm{HCl}$ (pH 7.5), $300 \mathrm{mM} \mathrm{NaCl}, 0.3 \%$ Triton X-100. CRB' refers to CRB buffer supplemented with cOmplete protease inhibitor cocktail (Roche) and phenylmethylsulfonyl fluoride (1 mM).

\section{Acylation of eDHFR-GFP within living cells}

$1.25 \times 10^{5}$ HEK293T cells in $0.5 \mathrm{~mL} \mathrm{DMEM}^{++}$were seeded into wells of a 24 well plate. After about 24 hours incubation (target confluency 80 - 90\%), the cells were transfected with pEGFP-N1-eDHFR plasmid ( $0.5 \mu \mathrm{g}$ per well; plasmid constructed as reported previously ${ }^{1}$ ) using Lipofectamine LTX and Plus reagents (Invitrogen) according to the manufacturer's instructions. After 24 hours, the medium was carefully removed and replaced with $0.5 \mathrm{~mL}$ OptiMem (supplemented with acyl donor, catalyst, and 1\% DMSO). After 5 hours, the cells were detached by pipetting vigorously, transferred to an Eppendorf tube, centrifuged ( $350 \mathrm{rcf}$ for 5 minutes at $4{ }^{\circ} \mathrm{C}$ ), and washed twice with PBS.

$200 \mu \mathrm{L}$ CRB' buffer was charged, and lysis proceeded for 30 minutes on ice with brief vortexing every 10 minutes. The lysate was clarified by centrifuging $\left(21,000 \mathrm{rcf}\right.$ for 15 minutes at $\left.4{ }^{\circ} \mathrm{C}\right)$ and then incubated with $4 \mu \mathrm{L}$ of GFP trap magnetic agarose beads (chromotek gtma) with agitation for 1 hour at $4{ }^{\circ} \mathrm{C}$. The beads were washed with $2 \mathrm{x}$ $0.5 \mathrm{~mL} \mathrm{CRB}$ then $2 \times 0.5 \mathrm{~mL} 100 \mathrm{mM} \mathrm{NH}_{4} \mathrm{HCO}_{3}$.

$20 \mu \mathrm{L} 100 \mathrm{mM} \mathrm{NH}_{4} \mathrm{HCO}_{3}, 20 \mu \mathrm{L} 1: 3 \mathrm{v} / \mathrm{v}$ propionic anhydride : $\mathrm{MeOH}$, and $14 \mu \mathrm{L} 28 \% \mathrm{NH}_{3}$ were charged (pH 8-9 is typical), the beads were shaken at room temperature for 30 minutes, and volatiles were removed on a SpeedVac evaporator at $80{ }^{\circ} \mathrm{C} .50 \mu \mathrm{L} 0.01 \%$ protease MAX in $50 \mathrm{mM} \mathrm{NH}_{4} \mathrm{HCO}_{3}$ and $1 \mu \mathrm{g}$ Trypsin Gold were charged, and the reactions were incubated on a shaker at $37{ }^{\circ} \mathrm{C}$. After 30 minutes, $50 \mu \mathrm{L} 0.01 \%$ protease $\mathrm{MAX}$ in $50 \mathrm{mM} \mathrm{NH}_{4} \mathrm{HCO}_{3}$ and $10 \mu \mathrm{L}$ Glu-C $(1 \mu \mathrm{g})$ were charged, and the reactions were incubated at $37^{\circ} \mathrm{C}$ for $3-15$ hours. The magnetic beads were removed, the $\mathrm{pH}$ was adjusted to 3 by charging $25 \mu \mathrm{L} 5 \%$ formic acid, and volatiles were removed on a SpeedVac evaporator at $80^{\circ} \mathrm{C}$.

The residue was suspended in $20 \mu \mathrm{L} 0.1 \%$ formic acid and clarified by centrifuging (21,000 rcf for 10 minutes at room temperature). The supernatant was analyzed by LC-MS/MS (see SI-17 for procedure). 


\section{HPLC methods}

Preparative HPLC used a JASCO HPLC system equipped with a PU4086 pump, a Jasco UV-2075 Plus UV detector, a DG-4580 degasser, and a MX-2080-32 mixer. A C18 column with $40{ }^{\circ} \mathrm{C}$ column temperature was used for all runs. A detection wavelength of $254 \mathrm{~nm}$ was generally used, except in the case of tryptophan-containing

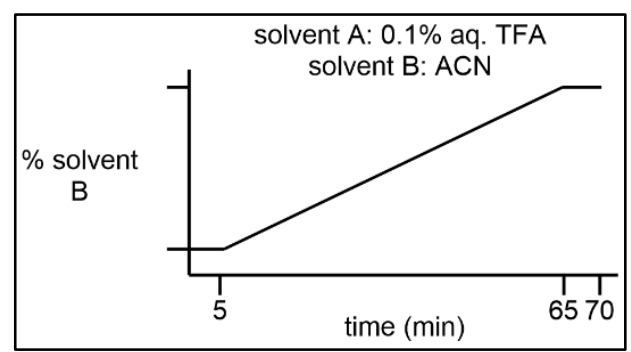
peptides, where $280 \mathrm{~nm}$ detection was used. Various solvent B start and end points were used, and are specified in the SI. Method A: YMC 10 x 250 mm column, flow rate 3 mL/min; method B: YMC 20 x $250 \mathrm{~mm}$ column, flow rate $10 \mathrm{~mL} / \mathrm{min}$.

Analytical HPLC used an JASCO HPLC system equipped with a PU-4180 pump, a UV2075 Plus UV detector, a DG-4580 degasser, a MX-2080-32 mixer, and a 4.6 x 150 mm YMC column. $40{ }^{\circ} \mathrm{C}$ column temperature and $1 \mathrm{~mL} / \mathrm{min}$ flow rate was used for all runs. Various detection wavelengths were used, and are specified in the SI. Method A: C18 column; method B: PROTEIN-RP column.

\begin{tabular}{|c|c|}
\hline \multicolumn{2}{|c|}{$\begin{array}{c}\text { solvent A: } 0.1 \% \text { aq. TFA } \\
\text { solvent B: ACN } \\
\text { time (min) }\end{array}$} \\
\hline 0 & 0 \\
2 & 0 \\
22 & 100 \\
26 & 100 \\
27 & 0 \\
35 & 0 \\
\hline
\end{tabular}

\section{LC-MS/MS methods}

LC-MS/MS analysis was carried out using a TripleTOF 5600+ instrument (AB Sciex) using a 3C18-CL-120 column $(0.5 \mathrm{~mm}$ ID $\times 100 \mathrm{~mm})$, a column temperature of $40^{\circ} \mathrm{C}$, a flow rate of $20 \mu \mathrm{L} / \mathrm{min}$,

solvent $\mathrm{A}: 0.1 \%$ formic acid in $\mathrm{H}_{2} \mathrm{O}$ and a collision energy of $43 \mathrm{~V}$. The retention time, precursor ion, and fragment ions for each peptide are shown in Table S-1 and Table S-2. Data analysis was carried out using PeakView version 1.2 (AB Sciex), and the averaged result obtained from duplicate measurements is reported as the result for each experiment. The yield of acylated lysine was calculated from the extracted ion chromatogram as a percentage of the peak area for acylated peptides divided by the combined peak areas for both acylated and propionylated peptides.

\section{LC-MS/MS ionization efficiency correction}

\begin{tabular}{|c|c|} 
solvent B: $0.1 \%$ formic acid in $\mathrm{ACN}$ \\
time (min) & $\%$ solvent B \\
\hline 0 & 2 \\
1 & 2 \\
1.5 & 30 \\
12 & 70 \\
13 & 90 \\
15 & 90 \\
15.1 & 2 \\
20 & 2 \\
\hline
\end{tabular}

Note: exposue to plastic surfaces was minimized and a ACN-containing diluent was used in order to minimize peptide loss due to adsorbtion, which results in non-linearity in LC-MS/MS analysis. Each peptide shown in Table S-4 (see SI-11 for details) was dissolved in DMSO ( $5 \mathrm{mM}$ final concentration). In Lo-bind Effendorf tubes, $5 \mu \mathrm{L}$ of peptide 1 stock solution was mixed with $5 \mu \mathrm{L}$ of each of peptides $2-14$ stock solutions and $1240 \mu \mathrm{L}$ diluent (75 : 25 : $0.1 / \mathrm{H}_{2} \mathrm{O}: \mathrm{ACN}$ : formic acid) to provide solutions nominally $20 \mu \mathrm{M}$ in propionyl and acyl-containing peptides (see Table S-4 for peptide structures). These $20 \mu \mathrm{M}$ solutions were analyzed by analytical HPLC (280 nm detection). The relative peak areas were used to accurately determine the relative concentration of the two peptides (Table S-3). In HPLC vials, the $20 \mu \mathrm{M}$ peptide solutions were diluted. For entries 2-12, the final concentrations were 0.125, 0.25, and $0.5 \mu \mathrm{M}$. For entires 13-15, the final concentrations were $0.5,1$ and $2 \mu \mathrm{M}$. Each sample was analyzed twice by 
LC-MS/MS, and the relative peak areas (acyl / propionyl) for each fragment ion was tabulated. The average of the six relative MS peak areas (from 2 replicates of 3 concentrations) were adjusted by the relative peptide concentrations and used as the final correction coefficients (Table S-3). Fragment ion peaks from acylated paptides were divided by their respective correction coefficients to provide corrected yields for acylation of eDHFR-GFP.

\section{Solid phase peptide synthesis}

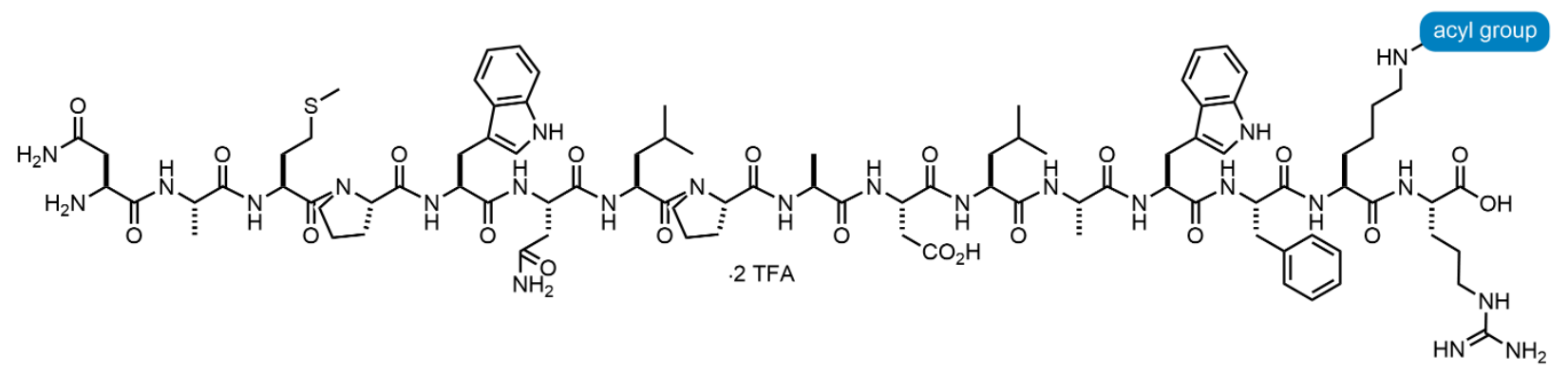

Note: the methionine residue in the target peptides is vulnerable to oxidation.

The following Wang resin-attached peptide (corresponding to residues 18-33 of E. coli dihydrofolate reducatase) was synthesized by standard Fmoc SPPS.

Fmoc-NH-N(Trt)-A-M-P-W(Boc)-N(Trt)-L-P-A-D(t-Bu)-L-A-W(Boc)-F-K(Mtt)-R(Pbf)-resin

To expose a free lysine, the Mtt group was removed by shaking with $97.5: 1.5: 1 \mathrm{v} / \mathrm{v} \mathrm{CH}_{2} \mathrm{Cl}_{2}$ : TFA : TIS for 5 minutes $x 8$ cycles. The resin was then rinsed with $1 \%$ v/v DIPEA in $\mathrm{CH}_{2} \mathrm{Cl}_{2}$ then $\mathrm{CH}_{2} \mathrm{Cl}_{2}$, and then dried under vacuum to obtain a gummy solid. Ca. $50 \mathrm{mg}$ of the resin was weighed into a fritted flask and swolen for 30 minutes in $\mathrm{CH}_{2} \mathrm{Cl}_{2}$. To reduce any oxidized methionine, the resin was shaken for 1 hour $\mathrm{x} 2$ cycles with a premix of $1 \mathrm{~mL}$ $\mathrm{DMF}$ and $50 \mu \mathrm{L} \mathrm{PhSSiMe}$. The resin was then rinsed with DMF.

Various carboxylic acids $(0.30 \mathrm{mmol})$ were preactivated with HCTU $(103 \mathrm{mg}, 0.25 \mathrm{mmol})$ and $\mathrm{N}$-methyl morpholine ( $132 \mu \mathrm{L}, 1.2 \mathrm{mmol})$ in $1 \mathrm{~mL}$ DMF. This solution was then added to the resin, and the resin was shaken. After 1 hour, the resin was washed with DMF and $\mathrm{CH}_{2} \mathrm{Cl}_{2}$.

Resin cleavage and global deprotection was performed by shaking with $1 \mathrm{~mL} 90: 5: 3: 2 \mathrm{v} / \mathrm{v} / \mathrm{TFA}$ : thioanisole : ethanedithiol : anisole for 1 to 1.5 hours. The supernatant was then drained into a round-bottomed flask and rinsed forward with $2 \times 0.5 \mathrm{~mL}$ TFA. Volatiles were removed on the rotovap. The crude peptide was precipitated with 1 $\mathrm{mL}$ ether and then washed with $2 \times 1 \mathrm{~mL}$ ether. The crude peptide was purified by preparative HPLC (method A, 0 $60 \% \mathrm{ACN})$. Results are summarized in Table S-4. 
Table S-1. LC-MS/MS conditions for the eDHFR-GFP(18-33)-derived NAMPWNLPADLAWFK(acyl)R peptide

\begin{tabular}{|c|c|c|c|}
\hline Acyl group & $\begin{array}{c}\text { Target precursor ion } \\
(\mathrm{m} / \mathrm{z})\end{array}$ & $\begin{array}{c}\text { LC-MS/MS retention } \\
\text { time (min) }\end{array}$ & Fragment ions \\
\hline & 993.5 & $3.8-4.1$ & $\begin{array}{c}\mathrm{b}_{7}\left(\mathrm{H}^{+}\right), \mathrm{y}_{9}\left(\mathrm{H}^{+}\right), \\
\mathrm{y}_{13}\left(2 \mathrm{H}^{+}\right), \mathrm{y}_{14}\left(2 \mathrm{H}^{+}\right)\end{array}$ \\
\hline & 986.5 & $3.7-3.9$ & $\begin{array}{c}\mathrm{b}_{7}\left(\mathrm{H}^{+}\right), \mathrm{y}_{9}\left(\mathrm{H}^{+}\right), \\
\mathrm{y}_{13}\left(2 \mathrm{H}^{+}\right), \mathrm{y}_{14}\left(2 \mathrm{H}^{+}\right)\end{array}$ \\
\hline & 1000.5 & $3.9-4.2$ & $\begin{array}{c}\mathrm{b}_{7}\left(\mathrm{H}^{+}\right), \mathrm{y}_{9}\left(\mathrm{H}^{+}\right), \\
\mathrm{y}_{13}\left(2 \mathrm{H}^{+}\right), \mathrm{y}_{14}\left(2 \mathrm{H}^{+}\right)\end{array}$ \\
\hline & 1022.5 & $3.9-4.1$ & $\begin{array}{c}\mathrm{b}_{7}\left(\mathrm{H}^{+}\right), \mathrm{y}_{9}\left(\mathrm{H}^{+}\right), \\
\mathrm{y}_{13}\left(2 \mathrm{H}^{+}\right), \mathrm{y}_{14}\left(2 \mathrm{H}^{+}\right)\end{array}$ \\
\hline & 1015.5 & $3.8-3.9$ & $\begin{array}{c}\mathrm{b}_{7}\left(\mathrm{H}^{+}\right), \mathrm{y}_{9}\left(\mathrm{H}^{+}\right), \\
\mathrm{y}_{13}\left(2 \mathrm{H}^{+}\right), \mathrm{y}_{14}\left(2 \mathrm{H}^{+}\right)\end{array}$ \\
\hline & 1074.5 & $3.8-4.1$ & $\begin{array}{c}\mathrm{b}_{7}\left(\mathrm{H}^{+}\right), \mathrm{y}_{9}\left(\mathrm{H}^{+}\right), \\
\mathrm{y}_{13}\left(2 \mathrm{H}^{+}\right), \mathrm{y}_{14}\left(2 \mathrm{H}^{+}\right)\end{array}$ \\
\hline & 1033.5 & $4.4-4.7$ & $\begin{array}{c}\mathrm{b}_{7}\left(\mathrm{H}^{+}\right), \mathrm{y}_{9}\left(\mathrm{H}^{+}\right), \\
\mathrm{y}_{13}\left(2 \mathrm{H}^{+}\right), \mathrm{y}_{14}\left(2 \mathrm{H}^{+}\right)\end{array}$ \\
\hline & 1016.5 & $3.9-4.3$ & $\begin{array}{c}\mathrm{b}_{7}\left(\mathrm{H}^{+}\right), \mathrm{y}_{9}\left(\mathrm{H}^{+}\right), \\
\mathrm{y}_{13}\left(2 \mathrm{H}^{+}\right), \mathrm{y}_{14}\left(2 \mathrm{H}^{+}\right)\end{array}$ \\
\hline & 1021.0 & $4.1-4.3$ & $\begin{array}{c}\mathrm{b}_{7}\left(\mathrm{H}^{+}\right), \mathrm{y}_{9}\left(\mathrm{H}^{+}\right), \\
\mathrm{y}_{13}\left(2 \mathrm{H}^{+}\right), \mathrm{y}_{14}\left(2 \mathrm{H}^{+}\right)\end{array}$ \\
\hline & 1063.5 & $3.8-4.0$ & $\begin{array}{c}\mathrm{b}_{7}\left(\mathrm{H}^{+}\right), \mathrm{y}_{9}\left(\mathrm{H}^{+}\right), \\
\mathrm{y}_{13}\left(2 \mathrm{H}^{+}\right), \mathrm{y}_{14}\left(2 \mathrm{H}^{+}\right)\end{array}$ \\
\hline & 1005.5 & $4.3-4.6$ & $\begin{array}{c}\mathrm{b}_{7}\left(\mathrm{H}^{+}\right), \mathrm{y}_{9}\left(\mathrm{H}^{+}\right), \\
\mathrm{y}_{13}\left(2 \mathrm{H}^{+}\right), \mathrm{y}_{14}\left(2 \mathrm{H}^{+}\right)\end{array}$ \\
\hline & 1033.5 & $4.0-4.1$ & $\begin{array}{l}b_{5}\left(\mathrm{H}^{+}\right), b_{6}\left(\mathrm{H}^{+}\right), \\
b_{7}\left(\mathrm{H}^{+}\right), \mathrm{b}_{13}\left(\mathrm{H}^{+}\right)\end{array}$ \\
\hline & 1020.5 & $4.1-4.4$ & $\begin{array}{l}\mathrm{b}_{7}\left(\mathrm{H}^{+}\right), \mathrm{b}_{10}\left(\mathrm{H}^{+}\right), \\
\mathrm{b}_{12}\left(\mathrm{H}^{+}\right), \mathrm{b}_{13}\left(\mathrm{H}^{+}\right)\end{array}$ \\
\hline & 1091.5 & $4.3-4.6$ & $\begin{array}{l}\mathrm{b}_{5}\left(\mathrm{H}^{+}\right), \mathrm{b}_{6}\left(\mathrm{H}^{+}\right) \\
\mathrm{b}_{7}\left(\mathrm{H}^{+}\right), \mathrm{b}_{13}\left(\mathrm{H}^{+}\right)\end{array}$ \\
\hline
\end{tabular}


Table S-2. LC-MS/MS conditions for other eDHFR-GFP(18-33)-derived peptides

\begin{tabular}{|c|c|c|c|c|}
\hline \multirow{2}{*}{ Residues } & Sequence & $\begin{array}{c}\text { Target precursor } \\
\text { ion } \\
(\mathrm{m} / \mathrm{z})\end{array}$ & $\begin{array}{c}\text { LC-MS/MS } \\
\text { retention time } \\
(\mathrm{min})\end{array}$ & Fragment ions \\
\hline \multirow{2}{*}{$34-44$} & NTLNK(acyl)PVIMGR & $\begin{array}{c}649.9(\mathrm{Pr}) \\
642.9(\mathrm{Ac})\end{array}$ & $\begin{array}{c}2.7(\mathrm{Pr}) \\
\text { n.d. }(\mathrm{Ac})\end{array}$ & $\mathrm{y} 6, \mathrm{y} 7, \mathrm{y} 8, \mathrm{y} 9$ \\
\hline \multirow{2}{*}{$58-71$} & K(acyl)NIILSSQPGTDDR & $\begin{array}{c}800.42(\mathrm{Pr}) \\
793.41(\mathrm{Ac})\end{array}$ & $\begin{array}{c}2.7(\mathrm{Pr}) \\
\text { n.d. (Ac) }\end{array}$ & $\mathrm{b} 3, \mathrm{y} 6, \mathrm{y} 9, \mathrm{y} 10$ \\
\hline $72-80$ & VTWVK(acyl)SVDE & $\begin{array}{c}1118.57(\mathrm{Pr}) \\
1104.56(\mathrm{Ac})\end{array}$ & $\begin{array}{c}2.8(\mathrm{Pr}) \\
\text { n.d. (Ac) }\end{array}$ & $\mathrm{b} 5, \mathrm{~b} 7, \mathrm{~b} 8, \mathrm{y} 5$ \\
\hline \multirow{2}{*}{$102-118$} & QFLPK(acyl)AQK(acyl)LYLTHIDAE & $\begin{array}{c}1064.08(\mathrm{Pr}, \mathrm{Pr}) \\
1057.07(\mathrm{Pr}, \mathrm{Ac})\end{array}$ & $\begin{array}{c}2.8(\mathrm{Pr}) \\
\text { n.d. (Pr, Ac) } \\
\text { n.d. (Ac, Ac) }\end{array}$ & b6, y10, y11, y12 \\
\hline
\end{tabular}


Table S-3. Determination of correction coefficients

\begin{tabular}{|c|c|c|c|c|c|c|c|}
\hline Entry & $\begin{array}{l}\text { Average } \\
\text { rel. MS } \\
\text { peak area }\end{array}$ & $\begin{array}{c}\text { Rel. } \\
\text { HPLC } \\
\text { peak area }\end{array}$ & $\begin{array}{c}\text { Final } \\
\text { correction } \\
\text { coef. }\end{array}$ & Entry & $\begin{array}{l}\text { Average } \\
\text { rel. MS } \\
\text { peak area }\end{array}$ & $\begin{array}{c}\text { Rel. } \\
\text { HPLC } \\
\text { peak area }\end{array}$ & $\begin{array}{c}\text { Final } \\
\text { correction } \\
\text { coef. }\end{array}$ \\
\hline $2-b_{7}\left(\mathrm{H}^{+}\right)$ & 0.88 & \multirow{4}{*}{1.14} & 0.77 & $9-b_{7}\left(\mathrm{H}^{+}\right)$ & 1.33 & \multirow{4}{*}{0.93} & 1.42 \\
\hline $2-\mathrm{y}_{9}\left(\mathrm{H}^{+}\right)$ & 0.93 & & 0.81 & $9-\mathrm{y}_{9}\left(\mathrm{H}^{+}\right)$ & 0.86 & & 0.93 \\
\hline $2-\mathrm{y}_{13}\left(2 \mathrm{H}^{+}\right)$ & 0.90 & & 0.79 & $9-\mathrm{y}_{13}\left(2 \mathrm{H}^{+}\right)$ & 1.26 & & 1.35 \\
\hline $2-\mathrm{y}_{14}\left(2 \mathrm{H}^{+}\right)$ & 0.93 & & 0.81 & $9-\mathrm{y}_{14}\left(2 \mathrm{H}^{+}\right)$ & 1.27 & & 1.36 \\
\hline $3-b_{7}\left(\mathrm{H}^{+}\right)$ & 0.87 & \multirow{4}{*}{0.95} & 0.91 & $10-b_{7}\left(H^{+}\right)$ & 0.86 & \multirow{4}{*}{0.95} & 0.91 \\
\hline $3-\mathrm{y}_{9}\left(\mathrm{H}^{+}\right)$ & 0.86 & & 0.90 & $10-\mathrm{y}_{9}\left(\mathrm{H}^{+}\right)$ & 0.63 & & 0.66 \\
\hline $3-\mathrm{y}_{13}\left(2 \mathrm{H}^{+}\right)$ & 0.87 & & 0.91 & $10-\mathrm{y}_{13}\left(2 \mathrm{H}^{+}\right)$ & 0.81 & & 0.86 \\
\hline $3-y_{14}\left(2 \mathrm{H}^{+}\right)$ & 0.85 & & 0.89 & $10-\mathrm{y}_{14}\left(2 \mathrm{H}^{+}\right)$ & 0.70 & & 0.74 \\
\hline $4-b_{7}\left(\mathrm{H}^{+}\right)$ & 1.33 & \multirow{4}{*}{1.00} & 1.33 & $11-b_{7}\left(\mathrm{H}^{+}\right)$ & 1.32 & \multirow{4}{*}{0.92} & 1.44 \\
\hline $4-\mathrm{y}_{9}\left(\mathrm{H}^{+}\right)$ & 1.15 & & 1.15 & $11-\mathrm{y}_{9}\left(\mathrm{H}^{+}\right)$ & 1.24 & & 1.35 \\
\hline $4-y_{13}\left(2 \mathrm{H}^{+}\right)$ & 1.30 & & 1.30 & $11-\mathrm{y}_{13}\left(2 \mathrm{H}^{+}\right)$ & 1.34 & & 1.46 \\
\hline $4-y_{14}\left(2 \mathrm{H}^{+}\right)$ & 1.28 & & 1.28 & $11-\mathrm{y}_{14}\left(2 \mathrm{H}^{+}\right)$ & 1.31 & & 1.42 \\
\hline $5-b_{7}\left(\mathrm{H}^{+}\right)$ & 1.43 & \multirow{4}{*}{0.94} & 1.53 & $12-b_{5}\left(\mathrm{H}^{+}\right)$ & 1.27 & \multirow{4}{*}{1.03} & 1.23 \\
\hline $5-\mathrm{y}_{9}\left(\mathrm{H}^{+}\right)$ & 1.12 & & 1.20 & $12-b_{6}\left(H^{+}\right)$ & 1.47 & & 1.43 \\
\hline $5-y_{13}\left(2 \mathrm{H}^{+}\right)$ & 1.42 & & 1.52 & $12-b_{7}\left(\mathrm{H}^{+}\right)$ & 1.52 & & 1.47 \\
\hline $5-y_{14}\left(2 \mathrm{H}^{+}\right)$ & 1.40 & & 1.49 & $12-b_{13}\left(H^{+}\right)$ & 1.58 & & 1.53 \\
\hline $6-b_{7}\left(\mathrm{H}^{+}\right)$ & 0.94 & \multirow{4}{*}{1.03} & 0.92 & $13-b_{7}\left(\mathrm{H}^{+}\right)$ & 1.32 & \multirow{4}{*}{1.07} & 1.23 \\
\hline $6-\mathrm{y}_{9}\left(\mathrm{H}^{+}\right)$ & 0.69 & & 0.67 & $13-b_{10}\left(\mathrm{H}^{+}\right)$ & 1.87 & & 1.74 \\
\hline $6-y_{13}\left(2 \mathrm{H}^{+}\right)$ & 0.83 & & 0.81 & $13-b_{12}\left(\mathrm{H}^{+}\right)$ & 1.41 & & 1.31 \\
\hline $6-y_{14}\left(2 H^{+}\right)$ & 0.74 & & 0.72 & $13-b_{13}\left(\mathrm{H}^{+}\right)$ & 1.32 & & 1.23 \\
\hline $7-b_{7}\left(\mathrm{H}^{+}\right)$ & 1.49 & \multirow{4}{*}{0.94} & 1.59 & $14-b_{5}\left(\mathrm{H}^{+}\right)$ & 1.55 & \multirow{4}{*}{0.87} & 1.78 \\
\hline $7-\mathrm{y}_{9}\left(\mathrm{H}^{+}\right)$ & 1.35 & & 1.44 & $14-b_{6}\left(H^{+}\right)$ & 1.79 & & 2.05 \\
\hline $7-\mathrm{y}_{13}\left(2 \mathrm{H}^{+}\right)$ & 1.63 & & 1.74 & $14-b_{7}\left(H^{+}\right)$ & 1.96 & & 2.24 \\
\hline $7-\mathrm{y}_{14}\left(2 \mathrm{H}^{+}\right)$ & 1.71 & & 1.83 & $14-b_{13}\left(\mathrm{H}^{+}\right)$ & 2.37 & & 2.72 \\
\hline $8-b_{7}\left(\mathrm{H}^{+}\right)$ & 0.91 & \multirow{4}{*}{0.80} & 1.13 & & & & \\
\hline $8-\mathrm{y}_{9}\left(\mathrm{H}^{+}\right)$ & 0.84 & & 1.05 & & & & \\
\hline $8-\mathrm{y}_{13}\left(2 \mathrm{H}^{+}\right)$ & 0.90 & & 1.13 & & & & \\
\hline $8-y_{14}\left(2 \mathrm{H}^{+}\right)$ & 0.90 & & 1.12 & & & & \\
\hline
\end{tabular}

a) acyl / propionyl 
Table S-4. Synthesis and characterization of peptides

\begin{tabular}{|c|c|c|c|c|c|c|c|}
\hline \multirow{2}{*}{ peptide } & \multirow{2}{*}{ Acyl group } & \multirow{2}{*}{$\begin{array}{c}\text { MW } \\
(\mathrm{g} / \mathrm{mol})\end{array}$} & \multirow{2}{*}{ Yield (mg) } & \multicolumn{2}{|c|}{ Method A, 280 nm } & \multirow{2}{*}{$\begin{array}{c}\text { Expected } \\
\text { HRMS } \\
{[\mathrm{M}+\mathrm{H}]^{+}}\end{array}$} & \multirow{2}{*}{$\begin{array}{c}\text { Observed } \\
\text { HRMS } \\
{[\mathrm{M}+\mathrm{H}]^{+}}\end{array}$} \\
\hline & & & & $\begin{array}{c}\text { aHPLC } \\
\text { retention } \\
\text { time (min) }\end{array}$ & $\begin{array}{c}\text { aHPLC } \\
\text { purity (\% } \\
\text { AN) }\end{array}$ & & \\
\hline 1 & & 2214.37 & 3.18 & 14.4 & 96.6 & 1986.0054 & 1985.9898 \\
\hline 2 & & 2200.35 & 2.26 & 14.2 & 97.2 & 1971.9898 & 1971.9641 \\
\hline 3 & & 2228.40 & 2.33 & 14.7 & 97.4 & 2000.0211 & 2000.0052 \\
\hline 4 & & 2272.41 & 2.26 & 14.5 & 96.6 & 2044.0109 & 2043.9842 \\
\hline 5 & & 2258.38 & 2.38 & 14.2 & 97.5 & 2029.9953 & 2029.9811 \\
\hline 6 & & 2376.56 & 3.08 & 14.4 & 96.5 & 2148.0947 & 2148.0855 \\
\hline 7 & & 2294.38 & 2.21 & 15.2 & 95.2 & 2065.9928 & 2065.9765 \\
\hline 8 & & 2260.46 & 3.21 & 14.7 & 94.1 & 2031.9932 & 2031.9812 \\
\hline 9 & & 2269.41 & 0.41 & 14.8 & 97.8 & 2041.0025 & 2040.9978 \\
\hline 10 & & 2354.56 & 2.97 & 14.4 & 96.6 & 2126.1004 & 2126.0897 \\
\hline 11 & & 2238.40 & 2.21 & 14.6 & 93.3 & 2010.0054 & 2009.9947 \\
\hline 12 & & 2294.35 & 1.79 & 13.9 & $>99$ & 2065.9718 & 2065.9414 \\
\hline 13 & & 2268.43 & 2.83 & 14.9 & $>99$ & 2040.0272 & 2040.0029 \\
\hline 14 & & 2410.47 & 0.30 & 14.4 & $>99$ & 2182.0191 & 2182.0097 \\
\hline
\end{tabular}




\section{Procedure and data for Figure S1}

Generation of calibration curves:

Solutions containing $0.1 \mathrm{mM}$ 1-napthoic acid (as internal standard) and various concententrations of $N^{\alpha}$-benzoyl- $N^{\varepsilon_{-}}$ acetyl lysine or $S$-acetyl glutathione ${ }^{2}$ in $95: 5 \mathrm{v} / \mathrm{v} \mathrm{H}_{2} \mathrm{O}$ : DMSO were prepared. $20 \mu \mathrm{L}$ of each standard solution was added to a HPLC vial containing $30 \mu \mathrm{L} \mathrm{1 \%}$ v/v TFA. The resulting samples were measured by analytical HPLC (method A, $240 \mathrm{~nm}$ detection) using $20 \mu \mathrm{L}$ injections. The peak area ratio (acetylated compound / internal standard) was used as normalized response for plotting of calibration curves.
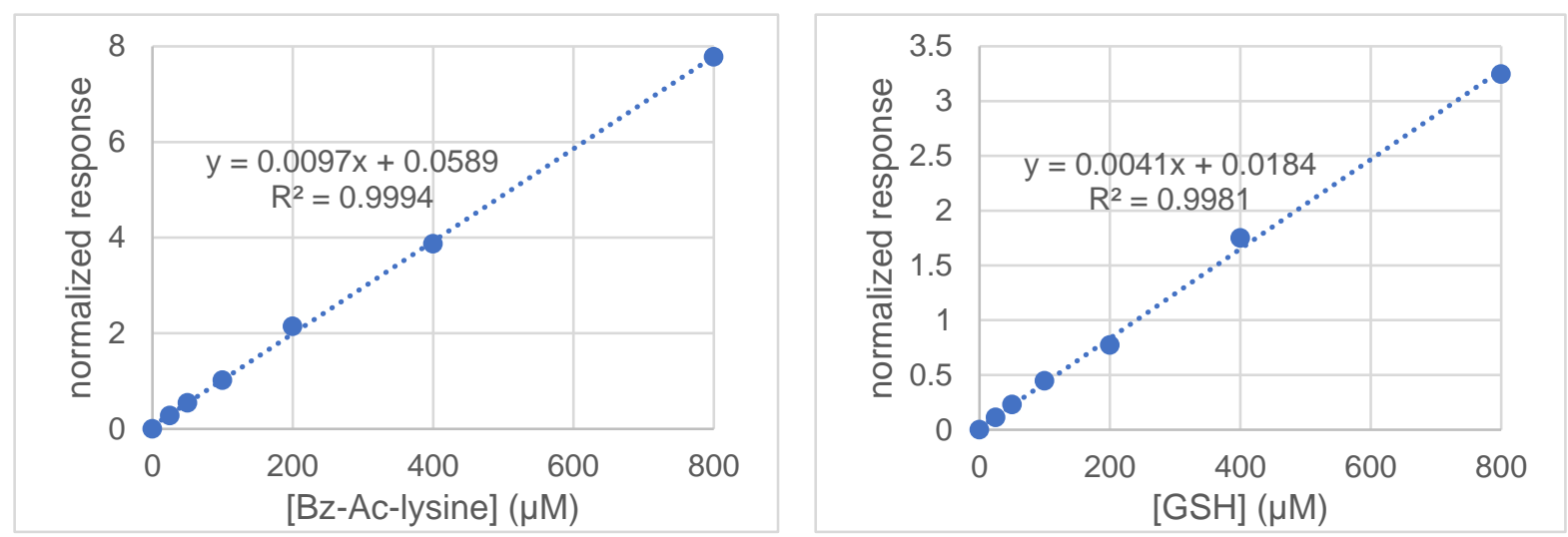

Reaction final concentrations:

\begin{tabular}{|c|c|}
\hline Material & Concentration \\
\hline$N^{\alpha}$-Bz-lysine & $40 \mathrm{mM}$ \\
\hline acetyl donor & $1.5 \mathrm{mM}$ \\
\hline 1-napthoic acid & $0.1 \mathrm{mM}$ \\
\hline phosphate & $50 \mathrm{mM}$ \\
\hline DMSO & $5 \% \mathrm{v} / \mathrm{v}$ \\
\hline
\end{tabular}

Solution Al:

$62.5 \mathrm{mM}$ phosphate buffer ( $\mathrm{pH} 7.50)$

$50 \mathrm{mM} N^{\alpha}$-Bz-lysine

\section{Solution B:}

$0.5 \mathrm{mM}$ 1-napthoic acid

$7.5 \mathrm{mM}$ acetyl donor

$25 \%$ v/v DMSO

\section{Procedure:}

Reactions were started by adding $80 \mu \mathrm{L}$ of either solution A1 or A2 to a $1.5 \mathrm{~mL}$ Eppendorf tube containing $20 \mu \mathrm{L}$ solution B (both prewarmed at $37^{\circ} \mathrm{C}$ ). The reactions were maintained in a $37^{\circ} \mathrm{C}$ heating block, and formation of acetylated product was monitored by quenching $20 \mu \mathrm{L}$ aliquots to a HPLC vial containing $30 \mu \mathrm{L} 1 \% \mathrm{v} / \mathrm{v}$ TFA.

Samples were then run on analytical HPLC (method A, $240 \mathrm{~nm}$ detection) using $20 \mu \mathrm{L}$ injections. (Note: no reaction was observed in reactions with SI-2). The peak area ratio of the acetylated compound and the internal standard was used as normalized response, which was converted to concentration using calibration curves. Data points were fitted with a straight line with the slope representing the reaction's initial rate. 
Data:

\begin{tabular}{|c|c|c|c|c|c|c|}
\hline & \multicolumn{3}{|c|}{$\left[N^{\alpha}\right.$-Bz- $N^{\varepsilon}$-Ac-lysine $](\mu \mathrm{M})$} & \multicolumn{3}{|c|}{$[S$-acetyl GSH $](\mu \mathrm{M})$} \\
\hline \multirow{6}{*}{ SI-1 } & $\mathrm{t}(\mathrm{s})$ & run 1 & run 2 & $\mathrm{t}(\mathrm{s})$ & run 1 & run 2 \\
\hline & 0 & 0 & 0 & 0 & 0 & 0 \\
\hline & 1800 & 4.2 & 4.2 & 300 & 43.2 & 39.4 \\
\hline & 3600 & 15.7 & 15.2 & 600 & 87.0 & 82.0 \\
\hline & 5400 & 26.7 & 24.4 & 900 & 124.1 & 121.7 \\
\hline & 7200 & 32.2 & 30.9 & 1200 & 159.4 & 153.1 \\
\hline \multirow{6}{*}{ SI-3 } & $\mathrm{t}(\mathrm{s})$ & run 1 & run 2 & $\mathrm{t}(\mathrm{s})$ & run 1 & run 2 \\
\hline & 0 & 0.0 & 0.0 & 0 & 0.0 & 0.0 \\
\hline & 1800 & 5.5 & 3.5 & 1800 & 4.0 & 3.6 \\
\hline & 3600 & 17.4 & 12.2 & 3600 & 10.6 & 10.0 \\
\hline & 5400 & 26.1 & 19.4 & 5400 & 15.5 & 16.2 \\
\hline & 7200 & 34.6 & 29.3 & 7200 & 22.0 & 21.5 \\
\hline \multirow{6}{*}{ SI-4 } & $\mathrm{t}(\mathrm{s})$ & run 1 & run 2 & $\mathrm{t}(\mathrm{s})$ & run 1 & run 2 \\
\hline & 0 & 0.0 & 0.0 & 0 & 0.0 & 0.0 \\
\hline & 1800 & 8.8 & 11.2 & 1800 & 20.3 & 19.5 \\
\hline & 3600 & 20.5 & 26.3 & 3600 & 40.3 & 37.1 \\
\hline & 5400 & 33.5 & 40.3 & 5400 & 56.5 & 53.5 \\
\hline & 7200 & 46.9 & 54.4 & 7200 & 69.8 & 65.7 \\
\hline \multirow{6}{*}{ D1 } & $\mathrm{t}(\mathrm{s})$ & run 1 & run 2 & $\mathrm{t}(\mathrm{s})$ & run 1 & run 2 \\
\hline & 0 & 0.0 & 0.0 & 0 & 0.0 & 0.0 \\
\hline & 1800 & 17.0 & 15.4 & 1800 & 8.4 & 8.3 \\
\hline & 3600 & 38.9 & 38.0 & 3600 & 19.0 & 18.6 \\
\hline & 5400 & 57.1 & 56.9 & 5400 & 26.7 & 27.7 \\
\hline & 7200 & 78.3 & 78.3 & 7200 & 33.8 & 33.8 \\
\hline \multirow{6}{*}{ D2 } & $\mathrm{t}(\mathrm{s})$ & run 1 & run 2 & $\mathrm{t}(\mathrm{s})$ & run 1 & run 2 \\
\hline & 0 & 0.0 & 0.0 & 0 & 0.0 & 0.0 \\
\hline & 1800 & 8.6 & 11.5 & 1800 & 5.2 & 4.4 \\
\hline & 3600 & 28.3 & 28.9 & 3600 & 15.1 & 13.9 \\
\hline & 5400 & 43.2 & 47.9 & 5400 & 21.0 & 19.6 \\
\hline & 7200 & 57.5 & 69.7 & 7200 & 27.5 & 26.8 \\
\hline \multirow{6}{*}{ D3 } & $\mathrm{t}(\mathrm{s})$ & run 1 & run 2 & $\mathrm{t}(\mathrm{s})$ & run 1 & run 2 \\
\hline & 0 & 0.0 & 0.0 & 0 & 0.0 & 0.0 \\
\hline & 1800 & 61.8 & 70.5 & 600 & 34.7 & 33.3 \\
\hline & 3600 & 122.2 & 130.1 & 1200 & 68.4 & 65.7 \\
\hline & 5400 & 184.6 & 190.3 & 1800 & 98.9 & 97.9 \\
\hline & 7200 & 236.1 & 258.3 & 2400 & 126.5 & 126.8 \\
\hline \multirow{6}{*}{ D4 } & $\mathrm{t}(\mathrm{s})$ & run 1 & run 2 & $\mathrm{t}(\mathrm{s})$ & run 1 & run 2 \\
\hline & 0 & 0.0 & 0.0 & 0 & 0.0 & 0.0 \\
\hline & 3600 & 6.7 & 7.2 & 3600 & 4.7 & 4.5 \\
\hline & 7200 & 14.0 & 14.1 & 7200 & 8.2 & 8.2 \\
\hline & 10800 & 21.8 & 21.5 & 10800 & 11.6 & 11.3 \\
\hline & 14400 & 29.9 & 29.6 & 14400 & 14.4 & 13.8 \\
\hline
\end{tabular}




\section{Data (continued):}

\begin{tabular}{|c|c|c|c|c|c|c|c|c|}
\hline & \multicolumn{4}{|c|}{ nucleophile: $N^{\alpha}$-Bz lysine } & \multicolumn{4}{|c|}{ nucleophile: GSH } \\
\hline & \multicolumn{3}{|c|}{ initial rate $\left(10^{-9} \mathrm{Ms}^{-1}\right)$} & \multirow{2}{*}{$\begin{array}{c}k \\
\left(10^{-5}\right. \\
\left.\mathrm{M}^{-1} \mathrm{~s}^{-1}\right)^{\mathrm{a}}\end{array}$} & \multicolumn{3}{|c|}{ initial rate $\left(10^{-9} \mathrm{Ms}^{-1}\right)$} & \multirow{2}{*}{$\begin{array}{c}k \\
\left(10^{-3}\right. \\
\left.\mathrm{M}^{-1} \mathrm{~s}^{-1}\right)^{\mathrm{b}}\end{array}$} \\
\hline $\begin{array}{l}\text { acetyl } \\
\text { donor }\end{array}$ & run 1 & run 2 & average & & run 1 & run 2 & average & \\
\hline SI-1 & 4.8 & 4.6 & 4.7 & 7.8 & 133 & 130 & 131 & 18 \\
\hline $\mathrm{SI}^{\mathrm{S}} 2^{\mathrm{c}}$ & n.d. & n.d. & n.d. & n.d. & n.d. & n.d. & n.d. & n.d. \\
\hline SI-3 & 5.0 & 4.1 & 4.6 & 7.6 & 3.1 & 3.1 & 3.1 & 0.41 \\
\hline SI-4 & 6.6 & 7.7 & 7.1 & 12 & 9.8 & 9.2 & 9.5 & 1.3 \\
\hline D1 & 10.9 & 11.0 & 11.0 & 18 & 4.8 & 4.8 & 4.8 & 0.64 \\
\hline D2 & 8.3 & 9.8 & 9.0 & 15 & 3.9 & 3.8 & 3.9 & 0.52 \\
\hline D3 & 33 & 35 & 34 & 57 & 53 & 53 & 53 & 7.1 \\
\hline D4 & 2.1 & 2.0 & 2.1 & 3.4 & 0.99 & 0.95 & 0.97 & 0.13 \\
\hline
\end{tabular}

a) calculated using the formula $\mathrm{k}=$ rate $_{\mathrm{t}=0} /(0.04 \mathrm{M} * 0.0015 \mathrm{M})$

b) calculated using the formula $\mathrm{k}=$ rate $_{\mathrm{t}=0} /(0.005 \mathrm{M} * 0.0015 \mathrm{M})$

c) the reaction was too slow to be studied by this method 


\section{Procedure for Figure S2}

A mixture of $3 \mathrm{~mL} \mathrm{D} \mathrm{D}_{2} \mathrm{O}$ and $0.2 \mathrm{mmol}$ 4-ethylmorpholine was prepared, the $\mathrm{pH}$ was adjusted to 7.5 with $\mathrm{HOAc}$, and the volume was adjusted to $4 \mathrm{~mL}$. This material was diluted $1: 1 \mathrm{v} / \mathrm{v}$ with ACN- $d_{3}$ to provide the NMR solvent (25 $\mathrm{mM}$ in 4-ethylmorpholine).

Separately, to a vial was charged boronic acid SI-55 $(1.0 \mathrm{mg}, 5 \mu \mathrm{mol})$, catalyst $8(6.0 \mathrm{mg}, 5 \mu \mathrm{mol})$, and $0.15 \mathrm{~mL}$ IPA, and incubated for 2 hours at room temperature. The mixture was purified by preparative HPLC (method A, 15 $100 \% \mathrm{ACN}$ ) to afford the corresponding bornoic ester (5.75 mg, $4.78 \mathrm{mmol}, 96 \%$ yield) as white solid.

The boronic ester was dissolved in $500 \mu \mathrm{L}$ NMR solvent ( $9.6 \mathrm{mM}$ in boronic acid; final $\mathrm{pH} 7$ to paper). Then, the ${ }^{11} \mathrm{~B}$ NMR spectrum recorded.

\section{Procedure for Figure S3}

HEK293T cells expressing recombinant eDHFR-GFP (samples 1 and 2) or untransfected cells (samples 3 and 4) were prepared in 4 wells in a 24 well plate (as described in SI-9). 24 hours after transfection (at which point the acylation reaction begins in a typical experiment), the cells were washed with PBS, trypsinized for 5 minutes, resuspended in DMEM ${ }^{+++}$, and counted by Trypan blue cytometry. $3.5 \times 10^{5}$ cells were washed twice with PBS and lysed using $100 \mu \mathrm{L}$ CRB' buffer with brief vortexing once about every 10 minutes. The lysates were clarified by centrifuging $\left(21,000 \mathrm{rcf}\right.$ for 15 minutes at $\left.4{ }^{\circ} \mathrm{C}\right)$.

$10 \mu \mathrm{L}$ of each lysate (representing $3.5 \times 10^{4}$ cells) was diluted with with $10 \mu \mathrm{L}$ of CRB'. In the $2 \mathrm{X}$ dilution step, lysates from untransfected cells (samples 3 and 4) were spiked with recombinant eDHFR-GFP (final concentrations $0,0.07825,0.3125,0.125$, and $0.5 \mu \mathrm{M}$ ) to obtain two sets of calibration standards. Lysates from transfected cells (samples 1 and 2) were analyzed in duplicate.

The samples were separated by SDS-PAGE (15\% bis-acrylamide) and analyzed by Western blotting ( $\alpha$-GFP). The backgroud-corrected intensity of each band was determined using the 'integrated intensity' feature of ImageJ 1.53 software. Next, a calibration curve was plotted, and was used to calculate eDHFR-GFP intracellular concentration (as an average of four measurements) as $31 \mu \mathrm{M}$ (assuming a cell volume of $1.436 \times 10^{-12} \mathrm{~L} /$ cell). 


\section{Procedure for Figure S5}

The calculation for the energy minimized structure of catalyst $\mathbf{8}$ was carried out with Gaussian 16 program (revision B.01) package. Geometry optimization and vibrational analysis were carried out at the level of B3LYP/6-31G*. Docking calculation with eDHFR (PDB: 3dau) was carried out with Auto-Dock vina program (http://vina.scripps.edu/).

\section{Procedure for Figure S6}

Test-tube acetylation of eDHFR-GFP (Figure S6b) was conducted as in Figure 3. PAMPA (Figure S6c) was performed according to the manufucturer's procedure (Merck Millipore, protocol note PC2004EN00). A hexadecane layer was constructed through carefully pipetting $15 \mu \mathrm{L}$ of a $5 \%$ solution of hexadecane in hexane onto the membrane of a donor plate (Merck Millipore: MPC4NTR10) and allowing the plate to dry for 1 hour in a fume hood. $300 \mu \mathrm{L}$ of 5\% DMSO in PBS buffer (pH 7.4) was added to an acceptor plate (Merck Millipore MPC4NTR10) and the hexadecane-treated donor plate was placed into the acceptor plate. Each catalyst $(200 \mu \mathrm{M})$ was dissolved in 5\% DMSO/PBS ( $\mathrm{pH} 7.4$ ) and $150 \mu \mathrm{L}$ of the solution was added to the donor plate. After closing the lid, the plates were incubated at room temperature for 5 hours with wet paper towels to maintain humidity. The catalyst concentration in the acceptor plate was determined with UV absorption $(254 \mathrm{~nm})$ from the standard curves shown below.
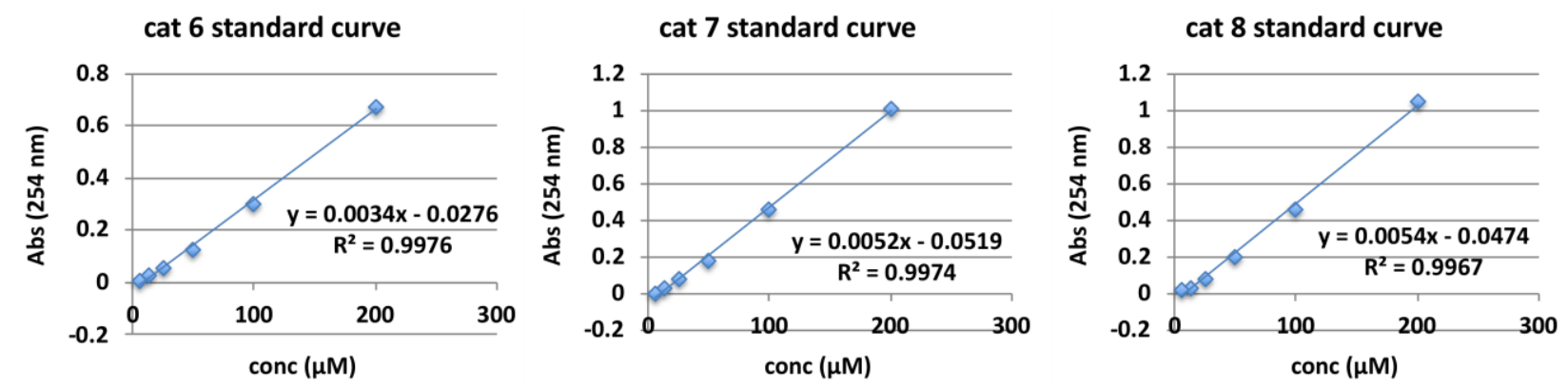


\section{Procedure for Figure S7a,b}

To a $1.5 \mathrm{~mL}$ Eppendorf tube was charged $495 \mu \mathrm{L}$ of human serum (Sigma-Aldrich H4522) or OptiMem (Thermo Fisher). Then, a solution of D4 (10 mM in DMSO; $5 \mu \mathrm{L}, 100 \mu \mathrm{M}$ final concentration) was charged, and the mixture was vortexed. After 0, 2.5, and 5 hours, the reaction mixture was loaded onto a Sep-Pak Short C18 (Waters). After washing with $1 \mathrm{~mL} \mathrm{H}_{2} \mathrm{O}$ and $1 \mathrm{~mL} \mathrm{10 \%} \mathrm{v/v} \mathrm{ACN} \mathrm{in} \mathrm{H}_{2} \mathrm{O}$, the boronic acid was eluted with $2 \mathrm{~mL} 50 \% \mathrm{v} / \mathrm{v}$ ACN in $\mathrm{H}_{2} \mathrm{O}$. The eluate was lyophilized and re-constituted in $180 \mu \mathrm{L} \mathrm{H}_{2} \mathrm{O}$ and $20 \mu \mathrm{L} 1 \mathrm{mM}$ 1-napthoic acid in DMSO. The resulting mixture was analyzed by analytical HPLC using $40 \mu \mathrm{L}$ injections (method A, $240 \mathrm{~nm}$ ). The relative integration of D4 and the internal standard was tabulated for each sample. The normalized D4 peak intensity of the $t$ $=0$ sample was defined as $100 \%$ recovery, and the D4 recovery for the 2.5 and 5 hour samples are reported as a percentage of the $t=0$ value.

\section{Procedure for Figure S7c}

\begin{tabular}{|c|c|c|}
\hline Material & Amount $(\mu \mathrm{L})$ & $\begin{array}{c}\text { Final concentration } \\
(\mathrm{mM})\end{array}$ \\
\hline $\begin{array}{c}200 \mathrm{mM} \text { phosphate } \\
(\mathrm{pH}=7.5)\end{array}$ & 137.5 & 50 \\
\hline $\begin{array}{c}\text { 10 mM 1-napthoic } \\
\text { acid (in DMSO) }\end{array}$ & 8.25 & 0.15 \\
\hline $\begin{array}{c}\text { Boronic acid in } \\
\text { DMSO (10 mM) }\end{array}$ & 11 & 0.2 \\
\hline MQ $\mathrm{H}_{2} \mathrm{O}$ & 388.25 & N/A \\
\hline $\begin{array}{c}\mathrm{H}_{2} \mathrm{O}_{2} \text { in } \mathrm{H}_{2} \mathrm{O} \\
(80 \mathrm{mM})\end{array}$ & 5 & 0.8 \\
\hline
\end{tabular}

To a $1.5 \mathrm{~mL}$ Eppendorf tube was charged the first 4 materials, and the mixture was vortexed. $50 \mu \mathrm{L}$ was removed for subsequent analysis. Then, the $\mathrm{H}_{2} \mathrm{O}_{2}$ solution was charged. The mixture was vortexed and incubated in a $25^{\circ} \mathrm{C}$ heating block. The $\mathrm{t}=0$ sample and subsequent $50 \mu \mathrm{L}$ aliquots were quenched to an Eppendorf tube (on ice) containing $25 \mu \mathrm{L}$ of $300 \mathrm{mM}$ sodium bisulfite in $1: 1 \mathrm{ACN}: \mathrm{H}_{2} \mathrm{O}$. The quenched aliquots were aged on ice for at least 30 minutes and then analyzed by analytical HPLC (method A, $240 \mathrm{~nm}$ ) using $40 \mu \mathrm{L}$ injections. The boronic acid peak intensity (normalized to internal standard) for the $\mathrm{t}=0$ sample was taken as $200 \mu \mathrm{M}$. 


\section{Procedure for Figure S9}

Note: wash buffer, protease inhibitor cocktail, extraction buffer I, and extraction buffer II refer to the components of ProteoExtract ${ }^{\circledR}$ Native Membrane Protein Extraction Kit (Sigma-Aldrich 444810).

HEK293T ( $2 \mathrm{~mL} ; 2 \times 10^{5} \mathrm{~mL}^{-1}$ in DMEM $\left.{ }^{++}\right)$was seeded in wells of a 6 well plate. The cells were incubated for 48 hours (confluency ca. 90\%). The medium was changed to a premix of $1485 \mu \mathrm{L}$ OptiMem and $15 \mu \mathrm{L}$ of acetyl donor (10 mM in DMSO; final concentration $100 \mu \mathrm{M}$ ). After 5 hours incubation, the cells were detached by vigorously pipetting. The cells were washed twice with wash buffer.

A premix of $0.5 \mu \mathrm{L}$ protease inhibitor cocktail and $50 \mu \mathrm{L}$ extraction buffer I was charged. The cells were suspended and incubated for 10 minutes at $4{ }^{\circ} \mathrm{C}$ with periodic gentle vortexing. The material was centrifuged $(16,000 \mathrm{rcf}$ for 15 minutes at $4{ }^{\circ} \mathrm{C}$ ). The supernatant (containing soluble proteins) was discarded. A premix of $0.5 \mu \mathrm{L}$ protease inhibitor cocktail and $50 \mu \mathrm{L}$ extraction buffer II was charged. The cells were suspended and incubated for 30 minutes at $4{ }^{\circ} \mathrm{C}$ with periodic gentle vortexing. The material was centrifuged $\left(16,000 \mathrm{rcf}\right.$ for 15 minutes at $\left.4{ }^{\circ} \mathrm{C}\right)$. The supernatant (containing membrane proteins) was collected. After Bradford assay, the protein concentration of each lysate was diluted to $2500 \mu \mathrm{g} / \mathrm{mL}$. Lysates were separated by SDS-PAGE ( $5-20 \%$ bis-acrylamide gradient). CBB analysis used $3 \mu$ g protein per lane, and western blotting $(\alpha-\mathrm{AcK})$ used $21 \mu \mathrm{g}$ protein per lane.

\section{Procedure for Figure S11}

CellTiter-Glo is a luminescent assay used to measure cell viability by ATP level. HEK293T cells $\left(4.5 \times 10^{5}\right.$ cells $/ 100 \mu \mathrm{L}$ in DMEM) were seeded into a 96-well plate (white) and incubated for $24 \mathrm{~h}$. After washing cells once with $100 \mu \mathrm{L}$ Opti-MEM, the medium was replaced with solutions of the acyl donor or catalyst in $100 \mu \mathrm{L}$ Opti-MEM and cells were incubated for 5 hours. The medium was changed to $50 \mu \mathrm{L}$ Opti-MEM, and cell viability was measured using a plate reader equipped with a luminescence module (GloMax EXPLORER, Promega) as follows. Cells were treated with $50 \mu \mathrm{L}$ CellTiter-Glo 2.0 reagent. After 2 minutes shaking (300 cycle/min, orbital, $2 \mathrm{~mm}$ ) and 10 minutes incubation, luminescence was detected. $100 \%$ viability is defined as the luminescence measured in the cells treated with $1 \%$ (for the acyl donors) or $4 \%$ (for the catalyst) DMSO in Opti-MEM. 


\section{Procedure for Figure S12}

Acetylation of eDHFR-GFP was performed as in Figure 3. After the reaction, $40 \mu \mathrm{L}$ of an aliquot was diluted with $450 \mu \mathrm{L}$ of phosphate $(50 \mathrm{mM}, \mathrm{pH} 7.0)$ containing $500 \mathrm{mM} \mathrm{NaCl}$. The mixture was concentrated with Amicon Ultra Centrifugal Filter Device (10kDa filter, $15 \mathrm{krpm}, 4{ }^{\circ} \mathrm{C}, 10$ minutes). Ultra-filtraton was repeated a total of five times to remove the catalyst and acetyl donor. Finally, the concentrate was diluted with phosphate $(50 \mathrm{mM}, \mathrm{pH} 7.0)$ without $\mathrm{NaCl}$ and filtered once with Amicon Ultra Centrifugal Filter Device (10 kDa, $15 \mathrm{krpm}, 4{ }^{\circ} \mathrm{C}, 10$ minutes) to afford eDHFR-GFP solution (ca. $40 \mu \mathrm{L}, 10 \mu \mathrm{M}$ ) for dihydrofolate reductase assay.

Dihydrofolate reductase assay was performed according to the literature (MEMS Microbiol. Lett. 1997, 156, 69). To a tube containing $986.5 \mu \mathrm{L}$ of buffer (50 mM phosphate, pH 7.0, 1 mM EDTA, $10 \mathrm{mM}$ 2-mercaptoethanol), $2.5 \mu \mathrm{L}$ of the eDHFR-GFP solution ( $c a .10 \mu \mathrm{M}$ ) prepared above and $5 \mu \mathrm{L}$ of $10 \mathrm{mM}$ dihydrofolic acid (Sigma-Aldrich, D7006) were added. UV absoption ( $340 \mathrm{~nm}$ ) of the mixture was used as a baseline. To the mixture, $6 \mu \mathrm{L}$ of $10 \mathrm{mM}$ NADPH was then added, quickly mixed, and UV absorption $(340 \mathrm{~nm}$ ) was monitored for 3 minutes at 0.5 -second intervals. 
Procedure and data for Figure 2

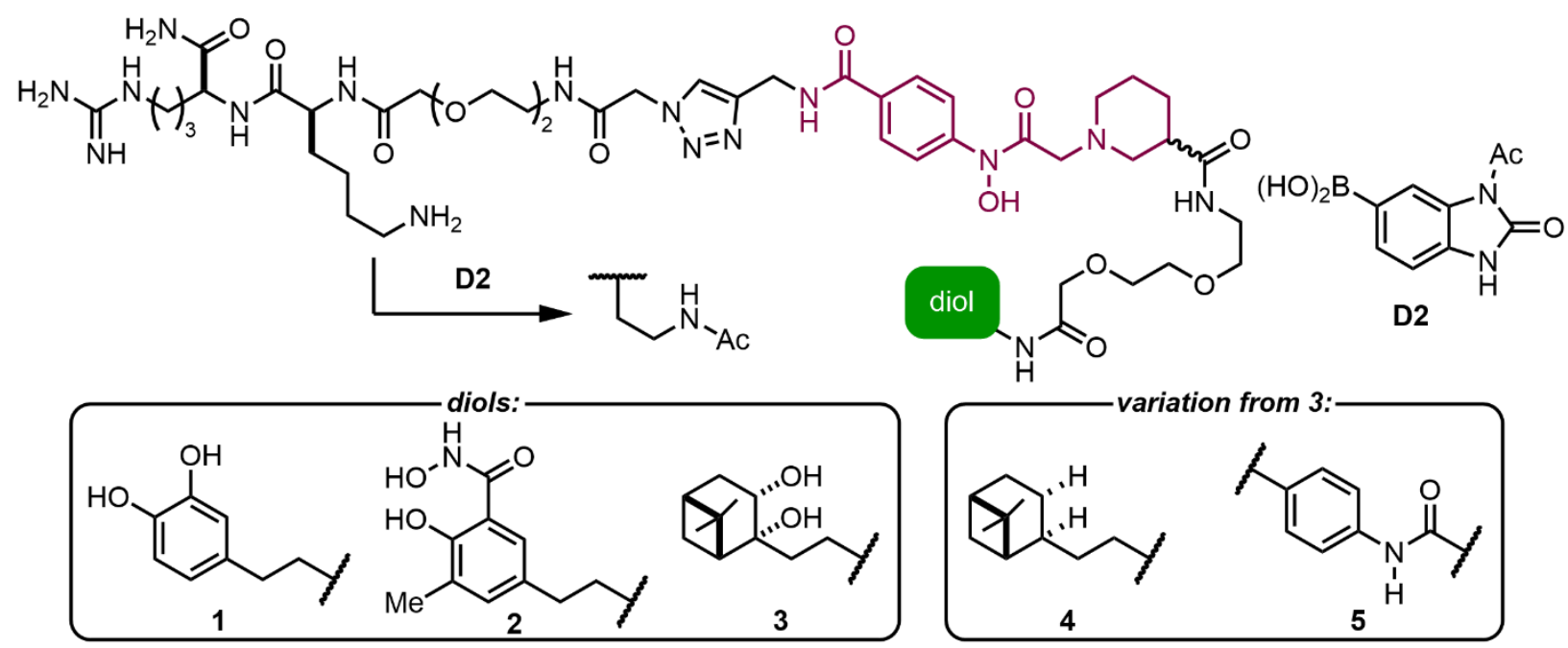

For Figure 2a:

\begin{tabular}{|c|c|c|}
\hline Material & $\begin{array}{c}\text { Amount used } \\
(\mu \mathrm{L})\end{array}$ & $\begin{array}{c}\text { Final conc. } \\
(\mathrm{mM})\end{array}$ \\
\hline $10 \mathrm{mM}$ model catalyst in $\mathrm{H}_{2} \mathrm{O}$ & 1 & 0.2 \\
\hline $10 \mathrm{mM} \mathrm{D2}$ in DMSO & 2 & 0.4 \\
\hline $200 \mathrm{mM} \mathrm{P}_{\mathrm{i}}, \mathrm{pH} 7.50$ & 12.5 & 50 \\
\hline $\mathrm{mq} \mathrm{H}_{2} \mathrm{O}$ & 34.5 & N/A \\
\hline \multicolumn{2}{|r}{}
\end{tabular}

For Figure 2b:

\begin{tabular}{|c|c|c|}
\hline Material & $\begin{array}{c}\text { Amount used } \\
(\mu \mathrm{L})\end{array}$ & $\begin{array}{c}\text { Final conc. } \\
(\mathrm{mM})\end{array}$ \\
\hline $10 \mathrm{mM}$ model catalyst in $\mathrm{H}_{2} \mathrm{O}$ & 2 & 0.2 \\
\hline D2 in DMSO & 10 & variable \\
\hline $200 \mathrm{mM} \mathrm{P}_{\mathrm{i}}, \mathrm{pH} 7.50$ & 25 & 50 \\
\hline $\mathrm{mq} \mathrm{H}_{2} \mathrm{O}$ & 63 & N/A \\
\hline
\end{tabular}

\section{Procedure:}

Reactions were started by adding the $\mathbf{D 2}$ solution to a $1.5 \mathrm{~mL}$ Eppendorf tube containing all other materials (both prewarmed at $37^{\circ} \mathrm{C}$ ). The reactions were maintained in a $37^{\circ} \mathrm{C}$ heating block, and formation of acetylated product was monitored by quenching $15 \mu \mathrm{L}$ aliquots to a HPLC vial containing $35 \mu \mathrm{L}$ quench solution $(125 \mathrm{mM}$ citric acid, $50 \mathrm{mM} \mathrm{KHF}_{2}$ ). The HPLC vials were aged at room temperature for at least 12 hours to cleave boronate esters, thus simplifying analysis. (Note: the quenched reaction mixture was noted to be stable with respect to percent conversion). Samples were then run on analytical HPLC (method B, $220 \mathrm{~nm}$ detection) using $20 \mu \mathrm{L}$ injections. The peaks corresponding to starting material and product were integrated, and percent conversion (defined as peak area of product divided by combined peak area of starting material and product) was calculated. 
Figure 2a data:

\begin{tabular}{|c|c|c|c|c|c|c|}
\hline & \multicolumn{6}{|c|}{ percent conversion } \\
\hline & \multicolumn{3}{|c|}{ model catalyst 2 } & \multicolumn{3}{c|}{ model catalyst 3 } \\
\hline time (min) & run 1 & run 2 & average & run 1 & run 2 & average \\
\hline 0 & 0 & 0 & 0 & 0 & 0 & 0 \\
\hline 10 & 12.9 & 12.4 & 12.7 & 22.3 & 21.2 & 21.8 \\
\hline 20 & 21.4 & 19.4 & 20.4 & 43.9 & 41.4 & 42.7 \\
\hline 40 & 32.8 & 29.7 & 31.3 & 63.3 & 60.5 & 61.9 \\
\hline 80 & 40.1 & 36.3 & 38.2 & 71.9 & 67.7 & 69.8 \\
\hline
\end{tabular}

For model catalysts $\mathbf{1}, \mathbf{4}$, and $\mathbf{5}$, since the reactions were slow, so we could not accurately integrate the reaction product peaks from 10, 20, and 40 minutes. Accordingly, only 80 minute data is tabulated.

\begin{tabular}{|c|c|c|c|c|c|c|c|c|c|}
\hline & \multicolumn{9}{|c|}{ percent conversion } \\
\hline & \multicolumn{3}{|c|}{ model catalyst 1 } & \multicolumn{3}{c|}{ model catalyst 4 } & \multicolumn{3}{c|}{ model catalyst 5 } \\
\hline time (min) & run 1 & run 2 & average & run 1 & run 2 & average & run 1 & run 2 & average \\
\hline 80 & 7.4 & 4.4 & 5.9 & 5.1 & 5.6 & 5.3 & 4.4 & 2.5 & 3.5 \\
\hline
\end{tabular}

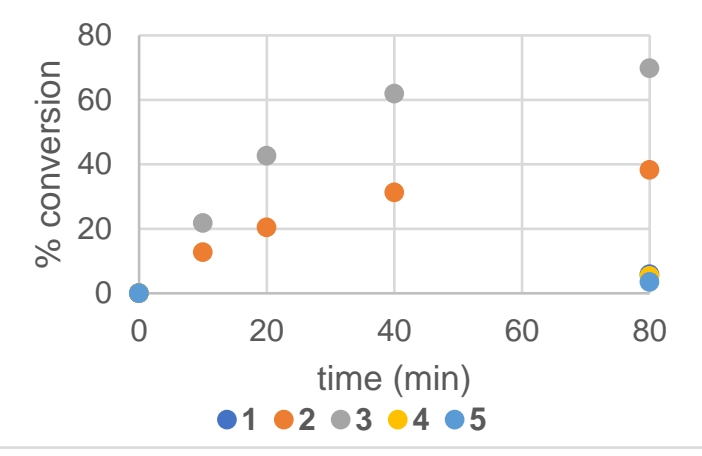

For model catalysts 2 and 3, using GraphPad Prism 9.1 software the data was fitted to an equation of the form

$$
\mathrm{Y}=\mathrm{C} 1-\mathrm{C} 2 * \exp (-\mathrm{k} * \mathrm{t})
$$

where $\mathrm{Y}$ is percent conversion and $\mathrm{C} 1, \mathrm{C} 2$, and $\mathrm{k}$ are constants. The first derivative at $\mathrm{t}=0$ was taken as the intial rate. For model catalysts $\mathbf{1}, \mathbf{4}$, and $\mathbf{5}$, the initial rate was estimated by drawing a straight line between the $\mathrm{t}=0$ and 80 minutes data points.

\begin{tabular}{|c|c|c|}
\hline $\begin{array}{c}\text { model } \\
\text { catalyst }\end{array}$ & $\begin{array}{c}\text { initial rate } \\
(\% / \mathrm{min})\end{array}$ & $\begin{array}{c}\text { initial rate } \\
(\mu \mathrm{mol} / \mathrm{min})\end{array}$ \\
\hline $\mathbf{1}$ & 0.054 & 0.11 \\
\hline $\mathbf{2}$ & 1.5 & 2.9 \\
\hline $\mathbf{3}$ & 3.2 & 6.4 \\
\hline $\mathbf{4}$ & 0.070 & 0.14 \\
\hline $\mathbf{5}$ & 0.031 & 0.062 \\
\hline
\end{tabular}


Figure $2 b$ data:

\begin{tabular}{|c|c|c|c|c|c|c|}
\hline \multicolumn{3}{|c|}{$0.25 \mathrm{mM}$} & & \multicolumn{3}{c|}{$0.3 \mathrm{mM}$} \\
\hline $\mathrm{t}(\mathrm{min})$ & \% conv., run 1 & \% conv., run 2 & & $\mathrm{t}(\mathrm{min})$ & \% conv., run 1 & \% conv., run 2 \\
\hline 5 & 4.5 & 3.1 & & 4 & 2.9 & 3.3 \\
\hline 6 & 6.3 & 4.5 & & 6 & 5.5 & 7.5 \\
\hline 7 & 8.0 & 5.7 & & 8 & 8.0 & 10.8 \\
\hline 8 & 9.6 & 8.1 & & 10 & 12.7 & 14.5 \\
\hline
\end{tabular}

\begin{tabular}{|c|c|c|c|c|c|}
\hline \multicolumn{3}{|c|}{$0.35 \mathrm{mM}$} & \multicolumn{3}{c|}{$0.4 \mathrm{mM}$} \\
\hline $\mathrm{t}(\mathrm{min})$ & \% conv., run 1 & \% conv., run 2 & $\mathrm{t}(\mathrm{min})$ & \% conv., run 1 & \% conv., run 2 \\
\hline 4 & 3.5 & 4.5 & 4 & 5.3 & 5.8 \\
\hline 6 & 7.1 & 10.5 & 6 & 9.1 & 12.2 \\
\hline 8 & 11.3 & 15.6 & 8 & 14 & 17.3 \\
\hline 10 & 15.6 & 18.3 & 10 & 18.3 & 22.2 \\
\hline
\end{tabular}

\begin{tabular}{|c|c|c|c|c|c|}
\hline \multicolumn{3}{|c|}{$0.5 \mathrm{mM}$} & \multicolumn{3}{c|}{$0.6 \mathrm{mM}$} \\
\hline $\mathrm{t}(\mathrm{min})$ & \% conv., run 1 & \% conv., run 2 & $\mathrm{t}(\mathrm{min})$ & \% conv., run 1 & \% conv., run 2 \\
\hline 4 & 6.4 & 4.8 & 4 & 5.9 & 6.7 \\
\hline 6 & 13.4 & 10.4 & 6 & 13.0 & 13.6 \\
\hline 8 & 21.8 & 16.7 & 8 & 19.9 & 22.8 \\
\hline 10 & 28.0 & 22.0 & 10 & 27.4 & 30.1 \\
\hline
\end{tabular}

\begin{tabular}{|c|c|c|c|c|c|}
\hline \multicolumn{3}{|c|}{$0.7 \mathrm{mM}$} & \multicolumn{3}{c|}{$0.8 \mathrm{mM}$} \\
\hline $\mathrm{t}(\mathrm{min})$ & \% conv., run 1 & \% conv., run 2 & $\mathrm{t}(\mathrm{min})$ & \% conv., run 1 & \% conv., run 2 \\
\hline 4 & 6.9 & 8.1 & 4 & 7.1 & 9.6 \\
\hline 6 & 13.9 & 13.1 & 6 & 13.7 & 18.7 \\
\hline 8 & 20.9 & 20.5 & 8 & 19.6 & 26.7 \\
\hline 10 & 27.9 & 26.7 & 10 & 26.3 & 34.0 \\
\hline
\end{tabular}

\begin{tabular}{|c|c|c|c|c|c|}
\hline \multicolumn{3}{|c|}{$1.0 \mathrm{mM}$} & \multicolumn{3}{c|}{$1.2 \mathrm{mM}$} \\
\hline $\mathrm{t}(\mathrm{min})$ & \% conv., run 1 & \% conv., run 2 & $\mathrm{t}(\mathrm{min})$ & \% conv., run 1 & \% conv., run 2 \\
\hline 4 & 6.6 & 6.6 & 4 & 7.4 & 7.1 \\
\hline 6 & 13.5 & 12.9 & 6 & 15 & 15.1 \\
\hline 8 & 20.8 & 22.5 & 8 & 22.5 & 22.8 \\
\hline 10 & 29.1 & 29 & 10 & 31.9 & 28 \\
\hline
\end{tabular}


Figure $2 b$ data (continued):

The time course data was fitted to straight lines with the slope representing the intial reaction rate.

\begin{tabular}{|c|c|c|c|c|}
\hline$[D 2](\mathrm{mM})$ & $\begin{array}{c}\text { initial rate, run 1 } \\
\left(\% \mathrm{~min}^{-1}\right)\end{array}$ & $\begin{array}{c}\text { initial rate, run 2 } \\
\left(\% \mathrm{~min}^{-1}\right)\end{array}$ & $\begin{array}{c}\text { average initial rate } \\
\left(\% \mathrm{~min}^{-1}\right)\end{array}$ & $\begin{array}{c}\text { average initial rate } \\
\left(\mu \mathrm{M} \mathrm{min}^{-1}\right)\end{array}$ \\
\hline 0.25 & 1.7 & 1.6 & 1.7 & 3.3 \\
\hline 0.3 & 1.6 & 1.8 & 1.7 & 3.4 \\
\hline 0.35 & 2.0 & 2.3 & 2.2 & 4.4 \\
\hline 0.4 & 2.2 & 2.7 & 2.5 & 4.9 \\
\hline 0.5 & 3.7 & 2.9 & 3.3 & 6.6 \\
\hline 0.6 & 3.6 & 4.0 & 3.8 & 7.5 \\
\hline 0.7 & 3.5 & 3.2 & 3.3 & 6.7 \\
\hline 0.8 & 3.2 & 4.1 & 3.6 & 7.2 \\
\hline 1 & 3.7 & 3.8 & 3.8 & 7.6 \\
\hline 1.2 & 4.1 & 3.5 & 3.8 & 7.6 \\
\hline
\end{tabular}


Procedure and data for Figure 3

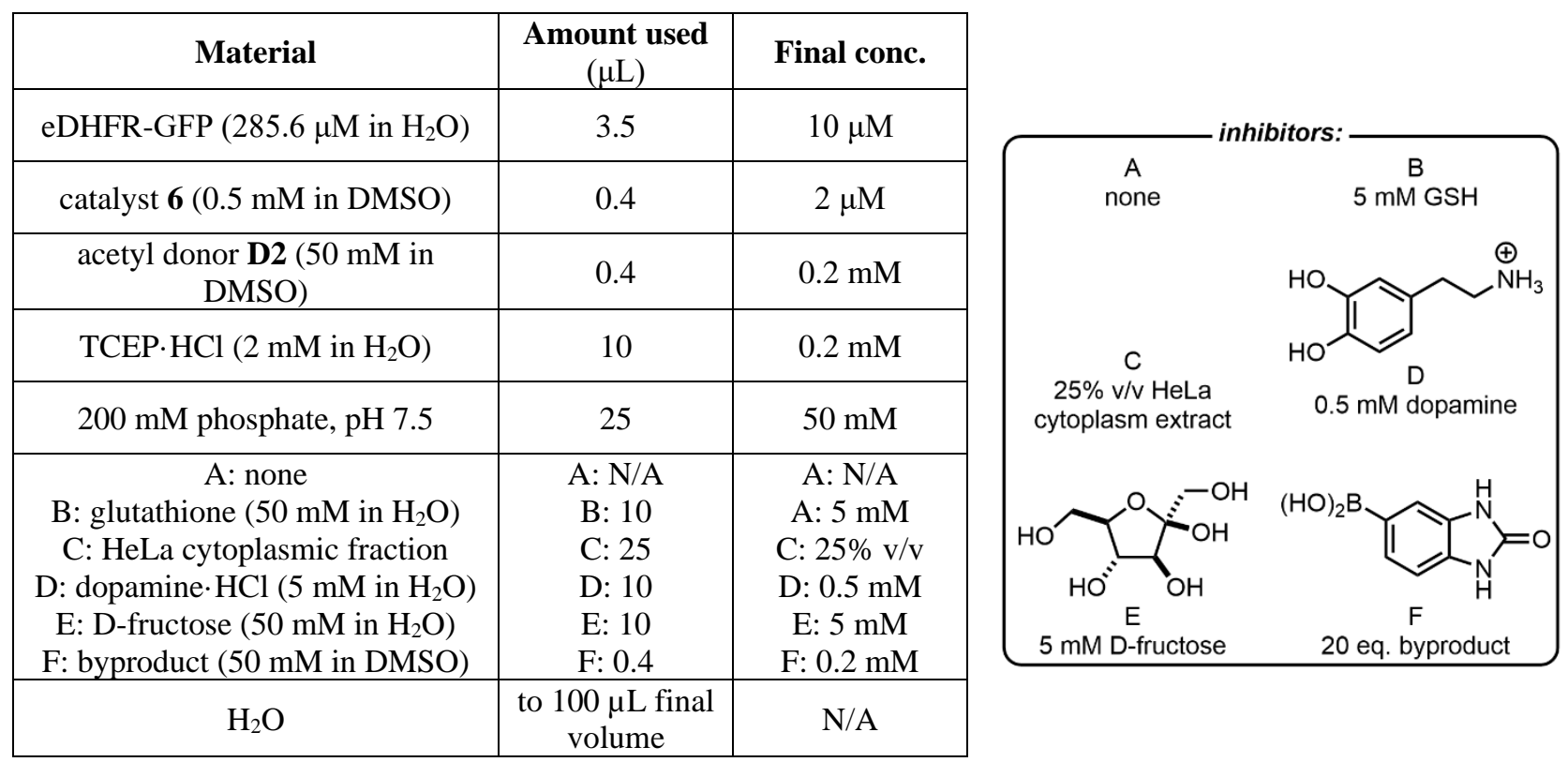

\section{Procedure:}

Reactions were started by adding eDHFR-GFP to a $1.5 \mathrm{~mL}$ Eppendorf tube containing all other materials (prewarmed at $37^{\circ} \mathrm{C}$ ). The reactions were maintained in a $37^{\circ} \mathrm{C}$ heating block. After 2,4 , and 8 hours, $10 \mu \mathrm{L}$ aliquots were quenched with $2 \mu \mathrm{L}$ trichloroacetic acid. The quenched samples were incubated on ice for 30 minutes and centrifuged $\left(21,000 \mathrm{rcf}\right.$ for 3 minutes at $\left.4{ }^{\circ} \mathrm{C}\right)$. The supernatant was discarded, and the pellet was washed twice with chilled acetone.

$20 \mu \mathrm{L} 100 \mathrm{mM} \mathrm{NH}_{4} \mathrm{HCO}_{3}, 20 \mu \mathrm{L} 1: 3 \mathrm{v} / \mathrm{v}$ propionic anhydride : $\mathrm{MeOH}$, and $14 \mu \mathrm{L} 28 \% \mathrm{NH}_{3}$ were charged, samples were shaken at room temperature for 30 minutes, and volatiles were removed on a SpeedVac evaporator at $80{ }^{\circ} \mathrm{C} .50 \mu \mathrm{L}$ 0.01\% protease MAX in $50 \mathrm{mM} \mathrm{NH}_{4} \mathrm{HCO}_{3}, 1 \mu \mathrm{g}$ Trypsin Gold, and $10 \mu \mathrm{L}$ Glu-C $(1 \mu \mathrm{g})$ were charged, and the samples were incubated at $37^{\circ} \mathrm{C}$ for $3-15$ hours. The pH was adjusted to 3 by charging $25 \mu \mathrm{L} 5 \%$ formic acid, and volatiles were removed on a SpeedVac evaporator at $80^{\circ} \mathrm{C}$.

The residue was suspended in $20 \mu \mathrm{L} 0.1 \%$ formic acid and clarified by centrifuging (21,000 rcf for 10 minutes at room temperature). The supernatant was analyzed by LC-MS/MS (see SI-17 for procedure). 
Time course data:

\begin{tabular}{|c|c|c|c|c|c|c|c|c|c|}
\hline & \multicolumn{3}{|c|}{$2 \mathrm{~h}$} & \multicolumn{3}{c|}{$4 \mathrm{~h}$} & \multicolumn{3}{c|}{$8 \mathrm{~h}$} \\
\hline inhibitor & run 1 & run 2 & average & run 1 & run 2 & average & run 1 & run 2 & average \\
\hline A & 38.8 & 46.0 & 42.4 & 53.6 & 56.9 & 55.2 & 67.4 & 64.4 & 65.9 \\
\hline B & 23.8 & 28.4 & 26.1 & 35.4 & 38.2 & 36.8 & 45.3 & 47.5 & 46.4 \\
\hline C & 32.4 & 36.1 & 34.2 & 44.2 & 47.0 & 45.6 & 55.7 & 54.4 & 55.1 \\
\hline D & 40.7 & 44.5 & 42.6 & 55.9 & 57.5 & 56.7 & 70.8 & 66.9 & 68.9 \\
\hline E & 37.0 & 39.3 & 38.2 & 53.1 & 52.3 & 52.7 & 65.3 & 61.0 & 63.1 \\
\hline F & 40.0 & 43.9 & 42.0 & 55.4 & 55.0 & 55.2 & 65.2 & 63.6 & 64.4 \\
\hline
\end{tabular}

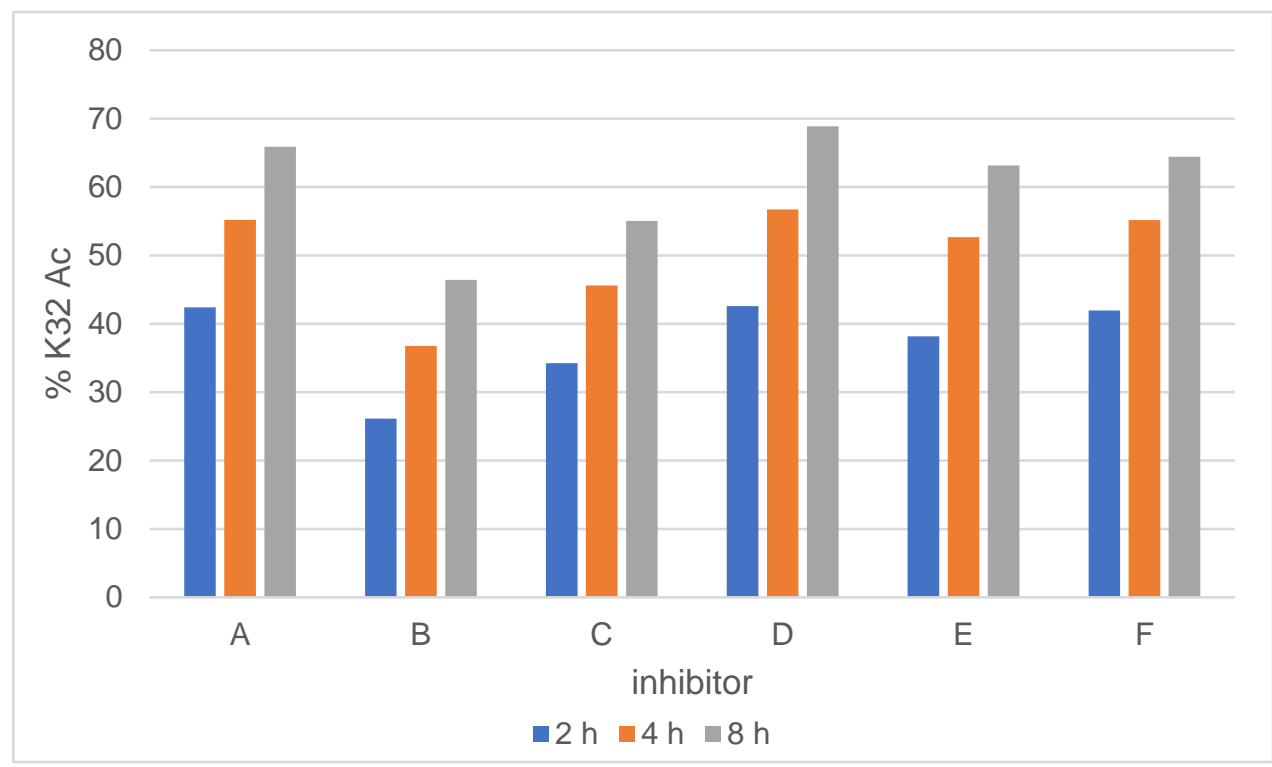

Detection of acetylation at other lysine residues (no inhibitor, 8 hours, $n=1$ ):

\begin{tabular}{|c|c|}
\hline lysine residue & acetylation yield \\
\hline 38 & not detected \\
\hline 58 & not detected \\
\hline 76 & not detected \\
\hline 106 & not detected \\
\hline 109 & not detected \\
\hline
\end{tabular}


Data for Figure 4a and Figure S4

\begin{tabular}{|c|c|c|c|c|}
\hline catalyst & donor & $\begin{array}{c}\text { \% K32 Ac } \\
\text { run 1 }\end{array}$ & $\begin{array}{c}\text { \% K32 Ac } \\
\text { run 2 }\end{array}$ & $\begin{array}{c}\text { average } \\
\% \text { K32 Ac }\end{array}$ \\
\hline $\mathbf{6}$ & D2 & 22.6 & 20.5 & 21.6 \\
\hline $\mathbf{7}$ & D2 & 58.0 & 54.2 & 56.1 \\
\hline $\mathbf{8}$ & D2 & 79.1 & 81.2 & 80.2 \\
\hline $\mathbf{8}$ & D3 & 79.3 & 82.6 & 81.0 \\
\hline $\mathbf{8}$ & D4 & 78.7 & 80.3 & 79.5 \\
\hline SI-5 & D2 & 46.5 & 44.5 & 45.5 \\
\hline SI-6 & D2 & 25.4 & 21.4 & 23.4 \\
\hline SI-7 & D2 & 41.2 & 50.6 & 45.9 \\
\hline SI-8 & D2 & 32.2 & 30.8 & 31.5 \\
\hline SI-9 & D2 & 32.5 & 34.5 & 33.5 \\
\hline
\end{tabular}


Data for Figure $4 b$

\begin{tabular}{|c|c|c|c|}
\hline$[8](\mathrm{uM})$ & $\begin{array}{c}\text { \% K32 Ac } \\
\text { run 1 }\end{array}$ & $\begin{array}{c}\text { \% K32 Ac } \\
\text { run 2 }\end{array}$ & $\begin{array}{c}\text { average } \\
\text { \% K32 Ac }\end{array}$ \\
\hline 0 & 0.0 & 0.0 & 0.0 \\
\hline 0.25 & 45.3 & 42.1 & 43.7 \\
\hline 0.50 & 60.6 & 69.3 & 65.0 \\
\hline 0.75 & 71.9 & 71.0 & 71.5 \\
\hline 1 & 80.1 & 83.3 & 81.7 \\
\hline 2 & 80.0 & 81.0 & 80.5 \\
\hline 3 & 81.9 & 79.9 & 80.9 \\
\hline 4 & 78.1 & 79.9 & 79.0 \\
\hline 10 & 77.8 & 72.1 & 75.0 \\
\hline
\end{tabular}

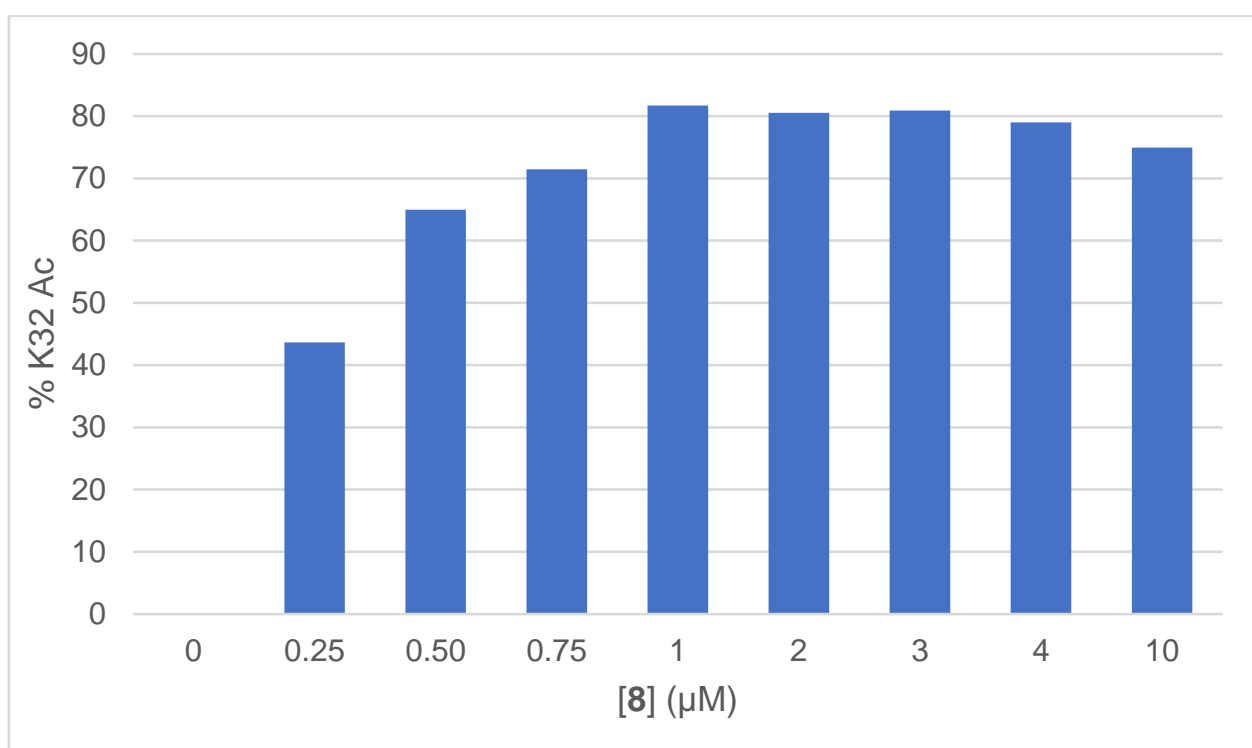




\section{Procedure for Figure $4 \mathrm{c}$ and Figure S8}

HEK293T were seeded into a 12 well plate in $\mathrm{DMEM}^{++}$at $3.0 \times 10^{5}$ cells $/ \mathrm{mL}$ and incubated for 24 hours. The cells were then transfected with pEGFP-N1-eDHFR (WT or K32R mutant) or empty plasmid (1.25 $\mu$ g per well; plasmids constructed as reported previously ${ }^{1}$ ) using lipofectamine LTX and Plus reagents (Invitrogen) according to the manufacturer's instructions. After 24 hours, the cells were incubated with an acyl donor, catalyst, and 1\% DMSO in Opti-MEM for $5 \mathrm{~h}$. The cells were harvested and lysed as described in SI-16.

For acetylation reactions, the lysate total protein concentration was diluted to $1 \mathrm{mg} / \mathrm{mL}$. Proteins were separated using 15\% SDS-PAGE and analyzed by Western blotting ( $\alpha$-acetyl lysine antibody) and CBB staining.

For 4-azidobuterylation reactions, the lysate total protein concentration was diluted to $0.5 \mathrm{mg} / \mathrm{mL}$. Proteins were denatured by boiling with SDS sample buffer not containing DTT. ADIBO-PEG4-TAMRA (final concentration 200 $\mu \mathrm{M}$, Sigma-Aldrich 760773) was added, and the mixture was incubated at $37^{\circ} \mathrm{C}$ for $2 \mathrm{~h}$. The reaction was quenched by adding chilled acetone ( $80 \%$ final concentration), and the mixture was incubated at $-20{ }^{\circ} \mathrm{C}$ for 30 minutes. After centrifugation $\left(21,000 \mathrm{rcf}\right.$ for 20 minutes at $\left.4{ }^{\circ} \mathrm{C}\right)$ the supernatant was removed, and the protein pellet was dissolved in SDS sample buffer. The samples were separated by 15\% SDS-PAGE, and the fluorescence was directly detected by Image Quant LAS4000 (GE Healthcare). Proteins were detected by CBB staining.

Data for Figure S10

\begin{tabular}{|c|c|c|c|c|}
\hline catalyst & acetyl donor & run 1 & run 2 & average \\
\hline none & $100 \mu \mathrm{M} \mathrm{NAC-Ac}$ & n.d. & n.d. & n.d. \\
\hline $1 \mu \mathrm{M} \mathrm{DSH}$ & $100 \mu \mathrm{M} \mathrm{NAC-Ac}$ & n.d. & n.d. & n.d. \\
\hline none & $100 \mu \mathrm{M} \mathrm{D4}$ & 0.75 & 0.78 & 0.77 \\
\hline $1 \mu \mathrm{M} \mathrm{8}$ & $100 \mu \mathrm{M} \mathrm{D4}$ & 83.0 & 83.5 & 83.3 \\
\hline
\end{tabular}


Data for Figure 5

\begin{tabular}{|c|c|c|c|c|}
\hline $\begin{array}{l}\text { acyl } \\
\text { donor }\end{array}$ & acyl donor structure ${ }^{a}$ & $\begin{array}{c}\text { K32Ac \% acylation, } \\
\text { run } 1\end{array}$ & $\begin{array}{c}\text { K32Ac } \% \text { acylation, } \\
\text { run } 1\end{array}$ & $\begin{array}{c}\text { K32Ac \% acylation, } \\
\text { average }\end{array}$ \\
\hline \multirow{2}{*}{ D4 } & & 80.1 & 83.3 & 81.7 \\
\hline & & $80.5^{\mathrm{b}}$ & $78.8^{\mathrm{b}}$ & $79.7^{\mathrm{b}}$ \\
\hline D5 & & 80.2 & 77.5 & 78.8 \\
\hline D6 & & 73.7 & 73.5 & 73.6 \\
\hline D7 & & 71.8 & 71.8 & 71.8 \\
\hline D8 & & 66.7 & 70.5 & 68.6 \\
\hline D9 & & 62.9 & 63.0 & 62.9 \\
\hline D10 & & 62.6 & 61.0 & 61.8 \\
\hline D11 & & 48.5 & 49.4 & 49.0 \\
\hline D12 & & 47.7 & 56.3 & 52.0 \\
\hline \multirow{2}{*}{ D13 } & \multirow{2}{*}{ OMe } & $72.6^{\mathrm{c}}$ & $74.3^{\mathrm{c}}$ & $73.5^{\mathrm{c}}$ \\
\hline & & $5.3^{\mathrm{d}}$ & $6.5^{\mathrm{d}}$ & $5.9^{\mathrm{d}}$ \\
\hline \multirow{2}{*}{ D14 } & & $44.5^{\mathrm{e}}$ & $44.9^{\mathrm{e}}$ & $44.7^{\mathrm{e}}$ \\
\hline & & $27.4^{\mathrm{f}}$ & $27.8^{\mathrm{f}}$ & $27.6^{\mathrm{f}}$ \\
\hline
\end{tabular}
a) parent structure of D4-14 is shown at right
b) cells were pretreated with $100 \mu \mathrm{M}$ buthionine sulfoximine for 16 hours
c) yield for installation of protected acyl group
d) yield for installation of deprotected acyl group
e) yield for installation of mono-protected acyl group
f) yield for installation of deprotected acyl group<smiles>CCn1c(=O)n(CC)c2cc([18OH])ccc21</smiles> 


\section{General synthetic procedures:}

Water was purified with a Millipore Milli-Q system (Merck K. Ga. Co., Darmstadt, Germany). Reactions were carried out in anydrous solvents under an argon atmosphere, unless otherwise stated. Reagents were used as received from commercial sources (Millipore-Sigma, TCI, Wako or Kanto), unless otherwise stated. Cold temperatures were maintained using the following conditions: $0-5^{\circ} \mathrm{C}$, ice-water bath; $-78{ }^{\circ} \mathrm{C}$, isopropanol-dry ice bath.

Normal phase column chromatography was carried out with 40 - $50 \mu \mathrm{m}$ spherical silica gel (Kanto) or $70 \mu \mathrm{m}$ aminefunctionalized silica (Yamazen). Removal of solvents was done with a Eyela N-1300 rotary evaporator and a Eyela EVP-1100 pump.

NMR spectra were recorded on a JEOL ECX500 (500 MHz for ${ }^{1} \mathrm{H}$ NMR, $126 \mathrm{MHz}$ for ${ }^{13} \mathrm{C}$ NMR) or JEOL ECS400 (392 MHz for ${ }^{1} \mathrm{H}$ NMR, $101 \mathrm{MHz}$ for ${ }^{13} \mathrm{C}$ NMR, $126 \mathrm{MHz}$ for ${ }^{11} \mathrm{~B}$ NMR) spectrometer. Spectra were recorded using $\mathrm{CDCl}_{3}, \mathrm{CD}_{3} \mathrm{CN}$, acetone- $d_{6}$, or DMSO- $d_{6} .{ }^{1} \mathrm{H}$ and ${ }^{13} \mathrm{C}$ signal positions $(\delta)$ are reported in parts per million from tetramethylsilane $(\delta 0)$ and were measured relative to the signal of the solvent $\left({ }^{1} \mathrm{H} \mathrm{NMR}: \mathrm{CDCl}_{3} \delta 7.24, \mathrm{CD}_{3} \mathrm{CN} \delta\right.$ 1.93, acetone- $d_{6} \delta 2.04$, DMSO- $d_{6} \delta 2.49 ; \mathrm{MeOH}-d_{4} \delta 3.20 ;{ }^{13} \mathrm{C}$ NMR: $\mathrm{CDCl}_{3} \delta 77.00, \mathrm{CD}_{3} \mathrm{CN} \delta 118.26$, acetone- $d_{6}$ $\delta 29.80$, DMSO- $d_{6} \delta 39.50 ; \mathrm{MeOH}-d_{4} \delta 48.96$ ). ${ }^{11} \mathrm{~B}$ NMR spectra were calibrated with respect to external $\mathrm{BF}_{3} \cdot \mathrm{OEt}_{2}$ in $\mathrm{CD}_{3} \mathrm{CN}(\delta 0)$. Coupling constants ( $J$ values) are reported in Hertz $(\mathrm{Hz}) .{ }^{1} \mathrm{H}$ NMR spectral data are tabulated in the order: multiplicity (s, singlet; d, doublet; t, triplet; q, quartet; m, multiplet; br., broad), coupling constant, number of protons. For broronic acids/esters, the carbon atom attached to the boron atom was undetectable in ${ }^{13} \mathrm{C}$ NMR spectra. Quantitative ${ }^{1} \mathrm{H}$ NMR was performed using 1,3,5-trimethoxybenzene as an internal standard and a 10 second relaxation time.

High resolution mass spectra were recorded using a Bruker microTOF ESI-TOF mass spectrometer. 


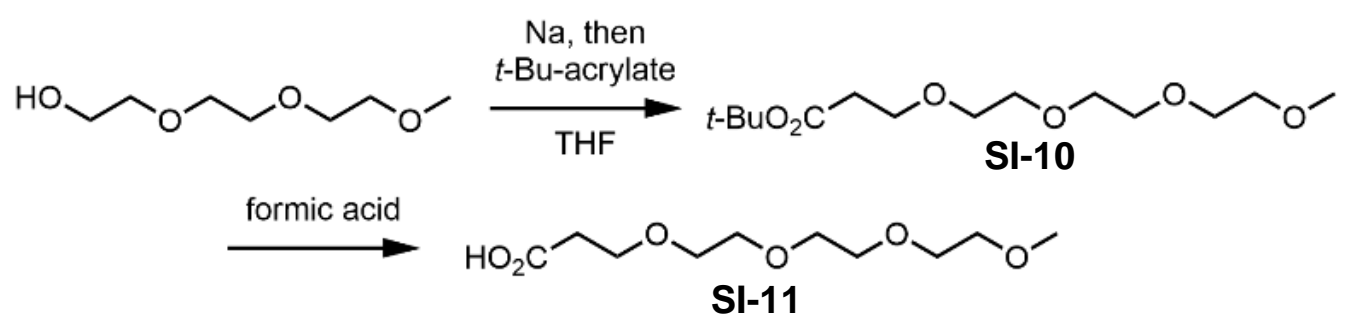

\section{Procedure:}

To a stirred solution of triethylene glycol monomethyl ether $(985 \mathrm{mg}, 6.0 \mathrm{mmol}, 3.0 \mathrm{eq})$ in $1 \mathrm{~mL}$ THF was charged sodium metal ( $9.2 \mathrm{mg}, 0.4 \mathrm{mmol}, 0.2 \mathrm{eq}$ ) (note: sodium slowly dissolved over 30 minutes). After 30 minutes was charged $t$-Bu-acrylate $(291 \mu \mathrm{L}, 2 \mathrm{mmol})$. The mixture was stirred for $1.5 \mathrm{~h}$ and then quenched to a stirred mixture of $10 \mathrm{~mL}$ EtOAc and $5 \mathrm{~mL} \mathrm{pH} 4$ buffer. The aqueous material was discarded, and the organic material was washed with brine, dried $\left(\mathrm{MgSO}_{4}\right)$, filtered, and concentrated on the rotovap. The crude material was chromatographed on $20 \mathrm{~g}$ silica (2 to $3 \% \mathrm{v} / \mathrm{v} \mathrm{MeOH}$ in $\mathrm{CH}_{2} \mathrm{Cl}_{2}$ ) to afford tert-butyl ester SI-10 (374 $\mathrm{mg}, 1.28 \mathrm{mmol}$ ) as an oil.

The intermediate SI-10 was dissolved in $3 \mathrm{~mL}$ formic acid and stirred for 4 hours. The mixture was concentrated on the rotovap, co-evaporated with IPA, dissolved in $1: 1 \mathrm{v} / \mathrm{v} \mathrm{ACN}: \mathrm{H}_{2} \mathrm{O}$, and lyophilized to afford SI-11 (264 mg, $1.03 \mathrm{mmol}, 52 \%$ yield over 2 steps) as an oil.

${ }^{1} \mathbf{H}$ NMR $\left(500 \mathrm{MHz}, \mathrm{CDCl}_{3}, 25^{\circ} \mathrm{C}, \delta\right)$ :

10.66 (br s, 1H), $3.71(\mathrm{~m}, 2 \mathrm{H}), 3.59(\mathrm{~m}, 10 \mathrm{H}), 3.51(\mathrm{~m}, 2 \mathrm{H}), 3.33(\mathrm{~m}, 3 \mathrm{H}), 2.57(\mathrm{~m}, 2 \mathrm{H})$.

${ }^{13} \mathrm{C}$ NMR $\left(126 \mathrm{MHz}, \mathrm{CDCl}_{3}, 25{ }^{\circ} \mathrm{C}, \delta\right)$ :

$175.8,71.8,70.5,70.5,70.3,70.3,70.2,66.3,58.8,34.8$.

HRMS (ESI-TOF, m/z):

Calc'd for $\mathrm{C}_{10} \mathrm{H}_{21} \mathrm{O}_{6}{ }^{+}\left([\mathrm{M}+\mathrm{H}]^{+}\right)$237.1333; found 237.1337.

Calc'd for $\mathrm{C}_{10} \mathrm{H}_{20} \mathrm{O}_{6} \mathrm{Na}^{+}\left([\mathrm{M}+\mathrm{Na}]^{+}\right)$259.1152; found 259.1143 . 


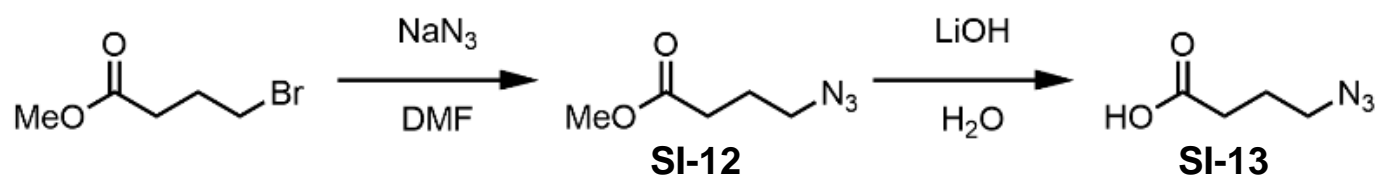

\section{Procedure:}

To a stirred solution of methyl-4-bromobenzoate $(905 \mathrm{mg}, 5.0 \mathrm{mmol})$ in $10 \mathrm{~mL} \mathrm{DMF}$ was charged $\mathrm{NaN}_{3}(406 \mathrm{mg}$, $6.25 \mathrm{mmol}, 1.25 \mathrm{eq}$ ), and the mixture was heated at $75-80^{\circ} \mathrm{C}$ for 3 hours. After cooling to room temperature, the mixture was poured into a sep. funnel containing $40 \mathrm{~mL} \mathrm{Et}_{2} \mathrm{O}$ and $40 \mathrm{~mL} 10 \%$ aqueous $\mathrm{NaCl}$. The mixture was extracted, and the aqueous material was discarded. The organic material was washed with $3 \times 20 \mathrm{~mL}$ brine, dried $\left(\mathrm{MgSO}_{4}\right)$, filtered, and concentrated on the rotovap to afford methyl ester SI-12 an oil (690 mg).

The intermediate SI-12 was stirred with $\mathrm{LiOH}\left(0.5 \mathrm{M}\right.$ in $\left.\mathrm{H}_{2} \mathrm{O}, 40 \mathrm{~mL}, 20 \mathrm{mmol}, 4.0 \mathrm{eq}\right)$. After 40 minutes, $40 \mathrm{~mL}$ $\mathrm{Et}_{2} \mathrm{O}$ was charged, and the aqueous $\mathrm{pH}$ was adjusted to $\sim 2$ with $12 \mathrm{~N} \mathrm{HCl}$. The aqueous material was discarded, and the organic material was washed with brine, dried $\left(\mathrm{MgSO}_{4}\right)$, filtered, and carefully concentrated on the rotovap to afford SI-13 (594 mg, $4.60 \mathrm{mmol}$, $92 \%$ yield over 2 steps) as an oil.

${ }^{1} \mathbf{H} \mathbf{N M R}\left(500 \mathrm{MHz}, \mathrm{CDCl}_{3}, 25^{\circ} \mathrm{C}, \delta\right)$ :

$3.36(\mathrm{t}, J=6.9 \mathrm{~Hz}, 2 \mathrm{H}), 2.45(\mathrm{t}, J=7.2 \mathrm{~Hz}, 2 \mathrm{H}), 1.90(\mathrm{~m}, 2 \mathrm{H})$. (Note: the ${ }^{1} \mathrm{H}$ spectrum indicates ca. $0.31 \mathrm{eq} . \mathrm{Et}_{2} \mathrm{O}$ contamination).

${ }^{13} \mathrm{C}$ NMR $\left(126 \mathrm{MHz}, \mathrm{CDCl}_{3}, 25{ }^{\circ} \mathrm{C}, \delta\right)$ :

$178.8,50.4,30.8,23.9$.

HRMS (ESI-TOF, m/z):

Calc'd for ${ }^{+}\left([\mathrm{M}+\mathrm{Na}]^{+}\right)$154.0430; found 154.0419. 


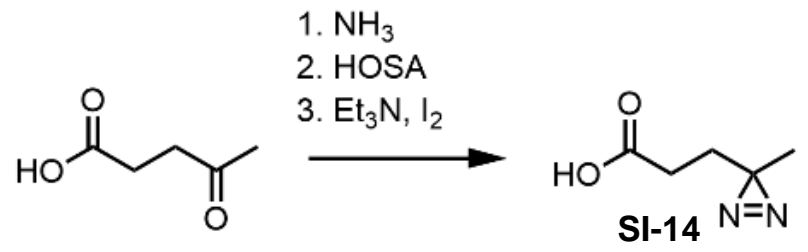

\section{Procedure:}

To a round bottom flask was charged levulinic acid (464 mg, $4.0 \mathrm{mmol})$. After cooling to $0-5{ }^{\circ} \mathrm{C}, \mathrm{NH}_{3}(7 \mathrm{~N}$ in $\mathrm{MeOH}, 4.6 \mathrm{~mL}, 32 \mathrm{mmol}, 8 \mathrm{eq}$ ) was charged, and the mixture was stirred (note: clear solution). After 2 hours, 12 $\mathrm{mL} \mathrm{MeOH}$ and then hydroxylamine $O$-sulfonic acid $(520 \mathrm{mg}, 4.6 \mathrm{mmol}, 1.15 \mathrm{eq}$ ) were charged, and the cooling bath was removed (note: white slurry). After 14 hours, the volume was reduced to about $10 \mathrm{~mL}$ on the rotovap, the slurry was filtered through fritted glass ( $\mathrm{MeOH}$ rinse). The volume was reduced to about $5 \mathrm{~mL}$ on the rotovap, stirring was applied, and $\mathrm{Et}_{3} \mathrm{~N}$ ( $\left.836 \mu \mathrm{L}, 6 \mathrm{mmol}, 1.5 \mathrm{eq}\right)$ was charged. Iodine (1051 mg, $\left.4.0 \mathrm{mmol}, 1.0 \mathrm{eq}\right)$ was then charged in portions over 5 minutes (note: a dark brown endpoint was reached when the final portion of iodine was charged). 5 $\mathrm{mL}$ EtOAc and $2.5 \mathrm{~mL} 10 \% \mathrm{NaCl}$ were charged, and the aqueous $\mathrm{pH}$ was adjusted to 2 with $2 \mathrm{~N} \mathrm{HCl}$. The mixture was extracted, and the aqueous material was discarded. The organic material was washed with saturated aqueous $\mathrm{NaHSO}_{3}$, washed with brine, dried $\left(\mathrm{MgSO}_{4}\right)$, filtered, and carefully concentrated on the rotovap to afford SI-14 (210 $\mathrm{mg}, 1.66 \mathrm{mmol}, 42 \%$ yield) as an oil.

${ }^{1} \mathbf{H}$ NMR $\left(500 \mathrm{MHz}, \mathrm{CDCl}_{3}, 25{ }^{\circ} \mathrm{C}, \delta\right)$ :

$2.21(\mathrm{t}, J=7.7 \mathrm{~Hz}, 2 \mathrm{H}), 1.69(\mathrm{t}, J=7.7 \mathrm{~Hz}, 2 \mathrm{H}), 1.02(\mathrm{~s}, 3 \mathrm{H})$.

${ }^{13} \mathbf{C}$ NMR $\left(126 \mathrm{MHz}, \mathrm{CDCl}_{3}, 25^{\circ} \mathrm{C}, \delta\right)$ :

$178.4,29.3,28.5,25.0,19.6$.

HRMS (ESI-TOF, m/z):

Note: we failed to detect $[\mathrm{M}+\mathrm{H}]^{+}$or $[\mathrm{M}+\mathrm{Na}]^{+}$. 


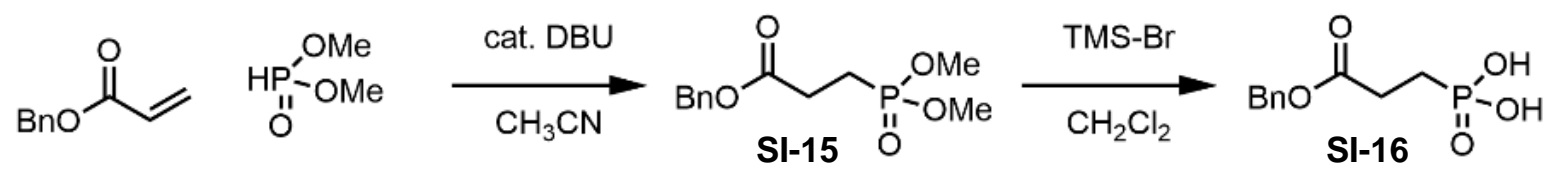

\section{Procedure:}

To a stirred solution of dimethyl phosphite $(853 \mu \mathrm{L}, 9.3 \mathrm{mmol})$ and benzyl acrylate $(1.66 \mathrm{~g}, 10.2 \mathrm{mmol}, 1.1 \mathrm{eq})$ in 20 $\mathrm{mL}$ ACN was charged DBU (347 $\mu \mathrm{L}, 2.3 \mathrm{mmol}, 0.25 \mathrm{eq})$. After 15 hours, the mixture was poured into a sep. funnel containing $50 \mathrm{~mL} \mathrm{Et}_{2} \mathrm{O}$ and $25 \mathrm{~mL}$ pH 2 buffer. The mixture was extracted, and the aqueous material was discarded. The organic material was washed with brine, dried $\left(\mathrm{MgSO}_{4}\right)$, filtered, and concentrated on the rotovap to afford intermediate dimethylphosphonate SI-15 (2.53 g) as an oil.

To a stirred 0 - $5{ }^{\circ} \mathrm{C}$ solution of $\mathbf{S I - 1 5}$ in $20 \mathrm{~mL} \mathrm{CH}_{2} \mathrm{Cl}_{2}$ was charged TMS-Br (3.92 mL, $\left.29.7 \mathrm{mmol}, 3.2 \mathrm{eq}\right)$, and the cooling bath was removed. After 1 hour, the mixture was concentrated on the rotovap and co-evaporated with 2 x 10 $\mathrm{mL} \mathrm{CH}_{2} \mathrm{Cl}_{2}$ and $10 \mathrm{~mL} \mathrm{ACN}$. The resulting oil was dissolved in $10 \mathrm{~mL} 2: 1 \mathrm{v} / \mathrm{v} \mathrm{ACN}: \mathrm{H}_{2} \mathrm{O}$, and the minor upper layer was skimmed off with a Pasteur pipette and discarded. The mixture was then lyophilized to afford phosphonic acid SI-16 (2.09 g, $8.56 \mathrm{mmol}, 92 \%$ yield over 2 steps) as a pale orange solid.

${ }^{1}$ H NMR (392 MHz, DMSO- $d_{6}, 25^{\circ} \mathrm{C}, \delta$ ):

$7.33(\mathrm{~m}, 5 \mathrm{H}), 5.06(\mathrm{~m}, 2 \mathrm{H}), 2.49(\mathrm{~m}, 2 \mathrm{H}), 1.80(\mathrm{~m}, 2 \mathrm{H})$.

${ }^{13} \mathrm{C}$ NMR $\left(99 \mathrm{MHz}\right.$, DMSO- $\left.d_{6}, 25^{\circ} \mathrm{C}, \delta\right)$ :

171.9, 136.1, 129.9, 128.5, 128.1, 127.9, 65.8, 27.8, 22.8 (d, $J=139 \mathrm{~Hz})$.

HRMS (ESI-TOF, m/z):

Calc'd for ${ }^{+}\left([\mathrm{M}+\mathrm{H}]^{+}\right)$245.0573; found 245.0579.

Calc'd for $^{+}\left([\mathrm{M}+\mathrm{Na}]^{+}\right)$267.0393; found 267.0397. 


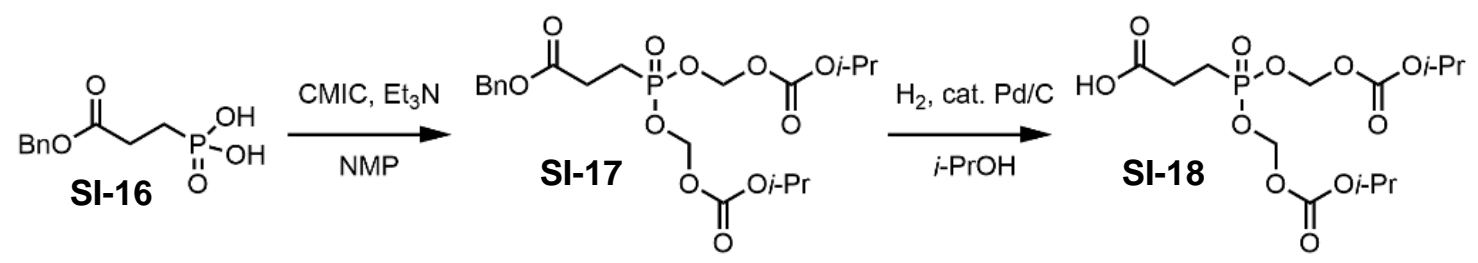

\section{Procedure:}

To a stirred solution of phosphonic acid SI-16 (977 mg, $4.0 \mathrm{mmol})$ in $12 \mathrm{~mL}$ NMP was charged $\mathrm{Et}_{3} \mathrm{~N}$ (2.23 mL, 16 mmol, 4.0 eq) followed by chloromethyl isopropyl carbonate $(3.66 \mathrm{~mL}, 24 \mathrm{mmol}, 6 \mathrm{eq})$, and the mixture was heated in a $70-75^{\circ} \mathrm{C}$ bath. After 14 hours, the mixture was cooled to room temperature and poured into a sep. funnel containing $50 \mathrm{~mL} \mathrm{Et}_{2} \mathrm{O}$ and $25 \mathrm{~mL} 10 \% \mathrm{NaCl}$. The mixture was extracted, and the aqueous material was discarded. The organic material was washed with brine, dried $\left(\mathrm{MgSO}_{4}\right)$, filtered, concentrated on the rotovap, and coevaporated three times with xylene to remove residual CMIC. The crude material was chromatographed on $25 \mathrm{~g}$ silica $\left(\mathrm{Et}_{2} \mathrm{O}\right)$ to afford $\mathbf{S I}-17(1.56 \mathrm{~g})$ as an oil.

A suspension of SI-17 (1.56 g), $15 \mathrm{~mL}$ IPA, and Pd/C (10\% Pd, $125 \mathrm{mg}$ ) was stirred under $\mathrm{H}_{2}$ (balloon). After 16 hours, the mixture was filtered through a Celite pad (EtOAc rinse) and concentrated on the rotovap to afford SI-18 $(1.22 \mathrm{~g}, 3.16 \mathrm{mmol}, 79 \%$ yield over 2 steps $)$.

${ }^{1} \mathbf{H}$ NMR $\left(392 \mathrm{MHz}, \mathrm{CDCl}_{3}, 25^{\circ} \mathrm{C}, \delta\right)$ :

$8.62(\mathrm{br} \mathrm{s}, 1 \mathrm{H}), 5.62(\mathrm{td}, J=13.2,5.2 \mathrm{~Hz}, 4 \mathrm{H}), 4.88(\mathrm{dt}, J=12.6,6.1 \mathrm{~Hz}, 2 \mathrm{H}), 2.60(\mathrm{dt}, J=14.5,6.2 \mathrm{~Hz}, 2 \mathrm{H}), 2.18$ $(\mathrm{dt}, J=18.5,8.1 \mathrm{~Hz}, 2 \mathrm{H}), 1.27(\mathrm{~d}, J=5.8 \mathrm{~Hz}, 12 \mathrm{H})$.

${ }^{13} \mathrm{C}$ NMR $\left(99 \mathrm{MHz}, \mathrm{CDCl}_{3}, 25{ }^{\circ} \mathrm{C}, \delta\right)$ :

$175.2(\mathrm{~d}, J=20.7 \mathrm{~Hz}), 153.1,84.0(\mathrm{~d}, J=5.6 \mathrm{~Hz}), 73.3,26.5(\mathrm{~d}, J=3.8 \mathrm{~Hz}), 21.5,21.5(\mathrm{~d}, J=146 \mathrm{~Hz})$.

\section{HRMS (ESI-TOF, m/z):}

Calc'd for $\mathrm{C}_{13} \mathrm{H}_{24} \mathrm{O}_{11} \mathrm{P}^{+}\left([\mathrm{M}+\mathrm{H}]^{+}\right)$387.1051; found 387.1047.

Calc'd for $\mathrm{C}_{13} \mathrm{H}_{23} \mathrm{O}_{11} \mathrm{PNa}^{+}\left([\mathrm{M}+\mathrm{Na}]^{+}\right)$409.0870; found 409.0868. 


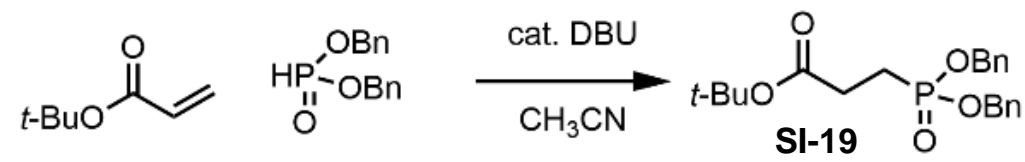

\section{Procedure:}

To a stirred solution of dibenzyl phosphite $(3.33 \mathrm{~mL}, 15 \mathrm{mmol})$ and $t$-Bu-acrylate $(2.40 \mathrm{~mL}, 16.5 \mathrm{mmol}, 1.1 \mathrm{eq})$ in $15 \mathrm{~mL}$ ACN was charged DBU $(560 \mu \mathrm{L}, 3.75 \mathrm{mmol}, 0.25$ eq). After 15 hours, the volume was reduced to about 10 $\mathrm{mL}$ on the rotovap. The residue was diluted with $50 \mathrm{~mL}$ EtOAc and $25 \mathrm{~mL} 10 \% \mathrm{NaCl}$, and the aqueous $\mathrm{pH}$ was adjusted to 2 with $12 \mathrm{~N} \mathrm{HCl}$. The mixture was extracted, and the aqueous material was discarded. The organic material was washed with brine, dried $\left(\mathrm{MgSO}_{4}\right)$, filtered, and concentrated on the rotovap to afford SI-19 (5.70 g, $14.6 \mathrm{mmol}, 97 \%$ yield) as an oil.

${ }^{1} \mathbf{H}$ NMR $\left(500 \mathrm{MHz}, \mathrm{CDCl}_{3}, 25^{\circ} \mathrm{C}, \delta\right)$ :

$7.32(\mathrm{~m}, 10 \mathrm{H}), 4.98$ (ddd, $J=37.9,11.9,8.7,4 \mathrm{H}), 2.45(\mathrm{~m}, 2 \mathrm{H}), 2.03(\mathrm{~m}, 2 \mathrm{H}), 1.38(\mathrm{~s}, 9 \mathrm{H})$.

${ }^{13} \mathbf{C}$ NMR $\left(126 \mathrm{MHz}, \mathrm{CDCl}_{3}, 25^{\circ} \mathrm{C}, \delta\right)$ :

$171.0(\mathrm{~d}, J=19.2 \mathrm{~Hz}), 136.2(\mathrm{~d}, J=6.0 \mathrm{~Hz}), 128.6,128.4,127.9,80.9,67.2(\mathrm{~d}, J=6.0 \mathrm{~Hz}), 28.4(\mathrm{~d}, J=3.6 \mathrm{~Hz})$, 27.9, $21.3(\mathrm{~d}, J=144 \mathrm{~Hz})$.

HRMS (ESI-TOF, m/z):

Calc'd for $\mathrm{C}_{21} \mathrm{H}_{28} \mathrm{O}_{5} \mathrm{P}^{+}\left([\mathrm{M}+\mathrm{H}]^{+}\right)$391.1669; found 391.1651.

Calc'd for $\mathrm{C}_{21} \mathrm{H}_{27} \mathrm{O}_{5} \mathrm{PNa}^{+}\left([\mathrm{M}+\mathrm{Na}]^{+}\right)$413.1488; found 413.1474. 


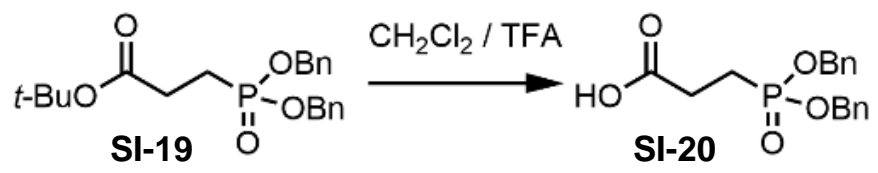

\section{Procedure:}

tert-butyl ester SI-19 (1.15 g, $2.95 \mathrm{mmol})$ was stirred with $20 \mathrm{~mL} \mathrm{1:1} \mathrm{v/v} \mathrm{CH}_{2} \mathrm{Cl}_{2}$ : TFA. After 45 minutes, the mixture was concentrated on the rotovap and co-evaporated twice with $\mathrm{CH}_{2} \mathrm{Cl}_{2}$. The crude material was chromatographed on $20 \mathrm{~g}$ silica (2.5 to $4 \% \mathrm{v} / \mathrm{v} \mathrm{MeOH}$ in $\mathrm{CH}_{2} \mathrm{Cl}_{2}$ ) to afford $\mathbf{S I - 2 0}$ (715 mg, $2.14 \mathrm{mmol}$, 73\% yield) as an oil.

${ }^{1} \mathbf{H}$ NMR $\left(392 \mathrm{MHz}, \mathrm{CDCl}_{3}, 25^{\circ} \mathrm{C}, \delta\right)$ :

$11.66(\mathrm{br} \mathrm{s}, 2 \mathrm{H}), 7.28(\mathrm{~m}, 10 \mathrm{H}), 4.95(\mathrm{ddd}, J=34.8,11.7,9.0 \mathrm{~Hz}, 4 \mathrm{H}), 2.51(\mathrm{dt}, J=14.8,6.8 \mathrm{~Hz}, 2 \mathrm{H}), 2.05(\mathrm{ddd}, J=$ $18.3,8.4,7.3 \mathrm{~Hz}, 2 \mathrm{H})$.

${ }^{13} \mathrm{C}$ NMR $\left(99 \mathrm{MHz}, \mathrm{CDCl}_{3}, 25^{\circ} \mathrm{C}, \delta\right)$ :

$177.0(\mathrm{~d}, J=17.9 \mathrm{~Hz}), 135.3(\mathrm{~d}, J=5.6 \mathrm{~Hz}), 128.9,128.7,128.1,68.4(\mathrm{~d}, J=7.5 \mathrm{~Hz}), 26.8(\mathrm{~d}, J=3.8 \mathrm{~Hz}), 20.8(\mathrm{~d}$, $J=146 \mathrm{~Hz})$.

HRMS (ESI-TOF, m/z):

Calc'd for $\mathrm{C}_{17} \mathrm{H}_{20} \mathrm{O}_{5} \mathrm{P}^{+}\left([\mathrm{M}+\mathrm{H}]^{+}\right)$335.1043; found 335.1036.

Calc'd for $\mathrm{C}_{17} \mathrm{H}_{19} \mathrm{O}_{5} \mathrm{PNa}^{+}\left([\mathrm{M}+\mathrm{Na}]^{+}\right)$357.0862; found 357.0868. 
<smiles>CC(C)(C)COP(=O)(CCC(=O)OC(C)(C)C)OCc1ccccc1</smiles>

\section{Procedure:}

To a stirred solution of SI-19 (2.97 g, $7.61 \mathrm{mmol})$ in $18 \mathrm{~mL}$ PhMe was charged DABCO (939 mg, $8.37 \mathrm{mmol}, 1.1$ eq). The mixture was heated at reflux for 4.5 hours and then cooled to room temperature. The reaction was poured into a sep. funnel containing $50 \mathrm{~mL}$ EtOAc and $25 \mathrm{~mL} 10 \% \mathrm{NaCl}$, and the aqueous $\mathrm{pH}$ was adjusted to 2 with $12 \mathrm{~N}$ $\mathrm{HCl}$. The mixture was extracted, and the aqueous material was discarded. The organic material was washed with brine, dried $\left(\mathrm{MgSO}_{4}\right)$, filtered, and concentrated on the rotovap. The crude material was chromatographed on $15 \mathrm{~g}$ silica (5\% v/v MeOH in $\left.\mathrm{CH}_{2} \mathrm{Cl}_{2}\right)$ to afford $\mathbf{S I - 2 1}(1.99 \mathrm{~g}, 6.63 \mathrm{mmol}, 87 \%$ yield) as an oil.

${ }^{1} \mathbf{H}$ NMR $\left(392 \mathrm{MHz}, \mathrm{CDCl}_{3}, 25^{\circ} \mathrm{C}, \delta\right)$ :

$10.71(\mathrm{br} \mathrm{s}, 1 \mathrm{H}), 7.28(\mathrm{~m}, 5 \mathrm{H}), 4.97(\mathrm{~d}, J=7.2 \mathrm{~Hz}, 2 \mathrm{H}), 2.45(\mathrm{~m}, 2 \mathrm{H}), 2.00(\mathrm{~m}, 2 \mathrm{H}), 1.36(\mathrm{~s}, 9 \mathrm{H})$.

${ }^{13} \mathrm{C}$ NMR $\left(99 \mathrm{MHz}, \mathrm{CDCl}_{3}, 25{ }^{\circ} \mathrm{C}, \delta\right)$ :

$171.0(\mathrm{~d}, J=19.7 \mathrm{~Hz}), 136.0(\mathrm{~d}, J=7.5 \mathrm{~Hz}), 128.5,128.3,127.7,80.9,66.6(\mathrm{~d}, J=6.6 \mathrm{~Hz}), 28.3(\mathrm{~d}, J=2.8 \mathrm{~Hz})$, 27.9, $21.4(\mathrm{~d}, J=147 \mathrm{~Hz})$.

HRMS (ESI-TOF, m/z):

Calc'd for $\mathrm{C}_{14} \mathrm{H}_{22} \mathrm{O}_{5} \mathrm{P}^{+}\left([\mathrm{M}+\mathrm{H}]^{+}\right)$301.1199; found 301.1203.

Calc'd for $\mathrm{C}_{14} \mathrm{H}_{21} \mathrm{O}_{5} \mathrm{PNa}^{+}\left([\mathrm{M}+\mathrm{Na}]^{+}\right)$323.1019; found 323.1019. 


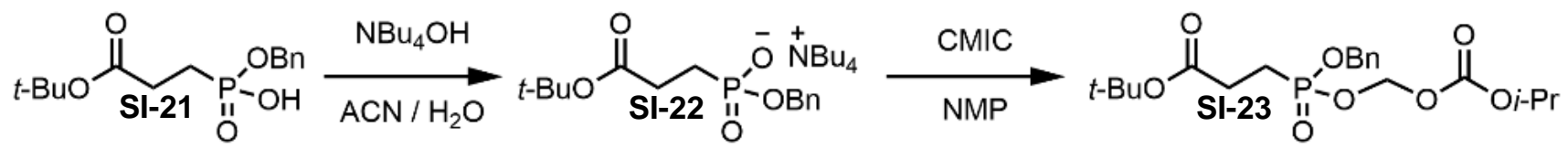

\section{Procedure:}

To a stirred solution of SI-21 (670 mg, $2.23 \mathrm{mmol}$ ) was charged tetrabutylammonium hydroxide (50\% solution in $\mathrm{H}_{2} \mathrm{O}, 1475 \mu \mathrm{mol}, 2.27 \mathrm{mmol}, 1.02 \mathrm{eq}$ ) (note: $\mathrm{pH}$ was 8). The reaction mixture was then lyophilized to afford quaternary ammonium salt SI-22 an oil (1.36 g).

To a stirred solution of the intermediate SI-22 (1.36 g) in $9 \mathrm{~mL}$ NMP was charged chloromethyl isopropyl carbonate ( $373 \mu \mathrm{L}, 2.79 \mathrm{mmol}, 1.25 \mathrm{eq}$ ), and the mixture was heated in a $55-60^{\circ} \mathrm{C}$ bath for 6 hours. The reaction was cooled to room temperature and poured into a sep. funnel containing $50 \mathrm{~mL} \mathrm{Et}_{2} \mathrm{O}$ and $25 \mathrm{~mL} 10 \% \mathrm{NaCl}$. The mixture was extracted, and the aqueous material was discarded. The organic material was washed with brine, dried $\left(\mathrm{MgSO}_{4}\right)$, filtered, and concentrated on the rotovap. The crude material was chromatographed on $50 \mathrm{~g}$ silica (75 to $100 \% \mathrm{v} / \mathrm{v}$ $\mathrm{Et}_{2} \mathrm{O}$ in pentane) to afford SI-23 (474 $\mathrm{mg}, 1.14 \mathrm{mmol}, 51 \%$ yield) as an oil.

${ }^{1} \mathbf{H}$ NMR $\left(500 \mathrm{MHz}, \mathrm{CDCl}_{3}, 25^{\circ} \mathrm{C}, \delta\right)$ :

$7.32(\mathrm{~m}, 5 \mathrm{H}), 5.58(\mathrm{~m}, 2 \mathrm{H}), 5.04(\mathrm{ddd}, J=39.2,11.7,8.0 \mathrm{~Hz}, 2 \mathrm{H}), 4.86(\mathrm{~m}, 1 \mathrm{H}), 2.45(\mathrm{~m}, 2 \mathrm{H}), 2.08(\mathrm{~m}, 2 \mathrm{H}), 1.37$

(s, 9H), $1.24(\mathrm{dd}, J=9.2,6.3 \mathrm{~Hz}, 6 \mathrm{H})$.

${ }^{13} \mathbf{C}$ NMR $\left(126 \mathrm{MHz}, \mathrm{CDCl}_{3}, 25^{\circ} \mathrm{C}, \delta\right)$ :

$170.7(\mathrm{~d}, J=20.4 \mathrm{~Hz}), 153.1(\mathrm{~d}, J=7.2 \mathrm{~Hz}), 135.7,128.5,128.4,127.9,84.0(\mathrm{~d}, J=7.2 \mathrm{~Hz}), 80.9,73.0,67.0(\mathrm{~d}, J=$ $6.0 \mathrm{~Hz}), 28.1(\mathrm{~d}, J=3.6 \mathrm{~Hz}), 27.9,21.6(\mathrm{~d}, J=144 \mathrm{~Hz}), 21.5$.

HRMS (ESI-TOF, m/z):

Calc'd for $\mathrm{C}_{19} \mathrm{H}_{30} \mathrm{O}_{8} \mathrm{P}^{+}\left([\mathrm{M}+\mathrm{H}]^{+}\right)$417.1673; found 417.1676.

Calc'd for $\mathrm{C}_{19} \mathrm{H}_{29} \mathrm{O}_{8} \mathrm{PNa}^{+}\left([\mathrm{M}+\mathrm{Na}]^{+}\right)$493.1492; found 439.1492 . 


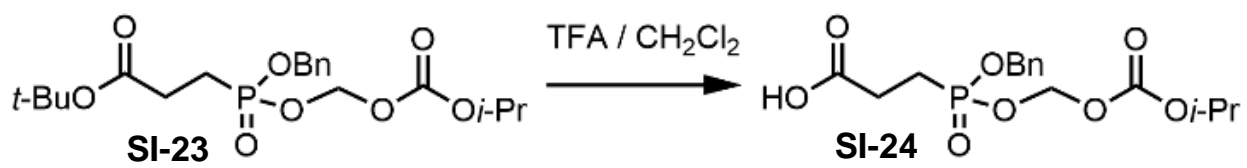

\section{Procedure:}

tert-butyl ester SI-23 (474 mg, $1.14 \mathrm{mmol}$ ) was stirred with $5 \mathrm{~mL} 40 \% \mathrm{v} / \mathrm{v}$ TFA in $\mathrm{CH}_{2} \mathrm{Cl}_{2}$. After 1 hour, the mixture was concentrated on the rotovap and co-evaporated with $\mathrm{CH}_{2} \mathrm{Cl}_{2}$ (note: time-senstive reaction). The crude material was chromatographed on $15 \mathrm{~g}$ silica $\left(5 \% \mathrm{v} / \mathrm{v} \mathrm{MeOH}\right.$ in $\mathrm{CH}_{2} \mathrm{Cl}_{2}$ ) to afford carboxylic acid SI-24 (363.2 mg, 1.01 mmol, $88 \%$ yield) as an oil.

${ }^{1} \mathbf{H}$ NMR $\left(500 \mathrm{MHz}, \mathrm{CDCl}_{3}, 25^{\circ} \mathrm{C}, \delta\right)$ :

10.09 (br s, 1H), 7.33 (m, 5H), 5.60 (m, 2H), 5.07 (ddd, $J=36.9,10.9,8.6 \mathrm{~Hz}, 2 \mathrm{H}), 4.87(\mathrm{~m}, 1 \mathrm{H}), 2.58(\mathrm{~m}, 2 \mathrm{H})$, $2.15(\mathrm{~m}, 2 \mathrm{H}), 1.26(\mathrm{~m}, 6 \mathrm{H})$.

${ }^{13} \mathrm{C}$ NMR $\left(126 \mathrm{MHz}, \mathrm{CDCl}_{3}, 25^{\circ} \mathrm{C}, \delta\right)$ :

$175.4(\mathrm{dd}, J=18.0,3.6 \mathrm{~Hz}), 153.1(\mathrm{~d}, J=3.6 \mathrm{~Hz}), 135.4(\mathrm{~d}, J=6.0 \mathrm{~Hz}), 128.6,128.6,128.0,84.3(\mathrm{~d}, J=6.0 \mathrm{~Hz})$, 73.3, $67.6(\mathrm{~d}, J=6.0 \mathrm{~Hz}), 26.7(\mathrm{~d}, J=3.6 \mathrm{~Hz}), 21.5,21.3(\mathrm{~d}, J=145 \mathrm{~Hz})$.

HRMS (ESI-TOF, m/z):

Calc'd for $\mathrm{C}_{15} \mathrm{H}_{22} \mathrm{O}_{8} \mathrm{P}^{+}\left([\mathrm{M}+\mathrm{H}]^{+}\right)$361.1047; found 361.1057.

Calc'd for $\mathrm{C}_{15} \mathrm{H}_{21} \mathrm{O}_{8} \mathrm{PNa}^{+}\left([\mathrm{M}+\mathrm{Na}]^{+}\right)$383.0866; found 383.0861. 

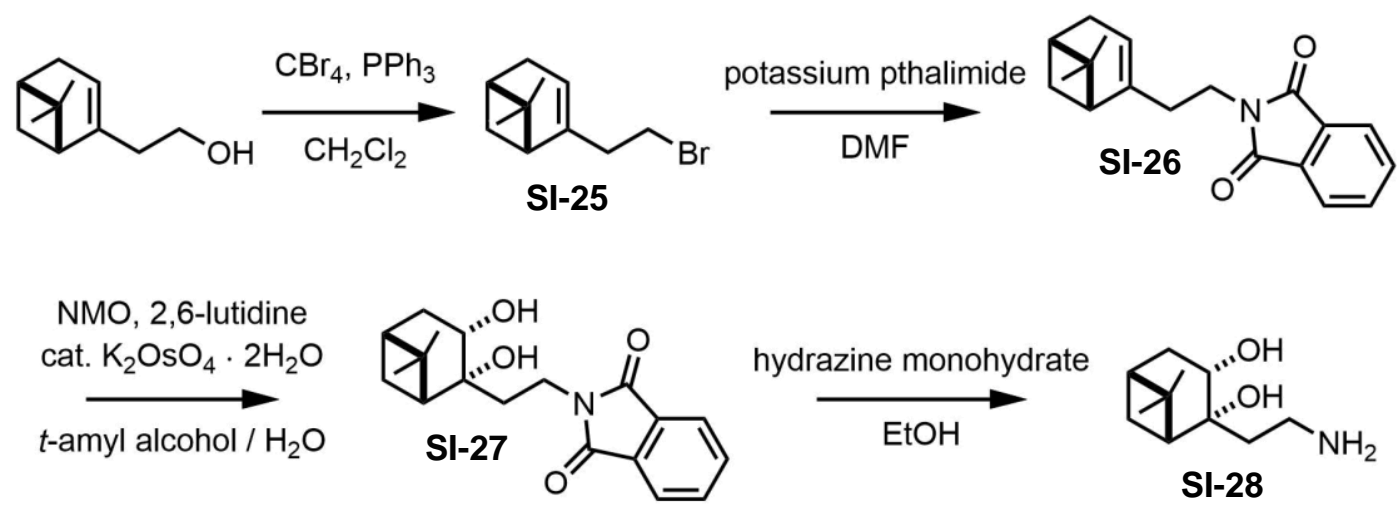


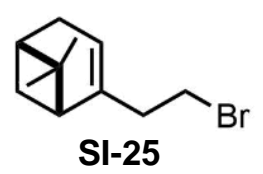

\section{Procedure:}

To a stirred solution of nopol (5.49 g, $33.0 \mathrm{mmol}, 1.1 \mathrm{eq})$ and $\mathrm{CBr}_{4}(10.4 \mathrm{~g}, 31.5 \mathrm{mmol}, 1.05 \mathrm{eq})$ in $100 \mathrm{~mL} \mathrm{CH}_{2} \mathrm{Cl}_{2}$ was charged $\mathrm{PPh}_{3}(7.87 \mathrm{~g}, 30 \mathrm{mmol})$ in portions over 5 minutes (note: exotherm). After one hour, $100 \mathrm{~mL} n$-heptane was charged, and the volume was reduced to ca. $100 \mathrm{~mL}$ on the rotovap (note: slurry formation). The slurry was filtered through a pad of $10 \mathrm{~g}$ silica and rinsed with $20 \mathrm{~mL}$ heptane. The filtrate was concentrated on the rotovap to afford alkyl bromide SI-25 as an oil (10.7 g). This crude material was used in the next reaction without further purification. To obtain a sample for characterization, a small amount of material was chromatographed on silica (hexane).

${ }^{1}$ H NMR: $\left(500 \mathrm{MHz}\right.$, DMSO- $\left.d_{6}, 25^{\circ} \mathrm{C}, \delta\right)$ :

$5.34(\mathrm{~m}, 1 \mathrm{H}), 3.49$ (tdd, $J=16.9,8.3,6.2 \mathrm{~Hz}, 2 \mathrm{H}), 2.50(\mathrm{~m}, 2 \mathrm{H}), 2.37$ (dt, $J=10.3,4.2 \mathrm{~Hz}, 1 \mathrm{H}), 2.24(\mathrm{~d}, 16.6 \mathrm{~Hz}$, 1H), $2.15(\mathrm{~d}, 16.6 \mathrm{~Hz}, 1 \mathrm{H}), 2.07$ (d, $J=5.2 \mathrm{~Hz}, 1 \mathrm{H}), 1.27$ (s, 3H), 1.12 (d, $J=8.6 \mathrm{~Hz}, 1 \mathrm{H}), 0.83$ (s, 3H).

${ }^{13} \mathrm{C}$ NMR: (126 MHz, DMSO- $\left.d_{6}, 25^{\circ} \mathrm{C}, \delta\right)$ :

144.8, 118.6, 44.5, 40.1, 39.6, 37.6, 32.0, 31.2, 30.8, 26.0, 21.1.

HRMS (ESI-TOF, m/z):

Note: we failed to detect $[\mathrm{M}+\mathrm{H}]^{+}$or $[\mathrm{M}+\mathrm{Na}]^{+}$. 


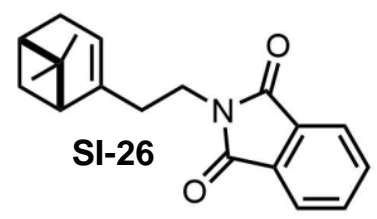

\section{Procedure:}

To a stirred solution of crude SI-25 (10.7 g) in $66 \mathrm{~mL}$ DMF was charged potassium pthalimide $(7.22 \mathrm{~g}, 39 \mathrm{mmol}$, $1.3 \mathrm{eq})$. The mixture was then heated in a $45-55^{\circ} \mathrm{C}$ bath. After 18 hours, the mixture was transferred to a sep.

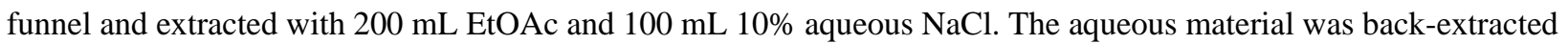
with $50 \mathrm{~mL}$ EtOAc. The pooled organic material was washed with brine $(3 \times 100 \mathrm{~mL})$, dried $\left(\mathrm{Na}_{2} \mathrm{SO}_{4}\right)$, filtered, and concentrated on the rotovap. The residue was adsorbed on $25 \mathrm{~g}$ silica and chromatographed on $75 \mathrm{~g}$ silica (10 to $20 \% \mathrm{v} / \mathrm{v}$ EtOAc in hex) to afford SI-26 (7.94 g, $26.9 \mathrm{mmol}, 90 \%$ yield over two steps) as a colorless oil.

${ }^{1}$ H NMR: $\left(392 \mathrm{MHz}\right.$, DMSO- $\left.d_{6}, 25^{\circ} \mathrm{C}, \delta\right)$ :

$7.83(\mathrm{~m}, 4 \mathrm{H}), 5.25(\mathrm{~m}, 1 \mathrm{H}), 3.58(\mathrm{~m}, 2 \mathrm{H}), 2.29(\mathrm{~m}, 3 \mathrm{H}), 2.06(\mathrm{~m}, 4 \mathrm{H}), 1.24(\mathrm{~s}, 3 \mathrm{H}), 1.00(\mathrm{~d}, J=8.5 \mathrm{~Hz}), 0.76(\mathrm{~s}$, $3 \mathrm{H})$.

${ }^{13}$ C NMR: (99 MHz, DMSO- $\left.d_{6}, 25^{\circ} \mathrm{C}, \delta\right)$ :

167.7, 144.6, 134.4, 131.6, 123.0, 118.1, 44.8, 40.0, 37.5, 35.7, 31.3, 30.9, 26.0, 20.9.

HRMS (ESI-TOF, m/z):

Calc'd for $\mathrm{C}_{19} \mathrm{H}_{21} \mathrm{NO}_{2} \mathrm{Na}^{+}\left([\mathrm{M}+\mathrm{Na}]^{+}\right) 318.1465$; found 318.1461. 


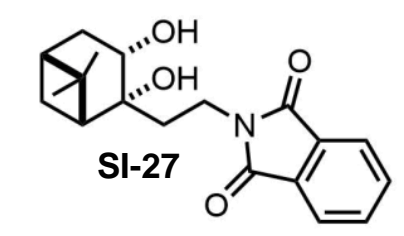

\section{Procedure:}

To a stirred solution of SI-26 (7.94 g, $7.94 \mathrm{mmol})$ in $120 \mathrm{~mL} t$-amyl alcohol was charged NMO (7.57 $\mathrm{g}$ of ca. 50\% aqueous solution, $32.3 \mathrm{mmol}, 1.2 \mathrm{eq}$ ), 2,6-lutidine ( $3.31 \mathrm{~g}, 30.9 \mathrm{mmol}, 1.15 \mathrm{eq}$ ), and $\mathrm{K}_{2} \mathrm{OsO}_{4}$ dihydrate (99 mg, 0.27 $\mathrm{mmol}, 0.01 \mathrm{eq}$ ). The mixture was heated in a $90-100^{\circ} \mathrm{C}$ bath. After 15 hours, the mixture was cooled to room temperature and $100 \mathrm{~mL}$ of $1: 1 \mathrm{v} / \mathrm{v}$ EtOAc $:$ hexane was charged (note: black precipitate). The mixture was filtered through cotton into a sep funnel. $50 \mathrm{~mL} 10 \% \mathrm{NaCl}$ was charged, and the aqueous $\mathrm{pH}$ was adjusted to $1-2$ with conc. HCl. The mixture was extracted, and the aqueous material was discarded. The organic material was washed with $50 \mathrm{~mL}$ brine, dried $\left(\mathrm{Na}_{2} \mathrm{SO}_{4}\right)$, filtered, and concentrated on the rotovap to obtain an oil (13.4 g). The residue was adsorbed on $35 \mathrm{~g}$ silica gel and chromatographed on $100 \mathrm{~g}$ silica gel to afford SI-27 (7.22 g, $21.9 \mathrm{mmol}, 81 \%$ yield) as a light brown solid.

${ }^{1}$ H NMR: $\left(392 \mathrm{MHz}\right.$, DMSO- $\left.d_{6}, 25^{\circ} \mathrm{C}, \delta\right)$ :

$7.81(\mathrm{~s}, 4 \mathrm{H}), 5.29(\mathrm{~s}, 1 \mathrm{H}), 4.34(\mathrm{~s}, 1 \mathrm{H}), 3.86(\mathrm{~s}, 1 \mathrm{H}), 3.68(\mathrm{~s}, 2 \mathrm{H}), 2.31(\mathrm{~m}, 1 \mathrm{H}), 2.00(\mathrm{~m}, 2 \mathrm{H}), 1.78(\mathrm{~s}, 2 \mathrm{H}), 1.66(\mathrm{~s}$, $1 \mathrm{H}), 1.54(\mathrm{~d}, J=11.7 \mathrm{~Hz}, 1 \mathrm{H}), 1.32(\mathrm{~d}, J=5.8 \mathrm{~Hz}, 1 \mathrm{H}), 1.16$ (s, 3H), 0.85 (s, 3H).

${ }^{13}$ C NMR: (99 MHz, DMSO- $\left.d_{6}, 25^{\circ} \mathrm{C}, \delta\right)$ :

167.9, 134.3, 131.8, 122.9, 73.5, 66.7, 50.8, 40.2, 39.9, 38.0, 38.0, 33.2, 27.7, 27.5, 23.8 (note: analysis of HMQC data showed that 40.2 and 39.9 ppm are obscured by the DMSO- $d_{6}$ peak; there are also overlapping peaks at 38.0 ppm).

HRMS (ESI-TOF, m/z):

Calc'd for $\mathrm{C}_{19} \mathrm{H}_{23} \mathrm{NO}_{4} \mathrm{Na}^{+}\left([\mathrm{M}+\mathrm{Na}]^{+}\right) 352.1519$; found 352.1524 . 


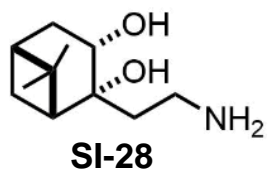

\section{Procedure:}

To a stirred solution of SI-27 $(82.4 \mathrm{mg}, 0.25 \mathrm{mmol})$ in $1.25 \mathrm{~mL}$ EtOH was charged hydrazine monohydrate $(36 \mu \mathrm{L}$, $7.5 \mathrm{mmol}, 3.0 \mathrm{eq}$ ). The mixture was heated in a $65-75^{\circ} \mathrm{C}$ bath for 4 hours (note: slurry formation). The mixture was cooled to room temperature, diluted with $1.25 \mathrm{~mL}$ EtOAc, and filtered through sintered glass $(1: 1 \mathrm{v} / \mathrm{v} \mathrm{EtOH}$ : EtOAc rinse). The filtrate was concentrated on the rotovap to obtain an oil $(99 \mathrm{mg})$. The residue was chromatographed on $0.8 \mathrm{~g}$ amino-silica (EtOAc to $15 \% \mathrm{v} / \mathrm{v} \mathrm{MeOH}$ in EtOAc) to afford SI-28 (48.4 mg, $0.243 \mathrm{mmol}$, $97 \%$ yield) as a tan semisolid.

${ }^{1}$ H NMR: $\left(392 \mathrm{MHz}, \mathrm{MeOH}-d_{4}, 25^{\circ} \mathrm{C}, \delta\right)$ :

$3.91(\mathrm{dd}, J=9.7,5.2 \mathrm{~Hz}, 1 \mathrm{H}), 2.74(\mathrm{~m}, 1 \mathrm{H}), 2.34(\mathrm{~m}, 1 \mathrm{H}), 2.06(\mathrm{~m}, 1 \mathrm{H}), 1.94(\mathrm{t}, J=5.6 \mathrm{~Hz}, 2 \mathrm{H}), 1.77(\mathrm{~m}, 1 \mathrm{H}), 1.69$ $(\mathrm{m}, 1 \mathrm{H}), 1.56(\mathrm{dq}, 13.7,2.5 \mathrm{~Hz}, 1 \mathrm{H}), 1.50(\mathrm{~m}, 1 \mathrm{H}), 1.34(\mathrm{~d}, J=9.7 \mathrm{~Hz}, 1 \mathrm{H}), 1.18(\mathrm{~s}, 3 \mathrm{H}), 0.87(\mathrm{~s}, 3 \mathrm{H})$.

${ }^{13}$ C NMR: (99 MHz, $\left.\mathrm{MeOH}-d_{4}, 25{ }^{\circ} \mathrm{C}, \delta\right)$ :

76.4, 68.9, 53.6, 45.5, 41.8, 39.7, 39.0, 37.7, 28.8, 28.4, 24.6.

HRMS (ESI-TOF, m/z):

Calc'd for $\mathrm{C}_{11} \mathrm{H}_{22} \mathrm{NO}_{2}{ }^{+}\left([\mathrm{M}+\mathrm{H}]^{+}\right)$200.1645; found 200.1649.

Calc'd for $\mathrm{C}_{11} \mathrm{H}_{21} \mathrm{NO}_{2} \mathrm{Na}^{+}\left([\mathrm{M}+\mathrm{Na}]^{+}\right)$222.1465; found 222.1465. 

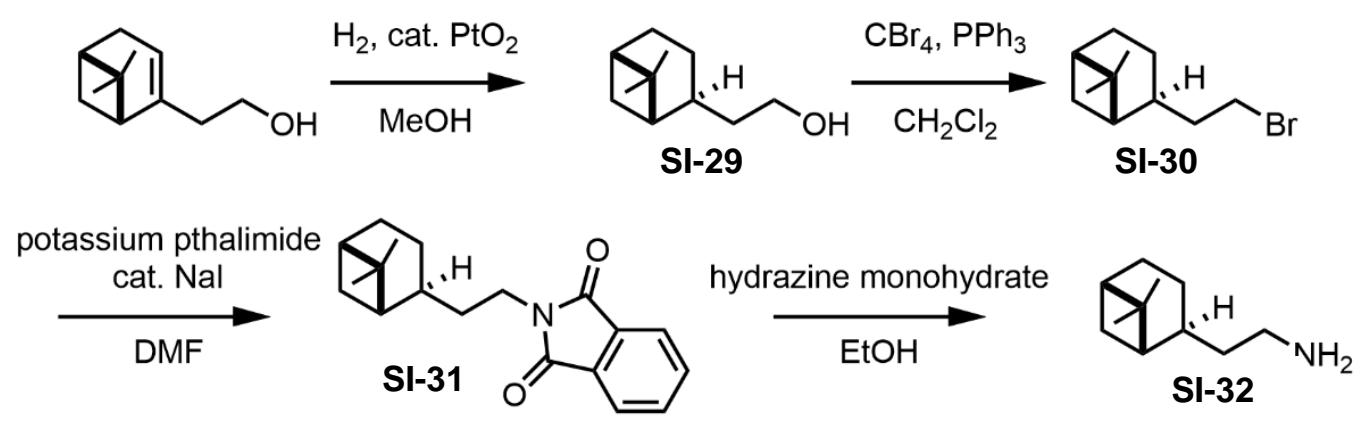


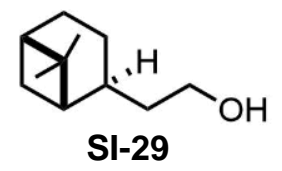

\section{Procedure:}

To a stirred solution of nopol (1247 mg, $7.5 \mathrm{mmol}$ ) in $15 \mathrm{~mL} \mathrm{MeOH}$ was charged $\mathrm{PtO}_{2}(125 \mathrm{mg})$. The mixture was stirred under $\mathrm{H}_{2}$ (balloon) for 84 hours. The reaction mixture was then filtered through a Celite pad (MeOH rinse) and concentrated on the rotovap. The residue was chromatographed on $5 \mathrm{~g}$ silica (pentane to $1: 1 \mathrm{v} / \mathrm{v} \mathrm{Et}_{2} \mathrm{O}:$ pentane) to afford alcohol SI-29 (1.25 g, $7.43 \mathrm{mmol}, 99 \%$ yield) as a colorless oil.

${ }^{1}$ H NMR: $\left(500 \mathrm{MHz}\right.$, DMSO- $\left.d_{6}, 25^{\circ} \mathrm{C}, \delta\right)$ :

$4.26(\mathrm{~m}, 1 \mathrm{H}), 3.34(\mathrm{~m}, 2 \mathrm{H}), 2.26(\mathrm{~m}, 1 \mathrm{H}), 2.03(\mathrm{~m}, 1 \mathrm{H}), 1.84(\mathrm{~m}, 3 \mathrm{H}), 1.77(\mathrm{~m}, 2 \mathrm{H}), 1.47(\mathrm{~m}, 1 \mathrm{H}), 1.38(\mathrm{~m}, 1 \mathrm{H})$, $1.12(\mathrm{~s}, 3 \mathrm{H}), 0.95(\mathrm{~s}, 3 \mathrm{H}), 0.81(\mathrm{~d}, J=10.0 \mathrm{~Hz}, 1 \mathrm{H})$.

${ }^{13}$ C NMR: (126 MHz, DMSO- $\left.d_{6}, 25{ }^{\circ} \mathrm{C}, \delta\right)$ :

59.3, 45.9, 40.9, 40.6, 38.3, 37.0, 33.2, 28.1, 26.1, 23.1, 21.9.

\section{HRMS (ESI-TOF, m/z):}

Note: we failed to detect $[\mathrm{M}+\mathrm{H}]^{+}$or $[\mathrm{M}+\mathrm{Na}]^{+}$. 


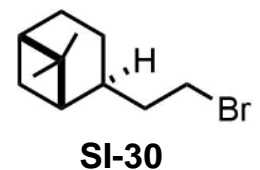

\section{Procedure:}

To a stirred solution of alcohol SI-29 (1.03 g, $6.12 \mathrm{mmol})$ and $\mathrm{CBr}_{4}(2.09 \mathrm{~g}, 6.30 \mathrm{mmol}, 1.03 \mathrm{eq})$ in $25 \mathrm{~mL} \mathrm{CH}_{2} \mathrm{Cl}_{2}$ was charged $\mathrm{PPh}_{3}(1.57 \mathrm{~g}, 6.00 \mathrm{~mol}, 0.98 \mathrm{eq}$ ) in portions over 5 minutes (note: exotherm). After 45 minutes, $20 \mathrm{~mL}$ $n$-heptane was charged (note: a hazy suspension) and the volume was reduced to ca. $20 \mathrm{~mL}$ on the rotovap (note: slurry formation). The slurry was filtered through a pad of $10 \mathrm{~g}$ silica and rinsed forward with $20 \mathrm{~mL} n$-heptane. The filtrate was concentrated on the rotovap to afford an oil. The crude material was chromatographed on $10 \mathrm{~g}$ silica (pentane) to afford alkyl bromide SI-30 (920 mg, $3.98 \mathrm{mmol}, 65 \%$ yield) as a colorless oil.

${ }^{1}$ H NMR: $\left(500 \mathrm{MHz}\right.$, DMSO- $\left.d_{6}, 25^{\circ} \mathrm{C}, \delta\right)$ :

$3.51(\mathrm{~m}, 2 \mathrm{H}), 2.31(\mathrm{~m}, 1 \mathrm{H}), 2.13(\mathrm{~m}, 1 \mathrm{H}), 1.85(\mathrm{~m}, 7 \mathrm{H}), 1.43(\mathrm{~m}, 1 \mathrm{H}), 1.16(\mathrm{~s}, 3 \mathrm{H}), 0.96(\mathrm{~s}, 3 \mathrm{H}), 0.86(\mathrm{~d}, J=9.7$ $\mathrm{Hz})$.

${ }^{13}$ C NMR: (126 MHz, DMSO- $\left.d_{6}, 25^{\circ} \mathrm{C}, \delta\right)$ :

45.1, 40.7, 39.9, 39.0, 38.3, 33.8, 33.0, 27.9, 25.8, 23.0, 20.9 (note: analysis of HMQC data showed that peaks at 39.9 and $39.0 \mathrm{ppm}$ are obscured by the DMSO- $d_{6}$ peak).

HRMS (ESI-TOF, m/z):

Note: we failed to detect $[\mathrm{M}+\mathrm{H}]^{+}$or $[\mathrm{M}+\mathrm{Na}]^{+}$. 


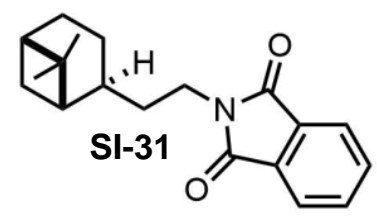

\section{Procedure:}

To a stirred solution of alkyl bromide SI-30 (920 mg, $3.98 \mathrm{mmol})$ in $4 \mathrm{~mL}$ DMF was charged potassium pthalimide (1106 mg, $5.97 \mathrm{mmol}, 1.5 \mathrm{eq}$ ) followed by sodium iodide ( $30 \mathrm{mg}, 0.20 \mathrm{mmol}, 0.05 \mathrm{eq}$ ), and the mixture was heated in a $30-40{ }^{\circ} \mathrm{C}$ bath. After 45 hours, the mixture was cooled to room temperature and poured into a sep. funnel containing $20 \mathrm{~mL}$ EtOAc and $10 \mathrm{~mL} \mathrm{10 \%} \mathrm{NaCl}$. The mixture was extracted, and the aqueous material was discarded. The organic material was washed with brine, dried $\left(\mathrm{MgSO}_{4}\right)$, filtered, and concentrated on the rotovap. The crude material was adsorbed on $4 \mathrm{~g}$ silica and chromatographed on $20 \mathrm{~g}$ silica ( 20 to $30 \% \mathrm{v} / \mathrm{v} \mathrm{Et}_{2} \mathrm{O}$ in pentane) to afford SI-31 (731 mg, $2.46 \mathrm{mmol}, 62 \%$ yield) as an off-white solid.

${ }^{1}$ H NMR: $\left(500 \mathrm{MHz}\right.$, DMSO- $\left.d_{6}, 25^{\circ} \mathrm{C}, \delta\right)$ :

$7.82(\mathrm{~m}, 4 \mathrm{H}), 3.52(\mathrm{t}, J=7.2 \mathrm{~Hz}), 2.25(\mathrm{~m}, 1 \mathrm{H}), 1.93(\mathrm{~m}, 2 \mathrm{H}), 1.81(\mathrm{~m}, 4 \mathrm{H}), 1.65(\mathrm{~m}, 2 \mathrm{H}), 1.42(\mathrm{~m}, 1 \mathrm{H}), 1.11(\mathrm{~s}$, $3 \mathrm{H}), 0.94(\mathrm{~s}, 3 \mathrm{H}), 0.80(\mathrm{~d}, J=9.7 \mathrm{~Hz}, 1 \mathrm{H})$.

${ }^{13} \mathrm{C}$ NMR: (126 MHz, DMSO- $d_{6}, 25^{\circ} \mathrm{C}, \delta$ ):

$167.9,134.4,131.6,123.0,45.6,40.7,38.2,38.1,36.1,35.6,32.9,27.9,25.9,23.0,21.5$.

HRMS (ESI-TOF, m/z):

Calc'd for $\mathrm{C}_{19} \mathrm{H}_{22} \mathrm{NO}_{2} \mathrm{Na}^{+}\left([\mathrm{M}+\mathrm{Na}]^{+}\right) 360.1621$; found 360.1621 . 


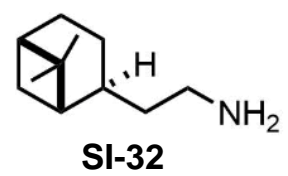

\section{Procedure:}

To a stirred solution of SI-31 (710 mg, $2.39 \mathrm{mmol})$ in $12 \mathrm{~mL} \mathrm{EtOH}$ was charged hydrazine monohydrate (348 $\mu \mathrm{L}$, $7.17 \mathrm{mmol}, 3.0 \mathrm{eq}$ ). The mixture was heated in a $65-75^{\circ} \mathrm{C}$ bath for 4 hours (note: slurry formation). The mixture was cooled to room temperature, diluted with $12 \mathrm{~mL}$ EtOAc, and filtered through sintered glass $(1: 1 \mathrm{v} / \mathrm{v} \mathrm{EtOH}$ :

EtOAc rinse). The filtrate was concentrated on the rotovap to obtain an oil (520 mg). The residue was chromatographed on $7 \mathrm{~g}$ amino-silica (50 to $100 \% \mathrm{v} / \mathrm{v} \mathrm{Et}{ }_{2} \mathrm{O}$ in pentane) to afford amine SI-32 (317.6 mg, 1.90 mmol, $79 \%$ yield) as a white solid.

${ }^{1}$ H NMR: $\left(392 \mathrm{MHz}, \mathrm{MeOH}-d_{4}, 25^{\circ} \mathrm{C}, \delta\right)$ :

$2.50(\mathrm{~m}, 2 \mathrm{H}), 2.26(\mathrm{~m}, 1 \mathrm{H}), 1.93(\mathrm{~m}, 1 \mathrm{H}), 1.86(\mathrm{~m}, 2 \mathrm{H}), 1.77(\mathrm{~m}, 3 \mathrm{H}), 1.47(\mathrm{~m}, 2 \mathrm{H}), 1.40(\mathrm{~m}, 1 \mathrm{H}), 1.10(\mathrm{~s}, 3 \mathrm{H}), 0.94$ (s, 3H), $0.82(\mathrm{~d}, J=9.7 \mathrm{~Hz}, 1 \mathrm{H})$.

${ }^{13}$ C NMR: $\left(99 \mathrm{MHz}, \mathrm{MeOH}-d_{4}, 25^{\circ} \mathrm{C}, \delta\right)$ :

$47.8,42.8,42.0,41.1,40.3,39.7,34.6,28.7,27.5,23.7,23.4$.

HRMS (ESI-TOF, m/z):

Calc'd for $\mathrm{C}_{11} \mathrm{H}_{22} \mathrm{~N}^{+}\left([\mathrm{M}+\mathrm{H}]^{+}\right)$168.1747; found 168.1751.

Calc'd for $\mathrm{C}_{11} \mathrm{H}_{21} \mathrm{NNa}^{+}\left([\mathrm{M}+\mathrm{Na}]^{+}\right)$190.1566; found 190.1563 . 


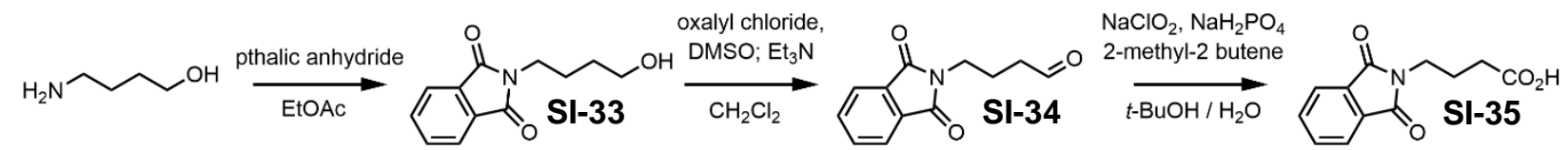

\section{Procedure:}

To a flask was charged pthalic anhydride (741 mg, $5.0 \mathrm{mmol}), 10 \mathrm{~mL}$ EtOAc, and 4-amino-1-butanol (479 mg, 5.4 mmol, $1.08 \mathrm{eq}$ ), and the mixture was stirred at reflux. After 2 hours, the mixture was cooled to room temperature and extracted with $10 \mathrm{~mL}$ MTBE and $10 \mathrm{~mL} \mathrm{10 \%} \mathrm{NaCl}$. The aqueous material was discarded, and the organic material was washed with brine, dried $\left(\mathrm{MgSO}_{4}\right)$, filtered, and concentrated on the rotovap. Chromatography on $10 \mathrm{~g}$ silica (50 to $60 \% \mathrm{v} / \mathrm{v}$ EtOAc in hexane) afforded alcohol SI-33 as an oil (374 mg, $1.70 \mathrm{mmol}, 34 \%$ yield)

To a stirred $-78{ }^{\circ} \mathrm{C}$ solution of DMSO $(362 \mu \mathrm{L}, 5.1 \mathrm{mmol}, 3.0 \mathrm{eq})$ in $11 \mathrm{~mL} \mathrm{CH}_{2} \mathrm{Cl}_{2}$ was charged oxalyl chloride (298 $\mu \mathrm{L}, 3.4 \mathrm{mmol}, 2.0$ eq) dropwise (note: gas evolution). After 25 minutes, a solution of SI-33 (374 mg) in $2 \mathrm{~mL}$ $\mathrm{CH}_{2} \mathrm{Cl}_{2}$ was charged dropwise. After 20 minutes, $\mathrm{Et}_{3} \mathrm{~N}(1184 \mu \mathrm{L}, 8.5 \mathrm{mmol}, 5.0 \mathrm{eq})$ was charged and the mixture was warmed to room temperature. The mixture was extracted with $25 \mathrm{~mL} \mathrm{Et}_{2} \mathrm{O}$ and $25 \mathrm{~mL} \mathrm{pH} 4$ buffer, and the aqueous material was discarded. The organic material was washed with brine, dried $\left(\mathrm{MgSO}_{4}\right)$, filtered, and concentrated on the rotovap to afford aldehyde SI-34 (480 $\mathrm{mg})$ as an oil.

To a vigorously stirred solution of crude aldehyde SI-34 (480 mg) and 2-methyl-2-butene (1807 $\mu \mathrm{L}, 17 \mathrm{mmol})$ in 10 $\mathrm{mL} t$-BuOH was charged dropwise a solution of sodium chlorite $(307 \mathrm{mg}, 3.4 \mathrm{mmol})$ and $\mathrm{NaH}_{2} \mathrm{PO}_{4}(816 \mathrm{mg}, 6.8$ mmol) in $8 \mathrm{~mL} \mathrm{H}_{2} \mathrm{O}$ (note: exotherm). After 2 hours, the $\mathrm{pH}$ of the aqueous layer was adjusted to 1 with $12 \mathrm{~N} \mathrm{HCl}$. $10 \mathrm{~mL}$ MTBE and $1 \mathrm{~g} \mathrm{NaCl}$ was charged. The mixture was extracted, and the aqueous material was discarded. The organic material was washed with brine, dried $\left(\mathrm{MgSO}_{4}\right)$, filtered, and concentrated on the rotovap. The crude material was chromatographed on $8 \mathrm{~g}$ silica $(60: 40: 1 \mathrm{v} / \mathrm{v}$ hexane : EtOAc : AcOH) to afford carboxylic acid SI-35 (288 $\mathrm{mg}, 1.23 \mathrm{mmol}, 25 \%$ yield over 3 steps) as a white solid.

${ }^{1} \mathbf{H}$ NMR: $\left(500 \mathrm{MHz}, \mathrm{CDCl}_{3}, 25^{\circ} \mathrm{C}, \delta\right)$ :

10.35 (br s, 1H), $7.81(\mathrm{~m}, 2 \mathrm{H}), 7.69(\mathrm{~m}, 2 \mathrm{H}), 3.73(\mathrm{t}, J=6.9 \mathrm{~Hz}, 2 \mathrm{H}), 2.39(\mathrm{t}, J=7.4 \mathrm{~Hz}, 2 \mathrm{H}), 1.98(\mathrm{~m}, 2 \mathrm{H})$.

${ }^{13}$ C NMR: $\left(126 \mathrm{MHz}, \mathrm{CDCl}_{3}, 25^{\circ} \mathrm{C}, \delta\right)$ :

178.5, 168.3, 134.0, 131.9, 123.3, 37.0, 31.2, 23.6.

HRMS (ESI-TOF, m/z):

Calc'd for $\mathrm{C}_{12} \mathrm{H}_{11} \mathrm{NO}_{4} \mathrm{Na}^{+}\left([\mathrm{M}+\mathrm{Na}]^{+}\right)$256.0580; found 256.0529. 


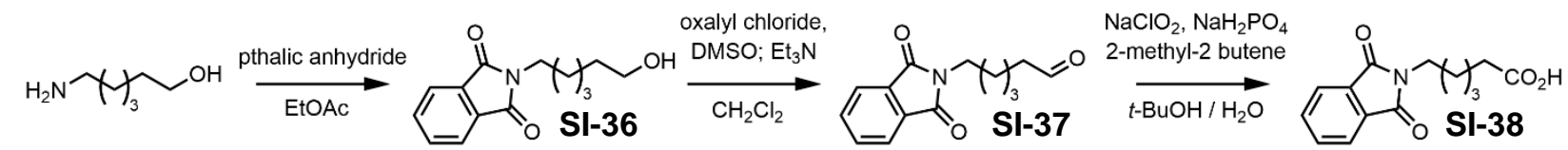

\section{Procedure:}

To a flask was charged pthalic anhydride (741 mg, $5.0 \mathrm{mmol}), 10 \mathrm{~mL}$ EtOAc, and 4-amino-1-hexanol (630 mg, 5.4 mmol, $1.08 \mathrm{eq}$ ), and the mixture was stirred at reflux. After 2 hours, the mixture was cooled to room temperature and extracted with $10 \mathrm{~mL}$ MTBE and $10 \mathrm{~mL} 10 \% \mathrm{NaCl}$. The aqueous material was discarded, and the organic material was washed with brine, dried $\left(\mathrm{MgSO}_{4}\right)$, filtered, and concentrated on the rotovap. Chromatography on $10 \mathrm{~g}$ silica (40 to 50\% v/v EtOAc in hexane) afforded alcohol SI-36 as an oil (352 mg, $1.42 \mathrm{mmol}, 28 \%$ yield).

To a stirred $-78^{\circ} \mathrm{C}$ solution of DMSO $\left(303 \mu \mathrm{L}, 4.3 \mathrm{mmol}, 3.0 \mathrm{eq}\right.$ ) in $9 \mathrm{~mL} \mathrm{CH}_{2} \mathrm{Cl}_{2}$ was charged oxalyl chloride (249 $\mu \mathrm{L}, 2.8 \mathrm{mmol}, 2.0 \mathrm{eq}$ ) dropwise (note: gas evolution). After 25 minutes, a solution of SI-36 $(352 \mathrm{mg})$ in $2 \mathrm{~mL}$ $\mathrm{CH}_{2} \mathrm{Cl}_{2}$ was charged dropwise. After 20 minutes, $\mathrm{Et}_{3} \mathrm{~N}(990 \mu \mathrm{L}, 7.1 \mathrm{mmol}, 5.0 \mathrm{eq})$ was charged and the mixture was warmed to room temperature. The mixture was extracted with $25 \mathrm{~mL} \mathrm{Et}_{2} \mathrm{O}$ and $25 \mathrm{~mL} \mathrm{pH} 4$ buffer, and the aqueous material was discarded. The organic material was washed with brine, dried $\left(\mathrm{MgSO}_{4}\right)$, filtered, and concentrated on the rotovap to afford aldehyde SI-37 (400 $\mathrm{mg}$ ) as an oil.

To a vigorously stirred solution of crude aldehyde SI-37 (400 mg) and 2-methyl-2-butene (1509 $\mu \mathrm{L}, 14.2 \mathrm{mmol})$ in $10 \mathrm{~mL} t-\mathrm{BuOH}$ was charged dropwise a solution of sodium chlorite $(255 \mathrm{mg}, 2.8 \mathrm{mmol})$ and $\mathrm{NaH}_{2} \mathrm{PO}_{4}(681 \mathrm{mg}, 5.7$ mmol) in $8 \mathrm{~mL} \mathrm{H}_{2} \mathrm{O}$ (note: exotherm). After 2 hours, the $\mathrm{pH}$ of the aqueous layer was adjusted to 1 with $12 \mathrm{~N} \mathrm{HCl}$. $10 \mathrm{~mL}$ MTBE and $1 \mathrm{~g} \mathrm{NaCl}$ was charged. The mixture was extracted, and the aqueous material was discarded. The organic material was washed with brine, dried $\left(\mathrm{MgSO}_{4}\right)$, filtered, and concentrated on the rotovap. The crude material was chromatographed on $8 \mathrm{~g}$ silica $(70: 30: 1 \mathrm{v} / \mathrm{v}$ hexane : EtOAc : AcOH) to afford carboxylic acid SI-38 (304 mg, $1.16 \mathrm{mmol}, 23 \%$ yield over 3 steps) as a white solid.

${ }^{1}$ H NMR: $\left(500 \mathrm{MHz}, \mathrm{CDCl}_{3}, 25^{\circ} \mathrm{C}, \delta\right)$ :

$10.33(\mathrm{br} \mathrm{s}, 1 \mathrm{H}), 7.80(\mathrm{~m}, 2 \mathrm{H}), 7.68(\mathrm{~m}, 2 \mathrm{H}), 3.65(\mathrm{t}, J=7.2 \mathrm{~Hz}, 2 \mathrm{H}), 2.32(\mathrm{t}, J=7.4 \mathrm{~Hz}, 2 \mathrm{H}), 1.66(\mathrm{~m}, 4 \mathrm{H}), 1.37$ $(\mathrm{m}, 2 \mathrm{H})$.

${ }^{13}$ C NMR: (126 MHz, $\left.\mathrm{CDCl}_{3}, 25^{\circ} \mathrm{C}, \delta\right)$ :

$179.5,168.4,133.9,132.0,123.2,37.7,33.8,28.2,26.2,24.1$.

HRMS (ESI-TOF, m/z):

Calc'd for $\mathrm{C}_{14} \mathrm{H}_{15} \mathrm{NO}_{4} \mathrm{Na}^{+}\left([\mathrm{M}+\mathrm{Na}]^{+}\right) 284.0893$; found 284.0903 . 


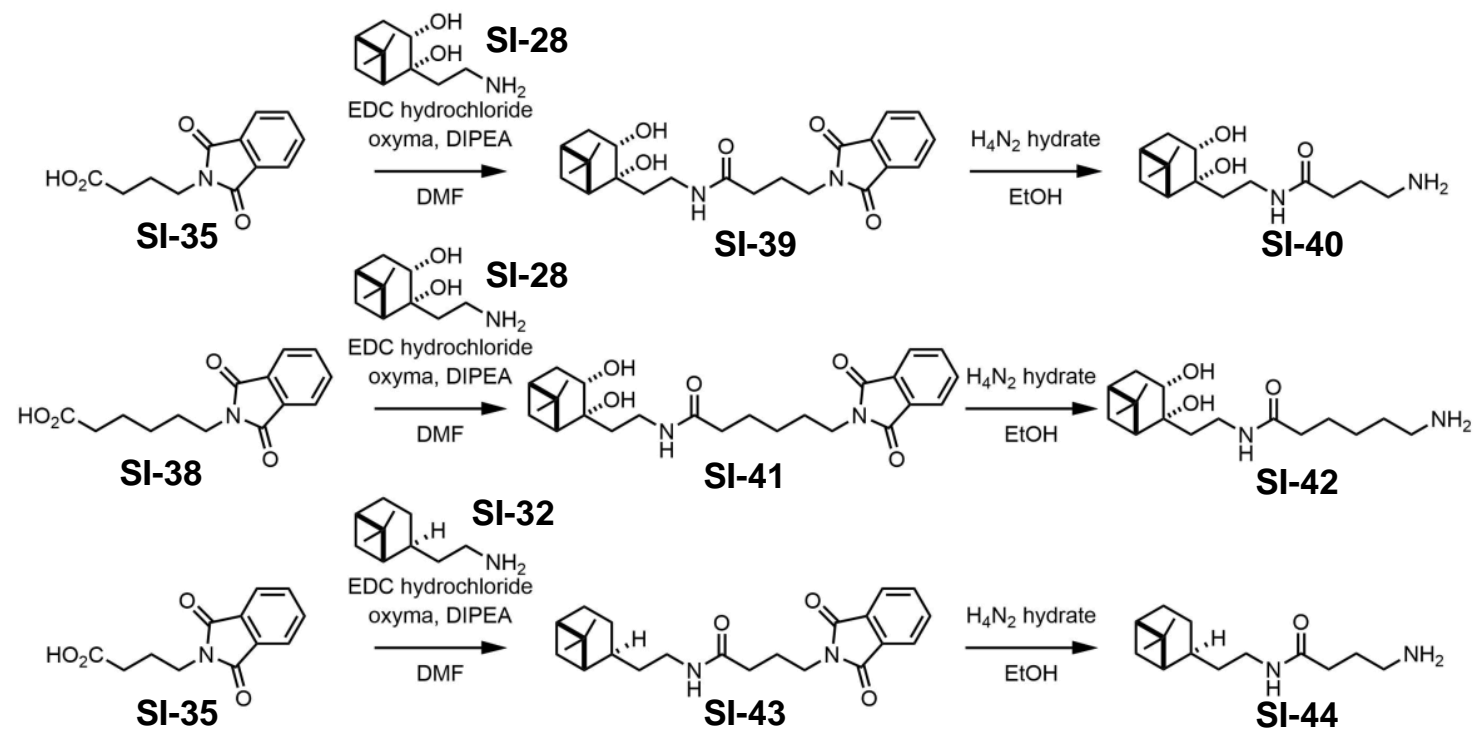




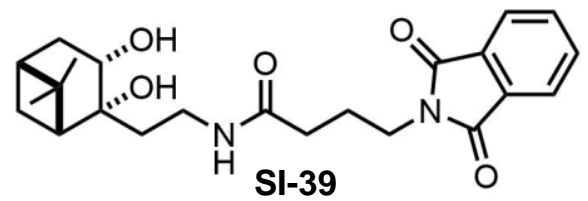

\section{Procedure:}

To a stirred solution of carboxylic acid SI-35 $(287.7 \mathrm{mg}, 1.23 \mathrm{mmol})$ in $6.8 \mathrm{~mL}$ DMF was charged amine SI-28 (281 $\mathrm{mg}, 1.41 \mathrm{mmol}, 1.15 \mathrm{eq})$, DIPEA ( $857 \mu \mathrm{L}, 4.92 \mathrm{mmol}, 4 \mathrm{eq})$, oxyma (17 mg, $0.12 \mathrm{mmol}, 0.1 \mathrm{eq})$, and EDC. $\mathrm{HCl}$ (365 mg, $1.85 \mathrm{mmol}, 1.5 \mathrm{eq}$ ). After 13 hours, most of the DMF was removed on the rotovap. The residue was stirred with $10 \mathrm{~mL}$ EtOAc and $10 \mathrm{~mL} \mathrm{NaCl}(10 \% \mathrm{aq})$. The aqueous material was adjusted to $\mathrm{pH} 1$ with $12 \mathrm{~N} \mathrm{HCl}$ and then discarded. The organic material was washed with brine, dried $\left(\mathrm{Na}_{2} \mathrm{SO}_{4}\right)$, filtered, and concentrated on the rotovap. The residue was chromatographed on $10 \mathrm{~g}$ silica (5 to $10 \% \mathrm{v} / \mathrm{v} \mathrm{MeOH}$ in $\mathrm{CH}_{2} \mathrm{Cl}_{2}$ ) to afford $\mathbf{S I - 3 9}$ (383.3 mg, 0.92 mmol, $75 \%$ yield) as a foam.

${ }^{1} \mathbf{H}$ NMR: $\left(500 \mathrm{MHz}, \mathrm{CDCl}_{3}, 25^{\circ} \mathrm{C}, \delta\right)$ :

$7.78(\mathrm{~m}, 2 \mathrm{H}), 7.67(\mathrm{~m}, 2 \mathrm{H}), 6.74(\mathrm{t}, J=4.6 \mathrm{~Hz}, 1 \mathrm{H}) 4.21(\mathrm{br} \mathrm{s}, 1 \mathrm{H}), 4.02(\mathrm{dd}, J=9.5,4.9 \mathrm{~Hz}, 1 \mathrm{H}), 3.98(\mathrm{br} \mathrm{s}, 1 \mathrm{H})$, $3.68(\mathrm{~m}, 2 \mathrm{H}), 3.47(\mathrm{~m}, 1 \mathrm{H}), 3.30(\mathrm{~m}, 1 \mathrm{H}), 2.42(\mathrm{~m}, 1 \mathrm{H}), 2.14(\mathrm{~m}, 3 \mathrm{H}), 2.02(\mathrm{t}, J=6.0 \mathrm{~Hz}, 1 \mathrm{H}), 1.96(\mathrm{~m}, 2 \mathrm{H}), 1.86$ (m, 1H), $1.79(\mathrm{~m}, 1 \mathrm{H}), 1.63(\mathrm{~m}, 2 \mathrm{H}), 1.34(\mathrm{~d}, J=10.3 \mathrm{~Hz} 1 \mathrm{H}), 1.21(\mathrm{~s}, 3 \mathrm{H}), 0.86(\mathrm{~s}, 3 \mathrm{H})$.

${ }^{13} \mathrm{C}$ NMR: $\left(126 \mathrm{MHz}, \mathrm{CDCl}_{3}, 25^{\circ} \mathrm{C}, \delta\right)$ :

172.2, 168.6, 134.0, 131.9, 123.2, 75.4, 67.5, 52.1, 40.9, 40.4, 38.6, 37.9, 37.2, 35.2, 33.7, 27.7, 27.5, 24.7, 24.2.

HRMS (ESI-TOF, m/z):

Calc'd for $\mathrm{C}_{23} \mathrm{H}_{31} \mathrm{~N}_{2} \mathrm{O}_{5}{ }^{+}\left([\mathrm{M}+\mathrm{H}]^{+}\right)$415.2227; found 415.2215.

Calc'd for $\mathrm{C}_{23} \mathrm{H}_{30} \mathrm{~N}_{2} \mathrm{O}_{5} \mathrm{Na}^{+}\left([\mathrm{M}+\mathrm{Na}]^{+}\right)$437.2047; found 437.2036. 


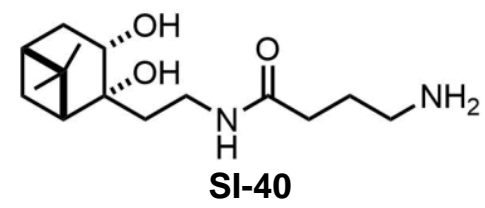

\section{Procedure:}

To a stirred solution of $\mathbf{S I - 3 9}$ ( $85 \mathrm{mg}, 0.21 \mathrm{mmol})$ in $1 \mathrm{~mL}$ EtOH was charged hydrazine monohydrate $(31 \mu \mathrm{L}, 0.62$ $\mathrm{mmol}, 3.0 \mathrm{eq}$ ). The mixture was heated in a $65-75^{\circ} \mathrm{C}$ bath for 4 hours (note: slurry formation). The mixture was cooled to room temperature, diluted with $1 \mathrm{~mL}$ EtOAc, and filtered through sintered glass $(1: 1 \mathrm{v} / \mathrm{v} \mathrm{EtOH}:$ EtOAc rinse). The filtrate was concentrated on the rotovap to obtain an oil (101 $\mathrm{mg})$. The residue was chromatographed on $1 \mathrm{~g}$ amino-silica (EtOAc to 20\% v/v MeOH in EtOAc) to afford amine SI-40 (55.7 mg, $0.196 \mathrm{mmol}, 93 \%$ yield) as a colorless oil.

${ }^{1}$ H NMR: $\left(392 \mathrm{MHz}, \mathrm{MeOH}-d_{4}, 25^{\circ} \mathrm{C}, \delta\right)$ :

$3.91(\mathrm{dd}, J=9.7,5.2 \mathrm{~Hz}, 1 \mathrm{H}), 3.22(\mathrm{t}, J=7.9 \mathrm{~Hz}, 2 \mathrm{H}), 2.54(\mathrm{t}, J=7.1 \mathrm{~Hz}, 2 \mathrm{H}), 2.35(\mathrm{~m}, 1 \mathrm{H}), 2.09(\mathrm{~m}, 3 \mathrm{H}), 1.94(\mathrm{~m}$, 2H), $1.77(\mathrm{~m}, 1 \mathrm{H}), 1.71(\mathrm{dd}, J=14.6,7.9 \mathrm{~Hz}, 1 \mathrm{H}), 1.64(\mathrm{t}, J=7.1 \mathrm{~Hz}, 2 \mathrm{H}), 1.54(\mathrm{~m}, 2 \mathrm{H}), 1.34(\mathrm{~d}, J=7.1 \mathrm{~Hz}, 1 \mathrm{H})$, $1.18(\mathrm{~s}, 3 \mathrm{H}), 0.86(\mathrm{~s}, 3 \mathrm{H})$.

${ }^{13}$ C NMR: $\left(99 \mathrm{MHz}, \mathrm{MeOH}-d_{4}, 25^{\circ} \mathrm{C}, \delta\right)$ :

$175.5,75.8,68.7,52.9,42.8,42.0,41.8,39.7,39.2,35.9,34.6,29.9,28.7,28.3,24.6$.

HRMS (ESI-TOF, m/z):

Calc'd for $\mathrm{C}_{15} \mathrm{H}_{29} \mathrm{~N}_{2} \mathrm{O}_{3}{ }^{+}\left([\mathrm{M}+\mathrm{H}]^{+}\right)$285.2173; found 285.2190.

Calc'd for $^{+}\left([\mathrm{M}+\mathrm{Na}]^{+}\right) 307.1992$; found 307.1997 


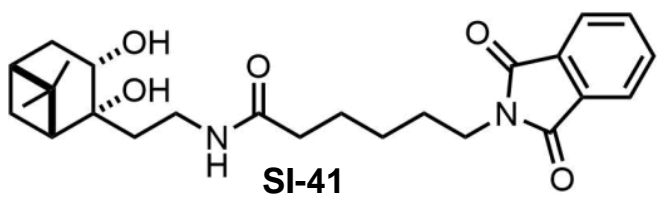

\section{Procedure:}

To a stirred solution of carboxylic acid SI-38 (303.9 mg, $1.16 \mathrm{mmol})$ in $6.7 \mathrm{~mL}$ DMF was charged amine SI-28 (265 mg, $1.33 \mathrm{mmol}, 1.15$ eq), DIPEA ( $808 \mu \mathrm{L}, 4.64 \mathrm{mmol}, 4 \mathrm{eq})$, oxyma (17 mg, $142.11 \mathrm{mmol}, 0.1 \mathrm{eq})$, and EDC. $\mathrm{HCl}$ (334 mg, $1.74 \mathrm{mmol}, 1.5 \mathrm{eq}$ ). After 13 hours, most of the DMF was removed on the rotovap. The residue was stirred with $10 \mathrm{~mL}$ EtOAc and $10 \mathrm{~mL} \mathrm{10 \%} \mathrm{NaCl}$. The aqueous material was adjusted to $\mathrm{pH} 1$ with conc. $\mathrm{HCl}$. The aqueous material was discarded, and the organic material was washed with brine, dried $\left(\mathrm{Na}_{2} \mathrm{SO}_{4}\right)$, filtered, and concentrated on the rotovap. The residue was chromatographed on $10 \mathrm{~g}$ silica (5 to $10 \% \mathrm{v} / \mathrm{v} \mathrm{MeOH}$ in $\mathrm{CH}_{2} \mathrm{Cl}_{2}$ ) to afford $\mathbf{S I - 4 1}$ (456 mg, $1.03 \mathrm{mmol}, 89 \%$ yield) as an oil.

${ }^{1} \mathbf{H}$ NMR: $\left(500 \mathrm{MHz}, \mathrm{CDCl}_{3}, 25^{\circ} \mathrm{C}, \delta\right)$ :

$7.79(\mathrm{~m}, 2 \mathrm{H}), 7.68(\mathrm{~m}, 2 \mathrm{H}), 6.55(\mathrm{~m}, 1 \mathrm{H}), 4.20(\mathrm{~m}, 1 \mathrm{H}), 4.02(\mathrm{~m}, 1 \mathrm{H}), 3.98(\mathrm{~m}, 1 \mathrm{H}), 3.63(\mathrm{t}, J=7.2 \mathrm{~Hz}, 2 \mathrm{H}), 3.47$ (m, 1H), $3.31(\mathrm{~m}, 1 \mathrm{H}), 2.43(\mathrm{~m}, 1 \mathrm{H}), 2.13(\mathrm{~m}, 3 \mathrm{H}), 2.04(\mathrm{t}, J=5.7 \mathrm{~Hz}, 1 \mathrm{H}), 1.87(\mathrm{~m}, 1 \mathrm{H}), 1.77(\mathrm{~m}, 1 \mathrm{H}), 1.63(\mathrm{~m}$, $6 \mathrm{H}), 1.33(\mathrm{~m}, 3 \mathrm{H}), 1.22(\mathrm{~s}, 3 \mathrm{H}), 0.87(\mathrm{~s}, 3 \mathrm{H})$.

${ }^{13}$ C NMR: (126 MHz, $\left.\mathrm{CDCl}_{3}, 25^{\circ} \mathrm{C}, \delta\right)$ :

$173.1,168.5,133.9,132.0,123.2,75.4,67.5,52.0,40.9,40.4,38.6,37.9,37.736 .5,35.1,28.2,27.7,27.5,26.3$, 25.1, 24.2.

HRMS (ESI-TOF, m/z):

Calc'd for $\mathrm{C}_{25} \mathrm{H}_{35} \mathrm{~N}_{2} \mathrm{O}_{5}^{+}\left([\mathrm{M}+\mathrm{H}]^{+}\right)$443.2540; found 443.2538.

Calc'd for $\mathrm{C}_{25} \mathrm{H}_{34} \mathrm{~N}_{2} \mathrm{O}_{5} \mathrm{Na}^{+}\left([\mathrm{M}+\mathrm{Na}]^{+}\right)$465.2360; found 465.2349. 


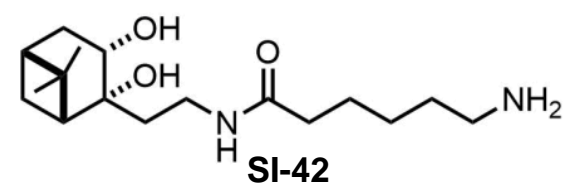

\section{Procedure:}

To a stirred solution of SI-41 (91 mg, $0.21 \mathrm{mmol})$ in $1 \mathrm{~mL}$ EtOH was charged hydrazine monohydrate (31 $\mu \mathrm{L}, 0.62$ $\mathrm{mmol}, 3.0 \mathrm{eq}$ ). The mixture was heated in a $65-75^{\circ} \mathrm{C}$ bath for 4 hours (note: slurry formation). The mixture was cooled to room temperature, diluted with $1 \mathrm{~mL}$ EtOAc, and filtered through sintered glass $(1: 1 \mathrm{v} / \mathrm{v} \mathrm{EtOH}:$ EtOAc rinse). The filtrate was concentrated on the rotovap to obtain an oil $(115 \mathrm{mg})$. The residue was chromatographed on $1 \mathrm{~g}$ amino-silica (0 to 20\% v/v MeOH in EtOAc) to afford $\mathbf{S I - 4 2 ~ ( 4 9 . 6 ~ m g , ~} 0.159 \mathrm{mmol}, 76 \%$ yield) as a colorless oil.

${ }^{1}$ H NMR: $\left(392 \mathrm{MHz}, \mathrm{MeOH}-d_{4}, 25^{\circ} \mathrm{C}, \delta\right)$ :

$3.91(\mathrm{dd}, J=9.7,5.2 \mathrm{~Hz}, 1 \mathrm{H}), 3.22(\mathrm{t}, J=7.9 \mathrm{~Hz}, 2 \mathrm{H}), 2.53(\mathrm{t}, J=7.1 \mathrm{~Hz}, 2 \mathrm{H}), 2.35(\mathrm{~m}, 1 \mathrm{H}), 2.07(\mathrm{~m}, 3 \mathrm{H}), 1.95(\mathrm{~m}$, 2H), $1.77(\mathrm{~m}, 1 \mathrm{H}), 1.71(\mathrm{~m}, 1 \mathrm{H}), 1.53(\mathrm{~m}, 4 \mathrm{H}), 1.38(\mathrm{~m}, 2 \mathrm{H}), 1.34(\mathrm{~d}, J=9.7 \mathrm{~Hz}, 1 \mathrm{H}), 1.24(\mathrm{~m}, 2 \mathrm{H}), 1.18(\mathrm{~s}, 3 \mathrm{H})$, $0.86(\mathrm{~s}, 3 \mathrm{H})$.

${ }^{13}$ C NMR: $\left(99 \mathrm{MHz}, \mathrm{MeOH}-d_{4}, 25{ }^{\circ} \mathrm{C}, \delta\right)$ :

175.9, 75.8, 68.7, 52.9, 42.8, 42.3, 41.8, 39.7, 39.2, 37.1, 35.9, 33.3, 28.7, 28.4, 27.5, 26.8, 24.6.

HRMS (ESI-TOF, m/z):

Calc'd for $\mathrm{C}_{17} \mathrm{H}_{33} \mathrm{~N}_{2} \mathrm{O}_{3}{ }^{+}\left([\mathrm{M}+\mathrm{H}]^{+}\right)$313.2486; found 313.2479.

Calc'd for ${ }^{+}\left([\mathrm{M}+\mathrm{Na}]^{+}\right) 335.2305$; found 335.2295. 


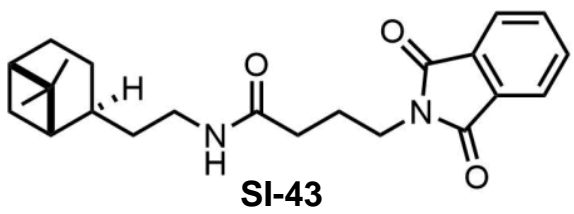

\section{Procedure:}

To a stirred solution of amine SI-32 (219 mg, $1.31 \mathrm{mmol}$ ), carboxylic acid SI-35 (321 mg, $1.37 \mathrm{mmol}, 1.05 \mathrm{eq}$ ), DIPEA ( $273 \mu \mathrm{L}, 1.57 \mathrm{mmol}, 1.2 \mathrm{eq})$ and oxyma ( $37 \mathrm{mg}, 0.26 \mathrm{mmol}, 0.2 \mathrm{eq})$ in $6 \mathrm{~mL}$ DMF was charged EDC.HCl (351 mg, $1.83 \mathrm{mmol}, 1.4 \mathrm{eq}$ ). After 15 hours, most of the DMF was removed on the rotovap. The residue was stirred with $5 \mathrm{~mL}$ EtOAc and $3 \mathrm{~mL} \mathrm{10 \%} \mathrm{NaCl}$. The aq. $\mathrm{pH}$ was adjusted to 3 with citric acid. The layers were separated, and the aqueous material was discarded. The organic material was washed with $3 \mathrm{~mL}$ of $2 \% \mathrm{~K}_{2} \mathrm{CO}_{3}$ then $3 \mathrm{~mL}$ brine, and was dried $\left(\mathrm{Na}_{2} \mathrm{SO}_{4}\right)$, filtered, and concentrated on the rotovap. The residue was adsorbed on $2 \mathrm{~g}$ silica and chromatographed on $10 \mathrm{~g}$ silica (60\% v/v EtOAc in hexane) to afford SI-43 (427.7 mg, $1.12 \mathrm{mmol}, 85 \%$ yield) as an oil which solidified on standing.

${ }^{1} \mathbf{H}$ NMR $\left(500 \mathrm{MHz}, \mathrm{CDCl}_{3}, 25^{\circ} \mathrm{C}, \delta\right)$ :

$7.80(\mathrm{~m}, 2 \mathrm{H}), 7.68(\mathrm{~m}, 2 \mathrm{H}), 5.94(\mathrm{br} \mathrm{s}, 1 \mathrm{H}), 4.07$ (q, $J=7.3 \mathrm{~Hz}, 1 \mathrm{H}), 3.69(\mathrm{t}, J=6.3 \mathrm{~Hz}, 2 \mathrm{H}), 3.16(\mathrm{~m}, 2 \mathrm{H}), 2.26(\mathrm{~m}$, $1 \mathrm{H}), 2.14(\mathrm{t}, J=7.2 \mathrm{~Hz}, 2 \mathrm{H}), 2.01$ to $1.69(\mathrm{~m}, 10 \mathrm{H}), 1.55(\mathrm{q}, J=7.3 \mathrm{~Hz}, 2 \mathrm{H}), 1.40(\mathrm{~m}, 1 \mathrm{H}), 1.21(\mathrm{t}, J=6.9 \mathrm{~Hz}, 1 \mathrm{H})$, $1.12(\mathrm{~s}, 3 \mathrm{H}), 0.94(\mathrm{~s}, 3 \mathrm{H}), 0.82(\mathrm{~d}, J=9.7 \mathrm{~Hz}, 1 \mathrm{H})$.

${ }^{13} \mathrm{C} \mathrm{NMR}\left(126 \mathrm{MHz}, \mathrm{CDCl}_{3}, 25{ }^{\circ} \mathrm{C}, \delta\right):$

171.7, 168.6, 134.0, 131.9, 123.2, 60.3, 46.2, 41.3, 38.7, 38.6, 38.2, 37.24, 37.20, 33.8, 33.5, 28.1, 26.3, 25.0, 23.2, 22.1 .

HRMS (ESI-TOF, m/z):

Calc'd for $\mathrm{C}_{23} \mathrm{H}_{31} \mathrm{~N}_{2} \mathrm{O}_{3}{ }^{+}\left([\mathrm{M}+\mathrm{H}]^{+}\right)$383.2329; found 383.2324.

Calc'd for $\mathrm{C}_{23} \mathrm{H}_{30} \mathrm{~N}_{2} \mathrm{O}_{3} \mathrm{Na}^{+}\left([\mathrm{M}+\mathrm{Na}]^{+}\right)$405.2149; found 405.2137. 


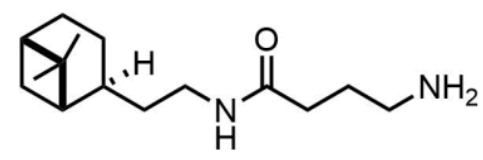

SI-44

\section{Procedure:}

To a stirred solution of SI-43 (96 mg, $0.25 \mathrm{mmol}$ ) in $1.25 \mathrm{~mL}$ EtOH was charged hydrazine monohydrate (36 $\mu \mathrm{L}$, $0.75 \mathrm{mmol}, 3.0 \mathrm{eq}$ ). The mixture was heated in a $65-75^{\circ} \mathrm{C}$ bath for 7.5 hours (note: slurry formation). The mixture was cooled to room temperature, diluted with $1.25 \mathrm{~mL}$ EtOAc, and filtered through sintered glass $(1: 1 \mathrm{v} / \mathrm{v} \mathrm{EtOH}$ : EtOAc rinse). The filtrate was concentrated on the rotovap to obtain white solids (91 $\mathrm{mg}$ ). The residue was chromatographed on $2 \mathrm{~g}$ amino-silica ( $\mathrm{Et}_{2} \mathrm{O}$ to EtOAc) to afford amine SI-44 (42.9 $\mathrm{mg}, 0.170 \mathrm{mmol}, 68 \%$ yield) as a colorless oil.

${ }^{1} \mathbf{H}$ NMR $\left(500 \mathrm{MHz}, \mathrm{MeOH}-d_{4}, 25^{\circ} \mathrm{C}, \delta\right)$ :

$3.05(\mathrm{~m}, 2 \mathrm{H}), 2.53(\mathrm{t}, J=7.2 \mathrm{~Hz}, 2 \mathrm{H}), 2.27(\mathrm{~m}, 1 \mathrm{H}), 2.10(\mathrm{t}, J=7.4 \mathrm{~Hz}, 2 \mathrm{H}), 1.91(\mathrm{~m}, 3 \mathrm{H}), 1.78(\mathrm{~m}, 3 \mathrm{H}), 1.64(\mathrm{~m}$, 2H), 1.49 (q, $J=7.3 \mathrm{~Hz}, 2 \mathrm{H}), 1.40(\mathrm{~m}, 1 \mathrm{H}), 1.10(\mathrm{~s}, 3 \mathrm{H}), 0.93(\mathrm{~s}, 3 \mathrm{H}), 0.82(\mathrm{~d}, J=9.2 \mathrm{~Hz}, 1 \mathrm{H})$.

${ }^{13} \mathrm{C}$ NMR $\left(126 \mathrm{MHz}, \mathrm{MeOH}-d_{4}, 25^{\circ} \mathrm{C}, \delta\right)$ :

175.6, 47.6, 42.8, 42.0, 40.1, 39.7, 39.0, 38.3, 34.54, 34.52, 30.1, 28.7, 27.4, 23.7, 23.3.

HRMS (ESI-TOF, m/z):

Calc'd for $\mathrm{C}_{15} \mathrm{H}_{29} \mathrm{~N}_{2} \mathrm{O}^{+}\left([\mathrm{M}+\mathrm{H}]^{+}\right)$253.2274; found 253.2272.

Calc'd for $\mathrm{C}_{15} \mathrm{H}_{28} \mathrm{~N}_{2} \mathrm{ONa}^{+}\left([\mathrm{M}+\mathrm{Na}]^{+}\right)$275.2094; found 275.2095. 


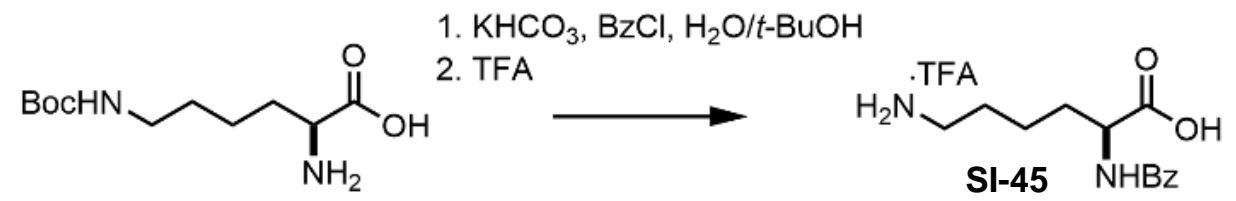

\section{Procedure:}

To a stirred solution of $N^{\varepsilon}$-Boc-lysine (985 mg, $4.0 \mathrm{mmol}$ ) in $9 \mathrm{~mL} 2: 1 \mathrm{v} / \mathrm{v} \mathrm{H}_{2} \mathrm{O}: t-\mathrm{BuOH}$ was charged $\mathrm{KHCO}_{3}$ (599 mg, $6.0 \mathrm{mmol}, 1.5 \mathrm{eq})$ followed by $\mathrm{BzCl}(520 \mu \mathrm{L}, 4.4 \mathrm{mmol}, 1.1 \mathrm{eq})$. (Note: slurry became too thick to stir properly). $10 \mathrm{~mL} \mathrm{H}_{2} \mathrm{O}$ was charged (note: mobile slurry, ninhydrin test showed remaining amine) followed by $\mathrm{BzCl}$ $(120 \mu \mathrm{L}, 1.0 \mathrm{mmol}, 0.25 \mathrm{eq})$. After 1 hour, the $\mathrm{pH}$ was adjusted to 1 with concentrated $\mathrm{HCl}$. The mixture was extracted twice with $10 \mathrm{~mL} \mathrm{CH}_{2} \mathrm{Cl}_{2}$, and the pooled organics were dried $\left(\mathrm{MgSO}_{4}\right)$, filtered, and concentrated. The crude intermediate was filtered through a plug of silica, rinsed with $9: 1 \mathrm{v} / \mathrm{v} \mathrm{CH}_{2} \mathrm{Cl}_{2}: \mathrm{MeOH}$, and concentrated to afford an oil (1.99 g).

To a flask containing the crude intermediate $N^{\alpha}$-Bz- $N^{\varepsilon}$-Boc-lysine was charged $4 \mathrm{~mL}$ TFA. After stirring for 1 hour, the mixture was concentrated on the rotovap. The crude product was purified by preparative HPLC (method B, 0 $100 \% \mathrm{ACN}$ ) in two equal loads to afford SI-45 (470 mg, $1.29 \mathrm{mmol}, 32 \%$ yield over 2 steps) as a white solid.

${ }^{1} \mathbf{H}$ NMR $\left(392 \mathrm{MHz}\right.$, DMSO- $\left.d_{6}, 25^{\circ} \mathrm{C}, \delta\right): 8.60(\mathrm{~d}, J=7.6 \mathrm{~Hz}, 1 \mathrm{H}), 7.88(\mathrm{~d}, J=7.2 \mathrm{~Hz}, 2 \mathrm{H}), 7.78$ (br s, 3H), 7.52 (m, 1H), $7.46(\mathrm{t}, J=7.4 \mathrm{~Hz}, 2 \mathrm{H}), 4.35(\mathrm{~m}, 1 \mathrm{H}), 2.77(\mathrm{~m}, 2 \mathrm{H}), 1.79(\mathrm{~m}, 2 \mathrm{H}), 1.55(\mathrm{~m}, 2 \mathrm{H}), 1.42(\mathrm{~m}, 2 \mathrm{H})$.

${ }^{13}$ C NMR (99 MHz, DMSO- $\left.d_{6}, 25^{\circ} \mathrm{C}, \delta\right): 173.8,166.7,134.0,131.5,128.3,127.6,52.5,48.7,30.1,26.7,22.9$.

HRMS (ESI-TOF, m/z):

Calc'd for $\mathrm{C}_{13} \mathrm{H}_{19} \mathrm{~N}_{2} \mathrm{O}_{3}{ }^{+}\left([\mathrm{M}+\mathrm{H}]^{+}\right)$251.1390; found 251.1398 .

Calc'd for $\mathrm{C}_{13} \mathrm{H}_{18} \mathrm{~N}_{2} \mathrm{O}_{3} \mathrm{Na}^{+}\left([\mathrm{M}+\mathrm{Na}]^{+}\right)$273.1210; found 273.1213. 


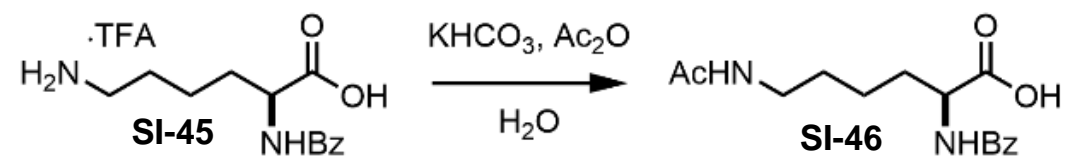

\section{Procedure:}

To a stirred solution of SI-45 (67 mg, $0.18 \mathrm{mmol})$ in $0.2 \mathrm{~mL} \mathrm{H} \mathrm{H}_{2} \mathrm{O}$ was charged $\mathrm{KHCO}_{3}(81.8 \mathrm{mg}, 0.83 \mathrm{mmol}, 4.5 \mathrm{eq})$ (note: gas evolution) followed by $\mathrm{Ac}_{2} \mathrm{O}(22 \mu \mathrm{L}, 0.23 \mathrm{mmol}, 1.25 \mathrm{eq})$. After 1.5 hours, the $\mathrm{pH}$ was adjusted to 4 with TFA. The crude reaction mixture was purified by preparative HPLC (method B, 0 - 100\% ACN) to afford SI-46 (48 $\mathrm{mg}, 0.16 \mathrm{mmol}, 91 \%$ yield) as a white solid.

${ }^{1} \mathbf{H}$ NMR $\left(392 \mathrm{MHz}, \mathrm{CDCl}_{3}, 25^{\circ} \mathrm{C}, \delta\right)$ :

$7.78(\mathrm{~d}, J=7.4 \mathrm{~Hz}, 2 \mathrm{H}), 7.42(\mathrm{~m}, 2 \mathrm{H}), 7.34(\mathrm{t}, J=7.4 \mathrm{~Hz}, 2 \mathrm{H}), 6.30(\mathrm{~m}, 1 \mathrm{H}), 4.80(\mathrm{~m}, 1 \mathrm{H}), 3.35(\mathrm{~m}, 1 \mathrm{H}), 3.18(\mathrm{~m}$, 1H), $1.96(\mathrm{~s}, 3 \mathrm{H}), 1.96(\mathrm{~m}, 1 \mathrm{H}), 1.89(\mathrm{~m}, 1 \mathrm{H}), 1.54(\mathrm{~m}, 2 \mathrm{H}), 1.43(\mathrm{~m}, 2 \mathrm{H})$.

${ }^{13} \mathbf{C}$ NMR $\left(99 \mathrm{MHz}, \mathrm{CDCl}_{3}, 25{ }^{\circ} \mathrm{C}, \delta\right)$ :

174.6, 172.4, 168.0, 133.2, 132.0, 128.5, 127.2, 52.4, 39.0, 31.4, 28.5, 22.7, 22.0.

\section{HRMS (ESI-TOF, m/z):}

Calc'd for $\mathrm{C}_{15} \mathrm{H}_{21} \mathrm{~N}_{2} \mathrm{O}_{4}{ }^{+}\left([\mathrm{M}+\mathrm{H}]^{+}\right)$293.1496; found 293.1508.

Calc'd for $\mathrm{C}_{15} \mathrm{H}_{20} \mathrm{~N}_{2} \mathrm{O}_{4} \mathrm{Na}^{+}\left([\mathrm{M}+\mathrm{Na}]^{+}\right) 315.1315$; found 315.1317. 

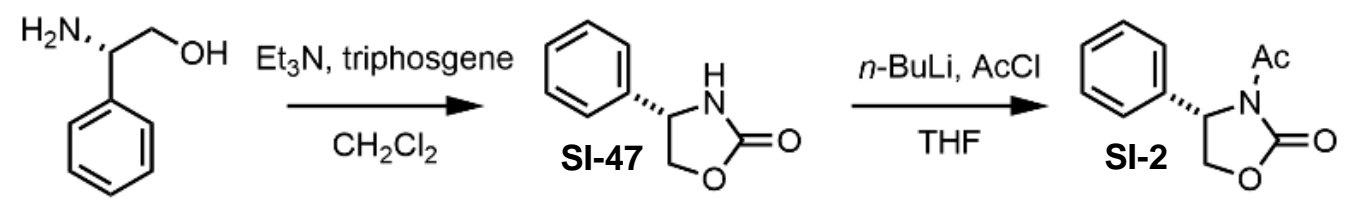

\section{Procedure:}

To a stirred $-10{ }^{\circ} \mathrm{C}$ solution of $(S)$-2-phenylglycinol $(69 \mathrm{mg}, 0.50 \mathrm{mmol}), \mathrm{Et}_{3} \mathrm{~N}(174 \mu \mathrm{L}, 1.25 \mathrm{mmol}, 2.5 \mathrm{eq})$ in $4 \mathrm{~mL}$ $\mathrm{CH}_{2} \mathrm{Cl}_{2}$ was charged dropwise a solution of triphosgene $(178 \mathrm{mg}, 0.6 \mathrm{mmol}, 1.2 \mathrm{eq})$ in $1 \mathrm{~mL} \mathrm{CH}_{2} \mathrm{Cl}_{2}$, and the cooling bath was removed. After 14 hours, the mixture was extracted with $5 \mathrm{~mL}$ EtOAc and $5 \mathrm{~mL} \mathrm{H}_{2} \mathrm{O}$. The aqueous material was discarded, and the organic material was washed with brine, dried $\left(\mathrm{MgSO}_{4}\right)$, filtered, and concentrated on the rotovap. The crude material was chromatographed on $3 \mathrm{~g}$ silica (40 to $80 \% \mathrm{v} / \mathrm{v}$ EtOAc in hexane) to afford the intermediate SI-47 (59.8 $\mathrm{mg}, 0.37 \mathrm{mmol}, 73 \%$ yield) as a white solid.

To a $-78{ }^{\circ} \mathrm{C}$ solution of SI-47 (48 $\left.\mathrm{mg}, 0.29 \mathrm{mmol}\right)$ in $1 \mathrm{~mL}$ THF was charged $n$-butyllithium (1.55 M solution, 0.22 $\mathrm{mL}, 0.33 \mathrm{mmol}, 1.15 \mathrm{eq})$. After 5 minutes, $\mathrm{AcCl}(41 \mu \mathrm{L}, 0.58 \mathrm{mmol}, 2 \mathrm{eq})$ was charged, and the cooling bath was removed. After 2.5 hours, the mixture was extracted with $3 \mathrm{~mL}$ MTBE and $2 \mathrm{~mL} \mathrm{10 \%} \mathrm{NaCl}$. The aqueous material was discarded, and the organic material was washed with brine, dried $\left(\mathrm{MgSO}_{4}\right)$, filtered, and concentrated on the rotovap. The crude material was chromatographed on $10 \mathrm{~g}$ silica (30 to 50\% v/v EtOAc in hexane) to afford SI-2 (33.9 mg, $0.17 \mathrm{mmol}, 57 \%$ yield) as a white solid.

${ }^{1} \mathbf{H} \mathbf{N M R}\left(500 \mathrm{MHz}, \mathrm{CDCl}_{3}, 25^{\circ} \mathrm{C}, \delta\right)$ :

$7.27(\mathrm{~m}, 5 \mathrm{H}), 5.37(\mathrm{dd}, J=8.6,3.4 \mathrm{~Hz}, 1 \mathrm{H}), 4.63(\mathrm{t}, J=8.9 \mathrm{~Hz}, 1 \mathrm{H}), 4.23(\mathrm{dd}, J=9.2,3.4 \mathrm{~Hz}, 1 \mathrm{H}), 2.47(\mathrm{~s}, 3 \mathrm{H})$.

${ }^{13} \mathrm{C}$ NMR $\left(126 \mathrm{MHz}, \mathrm{CDCl}_{3}, 25^{\circ} \mathrm{C}, \delta\right)$ :

$169.7,153.9,139.0,129.1,128.7,125.9,69.9,57.4,23.7$.

HRMS (ESI-TOF, m/z):

Calc'd for $\mathrm{C}_{11} \mathrm{H}_{11} \mathrm{NO}_{3} \mathrm{Na}^{+}\left([\mathrm{M}+\mathrm{Na}]^{+}\right)$228.0631; found 228.0636. 


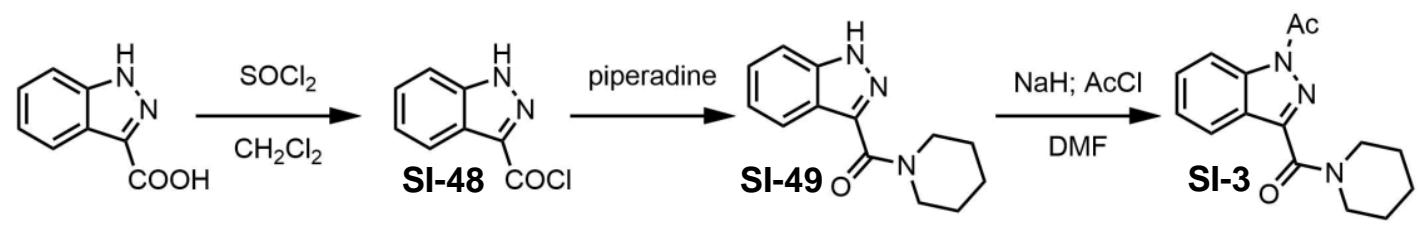

\section{Procedure:}

To a flask containing indazole-3-carboxylic acid $(162 \mathrm{mg}, 1.0 \mathrm{mmol})$ was charged $1.5 \mathrm{~mL}$ thionyl chloride. The mixture was stirred in an $80^{\circ} \mathrm{C}$ bath for 15 minutes, concentrated on the rotovap, and co-evaporated with $2 \times 5 \mathrm{~mL}$ PhMe to obtain crude acid chloride SI-48.

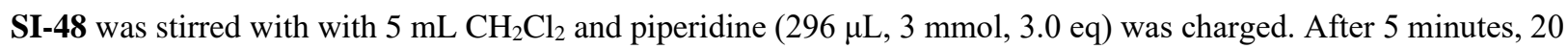
$\mathrm{mL} \mathrm{Et}_{2} \mathrm{O}$ was charged, the organics were washed with $3 \times 10 \mathrm{~mL} \mathrm{H}_{2} \mathrm{O}$, and the mixture was concentrated on the rotovap to obtain crude amide SI-49.

To a stirred solution of SI-49 in $6 \mathrm{~mL}$ DMF was charged $\mathrm{NaH}$ (55\% in mineral oil, $52 \mathrm{mg}, 1.2 \mathrm{mmol}, 1.2 \mathrm{eq}$ ). After $10 \mathrm{~min}, \mathrm{AcCl}$ ( $143 \mu \mathrm{L}, 2 \mathrm{mmol}, 2.0 \mathrm{eq})$ was charged. After 10 minutes, the reaction was quenched to stirred $50 \mathrm{~mL}$ EtOAc and $25 \mathrm{~mL} \mathrm{pH} 4$ buffer. The aqueous material was discarded, and the organics were washed with brine, dried $\left(\mathrm{MgSO}_{4}\right)$, filtered, and concentrated on the rotovap. The crude material was chromatographed on $12 \mathrm{~g}$ silica (1:1 $\mathrm{v} / \mathrm{vt}_{2} \mathrm{O}$ : pentane) to afford $\mathbf{S I - 3}$ (128.6 $\mathrm{mg}, 0.474 \mathrm{mmol}, 47 \%$ yield over 3 steps) as a white solid.

${ }^{1} \mathbf{H}$ NMR $\left(500 \mathrm{MHz}\right.$, DMSO-d $\left.6,2{ }^{\circ} \mathrm{C}, \delta\right)$ :

$8.33(\mathrm{~m}, 1 \mathrm{H}), 7.90(\mathrm{~m}, 1 \mathrm{H}), 7.66(\mathrm{~m}, 1 \mathrm{H}), 7.46(\mathrm{~m}, 1 \mathrm{H}), 3.69(\mathrm{~m}, 2 \mathrm{H}), 3.64(\mathrm{~m}, 2 \mathrm{H}), 2.71(\mathrm{~m}, 3 \mathrm{H}), 1.63(\mathrm{~m}, 4 \mathrm{H})$, $1.54(\mathrm{~m}, 2 \mathrm{H})$.

${ }^{13}$ C NMR $\left(126 \mathrm{MHz}\right.$, DMSO-d $\left.6,25{ }^{\circ} \mathrm{C}, \delta\right)$ :

171.0. 160.3, 144.1, 138.7, 130.1, 125.1, 124.7, 121.6, 114.8, 47.5, 42.7, 26.4, 25.4, 24.0, 22.8.

HRMS (ESI-TOF, m/z):

Calc'd for $\mathrm{C}_{15} \mathrm{H}_{18} \mathrm{~N}_{3} \mathrm{O}_{2}{ }^{+}\left([\mathrm{M}+\mathrm{H}]^{+}\right)$272.1394; found 272.1388.

Calc'd for $\mathrm{C}_{15} \mathrm{H}_{17} \mathrm{~N}_{3} \mathrm{O}_{2} \mathrm{Na}^{+}\left([\mathrm{M}+\mathrm{Na}]^{+}\right)$294.1213; found 294.1217. 


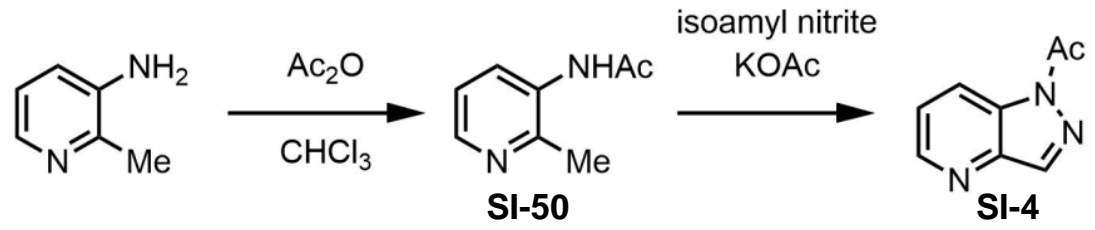

\section{Procedure:}

To a stirred solution of 2-methyl-3-aminopyridine (541 mg, $5.0 \mathrm{mmol})$ in $10.8 \mathrm{~mL} \mathrm{CHCl} 3$ was charged $\mathrm{Ac}_{2} \mathrm{O}(1087$ $\mu \mathrm{L}, 11.5 \mathrm{mmol}, 2.3 \mathrm{eq})$. After one hour, KOAc (147 mg, $1.5 \mathrm{mmol}, 0.3 \mathrm{eq})$ and isoamyl nitrite (1444 $\mu \mathrm{L}, 10.75$ mmol, 2.15 eq) were charged, and the mixture was heated in a $60-65{ }^{\circ} \mathrm{C}$ bath for 15 hours. The reaction was cooled to room temperature, $10 \mathrm{~mL}$ MTBE and $5 \mathrm{~mL} 10 \% \mathrm{NaCl}$ were charged, and the aqueous layer was basified to $\mathrm{pH} 5$ with trisodium citrate. The aqueous material was discarded, and the organics were washed with brine, dried $\left(\mathrm{Na}_{2} \mathrm{SO}_{4}\right)$, filtered, and concentrated on the rotovap. The crude material was purified by column chromatography on $25 \mathrm{~g}$ silica (60 to $80 \% \mathrm{v} / \mathrm{v}$ EtOAc in hexane) and then triturated with $2 \times 2 \mathrm{~mL} 1: 1 \mathrm{v} / \mathrm{v}$ MTBE : hexane to afford SI4 (37.6 mg, $0.23 \mathrm{mmol}, 4.7 \%$ over two steps) as a tan solid.

${ }^{1} \mathrm{H}$ NMR $\left(500 \mathrm{MHz}, \mathrm{CDCl}_{3}, 25^{\circ} \mathrm{C}, \delta\right)$ :

$8.68(\mathrm{~m}, 2 \mathrm{H}), 8.33(\mathrm{~m}, 1 \mathrm{H}), 7.43(\mathrm{~m}, 1 \mathrm{H}), 2.77(\mathrm{~s}, 3 \mathrm{H})$.

${ }^{13} \mathrm{C}$ NMR $\left(126 \mathrm{MHz}, \mathrm{CDCl}_{3}, 25^{\circ} \mathrm{C}, \delta\right)$ :

$171.2,148.4,144.2,140.3,132.5,123.3,123.2,22.4$.

HRMS (ESI-TOF, m/z):

Calc'd for $\mathrm{C}_{8} \mathrm{H}_{8} \mathrm{~N}_{3} \mathrm{O}^{+}\left([\mathrm{M}+\mathrm{H}]^{+}\right)$162.0662; found 162.0651. 


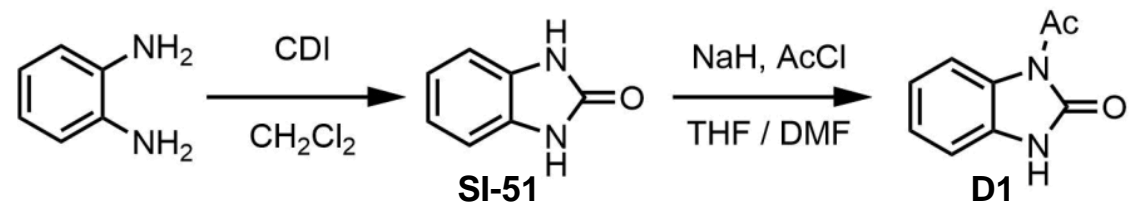

\section{Procedure:}

To a stirred solution of 1,2-phenylenediamine (216 mg, $2.0 \mathrm{mmol}$ ) in $1.5 \mathrm{~mL} \mathrm{CH}_{2} \mathrm{Cl}_{2}$ was charged $\mathrm{CDI}(357 \mathrm{mg}, 2.2$ mmol, $1.1 \mathrm{eq}$ ) (note: slurry formation). After 10 minutes, the slurry was filtered through fritted glass and rinsed with forward $2 \mathrm{~mL} 1: 1 \mathrm{v} / \mathrm{v} \mathrm{CH}_{2} \mathrm{Cl}_{2}$ : MTBE. The solids were dried on the rotovap to afford SI-51 (189 mg, $1.4 \mathrm{mmol}$, $70 \%$ yield) as a white powder.

To a stirred suspension of SI-51 (34 mg, $0.25 \mathrm{mmol}$ ) in $150 \mu \mathrm{L}$ THF and $50 \mu \mathrm{L}$ DMF was charged $\mathrm{NaH}$ (55\% in mineral oil, $11.4 \mathrm{mg}, 0.26 \mathrm{mmol}, 1.05 \mathrm{eq})$. After 5 minutes $\mathrm{AcCl}(36 \mu \mathrm{L}, 0.50 \mathrm{mmol}, 2.0 \mathrm{eq})$ was charged. After 30 minutes, the reaction was diluted with $2 \mathrm{~mL}$ EtOAc and $0.25 \mathrm{~mL} \mathrm{H}_{2} \mathrm{O}$, and the aqueous $\mathrm{pH}$ was adjusted to 5 with citric acid. The aqueous material was discarded, and the organic material was washed with brine, dried $\left(\mathrm{MgSO}_{4}\right)$, filtered, and concentrated on the rotovap. The crude material was chromatographed on $10 \mathrm{~g}$ silica ( 25 to $35 \% \mathrm{v} / \mathrm{v}$ EtOAc in hexane) to afford D1 (17.9 $\mathrm{mg}, 0.10 \mathrm{mmol}, 41 \%$ yield) as a white solid.

${ }^{1} \mathbf{H}$ NMR $\left(392 \mathrm{MHz}\right.$, DMSO-d $\left.6,25^{\circ} \mathrm{C}, \delta\right)$ :

$7.97(\mathrm{~d}, J=8.1 \mathrm{~Hz}, 1 \mathrm{H}), 7.16(\mathrm{t}, J=7.6 \mathrm{~Hz}, 1 \mathrm{H}), 7.05(\mathrm{t}, J=7.8 \mathrm{~Hz}, 1 \mathrm{H}), 7.02(\mathrm{~d}, J=7.6 \mathrm{~Hz}, 1 \mathrm{H}), 2.59$ (s, 3H).

${ }^{13} \mathrm{C}$ NMR $\left(99 \mathrm{MHz}\right.$, DMSO-d $\left.6,25^{\circ} \mathrm{C}, \delta\right)$ :

$170.5,152.5,128.9,127.0,124.5,121.7,114.9,109.1,25.3$.

HRMS (ESI-TOF, m/z):

Calc'd for $\mathrm{C}_{9} \mathrm{H}_{8} \mathrm{~N}_{2} \mathrm{O}_{2} \mathrm{Na}^{+}\left([\mathrm{M}+\mathrm{H}]^{+}\right)$199.0478; found 199.0448. 


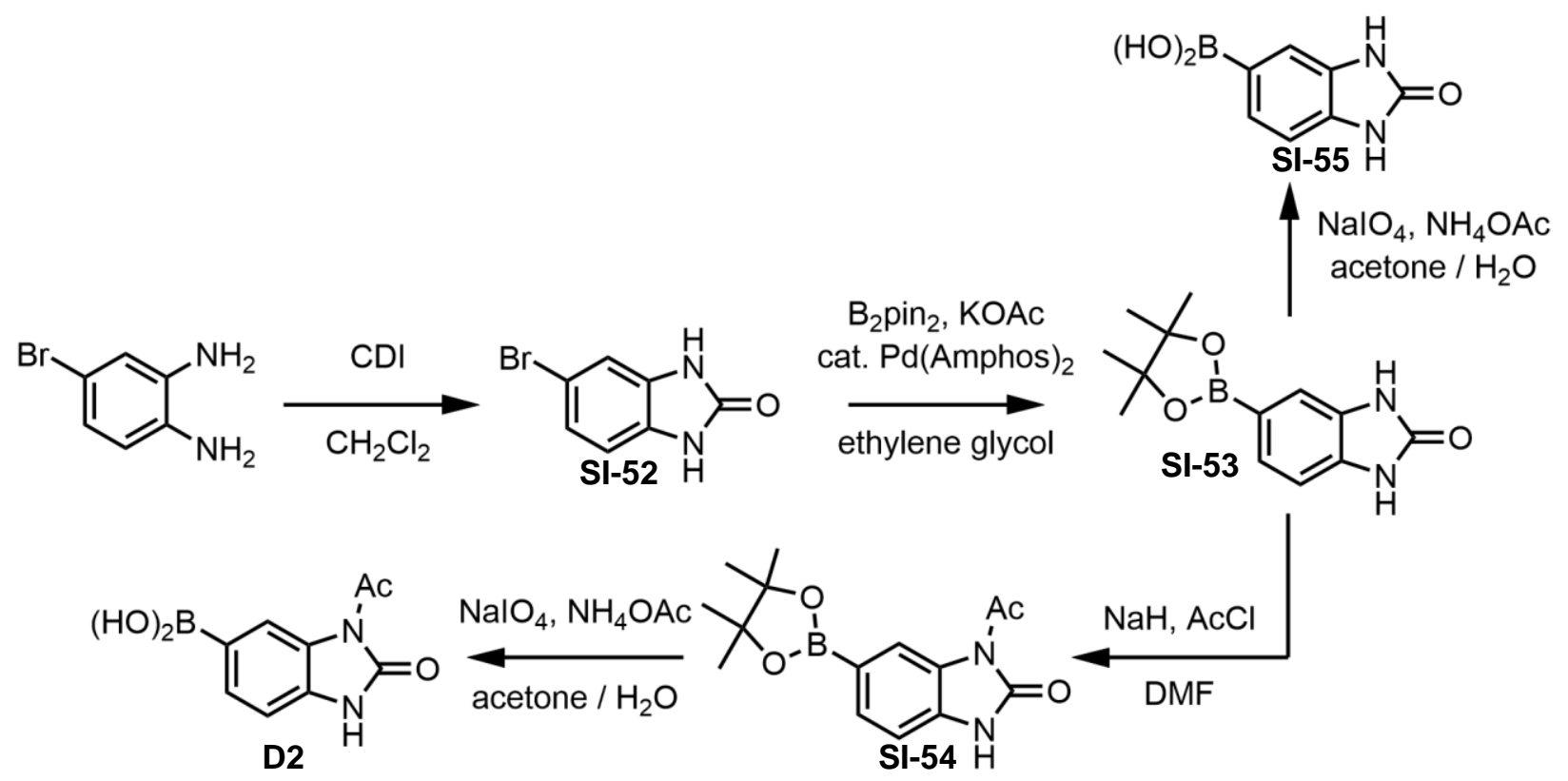




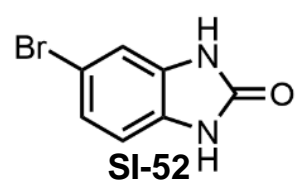

\section{Procedure:}

To a stirred 0 to $5^{\circ} \mathrm{C}$ suspension of 4-bromo-1,2-phenylenediamine $(3.40 \mathrm{~g}, 18.2 \mathrm{mmol})$ in $30 \mathrm{~mL} \mathrm{CH}_{2} \mathrm{Cl}_{2} \mathrm{was}$ charged CDI (3.24 g, $20.0 \mathrm{mmol}, 1.1 \mathrm{eq})$ in portions over 5 minutes. The cooling bath was then removed, and the mixture was aged for 1 hour. The mixture was concentrated, slurried in $40 \mathrm{~mL} 1: 1 \mathrm{v} / \mathrm{v} \mathrm{EtOH} / \mathrm{H}_{2} \mathrm{O}$, and filtered through fritted glass. The solids were dried on the rotovap to obtain a brown powder ( $3.4 \mathrm{~g})$. The crude material was adsorbed on $10 \mathrm{~g}$ silica and chromatographed on $50 \mathrm{~g}$ silica (5 to $10 \% \mathrm{v} / \mathrm{v} \mathrm{MeOH}$ in $\mathrm{CH}_{2} \mathrm{Cl}_{2}$ ) to afford $\mathbf{S I - 5 2}$ (2.32 g, $10.8 \mathrm{mmol}, 60 \%$ yield) as a brown powder.

${ }^{\mathbf{1}} \mathbf{H}$ NMR $\left(500 \mathrm{MHz}, \mathrm{DMSO}-d_{6}, 25^{\circ} \mathrm{C}, \delta\right)$ :

$10.73(\mathrm{~s}, 2 \mathrm{H}), 7.02(\mathrm{~m}, 2 \mathrm{H}), 6.83(\mathrm{~m}, 1 \mathrm{H})$.

${ }^{13}$ C NMR (126 MHz, DMSO- $\left.d_{6}, 25^{\circ} \mathrm{C}, \delta\right)$ :

$155.1,131.2,129.0,122.9,112.0,111.1,110.1$.

HRMS (ESI-TOF, m/z):

Calc'd for $\mathrm{C}_{7} \mathrm{H}_{6} \mathrm{BrN}_{2} \mathrm{O}^{+}\left([\mathrm{M}+\mathrm{H}]^{+}\right)$212.9658/214.9638; found 212.9642/214.9611. 


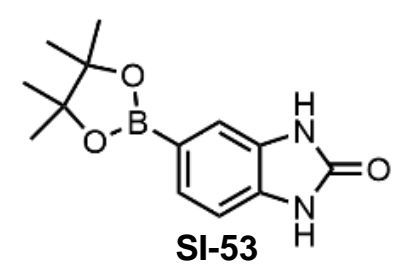

\section{Procedure:}

To a flask was charged SI-52 (2.30 g, $10.8 \mathrm{mmol})$, KOAc (2.96 g, $30.2 \mathrm{mmol}, 2.8 \mathrm{eq}), \mathrm{B}_{2} \operatorname{pin}_{2}(4.94 \mathrm{~g}, 19.4 \mathrm{mmol}$, $1.8 \mathrm{eq})$ and $\mathrm{PdCl}_{2}$ (amphos) $)_{2}(38 \mathrm{mg}, 54 \mu \mathrm{mol}, 0.5 \mathrm{~mol} \%$ ) followed by $23 \mathrm{~mL}$ ethylene glycol. The mixture was stirred at 85 to $95^{\circ} \mathrm{C}$ for 14 hours and cooled to room temperature. The mixture was diluted with $30 \mathrm{~mL} \mathrm{H}_{2} \mathrm{O}, 20 \mathrm{~mL}$ $\mathrm{Et}_{2} \mathrm{O}$, and $10 \mathrm{~mL}$ hexane. The slurry was filtered through sintered glass and rinsed forward with $10 \mathrm{~mL} \mathrm{H}_{2} \mathrm{O}$ and 10 $\mathrm{mL} 1: 1 \mathrm{v} / \mathrm{v} \mathrm{Et}_{2} \mathrm{O}$ : hexane. The solids were dried to afford $\mathbf{S I - 5 3}$ (2.72 g, $10.5 \mathrm{mmol}$, 97\% yield) as a brown powder.

${ }^{1} \mathbf{H}$ NMR $\left(500 \mathrm{MHz}\right.$, DMSO- $\left.d_{6}, 25^{\circ} \mathrm{C}, \delta\right)$ :

10.76 (br s, 1H), 10.67 (br s, 1H), 7.28 (s, 1H), $7.18(\mathrm{~s}, 1 \mathrm{H}), 6.92(\mathrm{~s}, 1 \mathrm{H}), 1.24(\mathrm{~s}, 12 \mathrm{H})$.

${ }^{13} \mathrm{C}$ NMR (126 MHz, DMSO- $\left.d_{6}, 25{ }^{\circ} \mathrm{C}, \delta\right): 155.3,132.6,129.4,127.6,114.0,108.1,83.3,24.7$.

HRMS (ESI-TOF, m/z):

Calc'd for $\mathrm{C}_{13} \mathrm{H}_{18} \mathrm{BN}_{2} \mathrm{O}_{3}{ }^{+}\left([\mathrm{M}+\mathrm{H}]^{+}\right)$261.1405; found 261.1392.

Calc'd for $\mathrm{C}_{13} \mathrm{H}_{17} \mathrm{BN}_{2} \mathrm{O}_{3} \mathrm{Na}^{+}\left([\mathrm{M}+\mathrm{H}]^{+}\right)$283.1224; found 283.1224. 


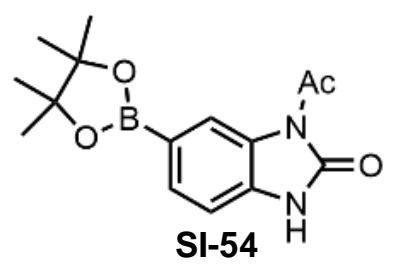

\section{Procedure:}

To a stirred solution of SI-53 ( $86.5 \mathrm{mg}, 0.33 \mathrm{mmol}$ ) in $1.3 \mathrm{~mL}$ DMF was charged NaH (55 w/w\% in mineral oil, $15.2 \mathrm{mg}, 0.35 \mathrm{mmol}, 1.05 \mathrm{eq})$. After 5 minutes $\mathrm{AcCl}(33 \mu \mathrm{L}, 0.46 \mathrm{mmol}, 1.4 \mathrm{eq})$ was charged. After 5 minutes $6 \mathrm{~mL}$ THF and $3 \mathrm{~mL} 10 \%$ aq. $\mathrm{NaCl}$ was charged. The aqueous material was discarded. The organic material was washed with $3 \times 2 \mathrm{~mL}$ brine, dried $\left(\mathrm{MgSO}_{4}\right)$, filtered, and concentrated. The crude material was chromatographed on $10 \mathrm{~g}$ silica (2\% v/v MeOH in EtOAc) to afford SI-54 (24.7 mg $0.082 \mathrm{mmol}, 25 \%$ yield) as a white solid (note: a ca. 1.5 : 1 mixture of the desired material (isomer A) and a regioisomer (isomer B)).

${ }^{1} \mathbf{H}$ NMR $\left(500 \mathrm{MHz}, \mathrm{CDCl}_{3}, 25^{\circ} \mathrm{C}, \delta\right)$ :

9.25 (br s, $1 \mathrm{H}$, isomers A and B), 8.52 (s, $1 \mathrm{H}$, isomer B), 8.10 (d, $J=8.0 \mathrm{~Hz}$, isomer A), $7.60(\mathrm{~d}, J=8.0 \mathrm{~Hz}$, isomer B), $7.55(\mathrm{~d}, J=8.0 \mathrm{~Hz}$, isomer A), $7.42(\mathrm{~s}, 1 \mathrm{H}$, isomer A), $6.98(\mathrm{~d}, J=8.0 \mathrm{~Hz}$, isomer B), 2.72 (s, 3H, isomer A), $2.70(\mathrm{~s}, 3 \mathrm{H}$ isomer $\mathrm{B}), 1.29(\mathrm{~s}, 12 \mathrm{H}$, isomer $\mathrm{A}), 1.27(\mathrm{~s}, 12 \mathrm{H}$, isomer $\mathrm{B})$.

${ }^{13} \mathrm{C}$ NMR $\left(126 \mathrm{MHz}, \mathrm{CDCl}_{3}, 25{ }^{\circ} \mathrm{C}, \delta\right)$ :

$170.5,170.2,153.64,153.59,131.7,130.2,129.9,129.7,127.3,127.1,121.8,115.3,114.9,108.6,84.1,83.9,25.79$, 25.76, 24.9.

HRMS (ESI-TOF, m/z):

Calc'd for $\mathrm{C}_{15} \mathrm{H}_{20} \mathrm{BN}_{2} \mathrm{O}_{4}{ }^{+}\left([\mathrm{M}+\mathrm{H}]^{+}\right)$303.1511; found 303.1512.

Calc'd for $\mathrm{C}_{15} \mathrm{H}_{19} \mathrm{BN}_{2} \mathrm{O}_{4} \mathrm{Na}^{+}\left([\mathrm{M}+\mathrm{Na}]^{+}\right)$325.1330; found 325.1336. 


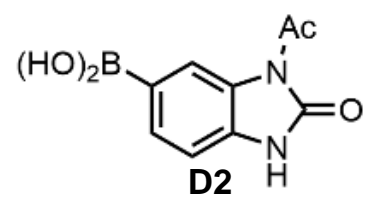

\section{Procedure:}

To a vial was charged SI-54 (302.8 mg, $1.0 \mathrm{mmol}), \mathrm{NH}_{4} \mathrm{OAc}(154 \mathrm{mg}, 2.0 \mathrm{mmol}, 2.0 \mathrm{eq})$, and $\mathrm{NaIO}_{4}(642 \mathrm{mg}, 3.0$ mmol, 3.0 eq) followed by $10 \mathrm{~mL} 2: 1 \mathrm{v} / \mathrm{v}$ acetone : $\mathrm{H}_{2} \mathrm{O}$. The mixture stirred at 35 to $45^{\circ} \mathrm{C}$. After 13 hours, the mixture was cooled to room temperature and concentrated on the rotovap. The residue was suspended in $20 \mathrm{~mL}$ acetone, filtered through Celite, and concentrated on the rotovap. The crude material was then suspended in $6 \mathrm{~mL}$ $1: 1 \mathrm{v} / \mathrm{v} \mathrm{MeOH} / \mathrm{H}_{2} \mathrm{O}$ and syringe filtered. Purification by preparative HPLC (method B, $5-70 \%$ ACN) in three 2 $\mathrm{mL}$ loads afforded D2. (9.88 mg, $44.9 \mu \mathrm{mol}, 4.5 \%$ yield) as a white solid (note: product is difficult to handle due to low solubility).

${ }^{1} \mathbf{H}$ NMR $\left(392 \mathrm{MHz}\right.$, acetone- $\left.d_{6}, 25{ }^{\circ} \mathrm{C}, \delta\right)$ :

10.30 (br s, 1H), 8.57 (s, 1H), $7.72(\mathrm{~d}, J=7.6 \mathrm{~Hz}, 1 \mathrm{H}), 7.51$ (br s, 1H), 7.05 (d, $J=7.6 \mathrm{~Hz}, 1 \mathrm{H}), 2.64$ (s, 3H).

${ }^{13} \mathbf{C}$ NMR $\left(99 \mathrm{MHz}\right.$, acetone- $\left.d_{6}, 25^{\circ} \mathrm{C}, \delta\right)$ :

$170.9,153.6,131.7,131.6,128.2,121.6,108.9,25.5$.

HRMS (ESI-TOF, m/z):

Calc'd for $\mathrm{C}_{9} \mathrm{H}_{8} \mathrm{BN}_{2} \mathrm{O}_{3}{ }^{-}\left([\mathrm{M}-\mathrm{H}]^{-}\right)$219.0583; found 219.0587.

(note: the expected $[\mathrm{M}+\mathrm{H}]^{+}$and $[\mathrm{M}+\mathrm{Na}]^{+}$peaks could not be detected). 


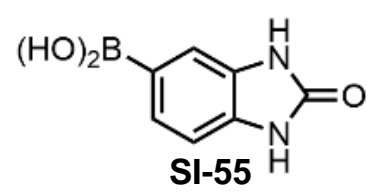

\section{Procedure:}

To a stirred suspension of SI-53 (66.4 mg, $0.26 \mathrm{mmol})$ in $1 \mathrm{~mL} 1: 1 \mathrm{v} / \mathrm{v}$ acetone : $\mathrm{H}_{2} \mathrm{O}$ was charged $\mathrm{NaIO}_{4}(165 \mathrm{mg}$, $0.77 \mathrm{mmol}, 3 \mathrm{eq})$ followed by $\mathrm{NH}_{4} \mathrm{OAc}(39 \mathrm{mg}, 0.51 \mathrm{mmol}, 2 \mathrm{eq})$, and the mixture was heated at $45-55{ }^{\circ} \mathrm{C}$. After 5 hours, the reaction was adsorbed onto $0.9 \mathrm{~g}$ silica and chromatographed on $2 \mathrm{~g}$ silica ( $30 \% \mathrm{v} / \mathrm{v} \mathrm{MeOH}$ in $\mathrm{CHCl}_{3}$ ). The product was then repurified by preparative HPLC (method B, 0 - 50\% ACN) to afford SI-55 (3.4 mg, 19.2 $\mu \mathrm{mol}, 7.4 \%$ yield) as a white solid.

${ }^{1} \mathbf{H}$ NMR (392 MHz, DMSO- $\left.d_{6}, 25^{\circ} \mathrm{C}, \delta\right)$ :

$10.61(\mathrm{~s}, 1 \mathrm{H}), 10.57(\mathrm{~s}, 2 \mathrm{H}), 7.40(\mathrm{~d}, J=7.6 \mathrm{~Hz}, 1 \mathrm{H}), 7.35$ (s, 1H), $6.86(\mathrm{~d}, J=7.6 \mathrm{~Hz}, 1 \mathrm{H})$.

${ }^{13} \mathrm{C}$ NMR $\left(99 \mathrm{MHz}\right.$, DMSO- $\left.d_{6}, 25^{\circ} \mathrm{C}, \delta\right)$ :

$155.4,131.5,129.2,127.1,114.0,107.6$.

HRMS (ESI-TOF, m/z):

Calc'd for $\mathrm{C}_{7} \mathrm{H}_{8} \mathrm{BN}_{2} \mathrm{O}_{3}{ }^{+}\left([\mathrm{M}+\mathrm{H}]^{-}\right)$179.0622; found 179.0636 . 


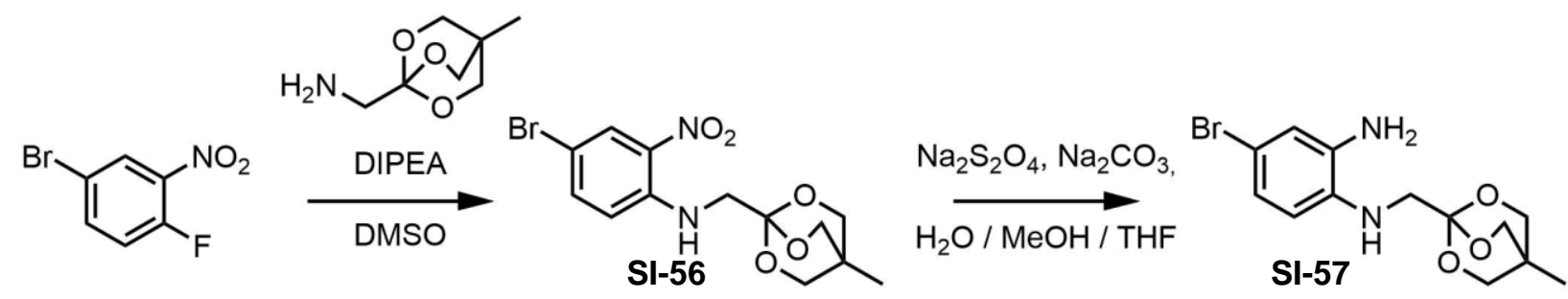

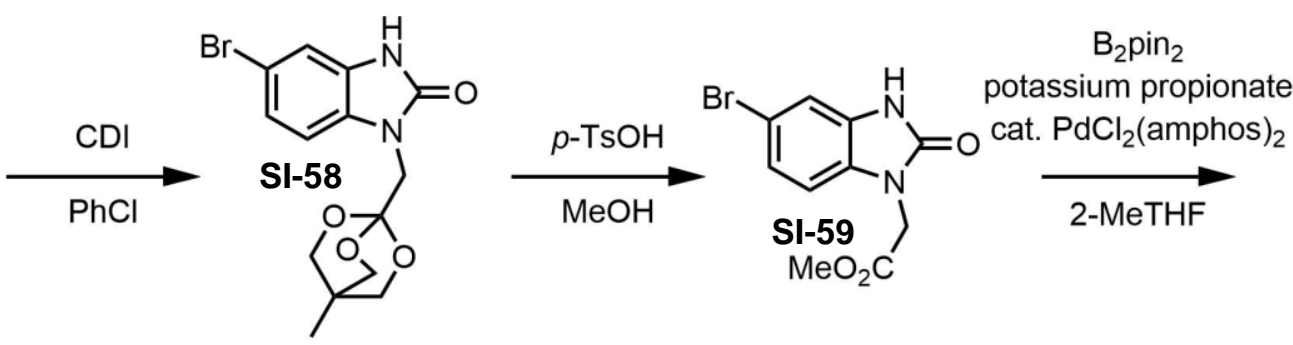<smiles>COCCn1c(=O)[nH]c2cc(B3OC(C)(C)C(C)(C)O3)ccc21</smiles><smiles>COCCn1c(=O)n(C)c2cc(B3OC(C)(C)C(C)(C)O3)ccc21</smiles>

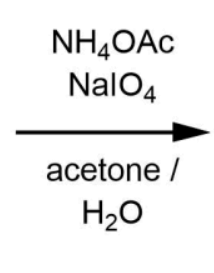

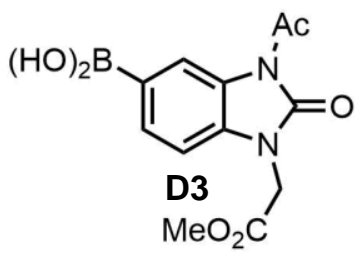




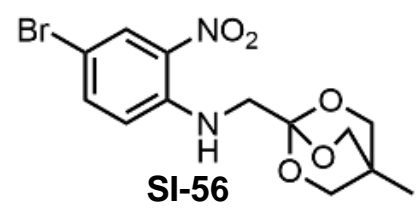

\section{Procedure:}

To a stirred solution of 4-bromo-1-fluoro-2-nitrobenzene (3.70 g, $16.8 \mathrm{mmol})$ in $50 \mathrm{~mL}$ DMSO was charged DIPEA (4.4 mL, $25.2 \mathrm{mmol}, 1.5 \mathrm{eq}$ ) and amine 1-(aminomethyl)-4-methyl-2,6,7-trioxabiyclo[2,2,2]octane ${ }^{3}$ (4.02 g, 25.2 mmol 1.5 eq). After 14.5 hours, the mixture was poured into a stirred mixture of $100 \mathrm{~mL}$ EtOAc and $100 \mathrm{~mL} 10 \%$ $\mathrm{NaCl} / 1 \% \mathrm{Na}_{2} \mathrm{HPO}_{4}$. The aqueous material was discarded. The organic material was washed with $3 \times 50 \mathrm{~mL}$ brine, dried $\left(\mathrm{Na}_{2} \mathrm{SO}_{4}\right)$, filtered, and concentrated on the rotovap. The crude material was adsorbed on $12 \mathrm{~g}$ amino-silica and chromatographed on $24 \mathrm{~g}$ amino-silica (20 to $40 \% \mathrm{v} / \mathrm{v}$ EtOAc in hexane) to afford SI-56 (5.89 g, $16.4 \mathrm{mmol}$, $98 \%$ yield) as a yellow solid.

${ }^{1} \mathbf{H}$ NMR $\left(392 \mathrm{MHz}, \mathrm{CDCl}_{3}, 25^{\circ} \mathrm{C}, \delta\right)$ :

$8.22(\mathrm{~d}, J=2.2 \mathrm{~Hz}, 1 \mathrm{H}), 8.15(\mathrm{br} \mathrm{t}, J=5.8 \mathrm{~Hz}, 1 \mathrm{H}), 7.39(\mathrm{~d}, J=9.2,2.2 \mathrm{~Hz}, 1 \mathrm{H}), 7.20(\mathrm{~d}, J=9.2 \mathrm{~Hz}, 1 \mathrm{H}), 3.89(\mathrm{~s}$, $6 \mathrm{H}), 3.40(\mathrm{~d}, J=5.8 \mathrm{~Hz}, 2 \mathrm{H}), 0.77$ (s, 3H).

${ }^{13} \mathrm{C}$ NMR (99 MHz, $\left.\mathrm{CDCl}_{3}, 25^{\circ} \mathrm{C}, \delta\right)$ :

144.3, 138.7, 132.6, 128.7, 116.1, 107.3, 106.6, 72.8, 47.8, 30.7, 14.3.

HRMS (ESI-TOF, m/z):

Calc'd for $\mathrm{C}_{13} \mathrm{H}_{16} \mathrm{BrN}_{2} \mathrm{O}_{5}^{+}\left([\mathrm{M}+\mathrm{H}]^{+}\right)$359.0237/361.0217; found 359.0213/361.0210. 


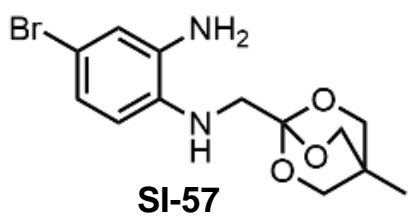

\section{Procedure:}

To a stirred suspension of $\mathrm{Na}_{2} \mathrm{CO}_{3}(11.1 \mathrm{~g}, 105 \mathrm{mmol}, 6.4 \mathrm{eq})$ and $\mathrm{Na}_{2} \mathrm{~S}_{2} \mathrm{O}_{4}(18.3 \mathrm{~g}, 105 \mathrm{mmol}, 6.4 \mathrm{eq})$ in $90 \mathrm{~mL}$ $\mathrm{H}_{2} \mathrm{O}, 30 \mathrm{~mL} \mathrm{MeOH}$, and $20 \mathrm{~mL}$ THF was charged SI-56 (5.89 g, $16.4 \mathrm{mmol}$ ) in portions over 20 minutes (note: exotherm). The starting material was rinsed forward with $10 \mathrm{~mL}$ THF. The completed reaction mixture was then diluted with $30 \mathrm{~mL} \mathrm{PhMe}$ and the aqueous material was discarded. The organic material was washed with $30 \mathrm{~mL}$ $10 \% \mathrm{NaCl}$ followed by $30 \mathrm{~mL}$ brine, and was dried $\left(\mathrm{Na}_{2} \mathrm{SO}_{4}\right)$, filtered, and concentrated on the rotovap. The crude material was chromatographed on $20 \mathrm{~g}$ amino-silica (50 to 100\% EtOAc in hexane) to afford SI-57 (4.12 g, 12.5 mmol, 76\% yield) as a pink solid.

${ }^{1} \mathbf{H}$ NMR $\left(500 \mathrm{MHz}, \mathrm{CD}_{3} \mathrm{CN}, 25^{\circ} \mathrm{C}, \delta\right)$ :

$6.76(\mathrm{~d}, J=2.3 \mathrm{ppm}, 1 \mathrm{H}), 6.72(\mathrm{dd}, J=8.6,2.3), 6.48(\mathrm{~d}, J=8.6 \mathrm{~Hz}, 1 \mathrm{H}), 3.89(\mathrm{~s}, 6 \mathrm{H}), 3.16(\mathrm{~d}, J=5.7 \mathrm{~Hz}, 2 \mathrm{H})$, $0.77(\mathrm{~s}, 3 \mathrm{H})$.

${ }^{13} \mathrm{C}$ NMR $\left(126 \mathrm{MHz}, \mathrm{CD}_{3} \mathrm{CN}, 25^{\circ} \mathrm{C}, \delta\right)$ :

138.0, 137.0, 122.1, 118.5, 114.3, 110.4, 108.5, 73.2, 49.9, 31.1, 14.2.

HRMS (ESI-TOF, m/z):

Calc'd for $\mathrm{C}_{13} \mathrm{H}_{18} \mathrm{BrN}_{2} \mathrm{O}_{3}{ }^{+}\left([\mathrm{M}+\mathrm{H}]^{+}\right)$329.0495/331.0475; found 329.0495/331.0477.

Calc'd for $\mathrm{C}_{13} \mathrm{H}_{17} \mathrm{BrN}_{2} \mathrm{O}_{3} \mathrm{Na}^{+}\left([\mathrm{M}+\mathrm{Na}]^{+}\right)$351.0315/353.0294; found 351.0311/353.0297. 


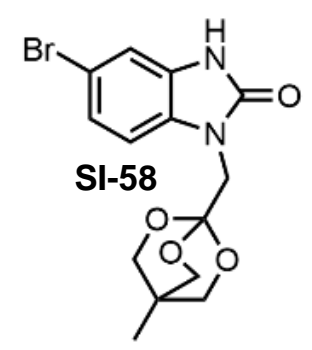

\section{Procedure:}

To a stirred solution of SI-57 (4.12 g, $12.5 \mathrm{mmol}$ ) in $40 \mathrm{~mL} \mathrm{PhCl}$ was charged CDI (2.23 g, $13.8 \mathrm{mmol}, 1.1 \mathrm{eq})$.

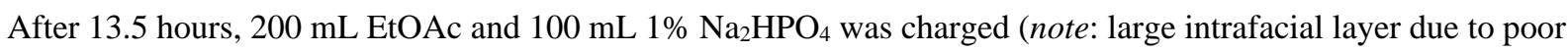
EtOAc solubility of SI-58). The aqueous material was discarded, and the organic material was washed with $100 \mathrm{~mL}$ $\mathrm{H}_{2} \mathrm{O}$ and concentrated on the rotovap. The crude material was adsorbed on $16 \mathrm{~g}$ amino-silica and chromatographed on $40 \mathrm{~g}$ amino-silica (80 to $100 \%$ EtOAc in hexane then $20 \% \mathrm{v} / \mathrm{v} \mathrm{MeOH}$ in EtOAc) to afford SI-58 (4.29 g, 12.1 mmol, $97 \%$ yield) as a pink solid.

${ }^{1}$ H NMR $\left(392 \mathrm{MHz}\right.$, DMSO- $\left.d_{6}, 25^{\circ} \mathrm{C}, \delta\right)$ :

$7.13(\mathrm{dd}, J=8.2,1.7 \mathrm{~Hz}, 1 \mathrm{H}), 7.07(\mathrm{~d}, J=1.7 \mathrm{~Hz}, 1 \mathrm{H}), 7.02(\mathrm{~d}, J=8.2 \mathrm{~Hz}, 1 \mathrm{H}), 3.87(\mathrm{~s}, 2 \mathrm{H}), 3.80(\mathrm{~s}, 6 \mathrm{H}), 0.71(\mathrm{~s}$, $3 \mathrm{H})$.

${ }^{13} \mathrm{C}$ NMR $\left(99 \mathrm{MHz}\right.$, DMSO- $\left.d_{6}, 25^{\circ} \mathrm{C}, \delta\right)$ :

$154.1,130.1,129.7,122.9,112.5,111.4,111.1,106.9,71.8,44.8,30.0,13.6$.

HRMS (ESI-TOF, m/z):

Calc'd for $\mathrm{C}_{14} \mathrm{H}_{15} \mathrm{BrN}_{2} \mathrm{O}_{4} \mathrm{Na}^{+}\left([\mathrm{M}+\mathrm{Na}]^{+}\right)$377.0107/379.0087; found 377.0102/379.0088. 


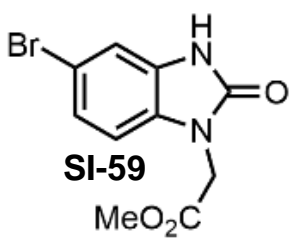

\section{Procedure:}

To a stirred solution of SI-58 $(4.29 \mathrm{~g}, 12.1 \mathrm{mmol})$ in $50 \mathrm{~mL} \mathrm{MeOH}$ was charged $p$-toluenesulfonic acid (3.46 g, 18.2 mmol, $1.5 \mathrm{eq}$ ). The mixture was heated in a 50 to $60^{\circ} \mathrm{C}$ bath for 6 hours, cooled to room temperature, and aged for a further 12 hours. The mixture was concentrated on the rotovap and extracted with $100 \mathrm{~mL}$ EtOAc and $100 \mathrm{~mL} \mathrm{10 \%}$ $\mathrm{NaCl}$ (note: the product does not fully dissolve in organic layer). The upper organic slurry layer was washed with 5 x $50 \mathrm{~mL} \mathrm{H}_{2} \mathrm{O}$ and concentrated. The crude material was adsorbed in $10 \mathrm{~g}$ silica and chromatographed on $25 \mathrm{~g}$ silica (60 to $100 \%$ EtOAc in hexane then $20 \%$ v/v MeOH in EtOAc) to afford SI-59 (3.30 g, $11.6 \mathrm{mmol}$, 96\% yield) as a white solid.

${ }^{1} \mathbf{H}$ NMR $\left(500 \mathrm{MHz}\right.$, DMSO- $\left.d_{6}, 25^{\circ} \mathrm{C}, \delta\right)$ :

11.09 (br s, 1H), $7.13(\mathrm{~m}, 2 \mathrm{H}), 7.06(\mathrm{~m}, 1 \mathrm{H}), 4.65$ (s, 2H), 3.65 (s, 3H).

${ }^{13} \mathrm{C}$ NMR $\left(126 \mathrm{MHz}\right.$, DMSO- $\left.d_{6}, 25{ }^{\circ} \mathrm{C}, \delta\right)$ :

168.6, 154.0, 129.7, 129.6, 123.2, 112.9, 111.5, 109.8, 52.3, 41.5.

HRMS (ESI-TOF, m/z):

Calc'd for $\mathrm{C}_{10} \mathrm{H}_{9} \mathrm{BrN}_{2} \mathrm{O}_{3} \mathrm{Na}^{+}\left([\mathrm{M}+\mathrm{Na}]^{+}\right)$306.9689/308.9668; found 306.9690/308.9670. 


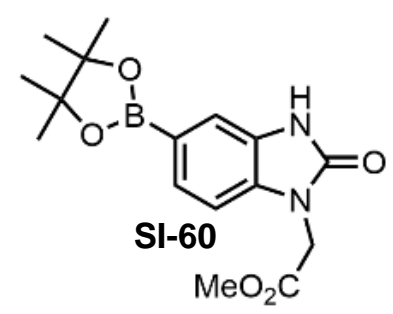

\section{Procedure:}

To a flask was charged SI-59 (1140 mg, $4.0 \mathrm{mmol})$, potassium propionate (1346 mg, $12.0 \mathrm{mmol}, 3.0$ eq), B pin $_{2}$ (2032 mg, $8.0 \mathrm{mmol}, 2.0 \mathrm{eq}$ ), and $\mathrm{PdCl}_{2}$ (amphos) $)_{2}(14.2 \mathrm{mg}, 20 \mu \mathrm{mol}, 0.5 \mathrm{~mol} \%$ ) followed by $16 \mathrm{~mL}$ 2-MeTHF. The mixture was heated in a 70 to $80^{\circ} \mathrm{C}$ bath for 7 hours, cooled to room temperature, and aged for a further 14 hours. The mixture was extracted with $20 \mathrm{~mL}$ EtOAc and $20 \mathrm{~mL} \mathrm{H}_{2} \mathrm{O}$ and the aqueous material was discarded. The organic material was washed with $20 \mathrm{~mL}$ brine, dried $\left(\mathrm{Na}_{2} \mathrm{SO}_{4}\right)$, filtered, and concentrated. The crude material was adsorbed on $9 \mathrm{~g}$ silica and chromatographed on $25 \mathrm{~g}$ silica (60 to $80 \%$ EtOAc in hexane) to afford an oily white solid. This material was triturated with $n$-heptane $(2 \times 5 \mathrm{~mL})$ to afford SI-60 (980 mg, $2.95 \mathrm{mmol}, 74 \%$ yield $)$ as a white solid.

${ }^{1} \mathbf{H}$ NMR $\left(500 \mathrm{MHz}, \mathrm{CDCl}_{3}, 25^{\circ} \mathrm{C}, \delta\right)$ :

$10.03(\mathrm{~s}, 1 \mathrm{H}), 7.54(\mathrm{~m}, 2 \mathrm{H}) 6.87(\mathrm{~d}, J=7.4 \mathrm{~Hz}, 1 \mathrm{H}), 4.63(\mathrm{~s}, 2 \mathrm{H}), 3.74(\mathrm{~s}, 3 \mathrm{H}), 1.31$ (s, 12H).

${ }^{13} \mathrm{C}$ NMR $\left(126 \mathrm{MHz}, \mathrm{CDCl}_{3}, 25{ }^{\circ} \mathrm{C}, \delta\right)$ :

168.1, 155.4, 132.4, 128.6, 127.6, 115.9, 107.2, 83.8, 52.6, 41.9, 24.8.

HRMS (ESI-TOF, m/z):

Calc'd for $\mathrm{C}_{16} \mathrm{H}_{22} \mathrm{BN}_{2} \mathrm{O}_{5}{ }^{+}\left([\mathrm{M}+\mathrm{H}]^{+}\right)$333.1616; found 333.1620.

Calc'd for $\mathrm{C}_{16} \mathrm{H}_{21} \mathrm{BN}_{2} \mathrm{O}_{5} \mathrm{Na}^{+}\left([\mathrm{M}+\mathrm{Na}]^{+}\right)$355.1436; found 355.1437. 


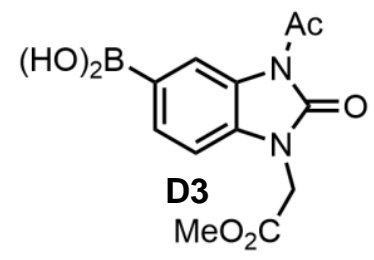

\section{Procedure:}

To a stirred solution of SI-60 (129 mg, $0.4 \mathrm{mmol}$ ) in $2 \mathrm{~mL} \mathrm{DMF}$ was charged $\mathrm{NaH}$ (55\% suspension, $21 \mathrm{mg}, 0.48$ mmol, $1.2 \mathrm{eq})$ and the mixture was stirred for 5 minutes. $\mathrm{AcCl}(57 \mu \mathrm{L}, 0.80 \mathrm{mmol}, 2.0 \mathrm{eq})$ was charged and the mixture was stirred for 5 minutes. The reaction was quenched to a stirred mixture of $10 \mathrm{~mL}$ EtOAc and $5 \mathrm{~mL} \mathrm{pH} 4$ buffer. The aqueous material was discarded, and the organic material was washed twice with brine, dried $\left(\mathrm{MgSO}_{4}\right)$ filtered, and concentrated on the rotovap. The crude material was chromatographed on $5 \mathrm{~g}$ silica ( $25 \mathrm{to} 35 \% \mathrm{v} / \mathrm{v}$ EtOAc in hexane) to afford the intermediate SI-61 $(138.5 \mathrm{mg})$ as a white solid.

To a stirred suspension of SI-61 $(138.5 \mathrm{mg}, 0.37 \mathrm{mmol})$ in $4 \mathrm{~mL} 2: 1 \mathrm{v} / \mathrm{v}$ acetone : $\mathrm{H}_{2} \mathrm{O}$ was charged $\mathrm{NH}_{4} \mathrm{OAc}(2 \mathrm{M}$ sol'n in $\mathrm{H}_{2} \mathrm{O}, 360 \mu \mathrm{L}, 0.72 \mathrm{mmol}, 1.8 \mathrm{eq}$ ) followed by $\mathrm{NaIO}_{4}(240 \mathrm{mg}, 1.12 \mathrm{mmol}, 2.8 \mathrm{eq})$, and the mixture was heated in a $30-40{ }^{\circ} \mathrm{C}$ bath for 15 hours. After cooling to room temperature, $4 \mathrm{~mL}$ acetone was charged, and the mixture was filtered through a silica pad (acetone rinse). Purification by preparative HPLC (method B, 10 - 80\% ACN) afforded $\mathbf{D 3}(29.0 \mathrm{mg}, 99 \mu \mathrm{mol}, 25 \%$ yield over 2 steps) as a white solid.

${ }^{1} \mathbf{H}$ NMR $\left(500 \mathrm{MHz}\right.$, acetone- $\left.\mathrm{d}_{6}, 25^{\circ} \mathrm{C}, \delta\right)$ :

$8.62(\mathrm{~s}, 1 \mathrm{H}), 7.78(\mathrm{~d}, J=7.4 \mathrm{~Hz}, 1 \mathrm{H}), 7.40(\mathrm{~s}, 2 \mathrm{H}), 7.14(\mathrm{~d}, J=7.4 \mathrm{~Hz}, 1 \mathrm{H}), 4.75(\mathrm{~s}, 2 \mathrm{H}), 3.74(\mathrm{~s}, 3 \mathrm{H}), 2.68(\mathrm{~s}, 3 \mathrm{H})$.

${ }^{13} \mathrm{C}$ NMR $\left(126 \mathrm{MHz}\right.$, acetone- $\left.\mathrm{d}_{6}, 25^{\circ} \mathrm{C}, \delta\right)$ :

$170.8,168.7,153.2,132.5,131.7,126.9,121.5,108.1,52.8,42.5,25.6$.

HRMS (ESI-TOF, m/z):

Calc'd for $\mathrm{C}_{12} \mathrm{H}_{14} \mathrm{BN}_{2} \mathrm{O}_{6}{ }^{+}\left([\mathrm{M}+\mathrm{H}]^{+}\right)$293.0939; found 293.1041.

Calc'd for $\mathrm{C}_{12} \mathrm{H}_{13} \mathrm{BN}_{2} \mathrm{O}_{6} \mathrm{Na}^{+}\left([\mathrm{M}+\mathrm{Na}]^{+}\right)$315.0759; found 315.0765. 

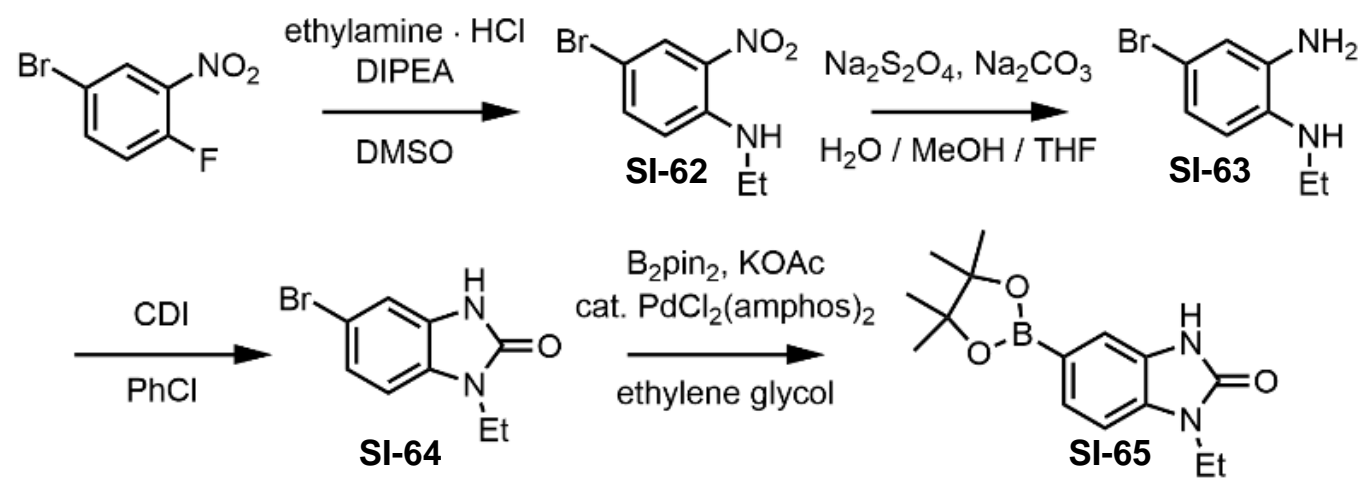


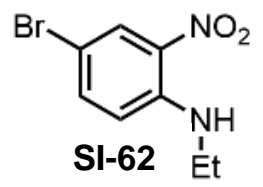

\section{Procedure:}

To a stirred suspension of ethylamine hydrochloride ( $1.96 \mathrm{~g}, 24.0 \mathrm{mmol}, 1.2 \mathrm{eq})$ in $60 \mathrm{~mL}$ DMSO was charged DIPEA (7.84 mL, $45.0 \mathrm{mmol}, 2.25 \mathrm{eq}$ ) followed by 4-bromo-1-fluoro-6-nitrobenzene (4.40 g, $20.0 \mathrm{mmol}$ ) After 1.25 hours, the reaction mixture was poured into a stirred solution containing $200 \mathrm{~mL}$ EtOAc and $200 \mathrm{~mL} \mathrm{10 \%}$ $\mathrm{NaCl}$. The aqueous $\mathrm{pH}$ was adjusted to 5 with citric acid, and the aqueous material was discarded. The organics material was washed with brine, dried $\left(\mathrm{MgSO}_{4}\right)$, filtered, and concentrated on the rotovap. The residue was triturated with $50 \mathrm{~mL} 20: 1 \mathrm{v} / \mathrm{v} n$-heptane : EtOAc to afford SI-62 (1.62 g, $6.61 \mathrm{mmol}, 33 \%$ yield) as an orange solid.

${ }^{1}$ H NMR $\left(500 \mathrm{MHz}\right.$, DMSO-d $\left.6,25{ }^{\circ} \mathrm{C}, \delta\right)$ :

8.34 to $7.99(\mathrm{~m}, 1 \mathrm{H}) 8.12(\mathrm{~d}, J=2.0 \mathrm{~Hz}, 1 \mathrm{H}), 7.61(\mathrm{dd}, J=9.0,2.0 \mathrm{~Hz}, 1 \mathrm{H}), 7.01(\mathrm{~d}, J=9.0 \mathrm{~Hz}, 1 \mathrm{H}), 1.20(\mathrm{t}, J=7.2$ $\mathrm{Hz}, 3 \mathrm{H})$ (note: the nitrogen-substituted $-\underline{\mathrm{C}}_{2}-$ peak is obscured by the DMSO peak).

${ }^{13} \mathrm{C}$ NMR $\left(126 \mathrm{MHz}\right.$, DMSO-d $\left.6,25^{\circ} \mathrm{C}, \delta\right)$ :

$144.1,138.8,131.2,127.8,116.9,105.0,37.2,14.0$.

HRMS (ESI-TOF, m/z):

Calc'd for $\mathrm{C}_{8} \mathrm{H}_{10} \mathrm{BrN}_{2} \mathrm{O}_{2}{ }^{+}\left([\mathrm{M}+\mathrm{H}]^{+}\right)$244.9920/246.9900; found 244.9951, 246.9907 . 


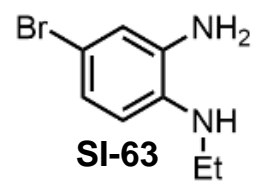

\section{Procedure:}

To a stirred solution of SI-62 $(1.60 \mathrm{~g}, 6.51 \mathrm{mmol})$ in $4 \mathrm{~mL} \mathrm{MeOH}$ and $12 \mathrm{~mL}$ THF was charged a suspension of $\mathrm{Na}_{2} \mathrm{CO}_{3}$ (4.49 g, $\left.42.4 \mathrm{mmol}, 6.5 \mathrm{eq}\right)$ and $\mathrm{Na}_{2} \mathrm{~S}_{2} \mathrm{O}_{4}(7.38 \mathrm{~g}, 42.4 \mathrm{mmol}, 6.5 \mathrm{eq})$ in $40 \mathrm{~mL} \mathrm{H}_{2} \mathrm{O}$ in portions over 5 minutes (note: exotherm). After 15 minutes, the reaction mixture was diluted with $100 \mathrm{~mL} \mathrm{Et}_{2} \mathrm{O}$ and $50 \mathrm{~mL} \mathrm{H}_{2} \mathrm{O}$. The aqueous material was discarded. The organic material was washed with brine, dried $\left(\mathrm{Na}_{2} \mathrm{SO}_{4}\right)$, filtered, and concentrated on the rotovap. The crude material was chromatographed on $20 \mathrm{~g}$ silica (1: $1 \mathrm{v} / \mathrm{v} \mathrm{Et}_{2} \mathrm{O}: \mathrm{pentane}$ $\left.100 \% \mathrm{Et}_{2} \mathrm{O}\right)$ to afford SI-63 (874 mg, $4.07 \mathrm{mmol}, 62 \%$ yield) as a white solid.

${ }^{1} \mathbf{H}$ NMR $\left(500 \mathrm{MHz}, \mathrm{CDCl}_{3}, 25^{\circ} \mathrm{C}, \delta\right)$ :

$6.89(\mathrm{dd}, J=8.5,2.2 \mathrm{~Hz}, 1 \mathrm{H}), 6.80(\mathrm{~d}, J=2.2 \mathrm{~Hz}, 1 \mathrm{H}), 6.48(\mathrm{~d}, J=8.5 \mathrm{~Hz}, 1 \mathrm{H}), 3.29(\mathrm{br} \mathrm{s}, 2 \mathrm{H}), 3.09(\mathrm{q}, J=7.2 \mathrm{~Hz}$, $2 \mathrm{H}), 1.27(\mathrm{t}, J=7.2 \mathrm{~Hz}, 3 \mathrm{H})$.

${ }^{13} \mathrm{C}$ NMR $\left(99 \mathrm{MHz}, \mathrm{CDCl}_{3}, 25^{\circ} \mathrm{C}, \delta\right)$ :

$136.9,135.5,123.0,118.7,112.8,110.2,38.7,14.8$.

HRMS (ESI-TOF, m/z):

Calc'd for $\mathrm{C}_{8} \mathrm{H}_{12} \mathrm{BrN}_{2}{ }^{+}\left([\mathrm{M}+\mathrm{H}]^{+}\right)$215.0178/217.0158; found 215.0190/217.0170. 


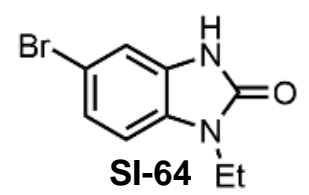

\section{Procedure:}

To a stirred $0-5^{\circ} \mathrm{C}$ solution of $\mathbf{S I - 6 3}$ (844 mg, $\left.4.07 \mathrm{mmol}\right)$ in $20 \mathrm{~mL} \mathrm{PhCl}$ was charged CDI (726 mg, $4.48 \mathrm{mmol}$, $1.1 \mathrm{eq}$ ) in portions over 30 minutes. The cooling bath was then removed, mixture was stirred for 2 hours, and the volatiles were removed on the rotovap. The residue was extracted with $50 \mathrm{~mL}$ EtOAc and $50 \mathrm{~mL} \mathrm{H}_{2} \mathrm{O}$, and the aqueous material was discarded. The organics material was washed with brine, dried $\left(\mathrm{MgSO}_{4}\right)$, filtered, and concentrated on the rotovap. The crude mixture was adsorbed on $5 \mathrm{~g}$ silica and chromatographed on $20 \mathrm{~g}$ silica (3 to $5 \% \mathrm{v} / \mathrm{v} \mathrm{MeOH}$ in $\mathrm{CH}_{2} \mathrm{Cl}_{2}$ ) to afford $\mathbf{S I - 6 4}(719 \mathrm{mg}, 2.98 \mathrm{mmol}, 73 \%$ yield) as a white solid.

${ }^{1} \mathbf{H}$ NMR $\left(500 \mathrm{MHz}\right.$, DMSO-d $\left.6,2{ }^{\circ} \mathrm{C}, \delta\right)$ :

10.96 (br s, 1H), $7.14(\mathrm{~m}, 1 \mathrm{H}) 7.08(\mathrm{~m}, 2 \mathrm{H}), 3.77$ (q, $J=7.1 \mathrm{~Hz}, 2 \mathrm{H}), 1.14(\mathrm{t}, J=7.1 \mathrm{~Hz}, 3 \mathrm{H})$.

${ }^{13} \mathrm{C}$ NMR $\left(126 \mathrm{MHz}, \mathrm{DMSO}-\mathrm{d}_{6}, 25{ }^{\circ} \mathrm{C}, \delta\right)$ :

$153.7,129.8,129.2,123.0,112.3,111.3,109.3,34.8,13.4$.

HRMS (ESI-TOF, m/z):

Calc'd for $\mathrm{C}_{9} \mathrm{H}_{10} \mathrm{BrN}_{2} \mathrm{O}^{+}\left([\mathrm{M}+\mathrm{H}]^{+}\right)$240.9971/242.9951; found 240.9974/242.9954 . 


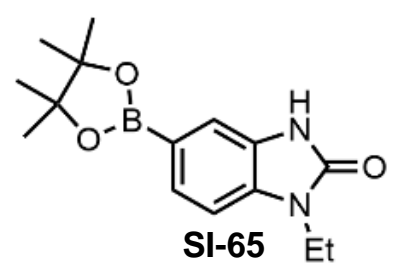

\section{Procedure:}

To a flask was charged SI-64 (708 mg, $2.94 \mathrm{mmol})$, KOAc (866 mg, $8.82 \mathrm{mmol}, 3.0 \mathrm{eq})$, B $_{2}$ pin $_{2}(1493 \mathrm{mg}, 5.88$ mmol, $2.0 \mathrm{eq}$ ), and $\mathrm{PdCl}_{2}$ (amphos) $)_{2}(10.4 \mathrm{mg}, 15 \mu \mathrm{mol}, 0.5 \mathrm{~mol} \%$ ) followed by $15 \mathrm{~mL}$ ethylene glycol. The mixture was stirred and heated at $75-80{ }^{\circ} \mathrm{C}$ for 4 hours, and then cooled to room temperature. The mixture was then extracted with $50 \mathrm{~mL} \mathrm{Et}_{2} \mathrm{O}$ and $25 \mathrm{~mL} \mathrm{H}_{2} \mathrm{O}$ and the aqueous material was discarded. The organic material was washed with brine, dried $\left(\mathrm{MgSO}_{4}\right)$, filtered, and concentrated on the rotovap. The crude material was chromatographed on $20 \mathrm{~g}$ silica $\left(\mathrm{Et}_{2} \mathrm{O}\right.$ then $3 \% \mathrm{v} / \mathrm{v} \mathrm{MeOH}$ in $\left.\mathrm{Et}_{2} \mathrm{O}\right)$ and then triturated with $2 \times 5 \mathrm{~mL}$ pentane to afford SI-65 (582 mg, $2.02 \mathrm{mmol}, 67 \%$ yield) as a white solid.

${ }^{1} \mathbf{H}$ NMR $\left(500 \mathrm{MHz}, \mathrm{CDCl}_{3}, 25^{\circ} \mathrm{C}, \delta\right)$ :

$10.51(\mathrm{~s}, 1 \mathrm{H}), 7.59(\mathrm{~s}, 1 \mathrm{H}), 7.55(\mathrm{~d}, J=7.4 \mathrm{~Hz}, 1 \mathrm{H}), 6.99(\mathrm{~d}, J=7.4 \mathrm{~Hz}, 1 \mathrm{H}), 3.94(\mathrm{q}, J=6.7 \mathrm{~Hz}, 2 \mathrm{H}), 1.32(\mathrm{~m}, 15$ $\mathrm{H})$.

${ }^{13} \mathrm{C}$ NMR $\left(126 \mathrm{MHz}, \mathrm{CDCl}_{3}, 25^{\circ} \mathrm{C}, \delta\right)$ :

$155.7,132.5,128.2,127.8,115.7,107.1,83.7,35.6,24.8,13.6$.

HRMS (ESI-TOF, m/z):

Calc'd for $\mathrm{C}_{15} \mathrm{H}_{22} \mathrm{BN}_{2} \mathrm{O}_{3}{ }^{+}\left([\mathrm{M}+\mathrm{H}]^{+}\right)$289.1718; found 289.1717.

Calc'd for $\mathrm{C}_{15} \mathrm{H}_{21} \mathrm{BN}_{2} \mathrm{O}_{3} \mathrm{Na}^{+}\left([\mathrm{M}+\mathrm{Na}]^{+}\right)$311.1537; found 311.1540. 


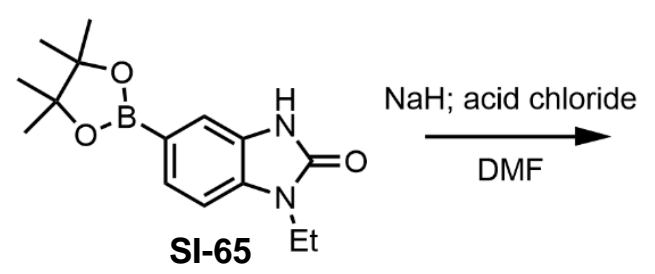<smiles>[R]C(=O)n1c(=O)n(CC)c2ccc(B3OC(C)(C)C(C)(C)O3)cc21</smiles>

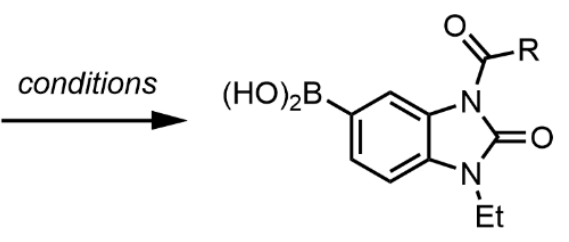

condition $\mathrm{A}$ : $\mathrm{NH}_{4} \mathrm{OAc}, \mathrm{NalO}_{4}$ acetone $/ \mathrm{H}_{2} \mathrm{O}$ or $\mathrm{THF} / \mathrm{H}_{2} \mathrm{O}$

condition $\mathrm{B}$ :

$\mathrm{MeB}(\mathrm{OH})_{2}$, TFA $\mathrm{CH}_{2} \mathrm{Cl}_{2}$ 


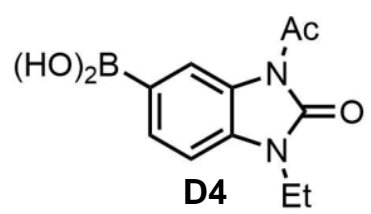

\section{Procedure:}

To a stirred 0.2 M solution of SI-65 (43.2 mg, $0.15 \mathrm{mmol}$ ) in DMF, was charged NaH (55\% suspension, $7.9 \mathrm{mg}$, $0.18 \mathrm{mmol}, 1.2 \mathrm{eq})$. After 10 minutes, $\mathrm{AcCl}(21.4 \mu \mathrm{L}, 0.30 \mathrm{mmol}, 2.0 \mathrm{eq})$ was charged. After 10 minutes, the reaction was quenched to a stirred mixture of $5 \mathrm{~mL}$ EtOAc and $2.5 \mathrm{~mL} \mathrm{pH} 4$ buffer. The aqueous material was discarded, and the organic material was washed twice with brine, dried $\left(\mathrm{MgSO}_{4}\right)$ filtered, and concentrated on the rotovap. The crude material was chromatographed on $5 \mathrm{~g}$ silica ( 1 to $1.5 \% \mathrm{v} / \mathrm{v} \mathrm{MeOH}$ in $\mathrm{CH}_{2} \mathrm{Cl}_{2}$ ) to afford the intermediate boronic ester (36.2 $\mathrm{mg}, 0.11 \mathrm{mmol}, 73 \%$ yield) as a white solid.

To a stirred suspension of the intermediate boronic ester $(36.2 \mathrm{mg}, 0.11 \mathrm{mmol})$ in $1.0 \mathrm{~mL} 2: 1 \mathrm{v} / \mathrm{v}$ acetone : $\mathrm{H}_{2} \mathrm{O}$ was charged $\mathrm{NH}_{4} \mathrm{OAc}\left(2 \mathrm{M}\right.$ sol'n in $\left.\mathrm{H}_{2} \mathrm{O}, 100 \mu \mathrm{L}, 0.20 \mathrm{mmol}, 1.8 \mathrm{eq}\right)$ followed by $\mathrm{NaIO}_{4}(66 \mathrm{mg}, 0.31 \mathrm{mmol}, 2.8$ eq), and the mixture was heated in a $40-45^{\circ} \mathrm{C}$ bath for 12 hours. The mixture was cooled to room temperature and most of the acetone was removed on the rotovap. The mixture was extracted with $5 \mathrm{~mL}$ EtOAc and $5 \mathrm{~mL} \mathrm{H}_{2} \mathrm{O}$ and the aqueous material was discarded. The organic material was washed with brine, dried $\left(\mathrm{Mg}_{2} \mathrm{SO}_{4}\right)$, and concentrated on the rotovap. Purification by preparative HPLC (method B, 10 - 80\% ACN) afforded D4 (9.5 mg, $38.3 \mu \mathrm{mol}, 26 \%$ yield over 2 steps) as a white solid.

${ }^{1} \mathbf{H}$ NMR $\left(500 \mathrm{MHz}\right.$, acetone-d $\left.6,25^{\circ} \mathrm{C}, \delta\right)$ : 8.59 (s, 1H), 7.79 (d, J = 8.0 Hz, 1H), 7.28 (br s, 2H), 7.18 (d, J=8.0 Hz, 1H), 3.94 (q, J = 7.3 Hz, $2 \mathrm{H}), 2.66$ (s, $3 \mathrm{H}), 1.30(\mathrm{t}, J=7.3 \mathrm{~Hz}, 3 \mathrm{H})$.

${ }^{13} \mathrm{C}$ NMR (126 MHz, acetone- $\left.\mathrm{d}_{6}, 25{ }^{\circ} \mathrm{C}, \delta\right)$ :

$170.9,153.2,133.8,131.6,126.6,121.3,108.5,25.7,23.2,6.4$.

HRMS (ESI-TOF, m/z):

Calc'd for $\mathrm{C}_{11} \mathrm{H}_{13} \mathrm{BN}_{2} \mathrm{O}_{4} \mathrm{Na}^{+}\left([\mathrm{M}+\mathrm{Na}]^{+}\right)$271.0861; found 271.0866. 


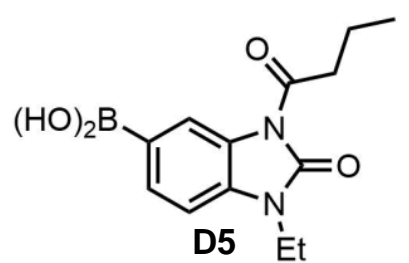

\section{Procedure:}

To a stirred 0.2 M solution of SI-65 (28.8 mg, $0.10 \mathrm{mmol}$ ) in DMF, was charged NaH (55\% suspension, $5.2 \mathrm{mg}$, $0.12 \mathrm{mmol}, 1.2 \mathrm{eq})$. After 10 minutes, butyryl chloride ( $20.7 \mu \mathrm{L}, 0.20 \mathrm{mmol}, 2.0 \mathrm{eq})$ was charged. After 10 minutes, the reaction was quenched to a stirred mixture of $5 \mathrm{~mL}$ EtOAc and $2.5 \mathrm{~mL} \mathrm{pH} 4$ buffer. The aqueous material was discarded, and the organic material was washed twice with brine, dried $\left(\mathrm{MgSO}_{4}\right)$ filtered, and concentrated on the rotovap. The crude material was chromatographed on $5 \mathrm{~g}$ silica ( 25 to $50 \% \mathrm{v} / \mathrm{v} \mathrm{Et}{ }_{2} \mathrm{O}$ in pentane) to afford the intermediate boronic ester (31.9 mg, $0.089 \mathrm{mmol}, 89 \%$ yield) as a white solid.

To a stirred suspension of the intermediate boronic ester $(31.9 \mathrm{mg}, 0.089 \mathrm{mmol})$ in $1.0 \mathrm{~mL} 2: 1 \mathrm{v} / \mathrm{v}$ acetone : $\mathrm{H}_{2} \mathrm{O}$ was charged $\mathrm{NH}_{4} \mathrm{OAc}$ ( $2 \mathrm{M}$ sol'n in $\mathrm{H}_{2} \mathrm{O}, 80 \mu \mathrm{L}, 0.16 \mathrm{mmol}, 1.8$ eq) followed by $\mathrm{NaIO}_{4}(53.5 \mathrm{mg}, 0.25 \mathrm{mmol}, 2.8$ eq), and the mixture was aged for 41 hours. Most of the acetone was removed on the rotovap. The mixture was extracted with $5 \mathrm{~mL}$ EtOAc and $5 \mathrm{~mL} \mathrm{H}_{2} \mathrm{O}$ and the aqueous material was discarded. The organic material was washed with brine, dried $\left(\mathrm{Mg}_{2} \mathrm{SO}_{4}\right)$, and concentrated on the rotovap. Purification by preparative HPLC (method A, 10 - 80\% ACN) afforded D5 (12.0 mg, $27.9 \mu \mathrm{mol}, 28 \%$ yield over 2 steps) as a white solid.

${ }^{1} \mathbf{H}$ NMR $\left(500 \mathrm{MHz}\right.$, acetone- $\left.\mathrm{d}_{6}, 25^{\circ} \mathrm{C}, \delta\right)$ :

$8.60(\mathrm{~s}, 1 \mathrm{H}), 7.79$ (d, $J=8.0 \mathrm{~Hz}), 7.27(\mathrm{br} \mathrm{s}, 1 \mathrm{H}), 7.17(\mathrm{~d}, J=8.0 \mathrm{~Hz}, 1 \mathrm{H}), 3.93(\mathrm{q}, J=7.3 \mathrm{~Hz}, 2 \mathrm{H}), 3.11(\mathrm{~d}, J=7.2$ $\mathrm{Hz}, 2 \mathrm{H}), 1.75(\mathrm{~m}, 2 \mathrm{H}), 1.29(\mathrm{t}, J=7.2 \mathrm{~Hz}, 3 \mathrm{H}), 1.00(\mathrm{t}, J=7.3 \mathrm{~Hz}, 3 \mathrm{H})$.

${ }^{13} \mathrm{C}$ NMR $\left(126 \mathrm{MHz}\right.$, acetone- $\left.\mathrm{d}_{6}, 25^{\circ} \mathrm{C}, \delta\right)$ :

$173.9,152.7,132.5,131.7,127.1,121.5,107.7,39.5,36.3,18.3,14.0,13.3$.

HRMS (ESI-TOF, m/z):

Calc'd for $\mathrm{C}_{13} \mathrm{H}_{17} \mathrm{BN}_{2} \mathrm{O}_{4} \mathrm{Na}^{+}\left([\mathrm{M}+\mathrm{Na}]^{+}\right)$299.1174; found 299.1169 . 


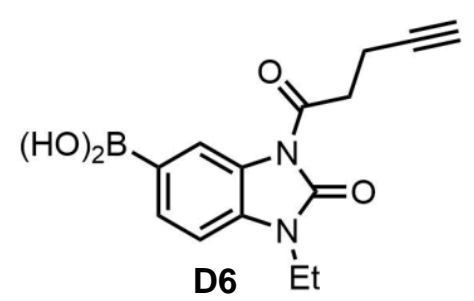

\section{Procedurt}

To a stirred solution of 4-pentynoic acid (49 $\mathrm{mg}, 0.50 \mathrm{mmol}, 2.0 \mathrm{eq}$ ) in $1.5 \mathrm{~mL} \mathrm{CH}_{2} \mathrm{Cl}_{2}$ was charged $1 \mu \mathrm{L}$ DMF followed by oxalyl chloride (127 $\mu \mathrm{L}, 0.75 \mathrm{mmol}, 3.0 \mathrm{eq}$ ) (note: gas evolution). After 45 minutes, the reaction was concentrated on the rotovap and co-evaporated with $3 \times 1 \mathrm{~mL} \mathrm{CH}_{2} \mathrm{Cl}_{2}$.

To a stirred 0.2 M solution of SI-65 (72 mg, $0.25 \mathrm{mmol}$ ) in DMF, was charged NaH (55\% suspension, $13 \mathrm{mg}, 0.30$ mmol, 1.2 eq). After 10 minutes, the crude acid chloride was charged as a solution in $0.25 \mathrm{~mL} \mathrm{CH}_{2} \mathrm{Cl}_{2}$. After 10 minutes, the reaction was quenched to a stirred mixture of $10 \mathrm{~mL}$ EtOAc and $5 \mathrm{~mL} \mathrm{pH} 4$ buffer. The aqueous material was discarded, and the organic material was washed twice with brine, dried $\left(\mathrm{MgSO}_{4}\right)$ filtered, and concentrated on the rotovap. The crude material was chromatographed on $8 \mathrm{~g}$ silica $(1: 1 \mathrm{v} / \mathrm{v}$ EtOAc : pentane then $1.5 \% \mathrm{v} / \mathrm{v} \mathrm{MeOH}$ in $\left.\mathrm{CH}_{2} \mathrm{Cl}_{2}\right)$ to afford the intermediate boronic ester $(61.9 \mathrm{mg}, 0.16 \mathrm{mmol}, 64 \%$ yield) as a white solid.

To a stirred suspension of the intermediate boronic ester $(61.9 \mathrm{mg}, 0.16 \mathrm{mmol})$ in $2.0 \mathrm{~mL} 2: 1 \mathrm{v} / \mathrm{v}$ acetone $: \mathrm{H}_{2} \mathrm{O}$ was charged $\mathrm{NH}_{4} \mathrm{OAc}\left(2 \mathrm{M}\right.$ sol'n in $\mathrm{H}_{2} \mathrm{O}, 144 \mu \mathrm{L}, 0.29 \mathrm{mmol}, 1.8 \mathrm{eq}$ ) followed by $\mathrm{NaIO}_{4}(96 \mathrm{mg}, 0.45 \mathrm{mmol}, 2.8$ eq), and the mixture aged for 15 hours. Most of the acetone was removed on the rotovap. The mixture was extracted with $10 \mathrm{~mL}$ EtOAc and $10 \mathrm{~mL} \mathrm{H}_{2} \mathrm{O}$ and the aqueous material was discarded. The organic material was washed with brine, dried $\left(\mathrm{Mg}_{2} \mathrm{SO}_{4}\right)$, and concentrated on the rotovap. Purification by preparative HPLC (method B, $10-80 \%$ ACN, in two equal loads) afforded D6 (13.6 mg, $47.5 \mu \mathrm{mol}, 19 \%$ yield over 2 steps) as a white solid.

${ }^{1} \mathbf{H}$ NMR $\left(500 \mathrm{MHz}\right.$, acetone- $\left.\mathrm{d}_{6}, 25^{\circ} \mathrm{C}, \delta\right)$ :

$8.60(\mathrm{~s}, 3 \mathrm{H}), 7.81(\mathrm{~d}, J=8.0 \mathrm{~Hz}, 1 \mathrm{H}), 7.19(\mathrm{~d}, J=8.0 \mathrm{~Hz}, 1 \mathrm{H}), 3.95(\mathrm{q}, J=7.3 \mathrm{~Hz}, 2 \mathrm{H}), 3.40(\mathrm{t}, J=7.3 \mathrm{~Hz}, 2 \mathrm{H})$, $2.62(\mathrm{td}, J=7.3,2.6 \mathrm{~Hz}, 2 \mathrm{H}), 2.38(\mathrm{t}, J=2.6 \mathrm{~Hz}, 1 \mathrm{H}), 1.30(\mathrm{t}, J=7.3 \mathrm{~Hz}, 3 \mathrm{H})$.

${ }^{13} \mathrm{C}$ NMR $\left(126 \mathrm{MHz}\right.$, acetone- $\left.\mathrm{d}_{6}, 25^{\circ} \mathrm{C}, \delta\right)$ :

172.2, 152.6, 132.5, 131.9, 126.9, 121.4, 117.6, 107.8, 83.9, 70.2, 37.1, 36.4, 13.8, 13.2.

HRMS (ESI-TOF, m/z):

Calc'd for $\mathrm{C}_{14} \mathrm{H}_{15} \mathrm{BN}_{2} \mathrm{O}_{4} \mathrm{Na}^{+}\left([\mathrm{M}+\mathrm{Na}]^{+}\right)$309.1017; found 309.1024 . 


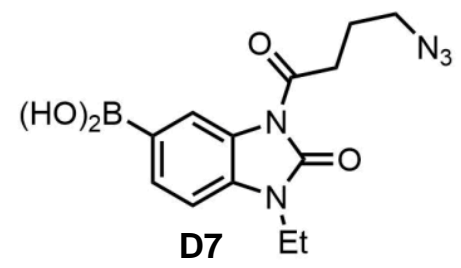

Proceduı ..

To a stirred solution of carboxylic acid SI-13 $(65 \mathrm{mg}, 0.50 \mathrm{mmol}, 2.0 \mathrm{eq})$ in $1.5 \mathrm{~mL} \mathrm{CH}_{2} \mathrm{Cl}_{2}$ was charged $1 \mu \mathrm{L}$ DMF followed by oxalyl chloride (127 $\mu \mathrm{L}, 0.75 \mathrm{mmol}, 3.0 \mathrm{eq}$ ) (note: gas evolution). After 90 minutes, the reaction was concentrated on the rotovap and co-evaporated with $3 \times 1 \mathrm{~mL} \mathrm{CH}_{2} \mathrm{Cl}_{2}$.

To a stirred 0.2 M solution of SI-65 (72 mg, $0.25 \mathrm{mmol}$ ) in DMF, was charged NaH (55\% suspension, $13 \mathrm{mg}, 0.30$ mmol, 1.2 eq). After 10 minutes, the crude acid chloride was charged as a solution in $0.25 \mathrm{~mL} \mathrm{CH}_{2} \mathrm{Cl}_{2}$. After 10 minutes, the reaction was quenched to a stirred mixture of $10 \mathrm{~mL}$ EtOAc and $5 \mathrm{~mL} \mathrm{pH} 4$ buffer. The aqueous material was discarded, and the organic material was washed twice with brine, dried $\left(\mathrm{MgSO}_{4}\right)$ filtered, and concentrated on the rotovap. The crude material was chromatographed on $8 \mathrm{~g}$ silica $(1: 1 \mathrm{v} / \mathrm{v}$ EtOAc : pentane then EtOAc) to afford the intermediate boronic ester $(84.8 \mathrm{mg}, 0.21 \mathrm{mmol}, 85 \%$ yield) as a white solid.

To a stirred suspension of the intermediate boronic ester $(84.8 \mathrm{mg}, 0.21 \mathrm{mmol})$ in $2.0 \mathrm{~mL} 2: 1 \mathrm{v} / \mathrm{v}$ acetone $: \mathrm{H}_{2} \mathrm{O}$ was charged $\mathrm{NH}_{4} \mathrm{OAc}\left(2 \mathrm{M}\right.$ sol'n in $\mathrm{H}_{2} \mathrm{O}, 192 \mu \mathrm{L}, 0.38 \mathrm{mmol}, 1.8$ eq) followed by $\mathrm{NaIO}_{4}(127 \mathrm{mg}, 0.60 \mathrm{mmol}, 2.8$ eq), and the mixture aged for 15 hours. Most of the acetone was removed on the rotovap. The mixture was extracted with $10 \mathrm{~mL}$ EtOAc and $10 \mathrm{~mL} \mathrm{H}_{2} \mathrm{O}$ and the aqueous material was discarded. The organic material was washed with brine, dried $\left(\mathrm{Mg}_{2} \mathrm{SO}_{4}\right)$, and concentrated on the rotovap. Purification by preparative HPLC (method B, $10-80 \%$ ACN, in two equal loads) afforded $\mathbf{D} 7(26.0 \mathrm{mg}, 82.0 \mu \mathrm{mol}, 33 \%$ yield over 2 steps) as a white solid.

${ }^{1} \mathbf{H}$ NMR $\left(500 \mathrm{MHz}\right.$, acetone- $\left.\mathrm{d}_{6}, 25^{\circ} \mathrm{C}, \delta\right)$ :

$8.61(\mathrm{~s}, 1 \mathrm{H}), 7.80(\mathrm{~d}, J=8.0 \mathrm{~Hz}, 1 \mathrm{H}), 7.29(\mathrm{br} \mathrm{s}, 2 \mathrm{H}), 7.18(\mathrm{~d}, J=8.0 \mathrm{~Hz}, 1 \mathrm{H}), 3.94(\mathrm{q}, J=7.1 \mathrm{~Hz}, 2 \mathrm{H}), 3.50(\mathrm{t}, J=$ $6.6 \mathrm{~Hz}, 2 \mathrm{H}), 3.26(\mathrm{t}, J=7.2 \mathrm{~Hz}, 2 \mathrm{H}), 2.04(\mathrm{~m}, 2 \mathrm{H}), 1.29(\mathrm{t}, J=7.1 \mathrm{~Hz}, 3 \mathrm{H})$ (note: the peak at $2.04 \mathrm{ppm}$ overlaps with the acetone- $d_{6}$ peak).

${ }^{13} \mathrm{C}$ NMR $\left(126 \mathrm{MHz}\right.$, acetone- $\left.\mathrm{d}_{6}, 25^{\circ} \mathrm{C}, \delta\right)$ :

173.3, 152.7, 132.5, 131.8, 127.0, 121.5, 107.8, 51.4, 36.4, 34.8, 24.2, 13.3.

HRMS (ESI-TOF, m/z):

Calc'd for $\mathrm{C}_{13} \mathrm{H}_{17} \mathrm{BN}_{5} \mathrm{O}_{4}{ }^{+}\left([\mathrm{M}+\mathrm{H}]^{+}\right)$318.1368; found 318.1376.

Calc'd for $\mathrm{C}_{13} \mathrm{H}_{16} \mathrm{BN}_{5} \mathrm{O}_{4} \mathrm{Na}^{+}\left([\mathrm{M}+\mathrm{Na}]^{+}\right) 340.1188$; found 340.1186 . 


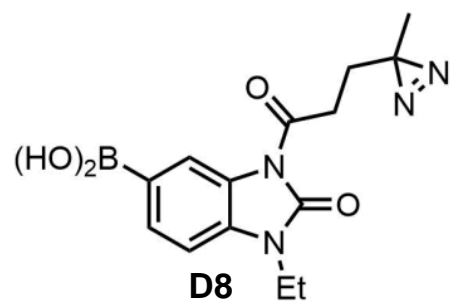

Procedure:

To a stirred solution of carboxylic acid SI-14 $(100 \mathrm{mg}, 0.79 \mathrm{mmol}, 5.3 \mathrm{eq})$ in $1.0 \mathrm{~mL} \mathrm{CH}_{2} \mathrm{Cl}_{2}$ was charged $1 \mu \mathrm{L}$ DMF followed by oxalyl chloride (102 $\mu \mathrm{L}, 1.19 \mathrm{mmol}, 7.9 \mathrm{eq})$ (note: gas evolution). After 45 minutes, the reaction was concentrated on the rotovap and co-evaporated with $3 \times 0.5 \mathrm{~mL} \mathrm{CH}_{2} \mathrm{Cl}_{2}$.

To a stirred 0.2 M solution of SI-65 (43.2 mg, $0.15 \mathrm{mmol}$ ) in DMF, was charged NaH (55\% suspension, $7.9 \mathrm{mg}$, $0.18 \mathrm{mmol}, 1.2 \mathrm{eq}$ ). After 5 minutes the crude acid chloride was charged as a solution in $0.25 \mathrm{~mL} \mathrm{CH}_{2} \mathrm{Cl}_{2}$. After 10 minutes, the reaction was quenched to a stirred mixture of $5 \mathrm{~mL}$ EtOAc and $2.5 \mathrm{~mL} \mathrm{pH} 4$ buffer. The aqueous material was discarded, and the organic material was washed twice with brine, dried $\left(\mathrm{MgSO}_{4}\right)$ filtered, and concentrated on the rotovap. The crude material was chromatographed on $5 \mathrm{~g}$ silica $(30 \% \mathrm{v} / \mathrm{v} \mathrm{Et} 2 \mathrm{O}$ in pentane followed by $\mathrm{Et}_{2} \mathrm{O}$ ) to afford the intermediate boronic ester $(66.3 \mathrm{mg}, 0.17 \mathrm{mmol}, 110 \%$ yield) as a tan solid (note: the ${ }^{1} \mathrm{H}$ NMR spectrum indicated contamination by ca. 0.75 eq 3-(3-methyl-3H-diazirine-3-yl)propionic acid).

To a stirred suspension of the intermediate boronic ester $(66.3 \mathrm{mg}, 0.17 \mathrm{mmol})$ in $1.0 \mathrm{~mL} 2: 1 \mathrm{v} / \mathrm{v}$ acetone $: \mathrm{H}_{2} \mathrm{O}$ was charged $\mathrm{NH}_{4} \mathrm{OAc}\left(2 \mathrm{M}\right.$ sol'n in $\mathrm{H}_{2} \mathrm{O}, 166 \mu \mathrm{L}, 0.33 \mathrm{mmol}, 2.0$ eq) followed by $\mathrm{NaIO}_{4}(107 \mathrm{mg}, 0.50 \mathrm{mmol}, 3.0$ eq), and the mixture was heated in a $30-35^{\circ} \mathrm{C}$ bath for 16 hours. The mixture was cooled to room temperature, and most of the acetone was removed on the rotovap. The mixture was extracted with $5 \mathrm{~mL}$ EtOAc and $5 \mathrm{~mL} \mathrm{H}_{2} \mathrm{O}$ and the aqueous material was discarded. The organic material was washed with brine, dried $\left(\mathrm{Mg}_{2} \mathrm{SO}_{4}\right)$, and concentrated on the rotovap. Purification by preparative HPLC (method A, 10 - 80\% ACN) afforded D8 (7.4 mg, $23.4 \mu \mathrm{mol}, 16 \%$ yield over 2 steps) as a white solid.

${ }^{1} \mathbf{H}$ NMR $\left(500 \mathrm{MHz}\right.$, acetone- $\left.\mathrm{d}_{6}, 25^{\circ} \mathrm{C}, \delta\right)$ :

$8.61(\mathrm{~s}, 1 \mathrm{H}), 7.81(\mathrm{~d}, J=8.0 \mathrm{~Hz}, 1 \mathrm{H}), 7.33(\mathrm{br} \mathrm{s}, 1 \mathrm{H}), 7.20(\mathrm{~d}, J=8.0 \mathrm{~Hz}, 1 \mathrm{H}), 3.95(\mathrm{q}, J=7.1 \mathrm{~Hz}, 2 \mathrm{H}), 3.10(\mathrm{t}, J=$ $7.4 \mathrm{~Hz}, 2 \mathrm{H}), 1.83(\mathrm{t}, J=7.4 \mathrm{~Hz}, 2 \mathrm{H}), 1.31(\mathrm{t}, J=7.1 \mathrm{~Hz}, 3 \mathrm{H}), 1.10(\mathrm{~s}, 3 \mathrm{H})$.

${ }^{13} \mathbf{C}$ NMR $\left(126 \mathrm{MHz}\right.$, acetone- $\left.\mathrm{d}_{6}, 25^{\circ} \mathrm{C}, \delta\right)$ :

$172.8,132.5,131.8,127.0,121.5,107.8,36.4,32.3,29.6,26.1,19.8,13.2$ (note: the peak at $29.6 \mathrm{ppm}$ was detected indirectly through HMQC).

\section{HRMS (ESI-TOF, m/z):}

Calc'd for $\mathrm{C}_{14} \mathrm{H}_{18} \mathrm{BN}_{2} \mathrm{O}_{4}{ }^{+}\left([\mathrm{M}+\mathrm{H}]^{+}\right)$317.1416; found 317.1418.

Calc'd for $\mathrm{C}_{14} \mathrm{H}_{17} \mathrm{BN}_{2} \mathrm{O}_{4} \mathrm{Na}^{+}\left([\mathrm{M}+\mathrm{Na}]^{+}\right)$339.1235; found 339.1241. 


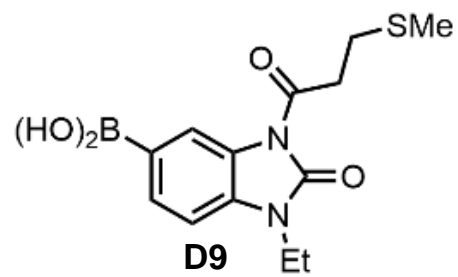

\section{Procedure:}

To a stirred solution of 3-(methylthio)propionic acid (36 mg, $0.30 \mathrm{mmol}, 3 \mathrm{eq}$ ) in $1 \mathrm{~mL} \mathrm{CH}_{2} \mathrm{Cl}_{2}$ was charged oxalyl chloride ( $34 \mu \mathrm{L}, 0.4 \mathrm{mmol}, 4 \mathrm{eq}$ ). After 1 hour, the mixture was concentrated on the rotovap and co-evaporated with $2 \times 0.5 \mathrm{~mL} \mathrm{CH}_{2} \mathrm{Cl}_{2}$.

To a stirred 0.2 M solution of SI-65 (29 mg, $0.10 \mathrm{mmol}$ ) in DMF was charged NaH (55\% suspension, $5.2 \mathrm{mg}, 0.12$ mmol, 1.2 eq). After 10 minutes, a solution of the crude acid chloride in $0.25 \mathrm{~mL} \mathrm{CH}_{2} \mathrm{Cl}_{2}$ was charged. After 10 minutes, the reaction the reaction was quenched to a stirred mixture of $5 \mathrm{~mL}$ EtOAc and $2.5 \mathrm{~mL} \mathrm{pH} 4$ buffer. The aqueous material was discarded, and the organic material was washed twice with brine, dried $\left(\mathrm{MgSO}_{4}\right)$ filtered, and concentrated on the rotovap. The crude material was chromatographed on $4 \mathrm{~g}$ silica $\left(0.4 \% \mathrm{MeOH}\right.$ in $\left.\mathrm{CH}_{2} \mathrm{Cl}_{2}\right)$ to afford the intermediate boronic ester $(33.0 \mathrm{mg}, 0.085 \mathrm{mmol}, 85 \%$ yield) as a white solid.

To a stirred solution of the intermediate boronic ester $(33.0 \mathrm{mg}, 0.085 \mathrm{mmol})$ in $850 \mu \mathrm{L} 95: 5 \mathrm{v} / \mathrm{v} \mathrm{CH}_{2} \mathrm{Cl}_{2}$ : TFA was charged $\mathrm{MeB}(\mathrm{OH})_{2}(25.3 \mathrm{mg}, 0.42 \mathrm{mmol}, 5 \mathrm{eq})$. After 13 hours, the mixture was concentrated on the rotovap and co-evaporated with $\mathrm{CH}_{2} \mathrm{Cl}_{2}$. Purification by preparative HPLC (method B, 5 - 70\% ACN) afforded D9 (18.3 mg, $59.4 \mu \mathrm{mol}, 59 \%$ yield over 2 steps) as a white solid.

${ }^{1} \mathbf{H}$ NMR $\left(392 \mathrm{MHz}\right.$, acetone- $\left.\mathrm{d}_{6}, 25^{\circ} \mathrm{C}, \delta\right)$ :

$8.54(\mathrm{~s}, 1 \mathrm{H}), 7.74(\mathrm{~d}, J=8.1 \mathrm{~Hz}, 1 \mathrm{H}), 7.22(\mathrm{br} \mathrm{s}, 1 \mathrm{H}), 7.13(\mathrm{~d}, J=8.1 \mathrm{~Hz}, 1 \mathrm{H}), 3.88(\mathrm{q}, J=7.3 \mathrm{~Hz}, 2 \mathrm{H}), 3.42(\mathrm{t}, J=$ $7.2 \mathrm{~Hz}, 2 \mathrm{H}), 2.83(\mathrm{t}, J=7.2 \mathrm{~Hz}, 2 \mathrm{H}), 2.08(\mathrm{~s}, 3 \mathrm{H}), 1.24(\mathrm{t}, J=7.3 \mathrm{~Hz}, 3 \mathrm{H})$.

${ }^{13} \mathbf{C}$ NMR $\left(99 \mathrm{MHz}\right.$, acetone- $\left.\mathrm{d}_{6}, 25^{\circ} \mathrm{C}, \delta\right)$ :

172.5, 152.6, 132.5, 131.8, 127.0, 121.5, 107.8, 38.0, 36.4, 15.4, 13.3.

HRMS (ESI-TOF, m/z):

Calc'd for $\mathrm{C}_{13} \mathrm{H}_{17} \mathrm{BN}_{2} \mathrm{O}_{4} \mathrm{SNa}^{+}\left([\mathrm{M}+\mathrm{Na}]^{+}\right)$331.0894; found 331.0902 . 


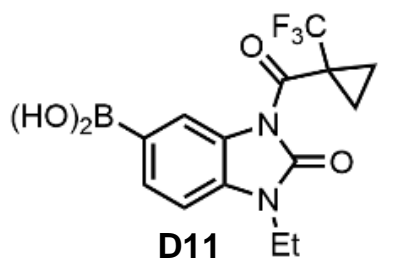

\section{Procedure:}

To a stirred solution of 1-trifluoromethyl-1-cyclopropanecarboxylic acid (31 mg, $0.20 \mathrm{mmol}, 2 \mathrm{eq})$ in $0.25 \mathrm{~mL}$ $\mathrm{CH}_{2} \mathrm{Cl}_{2}$ was charged $0.5 \mu \mathrm{L}$ DMF followed by oxalyl chloride ( $\left.26 \mu \mathrm{L}, 0.30 \mathrm{mmol}, 3 \mathrm{eq}\right)$. After 30 minutes, the mixture was concentrated on the rotovap and co-evaporated with $3 \times 0.5 \mathrm{~mL} \mathrm{CH}_{2} \mathrm{Cl}_{2}$.

To a stirred 0.2 M solution of SI-65 (29 mg, $0.10 \mathrm{mmol}$ ) in DMF was charged NaH (55\% suspension, $5.3 \mathrm{mg}, 0.12$ mmol, 1.2 eq). After 5 minutes, the crude acid chloride was charged as a solution in $0.25 \mathrm{~mL} \mathrm{CH}_{2} \mathrm{Cl}_{2}$. After 5 minutes, the reaction was quenched to a stirred mixture of $5 \mathrm{~mL}$ EtOAc and $2.5 \mathrm{~mL} \mathrm{pH} 4$ buffer. The aqueous material was discarded, and the organic material was washed twice with brine, dried $\left(\mathrm{MgSO}_{4}\right)$ filtered, and concentrated on the rotovap. The crude material was chromatographed on $5 \mathrm{~g}$ silica $(0.4$ to $0.8 \% \mathrm{v} / \mathrm{v} \mathrm{MeOH}$ in $\left.\mathrm{CH}_{2} \mathrm{Cl}_{2}\right)$ to afford the intermediate boronic ester $(26.9 \mathrm{mg}, 0.063 \mathrm{mmol}, 63 \%$ yield $)$ as a white solid.

To a stirred suspension of the intermediate boronic ester $(26.9 \mathrm{mg}, 0.063 \mathrm{mmol})$ in $1.5 \mathrm{~mL} 2: 1 \mathrm{v} / \mathrm{v}$ acetone : $\mathrm{H}_{2} \mathrm{O}$ was charged $\mathrm{NH}_{4} \mathrm{OAc}$ (2M sol'n in $\mathrm{H}_{2} \mathrm{O}, 63 \mu \mathrm{L}, 0.13 \mathrm{mmol}, 2.0$ eq) followed by $\mathrm{NaIO}_{4}(40 \mathrm{mg}, 0.19 \mathrm{mmol}, 3.0$ eq), and the mixture was heated in a $40-45^{\circ} \mathrm{C}$ bath for 15 hours. The mixture was cooled to room temperature, and most of the acetone was removed on the rotovap. The mixture was extracted with $2.5 \mathrm{~mL}$ EtOAc and $2.5 \mathrm{~mL} \mathrm{H}_{2} \mathrm{O}$ and the aqueous material was discarded. The organic material was washed with brine, dried $\left(\mathrm{Mg}_{2} \mathrm{SO}_{4}\right)$, and concentrated on the rotovap. Purification by preparative HPLC (method A, 5 - 70\% ACN) afforded D11 (6.9 mg, $20.2 \mu \mathrm{mol}, 20 \%$ yield over 2 steps) as a white solid.

${ }^{1} \mathbf{H}$ NMR $\left(500 \mathrm{MHz}\right.$, acetone- $\left.\mathrm{d}_{6}, 25^{\circ} \mathrm{C}, \delta\right)$ :

$8.48(\mathrm{~s}, 1 \mathrm{H}), 7.82(\mathrm{~d}, J=8.0 \mathrm{~Hz}, 1 \mathrm{H}), 7.32(\mathrm{br} \mathrm{s}, 1 \mathrm{H}), 7.21(\mathrm{~d}, J=8.0 \mathrm{~Hz}, 1 \mathrm{H}), 3.95(\mathrm{q}, J=7.2 \mathrm{~Hz}, 2 \mathrm{H}), 1.62(\mathrm{~m}$, $2 \mathrm{H}), 1.51(\mathrm{~m}, 2 \mathrm{H}), 1.30(\mathrm{t}, J=7.2 \mathrm{~Hz}, 3 \mathrm{H})$.

${ }^{13} \mathrm{C}$ NMR $\left(126 \mathrm{MHz}\right.$, acetone- $\left.\mathrm{d}_{6}, 25{ }^{\circ} \mathrm{C}, \delta\right)$ :

165.7, 151.4, 132.9, 132.3, 127.0, $126.1(\mathrm{q}, J=268 \mathrm{~Hz}), 121.3,108.0,36.5,31.8(\mathrm{q}, J=34.4 \mathrm{~Hz}), 13.2,12.3$.

\section{HRMS (ESI-TOF, m/z):}

Calc'd for $\mathrm{C}_{14} \mathrm{H}_{14} \mathrm{BF}_{3} \mathrm{~N}_{2} \mathrm{O}_{4} \mathrm{Na}^{+}\left([\mathrm{M}+\mathrm{Na}]^{+}\right)$365.0891; found 365.0897. 


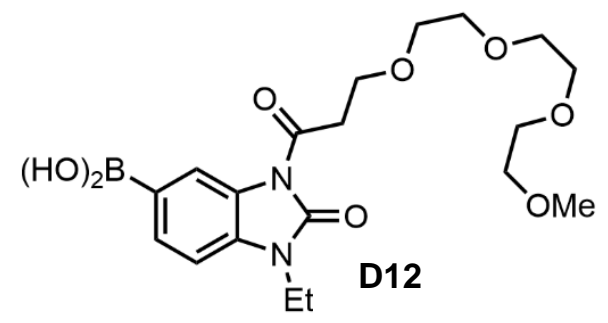

\section{Procedure:}

To a stirred solution of carboxylic acid SI-11 ( $84 \mathrm{mg}, 0.36 \mathrm{mmol}, 2 \mathrm{eq}$ ) in $2 \mathrm{~mL} \mathrm{CH}_{2} \mathrm{Cl}_{2}$ was charged $1 \mu \mathrm{L}$ DMF followed by oxalyl chloride ( $46 \mu \mathrm{L}, 0.53 \mathrm{mmol}, 3 \mathrm{eq}$ ). After 1.5 hours, the mixture was concentrated on the rotovap and co-evaporated with $3 \times 10 \mathrm{~mL} \mathrm{CH}_{2} \mathrm{Cl}_{2}$.

To a stirred 0.2 M solution of SI-65 (51.3 mg, $0.18 \mathrm{mmol}$ ) in DMF was charged NaH (55\% suspension, $9.3 \mathrm{mg}, 0.21$ mmol, 1.2 eq). After 5 minutes, the crude acid chloride was charged as a solution in $0.25 \mathrm{~mL} \mathrm{CH}_{2} \mathrm{Cl}_{2}$. After 5 minutes, the reaction was quenched to a stirred mixture of $5 \mathrm{~mL}$ EtOAc and $2.5 \mathrm{~mL} \mathrm{pH} 4$ buffer. The aqueous material was discarded, and the organic material was washed twice with brine, dried $\left(\mathrm{MgSO}_{4}\right)$ filtered, and concentrated on the rotovap. The crude material was chromatographed on $10 \mathrm{~g}$ silica ( 2 to $4 \% \mathrm{v} / \mathrm{v} \mathrm{MeOH}$ in $\mathrm{CH}_{2} \mathrm{Cl}_{2}$ ) to afford the intermediate boronic ester $(67.4 \mathrm{mg}, 0.141 \mathrm{mmol}, 79 \%$ yield) as a white solid.

To a stirred suspension of the intermediate boronic ester $(67.4 \mathrm{mg}, 0.141 \mathrm{mmol}, 79 \%$ yield $)$ in $3.0 \mathrm{~mL} 2: 1 \mathrm{v} / \mathrm{v}$ acetone : $\mathrm{H}_{2} \mathrm{O}$ was charged $\mathrm{NH}_{4} \mathrm{OAc}\left(2 \mathrm{M}\right.$ sol'n in $\mathrm{H}_{2} \mathrm{O}, 141 \mu \mathrm{L}, 0.28 \mathrm{mmol}, 2.0$ eq) followed by $\mathrm{NaIO}_{4}(90 \mathrm{mg}$, $0.42 \mathrm{mmol}, 3.0 \mathrm{eq}$ ), and the mixture was heated in a $30-35^{\circ} \mathrm{C}$ bath for 19 hours. The mixture was cooled to room temperature, and most of the acetone was removed on the rotovap. The mixture was extracted with $5 \mathrm{~mL}$ EtOAc and $5 \mathrm{~mL} \mathrm{H}_{2} \mathrm{O}$ and the aqueous material was discarded. The organic material was washed with brine, dried $\left(\mathrm{Mg}_{2} \mathrm{SO}_{4}\right)$, and concentrated on the rotovap. Purification by preparative HPLC (method A, 10 - 80\% ACN) afforded D12 (40.6 $\mathrm{mg}, 102 \mu \mathrm{mol}, 58 \%$ yield over 2 steps) as a sticky white solid.

${ }^{1} \mathbf{H}$ NMR $\left(500 \mathrm{MHz}\right.$, acetone- $\left.\mathrm{d}_{6}, 25^{\circ} \mathrm{C}, \delta\right)$ :

$8.60(\mathrm{~s}, 1 \mathrm{H}), 7.80(\mathrm{~d}, J=8.0 \mathrm{~Hz}), 7.24(\mathrm{~s}, 1 \mathrm{H}), 7.19(\mathrm{~d}, J=8.0 \mathrm{~Hz}), 3.95(\mathrm{q}, J=7.3 \mathrm{~Hz}, 2 \mathrm{H}), 3.89$ (t, $J=6.3 \mathrm{~Hz}$, 2H), $3.56(\mathrm{~m}, 12 \mathrm{H}), 3.44(\mathrm{~m}, 4 \mathrm{H}), 3.26(\mathrm{~m}, 3 \mathrm{H}), 1.30(\mathrm{t}, J=7.3 \mathrm{~Hz}, 3 \mathrm{H})$

${ }^{13} \mathbf{C}$ NMR $\left(126 \mathrm{MHz}\right.$, acetone- $\left.\mathrm{d}_{6}, 25^{\circ} \mathrm{C}, \delta\right)$ :

172.0, 152.7, 132.5, 131.8, 127.0, 121.5, 107.8, 72.6, 71.2, 71.1, 71.1, 71.0, 58.7, 38.3, 36.4, 13.3.

HRMS (ESI-TOF, m/z):

Calc'd for $\mathrm{C}_{19} \mathrm{H}_{30} \mathrm{BN}_{2} \mathrm{O}_{8}{ }^{+}\left([\mathrm{M}+\mathrm{H}]^{+}\right)$425.2090; found 425.2090.

Calc'd for $\mathrm{C}_{19} \mathrm{H}_{29} \mathrm{BN}_{2} \mathrm{O}_{8} \mathrm{Na}^{+}\left([\mathrm{M}+\mathrm{Na}]^{+}\right)$447.1909; found 447.1912. 


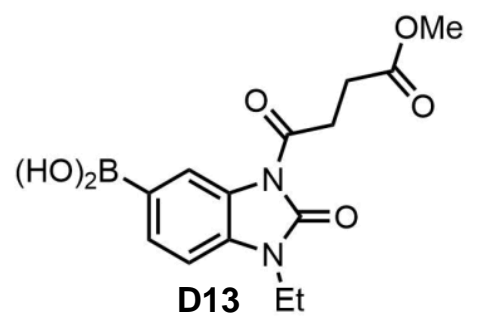

\section{Procedure:}

To a stirred solution of monomethyl succinate $(26.4 \mathrm{mg}, 0.20 \mathrm{mmol}$, $2.0 \mathrm{eq})$ in $1.0 \mathrm{~mL} \mathrm{CH}_{2} \mathrm{Cl}_{2}$ was charged $1 \mu \mathrm{L}$ DMF followed by oxalyl chloride ( $25.7 \mu \mathrm{L}, 0.3 \mathrm{mmol}, 3.0 \mathrm{eq})$ (note: gas evolution). After 90 minutes, the reaction was concentrated on the rotovap and co-evaporated with $2 \times 1 \mathrm{~mL} \mathrm{CH}_{2} \mathrm{Cl}_{2}$.

To a stirred 0.2 M solution of SI-65 (28.8 mg, $0.10 \mathrm{mmol}$ ) in DMF, was charged $\mathrm{NaH}$ (55\% suspension, $5.2 \mathrm{mg}$, $0.12 \mathrm{mmol}, 1.2 \mathrm{eq}$ ). After 10 minutes, the crude acid chloride was charged as a solution in $0.25 \mathrm{~mL} \mathrm{CH}_{2} \mathrm{Cl}_{2}$. After 10 minutes, the reaction was quenched to a stirred mixture of $5 \mathrm{~mL}$ EtOAc and $2.5 \mathrm{~mL} \mathrm{pH} 4$ buffer. The aqueous material was discarded, and the organic material was washed twice with brine, dried $\left(\mathrm{MgSO}_{4}\right)$ filtered, and concentrated on the rotovap. The crude material was chromatographed on $5 \mathrm{~g}$ silica (50 to $100 \% \mathrm{Et}_{2} \mathrm{O}$ in pentane) to afford the intermediate boronic ester $(22.4 \mathrm{mg}, 0.056 \mathrm{mmol}, 56 \%$ yield) as a white solid.

To a stirred suspension of the intermediate boronic ester $(22.4 \mathrm{mg}, 0.056 \mathrm{mmol})$ in $1.0 \mathrm{~mL} 2: 1 \mathrm{v} / \mathrm{v}$ acetone : $\mathrm{H}_{2} \mathrm{O}$ was charged $\mathrm{NH}_{4} \mathrm{OAc}$ ( $2 \mathrm{M}$ sol'n in $\mathrm{H}_{2} \mathrm{O}, 50 \mu \mathrm{L}, 0.10 \mathrm{mmol}, 1.8 \mathrm{eq}$ ) followed by $\mathrm{NaIO}_{4}(34.2 \mathrm{mg}, 0.16 \mathrm{mmol}, 2.8$ eq), and the mixture was heated in a $30-40{ }^{\circ} \mathrm{C}$ bath for 17 hours. The mixture was cooled to room temperature, and most of the acetone was removed on the rotovap. The mixture was extracted with $5 \mathrm{~mL}$ EtOAc and $5 \mathrm{~mL} \mathrm{H}_{2} \mathrm{O}$ and the aqueous material was discarded. The organic material was washed with brine, dried $\left(\mathrm{Mg}_{2} \mathrm{SO}_{4}\right)$, and concentrated on the rotovap. Purification by preparative HPLC (method A, 10 - 80\% ACN) afforded D13 (8.4 mg, $26.2 \mu \mathrm{mol}$, $26 \%$ yield over 2 steps) as a white solid.

${ }^{1} \mathbf{H}$ NMR $\left(500 \mathrm{MHz}\right.$, acetone- $\left.\mathrm{d}_{6}, 25^{\circ} \mathrm{C}, \delta\right)$ :

$8.57(\mathrm{~s}, 1 \mathrm{H}), 7.81(\mathrm{~d}, J=8.0 \mathrm{~Hz}, 1 \mathrm{H}), 7.33(\mathrm{br} \mathrm{s}, 2 \mathrm{H}), 7.20(\mathrm{~d}, J=8.0 \mathrm{~Hz}, 1 \mathrm{H}), 3.95(\mathrm{q}, J=7.1 \mathrm{~Hz}, 2 \mathrm{H}), 3.65(\mathrm{~s}$, $3 \mathrm{H}), 3.45(\mathrm{t}, J=6.4 \mathrm{~Hz}, 2 \mathrm{H}), 2.75(\mathrm{t}, J=6.4 \mathrm{~Hz}, 2 \mathrm{H}), 1.31(\mathrm{t}, J=7.1 \mathrm{~Hz}, 3 \mathrm{H})$.

${ }^{13} \mathrm{C}$ NMR $\left(126 \mathrm{MHz}\right.$, acetone- $\left.\mathrm{d}_{6}, 25^{\circ} \mathrm{C}, \delta\right)$ :

173.4, 173.0, 152.7, 132.5, 131.9, 126.9, 121.4, 107.9, 51.8, 36.4, 33.1, 28.6, 13.3.

HRMS (ESI-TOF, m/z):

Calc'd for $\mathrm{C}_{14} \mathrm{H}_{18} \mathrm{BN}_{2} \mathrm{O}_{6}{ }^{+}\left([\mathrm{M}+\mathrm{H}]^{+}\right)$321.1252; found 321.1245.

Calc'd for $\mathrm{C}_{14} \mathrm{H}_{17} \mathrm{BN}_{2} \mathrm{O}_{6} \mathrm{Na}^{+}\left([\mathrm{M}+\mathrm{Na}]^{+}\right)$343.1072; found 343.1073 . 


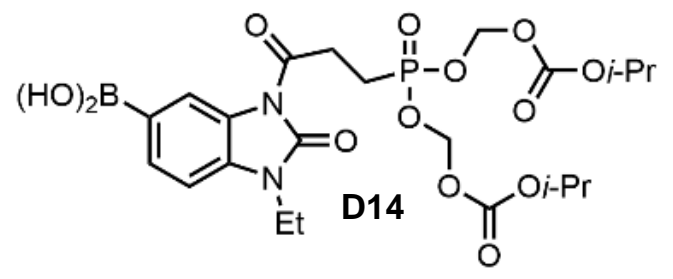

\section{Procedure:}

To a stirred solution of carboxylic acid SI-18 (77 mg, $0.20 \mathrm{mmol}, 2 \mathrm{eq})$ in $1 \mathrm{~mL} \mathrm{CH}_{2} \mathrm{Cl}_{2}$ was charged 1-chloro$N, N, 2$-trimethyl-1-propenylamine $(53 \mu \mathrm{L}, 0.40 \mathrm{mmol}, 4$ eq. After 1.5 hours, the mixture was concentrated on the rotovap an co-evaporated with $3 \times 1 \mathrm{~mL} \mathrm{PhMe}$.

To a stirred 0.2 M solution of SI-65 (29 mg, $0.10 \mathrm{mmol})$ in DMF was charged NaH (55\% suspension, $5.2 \mathrm{mg}, 0.12$ mmol, 1.2 eq). After 5 minutes, the crude acid chloride was charged as a solution of $0.25 \mathrm{~mL} \mathrm{CH}_{2} \mathrm{Cl}_{2}$. $\mathrm{After} 5$ minutes, the reaction was reverse quenched to a stirred solution of $5 \mathrm{~mL}$ EtOAc and $2.5 \mathrm{~mL} \mathrm{pH} 4$ buffer. The aqueous material was discarded, and the organic material was washed twice with brine, dried $\left(\mathrm{MgSO}_{4}\right)$ filtered, and

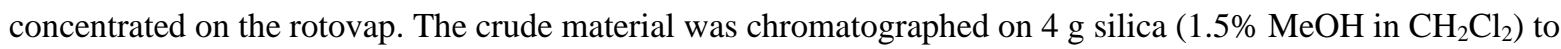
afford the intermediate boronic ester $(33.0 \mathrm{mg}, 0.078 \mathrm{mmol}, 78 \%$ yield $)$ as a white solid.

To a stirred solution of the intermediate boronic ester $(33.0 \mathrm{mg}, 0.078 \mathrm{mmol})$ in $1.6 \mathrm{~mL} 4: 1 \mathrm{v} / \mathrm{v} \mathrm{THF}: \mathrm{H}_{2} \mathrm{O}$ was charged $\mathrm{NH}_{4} \mathrm{OAc}\left(2 \mathrm{M}\right.$ sol'n in $\mathrm{H}_{2} \mathrm{O}, 78 \mu \mathrm{L}, 0.16 \mathrm{mmol}, 2.0$ eq) followed by $\mathrm{NaIO}_{4}(50 \mathrm{mg}, 0.23 \mathrm{mmol}, 3.0 \mathrm{eq})$, and the mixture was heated in a $35-40{ }^{\circ} \mathrm{C}$ bath for 13.5 hours. The mixture was cooled to room temperature, and most of the THF was removed on the rotovap. The mixture was extracted with $2.5 \mathrm{~mL}$ EtOAc and $2.5 \mathrm{~mL} \mathrm{H}_{2} \mathrm{O}$, and the

aqueous material was discarded. The organic material was washed with brine, dried $\left(\mathrm{Mg}_{2} \mathrm{SO}_{4}\right)$, and concentrated on the rotovap. Purification by preparative HPLC (method A, $10-80 \%$ ACN) afforded D14 (19.8 mg, $34.5 \mu \mathrm{mol}, 35 \%$ yield over 2 steps) as a white solid.

${ }^{1} \mathbf{H}$ NMR $\left(392 \mathrm{MHz}, \mathrm{DMSO}-\mathrm{d}_{6}, 25^{\circ} \mathrm{C}, \delta\right)$ :

$8.48(\mathrm{~s}, 1 \mathrm{H}), 8.02(\mathrm{~s}, 2 \mathrm{H}), 7.72(\mathrm{~d}, J=7.6 \mathrm{~Hz}, 1 \mathrm{H}), 7.24(\mathrm{~d}, J=7.6 \mathrm{~Hz}, 1 \mathrm{H}), 5.60(\mathrm{td}, J=13.0,5.4 \mathrm{~Hz}, 4 \mathrm{H}), 4.80(\mathrm{~m}$, $2 \mathrm{H}), 3.87(\mathrm{q}, J=6.3 \mathrm{~Hz}, 2 \mathrm{H}), 3.33(\mathrm{~m}, 2 \mathrm{H}), 2.29(\mathrm{~m}, 2 \mathrm{H}), 1.21(\mathrm{~m}, 15 \mathrm{H})$.

${ }^{13} \mathrm{C}$ NMR (99 MHz, DMSO-d $\left.6,25^{\circ} \mathrm{C}, \delta\right)$ :

$171.0(\mathrm{~d}, J=18.8 \mathrm{~Hz}), 152.7,151.4,131.1,130.9,125.5,120.5,107.4,84.1$ (d, $J=5.6 \mathrm{~Hz}), 72.9,35.5,29.7,21.3$. $20.2(\mathrm{~d}, J=143 \mathrm{~Hz}), 12.9$.

HRMS (ESI-TOF, m/z):

Calc'd for $\mathrm{C}_{22} \mathrm{H}_{33} \mathrm{BN}_{2} \mathrm{O}_{13} \mathrm{P}^{+}\left([\mathrm{M}+\mathrm{H}]^{+}\right)$575.1808; found 575.1821.

Calc'd for $\mathrm{C}_{22} \mathrm{H}_{32} \mathrm{BN}_{2} \mathrm{O}_{13} \mathrm{PNa}^{+}\left([\mathrm{M}+\mathrm{Na}]^{+}\right)$597.1627; found 597.1646. 

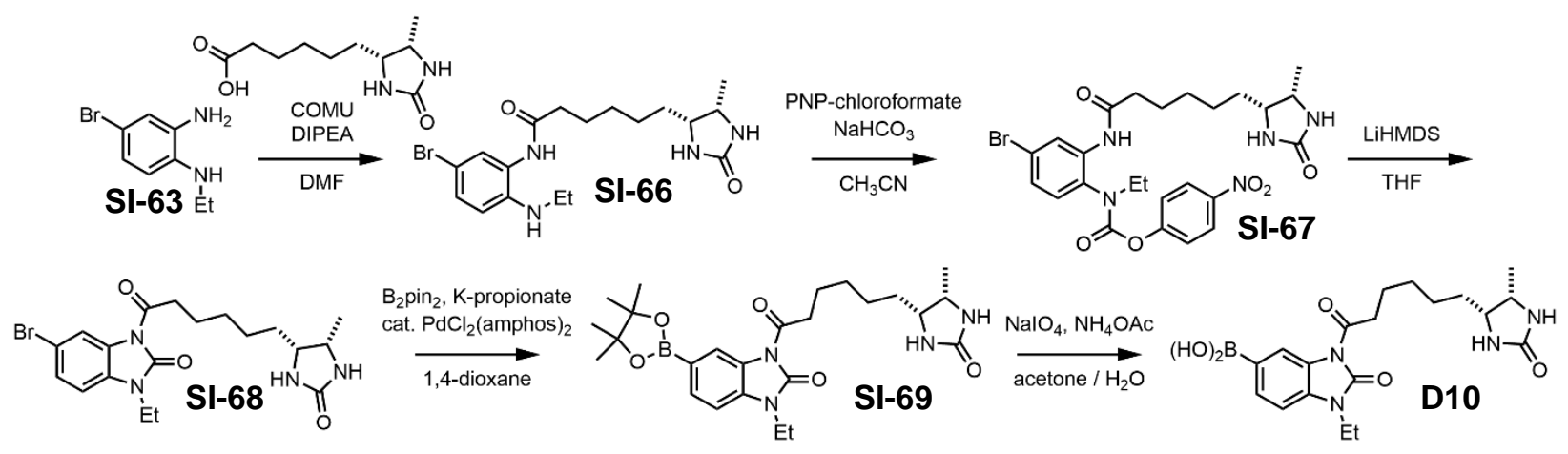


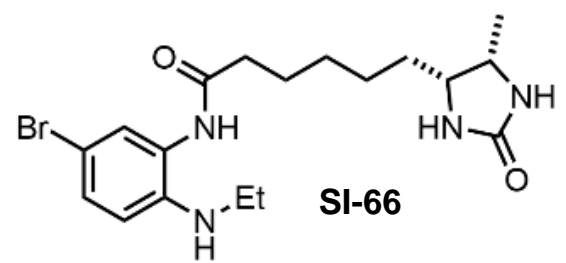

\section{Procedure:}

To a solution of desthiobiotin (412 mg, $1.92 \mathrm{mmol}, 1.2 \mathrm{eq})$ and DIPEA (557 $\mu \mathrm{L}, 3.2 \mathrm{mmol}, 2 \mathrm{eq})$ in $10 \mathrm{~mL}$ DMF was charged COMU (754 mg, 1.76 mmol, 1.1 eq). After 10 minutes was charged diamine SI-63 (334 mg, 1.60 mmol). After 15 hours, most of the DMF was removed on the rotovap. The residue was extracted with $10 \mathrm{~mL}$ EtOAc and $5 \mathrm{~mL} \mathrm{10 \%} \mathrm{NaCl}$, and the aqueous material was discarded. The organic material was washed with brine, dried $\left(\mathrm{MgSO}_{4}\right)$, filtered, and concentrated on the rotovap. The crude material was chromatographed on $15 \mathrm{~g}$ silica ( $\mathrm{Et}_{2} \mathrm{O}$ followed by 5 to $10 \% \mathrm{v} / \mathrm{v} \mathrm{MeOH}$ in $\mathrm{CH}_{2} \mathrm{Cl}_{2}$ ) to afford $\mathbf{S I - 6 6}$ (440 mg, $1.07 \mathrm{mmol}, 67 \%$ yield) as a reddish foam.

${ }^{1} \mathbf{H}$ NMR $\left(500 \mathrm{MHz}, \mathrm{CDCl}_{3}, 25^{\circ} \mathrm{C}, \delta\right)$ :

$8.52(\mathrm{~s}, 1 \mathrm{H}), 7.30(\mathrm{~s}, 1 \mathrm{H}), 7.11(\mathrm{~d}, J=8.6 \mathrm{~Hz}, 1 \mathrm{H}), 6.49(\mathrm{~d}, J=8.6 \mathrm{~Hz}, 1 \mathrm{H}), 6.30(\mathrm{~s}, 1 \mathrm{H}), 5.26(\mathrm{~m}, 1 \mathrm{H}), 4.11(\mathrm{~m}$, 1H), $3.75(\mathrm{~m}, 1 \mathrm{H}), 3.63(\mathrm{~m}, 1 \mathrm{H}), 3.00(\mathrm{~m}, 2 \mathrm{H}), 2.33(\mathrm{~m}, 2 \mathrm{H}), 1.66(\mathrm{~m}, 2 \mathrm{H}), 1.38(\mathrm{~m}, 5 \mathrm{H}), 1.22(\mathrm{~d}, J=6.9 \mathrm{~Hz}, 2 \mathrm{H})$, $1.17(\mathrm{t}, J=6.9 \mathrm{~Hz}, 3 \mathrm{H}), 1.02(\mathrm{~d}, J=5.7 \mathrm{~Hz}, 3 \mathrm{H})$.

${ }^{13} \mathrm{C}$ NMR $\left(126 \mathrm{MHz}, \mathrm{CDCl}_{3}, 25^{\circ} \mathrm{C}, \delta\right):$

$172.9,164.2,141.8,129.5,128.3,124.9,113.4,108.1,56.0,51.3,38.4,35.5,29.3,28.1,25.4,25.0,15.6,14.4$.

HRMS (ESI-TOF, m/z):

Calc'd for $\mathrm{C}_{18} \mathrm{H}_{28} \mathrm{BrN}_{4} \mathrm{O}_{2}{ }^{+}\left([\mathrm{M}+\mathrm{H}]^{+}\right)$411.1391/413.1370; found 411.1382/413.1365.

Calc'd for $\mathrm{C}_{18} \mathrm{H}_{27} \mathrm{BrN}_{4} \mathrm{O}_{2} \mathrm{Na}^{+}\left([\mathrm{M}+\mathrm{Na}]^{+}\right)$433.1210/435.1190; found 433.1202/435.1186. 


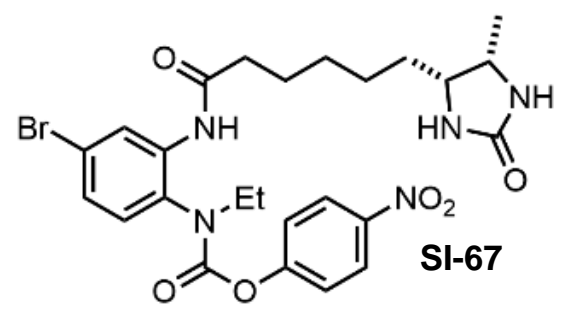

\section{Procedure:}

To a stirred solution of SI-66 (440 mg, $1.07 \mathrm{mmol})$ in $10 \mathrm{~mL}$ ACN was charged $\mathrm{NaHCO}_{3}(180 \mathrm{mg}, 2.14 \mathrm{mmol}, 2 \mathrm{eq})$ followed by 4-nitrophenyl chloroformate ( $238 \mathrm{mg}, 1.18 \mathrm{mmol}, 1.1 \mathrm{eq})$. After 1 hour, most of the ACN was removed on the rotovap. The residue was extracted with $10 \mathrm{~mL}$ EtOAc and $5 \mathrm{~mL} 10 \% \mathrm{NaCl}$, and the aqueous material was discarded. The organic material was washed with brine, dried $\left(\mathrm{MgSO}_{4}\right)$, filtered, and concentrated on the rotovap. The crude material was chromatographed on $25 \mathrm{~g}$ silica (5 to 7\% v/v $\mathrm{MeOH}$ in $\mathrm{CH}_{2} \mathrm{Cl}_{2}$ ) to afford $\mathbf{S I - 6 7}$ (590 mg, $1.02 \mathrm{mmol}, 96 \%$ yield) as a foam.

${ }^{1} \mathbf{H}$ NMR $\left(500 \mathrm{MHz}, \mathrm{CDCl}_{3}, 25^{\circ} \mathrm{C}, \delta\right)$ :

$8.61(\mathrm{~m}, 1 \mathrm{H}), 8.44$ (br s, 1H), 8.18 (br s, 3H), $7.27(\mathrm{~m}, 5 \mathrm{H}), 7.15(\mathrm{~m}, 3 \mathrm{H}), 6.39(\mathrm{~m}, 1 \mathrm{H}), 5.42(\mathrm{~m}, 1 \mathrm{H}), 3.95(\mathrm{~m}, 1 \mathrm{H})$, $3.74(\mathrm{~m}, 1 \mathrm{H}), 3.61$ (m. 1H), 3.40 (br s, 1H), 2.42 (br s, 3H), 2.35 (s, 1H), 1.68 (br s, 2H), 1.38 (m, 5H), 1.21 (m, 4H), $1.01(\mathrm{~s}, 3 \mathrm{H})$.

${ }^{13} \mathrm{C}$ NMR $\left(126 \mathrm{MHz}, \mathrm{CDCl}_{3}, 25^{\circ} \mathrm{C}, \delta\right):$

172.1, 164.1, 155.7, 152.6 (br), 144.7, 137.7, 136.0, 130.1 (br), 129.9 (br), 129.2 (br), 128.9, 128.0, 127.5 (br), 126.2 (br), 125.1, 124.8, 122.2, 55.9, 55.8, 51.2, 44.8 (br), 36.6 (br), 36.4 (br), 29.5 (br), 28.8 (br), 25.8 (br), 25.7 (br), 25.1 (br), 24.8 (br), 21.3, 15.5, 15.5, 12.7 (br).

(Note: the NMR spectra indicate a mixture of rotamers).

HRMS (ESI-TOF, m/z):

Calc'd for $\mathrm{C}_{25} \mathrm{H}_{30} \mathrm{BrN}_{5} \mathrm{O}_{6} \mathrm{Na}^{+}\left([\mathrm{M}+\mathrm{Na}]^{+}\right)$598.1272/600.1252; found 598.1269/600.1253 


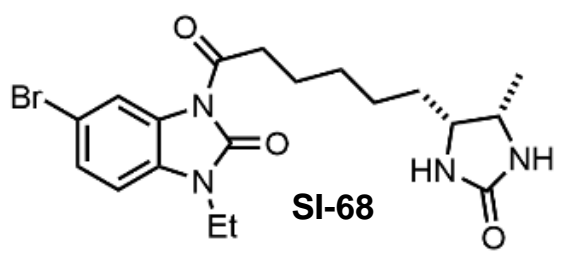

\section{Procedure:}

To a stirred $-78{ }^{\circ} \mathrm{C}$ solution SI-67 (590 mg, $1.02 \mathrm{mmol}$ ) in $10 \mathrm{~mL}$ THF was charged LiHMDS (1M in THF, 1.13 $\mathrm{mL}, 1.13 \mathrm{mmol}, 1.1 \mathrm{eq}$ ) over 5 minutes. After 30 minutes, the reaction was quenched by charging $0.25 \mathrm{~mL} 40 \%$ aqueous citric acid, and the mixture was warmed to room temperature. The mixture was extracted with $25 \mathrm{~mL}$ EtOAc and $25 \mathrm{~mL} \mathrm{10 \%} \mathrm{NaCl}$, and the aqueous material was discarded. The organic material was washed with brine, dried $\left(\mathrm{MgSO}_{4}\right)$, filtered, and concentrated on the rotovap. The crude material was chromatographed on $25 \mathrm{~g}$ silica (6 to $8 \%$ v/v MeOH in $\mathrm{CH}_{2} \mathrm{Cl}_{2}$ ) to afford $\mathbf{S I - 6 8}$ (410 $\mathrm{mg}, 0.94 \mathrm{mmol}, 92 \%$ yield) as an oil.

${ }^{1} \mathbf{H}$ NMR $\left(500 \mathrm{MHz}, \mathrm{CDCl}_{3}, 25^{\circ} \mathrm{C}, \delta\right)$ :

$8.25(\mathrm{~s}, 1 \mathrm{H}), 7.21(\mathrm{~d}, J=8.0 \mathrm{~Hz}, 1 \mathrm{H}), 6.70(\mathrm{~d}, J=8.0 \mathrm{~Hz}, 1 \mathrm{H}), 3.73(\mathrm{~m}, 4 \mathrm{H}), 3.58(\mathrm{~m}, 1 \mathrm{H}), 3.00(\mathrm{t}, J=6.9 \mathrm{~Hz}, 2 \mathrm{H})$, $1.62(\mathrm{~m}, 2 \mathrm{H}), 1.33(\mathrm{~m}, 5 \mathrm{H}), 1.18(\mathrm{t}, J=6.9 \mathrm{~Hz}, 4 \mathrm{H}), 0.99(\mathrm{~d}, J=6.9 \mathrm{~Hz}, 3 \mathrm{H})$.

(Note: ca. 0.18 eq 4-nitrophenol is present based on ${ }^{1} \mathrm{H}$ NMR spectrum).

${ }^{13} \mathbf{C ~ N M R}\left(126 \mathrm{MHz}, \mathrm{CDCl}_{3}, 25^{\circ} \mathrm{C}, \delta\right)$ :

173.4, 163.5, 151.5, 127.3, 126.1, 119.1, 115.6, 115.2, 108.5, 56.1, 51.5, 37.0, 36.1, 29.5, 28.9, 26.2, 23.9, 15.7, 13.0.

HRMS (ESI-TOF, m/z):

Calc'd for $\mathrm{C}_{19} \mathrm{H}_{26} \mathrm{BrN}_{4} \mathrm{O}_{3}{ }^{+}\left([\mathrm{M}+\mathrm{H}]^{+}\right)$437.1183/439.1163; found 437.1179/439.1162.

Calc'd for $\mathrm{C}_{19} \mathrm{H}_{25} \mathrm{BrN}_{4} \mathrm{O}_{3} \mathrm{Na}^{+}\left([\mathrm{M}+\mathrm{Na}]^{+}\right)$459.1003/461.0982; found 459.0998/461.0976. 


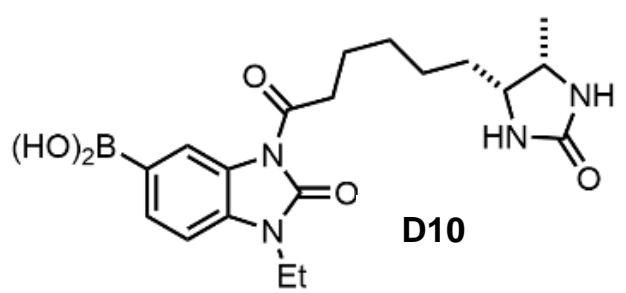

\section{Procedure:}

To a flask containing SI-68 (410 mg, $0.94 \mathrm{mmol}$ ) was charged $\mathrm{B}_{2} \mathrm{pin}_{2}(429 \mathrm{mg}, 1.69 \mathrm{mmol}, 1.8 \mathrm{eq})$, potassium propionate (295 mg, $2.63 \mathrm{mmol}, 2.8 \mathrm{eq})$, and $\mathrm{PdCl}_{2}$ (amphos) $)_{2}(16.6 \mathrm{mg}, 24 \mu \mathrm{mol}, 0.025 \mathrm{eq}$ ) followed by $5 \mathrm{~mL} 1,4-$ dioxane, and the mixture was stirred in a $75-80^{\circ} \mathrm{C}$ bath for 1 hour. The mixture was cooled to room temperature and extracted with $50 \mathrm{~mL} \mathrm{Et}_{2} \mathrm{O}$ and $50 \mathrm{~mL} 10 \% \mathrm{NaCl}$. The aqueous material was discarded. The organic material was washed with brine, dried $\left(\mathrm{MgSO}_{4}\right)$, filtered, and concentrated on the rotovap. The crude material was chromatographed on $50 \mathrm{~g}$ silica ( $1.5 \% \mathrm{v} / \mathrm{v} \mathrm{MeOH}$ in $\mathrm{Et}_{2} \mathrm{O}$ followed by $6 \% \mathrm{v} / \mathrm{v} \mathrm{MeOH}$ in $\mathrm{CH}_{2} \mathrm{Cl}_{2}$ ) to afford SI-69 (175 mg, $0.44 \mathrm{mmol}, 46 \%$ yield) as a tan semisolid.

To a stirred suspension of SI-69 $(62.8 \mathrm{mg}, 0.13 \mathrm{mmol})$ in $1.3 \mathrm{~mL} 2: 1 \mathrm{v} / \mathrm{v}$ acetone : $\mathrm{H}_{2} \mathrm{O}$ was charged $\mathrm{NH}_{4} \mathrm{OAc}(2 \mathrm{M}$ sol'n in $\mathrm{H}_{2} \mathrm{O}, 130 \mu \mathrm{L}, 0.26 \mathrm{mmol}, 2.0 \mathrm{eq}$ ) followed by $\mathrm{NaIO}_{4}(83 \mathrm{mg}, 0.39 \mathrm{mmol}, 3.0 \mathrm{eq}$ ), and the mixture was heated in a $35-40{ }^{\circ} \mathrm{C}$ bath for 18 hours. The mixture was cooled to room temperature, and most of the acetone was removed on the rotovap. The mixture was extracted with $2.5 \mathrm{~mL}$ EtOAc and $2.5 \mathrm{~mL} \mathrm{H}_{2} \mathrm{O}$ and the aqueous material was discarded. The organic material was washed with brine, dried $\left(\mathrm{Mg}_{2} \mathrm{SO}_{4}\right)$, and concentrated on the rotovap. Purification by preparative HPLC (method B, 10 - 80\% ACN) afforded D10 (5.5 mg, $13.7 \mu \mathrm{mol}, 4.8 \%$ yield over 2 steps) as a white solid.

${ }^{1} \mathbf{H}$ NMR $\left(500 \mathrm{MHz}\right.$, DMSO-d $\left.6,25^{\circ} \mathrm{C}, \delta\right)$ :

$8.49(\mathrm{~s}, 1 \mathrm{H}), 7.71(\mathrm{~d}, J=8.0 \mathrm{~Hz}, 1 \mathrm{H}), 7.23(\mathrm{~d}, J=8.0 \mathrm{~Hz}, 1 \mathrm{H}), 3.87(\mathrm{q}, J=7.1 \mathrm{~Hz}, 2 \mathrm{H}), 3.60(\mathrm{~m}, 1 \mathrm{H}), 3.09(\mathrm{t}, J=$ $7.2 \mathrm{~Hz}, 2 \mathrm{H}), 1.65(\mathrm{~m}, 1 \mathrm{H}), 1.36(\mathrm{~m}, 5 \mathrm{H}), 1.21(\mathrm{t}, J=7.1 \mathrm{~Hz}, 5 \mathrm{H}), 0.95(\mathrm{~d}, J=6.3 \mathrm{~Hz}, 3 \mathrm{H})$.

${ }^{13} \mathrm{C}$ NMR $\left(126 \mathrm{MHz}\right.$, DMSO-d $\left.6,25{ }^{\circ} \mathrm{C}, \delta\right)$ :

173.2, 162.9, 151.4, 131.1, 130.7, 125.7, 120.5, 107.3, 55.0, 50.3, 36.4, 29.6, 28.7, 25.7, 23.7, 15.5, 12.9.

HRMS (ESI-TOF, m/z):

Calc'd for $\mathrm{C}_{19} \mathrm{H}_{28} \mathrm{BN}_{4} \mathrm{O}_{5}{ }^{+}\left([\mathrm{M}+\mathrm{H}]^{+}\right)$403.2147; found 403.2146.

Calc'd for $\mathrm{C}_{19} \mathrm{H}_{27} \mathrm{BN}_{4} \mathrm{O}_{5} \mathrm{Na}^{+}\left([\mathrm{M}+\mathrm{Na}]^{+}\right) 425.1967$; found 425.1960 . 

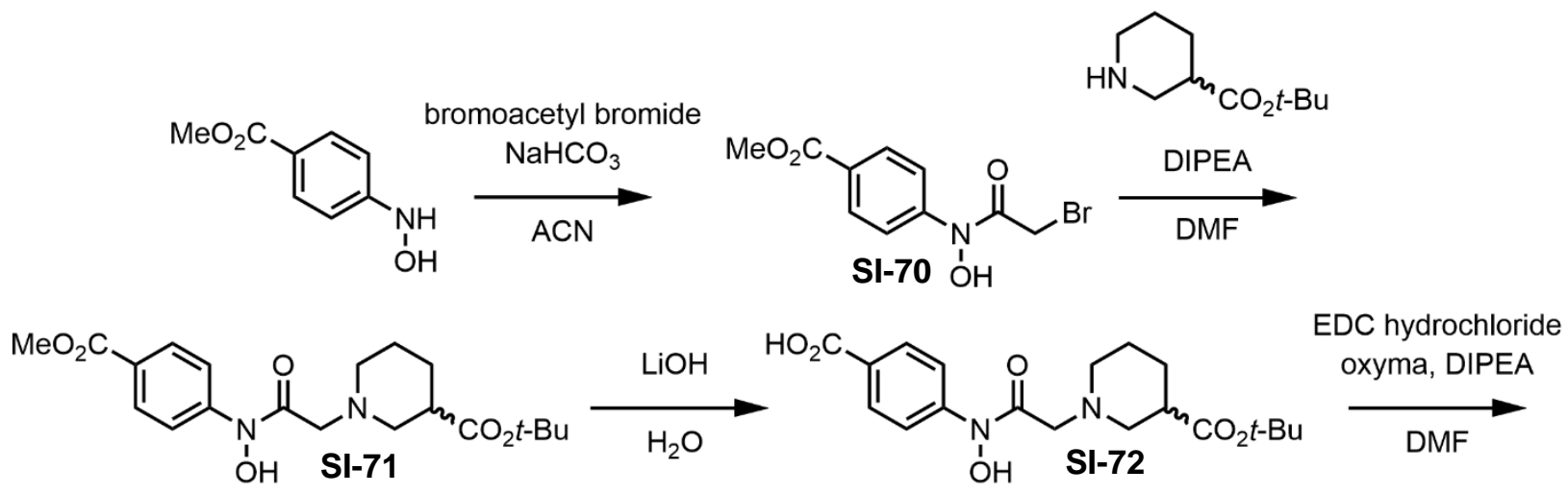<smiles>C#CCNC(=O)c1ccc(N(O)C(=O)CN2CCC[C@H](C(=O)OC(C)(C)C)C2)cc1</smiles> 


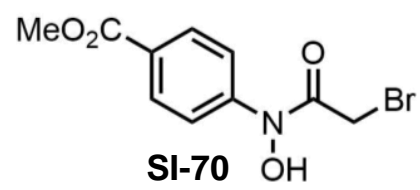

\section{Procedure:}

To a stirred $0-5^{\circ} \mathrm{C}$ suspension of $N$-[(4-methoxycarbonyl)phenyl]hydroxylamine ${ }^{4}(4.07 \mathrm{~g}, 24.3 \mathrm{mmol})$ and $\mathrm{NaHCO}_{3}$ (4.09 g, $48.7 \mathrm{mmol}, 2.0 \mathrm{eq}$ ) in $100 \mathrm{~mL}$ ACN was charged bromoacetyl bromide (3.34 mL, $27.5 \mathrm{mmol}, 1.1$ eq) in portions over 10 minutes, and the cooling bath was removed. After 30 minutes, $100 \mathrm{~mL}$ IPA was charged, the slurry was filtered through fritted glass (IPA rinse), and the filtrate was concentrated on the rotavap. The residue was suspended in $50 \mathrm{~mL} n$-heptane, cooled to $0-5^{\circ} \mathrm{C}$, and filtered through fritted glass. The solids were dried under vacuum at $50^{\circ} \mathrm{C}$ to afford SI-70 (7.14 g) as white solids. Quantitative NMR using 1,3,5-trimethoxybenzene as an internal standard indicated $86.5 \%$ purity (adjusted yield $21.4 \mathrm{mmol}, 88 \%$ ).

${ }^{1} \mathbf{H}$ NMR: $\left(500 \mathrm{MHz}\right.$, DMSO- $\left.d_{6}, 25^{\circ} \mathrm{C}, \delta\right)$ :

$11.22,7.97(\mathrm{~d}, J=8.6 \mathrm{~Hz}, 2 \mathrm{H}), 7.82(\mathrm{~d}, J=8.6 \mathrm{~Hz}, 2 \mathrm{H}), 4.42(\mathrm{~s}, 2 \mathrm{H}), 3.82(\mathrm{~s}, 3 \mathrm{H})$.

${ }^{13} \mathrm{C}$ NMR: $\left(126 \mathrm{MHz}\right.$, DMSO- $\left.d_{6}, 25^{\circ} \mathrm{C}, \delta\right)$ :

166.3, 165.7, 145.0, 130.0, 125.5, 118.9, 52.1, 30.0.

(Note: peaks of 1,3,5-trimethoxybenzene are also observed in NMR spectra).

HRMS (ESI-TOF, m/z):

Calc'd for $\mathrm{C}_{10} \mathrm{H}_{10} \mathrm{NBrNa}^{+}\left([\mathrm{M}+\mathrm{Na}]^{+}\right)$309.9685/931.6665; found 309.9685/311.9663. 


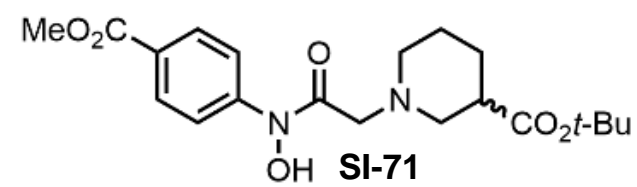

\section{Procedure:}

To a stirred solution of SI-70 (144 mg, $0.50 \mathrm{mmol})$ in $1.4 \mathrm{~mL}$ DMF was charged DIPEA (105 $\mu \mathrm{L}, 0.60 \mathrm{mmol}, 1.2$ eq) followed by $(R, S)$-t-butyl piperidine-3-carboxylate ${ }^{5}(107 \mathrm{mg}, 0.58 \mathrm{mmol}, 1.15 \mathrm{eq})$. The mixture was stirred at 40 to $50{ }^{\circ} \mathrm{C}$ for 2.5 hours and cooled to room temperature. $10 \mathrm{~mL} \mathrm{MTBE}$ and $4 \mathrm{~mL} 10 \%$ aq. $\mathrm{NaCl}$ was charged, and the mixture was extracted. The aqueous $\mathrm{pH}$ was increased from 7 to 9 with $\mathrm{Na}_{2} \mathrm{CO}_{3}$. The layers were separated, and the aqueous material was back-extracted with $2 \times 4 \mathrm{~mL}$ MTBE. The pooled organic material was washed with brine, dried $\left(\mathrm{Na}_{2} \mathrm{SO}_{4}\right)$, filtered, and concentrated. The crude material was chromatographed on $10 \mathrm{~g}$ silica gel (50 to $70 \%$ v/v EtOAc in hexane) to afford SI-71 (63.4 $\mathrm{mg}, 0.162 \mathrm{mmol}, 32 \%$ yield) as a white solid.

${ }^{1} \mathbf{H}$ NMR $\left(392 \mathrm{MHz}\right.$, acetone- $\left.d_{6}, 25^{\circ} \mathrm{C}, \delta\right)$ :

$7.87(\mathrm{~d}, J=9.0 \mathrm{~Hz}, 2 \mathrm{H}), 7.82(\mathrm{~d}, J=9.0 \mathrm{~Hz}, 2 \mathrm{H}), 3.74(\mathrm{~s}, 3 \mathrm{H}), 3.51(\mathrm{~d}, J=14.8 \mathrm{~Hz}, 1 \mathrm{H}), 3.44(\mathrm{~d}, J=14.8 \mathrm{~Hz}, 1 \mathrm{H})$, $2.83(\mathrm{~m}, 1 \mathrm{H}), 2.61(\mathrm{~m}, 2 \mathrm{H}), 2.44(\mathrm{~m}, 2 \mathrm{H}), 1.69(\mathrm{~m}, 1 \mathrm{H}), 1.59(\mathrm{~m}, 1 \mathrm{H}), 1.50(\mathrm{~m}, 2 \mathrm{H}), 1.29(\mathrm{~s}, 9 \mathrm{H})$.

${ }^{13} \mathrm{C}$ NMR $\left(99 \mathrm{MHz}\right.$, acetone- $\left.d_{6}, 25^{\circ} \mathrm{C}, \delta\right)$ :

173.3, 168.7, 166.7, 145.8, 130.6, 126.3, 118.8, 80.7, 63.1, 55.4, 53.8, 52.1, 42.6, 28.1, 26.8, 24.7.

HRMS (ESI-TOF, m/z):

Calc'd for $\mathrm{C}_{20} \mathrm{H}_{29} \mathrm{~N}_{2} \mathrm{O}_{6}{ }^{+}\left([\mathrm{M}+\mathrm{H}]^{+}\right)$393.2020; found 393.2019.

Calc'd for $\mathrm{C}_{20} \mathrm{H}_{28} \mathrm{~N}_{2} \mathrm{O}_{6} \mathrm{Na}^{+}\left([\mathrm{M}+\mathrm{Na}]^{+}\right)$418.1840; found 418.1838. 


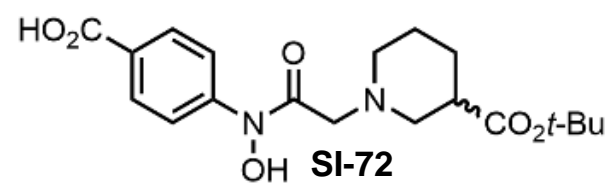

\section{Procedure:}

To a vial charged with SI-71 (87.9 mg, $0.22 \mathrm{mmol}$ ) was charged $\mathrm{LiOH}\left(0.5 \mathrm{M}\right.$ in $\mathrm{H}_{2} \mathrm{O}, 2.69 \mathrm{~mL}, 1.34 \mathrm{mmol}$, 6.0 eq), and the mixture was stirred. After 30 minutes the $\mathrm{pH}$ was adjusted to 4 with citric acid. The volume was reduced to $1 \mathrm{~mL}$ on the rotovap. The mixture was diluted with $1 \mathrm{~mL} \mathrm{MeOH}$ and syringe filtered. Purification by preparative HPLC (method B, 10 - 80\% ACN, in two equal loads) afforded SI-72 (69.6 mg, $0.141 \mathrm{mmol}, 63 \%$ yield) as a white solid.

${ }^{1} \mathbf{H}$ NMR $\left(500 \mathrm{MHz}, \mathrm{CD}_{3} \mathrm{CN}, 25^{\circ} \mathrm{C}, \delta\right)$ :

$8.01(\mathrm{~m}, 2 \mathrm{H}), 7.83(\mathrm{~m}, 2 \mathrm{H}), 4.43(\mathrm{~s}, 2 \mathrm{H}), 3.77(\mathrm{~m}, 1 \mathrm{H}), 3.63$ and $3.50(\mathrm{~m}, 1 \mathrm{H}), 3.27$ to $2.85(\mathrm{~m}, 3 \mathrm{H}), 2.12$ and 1.86 $(\mathrm{m}, 2 \mathrm{H}), 1.97(\mathrm{~m}, 1 \mathrm{H}), 1.48$ and $1.42(\mathrm{~s}, 9 \mathrm{H})$

${ }^{13} \mathrm{C}$ NMR $\left(126 \mathrm{MHz}, \mathrm{CD}_{3} \mathrm{CN}, 25^{\circ} \mathrm{C}, \delta\right)$ :

174.2, 171.0, 167.7, 165.3, 165.1, 145.1, 131.3, 127.8, 119.6, 83.6, 82.5, 59.4, 59.1, 55.4, 55.2, 55.1, 54.8, 41.0, $38.8,28.0,25.6,24.3,22.9,20.7$.

(note: some peaks are doubled in both the ${ }^{1} \mathrm{H}$ and ${ }^{13} \mathrm{C}$ spectra).

HRMS (ESI-TOF, m/z):

Calc'd for $\mathrm{C}_{19} \mathrm{H}_{27} \mathrm{~N}_{2} \mathrm{O}_{6}{ }^{+}\left([\mathrm{M}+\mathrm{H}]^{+}\right)$379.1864; found 379.1858.

Calc'd for $\mathrm{C}_{19} \mathrm{H}_{26} \mathrm{~N}_{2} \mathrm{O}_{6} \mathrm{Na}^{+}\left([\mathrm{M}+\mathrm{Na}]^{+}\right) 402.1683$; found 401.1683 . 


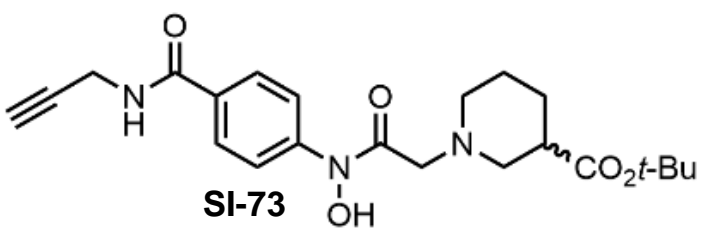

\section{Procedure:}

To a stirred solution of SI-72 (406.2 $\mathrm{mg}, 0.83 \mathrm{mmol})$ was charged propargylamine (264 $\mu \mathrm{L}, 4.1 \mathrm{mmol}, 5.0 \mathrm{eq})$ and EDC $\cdot \mathrm{HCl}$. The mixture was stirred for 24 hours and most of the DMF was removed on the rotovap. The residue was extracted with $8 \mathrm{~mL}$ EtOAc and $4 \mathrm{~mL} 10 \% \mathrm{NaCl}$, and the aqueous material was discarded. The organic material was washed with $2 \times 4 \mathrm{~mL}$ brine, dried $\left(\mathrm{Na}_{2} \mathrm{SO}_{4}\right)$, filtered, and concentrated. The crude material was adsorbed on $1.8 \mathrm{~g}$ silica and chromatographed on $25 \mathrm{~g}$ silica (EtOAc) to afford SI-73 (300.0 mg, $0.722 \mathrm{mmol}, 88 \%$ yield) as an oil.

${ }^{1} \mathbf{H}$ NMR $\left(392 \mathrm{MHz}, \mathrm{CDCl}_{3}, 25^{\circ} \mathrm{C}, \delta\right)$ :

$7.82(\mathrm{~d}, J=8.5 \mathrm{~Hz}, 2 \mathrm{H}), 7.72(\mathrm{~d}, J=8.5 \mathrm{~Hz}, 2 \mathrm{H}), 6.59(\mathrm{br} \mathrm{s}, 1 \mathrm{H}), 4.17$ (dd, $J=5.2,2.5 \mathrm{~Hz}, 2 \mathrm{H}), 3.46(\mathrm{~d}, J=13.9 \mathrm{~Hz}$, $1 \mathrm{H}), 3.40(\mathrm{~d}, J=13.9 \mathrm{~Hz}, 1 \mathrm{H}), 2.68(\mathrm{~m}, 3 \mathrm{H}), 2.49(\mathrm{~m}, 2 \mathrm{H}), 2.21(\mathrm{~m}, 1 \mathrm{H}), 1.63(\mathrm{~m}, 4 \mathrm{H}), 1.36(\mathrm{~s}, 9 \mathrm{H})$

${ }^{13} \mathrm{C}$ NMR $\left(99 \mathrm{MHz}, \mathrm{CDCl}_{3}, 25^{\circ} \mathrm{C}, \delta\right)$ :

173.5, 169.5, 166.6, 141.2, 128.7, 128.1, 119.1, 80.8, 79.9, 71.4, 62.3, 54.6, 54.4, 41.1, 29.5, 28.0, 26.0, 23.8.

HRMS (ESI-TOF, m/z):

Calc'd for $\mathrm{C}_{22} \mathrm{H}_{30} \mathrm{~N}_{3} \mathrm{O}_{5}{ }^{+}\left([\mathrm{M}+\mathrm{H}]^{+}\right)$416.2180; found 416.2168.

Calc'd for $\mathrm{C}_{22} \mathrm{H}_{29} \mathrm{~N}_{3} \mathrm{O}_{5} \mathrm{Na}^{+}\left([\mathrm{M}+\mathrm{Na}]^{+}\right)$438.1999; found 438.1992. 


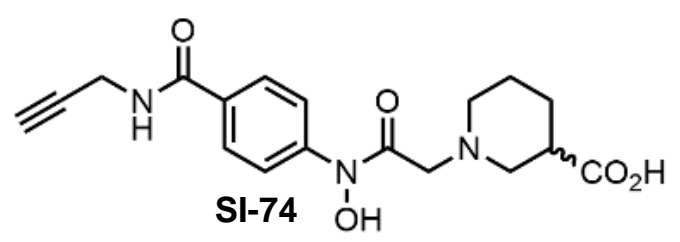

\section{Procedure:}

To a flask charged with $t$-butyl ester $\mathbf{S I - 7 3}$ (300.0 mg, $0.72 \mathrm{mmol})$ was charged $5 \mathrm{~mL} 50: 50: 0.5 \mathrm{v} / \mathrm{v}$ TFA :

$\mathrm{CH}_{2} \mathrm{Cl}_{2}: \mathrm{Et}_{3} \mathrm{SiH}$. The mixture was stirred for 8 hours, concentrated, co-evaporated with 2 x $5 \mathrm{~mL} \mathrm{PhMe}$, and lyophilized from $1: 1 \mathrm{v} / \mathrm{v}$ ACN $: \mathrm{H}_{2} \mathrm{O}$. The crude material was purified by preparative HPLC (method B, $5-80 \%$ ACN) to afford carboxylic acid SI-74 (275.3 $\mathrm{mg}, 0.582 \mathrm{mmol}, 81 \%$ yield) as a white solid.

${ }^{1} \mathbf{H}$ NMR $\left(500 \mathrm{MHz}, \mathrm{MeOH}-d_{4}, 25^{\circ} \mathrm{C}, \delta\right)$ :

$7.87(\mathrm{~d}, J=8.6 \mathrm{~Hz}, 2 \mathrm{H}), 7.84(\mathrm{~d}, J=8.6 \mathrm{~Hz}, 2 \mathrm{H}), 4.51(\mathrm{~s}, 2 \mathrm{H}), 4.14(\mathrm{~s}, 2 \mathrm{H}), 3.96$ to $3.64(\mathrm{~m}, 1 \mathrm{H}), 3.57$ to $2.92(\mathrm{~m}$, $3 \mathrm{H}), 2.59(\mathrm{~m}, 1 \mathrm{H}), 2.32$ to $1.47(\mathrm{~m}, 4 \mathrm{H})$.

${ }^{13} \mathrm{C}$ NMR $\left(126 \mathrm{MHz}, \mathrm{MeOH}-d_{4}, 25^{\circ} \mathrm{C}, \delta\right)$ :

174.1, 168.8, 165.3, 144.4, 131.9, 129.0, 120.3, 80.7, 72.1, 59.2, 55.3, 55.0, 40.5, 30.0, 26.1, 23.4.

\section{HRMS (ESI-TOF, m/z):}

Calc'd for $\mathrm{C}_{18} \mathrm{H}_{22} \mathrm{~N}_{3} \mathrm{O}_{5}{ }^{+}\left([\mathrm{M}+\mathrm{H}]^{+}\right)$360.1554; found 360.1554 .

Calc'd for $\mathrm{C}_{18} \mathrm{H}_{21} \mathrm{~N}_{3} \mathrm{O}_{5} \mathrm{Na}^{+}\left([\mathrm{M}+\mathrm{Na}]^{+}\right)$382.1373; found 382.1368 . 


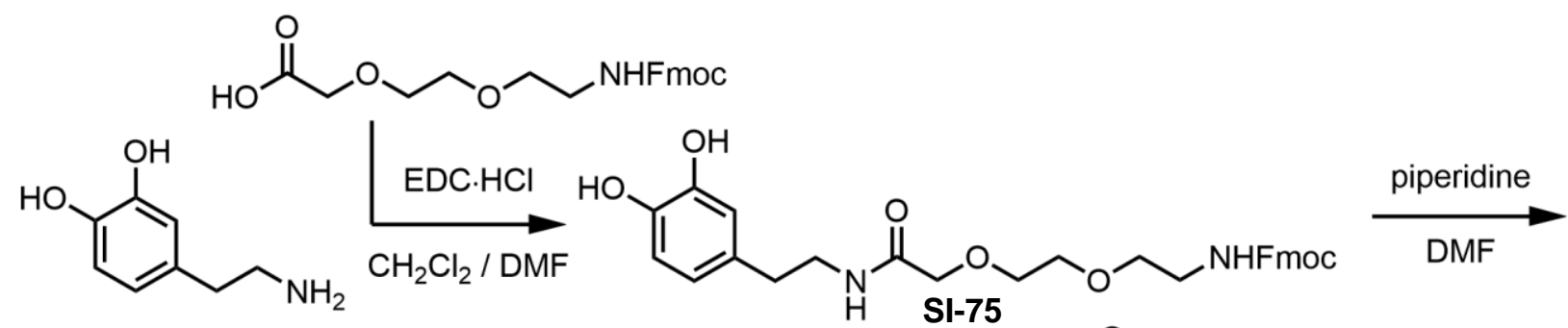

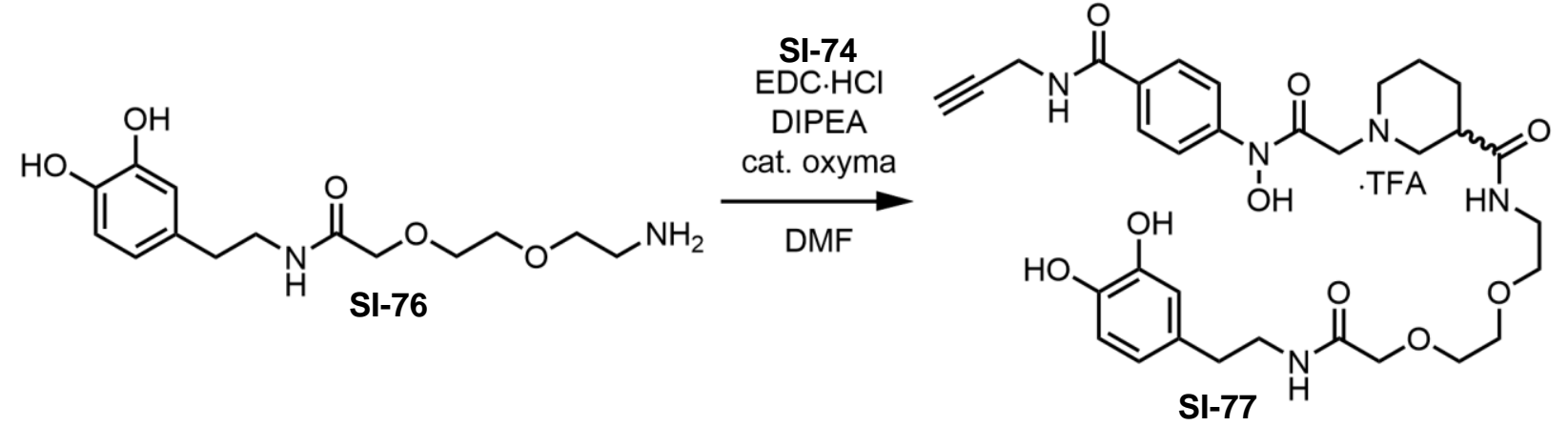




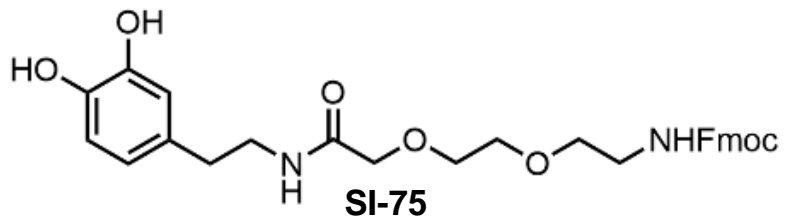

\section{Procedure:}

To a stirred solution of 3-hydroxytyramine $\cdot \mathrm{HCl}$ in $4 \mathrm{~mL} 1$ : v/v ACN : $\mathrm{H}_{2} \mathrm{O}$ was charged $760 \mathrm{mg}$ Amberlyst A26 (hydroxide form). After 30 minutes, the mixture was filtered and lyophilized to afford a tan solid (147 mg). To a stirred solution of the amine freebase in $6 \mathrm{~mL} 1: 1 \mathrm{v} / \mathrm{v} \mathrm{CH}_{2} \mathrm{Cl}_{2}$ DMF was charged \{2-[2-(Fmoc-

amino)ethoxy]ethoxy \}acetic acid (405 mg, $1.05 \mathrm{mmol}, 1.05 \mathrm{eq})$ and $\mathrm{EDC} \cdot \mathrm{HCl}(220 \mathrm{mg}, 1.15 \mathrm{mmol}, 1.15 \mathrm{eq})$. After 48 hours, the solvents were removed, and the residue was stirred with $10 \mathrm{~mL}$ EtOAc and $4 \mathrm{~mL} 10 \% \mathrm{NaCl}$. The aqueous $\mathrm{pH}$ was adjusted to 4 with citric acid, the layers were separated, and the aqueous material was discarded. The organic material was washed with brine, dried $\left(\mathrm{Na}_{2} \mathrm{SO}_{4}\right)$, filtered, and concentrated. The crude material was adsorbed on $2.2 \mathrm{~g}$ silica and chromatographed on $20 \mathrm{mg}$ silica (EtOAc to 10\% v/v MeOH in EtOAc) to afford SI-75 (501 mg, $0.96 \mathrm{mmol}, 96 \%$ yield) as a white solid (note: the ${ }^{1} \mathrm{H}$ spectrum showed a minor impurity). To obtain a sample for characterization, a $40 \mathrm{mg}$ aliquot was purified by preparative HPLC (method B, 10 - 80\% ACN), which afforded $30 \mathrm{mg}$ of a white solid.

${ }^{1} \mathbf{H}$ NMR $\left(500 \mathrm{MHz}, \mathrm{CDCl}_{3}, 25^{\circ} \mathrm{C}, \delta\right)$ :

$7.72(\mathrm{~d}, J=7.4 \mathrm{~Hz}, 2 \mathrm{H}), 7.54(\mathrm{~d}, J=7.4 \mathrm{~Hz}, 2 \mathrm{H}), 7.36(\mathrm{t}, J=7.4 \mathrm{~Hz}, 2 \mathrm{H}), 7.26(\mathrm{t}, J=7.4 \mathrm{~Hz}, 2 \mathrm{H}), 6.95(\mathrm{~m}, 1 \mathrm{H})$, $6.75(\mathrm{~d}, J=8.0 \mathrm{~Hz}, 1 \mathrm{H}), 6.67(\mathrm{~s}, 1 \mathrm{H}), 6.50(\mathrm{~d}, J=8.0 \mathrm{~Hz}, 1 \mathrm{H}), 5.33(\mathrm{br} \mathrm{s}, 1 \mathrm{H}), 4.43(\mathrm{~m}, 2 \mathrm{H}), 4.16(\mathrm{~m}, 1 \mathrm{H}), 3.92(\mathrm{~s}$, $2 \mathrm{H}), 3.57$ to $3.06(\mathrm{~m}, 10 \mathrm{H}), 2.62(\mathrm{t}, J=6.0 \mathrm{~Hz}, 2 \mathrm{H})$.

${ }^{13} \mathrm{C}$ NMR $\left(126 \mathrm{MHz}, \mathrm{CDCl}_{3}, 25^{\circ} \mathrm{C}, \delta\right)$ :

170.7, 157.0, 144.3, 143.7, 143.0, 141.3, 130.6, 127.7, 127.1, 124.9, 120.7, 120.0, 115.6, 115.4, 70.8, 70.1, 69.9, $66.9,65.9,47.1,40.7,40.2,34.5$.

HRMS (ESI-TOF, m/z):

Calc'd for $\mathrm{C}_{29} \mathrm{H}_{33} \mathrm{~N}_{2} \mathrm{O}_{7}{ }^{+}\left([\mathrm{M}+\mathrm{H}]^{+}\right)$521.2282; found 521.2292.

Calc'd for $\mathrm{C}_{29} \mathrm{H}_{32} \mathrm{~N}_{2} \mathrm{O}_{7} \mathrm{Na}^{+}\left([\mathrm{M}+\mathrm{Na}]^{+}\right)$543.2102; found 543.2101. 


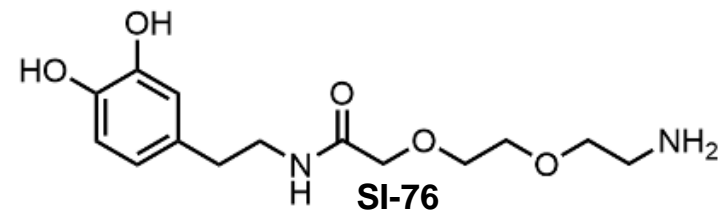

\section{Procedure:}

To a stirred solution of SI-75 (156.2 mg, $0.30 \mathrm{mmol})$ in $3 \mathrm{~mL}$ DMF was charged piperidine (296 $\mu \mathrm{L}, 3.0 \mathrm{mmol}, 10$ eq). After 3 hours, the solvents were removed, and the residue was co-evaporated with 2 × $2 \mathrm{~mL} \mathrm{IPA}$. The residue was suspended in $4 \mathrm{~mL} \mathrm{ACN}$, washed with $4 \times 4 \mathrm{~mL}$ pentane, filtered through Celite, and concentrated. The crude material was chromatographed on $4 \mathrm{~g}$ amino-silica (30 to 50\% v/v MeOH in EtOAc) to afford SI-76 (71.6 mg, 0.24 mmol, $80 \%$ yield) as an oil.

${ }^{1} \mathbf{H}$ NMR $\left(500 \mathrm{MHz}, \mathrm{MeOH}-d_{4}, 25^{\circ} \mathrm{C}, \delta\right)$ :

$6.57(\mathrm{~m}, 1 \mathrm{H}), 6.54(\mathrm{~m}, 1 \mathrm{H}), 6.41(\mathrm{~m}, 1 \mathrm{H}), 3.83(\mathrm{~m}, 2 \mathrm{H}), 3.48(\mathrm{~m}, 4 \mathrm{H}), 3.36(\mathrm{~m}, 2 \mathrm{H}), 3.30(\mathrm{~m}, 2 \mathrm{H}), 2.66(\mathrm{~m}, 2 \mathrm{H})$, $2.55(\mathrm{~m}, 2 \mathrm{H})$.

${ }^{13} \mathrm{C}$ NMR $\left(126 \mathrm{MHz}, \mathrm{MeOH}-d_{4}, 25{ }^{\circ} \mathrm{C}, \delta\right)$ :

172.5, 146.7, 145.2, 131.6, 120.9, 117.0, 116.4, 73.2, 71.9, 71.2, 71.1, 41.9, 41.6, 35.8.

HRMS (ESI-TOF, m/z):

Calc'd for $\mathrm{C}_{14} \mathrm{H}_{23} \mathrm{~N}_{2} \mathrm{O}_{5}{ }^{+}\left([\mathrm{M}+\mathrm{H}]^{+}\right)$299.1601; found 299.1606.

Calc'd for $\mathrm{C}_{14} \mathrm{H}_{22} \mathrm{~N}_{2} \mathrm{O}_{5} \mathrm{Na}^{+}\left([\mathrm{M}+\mathrm{Na}]^{+}\right) 321.1421$; found 321.1420 . 


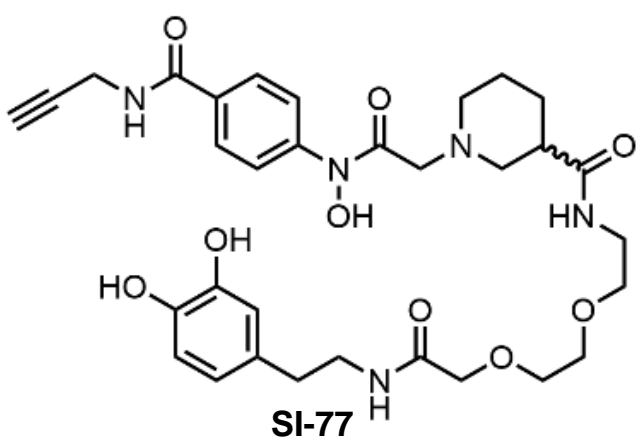

\section{Procedure:}

To a stirred solution of carboxylic acid SI-74 $(75.7 \mathrm{mg}, 0.16 \mathrm{mmol})$ was charged amine SI-76 (71.6 mg, $0.24 \mathrm{mmol}$, 1.5 eq), DIPEA (61.3 $\mu \mathrm{L}, 0.35 \mathrm{mmol}, 2.2 \mathrm{eq})$, oxyma ( $6 \mathrm{mg}, 0.04 \mathrm{mmol}, 0.25 \mathrm{eq})$, and EDC. $\mathrm{HCl}(36.8 \mathrm{mg}, 0.19$ mmol, 1.2 eq). After 11 hours, the solvent was removed. The residue was stirred with $4 \mathrm{~mL}$ EtOAc and $4 \mathrm{~mL} 10 \%$ $\mathrm{NaCl}$. The layers were separated, and the aqueous material was back-extracted with 2 x $1 \mathrm{~mL}$ EtOAc. The pooled organic material was washed with brine $(2 \times 2 \mathrm{~mL})$, dried $\left(\mathrm{Na}_{2} \mathrm{SO}_{4}\right)$, filtered, and concentrated. Purification by preparative HPLC (method A, 5 - 80\% ACN) afforded SI-77 (9.0 mg, $11.9 \mu \mathrm{mol}, 7.5 \%$ yield) as a white solid.

${ }^{1} \mathbf{H}$ NMR $\left(500 \mathrm{MHz}, \mathrm{CD}_{3} \mathrm{CN}, 25^{\circ} \mathrm{C}, \delta\right)$ :

9.37 (br s, 1H), $7.82(\mathrm{~m}, 4 \mathrm{H}), 7.46(\mathrm{~m}, 1 \mathrm{H}), 7.27(\mathrm{~m}, 1 \mathrm{H}), 7.00(\mathrm{~m}, 1 \mathrm{H}), 6.71(\mathrm{~d}, J=8.0 \mathrm{~Hz}, 1 \mathrm{H}), 6.67(\mathrm{~s}, 1 \mathrm{H}), 6.53$ $(\mathrm{d}, J=8.0 \mathrm{~Hz}, 1 \mathrm{H}), 4.43(\mathrm{~s}, 2 \mathrm{H}), 4.11(\mathrm{dd}, J=5.4,2.0 \mathrm{~Hz}, 2 \mathrm{H}), 3.86(\mathrm{~s}, 2 \mathrm{H}), 3.62(\mathrm{br} \mathrm{d}, J=11.5 \mathrm{~Hz}, 1 \mathrm{H}), 3.54(\mathrm{~m}$, 4H), $3.47(\mathrm{t}, J=4.3 \mathrm{~Hz}, 2 \mathrm{H}), 3.55(\mathrm{~m}, 4 \mathrm{H}), 3.18(\mathrm{br} \mathrm{d}, J=11.5 \mathrm{~Hz}, 1 \mathrm{H}), 2.62(\mathrm{t}, J=6.9 \mathrm{~Hz}, 2 \mathrm{H}), 2.46(\mathrm{t}, J=2.3 \mathrm{~Hz}$, 1H), 1.99 to $1.76(\mathrm{~m}, 4 \mathrm{H})$.

${ }^{13} \mathrm{C}$ NMR $\left(126 \mathrm{MHz}, \mathrm{CD}_{3} \mathrm{CN}, 25^{\circ} \mathrm{C}, \delta\right)$ :

175.6, 171.0, 166.9, 165.4, 145.5, 144.0, 132.2, 131.6, 128.7, 121.2, 119.8, 116.7, 116.2, 81.3, 71.7, 71.6, 71.0, 70.7, 69.9, 59.2, 56.0, 55.2, 47.4, 40.9, 39.9, 37.4, 35.4, 29.6, 25.4, 20.7.

HRMS (ESI-TOF, m/z):

Calc'd for $\mathrm{C}_{32} \mathrm{H}_{45} \mathrm{~N}_{5} \mathrm{O}_{9}{ }^{+}\left([\mathrm{M}+\mathrm{H}]^{+}\right)$640.2977; found 640.2985 .

Calc'd for $\mathrm{C}_{32} \mathrm{H}_{44} \mathrm{~N}_{5} \mathrm{O}_{9} \mathrm{Na}^{+}\left([\mathrm{M}+\mathrm{Na}]^{+}\right) 662.2796$; found 662.2805 . 

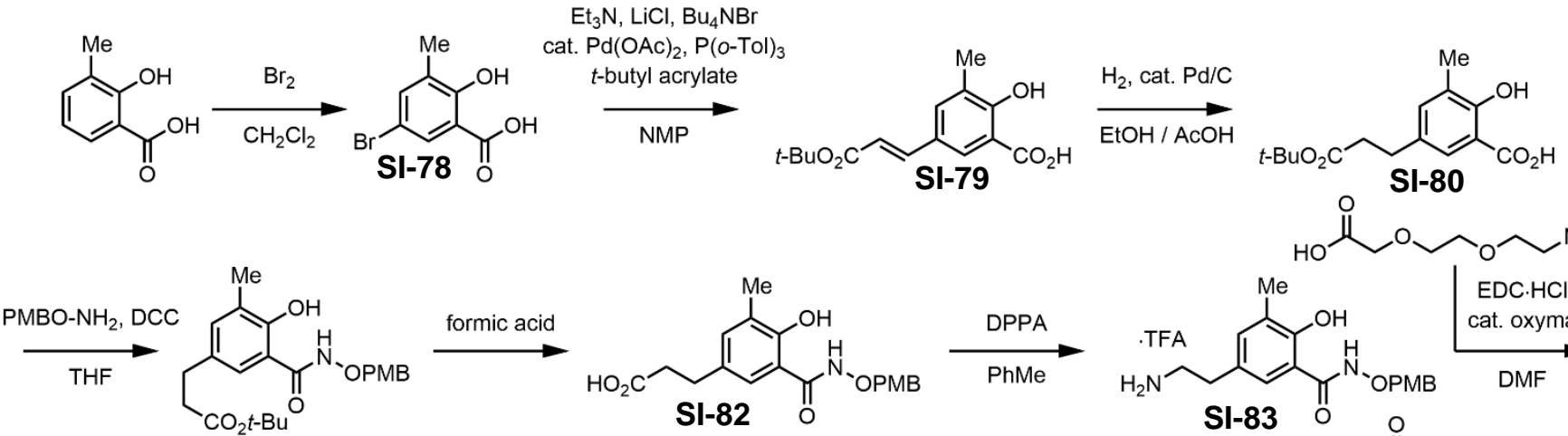

SI-81

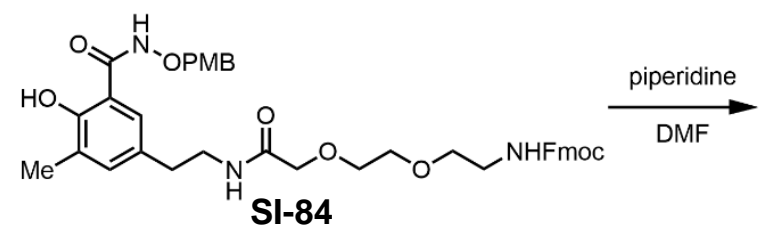

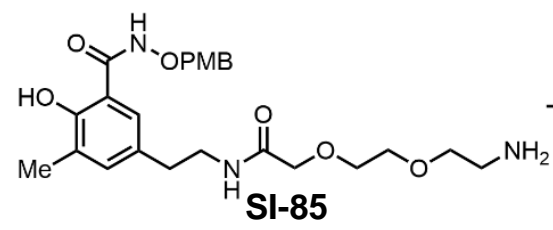
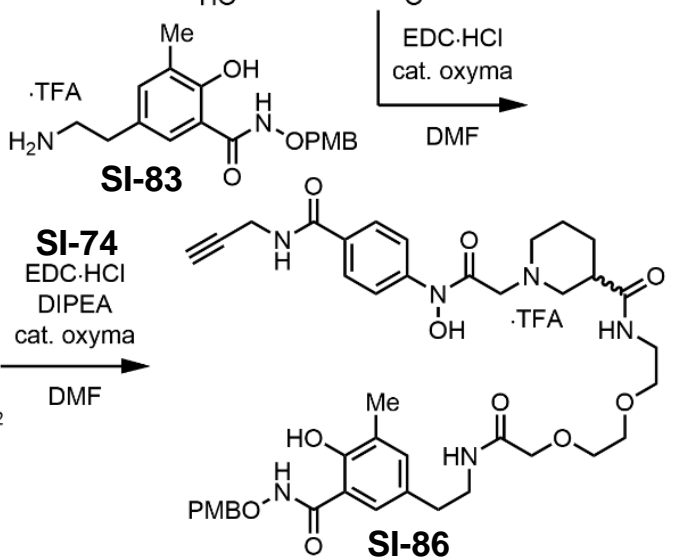


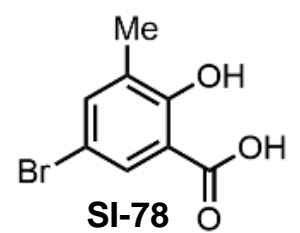

\section{Procedure:}

To a stirred slurry of 3-methylsalicylic acid $(1.52 \mathrm{~g}, 10 \mathrm{mmol})$ in $6 \mathrm{~mL} \mathrm{CH}_{2} \mathrm{Cl}_{2}$ was charged bromine $(0.54 \mathrm{~mL}, 10.5$ $\mathrm{mmol}, 1.05 \mathrm{eq})$. After 7 hours, $5 \mathrm{~mL}$ hexane was charged, and the slurry was filtered, rinsing forward with $10 \mathrm{~mL} 1$ : $1 \mathrm{v} / \mathrm{v} \mathrm{CH}_{2} \mathrm{Cl}_{2} /$ hexane. The solids were dried on the rotovap to afford SI-78 (2.16 g, $9.34 \mathrm{mmol}, 93 \%$ yield) as a tan solid.

${ }^{1} \mathbf{H}$ NMR (392 MHz, DMSO- $\left.d_{6}, 25^{\circ} \mathrm{C}, \delta\right)$ :

$7.69(\mathrm{~s}, 1 \mathrm{H}), 7.56(\mathrm{~s}, 1 \mathrm{H}), 2.15(\mathrm{~s}, 3 \mathrm{H})$

${ }^{13} \mathrm{C}$ NMR $\left(99 \mathrm{MHz}\right.$, DMSO- $\left.d_{6}, 25^{\circ} \mathrm{C}, \delta\right)$ :

171.3, 158.9, 138.3, 129.4, 128.9, 113.8, 109.4, 15.1 .

HRMS (ESI-TOF, m/z):

Calc'd for $\mathrm{C}_{8} \mathrm{H}_{7} \mathrm{BrO}_{3} \mathrm{Na}^{+}\left([\mathrm{M}+\mathrm{Na}]^{+}\right)$252.9471/254.9450; found 252.9479/254.9455. 


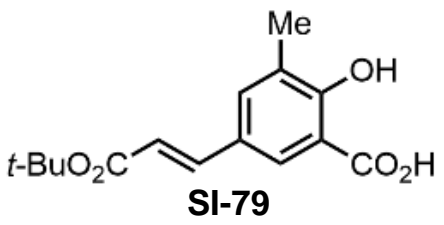

\section{Procedure:}

To a flask was charged SI-78 (3.87 g, $16.7 \mathrm{mmol}), \mathrm{P}(o-\mathrm{Tol})_{3}(408 \mathrm{mg}, 1.34 \mu \mathrm{mol}, 8 \mathrm{~mol} \%), \mathrm{Et}_{3} \mathrm{~N}(5.10 \mathrm{~g}, 50.2$ mmol, $3.0 \mathrm{eq})$, and $t$-butyl acrylate $(4.30 \mathrm{~g}, 33.5 \mathrm{mmol}, 2.0 \mathrm{eq})$ followed by $40 \mathrm{~mL}$ NMP. Argon was bubbled into the reaction mixture for 5 minutes, and then $\mathrm{Pd}(\mathrm{OAc})_{2}(150 \mathrm{mg}, 0.67 \mathrm{mmol}, 4 \mathrm{~mol} \%)$ was charged. The reaction was stirred and heated at $100-110^{\circ} \mathrm{C}$. After 40 hours, the reaction was cooled to room temperature and poured into a stirred biphasic mixture of $100 \mathrm{~mL} \mathrm{5 \%} \mathrm{NaCl}$ and $100 \mathrm{~mL}$ MTBE. The aqueous $\mathrm{pH}$ was adjusted to 2 with $\mathrm{HCl}$, the mixture was filtered through Celite, the layers were separated, and the aqueous material was discarded. The organic material was washed with brine $(5 \times 25 \mathrm{~mL})$, dried $\left(\mathrm{MgSO}_{4}\right)$, filtered, and concentrated. The crude material was slurried in $20 \mathrm{~mL} n$-heptane, filtered, and rinsed with $10 \mathrm{~mL} n$-heptane. The solids were dried on the rotovap to afford SI-79 (2.43 g, $8.73 \mathrm{mmol}, 52 \%$ yield).

${ }^{1} \mathbf{H}$ NMR $\left(500 \mathrm{MHz}\right.$, DMSO- $\left.d_{6}, 25^{\circ} \mathrm{C}, \delta\right)$ :

$7.84(\mathrm{~s}, 1 \mathrm{H}), 7.83(\mathrm{~s}, 1 \mathrm{H}), 7.46(\mathrm{~d}, J=16.0 \mathrm{~Hz}, 1 \mathrm{H}), 6.36(\mathrm{~d}, J=16.0 \mathrm{~Hz}, 1 \mathrm{H}), 2.18(\mathrm{~s}, 3 \mathrm{H}), 1.45(\mathrm{~s}, 9 \mathrm{H})$.

${ }^{13} \mathrm{C}$ NMR $\left(99 \mathrm{MHz}\right.$, DMSO- $\left.d_{6}, 25^{\circ} \mathrm{C}, \delta\right)$ :

172.2, 165.7, 161.5, 142.8, 134.7, 129.0, 126.8, 124.8, 117.8, 112.3, 79.7, 27.9, 15.3.

HRMS (ESI-TOF, m/z):

Calc'd for $\mathrm{C}_{15} \mathrm{H}_{18} \mathrm{O}_{5} \mathrm{Na}^{+}\left([\mathrm{M}+\mathrm{Na}]^{+}\right)$301.1046; found 301.1046. 


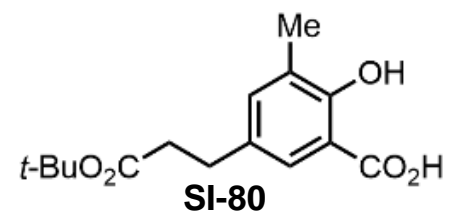

\section{Procedure:}

A suspension of SI-79 (2.43 g, $8.73 \mathrm{mmol}), \mathrm{Pd} / \mathrm{C}(10 \% \mathrm{Pd}$ content; $243 \mathrm{mg})$ and $40 \mathrm{~mL} 1: 1 \mathrm{v} / \mathrm{v} \mathrm{EtOH} / \mathrm{AcOH}$ was stirred under an atmosphere of $\mathrm{H}_{2}$ (balloon) for 40 hours. The reaction was filtered through Celite (EtOAc rinse) and concentrated. The crude material was chromatographed on $25 \mathrm{~g}$ silica ( $25 \% \mathrm{v} / \mathrm{v}$ EtOAc in hexane) to afford SI-80 $(1.95 \mathrm{~g}, 6.96 \mathrm{mmol}, 80 \%$ yield) as a white solid.

${ }^{1}$ H NMR $\left(392 \mathrm{MHz}\right.$, DMSO- $\left.d_{6}, 25^{\circ} \mathrm{C}, \delta\right)$ :

11.42 (br s, 1H), 7.45 (s, 1H), 7.25 (s, 1H), 2.70 (t, $J=7.1 \mathrm{~Hz}, 2 \mathrm{H}), 2.44(\mathrm{t}, J=7.1 \mathrm{~Hz}, 2 \mathrm{H}), 2.13(\mathrm{~s}, 3 \mathrm{H}), 1.33$ (s, $9 \mathrm{H})$.

${ }^{13}$ C NMR $\left(99 \mathrm{MHz}\right.$, DMSO- $\left.d_{6}, 25^{\circ} \mathrm{C}, \delta\right)$ :

172.6, 171.6, 158.1, 136.8, 130.5, 127.0, 125.5, 111.6, 79.8, 36.5, 29.6, 27.7, 15.4.

HRMS (ESI-TOF, m/z):

Calc'd for $\mathrm{C}_{15} \mathrm{H}_{20} \mathrm{O}_{5} \mathrm{Na}^{+}\left([\mathrm{M}+\mathrm{Na}]^{+}\right)$303.1203; found 303.1196. 


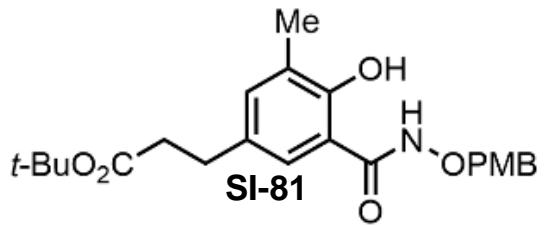

\section{Procedure:}

To a stirred solution of SI-80 (58.4 mg, $0.21 \mathrm{mmol})$ in $1 \mathrm{~mL}$ THF was charged $O$-(4-methoxybenzyl)hydroxylamine ${ }^{6}$ and DCC (51.6 mg, $0.25 \mathrm{mmol}, 1.2 \mathrm{eq}$ ) (note: white slurry). After 16 hours, $1 \mathrm{~mL}$ MTBE was charged, and the slurry was filtered through Celite (MTBE rinse). The crude material was chromatographed on $10 \mathrm{~g}$ silica (20 to 30\% v/v EtOAc in hexane) to afford SI-81 (68.0 mg, $0.164 \mathrm{mmol}, 78 \%$ yield) as an oil.

${ }^{1} \mathbf{H}$ NMR $\left(500 \mathrm{MHz}, \mathrm{CD}_{3} \mathrm{CN}, 25^{\circ} \mathrm{C}, \delta\right)$ :

12.01 (br s, 1H), 9.97 (br s, 1H), 7.33 (m, 2H), 7.13 (s, 1H), 7.04 (s, 1H), 6.89 (m, 2H), $5.40(\mathrm{~m}, 1 \mathrm{H}), 4.83(\mathrm{~s}, 2 \mathrm{H})$, $3.73(\mathrm{~s}, 3 \mathrm{H}), 2.69(\mathrm{t}, J=7.2 \mathrm{~Hz}, 2 \mathrm{H}), 2.41(\mathrm{t}, J=7.2 \mathrm{~Hz}, 2 \mathrm{H}), 1.32(\mathrm{~s}, 9 \mathrm{H})$.

${ }^{13} \mathrm{C}$ NMR $\left(99 \mathrm{MHz}, \mathrm{CD}_{3} \mathrm{CN}, 25^{\circ} \mathrm{C}, \delta\right):$

173.2, 170.0, 161.4, 159.2, 136.8, 132.5, 131.9, 129.0, 128.1, 124.3, 115.1, 112.6, 81.2, 79.0, 56.3, 38.0, 31.3, 28.6, 16.2 .

HRMS (ESI-TOF, m/z):

Calc'd for $\mathrm{C}_{23} \mathrm{H}_{30} \mathrm{NO}_{6}{ }^{+}\left([\mathrm{M}+\mathrm{H}]^{+}\right)$416.2068; found 416.2058.

Calc'd for $\mathrm{C}_{23} \mathrm{H}_{29} \mathrm{NO}_{6} \mathrm{Na}^{+}\left([\mathrm{M}+\mathrm{Na}]^{+}\right)$438.1887; found 438.1877 . 


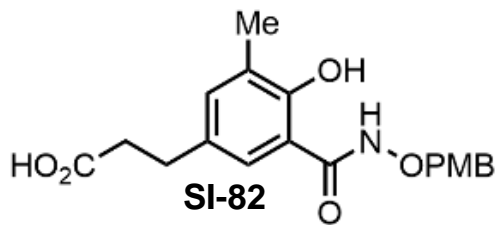

\section{Procedure:}

To a flask containing SI-81 (530.0 mg, $1.28 \mathrm{mmol}$ ) was charged $10.6 \mathrm{~mL}$ formic acid (note: clear solution). The mixture was stirred for 25 minutes, and the formic acid was fully removed on the rotovap (note: time-sensitive reaction; the PMB group is slowly removed in formic acid). The residue was co-evaporated with EtOAc ( $2 \times 10$ $\mathrm{mL}$ ), adsorbed on $1.3 \mathrm{~g}$ silica, and chromatographed on $25 \mathrm{~g}$ silica (45\% v/v EtOAc in hexane) to afford SI-82 (307.2 $\mathrm{mg}, 0.855 \mathrm{mmol}, 67 \%$ yield) as an oil.

${ }^{1} \mathbf{H}$ NMR $\left(500 \mathrm{MHz}, \mathrm{CDCl}_{3}, 25^{\circ} \mathrm{C}, \delta\right)$ :

9.28 (br s, 1H), 7.32 (d, $J=8.6,2 \mathrm{H}), 7.07$ (s, 1H), $6.92(\mathrm{br} \mathrm{s}, 1 \mathrm{H}), 6.86(\mathrm{~d}, J=8.6,2 \mathrm{H}), 4.90(\mathrm{~s}, 2 \mathrm{H}), 3.77$ (s, 3H), $2.74(\mathrm{t}, J=7.4,2 \mathrm{H}), 2.55(\mathrm{t}, J=7.4,2 \mathrm{H}), 2.20(\mathrm{~s}, 3 \mathrm{H})$.

${ }^{13} \mathrm{C}$ NMR $\left(99 \mathrm{MHz}, \mathrm{CDCl}_{3}, 25^{\circ} \mathrm{C}, \delta\right)$ :

177.6, 160.1, 135.4, 131.1, 130.2, 129.7, 127.8, 127.0, 122.3, 114.0, 111.6, 111.1, 78.2, 55.3, 35.5, 29.7, 15.8 .

HRMS (ESI-TOF, m/z):

Calc'd for $\mathrm{C}_{19} \mathrm{H}_{22} \mathrm{NO}_{6}{ }^{+}\left([\mathrm{M}+\mathrm{H}]^{+}\right) 360.1442$; found 360.1440 .

Calc'd for $\mathrm{C}_{19} \mathrm{H}_{21} \mathrm{NO}_{6} \mathrm{Na}^{+}\left([\mathrm{M}+\mathrm{Na}]^{+}\right)$382.3672; found 382.1257. 


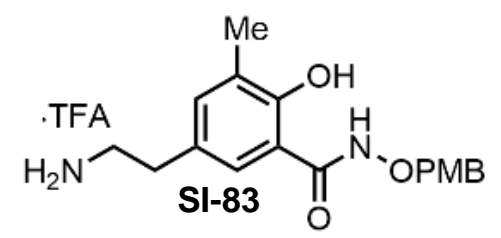

\section{Procedure:}

To a stirred solution of SI-82 (119.6 mg, $0.33 \mathrm{mmol})$ and $\mathrm{Et}_{3} \mathrm{~N}(58 \mu \mathrm{L}, 0.42 \mathrm{mmol}, 1.25 \mathrm{eq})$ in $1.7 \mathrm{~mL}$ PhMe was charged DPPA ( $79 \mu \mathrm{L}, 0.37 \mathrm{mmol}, 1.1 \mathrm{eq}$ ) dropwise. The mixture was then heated at 75 to $85^{\circ} \mathrm{C}$ for 2 hours and cooled to room temperature. The reaction was then charged dropwise to a stirred biphasic mixture of $3 \mathrm{~mL}$ THF and LiOH ( $0.5 \mathrm{M}$ solution; $2.7 \mathrm{~mL}, 1.3 \mathrm{mmol}, 4.0 \mathrm{eq})$ and aged for 12 hours (note: the product was almost entirely in the lower aqueous layer). The layers were separated, and upper organic layer was discarded. The $\mathrm{pH}$ was adjusted to 5 with citric acid and the mixture was extracted with $\mathrm{Et}_{2} \mathrm{O}(2 \times 1 \mathrm{~mL})$ (note: the product was almost entirely in the upper organic layer). The pooled organics were concentrated, and the residue was suspended in $1 \mathrm{~mL} 1: 1 \mathrm{v} / \mathrm{v} \mathrm{H}_{2} \mathrm{O}$ : ACN and syringe filtered. Purification by preparative HPLC (method B, 5 - 80\% ACN) afforded SI-83 (61.4 mg, $138 \mu \mathrm{mol}, 41 \%$ yield) as a white solid.

${ }^{1} \mathbf{H}$ NMR $\left(500 \mathrm{MHz}, \mathrm{CD}_{3} \mathrm{CN}, 25^{\circ} \mathrm{C}, \delta\right)$ :

$7.35(\mathrm{~d}, J=8.0 \mathrm{~Hz}, 2 \mathrm{H}), 7.31$ to $7.05(\mathrm{~m}, 10 \mathrm{H}), 6.89(\mathrm{~d}, J=8.0 \mathrm{~Hz}, 2 \mathrm{H}), 4.85(\mathrm{~s}, 2 \mathrm{H}), 3.75(\mathrm{~s}, 3 \mathrm{H}), 3.04(\mathrm{~m}, 2 \mathrm{H})$, $2.77(\mathrm{t}, J=7.2 \mathrm{~Hz}, 2 \mathrm{H}), 2.15$ (s, 3H).

${ }^{13} \mathrm{C}$ NMR (99 MHz, $\left.\mathrm{CD}_{3} \mathrm{CN}, 25^{\circ} \mathrm{C}, \delta\right)$ :

168.9, 160.8, 159.1, 153.1, 153.0, 136.3, 131.9, 130.3, 128.4, 128.2, 127.0, 125.0, 124.8, 121.00, 120.96, 114.5, $112.5,78.4,55.7,41.7,32.7,15.7$.

(Note: although the analytical HPLC purity was $98.9 \%$ AN (method A, $240 \mathrm{~nm}$ ), we observed unidentified peaks in the aromatic regions of the NMR spectra).

HRMS (ESI-TOF, m/z):

Calc'd for $\mathrm{C}_{18} \mathrm{H}_{23} \mathrm{~N}_{2} \mathrm{O}_{4}{ }^{+}\left([\mathrm{M}+\mathrm{H}]^{+}\right)$331.1652; found 331.1653.

Calc'd for $\mathrm{C}_{18} \mathrm{H}_{22} \mathrm{~N}_{2} \mathrm{O}_{4} \mathrm{Na}^{+}\left([\mathrm{M}+\mathrm{Na}]^{+}\right)$353.1472; found 353.1471. 


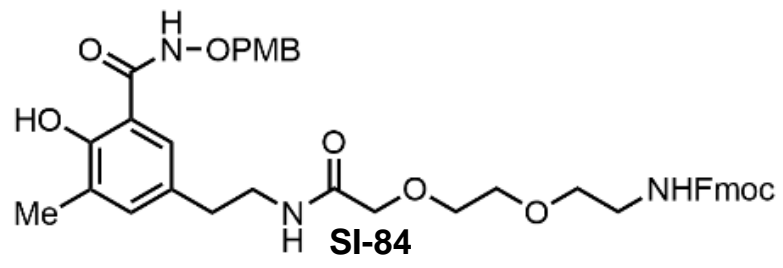

\section{Procedure:}

To a stirred solution of SI-83 (55.6 mg, $0.168 \mathrm{mmol})$ in $0.5 \mathrm{~mL}$ DMF was charged \{2-[2-(Fmocamino)ethoxy]ethoxy \}acetic acid ( $97.3 \mathrm{mg}, 0.252 \mathrm{mmol}, 1.5 \mathrm{eq})$, oxyma (12 mg, $0.084 \mathrm{mmol}, 0.5 \mathrm{eq})$, and EDC. $\mathrm{HCl}$ ( $48.4 \mathrm{mg}, 0.252 \mathrm{mmol}, 1.5 \mathrm{eq})$. After 48 hours, the solvent was removed on the rotovap. The residue was stirred with $2 \mathrm{~mL} \mathrm{Et}_{2} \mathrm{O}$ and $1 \mathrm{~mL} 10 \% \mathrm{NaCl}$, the aqueous $\mathrm{pH}$ was adjusted to 3 with citric acid, and the aqueous material was discarded. The organic material was washed with $1 \mathrm{~mL}$ sat. aqueous $\mathrm{Na}_{2} \mathrm{HPO}_{4}, 1 \mathrm{~mL}$ brine, and was dried $\left(\mathrm{Na}_{2} \mathrm{SO}_{4}\right)$, filtered, and concentrated. The crude material was adsorbed on $0.3 \mathrm{~g}$ silica and chromatographed on $10 \mathrm{~g}$ silica (80 to $100 \% \mathrm{v} / \mathrm{v}$ EtOAc in hexane) to afford SI-84 (57.9 $\mathrm{mg}, 83 \mu \mathrm{mol}, 49 \%$ yield) as an oil.

${ }^{1} \mathbf{H}$ NMR $\left(500 \mathrm{MHz}, \mathrm{CDCl}_{3}, 25{ }^{\circ} \mathrm{C}, \delta\right)$ :

$7.73(\mathrm{~d}, J=8.0 \mathrm{~Hz}, 2 \mathrm{H}), 7.48(\mathrm{~d}, J=7.4 \mathrm{~Hz}, 2 \mathrm{H}), 7.36(\mathrm{t}, J=7.4 \mathrm{~Hz}, 2 \mathrm{H}), 7.31(\mathrm{~d}, J=7.4 \mathrm{~Hz}, 2 \mathrm{H}), 7.25(\mathrm{t}, J=7.4$ $\mathrm{Hz}, 2 \mathrm{H}), 7.02(\mathrm{br} \mathrm{m}, 2 \mathrm{H}), 6.82(\mathrm{~d}, J=8.0 \mathrm{~Hz}, 2 \mathrm{H}), 5.05(\mathrm{~s}, 1 \mathrm{H}), 4.90(\mathrm{~s}, 2 \mathrm{H}), 4.33(\mathrm{~m}, 2 \mathrm{H}), 4.09(\mathrm{~s}, 1 \mathrm{H}), 3.86(\mathrm{~s}$, $2 \mathrm{H}), 3.73(\mathrm{~s}, 3 \mathrm{H}), 3.56$ to $3.12(\mathrm{~m}, 10 \mathrm{H}), 2.60(\mathrm{~s}, 2 \mathrm{H}), 2.17(\mathrm{~s}, 3 \mathrm{H}), 1.22(\mathrm{~m}, 2 \mathrm{H})$.

${ }^{13} \mathrm{C}$ NMR $\left(99 \mathrm{MHz}, \mathrm{CDCl}_{3}, 25^{\circ} \mathrm{C}, \delta\right)$ :

170.1, 169.0, 159.9, 158.3, 156.7, 143.7, 141.3, 135.7, 131.0, 127.7, 127.4, 127.1, 124.8, 122.9, 120.0, 113.8, 111.4, 78.0, 70.9, 70.3, 70.0, 69.7, 66.6, 65.8, 55.2, 47.0, 40.9, 39.7, 34.8, 29.7, 15.7.

HRMS (ESI-TOF, m/z):

Calc'd for $\mathrm{C}_{39} \mathrm{H}_{43} \mathrm{~N}_{3} \mathrm{O}_{9} \mathrm{Na}^{+}\left([\mathrm{M}+\mathrm{Na}]^{+}\right) 720.2892$; found 720.2899 . 


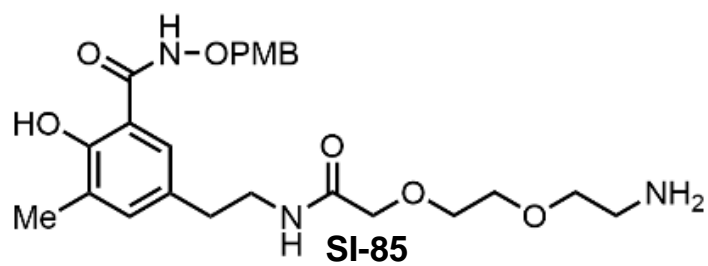

\section{Procedure:}

To a stirred solution of SI-84 (38.1 mg, $54.6 \mu \mathrm{mol})$ in $0.25 \mathrm{~mL}$ DMF was charged piperidine ( $54 \mu \mathrm{L}, 0.55 \mathrm{mmol}, 10$ eq). After 30 minutes, the solvent was removed on the rotovap, and the residue was co-evaporated with $2 \times 1 \mathrm{~mL}$ PhMe. The crude residue was dissolved in $2 \mathrm{~mL} \mathrm{ACN}$ and washed with $10 \times 1 \mathrm{~mL}$ pentane. The solvents were removed on the rotovap and the residue was lyophilized from $1: 1 \mathrm{v} / \mathrm{v} \mathrm{ACN}: \mathrm{H}_{2} \mathrm{O}$ to afford $\mathbf{S I - 8 5}(11.8 \mathrm{mg}, 24.8$ $\mu \mathrm{mol}, 45 \%$ yield) as a white solid.

${ }^{1} \mathbf{H}$ NMR $\left(392 \mathrm{MHz}, \mathrm{CDCl}_{3}, 25^{\circ} \mathrm{C}, \delta\right)$ :

$7.32(\mathrm{~d}, J=8.1 \mathrm{~Hz}, 2 \mathrm{H}), 7.22(\mathrm{~s}, 1 \mathrm{H}), 6.98(\mathrm{~s}, 1 \mathrm{H}), 6.85(\mathrm{~m}, 1 \mathrm{H}) 6.83(\mathrm{~d}, J=8.1 \mathrm{~Hz}, 2 \mathrm{H}), 4.87(\mathrm{~s}, 2 \mathrm{H}), 3.83(\mathrm{~s}, 2 \mathrm{H})$, $3.75(\mathrm{~s}, 3 \mathrm{H}), 3.43(\mathrm{~m}, 4 \mathrm{H}), 3.34(\mathrm{~m}, 4 \mathrm{H}), 2.67(\mathrm{~m}, 3 \mathrm{H}), 2.20(\mathrm{~s}, 3 \mathrm{H})$.

${ }^{13} \mathrm{C} \mathrm{NMR}\left(99 \mathrm{MHz}, \mathrm{CDCl}_{3}, 25^{\circ} \mathrm{C}, \delta\right)$ :

$170.1,166.5,159.8,156.8,134.0,130.9,128.5,127.5,126.8,123.9,114.3,113.8,76.9,70.6,70.3,70.1,69.3,55.2$, $40.1,39.6,34.3,15.9$.

HRMS (ESI-TOF, m/z):

Calc'd for $\mathrm{C}_{24} \mathrm{H}_{34} \mathrm{~N}_{3} \mathrm{O}_{7}{ }^{+}\left([\mathrm{M}+\mathrm{H}]^{+}\right)$476.2391; found 476.2401.

Calc'd for $\mathrm{C}_{24} \mathrm{H}_{33} \mathrm{~N}_{3} \mathrm{O}_{7} \mathrm{Na}^{+}\left([\mathrm{M}+\mathrm{Na}]^{+}\right)$498.2211; found 498.2206. 


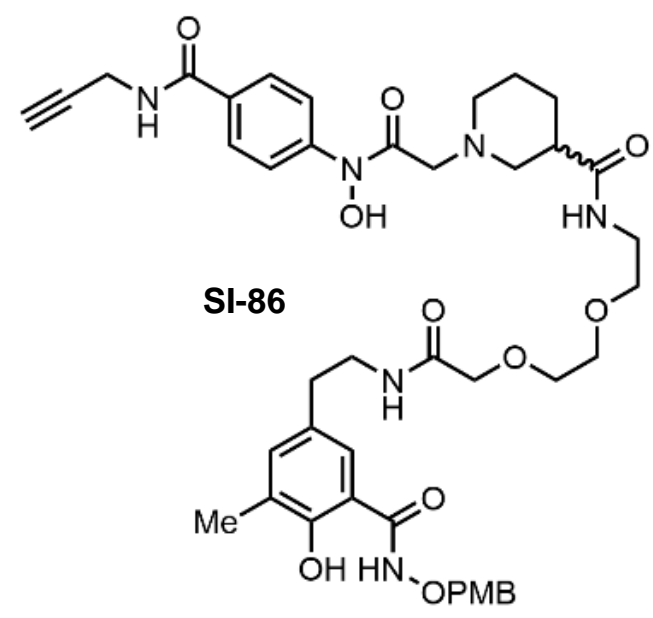

\section{Procedure:}

To a stirred solution of amine SI-85 (39.5 mg, $83.0 \mu \mathrm{mol})$ in $1.0 \mathrm{~mL}$ DMF was charged carboxylic acid SI-74 (35.4 mg, $74.7 \mu \mathrm{mol}, 0.9 \mathrm{eq}$ ), oxyma ( $3 \mathrm{mg}, 21 \mu \mathrm{mol}, 0.25 \mathrm{eq}$ ), DIPEA ( $36 \mu \mathrm{L}, 0.21 \mathrm{mmol}, 2.5 \mathrm{eq})$, and EDC $\cdot \mathrm{HCl}(20.0$ $\mathrm{mg}, 104 \mu \mathrm{mol} .1 .25 \mathrm{eq}$ ). After 15 hours, the solvent was removed on the rotovap. The residue was adsorbed on $0.5 \mathrm{~g}$ silica and chromatographed on $4 \mathrm{~g}$ silica (EtOAc to $20 \% \mathrm{v} / \mathrm{v} \mathrm{MeOH}$ in EtOAc) to afford an oil. This partially purified material was purified by preparative HPLC (method A, 5 - 70\% ACN) to afford SI-86 (29.9 mg, $32.1 \mu \mathrm{mol}$, $43 \%$ yield) as a white solid.

${ }^{1} \mathbf{H}$ NMR $\left(500 \mathrm{MHz}, \mathrm{CD}_{3} \mathrm{CN}, 25^{\circ} \mathrm{C}, \delta\right)$ :

10.66 (br s, 1H), 9.33 (br s, 1H), 7.79 (s, 4H), 7.57 (s, 1H), 7.35 (d, J = 8.0 Hz, 2H), 7.34 (m, 1H), 7.18 (s, 1H), 7.12 (s, 2H), $6.90(\mathrm{~d}, J=8.0 \mathrm{~Hz}, 2 \mathrm{H}), 4.87(\mathrm{~s}, 2 \mathrm{H}), 4.41(\mathrm{~s}, 2 \mathrm{H}), 4.10(\mathrm{~s}, 2 \mathrm{H}), 3.85(\mathrm{~s}, 2 \mathrm{H}), 3.76(\mathrm{~s}, 3 \mathrm{H}), 3.67$ to 3.25 (m, $10 \mathrm{H}), 3.19$ to $2.97(\mathrm{~m}, 1 \mathrm{H}), 2.90(\mathrm{~s}, 1 \mathrm{H}), 2.62(\mathrm{~m}, 2 \mathrm{H}), 2.47(\mathrm{~s}, 1 \mathrm{H}), 2.14(\mathrm{~s}, 3 \mathrm{H}), 1.97$ to $1.74(\mathrm{~m}, 4 \mathrm{H})$.

${ }^{13} \mathrm{C}$ NMR $\left(126 \mathrm{MHz}, \mathrm{CD}_{3} \mathrm{CN}, 25^{\circ} \mathrm{C}, \delta\right)$ :

175.6, 171.3, 169.3, 167.0, 165.4, 160.9, 158.7, 144.1, 136.6, 131.9, 131.4, 129.7, 128.7, 128.5, 127.7, 124.5, 119.7, 114.6, 112.3, 81.3, 78.6, 71.8, 71.5, 70.9, 70.7, 69.9, 59.2, 55.9, 55.8, 55.1, 40.6, 39.9, 37.4, 35.2, 29.6, 25.4, 20.7, 15.8 .

HRMS (ESI-TOF, m/z):

Calc'd for $\mathrm{C}_{42} \mathrm{H}_{53} \mathrm{~N}_{6} \mathrm{O}_{11}{ }^{+}\left([\mathrm{M}+\mathrm{H}]^{+}\right)$817.3767; found 817.3763.

Calc'd for $\mathrm{C}_{42} \mathrm{H}_{52} \mathrm{~N}_{6} \mathrm{O}_{11}{ }^{+}\left([\mathrm{M}+\mathrm{Na}]^{+}\right)$839.3586; found 839.3975. 

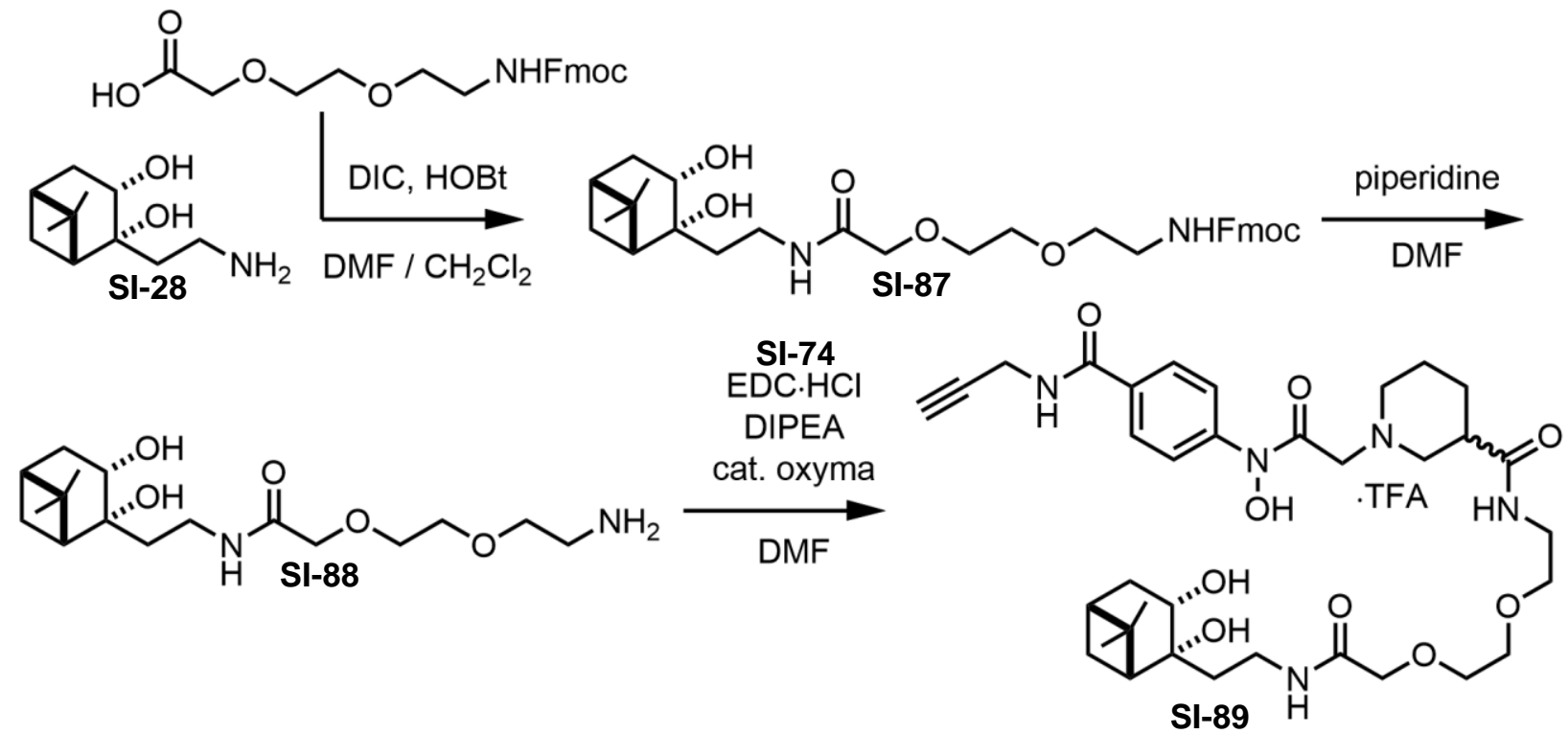


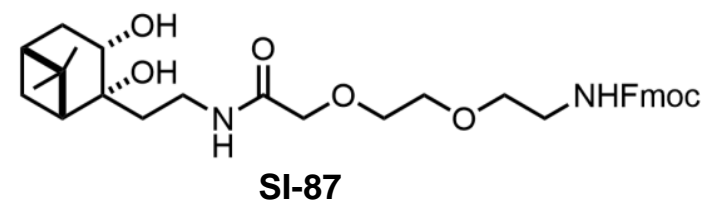

\section{Procedure:}

To a stirred solution of amine SI-28 (219 mg, $1.1 \mathrm{mmol})$ in $3 \mathrm{~mL} 1: 2 \mathrm{v} / \mathrm{v}$ DMF : $\mathrm{CH}_{2} \mathrm{Cl}_{2}$ was charged \{2-[2-(Fmocamino)ethoxy]ethoxy \}acetic acid (424 mg, $1.1 \mathrm{mmol}, 1.0 \mathrm{eq})$, DIC (343 $\mu \mathrm{L}, 2.2 \mathrm{mmol}, 2 \mathrm{eq})$, and $\mathrm{HOBt} \cdot \mathrm{H}_{2} \mathrm{O}(34$ $\mathrm{mg}, 0.22 \mathrm{mmol}, 0.2 \mathrm{eq})$. After 12 hours, the solvents were removed on the rotovap. The residue was adsorbed on $5 \mathrm{~g}$ silica and chromatographed on $25 \mathrm{~g}$ silica ( $5 \% \mathrm{v} / \mathrm{v} \mathrm{MeOH}$ in $\mathrm{CH}_{2} \mathrm{Cl}_{2}$ ) to afford a white solid (506 $\mathrm{mg}$ ). This partially purified material was purified by preparative HPLC (method B, $10-100 \%$ ACN, in 3 equal loads) to afford SI-87 (342.7 mg, $0.60 \mathrm{mmol}, 55 \%$ yield) as a white solid.

${ }^{1} \mathbf{H}$ NMR $\left(392 \mathrm{MHz}, \mathrm{CDCl}_{3}, 25^{\circ} \mathrm{C}, \delta\right)$ :

$7.69(\mathrm{~d}, J=7.4 \mathrm{~Hz}, 2 \mathrm{H}), 7.53(\mathrm{~d}, J=7.4 \mathrm{~Hz}, 2 \mathrm{H}), 7.51(\mathrm{~m}, 1 \mathrm{H}) 7.33(\mathrm{t}, J=7.4 \mathrm{~Hz}, 2 \mathrm{H}), 7.24(\mathrm{t}, J=7.4 \mathrm{~Hz}, 2 \mathrm{H})$, $5.66(\mathrm{br} \mathrm{s}, 1 \mathrm{H}), 4.36(\mathrm{~m}, 2 \mathrm{H}), 4.16(\mathrm{~m}, 1 \mathrm{H}), 3.91(\mathrm{~m}, 6 \mathrm{H}), 3.64$ to $3.10(\mathrm{~m}, 10 \mathrm{H}), 2.37(\mathrm{~m}, 1 \mathrm{H}), 2.09(\mathrm{~m}, 1 \mathrm{H}), 1.99(\mathrm{t}$, $J=5.6 \mathrm{~Hz}, 1 \mathrm{H}), 1.81(\mathrm{~m}, 1 \mathrm{H}), 1.74(\mathrm{~m}, 1 \mathrm{H}), 1.61(\mathrm{~m}, 2 \mathrm{H}), 1.30(\mathrm{~d}, J=10.3 \mathrm{~Hz}, 1 \mathrm{H}), 1.16(\mathrm{~s}, 3 \mathrm{H}), 0.82(\mathrm{~s}, 3 \mathrm{H})$.

${ }^{13} \mathrm{C}$ NMR $\left(99 \mathrm{MHz}, \mathrm{CDCl}_{3}, 25^{\circ} \mathrm{C}, \delta\right)$ :

170.2, 156.7, 143.8, 141.2, 127.6, 127.0, 125.0, 119.9, 77.2, 75.3, 70.9, 70.3, 70.2, 70.1, 67.4, 66.6, 52.0, 47.1, 40.8, $40.3,38.6,37.9,34.5,27.7,27.6,24.2$.

HRMS (ESI-TOF, m/z):

Calc'd for $\mathrm{C}_{32} \mathrm{H}_{43} \mathrm{~N}_{2} \mathrm{O}_{7}{ }^{+}\left([\mathrm{M}+\mathrm{H}]^{+}\right)$567.3065; found 567.3074.

Calc'd for $\mathrm{C}_{32} \mathrm{H}_{42} \mathrm{~N}_{2} \mathrm{O}_{7} \mathrm{Na}^{+}\left([\mathrm{M}+\mathrm{Na}]^{+}\right)$589.2884; found 589.2893. 


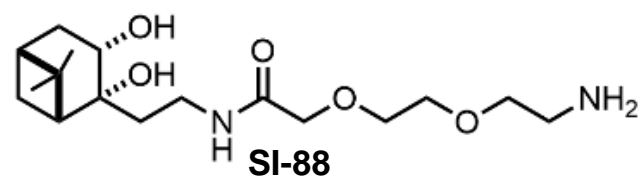

\section{Procedure:}

To a stirred solution of SI-87 (44.2 mg, $78 \mu \mathrm{mol})$ in $0.4 \mathrm{~mL}$ DMF was charged piperidine ( $77 \mu \mathrm{L}, 0.78 \mathrm{mmol}, 10$ eq). After 2.5 hours, the solvent was removed on the rotovap. The crude material was adsorbed on $0.25 \mathrm{~g}$ aminosilica and chromatographed on $0.5 \mathrm{~g}$ amino-silica (EtOAc to 20\% v/v MeOH in EtOAc) to afford SI-88 (26.5 mg, $76.9 \mu \mathrm{mol}, 99 \%$ yield) as an oil.

${ }^{1} \mathbf{H}$ NMR $\left(500 \mathrm{MHz}, \mathrm{MeOH}-d_{4}, 25^{\circ} \mathrm{C}, \delta\right)$ :

$3.92(\mathrm{dd}, J=9.7,5.2 \mathrm{H}, 1 \mathrm{H}), 3.87(\mathrm{~s}, 2 \mathrm{H}), 3.58(\mathrm{~m}, 4 \mathrm{H}), 3.44(\mathrm{t}, J=5.4 \mathrm{~Hz}, 2 \mathrm{H}), 3.31(\mathrm{~m}, 2 \mathrm{H}), 2.71(\mathrm{t}, J=5.2 \mathrm{~Hz}$, 2H), $2.36(\mathrm{~m}, 1 \mathrm{H}), 2.08(\mathrm{~m}, 1 \mathrm{H}), 1.98(\mathrm{t}, J=6.0 \mathrm{~Hz}, 1 \mathrm{H}), 1.75(\mathrm{~m}, 2 \mathrm{H}), 1.57(\mathrm{~m}, 2 \mathrm{H}), 1.34(\mathrm{~d}, J=10.3 \mathrm{~Hz}, 1 \mathrm{H})$, $1.18(\mathrm{~s}, 3 \mathrm{H}), 0.86(\mathrm{~s}, 3 \mathrm{H})$.

${ }^{13} \mathrm{C}$ NMR $\left(126 \mathrm{MHz}, \mathrm{MeOH}-d_{4}, 25^{\circ} \mathrm{C}, \delta\right)$ :

172.4, 76.0, 73.5, 72.0, 71.31, 71.26, 68.7, 52.9, 42.5, 42.0, 41.8, 39.7, 39.1, 35.6, 28.7, 28.3, 24.6.

HRMS (ESI-TOF, m/z):

Calc'd for $\mathrm{C}_{17} \mathrm{H}_{33} \mathrm{~N}_{2} \mathrm{O}_{5}{ }^{+}\left([\mathrm{M}+\mathrm{H}]^{+}\right)$345.2384; found 345.2397.

Calc'd for $\mathrm{C}_{17} \mathrm{H}_{32} \mathrm{~N}_{2} \mathrm{O}_{5} \mathrm{Na}^{+}\left([\mathrm{M}+\mathrm{Na}]^{+}\right)$345.4595; found 367.2201. 


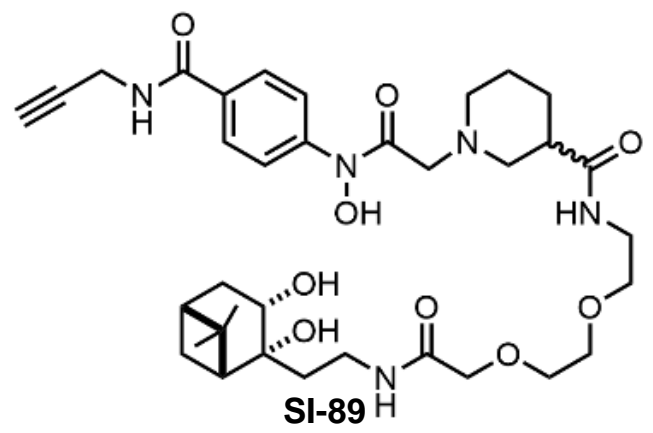

\section{Procedure:}

To a stirred solution of carboxylic acid SI-74 $(58.2 \mathrm{mg}, 123 \mu \mathrm{mol})$ in $1.2 \mathrm{~mL}$ DMF was charged amine SI-88 (59 $\mathrm{mg}, 172 \mu \mathrm{mol}, 1.4 \mathrm{eq}$ ), DIPEA ( $54 \mu \mathrm{L}, 0.31 \mathrm{mmol}, 2.5 \mathrm{eq}$ ), oxyma (4.4 mg, $31 \mu \mathrm{mol}, 0.25 \mathrm{eq})$, and EDC·HCl (28 $\mathrm{mg}, 145 \mu \mathrm{mol}, 1.2 \mathrm{eq})$. After 3 hours, the solvent was removed on the rotovap. The residue was adsorbed on $0.35 \mathrm{~g}$ silica and chromatographed on $1 \mathrm{~g}$ silica (EtOAc to $20 \% \mathrm{v} / \mathrm{v} \mathrm{MeOH}$ in EtOAc) to afford an oil. This partially purified product was purified by preparative HPLC (method A, 5 - 80\% ACN) to afford SI-89 (30.8 mg, $38.5 \mu \mathrm{mol}$ ) as a white solid.

${ }^{1} \mathbf{H}$ NMR $\left(392 \mathrm{MHz}, \mathrm{CD}_{3} \mathrm{CN}, 25^{\circ} \mathrm{C}, \delta\right)$ :

9.39 (br s, 1H), $7.81(\mathrm{~s}, 4 \mathrm{H}), 7.55(\mathrm{~s}, 1 \mathrm{H}), 7.46(\mathrm{~s}, 1 \mathrm{H}), 7.34(\mathrm{~s}, 1 \mathrm{H}), 4.41(\mathrm{~m}, 2 \mathrm{H}) 4.11(\mathrm{dd}, J=5.6,2.5 \mathrm{~Hz}, 2 \mathrm{H})$, $3.96(\mathrm{~m}, 1 \mathrm{H}), 3.89$ (s, 2H), 3.71 to $3.45(\mathrm{~m}, 9 \mathrm{H}), 3.42$ to $3.16(\mathrm{~m}, 5 \mathrm{H}), 3.06(\mathrm{~m}, 1 \mathrm{H}), 2.94(\mathrm{~s}, 1 \mathrm{H}), 2.47$ (t, $J=2.2$ $\mathrm{Hz}, 1 \mathrm{H}), 2.38(\mathrm{~s}, 1 \mathrm{H}), 2.09(\mathrm{~m}, 1 \mathrm{H}), 2.02$ to $1.68(\mathrm{~m}, 8 \mathrm{H}), 1.58(\mathrm{~m}, 2 \mathrm{H}), 1.31(\mathrm{~m}, 1 \mathrm{H}), 1.20(\mathrm{~s}, 3 \mathrm{H}), 0.87(\mathrm{~s}, 3 \mathrm{H})$.

${ }^{13} \mathrm{C} \mathrm{NMR}\left(99 \mathrm{MHz}, \mathrm{CD}_{3} \mathrm{CN}, 25^{\circ} \mathrm{C}, \delta\right)$ :

175.6, 171.3, 167.0, 165.4, 144.1, 131.5, 128.7, 119.8, 81.3, 75.7, 71.8, 71.6, 71.0, 70.9, 70.0, 68.1, 59.2, 56.0, 55.2, $52.5,42.0,41.3,39.9,39.2,38.7,37.4,35.2,29.6,28.3,28.0,25.4,24.3,20.7$.

HRMS (ESI-TOF, m/z):

Calc'd for $\mathrm{C}_{35} \mathrm{H}_{52} \mathrm{~N}_{5} \mathrm{O}_{9}{ }^{+}\left([\mathrm{M}+\mathrm{H}]^{+}\right)$686.3760; found 686.3744 .

Calc'd for $\mathrm{C}_{35} \mathrm{H}_{51} \mathrm{~N}_{5} \mathrm{O}_{9} \mathrm{Na}^{+}\left([\mathrm{M}+\mathrm{Na}]^{+}\right)$708.3575; found 708.3565. 


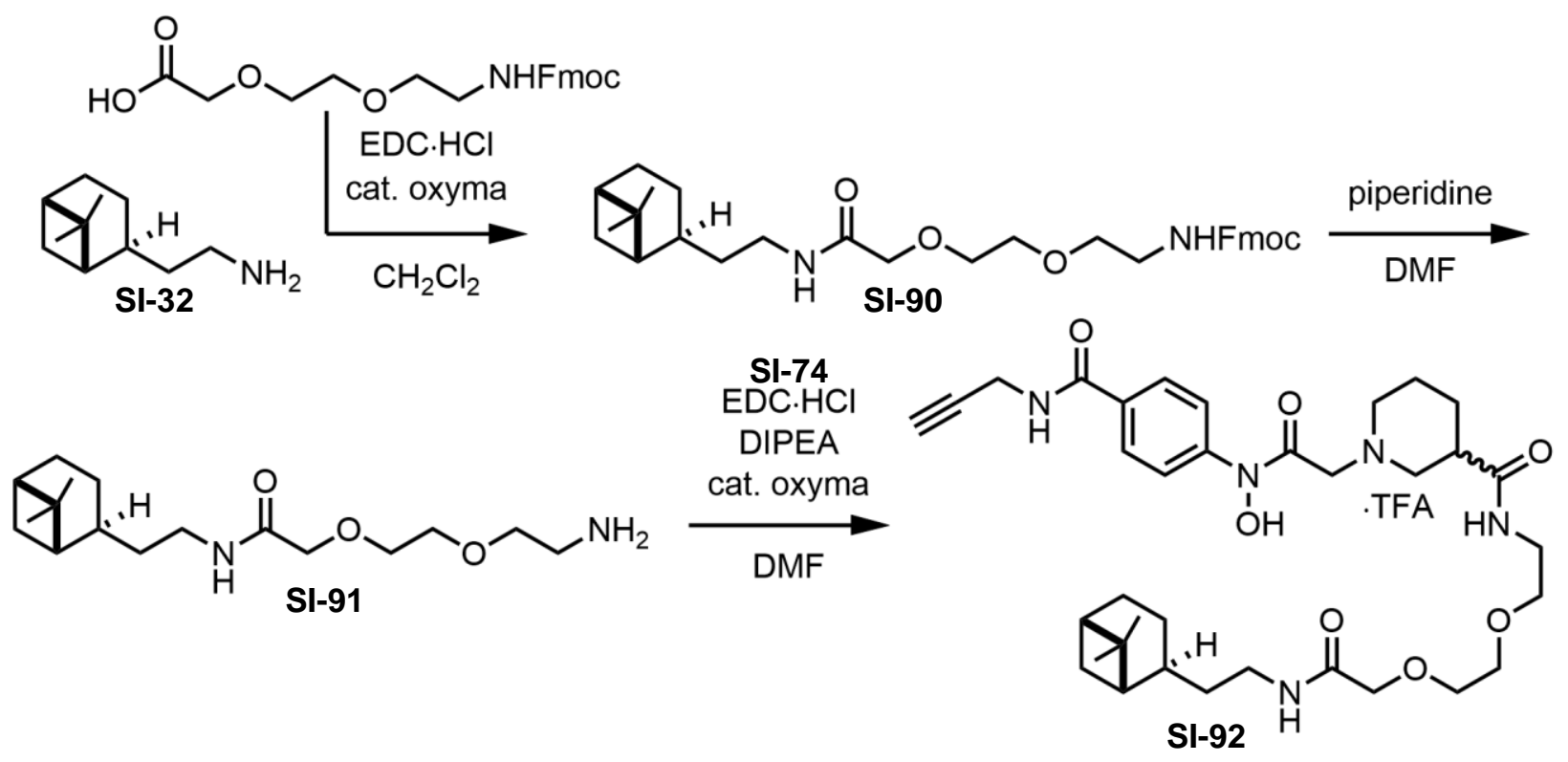




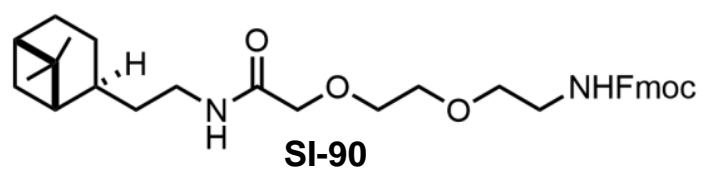

\section{Procedure:}

To a stirred solution of amine SI-32 (334.6 mg, $2.0 \mathrm{mmol}$ ) in $10 \mathrm{~mL} \mathrm{CH}_{2} \mathrm{Cl}_{2}$ was charged \{2-[2-(Fmocamino)ethoxy]ethoxy \}acetic acid (405 mg, $2.1 \mathrm{mmol}, 1.05 \mathrm{eq})$, oxyma (28 mg, $0.2 \mathrm{mmol}, 0.1 \mathrm{eq})$ and EDC. $\mathrm{HCl}$ (537 mg, $2.8 \mathrm{mmol}, 1.4 \mathrm{eq}$ ). After 16.5 hours, the solvent was removed on the rotovap. The residue was stirred with $20 \mathrm{~mL} \mathrm{Et}_{2} \mathrm{O}$ and $20 \mathrm{~mL} 10 \% \mathrm{NaCl}$. The aqueous $\mathrm{pH}$ was adjusted to 3 with citric acid and the aqueous material was discarded. The organic material was washed with brine, dried $\left(\mathrm{Na}_{2} \mathrm{SO}_{4}\right)$, filtered, and concentrated on the rotovap. The crude material was adsorbed on $3 \mathrm{~g}$ silica and chromatographed on $20 \mathrm{~g}$ silica (80 to $100 \% \mathrm{v} / \mathrm{v}$ EtOAc in hexane) to afford SI-90 (604.2 $\mathrm{mg}, 1.13 \mathrm{mmol}, 57 \%$ yield) as an oil.

${ }^{1} \mathbf{H}$ NMR $\left(500 \mathrm{MHz}, \mathrm{CDCl}_{3}, 25^{\circ} \mathrm{C}, \delta\right)$ :

$7.74(\mathrm{~d}, J=6.9 \mathrm{~Hz}, 2 \mathrm{H}), 7.57(\mathrm{~d}, J=6.9 \mathrm{~Hz}, 2 \mathrm{H}), 7.38(\mathrm{t}, J=6.9 \mathrm{~Hz}, 2 \mathrm{H}), 7.29(\mathrm{t}, J=6.9 \mathrm{~Hz}, 2 \mathrm{H}), 6.68(\mathrm{br} \mathrm{s}, 1 \mathrm{H})$, 5.19 (br s, 1H), $4.38(\mathrm{~m}, 2 \mathrm{H}), 4.19(\mathrm{~m}, 1 \mathrm{H}), 3.95(\mathrm{~s}, 2 \mathrm{H}), 3.62(\mathrm{~m}, 3 \mathrm{H}), 3.54(\mathrm{~m}, 2 \mathrm{H}), 3.38(\mathrm{~m}, 2 \mathrm{H}), 3.23(\mathrm{~m}, 2 \mathrm{H})$, $2.28(\mathrm{~m}, 1 \mathrm{H}), 1.99$ to $1.73(\mathrm{~m}, 8 \mathrm{H}), 1.56(\mathrm{~m}, 2 \mathrm{H}), 1.42(\mathrm{~m}, 1 \mathrm{H}), 1.20(\mathrm{~m}, 2 \mathrm{H}), 1.13(\mathrm{~s}, 3 \mathrm{H}), 0.95(\mathrm{~s}, 3 \mathrm{H}), 0.83(\mathrm{~d}, J=$ $9.2 \mathrm{~Hz}, 1 \mathrm{H})$.

${ }^{13} \mathrm{C}$ NMR $\left(126 \mathrm{MHz}, \mathrm{CDCl}_{3}, 25^{\circ} \mathrm{C}, \delta\right)$ :

169.5, 156.4, 143.9, 141.3, 127.7, 127.0, 125.0, 120.0, 70.8, 70.6, 70.2, 70.1, 66.7, 47.2, 46.2, 41.3, 40.8, 38.8, 38.6, $37.6,37.3,33.5,28.1,26.3,23.2,22.2$.

HRMS (ESI-TOF, m/z):

Calc'd for $\mathrm{C}_{32} \mathrm{H}_{43} \mathrm{~N}_{2} \mathrm{O}_{5}{ }^{+}\left([\mathrm{M}+\mathrm{H}]^{+}\right)$535.3166; found 535.3164.

Calc'd for $\mathrm{C}_{32} \mathrm{H}_{42} \mathrm{~N}_{2} \mathrm{O}_{5} \mathrm{Na}^{+}\left([\mathrm{M}+\mathrm{Na}]^{+}\right)$557.2986; found 557.2989. 


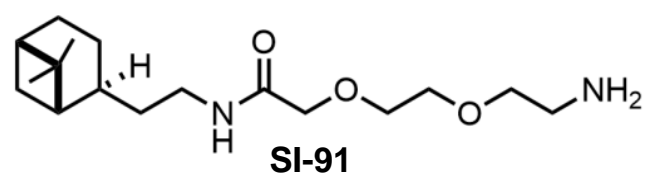

\section{Procedure:}

To a stirred solution of SI-90 (107.5 mg, $0.20 \mathrm{mmol}$ ) in $2 \mathrm{~mL} \mathrm{DMF}$ was charged piperidine (198 $\mu \mathrm{L}, 2 \mathrm{mmol}, 10$ eq). After 3.5 hours, the solvent was removed on the rotovap, and the residue was co-evaporated with $2 \times 2 \mathrm{~mL}$ IPA. The residue was dissolved in $4 \mathrm{~mL}$ ACN, washed with $4 \mathrm{x} 4 \mathrm{~mL}$ pentane, and concentrated to afford SI-91 $(52.7 \mathrm{mg}$, $0.169 \mathrm{mmol}, 84 \%$ yield) as an oil.

${ }^{1} \mathbf{H}$ NMR $\left(392 \mathrm{MHz}, \mathrm{MeOH}-d_{4}, 25^{\circ} \mathrm{C}, \delta\right)$ :

$3.96(\mathrm{~s}, 2 \mathrm{H}), 3.66(\mathrm{~m}, 4 \mathrm{H}), 3.53(\mathrm{t}, J=5.2 \mathrm{~Hz}, 2 \mathrm{H}), 3.22(\mathrm{t}, J=7.0 \mathrm{~Hz}, 2 \mathrm{H}), 2.81(\mathrm{t}, J=4.9 \mathrm{~Hz}, 2 \mathrm{H}), 2.35(\mathrm{~m}, 1 \mathrm{H})$, $1.98(\mathrm{~m}, 3 \mathrm{H}), 1.87(\mathrm{~m}, 3 \mathrm{H}), 1.62(\mathrm{~m}, 2 \mathrm{H}), 1.51(\mathrm{~m}, 1 \mathrm{H}), 1.19(\mathrm{~s}, 3 \mathrm{H}), 1.02(\mathrm{~s}, 3 \mathrm{H}), 0.91(\mathrm{~d}, J=9.4 \mathrm{~Hz}, 2 \mathrm{H})$.

${ }^{13} \mathrm{C}$ NMR $\left(99 \mathrm{MHz}, \mathrm{MeOH}-d_{4}, 25^{\circ} \mathrm{C}, \delta\right)$ :

$172.4,73.4,71.9,71.3,71.2,47.6,42.7,42.0,40.2,39.7,38.7,38.4,34.5,28.7,27.4,23.8,23.2$.

\section{HRMS (ESI-TOF, m/z):}

Calc'd for $\mathrm{C}_{17} \mathrm{H}_{33} \mathrm{~N}_{2} \mathrm{O}_{3}{ }^{+}\left([\mathrm{M}+\mathrm{H}]^{+}\right)$313.2486; found 313.2479.

Calc'd for $\mathrm{C}_{17} \mathrm{H}_{32} \mathrm{~N}_{2} \mathrm{O}_{3} \mathrm{Na}^{+}\left([\mathrm{M}+\mathrm{Na}]^{+}\right)$335.2305; found 335.2299. 


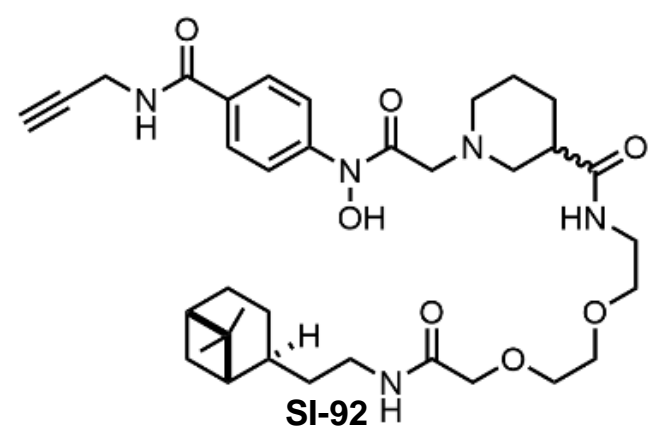

\section{Procedure:}

To a stirred solution of carboxylic acid SI-74 $(61.5 \mathrm{mg}, 130 \mu \mathrm{mol})$ in $0.65 \mathrm{~mL}$ DMF was charged amine SI-91 (52.7 $\mathrm{mg}, 169 \mu \mathrm{mol}, 1.3 \mathrm{eq}$ ), DIPEA (70 $\mu \mathrm{L}, 0.39 \mathrm{mmol}, 3 \mathrm{eq}$ ), oxyma (4.6 mg, $33 \mu \mathrm{mol}, 0.25 \mathrm{eq}$ ), and EDC. $\mathrm{HCl}(34.9$ $\mathrm{mg}, 182 \mu \mathrm{mol}, 1.4 \mathrm{eq})$. After 24 hours, the solvent was removed on the rotovap. The residue was stirred with $4 \mathrm{~mL}$ EtOAc and $2 \mathrm{~mL} 10 \% \mathrm{NaCl}$, and the aqueous $\mathrm{pH}$ was adjusted to 5 with citric acid. The layers were separated, and the aqueous material was extracted with $1 \mathrm{~mL}$ EtOAc. The pooled organics were washed with brine, dried $\left(\mathrm{Na}_{2} \mathrm{SO}_{4}\right)$, filtered, and concentrated. The crude material was purified by preparative HPLC (method A, $5-80 \%$ ACN) to afford SI-92 (38.2 mg, $49.8 \mu \mathrm{mol}, 38 \%$ yield) as a white solid.

${ }^{1} \mathbf{H}$ NMR $\left(500 \mathrm{MHz}, \mathrm{CD}_{3} \mathrm{CN}, 25^{\circ} \mathrm{C}, \delta\right)$ :

9.39 (br s, 1H), 7.82 (s, 4H), 7.59 (s, 1H), 7.35 (s, 1H), 7.04 (s, 1H), 4.45 (s, 2H), 4.11 (dd, J = 5.2, $2.3 \mathrm{~Hz}, 2 \mathrm{H})$, 3.88 (s, 2H), 3.64 (br d, $J=12.0 \mathrm{~Hz}, 1 \mathrm{H}), 3.58(\mathrm{~m}, 4 \mathrm{H}), 3.50(\mathrm{~m}, 3 \mathrm{H}), 3.37$ (t, $J=4.3 \mathrm{~Hz}, 2 \mathrm{H}), 3.21$ (br d, $J=12.0$ $\mathrm{Hz}, 1 \mathrm{H}), 3.16(\mathrm{~m}, 2 \mathrm{H}), 3.06(\mathrm{t}, J=11.7 \mathrm{~Hz}, 1 \mathrm{H}), 2.95(\mathrm{~s}, 1 \mathrm{H}), 2.47(\mathrm{~s}, 1 \mathrm{H}), 2.31(\mathrm{~m}, 1 \mathrm{H}), 2.01$ to $1.75(\mathrm{~m}, 10 \mathrm{H})$, $1.54(\mathrm{q}, J=7.3 \mathrm{~Hz}, 2 \mathrm{H}), 1.43(\mathrm{~m}, 1 \mathrm{H}), 1.15(\mathrm{~s}, 3 \mathrm{H}), 0.97$ (s, 3H), $0.85(\mathrm{~d}, J=9.2 \mathrm{~Hz}, 1 \mathrm{H})$.

${ }^{13} \mathrm{C}$ NMR $\left(126 \mathrm{MHz}, \mathrm{CD}_{3} \mathrm{CN}, 25^{\circ} \mathrm{C}, \delta\right)$ :

175.6, 171.1, 167.0, 165.4, 144.2, 131.5, 128.7, 119.7, 81.3, 71.8, 71.5, 71.0, 70.8, 70.0, 59.2, 56.0, 55.2, 47.1, 42.2, 39.9, 39.5, 39.3, 38.1, 37.4, 34.1, 29.6, 28.4, 27.0, 25.4, 23.5, 22.8, 20.7.

HRMS (ESI-TOF, m/z):

Calc'd for $\mathrm{C}_{35} \mathrm{H}_{52} \mathrm{~N}_{5} \mathrm{O}_{7}^{+}\left([\mathrm{M}+\mathrm{H}]^{+}\right)$654.3861; found 654.3841.

Calc'd for $\mathrm{C}_{35} \mathrm{H}_{51} \mathrm{~N}_{5} \mathrm{O}_{7} \mathrm{Na}^{+}\left([\mathrm{M}+\mathrm{Na}]^{+}\right)$676.3681; found 676.3690 . 


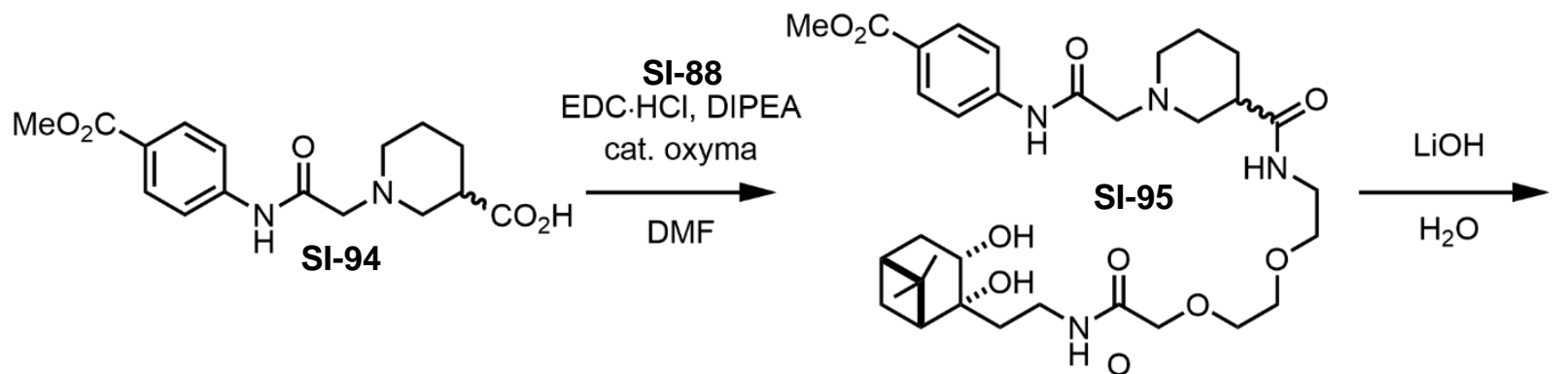<smiles>O=C(COCCOCCNC(=O)[C@@H]1CCCN(CC(=O)Nc2ccc(C(=O)O)cc2)C1)NCC[C@]1(O)C2C3C4C2[C@@H](O)[C@@H]4C31</smiles><smiles>C[C@H](OC(=O)O)[C@@H](Cl)C(=O)O</smiles><smiles></smiles> 


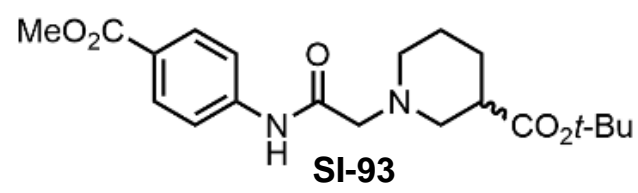

\section{Procedure:}

To a stirred solution of 2-bromo- $N$-(4-methoxycarbonyl)phenylacetamide ${ }^{7}$ (136 mg, $\left.0.5 \mathrm{mmol}\right)$ in $1 \mathrm{~mL}$ IPA was charged $(R, S)$-t -butylpiperidine-3-carboxylate $5(278 \mathrm{mg}, 1.5 \mathrm{mmol}, 3 \mathrm{eq})$ in portions over 10 minutes (note: cloudy grey suspension forms). After 4 hours, the solvent was removed on the rotovap. The residue was stirred with $3 \mathrm{~mL}$ EtOAc, washed with $3 \times 3 \mathrm{~mL} 10 \% \mathrm{NaCl}$, dried $\left(\mathrm{Na}_{2} \mathrm{SO}_{4}\right)$, filtered, and concentrated. The crude material was adsorbed on $0.75 \mathrm{~g}$ silica and chromatographed on $10 \mathrm{~g}$ silica (30 to 35\% v/v EtOAc in hexane) to afford SI-93 (135.4 mg, $0.360 \mathrm{mmol}, 72 \%$ yield) as an oil.

${ }^{1} \mathbf{H}$ NMR $\left(392 \mathrm{MHz}, \mathrm{CDCl}_{3}, 25^{\circ} \mathrm{C}, \delta\right)$ :

9.91 (br s, 1H), 7.94 (d, $J=8.6 \mathrm{~Hz}, 2 \mathrm{H}), 7.79(\mathrm{~d}, J=8.6 \mathrm{~Hz}, 2 \mathrm{H}), 3.82(\mathrm{~s}, 3 \mathrm{H}), 3.15(\mathrm{~d}, J=16.8 \mathrm{~Hz}, 1 \mathrm{H}), 2.97$ (d, $J$ $=16.8 \mathrm{~Hz}, 1 \mathrm{H}), 2.92(\mathrm{~m}, 1 \mathrm{H}), 2.58(\mathrm{~m}, 1 \mathrm{H}), 2.51(\mathrm{~m}, 1 \mathrm{H}), 2.40(\mathrm{~m}, 2 \mathrm{H}), 2.08(2,1 \mathrm{H}), 1.89(\mathrm{~m}, 1 \mathrm{H}), 1.58(\mathrm{~m}, 3 \mathrm{H})$, $1.43(\mathrm{~m}, 9 \mathrm{H})$.

${ }^{13} \mathrm{C}$ NMR $\left(126 \mathrm{MHz}, \mathrm{CDCl}_{3}, 25^{\circ} \mathrm{C}, \delta\right)$ :

173.5, 169.4, 166.7, 142.4, 130.5, 125.0, 118.8, 80.7, 62.3, 54.6, 54.3, 51.8, 41.0, 28.0, 26.0, 23.8.

HRMS (ESI-TOF, m/z):

Calc'd for $\mathrm{C}_{20} \mathrm{H}_{29} \mathrm{~N}_{2} \mathrm{O}_{5}{ }^{+}\left([\mathrm{M}+\mathrm{H}]^{+}\right)$377.2071; found 377.2076.

Calc'd for $\mathrm{C}_{20} \mathrm{H}_{28} \mathrm{~N}_{2} \mathrm{O}_{5} \mathrm{Na}^{+}\left([\mathrm{M}+\mathrm{Na}]^{+}\right)$399.1890; found 399.1890. 


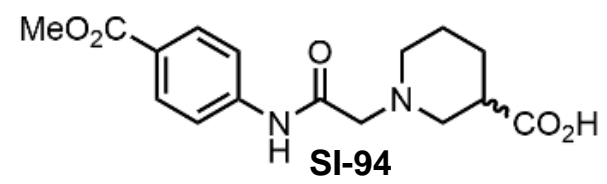

\section{Procedure:}

To a flask containing SI-93 (135.4 mg, $0.36 \mathrm{mmol})$ was charged $3 \mathrm{~mL} 100: 100: 1 \mathrm{v} / \mathrm{v}$ TFA : $\mathrm{CH}_{2} \mathrm{Cl}_{2}: \mathrm{Et}_{3} \mathrm{SiH}_{\mathrm{H}} \mathrm{The}$ mixture was stirred at 30 to $40{ }^{\circ} \mathrm{C}$ for 14 hours and cooled to room temperature. The solvents were removed on the rotovap and the residue was co-evaporated with $3 \times 2 \mathrm{~mL}$ IPA to afford SI-94 (143.8 mg, 0.331 mmol, $92 \%$ yield) as a white solid.

${ }^{1} \mathbf{H}$ NMR $\left(500 \mathrm{MHz}, \mathrm{CD}_{3} \mathrm{CN}, 25^{\circ} \mathrm{C}, \delta\right)$ :

9.79 (br s, 1H), 7.93 (d, $J=8.0 \mathrm{~Hz}, 1 \mathrm{H}), 7.64$ (d, $J=8.0 \mathrm{~Hz}, 1 \mathrm{H}), 4.09$ (s, 2H), 3.82 (s, 3H), 3.82 to 3.42 (m, $2 \mathrm{H}$ ), 3.29 to $2.94(\mathrm{~m}, 3 \mathrm{H}), 2.22$ to $1.44(\mathrm{~m}, 4 \mathrm{H})$.

${ }^{13} \mathrm{C}$ NMR $\left(126 \mathrm{MHz}, \mathrm{CD}_{3} \mathrm{CN}, 25^{\circ} \mathrm{C}, \delta\right)$ :

$176.9,173.0,166.4,163.0,141.8,130.6,126.3,119.4,58.4,54.2,51.9,39.3,37.6,24.7,23.4,22.2,19.9$.

\section{HRMS (ESI-TOF, m/z):}

Calc'd for $\mathrm{C}_{16} \mathrm{H}_{21} \mathrm{~N}_{2} \mathrm{O}_{5}{ }^{+}\left([\mathrm{M}+\mathrm{H}]^{+}\right)$321.1445; found 321.1459.

Calc'd for $\mathrm{C}_{16} \mathrm{H}_{20} \mathrm{~N}_{2} \mathrm{O}_{5} \mathrm{Na}^{+}\left([\mathrm{M}+\mathrm{Na}]^{+}\right)$343.1264; found 343.1269. 


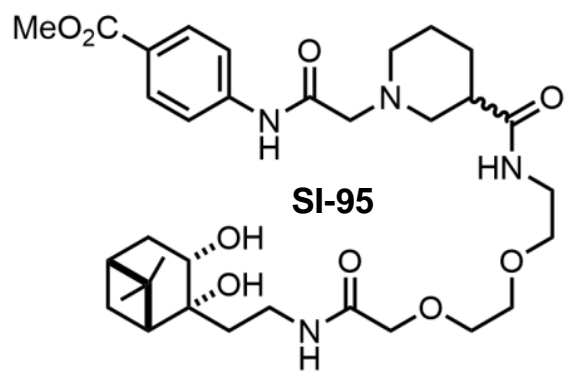

\section{Procedure:}

To a stirred solution of carboxylic acid SI-94 (143.8 mg, $0.33 \mathrm{mmol})$ in $3.3 \mathrm{~mL}$ DMF was charged amine SI-88 (172.2 mg, $0.50 \mathrm{mmol}, 1.5 \mathrm{eq}$ ), DIPEA ( $144 \mu \mathrm{L}, 0.83 \mathrm{mmol}, 2.5 \mathrm{eq})$, oxyma (12 mg, $0.08 \mathrm{mmol}, 0.25 \mathrm{eq}$ ), and $\mathrm{EDC} \cdot \mathrm{HCl}(79 \mathrm{mg}, 0.41 \mathrm{mmol}, 1.25 \mathrm{eq})$. After 3.5 hours, the solvent was removed on the rotovap. The residue was stirred with $8 \mathrm{~mL}$ EtOAc and washed with $2 \times 2 \mathrm{~mL} 1 \% \mathrm{Na}_{2} \mathrm{HPO}_{4}$ and $2 \mathrm{~mL}$ brine, and was dried $\left(\mathrm{Na}_{2} \mathrm{SO}_{4}\right)$, filtered, and concentrated. The crude material was chromatographed on $10 \mathrm{~g}$ silica (5 to $10 \% \mathrm{v} / \mathrm{v} \mathrm{MeOH}$ in $\mathrm{CH}_{2} \mathrm{Cl}_{2}$ ) to afford SI-95 (151.2 mg, $0.234 \mathrm{mmol}, 71 \%$ yield) as an oil.

${ }^{1} \mathbf{H}$ NMR $\left(392 \mathrm{MHz}, \mathrm{CDCl}_{3}, 25^{\circ} \mathrm{C}, \delta\right)$ :

9.85 (br s, 1H), 7.92 (d, $J=8.3,2 \mathrm{H}), 7.74(\mathrm{~d}, J=8.3,2 \mathrm{H}), 7.47$ (s, 1H), $7.01(\mathrm{~s}, 1 \mathrm{H}), 3.97$ (dd, $J=9.0,4.9 \mathrm{~Hz}, 1 \mathrm{H})$, $3.87(\mathrm{~m}, 2 \mathrm{H}), 3.82(\mathrm{~s}, 3 \mathrm{H}), 3.60$ to $3.39(\mathrm{~m}, 9 \mathrm{H}), 3.31(\mathrm{~m}, 1 \mathrm{H}), 3.15(\mathrm{~d}, J=16.6 \mathrm{~Hz}, 1 \mathrm{H}), 3.02(\mathrm{~d}, J=16.6 \mathrm{~Hz}, 1 \mathrm{H})$, $2.84(\mathrm{~m}, 2 \mathrm{H}), 2.50(\mathrm{~m}, 4 \mathrm{H}), 2.37(\mathrm{t}, J=11.0 \mathrm{~Hz}, 1 \mathrm{H}), 2.09(\mathrm{~m}, 1 \mathrm{H}), 1.98(\mathrm{~m}, 1 \mathrm{H}), 1.81(\mathrm{~m}, 1 \mathrm{H}), 1.72(\mathrm{~m}, 4 \mathrm{H}), 1.58$ $(\mathrm{m}, 3 \mathrm{H}), 1.30(\mathrm{~d}, J=10.3 \mathrm{~Hz}, 1 \mathrm{H}), 1.87(\mathrm{~s}, 3 \mathrm{H}), 0.82(\mathrm{~s}, 3 \mathrm{H})$.

${ }^{13} \mathbf{C}$ NMR $\left(99 \mathrm{MHz}, \mathrm{CDCl}_{3}, 25^{\circ} \mathrm{C}, \delta\right)$ :

174.2, 170.0, 169.5, 166.7, 142.3, 130.5, 125.1, 118.9, 75.2, 70.8, 70.4, 70.1, 70.0, 67.2, 62.2, 55.3, 54.1, 51.9, 41.6, $40.7,40.3,39.1,38.5,37.9,36.5,34.5,31.4,27.64,27.59,26.72,26.70,24.1,23.7$.

HRMS (ESI-TOF, m/z):

Calc'd for $\mathrm{C}_{33} \mathrm{H}_{51} \mathrm{~N}_{4} \mathrm{O}_{9}{ }^{+}\left([\mathrm{M}+\mathrm{H}]^{+}\right)$647.3651; found 647.3634.

Calc'd for $\mathrm{C}_{33} \mathrm{H}_{50} \mathrm{~N}_{4} \mathrm{O}_{9} \mathrm{Na}^{+}\left([\mathrm{M}+\mathrm{Na}]^{+}\right)$669.3470; found 669.3466. 


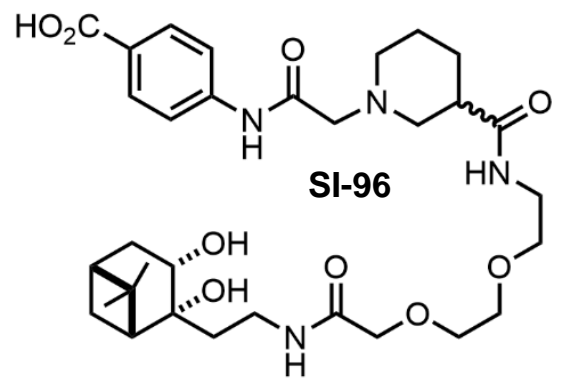

\section{Procedure:}

To a flask containing methyl ester SI-95 (151.2 $\mathrm{mg}, 0.23 \mathrm{mmol})$ was charged LiOH (0.5 M aqueous solution; 2.8

$\mathrm{mL}, 1.4 \mathrm{mmol}, 6 \mathrm{eq}$ ), and the mixture was stirred (note: solids slowly go into solution). After 50 minutes, the $\mathrm{pH}$ was adjusted to 5 with citric acid, and the volume was reduced to $1 \mathrm{~mL}$ on the rotovap (note: slurry formation). 1 $\mathrm{mL} \mathrm{ACN}$ was charged, and the resulting clear solution was syringe filtered. The crude material was purified by preparative HPLC (method B, 10 - 80\% ACN) to afford carboxylic acid SI-96 (118.7 mg, $0.156 \mathrm{mmol}, 67 \%$ yield) as a white solid.

${ }^{1} \mathbf{H}$ NMR $\left(392 \mathrm{MHz}, \mathrm{CD}_{3} \mathrm{CN}, 25^{\circ} \mathrm{C}, \delta\right)$ :

9.75 (s, 1H), 9.46 (br s, 1H), 7.92 (d, $J=7.9 \mathrm{~Hz}, 2 \mathrm{H}), 7.68$ (br s, 1H), 7.62 (d, $J=7.9 \mathrm{~Hz}, 2 \mathrm{H}), 7.41$ (br s, 1H), 3.97 (m, 5H), 3.70 to $3.44(\mathrm{~m}, 8 \mathrm{H}), 3.35(\mathrm{~m}, 4 \mathrm{H}), 3.19(\mathrm{~m}, 1 \mathrm{H}), 3.05(\mathrm{~m}, 1 \mathrm{H}), 2.93(\mathrm{~m}, 1 \mathrm{H}), 2.36(\mathrm{t}, J=10.8 \mathrm{~Hz}, 1 \mathrm{H})$, $2.08(\mathrm{~m}, 1 \mathrm{H}), 2.01$ to $1.70(\mathrm{~m}, 7 \mathrm{H}), 1.58(\mathrm{~m}, 2 \mathrm{H}), 1.29(\mathrm{~d}, J=9.9 \mathrm{~Hz}, 1 \mathrm{H}), 1.17(\mathrm{~s}, 3 \mathrm{H}), 0.84(\mathrm{~s}, 3 \mathrm{H})$.

${ }^{13} \mathrm{C}$ NMR $\left(99 \mathrm{MHz}, \mathrm{CD}_{3} \mathrm{CN}, 25^{\circ} \mathrm{C}, \delta\right)$ :

175.8, 172.1, 167.9, 163.8, 142.6, 131.7, 127.0, 120.0, 75.8, 71.6, 70.7, 70.6, 69.9, 68.1, 59.1, 55.8, 54.9, 52.3, 41.7, $41.2,39.9,39.1,38.6,37.3,35.4,28.3,28.0,25.4,24.2,20.6$.

HRMS (ESI-TOF, m/z):

Calc'd for $\mathrm{C}_{32} \mathrm{H}_{49} \mathrm{~N}_{4} \mathrm{O}_{9}{ }^{+}\left([\mathrm{M}+\mathrm{H}]^{+}\right)$633.3494; found 633.3517.

Calc'd for $\mathrm{C}_{32} \mathrm{H}_{48} \mathrm{~N}_{4} \mathrm{O}_{9} \mathrm{Na}^{+}\left([\mathrm{M}+\mathrm{Na}]^{+}\right)$655.3314; found 655.3325. 


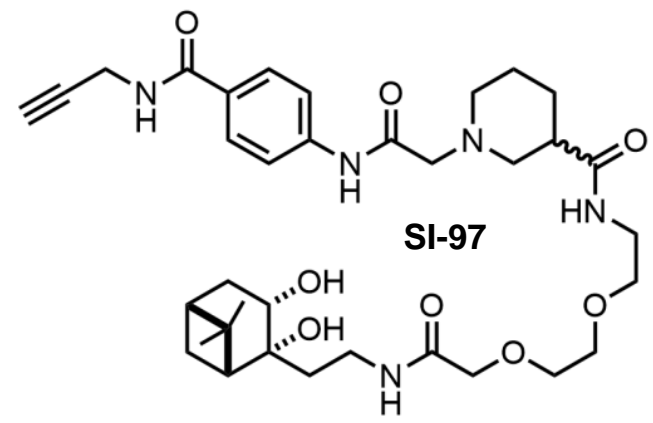

\section{Procedure:}

To a stirred solution of carboxylic acid SI-96 $(118.7 \mathrm{mg}, 0.156 \mathrm{mmol})$ in $1.6 \mathrm{~mL}$ DMF was charged propargylamine ( $55 \mu \mathrm{L}, 0.86 \mathrm{mmol}, 5.5 \mathrm{eq})$ and $\mathrm{EDC} \cdot \mathrm{HCl}(35.8 \mathrm{mg}, 0.19 \mathrm{mmol}, 1.2 \mathrm{eq})$. After 7 hours, the solvent was removed on the rotovap. The residue was stirred with $6 \mathrm{~mL}$ EtOAc and washed with $3 \mathrm{~mL} 2 \%$ aqueous $\mathrm{Na}_{2} \mathrm{HPO}_{4}$ and $3 \mathrm{~mL}$ brine, and was dried $\left(\mathrm{Na}_{2} \mathrm{SO}_{4}\right)$, filtered, and concentrated. The crude material was adsorbed on $0.3 \mathrm{~g}$ silica and chromatographed on $10 \mathrm{~g}$ silica (10\% v/v MeOH in $\mathrm{CH}_{2} \mathrm{Cl}_{2}$ ) to afford SI-97 (76.6 mol, $0.114 \mathrm{mmol}, 73 \%$ yield) as an oil.

${ }^{1} \mathbf{H}$ NMR $\left(500 \mathrm{MHz}, \mathrm{CD}_{3} \mathrm{CN}, 25^{\circ} \mathrm{C}, \delta\right)$ :

9.91 (br s, 1H), $7.73(\mathrm{~m}, 4 \mathrm{H}), 7.51(\mathrm{br} \mathrm{s}, 1 \mathrm{H}), 7.35(\mathrm{br} \mathrm{d}, J=24.6 \mathrm{~Hz}, 1 \mathrm{H}), 7.24(\mathrm{~m}, 3 \mathrm{H}), 7.12(\mathrm{~m}, 1 \mathrm{H}), 4.16(\mathrm{~m}, 2 \mathrm{H})$, $3.99(\mathrm{~m}, 2 \mathrm{H}), 3.85(\mathrm{~m}, 2 \mathrm{H}), 3.69$ to $3.24(\mathrm{~m}, 11 \mathrm{H}), 3.13(\mathrm{~m}, 1 \mathrm{H}), 3.04(\mathrm{~m}, 1 \mathrm{H}), 2.86(\mathrm{dm}, J=41.8 \mathrm{~Hz}, 1 \mathrm{H}), 2.76(\mathrm{~m}$, 1H), $2.52(\mathrm{~m}, 4 \mathrm{H}), 2.38(\mathrm{~m}, 1 \mathrm{H}), 2.23(\mathrm{~m}, 1 \mathrm{H}), 2.11(\mathrm{~m}, 1 \mathrm{H}), 2.00(\mathrm{~m}, 1 \mathrm{H}), 1.83(\mathrm{~m}, 1 \mathrm{H}), 1.72(\mathrm{~m}, 4 \mathrm{H}), 1.60(\mathrm{~m}$, $3 \mathrm{H}), 1.38(\mathrm{~m}, 2 \mathrm{H}), 1.32(\mathrm{~m}, 1 \mathrm{H}), 1.18(\mathrm{~s}, 3 \mathrm{H}), 0.83(\mathrm{~s}, 3 \mathrm{H})$

${ }^{13} \mathrm{C}$ NMR $\left(126 \mathrm{MHz}, \mathrm{CD}_{3} \mathrm{CN}, 25{ }^{\circ} \mathrm{C}, \delta\right)$ :

174.3, 170.0, 169.5, 160.9, 141.1, 128.8, 128.2, 119.1, 79.9, 75.2, 71.6, 71.4, 70.8, 70.4, 70.1, 69.9, 67.3, 62.2, 55.4, $54.1,51.7,41.8,40.7,40.3,39.1,38.5,37.9,34.5,29.5,28.0,27.7,27.6,24.1$.

\section{HRMS (ESI-TOF, m/z):}

Calc'd for $\mathrm{C}_{35} \mathrm{H}_{52} \mathrm{~N}_{5} \mathrm{O}_{8}{ }^{+}\left([\mathrm{M}+\mathrm{H}]^{+}\right)$670.3810; found 670.3812 .

Calc'd for $\mathrm{C}_{35} \mathrm{H}_{51} \mathrm{~N}_{5} \mathrm{O}_{8} \mathrm{Na}^{+}\left([\mathrm{M}+\mathrm{Na}]^{+}\right)$692.3630; found 692.3630 . 
<smiles>[R]NCCCC[C@H](NC(=O)COCCOCCNC(=O)CN)C(=O)N[C@@H](CCCNC(=N)N)C(N)=O</smiles>

\section{Procedure:}

These materials were synthesized using standard Fmoc SPPS (Rink amide resin, $0.35 \mathrm{mmol}$ scale). SI-98 used Fmoc-Lys(Boc)-H in the second coupling step, and SI-98-Ac used Fmoc-Lys(Ac)-H in the second coupling step.

The crude peptides were purified by preparative HPLC (method B, 10 - 90\% ACN) to afford SI-98 (199.8 mg, 0.263 mmol, 75\% yield) as a bis-TFA salt and SI-98-Ac (226.9 $\mathrm{mg}, 0.331 \mathrm{mmol}, 95 \%$ yield) as a mono-TFA salt.

\section{Characterization:}

\begin{tabular}{|c|c|c|c|}
\hline \multirow{2}{*}{ Compound } & \multicolumn{2}{|c|}{$\begin{array}{c}\text { Analytical HPLC } \\
\text { method A, 240 nm }\end{array}$} & \multirow{2}{*}{ HRMS } \\
\cline { 2 - 3 } & tR (min) & $\begin{array}{c}\text { Purity } \\
\text { (\% AN })\end{array}$ & \\
\hline SI-98 & 8.8 & $>99$ & $\begin{array}{c}\text { Calc'd for } \mathrm{C}_{20} \mathrm{H}_{40} \mathrm{~N}_{11} \mathrm{O}_{6}^{+}\left([\mathrm{M}+\mathrm{H}]^{+}\right) 530.3158 \text {; found 530.3169. } \\
\text { Calc'd for } \mathrm{C}_{20} \mathrm{H}_{39} \mathrm{~N}_{11} \mathrm{O}_{6} \mathrm{Na}^{+}\left([\mathrm{M}+\mathrm{Na}]^{+}\right) 552.2977 \text {; found 552.2983. }\end{array}$ \\
\hline SI-98-Ac & 9.8 & $>99$ & $\begin{array}{c}\text { Calc'd for } \mathrm{C}_{22} \mathrm{H}_{42} \mathrm{~N}_{11} \mathrm{O}_{7}^{+}\left([\mathrm{M}+\mathrm{H}]^{+}\right) 572.3263 \text {; found 572.3276. } \\
\text { Calc'd for } \mathrm{C}_{22} \mathrm{H}_{41} \mathrm{~N}_{11} \mathrm{O}_{7} \mathrm{Na}^{+}\left([\mathrm{M}+\mathrm{Na}]^{+}\right) 594.3083 \text {; found 594.3089. }\end{array}$ \\
\hline
\end{tabular}


<smiles>[R]NCCCC[C@H](NC(=O)COCCOCCNC(=O)CN)C(=O)N[C@@H](CCCNC(=N)N)C(N)=O</smiles>

Procedure:

To a suspension of the azide (SI-98 or -98-Ac) and alkyne (SI-77, -86, -89, -92, or -97) in $3: 2 \mathrm{H}_{2} \mathrm{O} / t$-BuOH was charged sodium ascorbate (from a $250 \mathrm{mM}$ aqueous stock solution), TBTA (from a $200 \mathrm{mM}$ stock solution in DMSO), and finally $\mathrm{CuSO}_{4}$ (from a $100 \mathrm{mM}$ aqueous stock solution). The mixture was vortexed until a clear solution was obtained and aged overnight. Most of the volatiles were removed on

\begin{tabular}{|c|c|}
\hline Material & Final concentration $(\mathrm{mM})$ \\
\hline azide & 20 \\
\hline alkyne & 20 \\
\hline $\mathrm{CuSO}_{4}$ & 5 \\
\hline $\begin{array}{c}\text { sodium } \\
\text { ascorbate }\end{array}$ & 20 \\
\hline TBTA & 5 \\
\hline
\end{tabular}
the rotovap, the residue was suspended in $1 \mathrm{~mL} 1: 1 \mathrm{v} / \mathrm{v} \mathrm{ACN}: \mathrm{H}_{2} \mathrm{O}$ and syringe filtered. Purification by preparative HPLC (method A, 0 - 60\% ACN) afforded the target model catalysts as white solids. These are tris-TFA salts for materials with a free lysine, and bis-TFA salts for materials with an acetylated lysine. 
Characterization data:

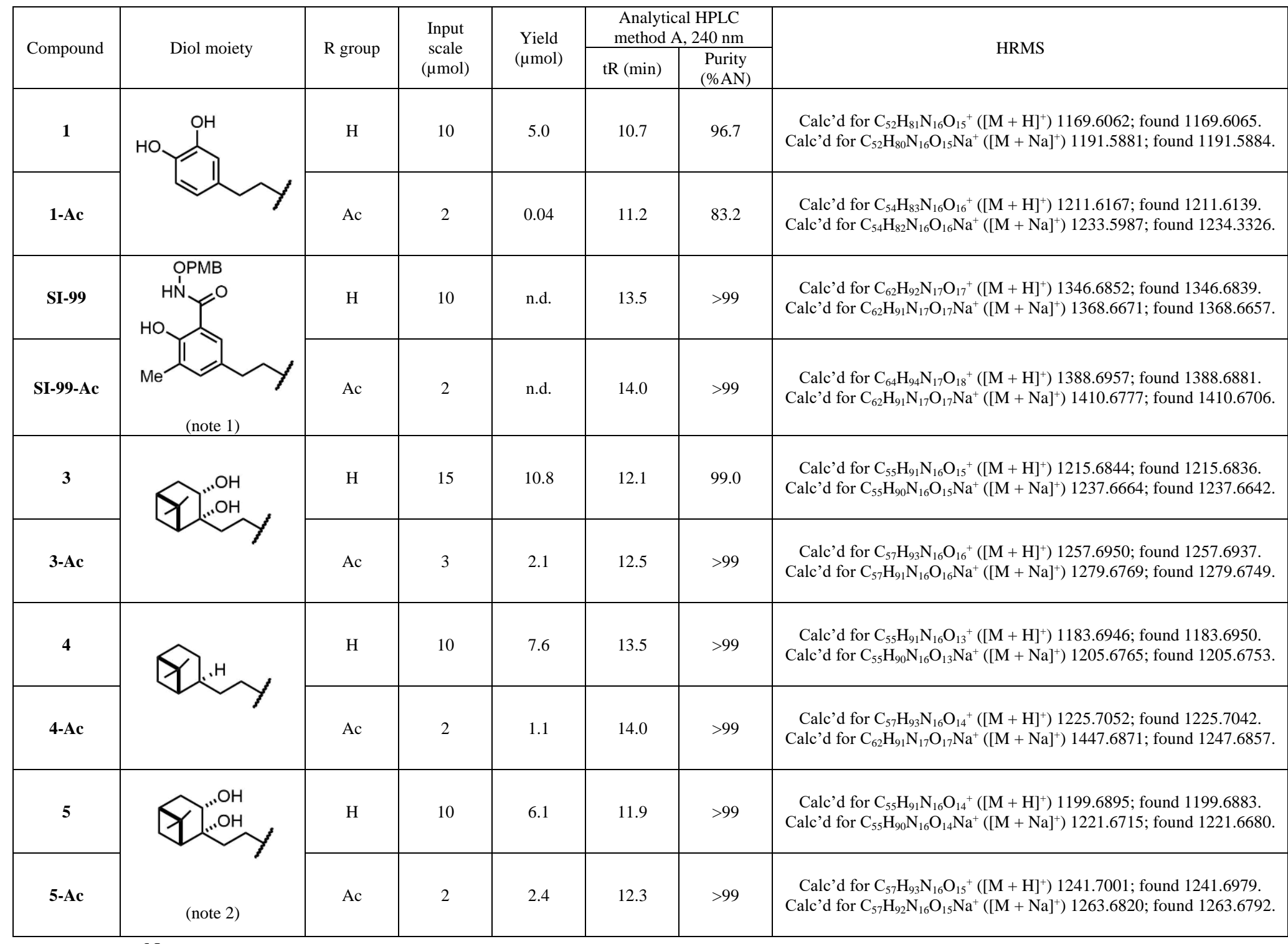

Notes:

1. These materials were subjected to PMB deprotection (see below)

2. These materials lack the Lewis base moiety:<smiles>[Mg]</smiles> 
Procedure and data for compounds 2 and 2-Ac:

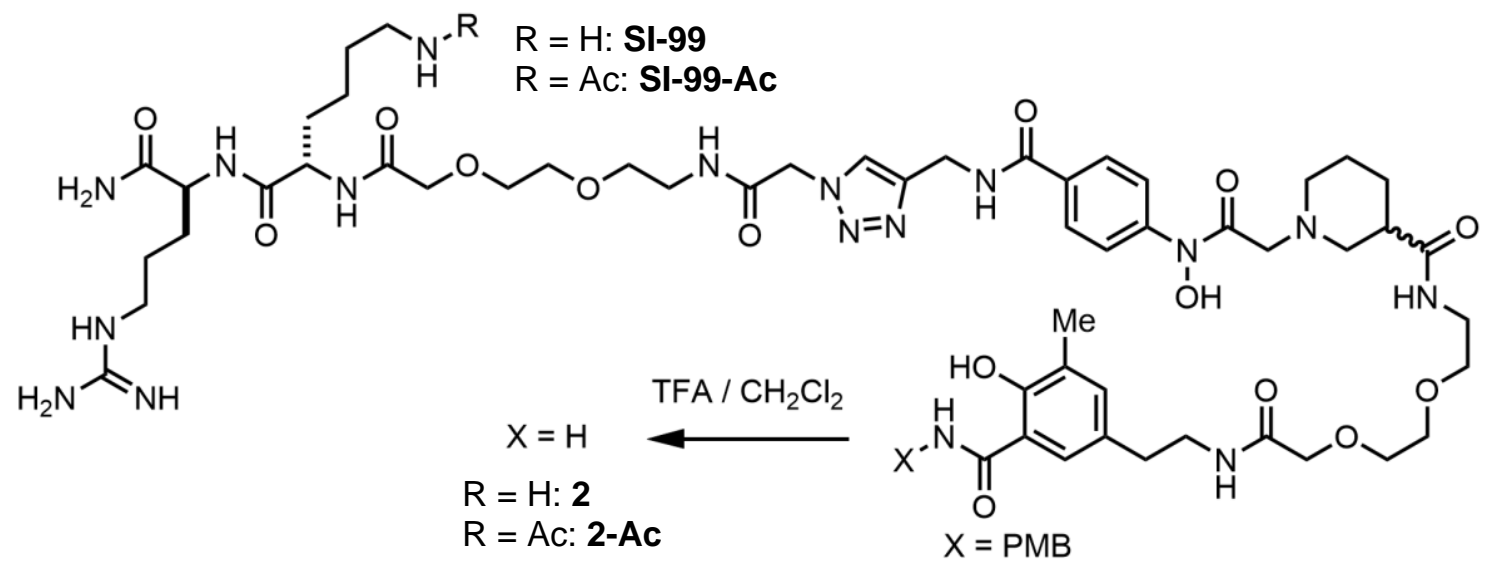

To a flask containing the starting material was charged $1: 1 \mathrm{v} / \mathrm{v}$ TFA : $\mathrm{CH}_{2} \mathrm{Cl}_{2}(\mathrm{R}=\mathrm{H}: 230 \mu \mathrm{L} ; \mathrm{R}=\mathrm{Ac}: 100 \mu \mathrm{L})$. After 1 hour, the volatiles were removed under an argon stream, and the residue was co-evaporated with ACN. Purification by preparative HPLC (method A, $0-60 \%$ ACN) afforded the target materials as white solids.

\begin{tabular}{|c|c|c|c|c|}
\hline \multirow{2}{*}{ Compound } & \multirow{2}{*}{$\begin{array}{c}\text { Yield } \\
(\mu \mathrm{mol})\end{array}$} & \multicolumn{2}{|c|}{ Analytical HPLC } & \multirow{2}{*}{ HRMS } \\
\hline & & $\mathrm{tR}(\min )$ & $\begin{array}{l}\text { Purity } \\
(\% \mathrm{AN})\end{array}$ & \\
\hline 2 & 3.4 & 11.3 & $>99$ & $\begin{array}{l}\text { Calc'd for } \mathrm{C}_{54} \mathrm{H}_{84} \mathrm{~N}_{17} \mathrm{O}_{16}^{+}\left([\mathrm{M}+\mathrm{H}]^{+}\right) \text {1226.6276; found 1226.6273. } \\
\text { Calc'd for } \mathrm{C}_{54} \mathrm{H}_{83} \mathrm{~N}_{17} \mathrm{O}_{16} \mathrm{Na}^{+}\left([\mathrm{M}+\mathrm{Na}]^{+}\right) \text {1248.6096; found 1248.6078. }\end{array}$ \\
\hline 2-Ac & 0.15 & 11.7 & $>99$ & $\begin{array}{l}\text { Calc'd for } \mathrm{C}_{56} \mathrm{H}_{86} \mathrm{~N}_{17} \mathrm{O}_{17}+\left([\mathrm{M}+\mathrm{H}]^{+}\right) \text {1268.6382; found 1268.6356. } \\
\text { Calc'd for } \mathrm{C}_{56} \mathrm{H}_{85} \mathrm{~N}_{17} \mathrm{O}_{17} \mathrm{Na}^{+}\left([\mathrm{M}+\mathrm{Na}]^{+}\right) \text {1290.6202; found } 1290.6175 \text {. }\end{array}$ \\
\hline
\end{tabular}




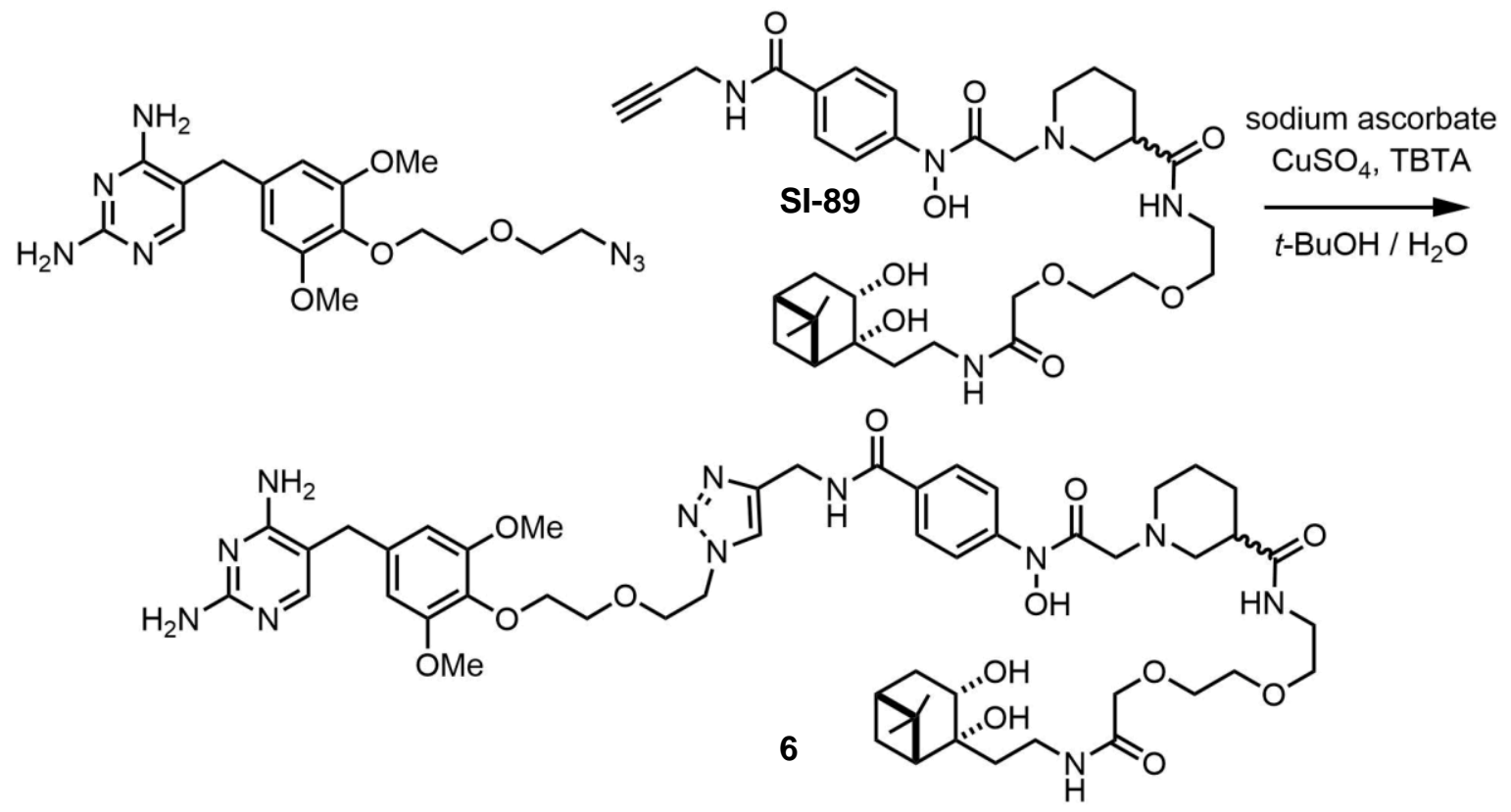

\section{Procedure:}

To a stirred solution of alkyne SI-89 (4.3 mg, $5.4 \mu \mathrm{mol})$, TMP-azide ${ }^{1}(2.1 \mathrm{mg}, 5.4 \mu \mathrm{mol}, 1.0 \mathrm{eq})$, sodium ascorbate (1.1 mg, $5.4 \mu \mathrm{mol}, 1.0 \mathrm{eq})$, and TBTA $(0.72 \mathrm{mg}, 1.4 \mu \mathrm{mol}, 0.25 \mathrm{eq})$ in $270 \mu \mathrm{L} 2: 3 \mathrm{v} / \mathrm{v} t-\mathrm{BuOH}: \mathrm{H}_{2} \mathrm{O}$ was charged $\mathrm{CuSO}_{4}(0.22 \mathrm{mg}, 1.4 \mu \mathrm{mol}, 0.25 \mathrm{eq})$. After 4 hours, the reaction mixture was purified by preparative HPLC (method A, $0-80 \%$ ACN) to afford 6 (5.1 $\mathrm{mg}, 4.3 \mu \mathrm{mol}, 79 \%$ yield) as a white solid.

${ }^{1} \mathrm{H}$ NMR: (500 MHz, $\left.\mathrm{CD}_{3} \mathrm{CN}, 25^{\circ} \mathrm{C}, \delta\right): 9.37$ (br s, 1H), 7.85 (m, 2H), $7.74(\mathrm{~m}, 6 \mathrm{H}), 7.58(\mathrm{~m}, 3 \mathrm{H}), 7.40$ (m, 1H), $7.33(\mathrm{~s}, 2 \mathrm{H}), 7.26(\mathrm{~m}, 1 \mathrm{H}), 7.21(\mathrm{~m}, 1 \mathrm{H}), 6.73(\mathrm{br} \mathrm{s}, 1 \mathrm{H}), 6.46(\mathrm{~s}, 3 \mathrm{H}), 6.33(\mathrm{br} \mathrm{s}, 1 \mathrm{H}), 4.58$ (br s, 3H), $4.48(\mathrm{t}, J=$ $4.3 \mathrm{~Hz}, 3 \mathrm{H}), 4.44(\mathrm{br} \mathrm{s}, 3 \mathrm{H}), 4.28(\mathrm{~d}, J=8.0 \mathrm{~Hz}, 1 \mathrm{H}), 3.95(\mathrm{dd}, J=4.6,4.0 \mathrm{~Hz}, 4 \mathrm{H}), 3.90(\mathrm{br} \mathrm{s}, 3 \mathrm{H}), 3.85(\mathrm{t}, J=4.9$ $\mathrm{Hz}, 3 \mathrm{H}), 3.69(\mathrm{~m}, 10 \mathrm{H}), 3.65(\mathrm{~m}, 4 \mathrm{H}), 3.60(\mathrm{~m}, 9 \mathrm{H}), 3.52(\mathrm{~m}, 4 \mathrm{H}), 3.30(\mathrm{~m}, 6 \mathrm{H}), 3.07(\mathrm{~m}, 1 \mathrm{H}), 2.95(\mathrm{br} \mathrm{s}, 1 \mathrm{H}), 2.34$ (m, 1H), $2.20(\mathrm{~m}, 1 \mathrm{H}), 2.08(\mathrm{~m}, 2 \mathrm{H}), 1.98(\mathrm{~m}, 2 \mathrm{H}), 1.85(\mathrm{~m}, 4 \mathrm{H}), 1.75(\mathrm{~d}, J=13.7 \mathrm{~Hz}, 1 \mathrm{H}), 1.57(\mathrm{~m}, 1 \mathrm{H}), 1.23(\mathrm{~m}$, $5 \mathrm{H}), 1.14(\mathrm{~d}, J=10.9 \mathrm{~Hz}, 1 \mathrm{H}), 0.79(\mathrm{~m}, 4 \mathrm{H})$.

${ }^{13} \mathrm{C}$ NMR: $\left(126 \mathrm{MHz}, \mathrm{CD}_{3} \mathrm{CN}, 25{ }^{\circ} \mathrm{C}, \delta\right): 165.6,156.3,154.4,141.1,136.7,133.1,128.6,119.8,109.8,106.9,86.3$, 79.1, 76.3, 72.8, 71.4, 71.2, 71.0, 70.9, 70.0, 69.7, 56.6, 56.0, 55.2, 51.1, 49.8, 41.3, 40.4, 39.0, 37.5, 36.4, 35.9, 34.9, 33.7, 28.3, 27.2, 26.4, 25.4, 24.3, 23.9, 20.7.

(Note: we were unable to detect all the expected peaks in the ${ }^{13} \mathrm{C}$ spectrum due to low signal intensity).

HRMS (ESI-TOF, m/z):

Calc'd for $\mathrm{C}_{52} \mathrm{H}_{75} \mathrm{~N}_{12} \mathrm{O}_{13}{ }^{+}\left([\mathrm{M}+\mathrm{H}]^{+}\right)$1075.5571; found 1075.5582.

Calc'd for $\mathrm{C}_{52} \mathrm{H}_{74} \mathrm{~N}_{12} \mathrm{O}_{13} \mathrm{Na}^{+}\left([\mathrm{M}+\mathrm{Na}]^{+}\right)$1097.5391; found 1097.5407. 

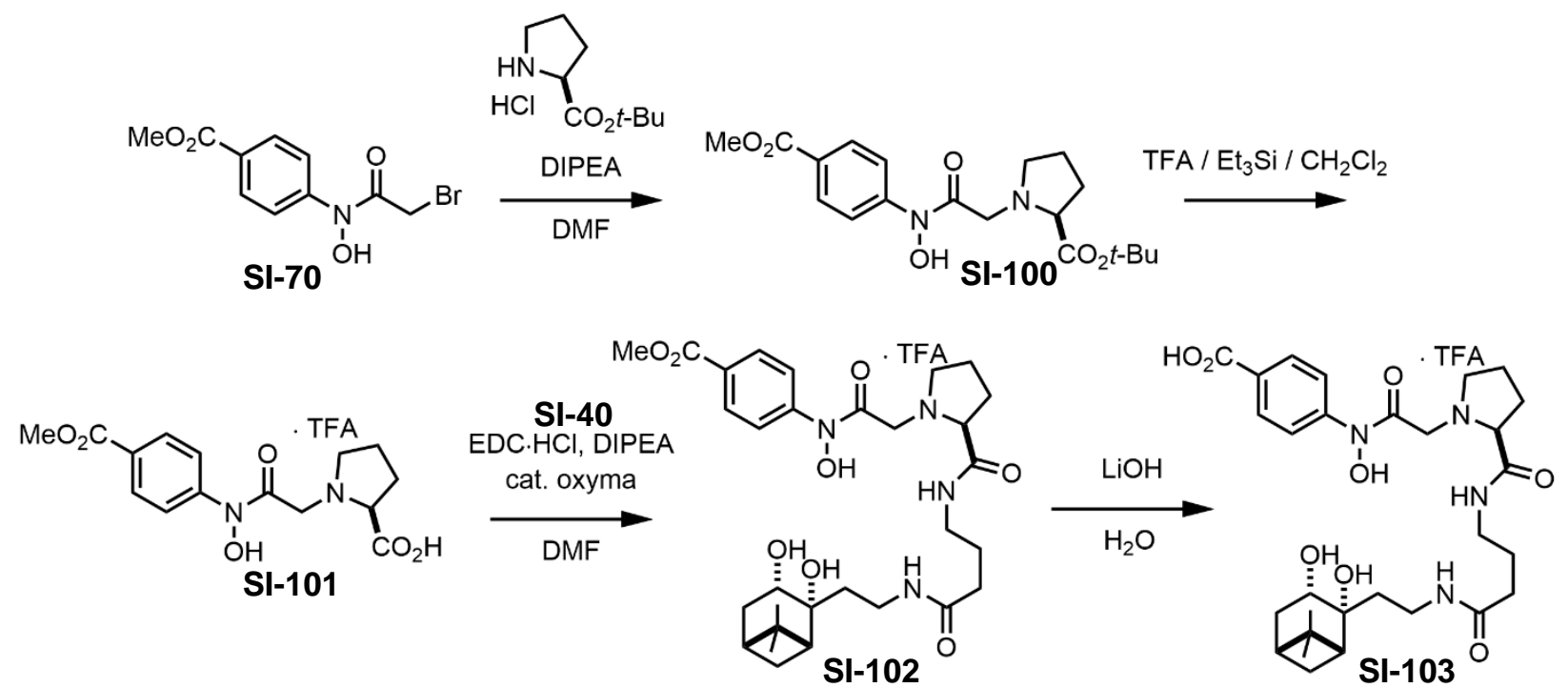

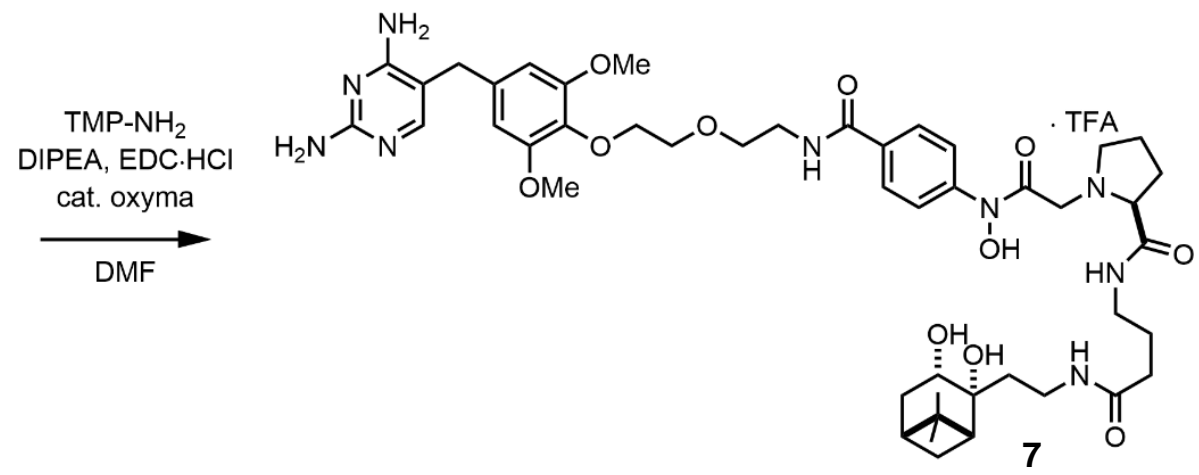




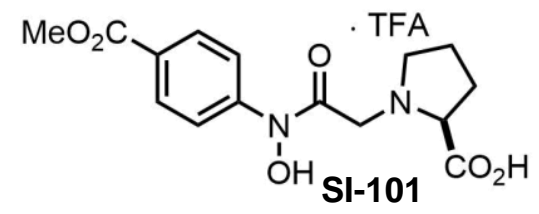

\section{Procedure:}

To a stirred solution of SI-70 (286 mg, $1.00 \mathrm{mmol}$ ) in $5 \mathrm{~mL}$ DMF was charged L-proline-t-butyl ester hydrochloride (415 mg, $2.00 \mathrm{mmol}, 2.0 \mathrm{eq}$ ) and DIPEA ( $575 \mu \mathrm{L}, 3.30 \mathrm{mmol}, 3.3 \mathrm{eq}$ ). After 14 hours, most of the DMF was removed on the rotovap. The residue was suspended in $10 \mathrm{~mL}$ MTBE, washed with $2 \times 2 \mathrm{~mL}$ brine, dried $\left(\mathrm{Na}_{2} \mathrm{SO}_{4}\right)$, and concentrated on the rotovap. The crude intermediate was adsorbed onto $1.1 \mathrm{~g}$ silica and chromatographed on 10 g silica (1 : $1 \mathrm{v} / \mathrm{v}$ EtOAc : hexane) to afford SI-100 $(299 \mathrm{mg})$ as an oil which solidified.

SI-100 $\left(299 \mathrm{mg}\right.$ ) was dissolved in $3 \mathrm{~mL} 50: 50: 1 \mathrm{v} / \mathrm{v} \mathrm{CH}_{2} \mathrm{Cl}_{2}: \mathrm{TFA}: \mathrm{Et}_{3} \mathrm{SiH}$ and heated in a $40-50{ }^{\circ} \mathrm{C}$ bath for 5.5 hours. The reaction mixture was concentrated on the rotovap and the residue was co-evaporated with toluene, dissolved in $1: 1 \mathrm{v} / \mathrm{v} \mathrm{H}_{2} \mathrm{O}: \mathrm{ACN}$, and lyophilized to afford SI-101 (348 mg, $0.80 \mathrm{mmol}$, 80\% yield over 2 steps) as a foam.

${ }^{1}$ H NMR: $\left(500 \mathrm{~Hz}, \mathrm{CD}_{3} \mathrm{CN}, 25^{\circ} \mathrm{C}, \delta\right)$ :

$7.98(\mathrm{~d}, J=8.6 \mathrm{~Hz}, 2 \mathrm{H}), 7.80(\mathrm{~d}, J=8.6 \mathrm{~Hz}, 2 \mathrm{H}), 4.65(\mathrm{~d}, J=14.9 \mathrm{~Hz}, 2 \mathrm{H}), 4.58(\mathrm{~d}, J=14.9 \mathrm{~Hz}, 2 \mathrm{H}), 4.40(\mathrm{~m}, 1 \mathrm{H})$, $3.88(\mathrm{~m}, 1 \mathrm{H}), 3.84(\mathrm{~s}, 3 \mathrm{H}), 3.31(\mathrm{~m}, 1 \mathrm{H}), 2.46(\mathrm{~m}, 1 \mathrm{H}), 2.14(\mathrm{~m}, 2 \mathrm{H}), 2.00(\mathrm{~m}, 1 \mathrm{H})$.

${ }^{13} \mathrm{C}$ NMR: $\left(126 \mathrm{MHz}, \mathrm{CD}_{3} \mathrm{CN}, 25^{\circ} \mathrm{C}, \delta\right)$ :

171.6, 166.9, 165.9, 145.0, 130.9, 127.7, 119.6, 69.1, 58.4, 57.6, 52.6, 29.2, 24.0.

HRMS (ESI-TOF, m/z):

Calc'd for $\mathrm{C}_{15} \mathrm{H}_{19} \mathrm{~N}_{2} \mathrm{O}_{6}{ }^{+}\left([\mathrm{M}+\mathrm{H}]^{+}\right)$323.1238; found 323.1225. 


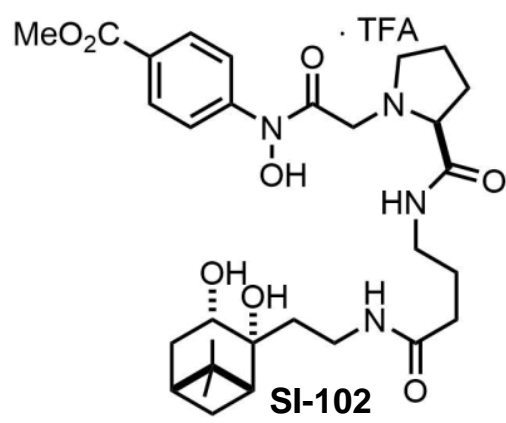

\section{Procedure:}

A to a stirred solution of carboxylic acid SI-101 (30.6 mg, $70 \mu \mathrm{mol})$, amine SI-40 (35.7 mg, $126 \mu \mathrm{mol}, 1.8 \mathrm{eq})$, DIPEA ( $49 \mu \mathrm{L}, 0.28 \mathrm{mmol}, 4 \mathrm{eq})$, and oxyma ( $1 \mathrm{mg}, 7 \mu \mathrm{mol}, 0.1 \mathrm{eq})$ in $1 \mathrm{~mL}$ DMF was charged $\mathrm{EDC} \cdot \mathrm{HCl}(21 \mathrm{mg}$, $0.11 \mathrm{~mol}, 1.5 \mathrm{eq})$. The mixture was stirred for 14 hours and most of the DMF was removed on the rotovap. The crude residue was chromatographed on $5 \mathrm{~g}$ silica (8 to $10 \% \mathrm{v} / \mathrm{v} \mathrm{MeOH}$ in $\mathrm{CH}_{2} \mathrm{Cl}_{2}$ ) to afford an oil $(25.2 \mathrm{mg}$ ). This material was purified by preparative HPLC (method A, 0 - 80\% ACN) to afford SI-102 (11.8 mg, $16.7 \mu \mathrm{mol}, 24 \%$ yield) as a white solid.

${ }^{1}$ H NMR: $\left(500 \mathrm{MHz}, \mathrm{CD}_{3} \mathrm{CN}, 25^{\circ} \mathrm{C}, \delta\right)$ :

7.99 (m, 2H, $7.83(\mathrm{~m}, 2 \mathrm{H}), 7.47$ (br s, 1H), 6.90 (br s, 1H), 4.69 (d, J = 16.9 Hz, 1H), 4.62 (d, J = 16.9 Hz, 1H), 4.34 $(\mathrm{dd}, J=8.9,4.9 \mathrm{~Hz}, 1 \mathrm{H}), 3.94(\mathrm{~m}, 1 \mathrm{H}), 3.88(\mathrm{~m}, 1 \mathrm{H}), 3.84(\mathrm{~s}, 3 \mathrm{H}), 3.28(\mathrm{~m}, 4 \mathrm{H}), 3.16(\mathrm{~m}, 1 \mathrm{H}), 2.48(\mathrm{~m}, 1 \mathrm{H}), 2.38$ (t, $J=11.2 \mathrm{~Hz}, 1 \mathrm{H}), 2.16(\mathrm{~m}, 3 \mathrm{H}), 2.08(\mathrm{~m}, 2 \mathrm{H}), 2.01(\mathrm{~m}, 1 \mathrm{H}), 1.78(\mathrm{~m}, 2 \mathrm{H}), 1.71(\mathrm{~m}, 2 \mathrm{H}), 1.55(\mathrm{~m}, 2 \mathrm{H}), 1.31(\mathrm{~d}, J$ $=10.3 \mathrm{~Hz}, 1 \mathrm{H}), 1.20(\mathrm{~s}, 3 \mathrm{H}), 0.86(\mathrm{~s}, 3 \mathrm{H})$.

${ }^{13}$ C NMR: $\left(126 \mathrm{MHz}, \mathrm{CD}_{3} \mathrm{CN}, 25^{\circ} \mathrm{C}, \delta\right)$ :

173.9, 169.0, 166.9, 166.0, 145.2, 130.9, 127.7, 119.5, 75.6, 69.4, 68.2, 58.3, 57.7, 52.8, 52.6, 42.2, 41.3, 40.0, 39.2, $38.8,35.6,33.8,30.7,28.4,28.0,25.7,24.5,24.3$.

HRMS (ESI-TOF, m/z):

Calc'd for $\mathrm{C}_{30} \mathrm{H}_{44} \mathrm{~N}_{4} \mathrm{O}_{8} \mathrm{Na}^{+}\left([\mathrm{M}+\mathrm{Na}]^{+}\right)$611.3051; found 611.3060. 


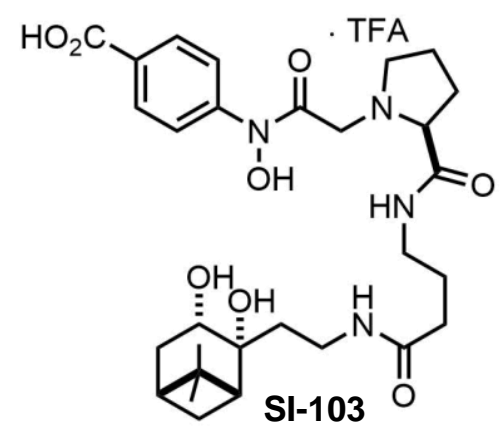

\section{Procedure:}

To a stirred suspension of methyl ester SI-102 $(72.2 \mathrm{mg}, 123 \mu \mathrm{mol})$ in $2 \mathrm{~mL} \mathrm{H}_{2} \mathrm{O}$ was charged $\mathrm{LiOH}\left(0.5 \mathrm{M}\right.$ in $\mathrm{H}_{2} \mathrm{O}$, $1.5 \mathrm{~mL}, 0.74 \mathrm{mmol}, 6 \mathrm{eq}$ ) (note: becomes a clear solution). After 25 minutes, the $\mathrm{pH}$ was adjusted to 5 with AcOH and the volume was reduced to $\sim 1 \mathrm{~mL}$ on the rotovap. This material was purified by preparative HPLC (method A, $5-80 \%$ ACN) to afford carboxylic acid SI-103 (26.1 mg, $37.9 \mu \mathrm{mol}, 31 \%$ yield) as a white solid.

${ }^{1}$ H NMR: $\left(500 \mathrm{MHz}, \mathrm{CD}_{3} \mathrm{CN}, 25^{\circ} \mathrm{C}, \delta\right)$ :

7.97 (m, 2H), 7.78 (m, 2H), 7.49 (br s, 1H), $7.03(\mathrm{br} \mathrm{s}, 1 \mathrm{H}), 4.64(\mathrm{~d}, J=16.6 \mathrm{~Hz}, 1 \mathrm{H}), 4.58(\mathrm{~d}, J=16.6 \mathrm{~Hz}, 1 \mathrm{H})$, 4.33, $3.94(\mathrm{dd}, J=8.9,4.9 \mathrm{~Hz}, 1 \mathrm{H}), 3.87(\mathrm{~m}, 1 \mathrm{H}), 3.28(\mathrm{~m}, 4 \mathrm{H}), 3.13(\mathrm{~m}, 1 \mathrm{H}), 2.46(\mathrm{~m}, 1 \mathrm{H}), 2.36(\mathrm{~m}, 1 \mathrm{H}), 2.09(\mathrm{~m}$, $6 \mathrm{H}), 1.73(\mathrm{~m}, 4 \mathrm{H}), 1.53(\mathrm{~m}, 2 \mathrm{H}), 1.29(\mathrm{~m}, 1 \mathrm{H}), 1.18(\mathrm{~s}, 3 \mathrm{H}), 0.84(\mathrm{~s}, 3 \mathrm{H})$.

${ }^{13} \mathrm{C}$ NMR: $\left(125, \mathrm{MHz} \mathrm{CD}_{3} \mathrm{CN}, 25^{\circ} \mathrm{C}, \delta\right)$ :

174.4, 169.1, 167.7, 165.9, 145.1, 131.3, 127.8, 119.5, 75.7, 69.4, 68.2, 58.3, 57.7, 52.7, 42.1, 41.3, 40.0, 39.2, 38.7, $35.8,35.8,33.7,30.8,30.7,28.4,28.0,25.7,24.5,24.3$.

HRMS (ESI-TOF, m/z):

Calc'd for $\mathrm{C}_{29} \mathrm{H}_{43} \mathrm{~N}_{4} \mathrm{O}_{8}{ }^{+}\left([\mathrm{M}+\mathrm{H}]^{+}\right)$575.3075; found 575.3097.

Calc'd for $\mathrm{C}_{29} \mathrm{H}_{42} \mathrm{~N}_{4} \mathrm{O}_{8} \mathrm{Na}^{+}\left([\mathrm{M}+\mathrm{Na}]^{+}\right) 597.2895$ found 597.2899. 


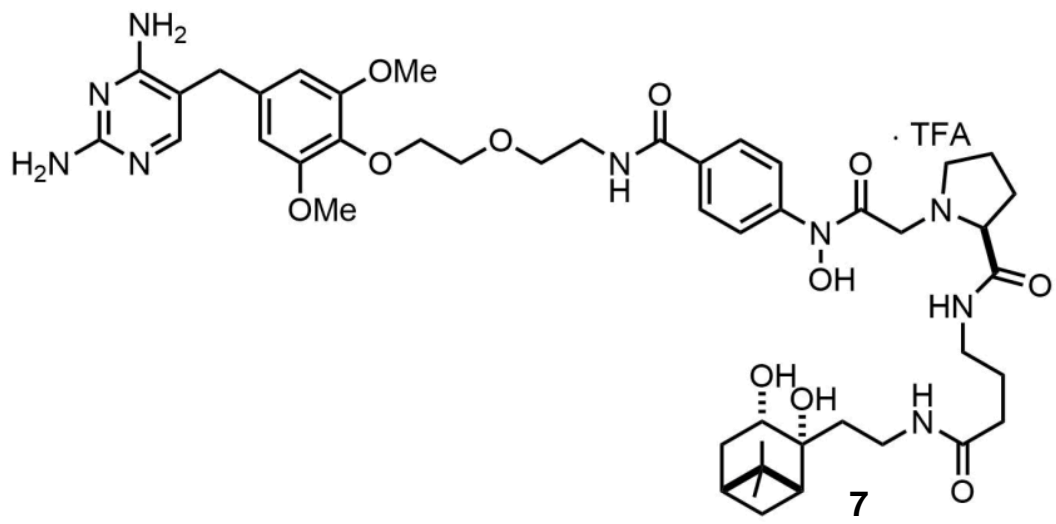

\section{Procedure:}

To a stirred solution of carboxylic acid SI-103 (20.3 mg, $29.5 \mu \mathrm{mol}$ ), TMP-amine ${ }^{1}$ (17.2 mg, $\left.36.0 \mu \mathrm{mol}, 1.2 \mathrm{eq}\right)$, DIPEA ( $25.7 \mu \mathrm{L}, 0.15 \mathrm{mmol}, 5 \mathrm{eq})$, and oxyma $(0.6 \mathrm{mg}, 4 \mu \mathrm{mol}, 0.15 \mathrm{eq})$ in $0.3 \mathrm{~mL}$ DMF was charged EDC $\cdot \mathrm{HCl}$ ( $8.5 \mathrm{mg}, 44.3 \mu \mathrm{mol}, 1.5 \mathrm{eq}$ ). The mixture was stirred for 8 hours and most of the DMF was removed on the rotovap. The crude residue was chromatographed on $1 \mathrm{~g}$ silica (EtOAc to 20\% v/v MeOH in EtOAc) to afford an oil. This material was purified by preparative HPLC (method A, 5 - 80\% ACN) to afford 7 (15.1 mg, $14.6 \mu \mathrm{mol}, 49 \%$ yield) as a white solid.

${ }^{1} \mathrm{H}$ NMR: $\left(500 \mathrm{MHz}, \mathrm{CD}_{3} \mathrm{CN}, 25^{\circ} \mathrm{C}, \delta\right)$ :

$7.74(\mathrm{~d}, J=8.6 \mathrm{~Hz}, 1 \mathrm{H}), 7.66(\mathrm{~d}, J=8.6 \mathrm{~Hz}, 1 \mathrm{H}), 7.46(\mathrm{~m}, 2 \mathrm{H}), 7.30$ (s, 1H), 6.97 (br s, 1H), 6.82 (br s, 1H), 6.47 (s, 2H), $6.34(\mathrm{br} \mathrm{s}, 1 \mathrm{H}), 4.64$ (d, $J=17.0 \mathrm{~Hz}, 1 \mathrm{H}), 4.57(\mathrm{~d}, J=17.0 \mathrm{~Hz}, 1 \mathrm{H}), 4.33(\mathrm{~m}, 1 \mathrm{H}), 4.01(\mathrm{t}, J=4.3 \mathrm{~Hz}, 1 \mathrm{H}), 3.94$ (m, 1H), $3.87(\mathrm{~m}, 1 \mathrm{H}), 3.70(\mathrm{~m}, 8 \mathrm{H}), 3.65(\mathrm{t}, J=4.9 \mathrm{~Hz}, 2 \mathrm{H}), 3.58(\mathrm{~s}, 2 \mathrm{H}), 3.52(\mathrm{~m}, 2 \mathrm{H}), 3.27(\mathrm{~m}, 3 \mathrm{H}), 3.13(\mathrm{~m}$, $1 \mathrm{H}), 2.47(\mathrm{~m}, 1 \mathrm{H}), 2.37(\mathrm{~m}, 1 \mathrm{H}), 2.16(\mathrm{~m}, 3 \mathrm{H}), 2.07(\mathrm{~m}, 2 \mathrm{H}), 2.01(\mathrm{~m}, 1 \mathrm{H}), 1.74(\mathrm{~m}, 5 \mathrm{H}), 1.54(\mathrm{~m}, 2 \mathrm{H}), 1.30(\mathrm{~d}, J=$ $10.3 \mathrm{~Hz}, 1 \mathrm{H}), 1.19$ (s, 3H), 0.85 (s, 3H).

${ }^{13} \mathrm{C}$ NMR: $\left(126 \mathrm{MHz}, \mathrm{CD}_{3} \mathrm{CN}, 25^{\circ} \mathrm{C}, \delta\right)$ :

169.1, 167.6, 165.7, 165.6, 156.2, 154.4, 143.7, 141.3, 136.5, 133.3, 129.8, 129.1, 128.6, 119.7, 109.8, 106.9, 75.7, 72.9, 71.0, 70.0, 69.5, 68.2, 58.3, 57.7, 56.6, 52.7, 42.1, 41.3, 40.6, 40.0, 39.2, 38.7, 35.8, 33.7, 33.7, 30.7, 28.4, $28.0,25.7,24.5,24.3$.

\section{HRMS (ESI-TOF, m/z):}

Calc'd for $\mathrm{C}_{46} \mathrm{H}_{66} \mathrm{~N}_{9} \mathrm{O}_{11}{ }^{+}\left([\mathrm{M}+\mathrm{H}]^{+}\right)$920.4879; found 920.4895 .

Calc'd for $\mathrm{C}_{46} \mathrm{H}_{65} \mathrm{~N}_{9} \mathrm{O}_{11} \mathrm{Na}^{+}\left([\mathrm{M}+\mathrm{Na}]^{+}\right)$942.4696; found 942.4710 . 


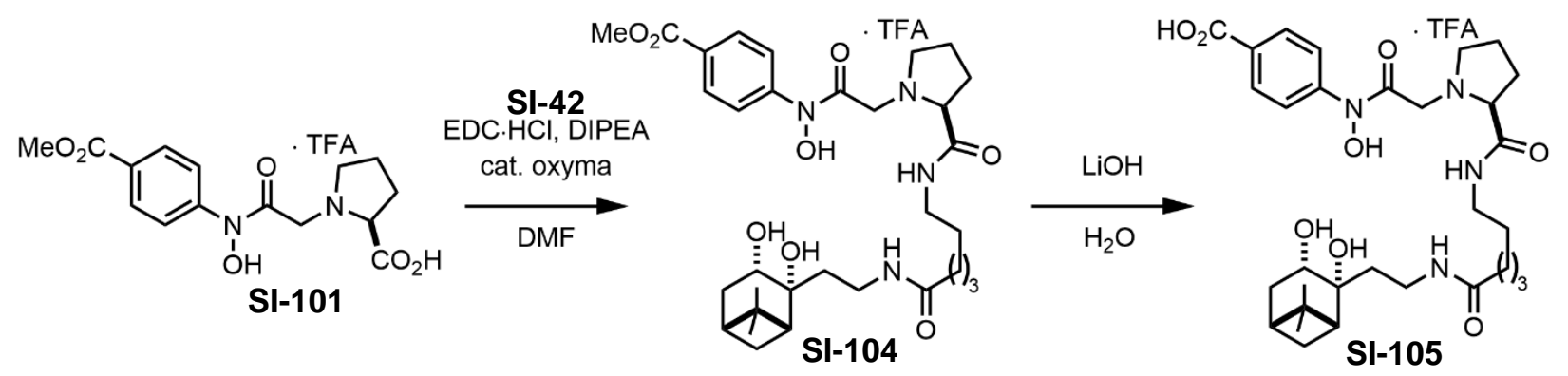

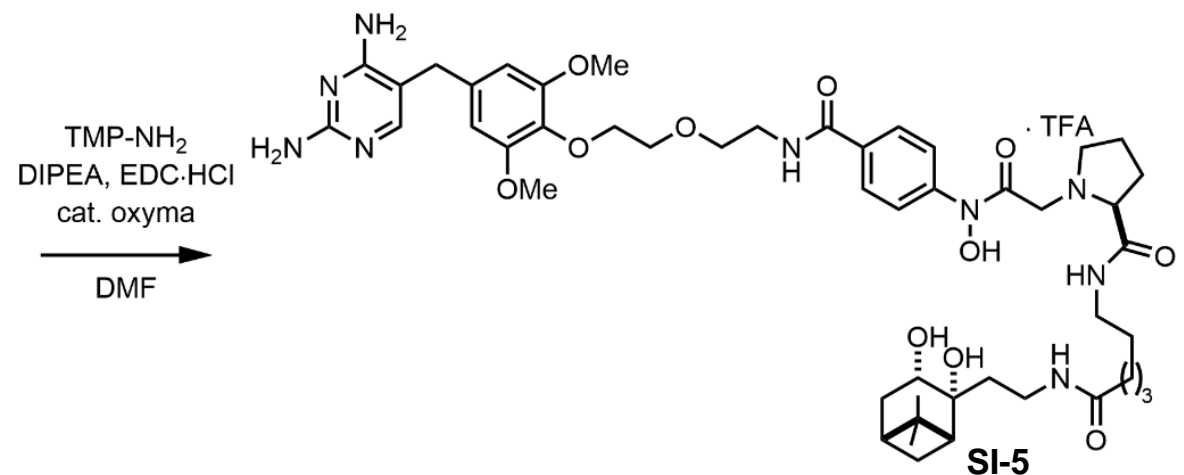




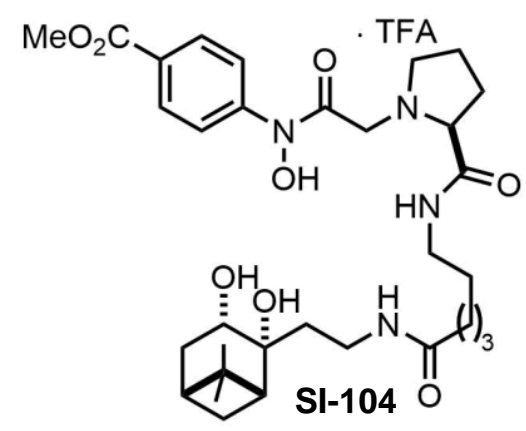

\section{Procedure:}

A to a stirred solution of carboxylic acid SI-101 $(82.5 \mathrm{mg}, 0.189 \mathrm{mmol}), \mathbf{S I}-\mathbf{4 2}(59.2 \mathrm{mg}, 0.189 \mathrm{mmol}, 1.0 \mathrm{eq})$, DIPEA ( $72.4 \mu \mathrm{L}, 0.42 \mathrm{mmol}, 2.2 \mathrm{eq})$, and oxyma $(5.4 \mathrm{mg}, 38 \mu \mathrm{mol}, 0.2 \mathrm{eq})$ in $1 \mathrm{~mL}$ DMF was charged EDC $\cdot \mathrm{HCl}$ (51 mg, $0.27 \mathrm{mmol}, 1.4 \mathrm{eq}$ ). The mixture was stirred for 30 hours and most of the DMF was removed on the rotovap. The crude residue was chromatographed on $3 \mathrm{~g}$ silica (EtOAc to 15\% v/v MeOH in EtOAc) to afford an oil. This material was purified by preparative HPLC (method B, 0 - 70\% ACN) to afford SI-104 (23.2 mg, $31.7 \mu \mathrm{mol}$, $17 \%$ yield) as a pinkish foam.

${ }^{1} \mathbf{H}$ NMR: $\left(500 \mathrm{MHz}, \mathrm{CD}_{3} \mathrm{CN}, 25^{\circ} \mathrm{C}, \delta\right)$ :

$7.98(\mathrm{~d}, J=8.0 \mathrm{~Hz}, 2 \mathrm{H}), 7.80(\mathrm{~d}, J=8.0 \mathrm{~Hz}, 2 \mathrm{H}), 7.29$ (br s, 1H), 6.99 (br s, $1 \mathrm{H}), 4.56(\mathrm{~d}, J=17.0 \mathrm{~Hz}, 1 \mathrm{H}), 4.52(\mathrm{~d}$, $J=17.0 \mathrm{~Hz}, 1 \mathrm{H}), 4.30(\mathrm{~m}, 1 \mathrm{H}), 3.82(\mathrm{~s}, 3 \mathrm{H}), 3.25(\mathrm{~m}, 3 \mathrm{H}), 3.15(\mathrm{~m}, 1 \mathrm{H}), 2.45(\mathrm{~m}, 1 \mathrm{H}), 2.36(\mathrm{~m}, 1 \mathrm{H}), 2.02(\mathrm{~m}, 7 \mathrm{H})$, $1.75(\mathrm{~m}, 1 \mathrm{H}), 1.49(\mathrm{~m}, 5 \mathrm{H}), 1.26(\mathrm{~m}, 3 \mathrm{H}), 1.18(\mathrm{~s}, 3 \mathrm{H}), 0.85(\mathrm{~s}, 3 \mathrm{H})$.

${ }^{13}$ C NMR: $\left(126 \mathrm{MHz}, \mathrm{CD}_{3} \mathrm{CN}, 25^{\circ} \mathrm{C}, \delta\right)$ :

170.6, 168.5, 166.9, 165.8, 145.1, 130.9, 127.7, 119.5, 75.4, 69.4, 68.0, 58.1, 57.5, 52.6, 42.0, 41.3, 40.1, 39.3, 38.8, $36.5,36.4,35.8,30.6,29.1,28.4,28.0,26.6,25.7,24.4,23.3$.

HRMS (ESI-TOF, m/z):

Calc'd for $\mathrm{C}_{32} \mathrm{H}_{49} \mathrm{~N}_{4} \mathrm{O}_{8}{ }^{+}\left([\mathrm{M}+\mathrm{H}]^{+}\right)$617.3545; found 617.3566.

Calc'd for $\mathrm{C}_{32} \mathrm{H}_{48} \mathrm{~N}_{4} \mathrm{O}_{8} \mathrm{Na}^{+}\left([\mathrm{M}+\mathrm{Na}]^{+}\right)$639.3364; found 639.3388 . 


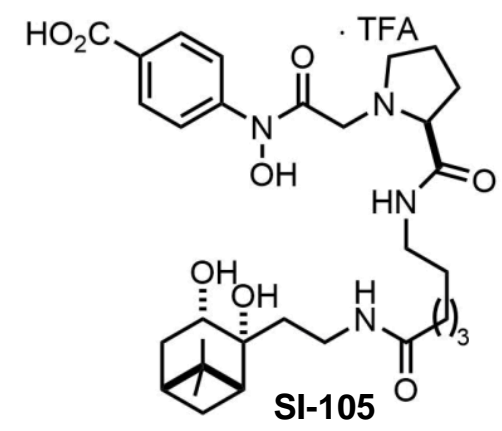

\section{Procedure:}

To a stirred suspension of methyl ester SI-104 $(23.2 \mathrm{mg}, 31.7 \mu \mathrm{mol})$ in $0.27 \mathrm{~mL} \mathrm{H}_{2} \mathrm{O}$ was charged $\mathrm{LiOH}(0.5 \mathrm{M}$ in $\mathrm{H}_{2} \mathrm{O}, 0.51 \mathrm{~mL}, 0.25 \mathrm{mmol}, 8 \mathrm{eq}$ ) (note: becomes a clear solution). After 60 minutes, the $\mathrm{pH}$ was adjusted to 4 with citric acid and the volume was reduced to $\sim 0.5 \mathrm{~mL}$ on the rotovap. This material was purified by preparative HPLC (method A, 0 - 70\% ACN) to afford carboxylic acid SI-105 (16.9 mg, $23.6 \mu \mathrm{mol}, 74 \%$ yield) as a white solid.

${ }^{1} \mathrm{H}$ NMR: $\left(500 \mathrm{MHz}, \mathrm{CD}_{3} \mathrm{CN}, 25^{\circ} \mathrm{C}, \delta\right)$ :

7.99 (d, $J=8.3 \mathrm{~Hz}, 2 \mathrm{H}), 7.80$ (d, $J=8.3 \mathrm{~Hz}, 2 \mathrm{H}), 7.39$ (br s, 1H), $6.92(\mathrm{br} \mathrm{s}, 1 \mathrm{H}), 4.62(\mathrm{~d}, J=17.5 \mathrm{~Hz}, 1 \mathrm{H}), 4.57$ (d, $J=17.5 \mathrm{~Hz}, 1 \mathrm{H}), 4.34(\mathrm{~m}, 1 \mathrm{H}), 3.95(\mathrm{br} \mathrm{s}, 1 \mathrm{H}), 3.88(\mathrm{~m}, 1 \mathrm{H}), 3.29(\mathrm{~m}, 1 \mathrm{H}), 3.15(\mathrm{~m}, 1 \mathrm{H}), 2.47(\mathrm{~m}, 1 \mathrm{H}), 2.38(\mathrm{t}, J=$ $10.9 \mathrm{~Hz}, 1 \mathrm{H}), 2.04(\mathrm{~m}, 7 \mathrm{H}), 1.82(\mathrm{~m}, 1 \mathrm{H}), 1.71(\mathrm{~m}, 1 \mathrm{H}), 1.50(\mathrm{~m}, 5 \mathrm{H}), 1.28(\mathrm{~m}, 3 \mathrm{H}), 1.20(\mathrm{~s}, 3 \mathrm{H}), 0.86(\mathrm{~s}, 3 \mathrm{H})$.

${ }^{13}$ C NMR: $\left(125, \mathrm{MHz} \mathrm{CD} 3 \mathrm{CN}, 25^{\circ} \mathrm{C}, \delta\right)$ :

175.0, 168.7, 167.6, 165.9, 145.2, 131.3, 127.9, 119.5, 75.6, 69.4, 68.1, 58.2, 57.6, 52.7, 42.2, 41.3, 40.2, 39.3, 38.8, $36.6,35.7,30.7,29.2,28.4,28.1,26.6,25.8,24.4,24.3$.

HRMS (ESI-TOF, m/z):

Calc'd for $\mathrm{C}_{31} \mathrm{H}_{47} \mathrm{~N}_{4} \mathrm{O}_{8}{ }^{+}\left([\mathrm{M}+\mathrm{H}]^{+}\right)$603.3388; found 603.3406.

Calc'd for $\mathrm{C}_{31} \mathrm{H}_{46} \mathrm{~N}_{4} \mathrm{O}_{8} \mathrm{Na}^{+}\left([\mathrm{M}+\mathrm{Na}]^{+}\right)$625.3208; found 625.3227. 
<smiles>COc1cc(Cc2cnc(N)nc2N)cc(OC)c1OCCOCCNC(=O)c1ccc(N(O)C(=O)CN2CCCC2C(=O)NCC2CCCC2C(F)(F)F)cc1</smiles>

\section{Procedure:}

A to a stirred solution of carboxylic acid SI-105 $(16.9 \mathrm{mg}, 23.6 \mu \mathrm{mol})$, TMP-amine ${ }^{1}(14.7 \mathrm{mg}, 30.7 \mu \mathrm{mol}, 1.3 \mathrm{eq})$, DIPEA ( $16.4 \mu \mathrm{L}, 0.094 \mathrm{mmol}, 4 \mathrm{eq})$, and oxyma ( $1 \mathrm{mg}, 7 \mu \mathrm{mol}, 0.3 \mathrm{eq})$ in $0.24 \mathrm{~mL}$ DMF was charged EDC $\cdot \mathrm{HCl}$ (6.1 mg, $31.9 \mu \mathrm{mol}, 1.35 \mathrm{eq}$ ). The mixture was stirred for 8 hours and most of the DMF was removed on the rotovap. The crude residue was chromatographed on $1 \mathrm{~g}$ silica (EtOAc to $20 \% \mathrm{v} / \mathrm{v} \mathrm{MeOH}$ in EtOAc) to afford an oil. This material was purified by preparative HPLC (method A, 0 - 70\% ACN) to afford SI-5 (12.1 mg, $11.4 \mu \mathrm{mol}$, $48 \%$ yield) as a white solid.

${ }^{1} \mathbf{H}$ NMR: $\left(500 \mathrm{MHz}, \mathrm{CD}_{3} \mathrm{CN}, 25^{\circ} \mathrm{C}, \delta\right)$ :

$7.76(\mathrm{~d}, J=8.0 \mathrm{~Hz}, 2 \mathrm{H}), 7.68(\mathrm{~d}, J=8.0 \mathrm{~Hz}, 2 \mathrm{H}), 7.48(\mathrm{br} \mathrm{s}, 1 \mathrm{H}), 7.45(\mathrm{br} \mathrm{s}, 1 \mathrm{H}), 7.33(\mathrm{~s}, 1 \mathrm{H}), 6.86$ (br s, $1 \mathrm{H}), 6.83$ (br s, 1H), 6.47 (s, 2H), 6.34 (br s, 1H), 4.64 (d, $J=17.2 \mathrm{~Hz}, 2 \mathrm{H}), 4.57$ (d, $J=8.0 \mathrm{~Hz}, 2 \mathrm{H}), 4.34$ (m, 1H), 4.01 (m, 2H), $3.87(\mathrm{~m}, 1 \mathrm{H}), 3.71(\mathrm{~m}, 8 \mathrm{H}), 3.65(\mathrm{t}, J=5.2 \mathrm{~Hz}, 2 \mathrm{H}), 3.59(\mathrm{~s}, 2 \mathrm{H}), 3.52(\mathrm{~m}, 2 \mathrm{H}), 3.28(\mathrm{~m}, 3 \mathrm{H}), 3.12(\mathrm{~m}, 1 \mathrm{H})$, $2.48(\mathrm{~m}, 1 \mathrm{H}), 2.38(\mathrm{~m}, 1 \mathrm{H}), 2.07(\mathrm{~m}, 6 \mathrm{H}), 1.81(\mathrm{~m}, 1 \mathrm{H}), 1.70(\mathrm{~m}, 1 \mathrm{H}), 1.50(\mathrm{~m}, 5 \mathrm{H}), 1.29(\mathrm{~m}, 3 \mathrm{H}), 1.20(\mathrm{~s}, 3 \mathrm{H}), 0.86$ (s, 3H).

${ }^{13}$ C NMR: $\left(126 \mathrm{MHz}, \mathrm{CD}_{3} \mathrm{CN}, 25^{\circ} \mathrm{C}, \delta\right)$ :

168.8, 167.5, 165.6, 165.6, 161.4, 156.3, 154.3, 143.7, 141.4, 136.5, 133.3, 132.1, 128.6, 119.5, 109.7, 106.8, 75.5, 72.9, 70.9, 69.9, 69.4, 68.1, 58.2, 57.5, 56.6, 52.7, 42.2, 41.3, 40.5, 40.2, 39.2, 38.8, 36.6, 35.6, 33.7, 30.7, 29.2, $28.3,28.0,26.6,25.7,24.4,24.3$.

HRMS (ESI-TOF, m/z):

Calc'd for $\mathrm{C}_{48} \mathrm{H}_{70} \mathrm{~N}_{9} \mathrm{O}_{11}{ }^{+}\left([\mathrm{M}+\mathrm{H}]^{+}\right)$948.5189; found 948.5164.

Calc'd for $\mathrm{C}_{48} \mathrm{H}_{69} \mathrm{~N}_{9} \mathrm{O}_{11} \mathrm{Na}^{+}\left([\mathrm{M}+\mathrm{Na}]^{+}\right)$970.5009; found 970.4983 . 

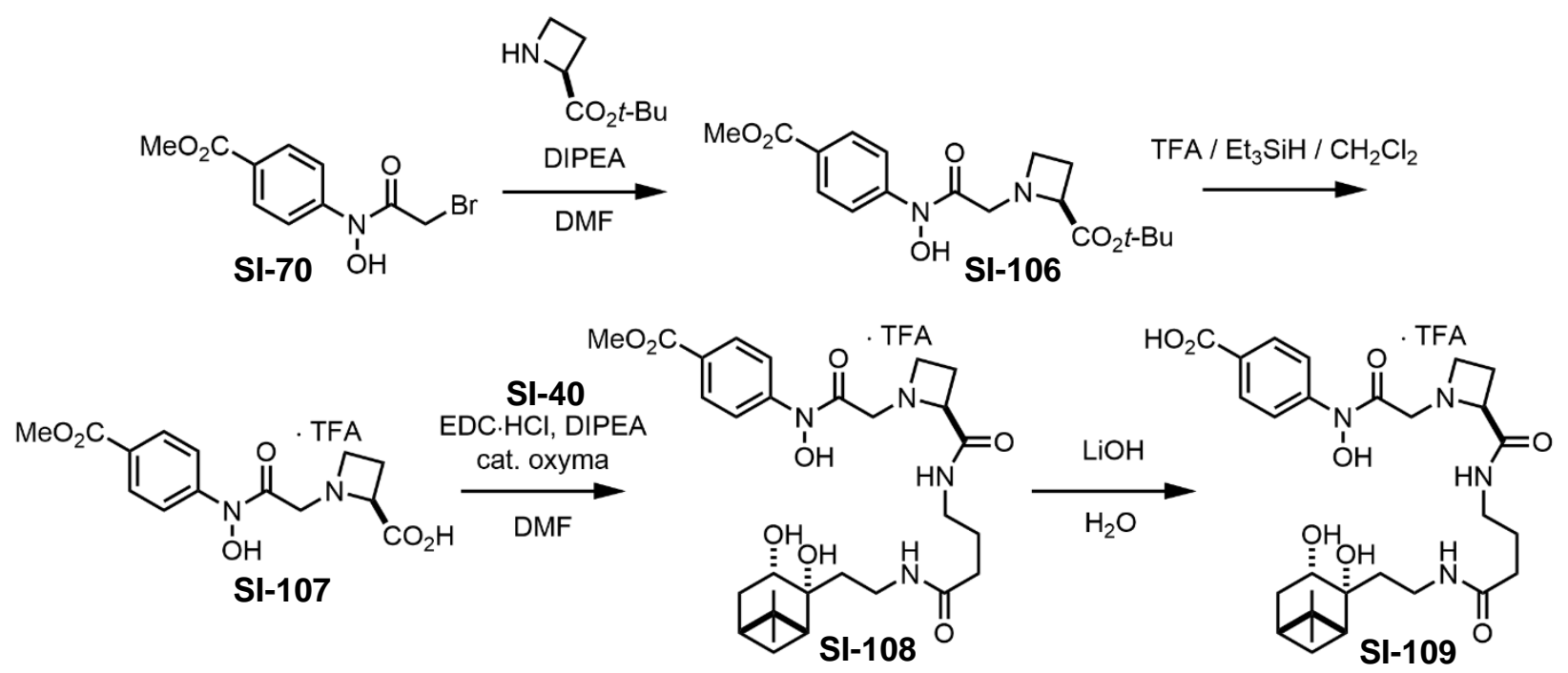

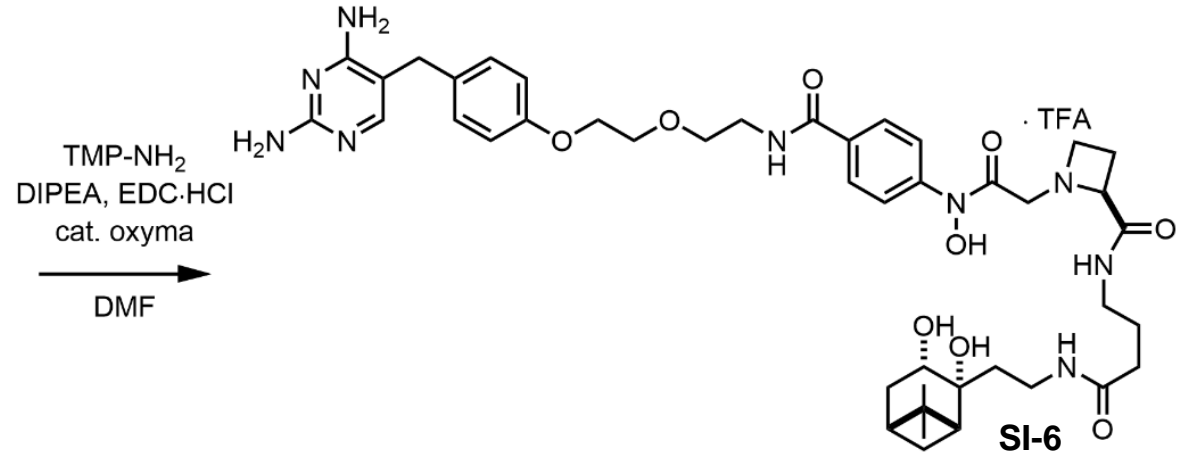




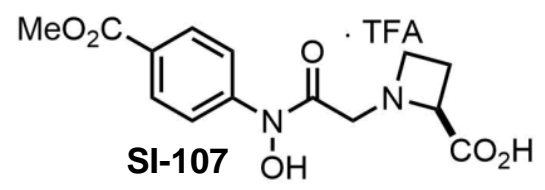

\section{Procedure:}

To a stirred solution of SI-70 (37 mg, $0.13 \mathrm{mmol})$ in $0.5 \mathrm{~mL}$ DMF was charged $(S)$ - $t$-butyl azetidine 2-carboxylic acid (25 mg, $0.16 \mathrm{mmol}, 1.25 \mathrm{eq})$ and DIPEA (34 $\mu \mathrm{L}, 0.20 \mathrm{mmol}, 1.5 \mathrm{eq})$. After 15 hours, most of the DMF was removed on the rotovap. The residue was extracted with $4 \mathrm{~mL}$ MTBE and $1 \mathrm{~mL}$ brine (note: the intermediate SI-106 is water soluble). The aqueous $\mathrm{pH}$ was adjusted from 5 to 7 using trisodium citrate. The aqueous material was backextracted with $3 \times 1 \mathrm{~mL}$ MTBE. The pooled organic material was washed with $0.25 \mathrm{~mL}$ brine, $\operatorname{dried}\left(\mathrm{Na}_{2} \mathrm{SO}_{4}\right)$, filtered, and concentrated on the rotovap. The crude intermediate was adsorbed onto $0.3 \mathrm{~g}$ silica and chromatographed on $10 \mathrm{~g}$ silica (50 to $60 \% \mathrm{v} / \mathrm{v}$ EtOAc : hexane) to afford SI-106 (31.2 mg).

SI-106 (31.2 mg) was dissolved in $0.3 \mathrm{~mL} 50: 50: 1 \mathrm{v} / \mathrm{v} \mathrm{CH}_{2} \mathrm{Cl}_{2}$ : TFA : $\mathrm{Et}_{3} \mathrm{SiH}$ and heated in a $40-50{ }^{\circ} \mathrm{C}$ bath for 5.5 hours. The reaction mixture was concentrated on the rotovap and the residue was co-evaporated with toluene, dissolved in $1: 1 \mathrm{v} / \mathrm{v} \mathrm{H}_{2} \mathrm{O}: \mathrm{ACN}$, and lyophilized to afford SI-107 (34.8 mg, $0.082 \mathrm{mmol}, 51 \%$ yield over 2 steps) as a foam.

${ }^{1}$ H NMR: $\left(500 \mathrm{MHz}, \mathrm{CD}_{3} \mathrm{CN}, 25^{\circ} \mathrm{C}, \delta\right)$ :

$7.93(\mathrm{~m}, 2 \mathrm{H}), 7.77(\mathrm{~m}, 2 \mathrm{H}), 6.95(\mathrm{br} \mathrm{s}, 1 \mathrm{H}), 4.96(\mathrm{~m}, 1 \mathrm{H}), 4.67(\mathrm{~d}, J=16.6 \mathrm{~Hz}, 1 \mathrm{H}), 4.60(\mathrm{~d}, J=16.6 \mathrm{~Hz}, 1 \mathrm{H}), 4.31$ (m, 1H), $4.04(\mathrm{~m}, 1 \mathrm{H}), 3.80(\mathrm{~m}, 3 \mathrm{H}), 2.75(\mathrm{~m}, 1 \mathrm{H}), 2.58(\mathrm{~m}, 1 \mathrm{H})$.

${ }^{13}$ C NMR: $\left(126 \mathrm{MHz}, \mathrm{CD}_{3} \mathrm{CN}, 25{ }^{\circ} \mathrm{C}, \delta\right)$ :

$170.6,166.9,165.8,145.1,130.8,127.4,119.4,66.5,56.8,53.6,52.5,25.6,22.0$

HRMS (ESI-TOF, m/z):

Calc'd for $\mathrm{C}_{14} \mathrm{H}_{17} \mathrm{~N}_{2} \mathrm{O}_{6}{ }^{+}\left([\mathrm{M}+\mathrm{H}]^{+}\right)$309.1081; found 309.1083.

Calc'd for $\mathrm{C}_{14} \mathrm{H}_{16} \mathrm{~N}_{2} \mathrm{O}_{6} \mathrm{Na}^{+}\left([\mathrm{M}+\mathrm{Na}]^{+}\right)$331.0901; found 331.0903. 


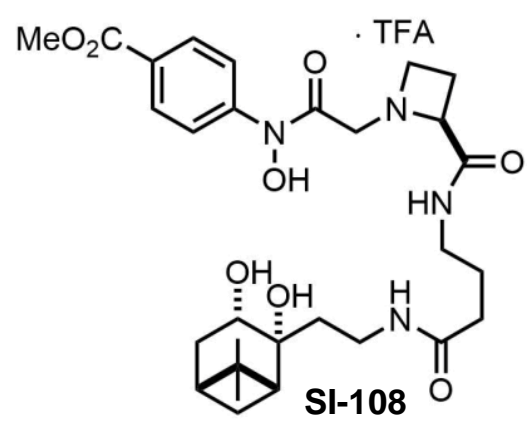

\section{Procedure:}

To a stirred solution of carboxylic acid SI-107 (54.3 mg, $129 \mu \mathrm{mol}$ ), amine SI-40 (48.3 mg, $170 \mu \mathrm{mol}, 1.32 \mathrm{eq}$ ), DIPEA (47 $\mu \mathrm{L}, 0.27 \mathrm{mmol}, 2.1 \mathrm{eq})$, and oxyma ( $4 \mathrm{mg}, 30 \mu \mathrm{mol}, 0.2 \mathrm{eq})$ in $1 \mathrm{~mL}$ DMF was charged EDC. HCl (35 $\mathrm{mg}, 0.18 \mathrm{~mol}, 1.4 \mathrm{eq}$ ). The mixture was stirred for 20 hours and most of the DMF was removed on the rotovap. The crude residue was chromatographed on $4 \mathrm{~g}$ silica (EtOAc to $15 \% \mathrm{v} / \mathrm{v} \mathrm{MeOH}$ in EtOAc) to afford an oil. This material was purified by preparative HPLC (method A, 0 - 70\% ACN) to afford SI-108 (21.9 mg, $31.8 \mu \mathrm{mol}, 25 \%$ yield) as a pale yellow solid.

${ }^{1}$ H NMR: $\left(500 \mathrm{MHz}, \mathrm{CD}_{3} \mathrm{CN}, 25^{\circ} \mathrm{C}, \delta\right)$ :

$7.96(\mathrm{~d}, J=8.3 \mathrm{~Hz}, 1 \mathrm{H}), 7.80(\mathrm{~d}, J=8.3 \mathrm{~Hz}, 1 \mathrm{H}), 7.61(\mathrm{br} \mathrm{s}, 1 \mathrm{H}), 6.96(\mathrm{br} \mathrm{s}, 1 \mathrm{H}), 4.99$ (t, $J=8.0 \mathrm{~Hz}, 1 \mathrm{H}), 4.78(\mathrm{~d}, J$ $=16.6 \mathrm{~Hz}, 1 \mathrm{H}), 4.61(\mathrm{~d}, J=16.6 \mathrm{~Hz}, 1 \mathrm{H}), 4.34(\mathrm{~m}, 1 \mathrm{H}), 4.14(\mathrm{~m}, 1 \mathrm{H}), 3.95(\mathrm{~m}, 1 \mathrm{H}), 3.84(\mathrm{~s}, 3 \mathrm{H}), 3.82(\mathrm{~m}, 1 \mathrm{H}), 3.19$ (m, 4H), $2.76(\mathrm{~m}, 1 \mathrm{H}), 2.52(\mathrm{~m}, 1 \mathrm{H}), 2.37(\mathrm{t}, J=11.2 \mathrm{~Hz}, 1 \mathrm{H}), 2.16(\mathrm{~m}, 2 \mathrm{H}), 2.09(\mathrm{~m}, 1 \mathrm{H}), 1.95(\mathrm{~m}, 1 \mathrm{H}), 1.81(\mathrm{~m}$, $1 \mathrm{H}), 1.73(\mathrm{~m}, 3 \mathrm{H}), 1.55(\mathrm{~m}, 2 \mathrm{H}), 1.32(\mathrm{~d}, J=11.2 \mathrm{~Hz}, 1 \mathrm{H}), 1.20(\mathrm{~s}, 3 \mathrm{H}), 0.86(\mathrm{~s}, 3 \mathrm{H})$.

${ }^{13} \mathrm{C}$ NMR: $\left(126 \mathrm{MHz}, \mathrm{CD}_{3} \mathrm{CN}, 25^{\circ} \mathrm{C}, \delta\right)$ :

173.9, 167.6, 167.0, 165.8, 145.2, 130.9, 127.4, 119.4, 75.6, 68.1, 67.7, 57.0, 53.8, 52.7, 52.6, 42.2, 41.3, 39.7, 39.2, $38.7,35.6,33.7,28.3,28.0,25.7,24.3,21.9$.

HRMS (ESI-TOF, m/z):

Calc'd for $\mathrm{C}_{29} \mathrm{H}_{43} \mathrm{~N}_{4} \mathrm{O}_{8}{ }^{+}\left([\mathrm{M}+\mathrm{H}]^{+}\right)$575.3075; found 575.3087.

Calc'd for $\mathrm{C}_{29} \mathrm{H}_{42} \mathrm{~N}_{4} \mathrm{O}_{8} \mathrm{Na}^{+}\left([\mathrm{M}+\mathrm{Na}]^{+}\right)$597.2895; found 597.2907. 


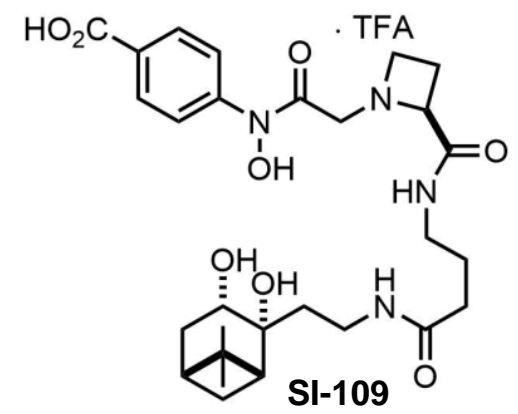

\section{Procedure:}

To a stirred suspension of methyl ester SI-108 $(21.9 \mathrm{mg}, 31.8 \mu \mathrm{mol})$ in $0.29 \mathrm{~mL} \mathrm{H}_{2} \mathrm{O}$ was charged $\mathrm{LiOH}(0.5 \mathrm{M}$ in $\mathrm{H}_{2} \mathrm{O}, 0.51 \mathrm{~mL}, 0.25 \mathrm{mmol}, 8 \mathrm{eq}$ ) (note: becomes a clear solution). After 45 minutes, the pH was adjusted to 4 with citric acid and the volume was reduced to $0.5 \mathrm{~mL}$ on the rotovap. This material was purified by preparative HPLC (method A, 0 - 70\% ACN) to afford carboxylic acid SI-109 (16.7 mg, $24.7 \mu \mathrm{mol}, 78 \%$ ).

${ }^{1}$ H NMR: $\left(500 \mathrm{MHz}, \mathrm{CD}_{3} \mathrm{CN}, 25^{\circ} \mathrm{C}, \delta\right)$ :

$7.96(\mathrm{~d}, J=8.6 \mathrm{~Hz}, 2 \mathrm{H}), 7.76(\mathrm{~d}, J=8.6 \mathrm{~Hz}, 2 \mathrm{H}), 7.47(\mathrm{br} \mathrm{s}, 1 \mathrm{H}), 6.97(\mathrm{br} \mathrm{s}, 1 \mathrm{H}), 4.96(\mathrm{t}, J=8.0 \mathrm{~Hz}, 2 \mathrm{H}), 4.73(\mathrm{~d}, J$ $=16.3 \mathrm{~Hz}, 2 \mathrm{H}), 4.58(\mathrm{~d}, J=16.3 \mathrm{~Hz}, 2 \mathrm{H}), 4.35(\mathrm{~m}, 1 \mathrm{H}), 4.14(\mathrm{~m}, 1 \mathrm{H}), 3.95(\mathrm{~m}, 1 \mathrm{H}), 2.77(\mathrm{~m}, 1 \mathrm{H}), 2.52(\mathrm{~m}, 1 \mathrm{H})$, $2.38(\mathrm{~m}, 1 \mathrm{H}), 2.17(\mathrm{~m}, 2 \mathrm{H}), 2.09(\mathrm{~m}, 1 \mathrm{H}), 1.95(\mathrm{~m}, 1 \mathrm{H}), 1.81(\mathrm{~m}, 1 \mathrm{H}), 1.73(\mathrm{~m}, 3 \mathrm{H}), 1.55(\mathrm{~m}, 2 \mathrm{H}), 1.32(\mathrm{~d}, J 9.7 \mathrm{~Hz}$, 1H), $1.20(\mathrm{~s}, 3 \mathrm{H}), 1.12(\mathrm{~s}, 1 \mathrm{H}), 0.86(\mathrm{~s}, 3 \mathrm{H})$.

${ }^{13} \mathrm{C}$ NMR: $\left(125, \mathrm{MHz} \mathrm{CD}_{3} \mathrm{CN}, 25^{\circ} \mathrm{C}, \delta\right)$ :

174.2, 167.6, 167.5, 165.6, 145.1, 131.2, 127.7, 119.4, 68.2, 67.7, 57.0, 53.9, 52.7, 42.1, 41.3, 39.7, 39.2, 38.7, 35.7, $33.7,28.4,28.0,27.1,25.7,24.3,22.0$.

HRMS (ESI-TOF, m/z):

Calc'd for $\mathrm{C}_{28} \mathrm{H}_{41} \mathrm{~N}_{4} \mathrm{O}_{8}{ }^{+}\left([\mathrm{M}+\mathrm{H}]^{+}\right)$561.2919; found 561.2930.

Calc'd for $\mathrm{C}_{28} \mathrm{H}_{40} \mathrm{~N}_{4} \mathrm{O}_{8} \mathrm{Na}^{+}\left([\mathrm{M}+\mathrm{Na}]^{+}\right)$583.2738; found 583.2753. 


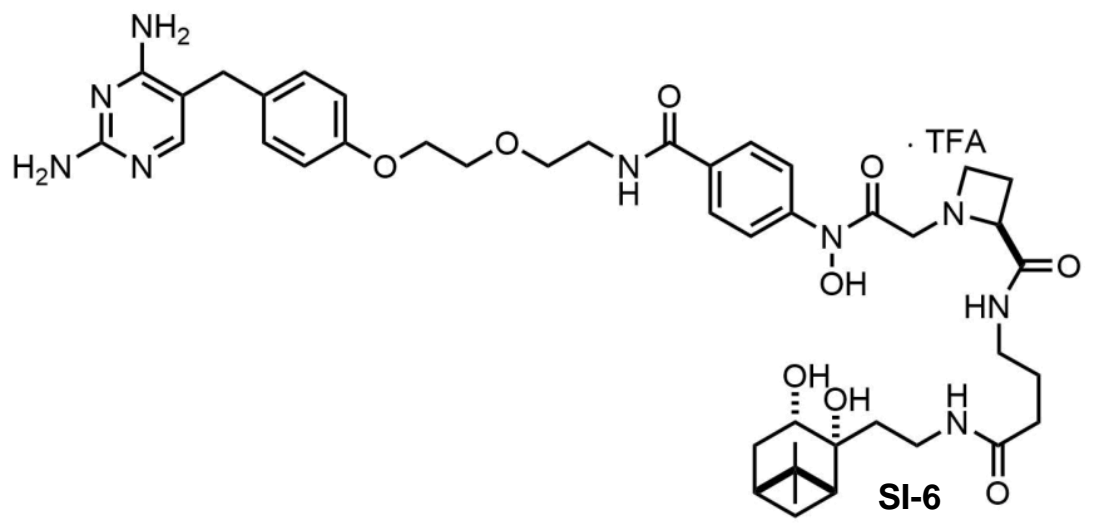

\section{Procedure:}

To a stirred solution of carboxylic acid SI-109 (16.7 mg, $24.7 \mu \mathrm{mol})$, TMP-amine ${ }^{1}$ (14.7 mg, $\left.30.9 \mu \mathrm{mol}, 1.25 \mathrm{eq}\right)$, DIPEA (13.3 $\mu \mathrm{L}, 0.077 \mathrm{mmol}, 3.1 \mathrm{eq})$, and oxyma $(0.9 \mathrm{mg}, 6 \mu \mathrm{mol}, 0.25 \mathrm{eq})$ in $0.25 \mathrm{~mL}$ DMF was charged $\mathrm{EDC} \cdot \mathrm{HCl}(6.6 \mathrm{mg}, 34.6 \mu \mathrm{mol}, 1.4 \mathrm{eq})$. The mixture was stirred for 22 hours and then most of the DMF was removed on the rotovap. The crude residue was chromatographed on $1 \mathrm{~g}$ silica (EtOAc to $30 \% \mathrm{v} / \mathrm{v} \mathrm{MeOH}$ in EtOAc) to afford an oil. This material was purified by preparative HPLC (method A, 0 - 70\% ACN) to afford SI-6 $(8.79 \mathrm{mg}, 8.62$ $\mu \mathrm{mol}, 35 \%$ yield) as a white solid.

${ }^{1} \mathrm{H}$ NMR: $\left(500 \mathrm{MHz}, \mathrm{CD}_{3} \mathrm{CN}, 25^{\circ} \mathrm{C}, \delta\right)$ : $7.73(\mathrm{~d}, J=8.3 \mathrm{~Hz}, 1 \mathrm{H}), 7.64(\mathrm{~d}, J=8.3 \mathrm{~Hz}, 1 \mathrm{H}), 7.50(\mathrm{br} \mathrm{s}, 1 \mathrm{H}), 7.45$ (br s, 1H), $7.33(\mathrm{~s}, 1 \mathrm{H}), 6.92$ (br s, $1 \mathrm{H}), 6.83$ (br s, 1H), $6.64(\mathrm{~m}, 1 \mathrm{H}), 6.47$ (s, 2H), 6.35 (br s, 1H), 4.95 (t, $J=7.4 \mathrm{~Hz}, 1 \mathrm{H}), 4.73(\mathrm{~d}, J=17.0 \mathrm{~Hz}, 1 \mathrm{H}), 4.56(\mathrm{~d}, J=$ $17.0 \mathrm{~Hz}, 1 \mathrm{H}), 4.33(\mathrm{~m}, 1 \mathrm{H}), 4.13(\mathrm{~m}, 1 \mathrm{H}), 4.01(\mathrm{~m}, 2 \mathrm{H}), 3.95(\mathrm{~m}, 1 \mathrm{H}), 3.70(\mathrm{~m}, 6 \mathrm{H}), 3.65(\mathrm{t}, J=5.2 \mathrm{~Hz}, 2 \mathrm{H}), 3.59$ (s, 2H), $3.52(\mathrm{~m}, 2 \mathrm{H}), 3.24(\mathrm{~m}, 3 \mathrm{H}), 2.50(\mathrm{~m}, 1 \mathrm{H}), 2.37(\mathrm{t}, J=11.5 \mathrm{~Hz}, 1 \mathrm{H}), 2.15(\mathrm{~m}, 1 \mathrm{H}), 2.08(\mathrm{~m}, 1 \mathrm{H}), 1.96(\mathrm{~m}$, $1 \mathrm{H}), 1.81(\mathrm{~m}, 1 \mathrm{H}), 1.73(\mathrm{~m}, 3 \mathrm{H}), 1.55(\mathrm{~m}, 2 \mathrm{H}), 1.31(\mathrm{~d}, J=9.7 \mathrm{~Hz}, 1 \mathrm{H}), 1.19(\mathrm{~s}, 3 \mathrm{H}), 0.85(\mathrm{~s}, 3 \mathrm{H})$.

${ }^{13} \mathrm{C}$ NMR: $\left(126 \mathrm{MHz}, \mathrm{CD}_{3} \mathrm{CN}, 25^{\circ} \mathrm{C}, \delta\right)$ :

173.9, 167.6, 165.6, 165.4, 156.3, 154.4, 143.7, 141.4, 136.5, 133.3, 132.1, 129.8, 128.6, 119.6, 109.7, 106.9, 75.6, 72.9, 71.0, 70.0, 68.2, 67.8. 57.0, 56.6, 53.8, 52.7, 50.0, 41.3, 40.6, 40.4, 39.7, 39.2, 38.8, 35.6, 33.7, 28.4, 28.0, $25.8,24.3,21.9$.

HRMS (ESI-TOF, m/z):

Calc'd for $\mathrm{C}_{45} \mathrm{H}_{64} \mathrm{~N}_{9} \mathrm{O}_{11}{ }^{+}\left([\mathrm{M}+\mathrm{H}]^{+}\right)$906.4720; found 906.4741 .

Calc'd for $\mathrm{C}_{45} \mathrm{H}_{63} \mathrm{~N}_{9} \mathrm{O}_{11} \mathrm{Na}^{+}\left([\mathrm{M}+\mathrm{Na}]^{+}\right)$928.4539; found 928.4568 . 


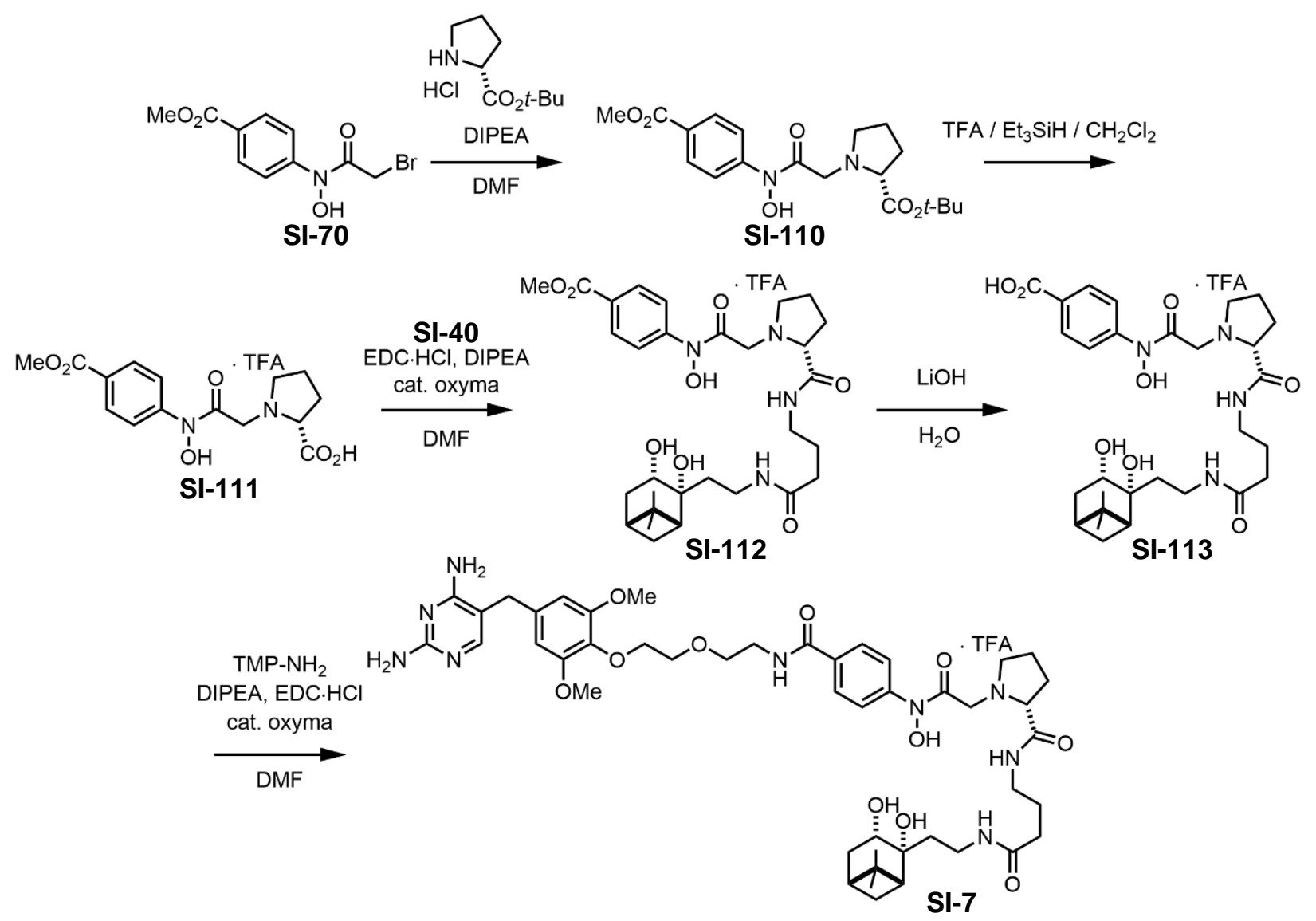




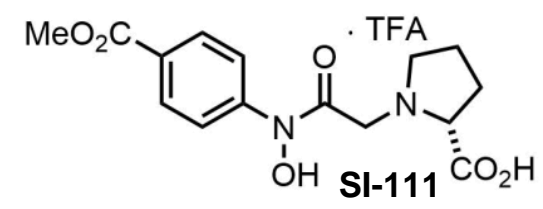

\section{Procedure:}

To a stirred solution of SI-70 ( $288 \mathrm{mg}, 1.0 \mathrm{mmol}$ ) in $4 \mathrm{~mL}$ DMF was charged D-proline $t$-butyl ester hydrochloride (374 mg, $1.8 \mathrm{mmol}, 1.8 \mathrm{eq}$ ) and DIPEA (597 $\mu \mathrm{L}, 3.2 \mathrm{mmol}, 3.2 \mathrm{eq}$ ). After 4 hours, most of the DMF was removed on the rotovap. The residue was extracted with $5 \mathrm{~mL}$ EtOAc and $1 \mathrm{~mL} \mathrm{H}_{2} \mathrm{O}$, and the aqueous material was backextracted with $1 \mathrm{~mL}$ EtOAc. The pooled organic material was washed with $1 \mathrm{~mL}$ brine, dried $\left(\mathrm{Na}_{2} \mathrm{SO}_{4}\right)$, filtered, and concentrated on the rotovap. The crude intermediate was adsorbed onto $1 \mathrm{~g}$ silica and chromatographed on $25 \mathrm{~g}$ silica (45 to $55 \%$ v/v EtOAc : hexane) to afford SI-110 (203 mg) as an oil which solidified on standing.

This material was dissolved in $5 \mathrm{~mL} 3 \mathrm{~mL} 50: 50: 1 \mathrm{v} / \mathrm{v} \mathrm{CH}_{2} \mathrm{Cl}_{2}$ : TFA : $\mathrm{Et}_{3} \mathrm{SiH}$ and heated in a $40-50{ }^{\circ} \mathrm{C}$ bath for 12 hours. The reaction mixture was concentrated on the rotovap and the residue was co-evaporated with toluene, dissolved in $1: 1 \mathrm{v} / \mathrm{v} t-\mathrm{BuOH}: \mathrm{H}_{2} \mathrm{O}$, and lyophilized to afford SI-111 $\left(242 \mathrm{mg}\right.$ ) as a foam (note: the ${ }^{1} \mathrm{H}$ NMR spectrum indicated 0.9 eq. residual $t$ - $\mathrm{BuOH}$; adjusted yield $0.48 \mathrm{mmol}, 48 \%$ yield over 2 steps).

${ }^{1}$ H NMR: $\left(500 \mathrm{MHz}, \mathrm{CD}_{3} \mathrm{CN}, 25^{\circ} \mathrm{C}, \delta\right)$ :

$7.97(\mathrm{~d}, J=8.0 \mathrm{~Hz}, 2 \mathrm{H}), 7.80(\mathrm{~d}, J=8.0 \mathrm{~Hz}, 2 \mathrm{H}), 4.66(\mathrm{~d}, J=14.9 \mathrm{~Hz}, 1 \mathrm{H}), 4.58(\mathrm{~d}, J=14.9 \mathrm{~Hz}, 1 \mathrm{H}) 4.40(\mathrm{~m}, 1 \mathrm{H})$, $3.88(\mathrm{~m}, 1 \mathrm{H}), 3.83(\mathrm{~s}, 3 \mathrm{H}), 3.32$, (m, 1H) $2.46(\mathrm{~m}, 1 \mathrm{H}), 2.15(\mathrm{~m}, 2 \mathrm{H}), 1.99(\mathrm{~m}, 1 \mathrm{H})$.

${ }^{13} \mathrm{C}$ NMR: $\left(126 \mathrm{MHz}, \mathrm{CD}_{3} \mathrm{CN}, 25^{\circ} \mathrm{C}, \delta\right)$ :

171.6, 167.0, 165.9, 145.1, 130.9, 127.7, 119.6, 69.1, 58.3, 57.6, 52.6, 29.2, 24.0.

\section{HRMS (ESI-TOF, m/z):}

Calc'd for $\mathrm{C}_{15} \mathrm{H}_{19} \mathrm{~N}_{2} \mathrm{O}_{6}{ }^{+}\left([\mathrm{M}+\mathrm{H}]^{+}\right)$323.1238; found 323.1240.

Calc'd for $\mathrm{C}_{15} \mathrm{H}_{18} \mathrm{~N}_{2} \mathrm{O}_{6} \mathrm{Na}^{+}\left([\mathrm{M}+\mathrm{Na}]^{+}\right)$345.1057; found 345.1056. 


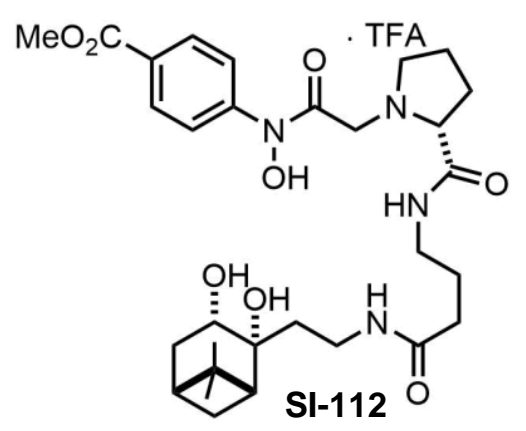

\section{Procedure:}

To a stirred solution of SI-111 (241.7 mg, $0.470 \mathrm{mmol}$ ), SI-40 (414 mg $1.00 \mathrm{mmol}, 2.13 \mathrm{eq})$, DIPEA (246 $\mu \mathrm{L}, 1.41$ mmol, $3 \mathrm{eq}$ ), and oxyma (13.4 mg, $94 \mu \mathrm{mol}, 0.2 \mathrm{eq})$ in $10 \mathrm{~mL}$ DMF was charged $\mathrm{EDC} \cdot \mathrm{HCl}(135 \mathrm{mg}, 0.705 \mathrm{~mol}, 1.5$ eq). The mixture was stirred for 15 hours and most of the DMF was removed on the rotovap. The crude residue was chromatographed on $10 \mathrm{~g}$ silica (EtOAc to $15 \% \mathrm{v} / \mathrm{v} \mathrm{MeOH}$ in EtOAc) to afford a semisolid (206 $\mathrm{mg}$ ). This material was purified by preparative HPLC (method A, 0 - 70\% ACN, in two equal loads) to afford SI-112 (110 mg, 157 $\mu \mathrm{mol}, 33 \%$ yield) as a white solid.

${ }^{1} \mathbf{H}$ NMR: $\left(500 \mathrm{MHz}, \mathrm{CD}_{3} \mathrm{CN}, 25^{\circ} \mathrm{C}, \delta\right)$ :

$7.96(\mathrm{~d}, J=8.0 \mathrm{~Hz}, 1 \mathrm{H}), 7.80(\mathrm{~d}, J=8.0 \mathrm{~Hz}, 1 \mathrm{H}), 7.63(\mathrm{br} \mathrm{s}, 1 \mathrm{H}), 7.09(\mathrm{br} \mathrm{s}, 1 \mathrm{H}), 4.66(\mathrm{~d}, J=16.9 \mathrm{~Hz}, 1 \mathrm{H}), 4.61(\mathrm{~d}$, $J=16.9 \mathrm{~Hz}, 1 \mathrm{H}), 4.36(\mathrm{~m}, 1 \mathrm{H}), 3.91(\mathrm{~m}, 2 \mathrm{H}), 3.84(\mathrm{~s}, 3 \mathrm{H}), 3.28(\mathrm{~m}, 4 \mathrm{H}), 3.16(\mathrm{~m}, 1 \mathrm{H}), 2.47(\mathrm{~m}, 1 \mathrm{H}), 2.36(\mathrm{~m}, 1 \mathrm{H})$, $2.09(\mathrm{~m}, 6 \mathrm{H}), 1.73(\mathrm{~m}, 4 \mathrm{H}), 1.54(\mathrm{~m}, 2 \mathrm{H}), 1.30(\mathrm{~d}, J=9.2 \mathrm{~Hz}, 1 \mathrm{H}), 1.18(\mathrm{~s}, 3 \mathrm{H}), 0.84$ (s, 3H).

${ }^{13}$ C NMR: $\left(126 \mathrm{MHz}, \mathrm{CD}_{3} \mathrm{CN}, 25^{\circ} \mathrm{C}, \delta\right)$ :

174.3, 169.1, 167.0, 165.9, 145.1, 130.9, 127.6, 119.5, 75.5, 69.4, 68.1, 58.3, 57.7, 52.6, 52.6, 42.0, 41.3, 40.0, 39.2, $38.7,35.8,33.8,30.7,28.3,28.0,25.7,24.4,24.3$.

HRMS (ESI-TOF, m/z):

Calc'd for $\mathrm{C}_{30} \mathrm{H}_{45} \mathrm{~N}_{4} \mathrm{O}_{8}{ }^{+}\left([\mathrm{M}+\mathrm{H}]^{+}\right)$589.3232; found 589.3237.

Calc'd for $\mathrm{C}_{30} \mathrm{H}_{44} \mathrm{~N}_{4} \mathrm{O}_{8} \mathrm{Na}^{+}\left([\mathrm{M}+\mathrm{Na}]^{+}\right)$611.3051; found 611.3053. 


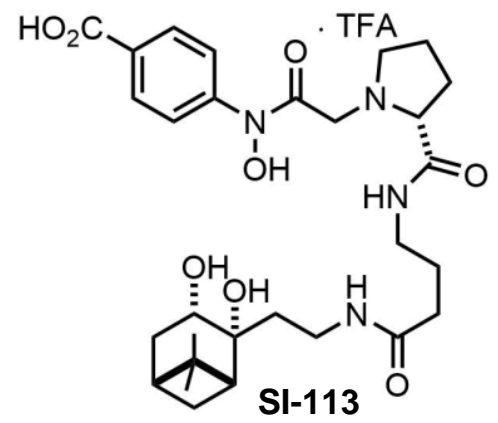

\section{Procedure:}

To a flask containing methyl ester SI-112 $(110 \mathrm{mg}, 157 \mu \mathrm{mol})$ was charged $\mathrm{LiOH}\left(0.5 \mathrm{M}\right.$ in $\mathrm{H}_{2} \mathrm{O}, 2.51 \mathrm{~mL}, 1.26$

mmol, $8 \mathrm{eq}$ ), and the mixture was stirred (note: becomes a clear solution). After 35 minutes, the $\mathrm{pH}$ was adjusted to 4 with $36 \mu \mathrm{L}$ TFA ( $0.47 \mathrm{mmol}, 3 \mathrm{eq}$ ) followed by citric acid (note: cloudy suspension). $0.5 \mathrm{~mL} \mathrm{MeOH}$ was charged (note: clear solution). This material was purified by preparative HPLC (method B, 5 - 70\% ACN) to afford carboxylic acid SI-113 (105.3 mg, $153 \mu \mathrm{mol}, 97 \%$ yield) as a white solid.

${ }^{1}$ H NMR: $\left(500 \mathrm{MHz}, \mathrm{CD}_{3} \mathrm{CN}, 25^{\circ} \mathrm{C}, \delta\right)$ :

$7.98(\mathrm{~d}, J=8.0 \mathrm{~Hz}, 1 \mathrm{H}), 7.78(\mathrm{~d}, J=8.0 \mathrm{~Hz}, 1 \mathrm{H}), 7.55(\mathrm{br} \mathrm{s}, 1 \mathrm{H}), 7.12(\mathrm{br} \mathrm{s}, 1 \mathrm{H}), 4.63(\mathrm{~d}, J=17.2 \mathrm{~Hz}, 2 \mathrm{H}), 4.58(\mathrm{~d}$, $J=17.2 \mathrm{~Hz}, 2 \mathrm{H}), 4.35(\mathrm{dd}, J=8.6,5.2 \mathrm{~Hz}, 1 \mathrm{H}), 3.94(\mathrm{dd}, J=9.5,4.9 \mathrm{~Hz}, 1 \mathrm{H}), 3.90(\mathrm{~m}, 1 \mathrm{H}), 3.29(\mathrm{~m}, 4 \mathrm{H}), 3.17(\mathrm{~m}$, 1H), $2.48(\mathrm{~m}, 1 \mathrm{H}), 2.37(\mathrm{~m}, 1 \mathrm{H}), 2.20(\mathrm{t}, J=7.2 \mathrm{~Hz}, 1 \mathrm{H}), 2.14(\mathrm{~m}, 1 \mathrm{H}), 2.08(\mathrm{~m}, 2 \mathrm{H}), 2.01(\mathrm{~m}, 1 \mathrm{H}), 1.95(\mathrm{t}, J=5.7$ $\mathrm{Hz}, 1 \mathrm{H}), 1.75(\mathrm{~m}, 4 \mathrm{H}), 1.55(\mathrm{~m}, 2 \mathrm{H}), 1.30(\mathrm{~d}, J=10.3 \mathrm{~Hz}, 1 \mathrm{H}), 1.19(\mathrm{~s}, 3 \mathrm{H}), 0.85(\mathrm{~s}, 3 \mathrm{H})$.

${ }^{13}$ C NMR: (125, $\left.\mathrm{MHz} \mathrm{CD} \mathrm{CN}_{3}, 25^{\circ} \mathrm{C}, \delta\right)$ :

174.6, 169.1, 167.6, 165.8, 145.0, 131.2, 127.9, 119.5, 75.6, 69.4, 68.1, 58.2, 57.7, 52.5, 41.9, 41.2, 40.0, 39.2, 38.7, $35.9,33.7,30.7,28.3,28.0,25.8,24.4,24.2$.

HRMS (ESI-TOF, m/z):

Calc'd for $\mathrm{C}_{29} \mathrm{H}_{43} \mathrm{~N}_{4} \mathrm{O}_{8}{ }^{+}\left([\mathrm{M}+\mathrm{H}]^{+}\right)$575.3075; found 575.3078.

Calc'd for $\mathrm{C}_{29} \mathrm{H}_{42} \mathrm{~N}_{4} \mathrm{O}_{8} \mathrm{Na}^{+}\left([\mathrm{M}+\mathrm{Na}]^{+}\right) 597.2895$ found 597.2890. 


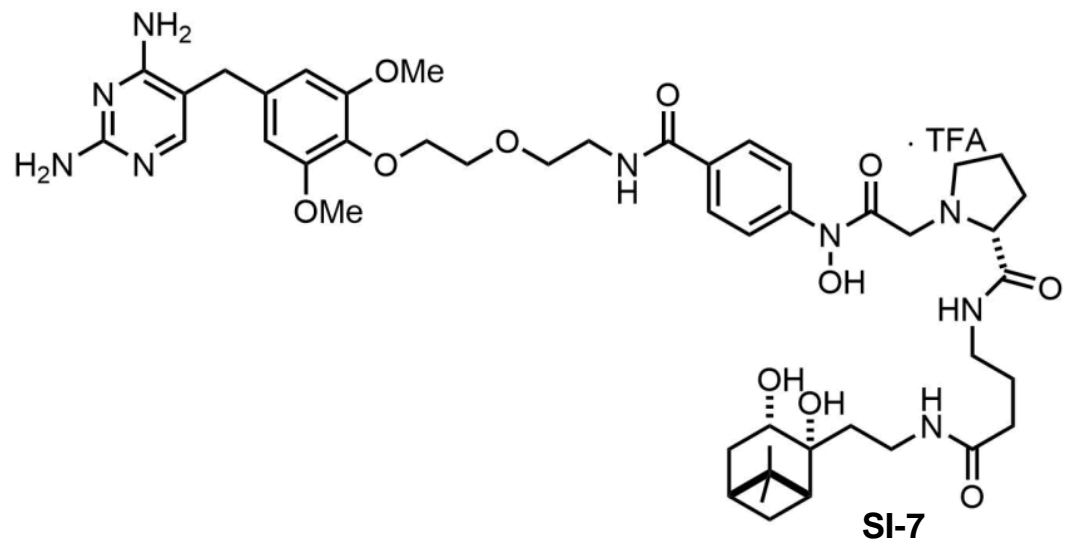

\section{Procedure:}

To a stirred solution of carboxylic acid SI-113 (39.7 mg, $57.6 \mu \mathrm{mol}$ ), TMP-amine ${ }^{1}$ (33.0 mg, 69.2 $\mu \mathrm{mol}, 1.2 \mathrm{eq}$ ), DIPEA ( $40 \mu \mathrm{L}, 0.23 \mathrm{mmol}, 4 \mathrm{eq}$ ), and oxyma ( $2 \mathrm{mg}, 14 \mu \mathrm{mol}, 0.25 \mathrm{eq}$ ) in $0.58 \mathrm{~mL}$ DMF was charged EDC. $\mathrm{HCl}$ (13.8 mg, $72 \mu \mathrm{mol}, 1.25 \mathrm{eq}$ ). The mixture was stirred for 29 hours and most of the DMF was removed on the rotovap. The crude residue was chromatographed on $2 \mathrm{~g}$ silica (EtOAc to 30\% v/v MeOH in EtOAc) to afford an oil. This material was purified by preparative HPLC (method B, 0 - 70\% ACN) to afford SI-7 (13.4 mg, $13.0 \mu \mathrm{mol}, 22 \%$ yield) as a white solid.

${ }^{1} \mathrm{H}$ NMR: $\left(500 \mathrm{MHz}, \mathrm{CD}_{3} \mathrm{CN}, 25^{\circ} \mathrm{C}, \delta\right)$ :

$7.72(\mathrm{~d}, J=8.3 \mathrm{~Hz}, 2 \mathrm{H}), 7.64(\mathrm{~d}, J=8.3 \mathrm{~Hz}, 2 \mathrm{H}), 7.62$ (br s, 1H), $7.43(\mathrm{br} \mathrm{s}, 1 \mathrm{H}), 7.31$ (s, 1H), 6.88 (br s, 1H), 6.81 (br s, 1H), $6.45(\mathrm{~s}, 2 \mathrm{H}), 6.32(\mathrm{br} \mathrm{s}, 1 \mathrm{H}), 4.65(\mathrm{~d}, J=16.9 \mathrm{~Hz}, 1 \mathrm{H}), 4.56(\mathrm{~d}, J=16.9 \mathrm{~Hz}, 1 \mathrm{H}), 4.33(\mathrm{~m}, 1 \mathrm{H}), 3.98(\mathrm{~m}$, 2H), $3.90(\mathrm{dd}, U=9.2,5.2 \mathrm{~Hz}, 1 \mathrm{H}), 3.83(\mathrm{~m}, 1 \mathrm{H}), 3.69(\mathrm{t}, J=4.6 \mathrm{~Hz}, 2 \mathrm{H}), 3.66(\mathrm{~s}, 6 \mathrm{H}), 3.62(\mathrm{t}, J=5.2 \mathrm{~Hz}, 2 \mathrm{H})$, $3.56(\mathrm{~s}, 2 \mathrm{H}), 3.48(\mathrm{q}, J=5.5 \mathrm{~Hz}, 2 \mathrm{H}), 3.24(\mathrm{~m}, 4 \mathrm{H}), 3.10(\mathrm{~m}, 1 \mathrm{H}), 2.11(\mathrm{t}, J=7.2 \mathrm{~Hz}, 2 \mathrm{H}), 2.05(\mathrm{~m}, 1 \mathrm{H}), 1.96(\mathrm{~m}$, $1 \mathrm{H}), 1.70(\mathrm{~m}, 4 \mathrm{H}), 1.51(\mathrm{~m}, 2 \mathrm{H}), 1.27(\mathrm{~d}, J=10.3 \mathrm{~Hz}, 1 \mathrm{H}), 1.16(\mathrm{~s}, 3 \mathrm{H}), 0.82(\mathrm{~m}, 3 \mathrm{H})$.

${ }^{13} \mathrm{C}$ NMR: $\left(126 \mathrm{MHz}, \mathrm{CD}_{3} \mathrm{CN}, 25^{\circ} \mathrm{C}, \delta\right)$ :

169.1, 167.4, 165.7, 165.6, 156.4, 154.3, 143.7, 141.4, 136.5, 133.4, 129.8, 129.1, 128.5, 119.6, 109.6, 106.8, 75.5, 72.9, 70.9, 69.9, 69.4, 68.1, 58.3, 57.6, 56.6, 52.7, 42.2, 41.3, 40.5, 39.9, 39.1, 38.7, 35.6, 33.8, 33.7, 30.7, 28.3, $28.0,25.7,24.4,24.3$.

HRMS (ESI-TOF, m/z):

Calc'd for $\mathrm{C}_{46} \mathrm{H}_{66} \mathrm{~N}_{9} \mathrm{O}_{11}{ }^{+}\left([\mathrm{M}+\mathrm{H}]^{+}\right)$920.4879; found 920.4871 .

Calc'd for $\mathrm{C}_{46} \mathrm{H}_{65} \mathrm{~N}_{9} \mathrm{O}_{11} \mathrm{Na}^{+}\left([\mathrm{M}+\mathrm{Na}]^{+}\right)$942.4696; found 942.4705. 


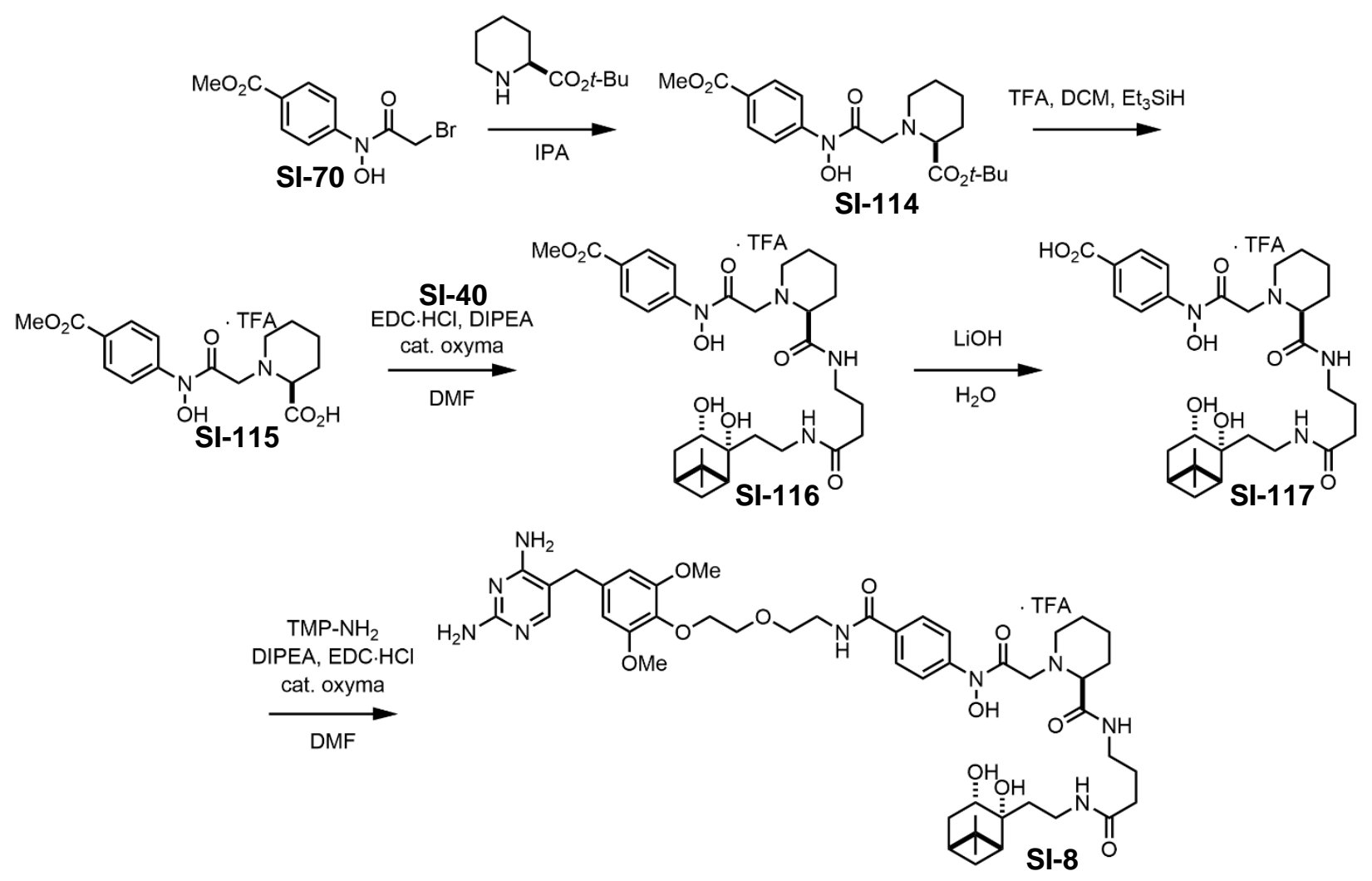




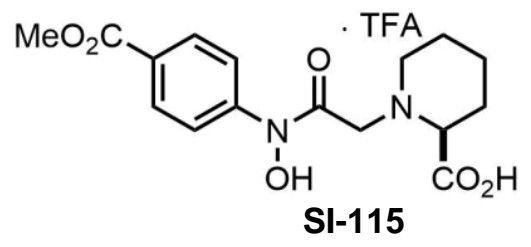

\section{Procedure:}

To a stirred solution of SI-70 (144 mg, $0.50 \mathrm{mmol})$ in $3 \mathrm{~mL}$ IPA was charged tert-butyl (2S)-piperidine-2carboxylate $^{8}(278 \mathrm{mg}, 1.5 \mathrm{mmol}, 3.0 \mathrm{eq})$. After 2 hours, the volatiles were removed on the rotovap, and the residue was extracted with $10 \mathrm{~mL}$ EtOAc and $5 \mathrm{~mL} \mathrm{10 \%} \mathrm{NaCl}$. The aqueous material was discarded, the organic material was washed with brine, dried $\left(\mathrm{Na}_{2} \mathrm{SO}_{4}\right)$, filtered, and concentrated on the rotovap. The crude material was adsorbed on $1.2 \mathrm{~g}$ silica and chromatographed on $10 \mathrm{~g}$ silica (35 to 45\% v/v EtOAc in hexane) to afford SI-114 (220 mg) as a white solid.

SI-114 (220 mg) was stirred with $4 \mathrm{~mL} 60: 40: 0.5 \mathrm{v} / \mathrm{v}$ TFA / $\mathrm{CH}_{2} \mathrm{Cl}_{2} / \mathrm{Et}_{3} \mathrm{SiH}$ for 4 hours. The reaction mixture was concentrated on the rotovap, co-evaporated with PhMe, dissolved in $1: 1 \mathrm{v} / \mathrm{v} \mathrm{ACN}: \mathrm{H}_{2} \mathrm{O}$, and lyophilized to afford SI-115 (198 mg, $0.44 \mathrm{mmol}, 88 \%$ yield over 2 steps) as a foam.

${ }^{1}$ H NMR: $\left(500 \mathrm{MHz}, \mathrm{CD}_{3} \mathrm{CN}, 25^{\circ} \mathrm{C}, \delta\right)$ :

$8.01(\mathrm{~d}, J=8.6 \mathrm{~Hz}, 2 \mathrm{H}), 7.82(\mathrm{~d}, J=8.6 \mathrm{~Hz}, 2 \mathrm{H}), 4.55(\mathrm{~d}, J=16.6 \mathrm{~Hz}, 1 \mathrm{H}), 4.43(\mathrm{~d}, J=16.6 \mathrm{~Hz}, 1 \mathrm{H}), 4.20(\mathrm{~m}, 1 \mathrm{H})$, $3.85(\mathrm{~s}, 3 \mathrm{H}), 3.60(\mathrm{~m}, 1 \mathrm{H}), 3.24(\mathrm{~m}, 1 \mathrm{H}), 2.21(\mathrm{~m}, 1 \mathrm{H}), 2.08(\mathrm{~m}, 1 \mathrm{H}), 1.84(\mathrm{~m}, 2 \mathrm{H}), 1.66(\mathrm{~m}, 2 \mathrm{H})$.

${ }^{13} \mathrm{C}$ NMR: $\left(126 \mathrm{MHz}, \mathrm{CD}_{3} \mathrm{CN}, 25^{\circ} \mathrm{C}, \delta\right)$ :

$170.3,166.9,165.5,145.0,131.0,128.0,119.8,64.8,57.6,54.9,52.7,25.4,21.5,20.9$.

(Note: broad peaks were observed in both ${ }^{1} \mathrm{H}$ and ${ }^{13} \mathrm{C}$ spectra).

HRMS (ESI-TOF, m/z):

Calc'd for $\mathrm{C}_{16} \mathrm{H}_{21} \mathrm{~N}_{2} \mathrm{O}_{6}{ }^{+}\left([\mathrm{M}+\mathrm{H}]^{+}\right)$337.1394; found 337.1403.

Calc'd for $\mathrm{C}_{16} \mathrm{H}_{20} \mathrm{~N}_{2} \mathrm{O}_{6} \mathrm{Na}^{+}\left([\mathrm{M}+\mathrm{Na}]^{+}\right)$359.1214; found 359.1211. 


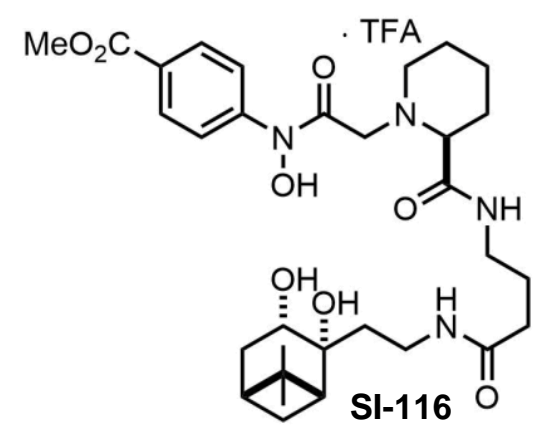

\section{Procedure:}

To a stirred solution of carboxylic acid SI-115 (34.0 mg, $75.5 \mu \mathrm{mol})$, amine SI-40 (30.1 mg, $106 \mu \mathrm{mol}, 1.4 \mathrm{eq})$, DIPEA (33 $\mu \mathrm{L}, 0.19 \mathrm{mmol}, 2.5 \mathrm{eq})$, and oxyma $(2.7 \mathrm{mg}, 20 \mu \mathrm{mol}, 0.25 \mathrm{eq})$ in $0.5 \mathrm{~mL} \mathrm{DMF}$ was charged EDC $\mathrm{HCl}$ (17.4 mg, $91 \mu \mathrm{mol}, 1.2 \mathrm{eq}$ ). The mixture was stirred for 15 hours and most of the DMF was removed on the rotovap. The crude residue was chromatographed on $1 \mathrm{~g}$ silica (EtOAc to 15\% v/v MeOH in EtOAc) to afford an oil. This material was purified by preparative HPLC (method A, 0 - 70\% ACN) to afford SI-116 (27.7 mg, $38.6 \mu \mathrm{mol}, 51 \%$ yield) as a white solid.

${ }^{1}$ H NMR: $\left(500 \mathrm{MHz}, \mathrm{CD}_{3} \mathrm{CN}, 25^{\circ} \mathrm{C}, \delta\right)$ :

$8.00(\mathrm{~d}, J=8.6 \mathrm{~Hz}, 2 \mathrm{H}), 7.85(\mathrm{~d}, J=8.6 \mathrm{~Hz}, 2 \mathrm{H}), 7.84$ (br s, $1 \mathrm{H}), 7.07$ (br s, $1 \mathrm{H}), 4.52(\mathrm{~d}, J=16.8 \mathrm{~Hz}, 1 \mathrm{H}), 4.40(\mathrm{~d}$, $J=16.8 \mathrm{~Hz}, 1 \mathrm{H}), 4.17(\mathrm{~d}, J=9.7 \mathrm{~Hz}, 1 \mathrm{H}), 3.85(\mathrm{~s}, 3 \mathrm{H}), 3.67(\mathrm{~d}, J=12.0 \mathrm{~Hz}, 1 \mathrm{H}), 3.26(\mathrm{~m}, 3 \mathrm{H}), 3.14(\mathrm{~m}, 1 \mathrm{H}), 2.37$ (m, 1H), $2.12(\mathrm{~m}, 4 \mathrm{H}), 1.96(\mathrm{~m}, 2 \mathrm{H}), 1.79(\mathrm{~m}, 7 \mathrm{H}), 1.57(\mathrm{~m}, 3 \mathrm{H}), 1.32(\mathrm{~m}, 1 \mathrm{H}), 1.20(\mathrm{~s}, 3 \mathrm{H}), 0.87(\mathrm{~s}, 3 \mathrm{H})$.

${ }^{13}$ C NMR: $\left(126 \mathrm{MHz}, \mathrm{CD}_{3} \mathrm{CN}, 25^{\circ} \mathrm{C}, \delta\right)$ :

174.1, 168.1, 166.9, 165.4, 145.2, 130.8, 127.7, 119.6, 75.4, 68.0, 66.2, 57.8, 55.2, 52.8, 52.6, 42.1, 41.3, 39.9, 39.2, $38.8,35.7,34.1,28.3,28.0,27.9,25.5,24.3,22.5,21.2$.

(Note: broad peaks were observed in both ${ }^{1} \mathrm{H}$ and ${ }^{13} \mathrm{C}$ spectra).

HRMS (ESI-TOF, m/z):

Calc'd for $\mathrm{C}_{31} \mathrm{H}_{47} \mathrm{~N}_{4} \mathrm{O}_{8}{ }^{+}\left([\mathrm{M}+\mathrm{H}]^{+}\right)$603.3388; found 603.3399.

Calc'd for $\mathrm{C}_{31} \mathrm{H}_{46} \mathrm{~N}_{4} \mathrm{O}_{8} \mathrm{Na}^{+}\left([\mathrm{M}+\mathrm{Na}]^{+}\right)$625.3208; found 625.3219. 


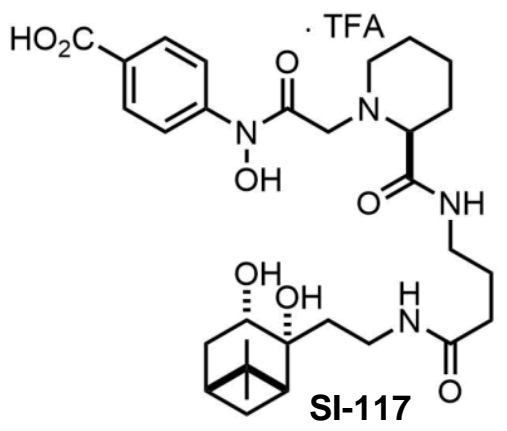

\section{Procedure:}

To a flask containing methyl ester SI-116 $(27.7 \mathrm{mg}, 38.6 \mu \mathrm{mol})$ was charged $\mathrm{LiOH}\left(0.5 \mathrm{M}\right.$ in $\mathrm{H}_{2} \mathrm{O}, 0.54 \mathrm{~mL}, 0.27$ mmol, 7 eq), and the mixture was stirred (note: becomes a clear solution). After 25 minutes, the $\mathrm{pH}$ was adjusted to 4 with citric acid then $0.5 \mathrm{~mL} \mathrm{ACN}$ was charged. This material was purified by preparative HPLC (method A, 0 $70 \% \mathrm{ACN})$ to afford carboxylic acid SI-117 (17.7 mg, $25.2 \mu \mathrm{mol}, 65 \%$ yield) as a white solid.

${ }^{1}$ H NMR: $\left(500 \mathrm{MHz}, \mathrm{CD}_{3} \mathrm{CN}, 25^{\circ} \mathrm{C}, \delta\right)$ :

$8.01(\mathrm{~d}, J=8.0 \mathrm{~Hz}, 2 \mathrm{H}), 7.83(\mathrm{~d}, J=8.0 \mathrm{~Hz}, 2 \mathrm{H}), 7.64(\mathrm{br} \mathrm{s}, 1 \mathrm{H}), 7.04(\mathrm{br} \mathrm{s}, 1 \mathrm{H}), 4.45(\mathrm{~d}, J=16.9 \mathrm{~Hz}, 1 \mathrm{H}), 4.35(\mathrm{~d}$, $J=16.9 \mathrm{~Hz}, 1 \mathrm{H}), 4.13(\mathrm{~d}, J=10.3 \mathrm{~Hz}, 1 \mathrm{H}), 3.93(\mathrm{~m}, 1 \mathrm{H}), 3.67(\mathrm{~d}, J=12.6 \mathrm{~Hz}, 1 \mathrm{H}), 3.27(\mathrm{~m}, 4 \mathrm{H}), 3.11(\mathrm{~m}, 1 \mathrm{H})$, $2.37(\mathrm{t}, J=10.3 \mathrm{~Hz}, 1 \mathrm{H}), 2.16(\mathrm{~m}, 3 \mathrm{H}), 2.09(\mathrm{~m}, 1 \mathrm{H}), 1.95(\mathrm{~m}, 2 \mathrm{H}), 1.88(\mathrm{~m}, 2 \mathrm{H}), 1.80(\mathrm{~m}, 3 \mathrm{H}), 1.70(\mathrm{~m}, 2 \mathrm{H}), 1.56$ (m, 3H), $1.31(\mathrm{~d}, J=9.7 \mathrm{~Hz}, 1 \mathrm{H}), 1.20(\mathrm{~s}, 3 \mathrm{H}) .0 .85(\mathrm{~s}, 3 \mathrm{H})$.

${ }^{13}$ C NMR: (125, $\left.\mathrm{MHz} \mathrm{CD} \mathrm{CDN}_{3}, 25^{\circ} \mathrm{C}, \delta\right)$ :

174.4, 168.1, 167.3, 165.4, 145.1, 131.3, 128.0, 119.7, 75.6, 68.2, 66.5, 58.0, 55.5, 52.7, 42.0, 41.3, 40.0, 39.2, 38.8, $35.9,34.2,28.4,28.0,28.0,25.5,24.3,22.7,21.2$.

(Note: broad peaks were observed in both ${ }^{1} \mathrm{H}$ and ${ }^{13} \mathrm{C}$ spectra).

HRMS (ESI-TOF, m/z):

Calc'd for $\mathrm{C}_{30} \mathrm{H}_{45} \mathrm{~N}_{4} \mathrm{O}_{8}{ }^{+}\left([\mathrm{M}+\mathrm{H}]^{+}\right)$589.3232; found 589.3239.

Calc'd for $\mathrm{C}_{30} \mathrm{H}_{44} \mathrm{~N}_{4} \mathrm{O}_{8} \mathrm{Na}^{+}\left([\mathrm{M}+\mathrm{Na}]^{+}\right)$611.3051; found 611.3066. 


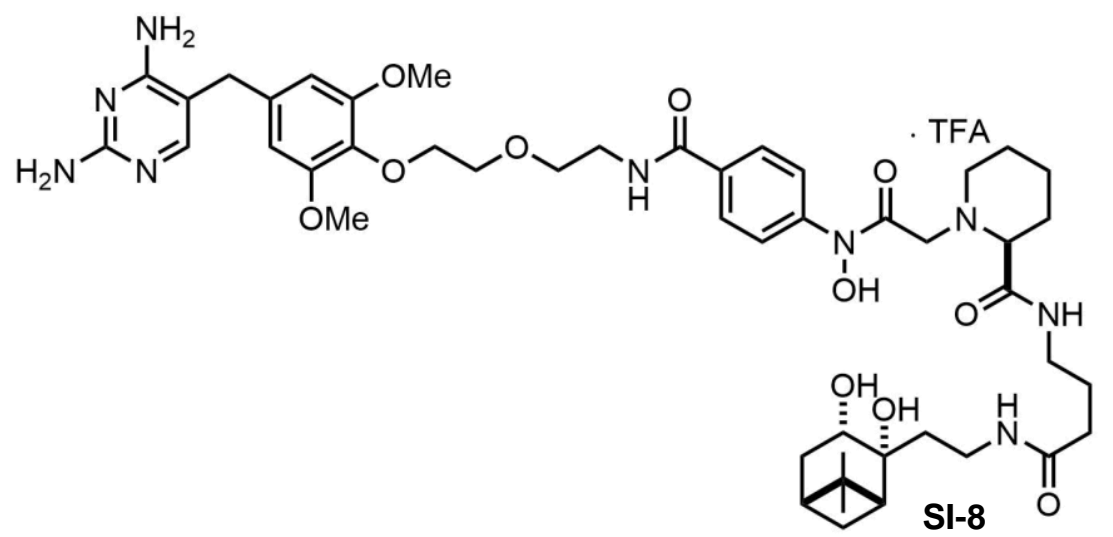

\section{Procedure:}

To a stirred solution of carboxylic acid SI-117 (17.7 mg, $25.2 \mu \mathrm{mol}$ ), TMP-amine ${ }^{1}$ (14.4 mg, $30.2 \mu \mathrm{mol}, 1.2 \mathrm{eq}$ ), DIPEA ( $13.2 \mu \mathrm{L}, 0.076 \mathrm{mmol}, 3 \mathrm{eq})$, and oxyma $(0.9 \mathrm{mg}, 6 \mu \mathrm{mol}, 0.25 \mathrm{eq})$ in $0.25 \mathrm{~mL}$ DMF was charged EDC $\cdot \mathrm{HCl}$ (5.8 mg, $30.2 \mu \mathrm{mol}, 1.2 \mathrm{eq}$ ). The mixture was stirred for 8 hours and most of the DMF was removed on the rotovap. The crude residue was chromatographed on $1 \mathrm{~g}$ silica (EtOAc to 20\% v/v MeOH in EtOAc) to afford an oil. This material was purified by preparative HPLC (method A, 0 - 60\% ACN) to afford SI-8 (13.8 mg, $13.2 \mu \mathrm{mol}, 52 \%$ yield) as a white solid.

${ }^{1} \mathrm{H}$ NMR: $\left(500 \mathrm{MHz}, \mathrm{CD}_{3} \mathrm{CN}, 25^{\circ} \mathrm{C}, \delta\right)$ :

7.85 (br s, 1H) $7.74(\mathrm{~d}, J=8.0 \mathrm{~Hz}, 2 \mathrm{H}), 7.67(\mathrm{~d}, J=8.0 \mathrm{~Hz}, 2 \mathrm{H}), 7.42(\mathrm{~m}, 1 \mathrm{H}), 7.33(\mathrm{~s}, 1 \mathrm{H}), 7.04(\mathrm{br} \mathrm{s}, 1 \mathrm{H}), 6.84(\mathrm{br}$ s, 1H), $6.46(\mathrm{~s}, 2 \mathrm{H}), 6.30(\mathrm{br} \mathrm{s}, 1 \mathrm{H}), 4.47(\mathrm{~d}, J=16.9 \mathrm{~Hz}, 1 \mathrm{H}), 4.36(\mathrm{~d}, J=16.9 \mathrm{~Hz}, 1 \mathrm{H}), 4.14(\mathrm{~m}, 1 \mathrm{H}), 4.00(\mathrm{~m}, 2 \mathrm{H})$, $3.71(\mathrm{~m}, 2 \mathrm{H}), 3.68(\mathrm{~s}, 6 \mathrm{H}), 3.65(\mathrm{t}, J=5.2 \mathrm{~Hz}, 2 \mathrm{H}), 3.58(\mathrm{~s}, 2 \mathrm{H}), 3.51(\mathrm{~m}, 2 \mathrm{H}), 3.25(\mathrm{~m}, 3 \mathrm{H}), 3.11(\mathrm{~m}, 1 \mathrm{H}), 2.36(\mathrm{~m}$, $1 \mathrm{H}), 2.12(\mathrm{~m}, 3 \mathrm{H}), 2.07(\mathrm{~m}, 1 \mathrm{H}), 1.95(\mathrm{~m}, 2 \mathrm{H}), 1.78(\mathrm{~m}, 7 \mathrm{H}), 1.55(\mathrm{~m}, 2 \mathrm{H}), 1.30(\mathrm{~d}, J=9.7 \mathrm{~Hz}, 1 \mathrm{H}), 1.18(\mathrm{~s}, 3 \mathrm{H})$, $0.84(\mathrm{~s}, 3 \mathrm{H})$.

${ }^{13} \mathrm{C}$ NMR: $\left(126 \mathrm{MHz}, \mathrm{CD}_{3} \mathrm{CN}, 25^{\circ} \mathrm{C}, \delta\right)$ :

174.1, 168.1, 167.4, 165.6, 165.2, 156.5, 154.4, 143.7, 141.5, 136.5, 133.4, 132.4, 128.6, 119.8, 109.5, 106.8, 86.1, 75.6, 72.9, 71.0, 70.0, 68.2, 66.3, 56.6, 55.2, 52.7, 50.1, 42.1, 41.3, 40.6, 40.0, 39.2, 38.8, 35.7, 34.1, 33.7, 28.4, 28.1, 25.5, 24.3, 22.6, 21.2.

HRMS (ESI-TOF, m/z):

Calc'd for $\mathrm{C}_{47} \mathrm{H}_{68} \mathrm{~N}_{9} \mathrm{O}_{11}{ }^{+}\left([\mathrm{M}+\mathrm{H}]^{+}\right)$934.5033; found 934.5018.

Calc'd for $\mathrm{C}_{47} \mathrm{H}_{67} \mathrm{~N}_{9} \mathrm{O}_{11} \mathrm{Na}^{+}\left([\mathrm{M}+\mathrm{Na}]^{+}\right)$956.4852; found 956.4826. 

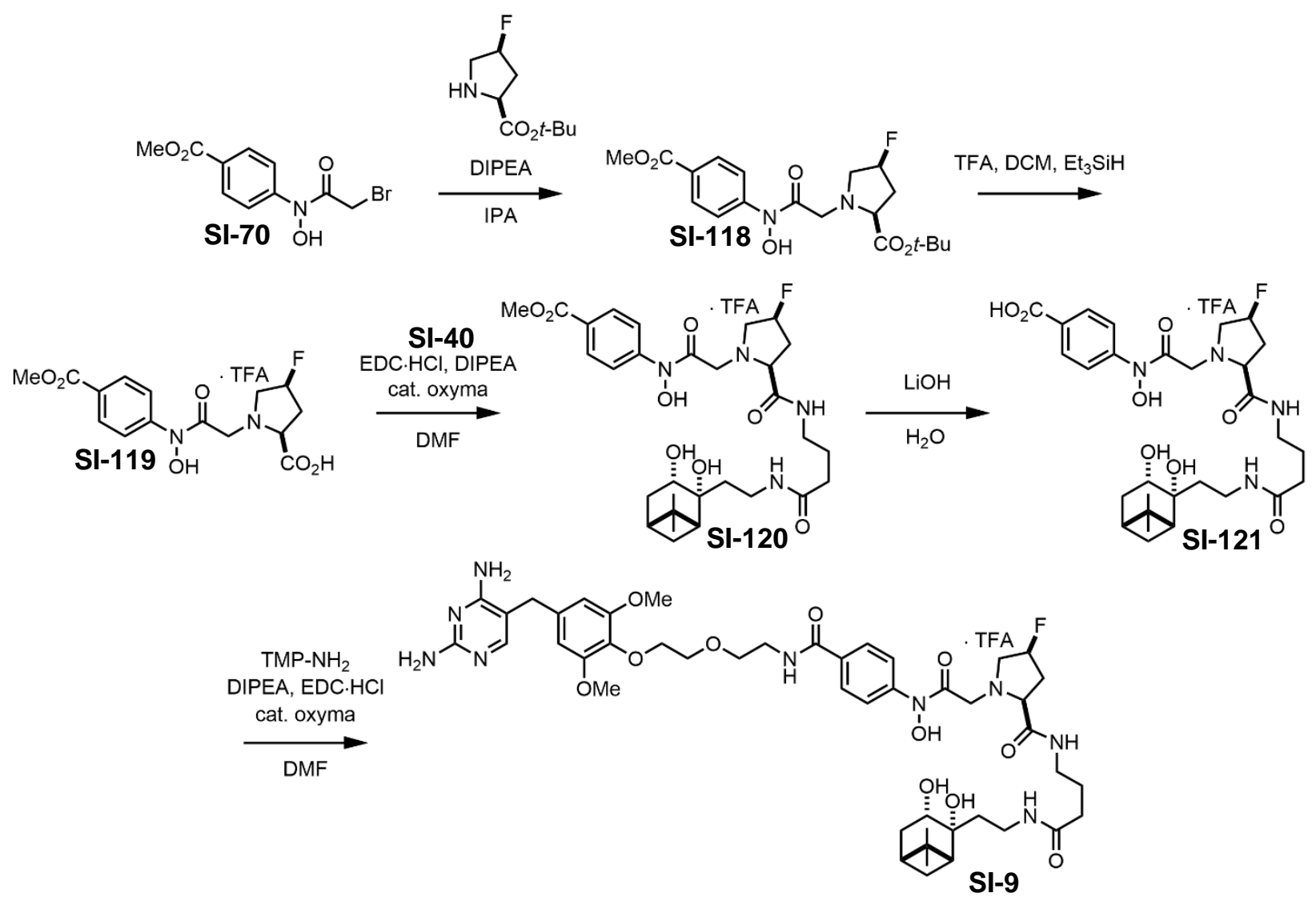


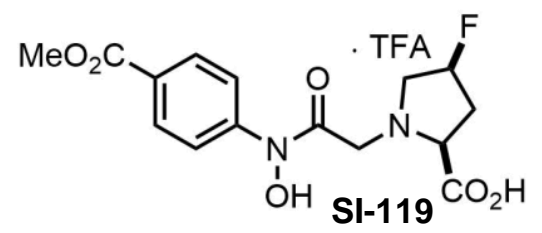

\section{Procedure:}

To as stirred solution of SI-70 (149 mg, $0.516 \mathrm{mmol})$ in $3 \mathrm{~mL}$ IPA was charged tert-butyl (2S,4S)-4-

fluoropyrrolidine-2-carboxylate ${ }^{9}(147 \mathrm{mg}, 0.774 \mathrm{mmol}, 1.5 \mathrm{eq})$ and DIPEA (135 $\left.\mu \mathrm{L}, 0.774 \mathrm{mmol}, 1.5 \mathrm{eq}\right)$. After 2 hours, the volatiles were removed on the rotovap, and the residue was extracted with $10 \mathrm{~mL}$ EtOAc and $10 \mathrm{~mL} 10 \%$ $\mathrm{NaCl}$. The organic material was washed with brine, dried $\left(\mathrm{Na}_{2} \mathrm{SO}_{4}\right)$, filtered, and concentrated on the rotovap. The crude intermediate was adsorbed on $1 \mathrm{~g}$ silica and chromatographed on $5 \mathrm{~g}$ silica (40\% v/v EtOAc in hex) to afford SI-118 (170 mg) as a colorless oil.

SI-118 $\left(170 \mathrm{mg}\right.$ ) was stirred with $3 \mathrm{~mL} 60: 40: 0.5 \mathrm{v} / \mathrm{v}$ TFA : $\mathrm{CH}_{2} \mathrm{Cl}_{2}: \mathrm{Et}_{3} \mathrm{SiH}$ for 5 hours. The reaction mixture was concentrated on the rotovap, co-evaporated with $\mathrm{PhMe}$, dissolved in $1: 1 \mathrm{v} / \mathrm{v} \mathrm{ACN} \mathrm{:} \mathrm{H}_{2} \mathrm{O}$, and lyophilized. This crude material was purified with preparative HPLC (method B, 0 - 70\% ACN) to afford SI-119 (79.4 mg, 0.17 mmol, $34 \%$ yield over 2 steps) as a white solid.

${ }^{1}$ H NMR: $\left(500 \mathrm{MHz}, \mathrm{CD}_{3} \mathrm{CN}, 25^{\circ} \mathrm{C}, \delta\right)$ :

$7.98(\mathrm{~d}, J=8.0 \mathrm{~Hz}, 2 \mathrm{H}), 7.80(\mathrm{~d}, J=8.0 \mathrm{~Hz}, 2 \mathrm{H}), 5.42(\mathrm{~d}, J=51.0 \mathrm{~Hz}, 1 \mathrm{H}), 4.71(\mathrm{~m}, 1 \mathrm{H}), 4.65(\mathrm{dd}, J=30.4,11.5$ $\mathrm{Hz}, 2 \mathrm{H}), 4.17(\mathrm{t}, J=16.0 \mathrm{~Hz}, 1 \mathrm{H}), 3.84(\mathrm{~s}, 3 \mathrm{H}), 3.66(\mathrm{dd}, J=35.8,12.9 \mathrm{~Hz}, 1 \mathrm{H}), 2.82(\mathrm{dt}, J=41.0,11.9 \mathrm{~Hz}, 1 \mathrm{H})$, $2.64(\mathrm{t}, J=16.9 \mathrm{~Hz}, 1 \mathrm{H})$.

${ }^{13} \mathrm{C}$ NMR: (126 MHz, $\left.\mathrm{CD}_{3} \mathrm{CN}, 25^{\circ} \mathrm{C}, \delta\right)$ :

171.4, 166.9, 165.7, 144.9, 130.9, 127.8, 119.7, 92.6 (d, $J=176.3 \mathrm{~Hz}), 67.8,62.7(\mathrm{~d}, J=22.8 \mathrm{~Hz}), 58.0,52.6,36.3$ $(\mathrm{d}, J=21.6 \mathrm{~Hz})$.

HRMS (ESI-TOF, m/z):

Calc'd for $\mathrm{C}_{15} \mathrm{H}_{18} \mathrm{FN}_{2} \mathrm{O}_{6}{ }^{+}\left([\mathrm{M}+\mathrm{H}]^{+}\right)$341.1143; found 341.1145.

Calc'd for $\mathrm{C}_{15} \mathrm{H}_{17} \mathrm{FN}_{2} \mathrm{O}_{6} \mathrm{Na}^{+}\left([\mathrm{M}+\mathrm{Na}]^{+}\right)$363.0963; found 363.0959. 


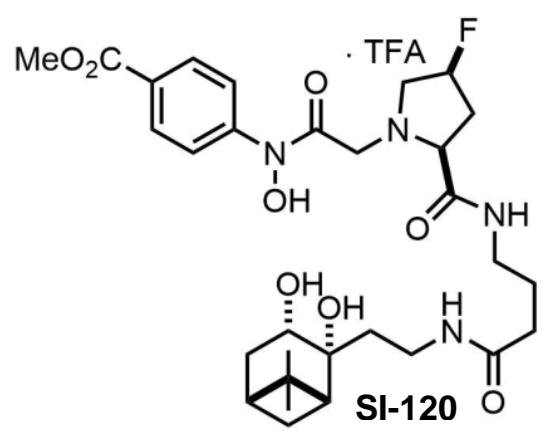

\section{Procedure:}

To a stirred solution of carboxylic acid SI-119 (34.3 mg, $75.5 \mu \mathrm{mol})$, amine SI-40 (30.1 mg, $106 \mu \mathrm{mol}, 1.4 \mathrm{eq})$, DIPEA (33 $\mu \mathrm{L}, 0.19 \mathrm{mmol}, 2.5 \mathrm{eq})$, and oxyma ( $3 \mathrm{mg}, 20 \mu \mathrm{mol}, 0.25 \mathrm{eq})$ in $0.5 \mathrm{~mL} \mathrm{DMF}$ was charged EDC $\cdot \mathrm{HCl}$ (17.4 mg, $91 \mu \mathrm{mol}, 1.2 \mathrm{eq}$ ). The mixture was stirred for 15 hours and most of the DMF was removed on the rotovap. The crude residue was chromatographed on $1 \mathrm{~g}$ silica (EtOAc to 15\% v/v MeOH in EtOAc) to afford an oil. This material was purified by preparative HPLC (method A, 0 - 70\% ACN) to afford SI-120 $(22.7 \mathrm{mg}, 31.7 \mu \mathrm{mol}, 42 \%$ yield) as a white solid.

${ }^{1} \mathbf{H}$ NMR: $\left(500 \mathrm{MHz}, \mathrm{CD}_{3} \mathrm{CN}, 25^{\circ} \mathrm{C}, \delta\right)$ :

$7.99(\mathrm{~d}, J=8.0 \mathrm{~Hz}, 2 \mathrm{H}), 7.84$ (d, $J=8.0 \mathrm{~Hz}, 2 \mathrm{H}), 7.78$ (br s, 1H), 6.93 (br s, 1H), 5.37 (d, $J=51.6 \mathrm{~Hz}, 1 \mathrm{H}), 4.63$ (d, $J=17.5 \mathrm{~Hz}, 1 \mathrm{H}), 4.58(\mathrm{~d}, J=17.5 \mathrm{~Hz}, 1 \mathrm{H}), 4.44(\mathrm{~d}, J=9.2 \mathrm{~Hz}, 1 \mathrm{H}), 4.02(\mathrm{dd}, J=18.0,13.5 \mathrm{~Hz}, 1 \mathrm{H}), 3.93(\mathrm{dd}, J=$ 9.2, $5.2 \mathrm{~Hz}, 1 \mathrm{H}), 3.85$ (s, 3H), $3.56(\mathrm{dd}, J=36.9,12.9 \mathrm{~Hz}, 1 \mathrm{H}), 3.23(\mathrm{~m}, 4 \mathrm{H}), 2.83(\mathrm{dt}, J=41.2,12.6 \mathrm{~Hz}, 1 \mathrm{H}), 2.40$ $(\mathrm{m}, 2 \mathrm{H}), 2.14(\mathrm{t}, J=7.2 \mathrm{~Hz}, 2 \mathrm{H}), 2.08(\mathrm{~m}, 1 \mathrm{H}), 1.94(\mathrm{~m}, 1 \mathrm{H}), 1.80(\mathrm{~m}, 1 \mathrm{H}), 1.72(\mathrm{~m}, 3 \mathrm{H}), 1.54(\mathrm{~m}, 2 \mathrm{H}), 1.30(\mathrm{~d}, J=$ $10.3 \mathrm{~Hz}, 1 \mathrm{H}), 1.19(\mathrm{~s}, 3 \mathrm{H}), 0.86(\mathrm{~s}, 3 \mathrm{H})$.

${ }^{13} \mathrm{C}$ NMR: (126 MHz, $\left.\mathrm{CD}_{3} \mathrm{CN}, 25^{\circ} \mathrm{C}, \delta\right)$ :

173.9, 169.6, 167.0, 166.8, 145.4, 130.9, 127.5, 119.6, 93.0 (d, $J=176.3 \mathrm{~Hz}), 75.5,68.1,67.4,61.9$ (d, J = 22.8 Hz), 57.3, 52.7, 52.6, 42.2, 41.3, 40.1, 39.2, 38.8, 37.7 (d, 21.6 Hz), 35.6, 33.8, 28.4, 28.0, 25.7, 24.3.

HRMS (ESI-TOF, m/z):

Calc'd for $\mathrm{C}_{30} \mathrm{H}_{42} \mathrm{FN}_{4} \mathrm{O}_{8} \mathrm{Na}^{+}\left([\mathrm{M}+\mathrm{Na}]^{+}\right)$629.2957; found 629.2967. 


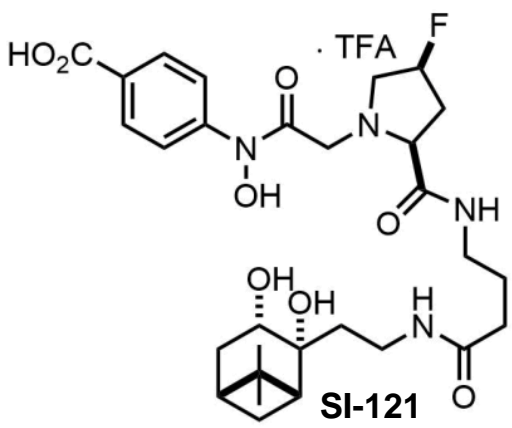

\section{Procedure:}

To a flask containing methyl ester SI-120 $(22.7 \mathrm{mg}, 31.7 \mu \mathrm{mol})$ was charged $\mathrm{LiOH}\left(0.5 \mathrm{M}\right.$ in $\mathrm{H}_{2} \mathrm{O}, 0.44 \mathrm{~mL}, 0.22$ mmol, 7 eq) (note: becomes a clear solution). After 15 minutes, the $\mathrm{pH}$ was adjusted to 4 with citric acid, and 0.5 $\mathrm{mL}$ ACN was charged. This material was purified by preparative HPLC (method A, 0 - 70\% ACN) to afford carboxylic acid SI-121 (19.3 mg, $27.3 \mu \mathrm{mol}, 86 \%$ yield) as a white solid.

${ }^{1}$ H NMR: $\left(500 \mathrm{MHz}, \mathrm{CD}_{3} \mathrm{CN}, 25^{\circ} \mathrm{C}, \delta\right)$ :

$7.99(\mathrm{~d}, J=8.0 \mathrm{~Hz}, 2 \mathrm{H}), 7.81(\mathrm{~d}, J=8.0 \mathrm{~Hz}, 2 \mathrm{H}), 7.66(\mathrm{~m}, 1 \mathrm{H}), 6.94(\mathrm{~m}, 1 \mathrm{H}), 5.40(\mathrm{~d}, J=51.0 \mathrm{~Hz}, 1 \mathrm{H}), 4.66(\mathrm{~m}$, 2H), $4.55(\mathrm{~d}, J=10.3 \mathrm{~Hz}, 1 \mathrm{H}), 4.10(\mathrm{dd}, J=17.8,13.7 \mathrm{~Hz}, 1 \mathrm{H}), 3.94(\mathrm{dd}, J=9.2,5.2 \mathrm{~Hz}, 1 \mathrm{H}), 3.62(\mathrm{dd}, J=36.1$, $13.2 \mathrm{~Hz}, 1 \mathrm{H}), 3.25(\mathrm{~m}, 4 \mathrm{H}), 2.86(\mathrm{dt}, J=41.6,13.0 \mathrm{~Hz}, 1 \mathrm{H}), 2.48(\mathrm{t}, J=17.8 \mathrm{~Hz}, 1 \mathrm{H}), 2.37(\mathrm{t}, J=11.5 \mathrm{~Hz}, 1 \mathrm{H})$, $2.16(\mathrm{t}, J=6.9 \mathrm{~Hz}, 2 \mathrm{H}), 2.08(\mathrm{~m}, 1 \mathrm{H}), 1.95(\mathrm{~m}, 1 \mathrm{H}), 1.81(\mathrm{~m}, 1 \mathrm{H}), 1.72(\mathrm{~m}, 3 \mathrm{H}), 1.54(\mathrm{~m}, 2 \mathrm{H}), 1.31(\mathrm{~d}, J=10.3 \mathrm{~Hz}$, $1 \mathrm{H}), 1.19(\mathrm{~s}, 3 \mathrm{H}), 0.86(\mathrm{~s}, 3 \mathrm{H})$.

${ }^{13}$ C NMR: $\left(125, \mathrm{MHz} \mathrm{CD} 3 \mathrm{CN}, 25^{\circ} \mathrm{C}, \delta\right)$ :

174.1, 168.9, 167.5, 166.1, 145.2, 131.3, 127.8, 119.6, 92.8 (d, $J=176.3 \mathrm{~Hz}), 75.6,68.2,67.5,62.2(\mathrm{~d}, J=22.8 \mathrm{~Hz})$, $57.4,52.7,42.2,41.3,40.4,39.2,38.8,37.7$ (d, $J=21.6 \mathrm{~Hz}), 35.7,33.8,28.4,28.0,25.7,24.3$.

HRMS (ESI-TOF, m/z):

Calc'd for $\mathrm{C}_{29} \mathrm{H}_{42} \mathrm{FN}_{4} \mathrm{O}_{8}{ }^{+}\left([\mathrm{M}+\mathrm{H}]^{+}\right)$593.2981; found 593.2991.

Calc'd for $\mathrm{C}_{29} \mathrm{H}_{41} \mathrm{FN}_{4} \mathrm{O}_{8} \mathrm{Na}^{+}\left([\mathrm{M}+\mathrm{Na}]^{+}\right)$615.2081; found 615.2812. 


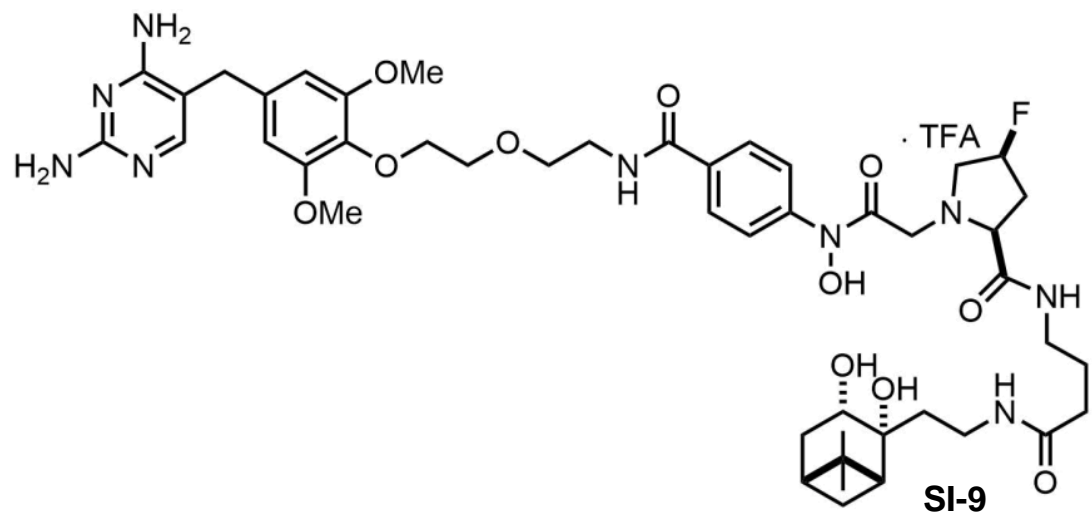

\section{Procedure:}

To a stirred solution of carboxylic acid SI-121 (19.3 mg, $27.3 \mu \mathrm{mol})$, TMP-amine ${ }^{1}$ (13.8 mg, $\left.28.9 \mu \mathrm{mol}, 1.06 \mathrm{eq}\right)$, DIPEA (14.3 $\mu \mathrm{L}, 0.082 \mathrm{mmol}, 3 \mathrm{eq})$, and oxyma ( $1 \mathrm{mg}, 7 \mu \mathrm{mol}, 0.25 \mathrm{eq})$ in $0.27 \mathrm{~mL}$ DMF was charged EDC $\cdot \mathrm{HCl}$ ( $6.0 \mathrm{mg}, 31.4 \mu \mathrm{mol}, 1.15 \mathrm{eq}$ ). The mixture was stirred for 30 hours and most of the DMF was removed on the rotovap. The crude residue was chromatographed on $1 \mathrm{~g}$ silica (EtOAc to $20 \% \mathrm{v} / \mathrm{v} \mathrm{MeOH}$ in EtOAc) to afford an oil. This material was purified by preparative HPLC (method A, 0 - 60\% ACN) to afford SI-9 (13.0 mg, $12.3 \mu \mathrm{mol}, 45 \%$ yield) as a white solid.

${ }^{1} \mathrm{H}$ NMR: $\left(500 \mathrm{MHz}, \mathrm{CD}_{3} \mathrm{CN}, 25^{\circ} \mathrm{C}, \delta\right)$ :

$7.74(\mathrm{~m}, 1 \mathrm{H}), 7.74(\mathrm{~d}, J=8.0 \mathrm{~Hz}, 2 \mathrm{H}), 7.66(\mathrm{~d}, J=8.0 \mathrm{~Hz}, 2 \mathrm{H}), 7.42(\mathrm{t}, J=5.2 \mathrm{~Hz}, 1 \mathrm{H}), 7.34(\mathrm{~s}, 1 \mathrm{H}), 6.90(\mathrm{~m}, 1 \mathrm{H})$, 6.83 (br s, 1H), 6.48 (s, 2H), 6.32 (br s, 1H), 5.36 (d, $J=51.6 \mathrm{~Hz}, 1 \mathrm{H}), 4.56(\mathrm{~d}, J=16.6 \mathrm{~Hz}, 1 \mathrm{H}), 4.51$ (d, $J=16.6$ $\mathrm{Hz}, 1 \mathrm{H}), 4.38(\mathrm{~d}, J=9.2 \mathrm{~Hz}, 1 \mathrm{H}), 4.01(\mathrm{~m}, 2 \mathrm{H}), 3.93(\mathrm{~m}, 1 \mathrm{H}), 3.72(\mathrm{t}, J=4.6 \mathrm{~Hz}, 2 \mathrm{H}), 3.69(\mathrm{~s}, 3 \mathrm{H}), 3.66(\mathrm{t}, J=5.2$ $\mathrm{Hz}, 2 \mathrm{H}), 3.59(\mathrm{~s}, 2 \mathrm{H}), 3.52(\mathrm{~m}, 2 \mathrm{H}), 3.22(\mathrm{~m}, 4 \mathrm{H}), 2.39(\mathrm{~m}, 2 \mathrm{H}), 2.13(\mathrm{t}, J=7.2 \mathrm{~Hz}, 2 \mathrm{H}), 2.07(\mathrm{~m}, 1 \mathrm{H}), 1.95,(\mathrm{~m}$, $1 \mathrm{H}), 1.80(\mathrm{~m}, 1 \mathrm{H}), 1.71(\mathrm{~m}, 3 \mathrm{H}), 1.53(\mathrm{~m}, 2 \mathrm{H}) 1.30(\mathrm{~d}, J=10.3 \mathrm{~Hz}, 1 \mathrm{H}), 1.19(\mathrm{~s}, 3 \mathrm{H}), 0.85(\mathrm{~s}, 3 \mathrm{H})$.

${ }^{13} \mathrm{C}$ NMR: $\left(126 \mathrm{MHz}, \mathrm{CD}_{3} \mathrm{CN}, 25^{\circ} \mathrm{C}, \delta\right)$ :

$173.9,169.9,167.4,166.8,165.6,156.4,143.9,141.5,136.5,133.4,132.1,128.5,119.7,109.6,106.9,93.1(\mathrm{~d}, J=$ $176.3 \mathrm{~Hz}), 75.6,72.9,71.0,70.0,68.2,67.4,61.9(\mathrm{~d}, J=22.8 \mathrm{~Hz}), 56.6,52.7,42.2,41.3,40.6,40.1,39.2,38.8$, 37.8, 37.6, 35.6, $33.8(\mathrm{~d}, J=14.4 \mathrm{~Hz}), 28.4,28.0,25.8,24.3,21.1$.

\section{HRMS (ESI-TOF, m/z):}

Calc'd for $\mathrm{C}_{46} \mathrm{H}_{65} \mathrm{FN}_{9} \mathrm{O}_{11}{ }^{+}\left([\mathrm{M}+\mathrm{H}]^{+}\right)$983.4782; found 938.4761.

Calc'd for $\mathrm{C}_{46} \mathrm{H}_{64} \mathrm{FN}_{9} \mathrm{O}_{11} \mathrm{Na}^{+}\left([\mathrm{M}+\mathrm{Na}]^{+}\right)$960.4602; found 960.4580 . 


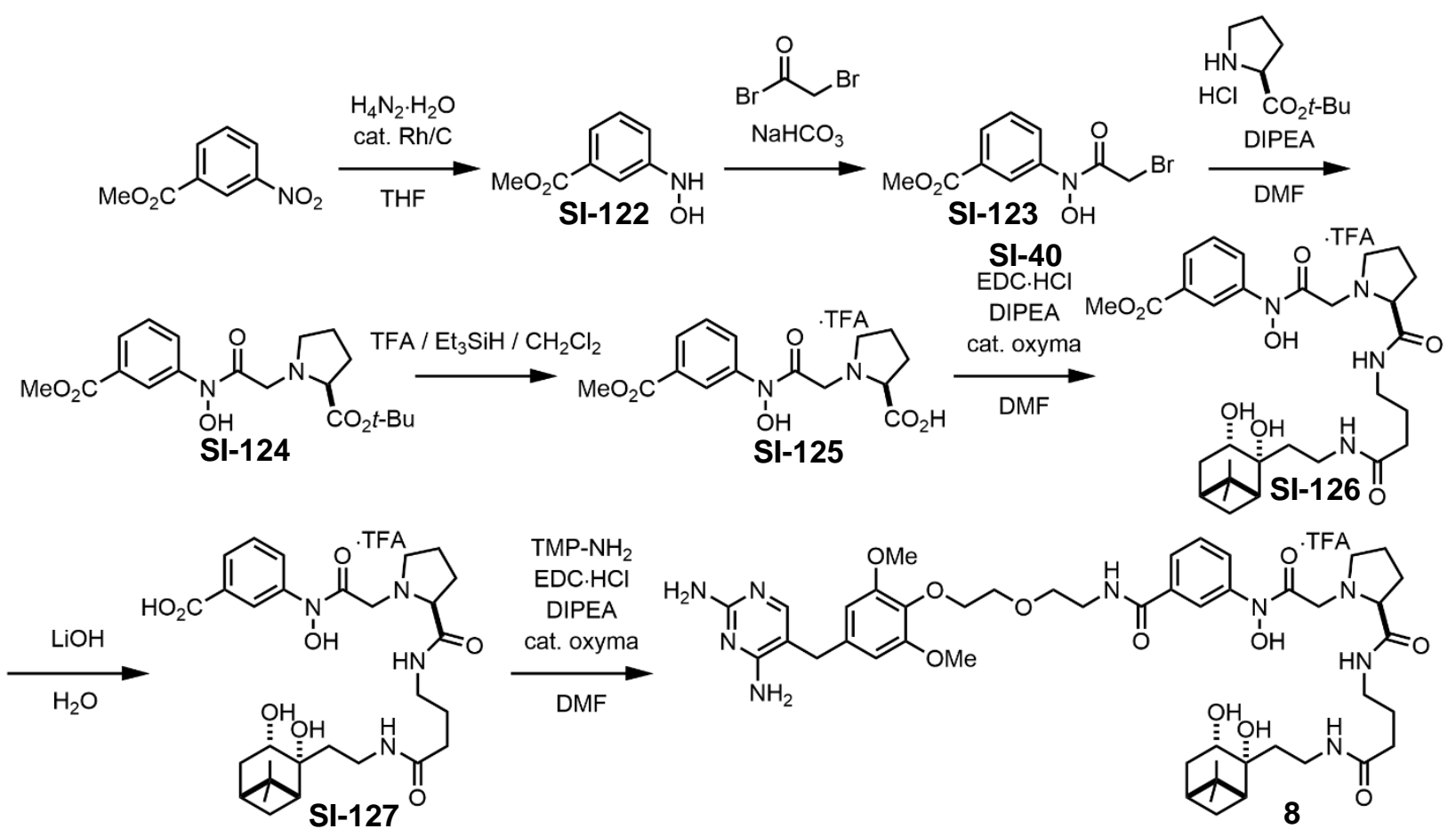




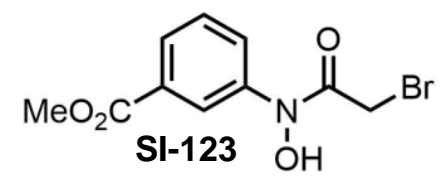

\section{Procedure:}

To a stirred $0-5^{\circ} \mathrm{C}$ solution of methyl 3-nitrobenzoate ( $\left.1.00 \mathrm{~g}, 5.52 \mathrm{mmol}\right)$ in $15 \mathrm{~mL}$ THF was charged $\mathrm{Rh} / \mathrm{C}(5 \%$ $\mathrm{Rh} ; 148 \mathrm{mg}, 0.072 \mathrm{mmol}, 0.013 \mathrm{eq}$ ) followed by hydrazine hydrate ( $323 \mu \mathrm{L}, 6.62 \mathrm{mmol}, 1.2 \mathrm{eq}$ ). After 60 minutes, the reaction mixture was filtered through a Celite pad and rinsed forward with $10 \mathrm{~mL}$ THF. To the solution of crude SI-122 was charged $\mathrm{NaHCO}_{3}\left(4.64 \mathrm{~g}, 55.2 \mathrm{mmol}, 10 \mathrm{eq}\right.$.), the mixture was cooled to $0-5{ }^{\circ} \mathrm{C}$, and bromoacetyl bromide (5.57 g, $27.6 \mathrm{mmol}, 5.0$ eq.) was charged dropwise. After 60 minutes, $10 \mathrm{~mL}$ water was charged, and most of the THF was removed on the rotovap. The mixture was extracted with EtOAc $(3 \times 10 \mathrm{~mL})$, washed with brine, dried $\left(\mathrm{Na}_{2} \mathrm{SO}_{4}\right)$, filtered, and concentrated on the rotovap. The crude material slurried in $15 \mathrm{~mL} n$-heptane, filtered through fritted glass, and dried under vacuum to afford SI-123 (1.25 g, $4.34 \mathrm{mmol}, 79 \%$ yield) as a tan solid.

${ }^{1}$ H NMR: (500 MHz, DMSO- $\left.d_{6}, 25^{\circ} \mathrm{C}, \delta\right): 11.18(\mathrm{br} \mathrm{s}, 1 \mathrm{H}), 8.26(\mathrm{~s}, 1 \mathrm{H}), 7.91(\mathrm{~d}, J=8.0 \mathrm{~Hz}, 1 \mathrm{H}), 7.77(\mathrm{~d}, J=8.0$ $\mathrm{Hz}, 1 \mathrm{H}), 7.55(\mathrm{t}, J=8.0 \mathrm{~Hz}, 1 \mathrm{H}), 4.40(\mathrm{~s}, 2 \mathrm{H}), 3.86(\mathrm{~s}, 3 \mathrm{H})$.

${ }^{13}$ C NMR: (126 MHz, DMSO- $\left.d_{6}, 25{ }^{\circ} \mathrm{C}, \delta\right): 166.0,165.9,141.5,130.0,129.3,125.8,124.4,120.4,52.4,29.6$.

\section{HRMS (ESI-TOF, m/z):}

Calc'd for $\mathrm{C}_{10} \mathrm{H}_{11} \mathrm{BrNO}_{4}{ }^{+}\left([\mathrm{M}+\mathrm{H}]^{+}\right)$287.9866/289.9848; found 287.9865/289.9846.

Calc'd for $\mathrm{C}_{10} \mathrm{H}_{10} \mathrm{BrNO}_{4} \mathrm{Na}^{+}\left([\mathrm{M}+\mathrm{Na}]^{+}\right)$309.9686/311.9665; found 309.9685/311.9665. 


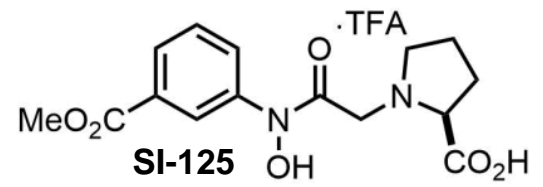

\section{Procedure:}

To a stirred solution of SI-123 $(86.5 \mathrm{mg}, 0.30 \mathrm{mmol})$ in $3 \mathrm{~mL}$ IPA was charged L-proline-tert-butyl ester hydrochloride (94 mg, $0.45 \mathrm{mmol} .1 .5 \mathrm{eq}$ ) followed by DIPEA (107 $\mu \mathrm{L}, 0.60 \mathrm{mmol}, 2 \mathrm{eq})$. After 4 hours, most of the DMF was removed on the rotovap. The residue was extracted with $10 \mathrm{~mL}$ EtOAc and $5 \mathrm{~mL} 10 \% \mathrm{NaCl}$. The aqueous material was discarded, and the organic material was washed with brine, dried $\left(\mathrm{MgSO}_{4}\right)$, filtered, and concentrated on the rotovap. The crude material chromatographed on $5 \mathrm{~g}$ silica (40 to $50 \% \mathrm{v} / \mathrm{v}$ EtOAc in hexane) to afford SI-124 (80.0 $\mathrm{mg})$ as a white solid.

SI-124 (80.0 mg) was dissolved in $3 \mathrm{~mL} 50: 50: 0.5 \mathrm{v} / \mathrm{v} \mathrm{CH}_{2} \mathrm{Cl}_{2}$ : TFA : $\mathrm{Et}_{3} \mathrm{SiH}$ and heated in a $40-50{ }^{\circ} \mathrm{C}$ bath. After 4 hours, the reaction mixture was concentrated on the rotovap, and the residue was co-evaporated with toluene. The residue was dissolved in $1: 1 \mathrm{v} / \mathrm{v} \mathrm{H}_{2} \mathrm{O}: \mathrm{ACN}$, filtered through cotton to remove minor debris, and lyophilized to afford SI-125 (90.0 mg, $0.210 \mathrm{mmol}, 70 \%$ yield over 2 steps) as a light brown solid.

${ }^{1}$ H NMR: $\left(500 \mathrm{MHz}, \mathrm{CD}_{3} \mathrm{CN}, 25^{\circ} \mathrm{C}, \delta\right): 8.31(\mathrm{~s}, 1 \mathrm{H}), 7.88(\mathrm{~d}, J=8.0 \mathrm{~Hz}, 1 \mathrm{H}), 7.78(\mathrm{~d}, J=8.0 \mathrm{~Hz}, 1 \mathrm{H}), 7.47(\mathrm{~d}, J=$ $8.0 \mathrm{~Hz}, 1 \mathrm{H}), 4.65(\mathrm{~d}, J=16.9 \mathrm{~Hz}, 1 \mathrm{H}), 4.58(\mathrm{~d}, J=16.9 \mathrm{~Hz}, 1 \mathrm{H}), 4.31(\mathrm{~m}, 1 \mathrm{H}), 4.17(\mathrm{~m}, 1 \mathrm{H}), 3.84(\mathrm{~m}, 5 \mathrm{H}), 3.28(\mathrm{~m}$, 1H), $2.41(\mathrm{~m}, 1 \mathrm{H}), 2.09(\mathrm{~m}, 3 \mathrm{H}), 1.76(\mathrm{~m}, 1 \mathrm{H})$.

${ }^{13}$ C NMR: $\left(126 \mathrm{MHz}, \mathrm{CD}_{3} \mathrm{CN}, 25{ }^{\circ} \mathrm{C}, \delta\right): 172.3,167.1,165.9,141.8,131.5,130.0,127.2,125.0,121.4,69.7,58.0$, $57.4,52.9,29.3,24.2$.

HRMS (ESI-TOF, m/z):

Calc'd for $\mathrm{C}_{15} \mathrm{H}_{19} \mathrm{~N}_{2} \mathrm{O}_{6}{ }^{+}\left([\mathrm{M}+\mathrm{H}]^{+}\right)$323.1238; found 323.1220.

Calc'd for $\mathrm{C}_{15} \mathrm{H}_{18} \mathrm{~N}_{2} \mathrm{O}_{6}{ }^{+}\left([\mathrm{M}+\mathrm{Na}]^{+}\right)$345.1057; found 345.1056. 


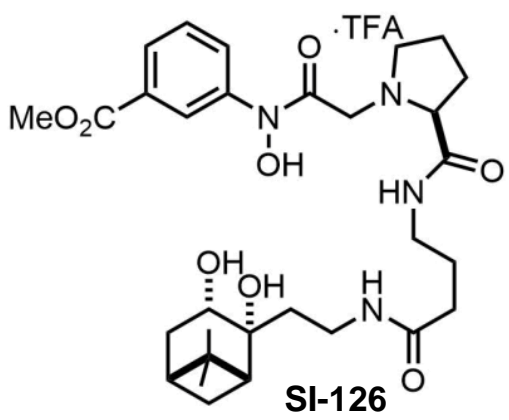

\section{Procedure:}

To a stirred solution of carboxylic acid SI-125 (708 mg, $1.62 \mathrm{mmol}$ ), amine SI-40 (599 mg, $2.11 \mathrm{mmol}, 1.3 \mathrm{eq}$ ), DIPEA ( $577 \mu \mathrm{L}, 3.24 \mathrm{mmol}, 2.0 \mathrm{eq}$ ), and oxyma ( $57 \mathrm{mg}, 0.41 \mathrm{mmol}, 0.25 \mathrm{eq})$ in $8.1 \mathrm{~mL}$ DMF was charged $\mathrm{EDC} \cdot \mathrm{HCl}(357 \mathrm{mg}, 1.86 \mathrm{mmol}, 1.15 \mathrm{eq})$. After 12 hours, most of the DMF was removed on the rotovap. The residue was chromatographed on $15 \mathrm{~g}$ silica (EtOAc to $10 \% \mathrm{v} / \mathrm{v} \mathrm{MeOH}$ in EtOAc) to afford and oil/foam $(721 \mathrm{mg}$ ). This material was purified by preparative HPLC (method B, 15 - 100\% ACN, in two equal loads) to afford SI-126 (512.2 $\mathrm{mg}, 0.729 \mathrm{mmol}, 45 \%$ yield) as a white solid.

${ }^{1} \mathrm{H}$ NMR: $\left(500 \mathrm{MHz}\right.$, acetone- $\left.d_{6}, 25^{\circ} \mathrm{C}, \delta\right)$ :

$8.42(\mathrm{~s}, 1 \mathrm{H}), 8.38(\mathrm{t}, J=5.4 \mathrm{~Hz}, 1 \mathrm{H}), 7.99(\mathrm{~d}, J=8.6 \mathrm{~Hz}, 1 \mathrm{H}), 7.80(\mathrm{~d}, J=6.9 \mathrm{~Hz}, 1 \mathrm{H}), 7.52(\mathrm{~m}, 1 \mathrm{H}), 7.51(\mathrm{t}, J=8.0$ $\mathrm{Hz}, 1 \mathrm{H}), 5.01(\mathrm{~d}, J=16.9 \mathrm{~Hz}, 1 \mathrm{H}), 4.91(\mathrm{~d}, J=16.9 \mathrm{~Hz}, 1 \mathrm{H}), 4.69(\mathrm{dd}, J=8.6,5.2 \mathrm{~Hz}, 1 \mathrm{H}), 4.11(\mathrm{~m}, 1 \mathrm{H}), 4.02(\mathrm{dd}$, $J=9.5,4.9 \mathrm{~Hz}, 1 \mathrm{H}), 3.88(\mathrm{~s}, 3 \mathrm{H}), 3.64(\mathrm{~m}, 1 \mathrm{H}), 3.36(\mathrm{~m}, 3 \mathrm{H}), 3.28(\mathrm{~m}, 1 \mathrm{H}), 2.68(\mathrm{~m}, 1 \mathrm{H}), 2.40(\mathrm{~m}, 1 \mathrm{H}), 2.27(\mathrm{~m}$, 4H), $2.17(\mathrm{~m}, 1 \mathrm{H}), 2.07(\mathrm{~m}, 1 \mathrm{H}), 1.98(\mathrm{t}, J=5.7 \mathrm{~Hz}, 1 \mathrm{H}), 1.81(\mathrm{~m}, 5 \mathrm{H}), 1.61(\mathrm{~m}, 2 \mathrm{H}), 1.41(\mathrm{~d}, J=9.7 \mathrm{~Hz}, 1 \mathrm{H}), 1.20$ (s, 3H), 0.89 (s, 3H).

${ }^{13}$ C NMR: (126 MHz, acetone- $\left.d_{6}, 25^{\circ} \mathrm{C}, \delta\right)$ :

173.6, 169.1, 166.8, 165.9, 142.0, 131.4, 129.6, 126.8, 124.6, 121.1, 75.2, 69.4, 68.0, 58.3, 57.5, 52.8, 52.5, 42.5, $41.3,40.0,39.1,38.9,35.6,33.7,30.7,28.4,28.2,25.9,24.4,24.4$.

HRMS (ESI-TOF, m/z):

Calc'd for $\mathrm{C}_{30} \mathrm{H}_{45} \mathrm{~N}_{4} \mathrm{O}_{8}{ }^{+}\left([\mathrm{M}+\mathrm{H}]^{+}\right)$589.3232; found 589.3184.

Calc'd for $\mathrm{C}_{30} \mathrm{H}_{44} \mathrm{~N}_{4} \mathrm{O}_{8} \mathrm{Na}^{+}\left([\mathrm{M}+\mathrm{Na}]^{+}\right)$611.3051; found 611.3040 . 


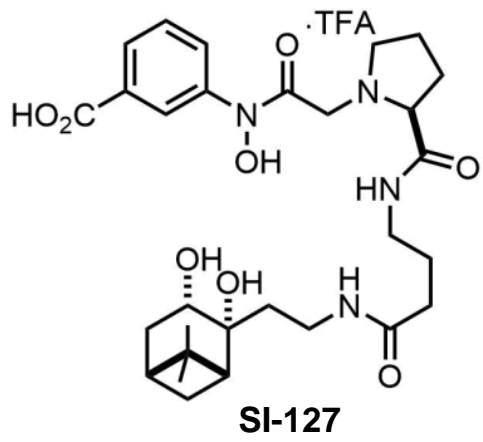

\section{Procedure:}

To a flask containing methyl ester SI-126 (512.2 mg, 0.729 mmol) was charged LiOH (0.5 M in $\mathrm{H}_{2} \mathrm{O}, 10.2 \mathrm{~mL}, 5.10$ mmol, $7.0 \mathrm{eq})$. After stirring for 40 minutes, the $\mathrm{pH}$ was adjusted to 5 with citric acid, and the volume was reduced to ca. $2 \mathrm{~mL}$ on the rotovap (note: a slurry forms). $2 \mathrm{~mL} \mathrm{ACN} \mathrm{was} \mathrm{charged,} \mathrm{and} \mathrm{the} \mathrm{resulting} \mathrm{clear} \mathrm{solution} \mathrm{was}$ purified by preparative HPLC (method B, 10 - 80\% ACN, in two equal loads) to afford carboxylic acid SI-127 (419.0 mg, $0.608 \mathrm{mmol}, 83 \%$ yield) as a white solid.

${ }^{1}$ H NMR: $\left(500 \mathrm{MHz}, \mathrm{CD}_{3} \mathrm{CN}, 25^{\circ} \mathrm{C}, \delta\right)$ :

8.34 (s, 1H), $7.86(\mathrm{~d}, J=8.0 \mathrm{~Hz}, 1 \mathrm{H}), 7.80(\mathrm{~d}, J=8.0 \mathrm{~Hz}, 1 \mathrm{H}), 7.47$ (t, $J=8.0 \mathrm{~Hz}, 1 \mathrm{H}), 7.41$ (br s, $1 \mathrm{H}), 6.65$ (br s, $1 \mathrm{H}), 4.70(\mathrm{~d}, J=16.9 \mathrm{~Hz}, 1 \mathrm{H}), 4.60(\mathrm{~d}, J=16.9 \mathrm{~Hz}, 1 \mathrm{H}), 4.34(\mathrm{dd}, J=8.6,4.6 \mathrm{~Hz}, 1 \mathrm{H}), 4.24(\mathrm{~d}, J=8.6 \mathrm{~Hz}, 1 \mathrm{H})$, $3.84(\mathrm{~m}, 1 \mathrm{H}), 3.32(\mathrm{~m}, 2 \mathrm{H}), 3.16(\mathrm{~m}, 2 \mathrm{H}), 2.45(\mathrm{~m}, 1 \mathrm{H}), 2.29(\mathrm{~m}, 1 \mathrm{H}), 2.14(\mathrm{~m}, 4 \mathrm{H}), 2.03(\mathrm{~m}, 3 \mathrm{H}), 1.96(\mathrm{~m}, 1 \mathrm{H})$, $1.84(\mathrm{~m}, 1 \mathrm{H}), 1.74(\mathrm{~m}, 5 \mathrm{H}), 1.20(\mathrm{~s}, 3 \mathrm{H}), 1.10(\mathrm{~d}, J=10.9 \mathrm{~Hz}, 1 \mathrm{H}), 0.75(\mathrm{~s}, 3 \mathrm{H})$.

${ }^{13}$ C NMR: $\left(126 \mathrm{MHz}, \mathrm{CD}_{3} \mathrm{CN}, 25^{\circ} \mathrm{C}, \delta\right)$ :

173.5, 169.1, 167.6, 165.6, 141.8, 131.8, 130.0, 127.6, 124.8, 121.8, 86.2, 76.3, 69.4, 58.2, 57.6, 50.1, 40.4, 40.3, $40.1,39.0,36.5,35.4,33.7,30.8,27.2,26.4,25.7,24.5,23.9$.

HRMS (ESI-TOF, m/z):

Calc'd for $\mathrm{C}_{29} \mathrm{H}_{43} \mathrm{~N}_{4} \mathrm{O}_{8}{ }^{+}\left([\mathrm{M}+\mathrm{H}]^{+}\right)$575.3075; found 575.3066.

Calc'd for $\mathrm{C}_{29} \mathrm{H}_{43} \mathrm{~N}_{4} \mathrm{O}_{8} \mathrm{Na}^{+}\left([\mathrm{M}+\mathrm{Na}]^{+}\right)$597.2895; found 597.2885. 


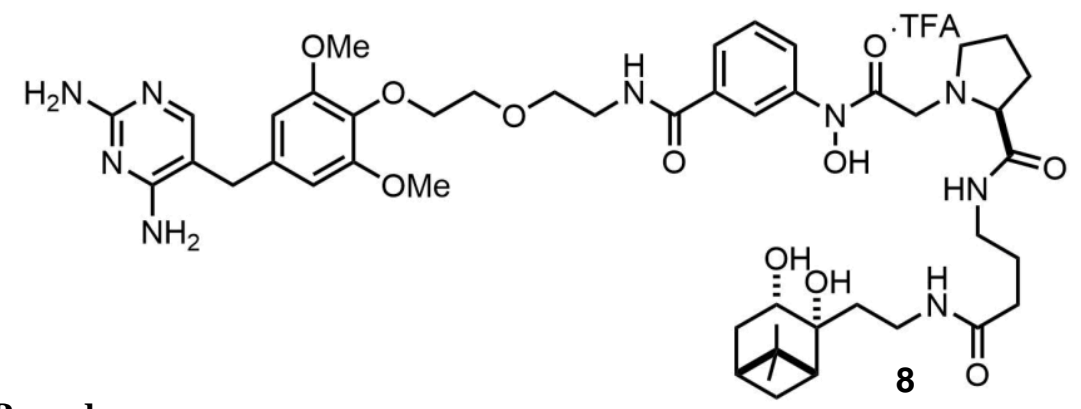

\section{Procedure:}

To a stirred solution of carboxylic acid SI-127 (27.5 mg, $40 \mu \mathrm{mol})$, TMP-amine ${ }^{1}$ (23.9 mg, $\left.50 \mu \mathrm{mol}, 1.25 \mathrm{eq}\right)$ DIPEA ( $28 \mu \mathrm{L}, 0.16 \mathrm{mmol}, 4 \mathrm{eq})$, and oxyma ( $2.3 \mathrm{mg}, 16 \mu \mathrm{mol}, 0.4 \mathrm{eq})$ in $0.4 \mathrm{~mL}$ DMF was charged EDC.HCl ( 8.8 $\mathrm{mg}, 46 \mu \mathrm{mol}, 1.15 \mathrm{eq})$. After 18 hours, most of the DMF was removed on the rotovap. The residue was chromatographed on $1 \mathrm{~g}$ silica (EtOAc to $20 \% \mathrm{v} / \mathrm{v} \mathrm{MeOH}$ in EtOAc) to afford an oil. This material was purified by preparative HPLC (method A, 5 - 70\% ACN) to afford 8 (22.7 mg, $22.0 \mu \mathrm{mol}, 55 \%$ yield) as a white solid.

${ }^{1}$ H NMR: $\left(500 \mathrm{MHz}, \mathrm{CD}_{3} \mathrm{CN}, 25^{\circ} \mathrm{C}, \delta\right)$ :

$8.15(\mathrm{~s}, 1 \mathrm{H}), 7.76(\mathrm{~d}, J=8.0 \mathrm{~Hz}, 1 \mathrm{H}), 7.51(\mathrm{~d}, J=7.4 \mathrm{~Hz}, 1 \mathrm{H}), 7.48(\mathrm{~m}, 2 \mathrm{H}), 7.32(\mathrm{~m}, 2 \mathrm{H}), 6.93(\mathrm{br} \mathrm{s}, 1 \mathrm{H}), 6.77$ (br s, 1H), $6.46(\mathrm{~s}, 2 \mathrm{H}), 6.26(\mathrm{br} \mathrm{s}, 1 \mathrm{H}), 4.67(\mathrm{~d}, J=16.9 \mathrm{~Hz}, 1 \mathrm{H}), 4.60(\mathrm{~d}, J=16.9 \mathrm{~Hz}, 1 \mathrm{H}), 4.34(\mathrm{~m}, 1 \mathrm{H}), 4.00(\mathrm{dd}, J=$ 4.6, $3.4 \mathrm{~Hz}, 2 \mathrm{H}), 3.89(\mathrm{~m}, 1 \mathrm{H}), 3.70(\mathrm{~m}, 8 \mathrm{H}), 3.64(\mathrm{~m}, 2 \mathrm{H}), 3.57(\mathrm{~s}, 2 \mathrm{H}), 3.51(\mathrm{~m}, 2 \mathrm{H}), 3.23(\mathrm{~m}, 5 \mathrm{H}), 2.47(\mathrm{~m}, 1 \mathrm{H})$, $2.36(\mathrm{~m}, 1 \mathrm{H}), 2.15(\mathrm{~m}, 3 \mathrm{H}), 2.07(\mathrm{~m}, 1 \mathrm{H}), 2.00(\mathrm{~m}, 1 \mathrm{H}), 1.77(\mathrm{~m}, 2 \mathrm{H}), 1.69(\mathrm{~m}, 2 \mathrm{H}), 1.53(\mathrm{~m}, 2 \mathrm{H}), 1.30(\mathrm{~d}, J=9.2$ $\mathrm{Hz}, 1 \mathrm{H}), 1.18$ (s, 3H), 0.84 (s, 3H).

${ }^{13} \mathrm{C}$ NMR: $\left(126 \mathrm{MHz}, \mathrm{CD}_{3} \mathrm{CN}, 25^{\circ} \mathrm{C}, \delta\right)$ :

169.0, 167.8, 165.6, 165.5, 156.4, 154.3, 141.6, 141.4, 136.4, 136.0, 133.3, 129.6, 124.8, 123.3, 119.8, 116.2, 109.5, $106.7,75.6,72.8,71.0,69.9,69.4,68.2,58.1,57.6,56.6,52.7,42.2,41.3,40.6,40.0,39.2,38.7,35.6,33.7,33.6$, $30.7,28.3,28.0,25.6,24.5,24.3$.

HRMS (ESI-TOF, m/z):

Calc'd for $\mathrm{C}_{46} \mathrm{H}_{66} \mathrm{~N}_{9} \mathrm{O}_{11}{ }^{+}\left([\mathrm{M}+\mathrm{H}]^{+}\right)$920.4876; found 920.4868 .

Calc'd for $\mathrm{C}_{46} \mathrm{H}_{65} \mathrm{~N}_{9} \mathrm{O}_{11} \mathrm{Na}^{+}\left([\mathrm{M}+\mathrm{Na}]^{+}\right)$942.4696; found 942.4679 . 


\section{References}

(1) Hamajima, W.; Fujimura, A.; Fujiwara, Y.; Yamatsugu, K.; Kawashima, S. A.; Kanai, M. Site-Selective Synthetic Acylation of a Target Protein in Living Cells Promoted by a Chemical Catalyst/Donor System. ACS Chemical Biology 2019, 14, 1102-1109.

(2) Fu, K.; Wang, Q. F.; Zhan, F. X.; Yang, L.; Yang, Q.; Zheng, G. X. An Improved Process for Preparation of S-Acetyl-1-Glutathione. Organic Process Research and Development 2015, 19, 590-593.

(3) Raghavan, B.; Johnson, R. L. Short Stereoselective Synthesis of $\alpha$-Substituted $\gamma$-Lactams. Journal of Organic Chemistry 2006, 71, 2151-2154.

(4) Hojczyk, K. N.; Feng, P.; Zhan, C.; Ngai, M. Y. Trifluoromethoxylation of Arenes: Synthesis of OrthoTrifluoromethoxylated Aniline Derivatives by OCF3 Migration. Angewandte Chemie - International Edition 2014, 53, 14559-14563.

(5) Gunawardana, I. W. Cell Adhesion-Inhibiting Antiinflammatory and Immune-Suppressive Compounds. US Patent US 2004/0116518 A1, June 17, 2004.

(6) Zhu, G.; Yang, F.; Balachandran, R.; Höök, P.; Vallee, R. B.; Curran, D. P.; Day, B. W. Synthesis and Biological Evaluation of Purealin and Analogues as Cytoplasmic Dynein Heavy Chain Inhibitors. Journal of Medicinal Chemistry 2006, 49, 2063-2076.

(7) Xie, H.; Ng, D.; Savinov, S. N.; Dey, B.; Kwong, P. D.; Wyatt, R.; Smith, A. B.; Hendrickson, W. A. Structure-Activity Relationships in the Binding of Chemically Derivatized CD4 to Gp120 from Human Immunodeficiency Virus. Journal of Medicinal Chemistry 2007, 50, 4898-4908.

(8) Atack, T. C.; Raymond, D. D.; Blomquist, C. A.; Pasaje, C. F.; McCarren, P. R.; Moroco, J.; Befekadu, H. B.; Robinson, F. P.; Pal, D.; Esherick, L. Y.; Ianari, A.; Niles, J. C.; Sellers, W. R. Targeted Covalent Inhibition of Plasmodium FK506 Binding Protein 35. ACS Medicinal Chemistry Letters 2020, 11, 21312138 .

(9) Liu, T.; Yan, N.; Zhao, H.; Wang, Z. X.; Hu, X. G. Synthesis and Antibacterial Activity of 6(R)- and 6(S)Fluoropenibruguieramine As: Fluorine as a Probe for Testing the Powerfulness of Memory of Chirality (MOC). Journal of Fluorine Chemistry 2018, 207, 18-23. 

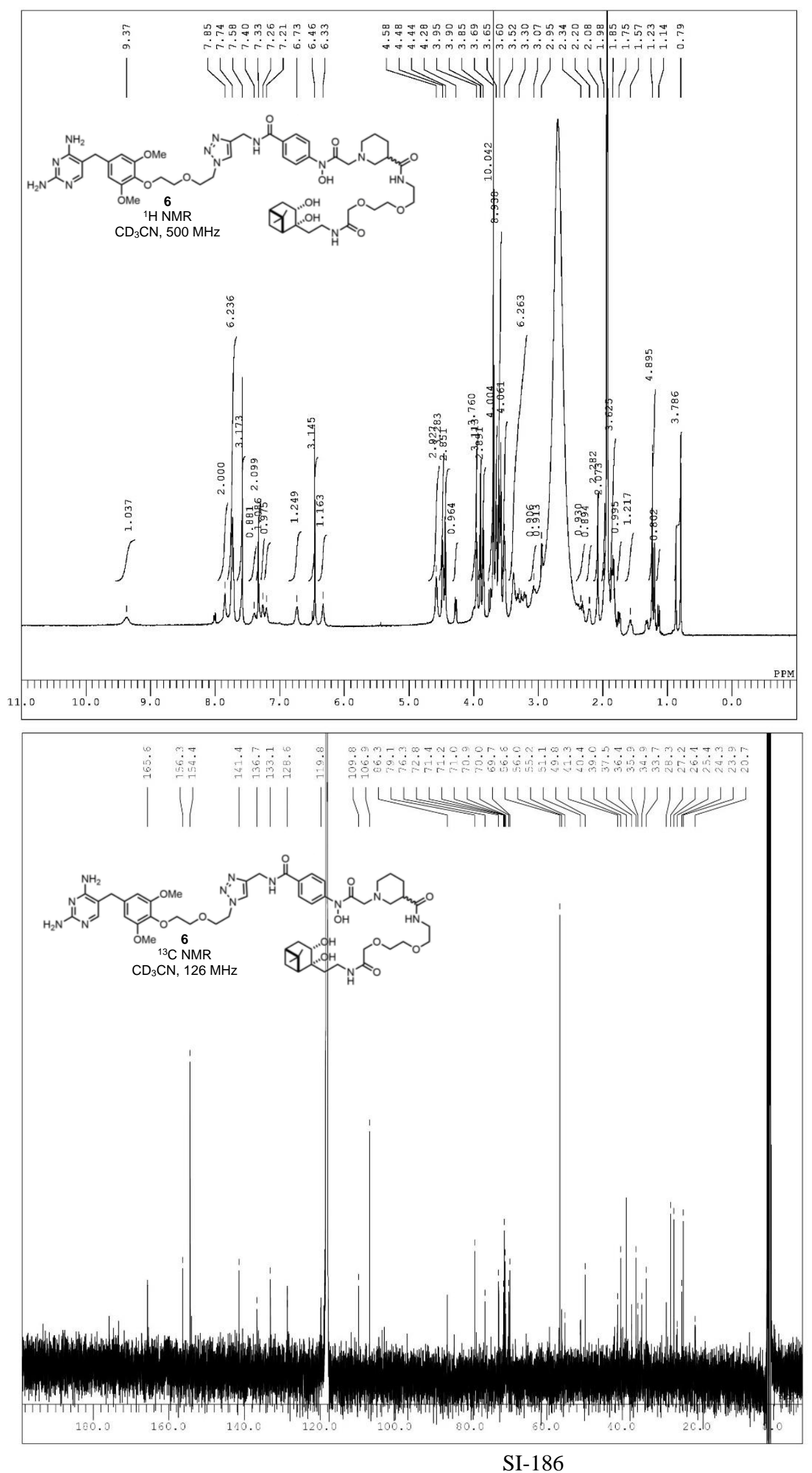

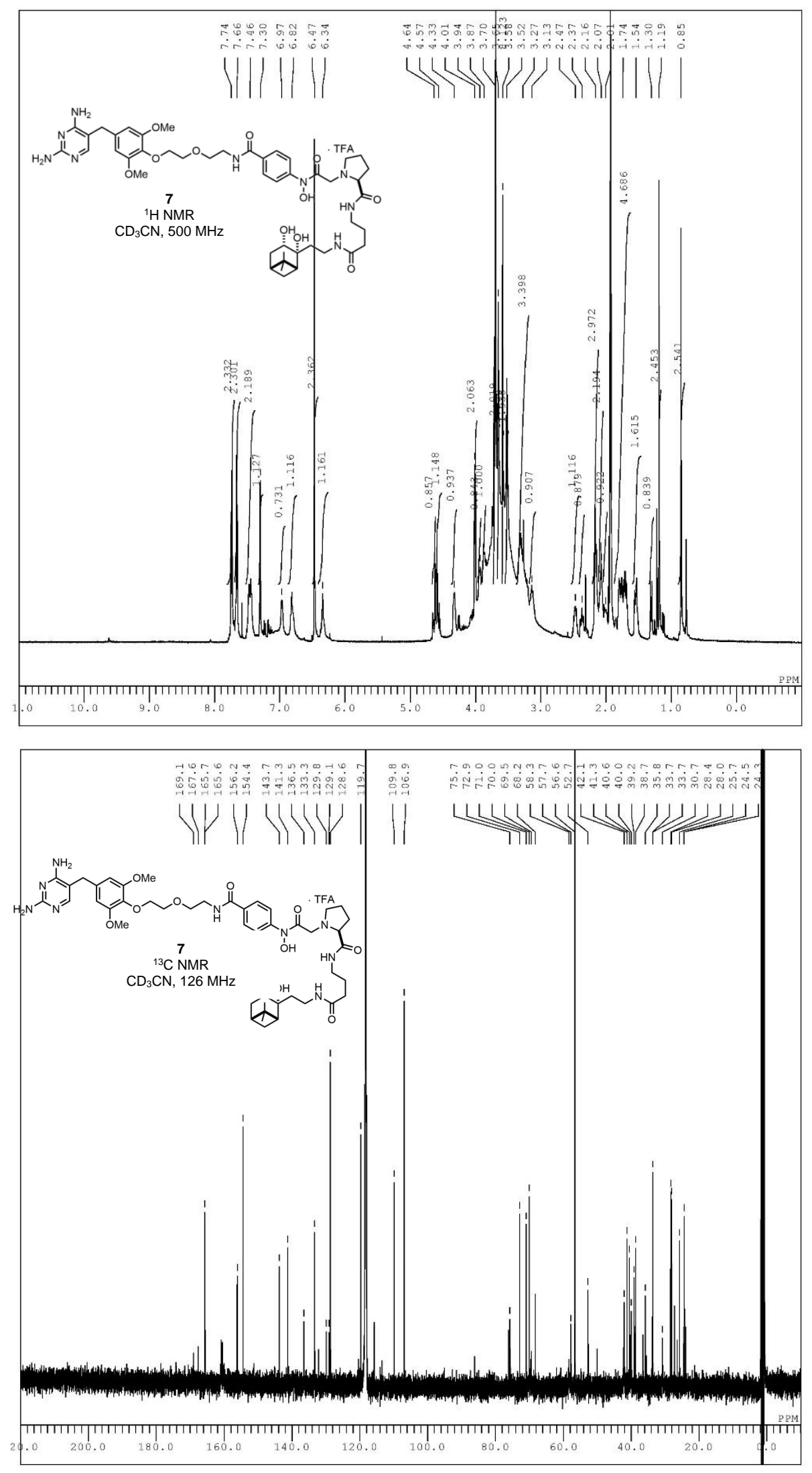

SI-187 

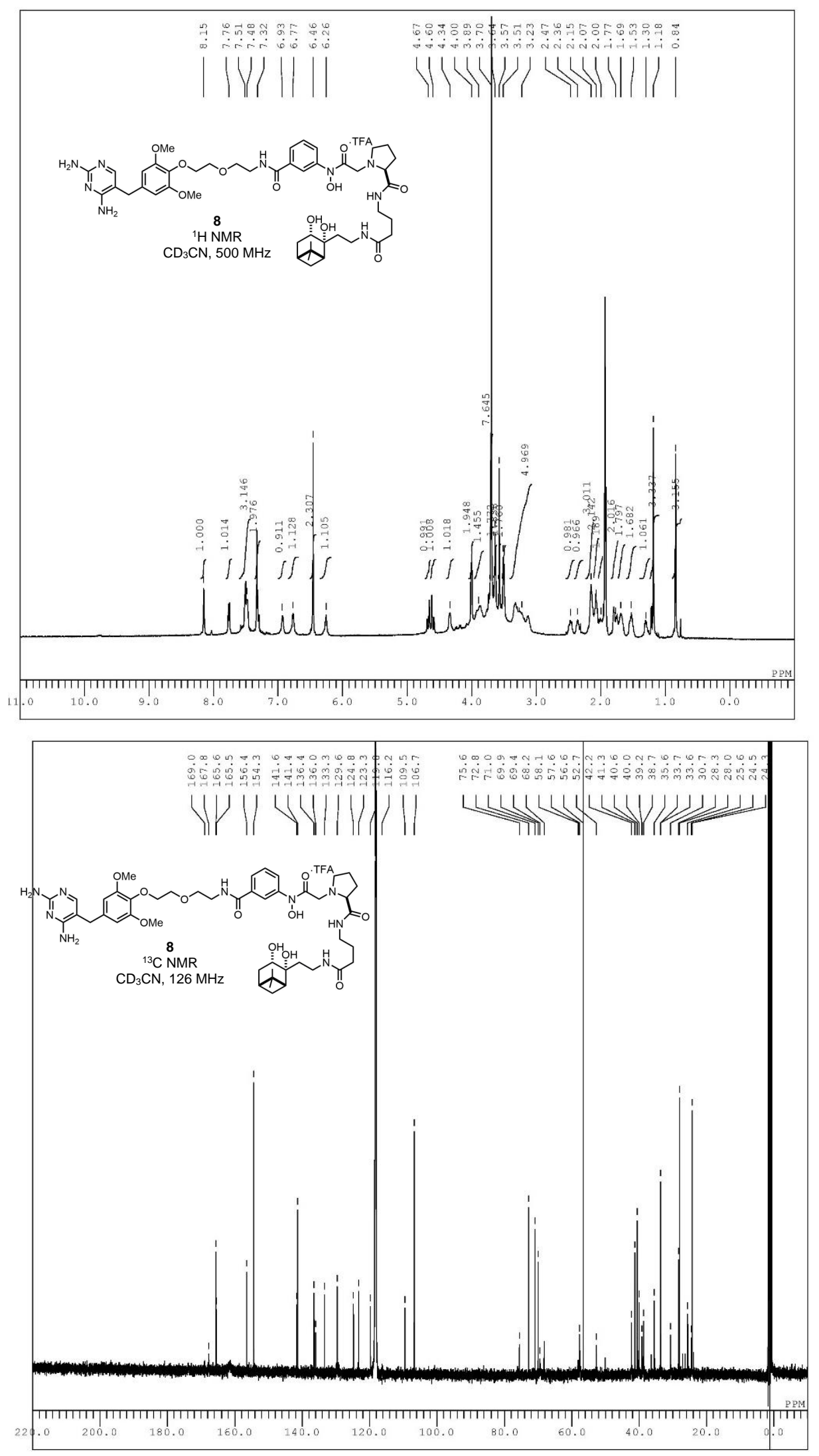

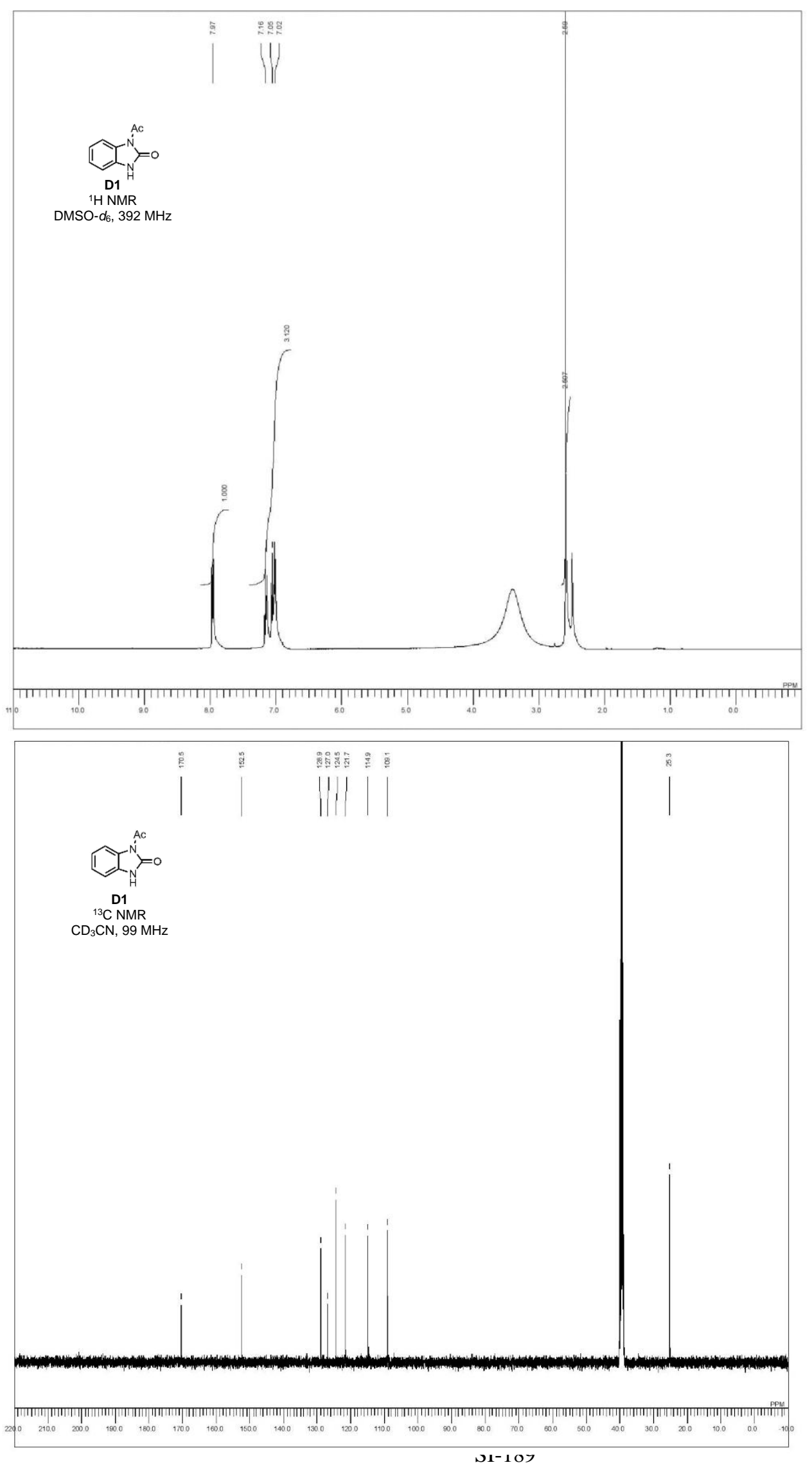

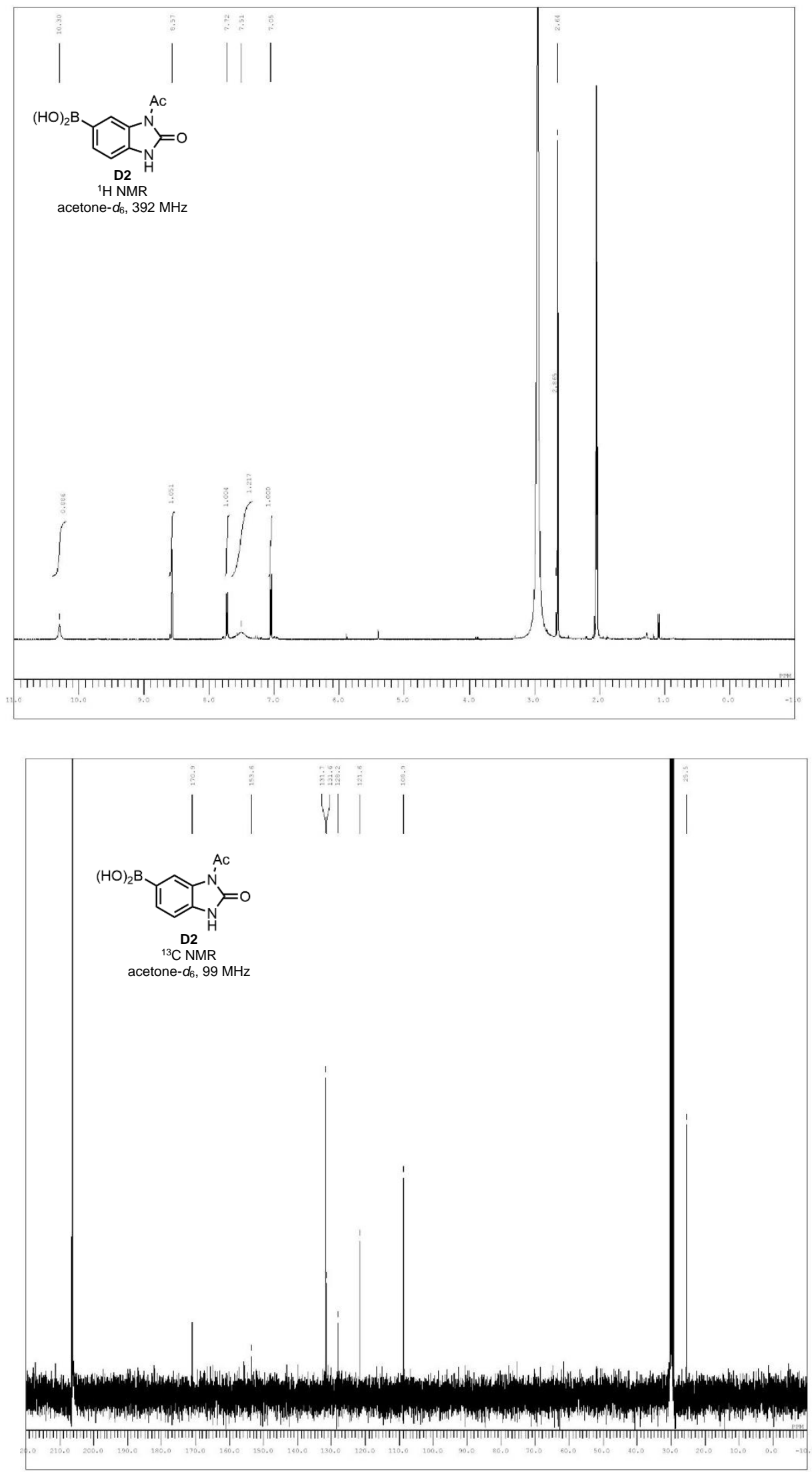

SI-190 

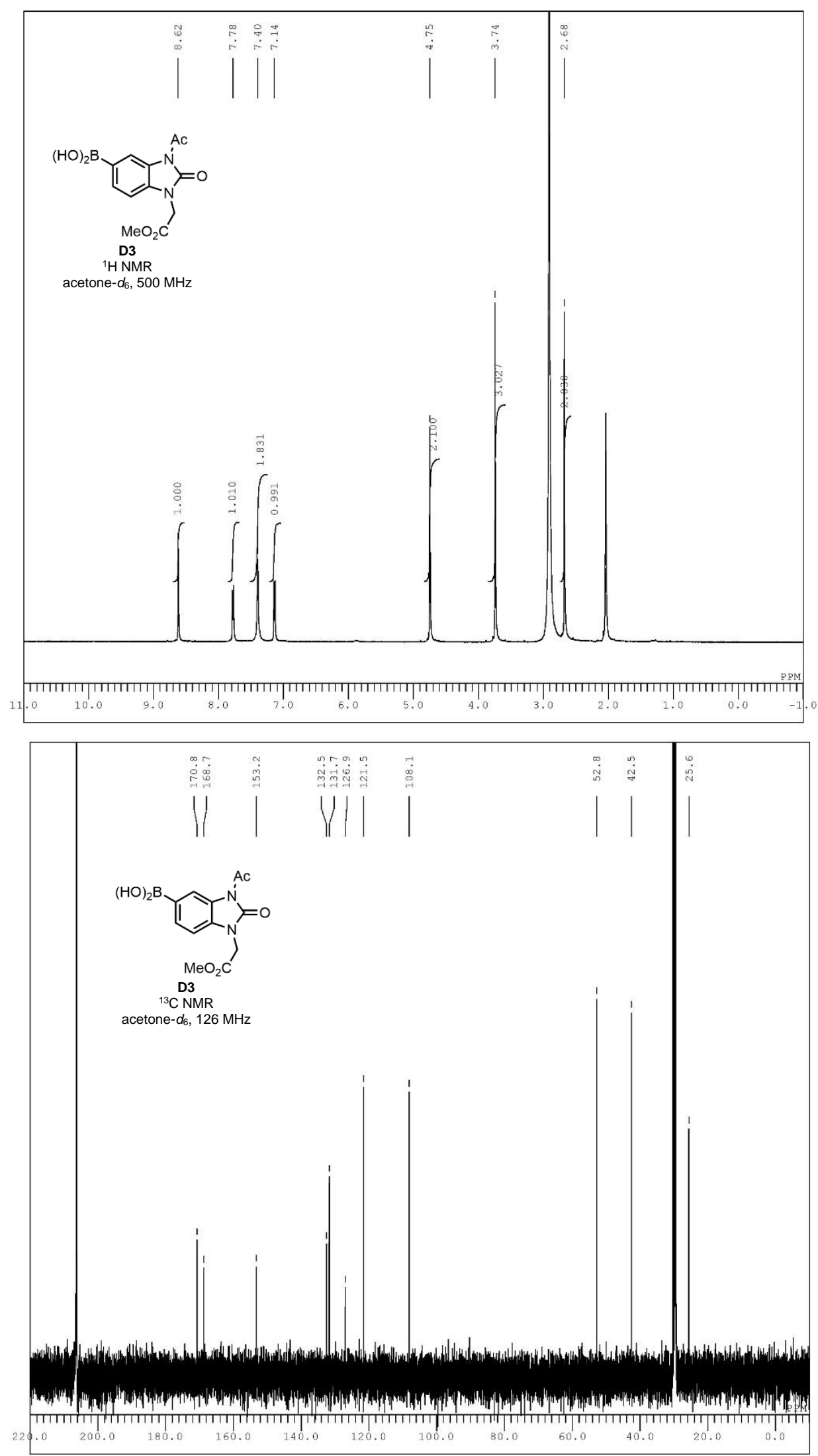

SI-191 

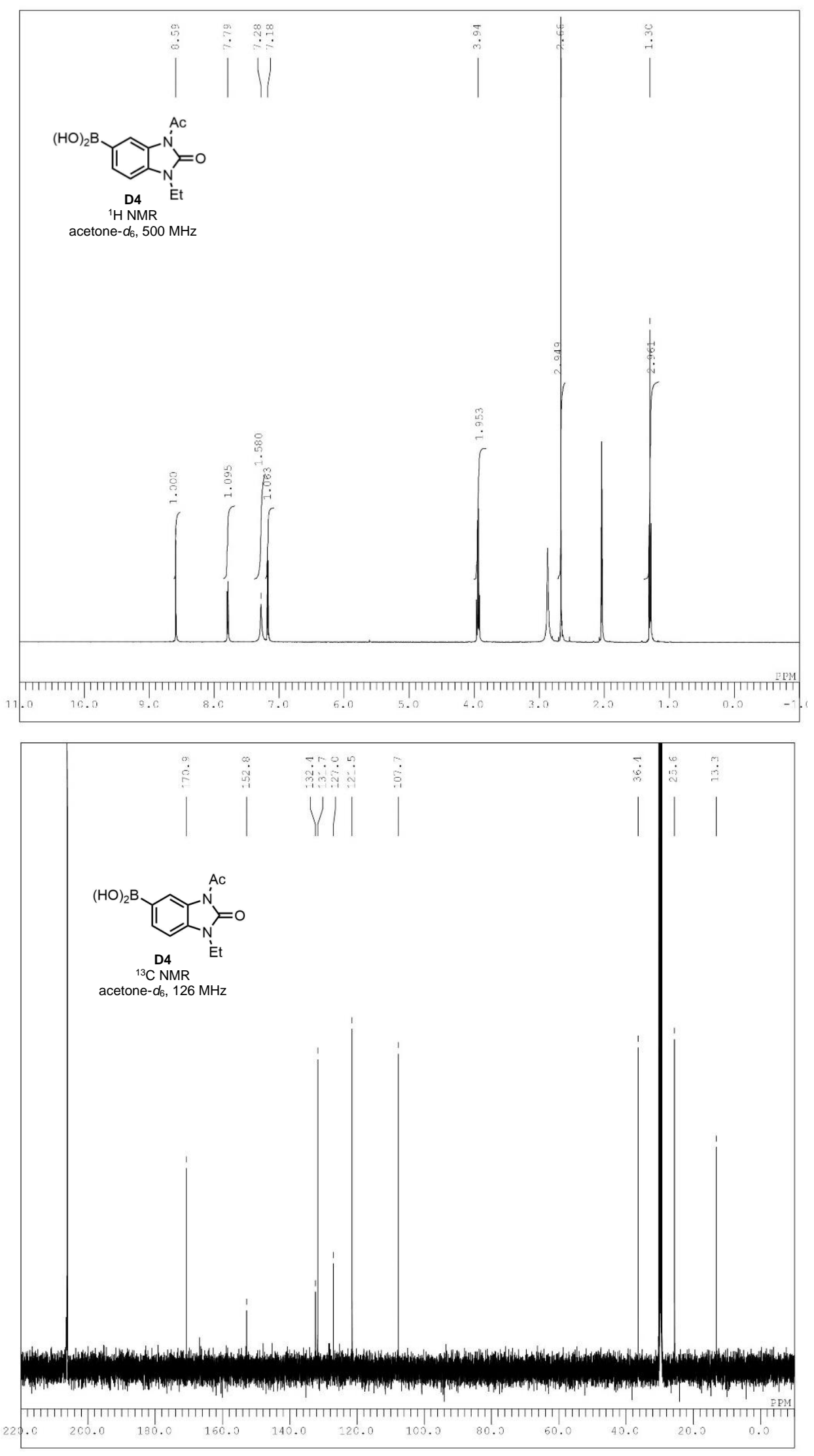

SI-192 

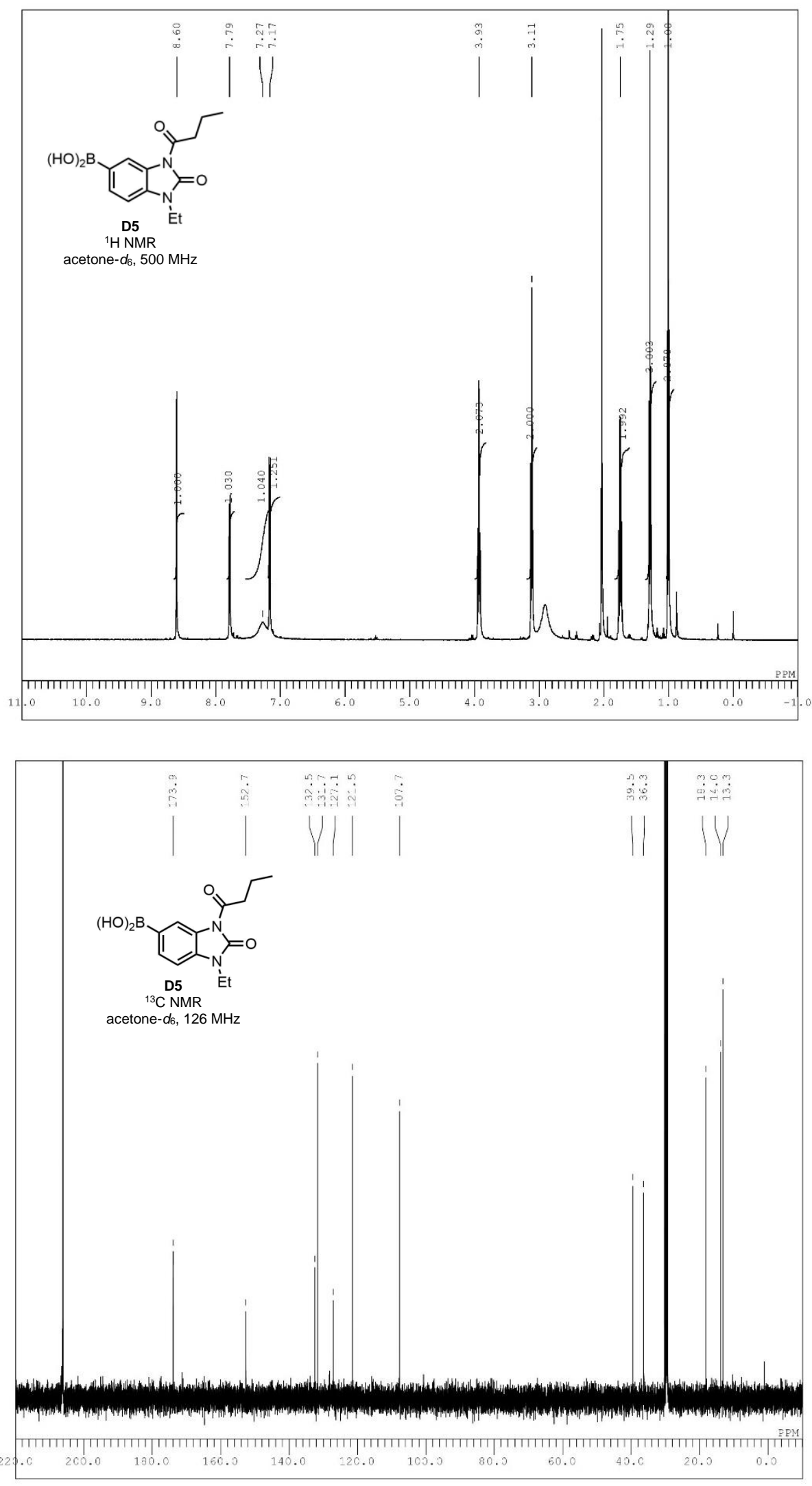

SI-193 

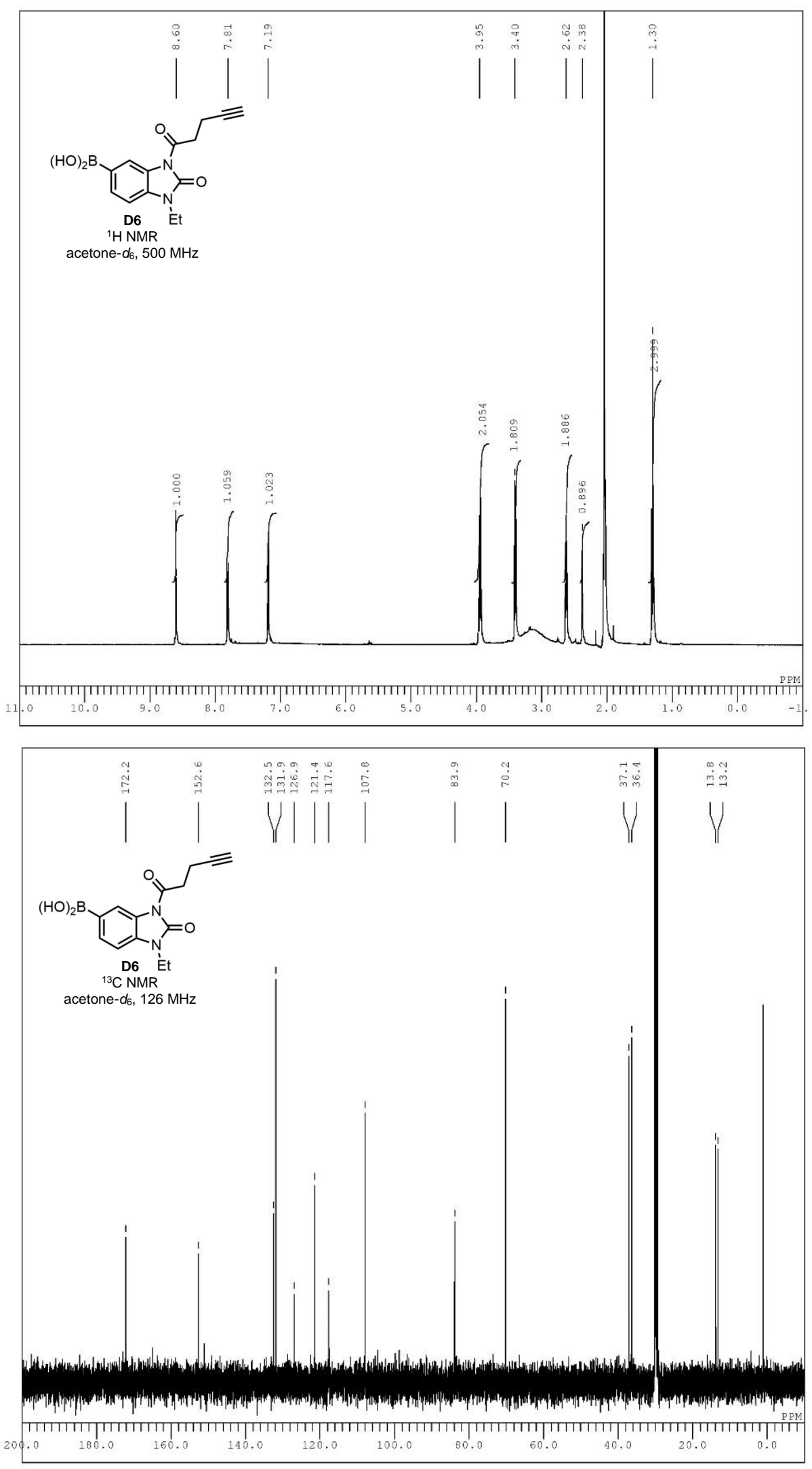

SI-194 


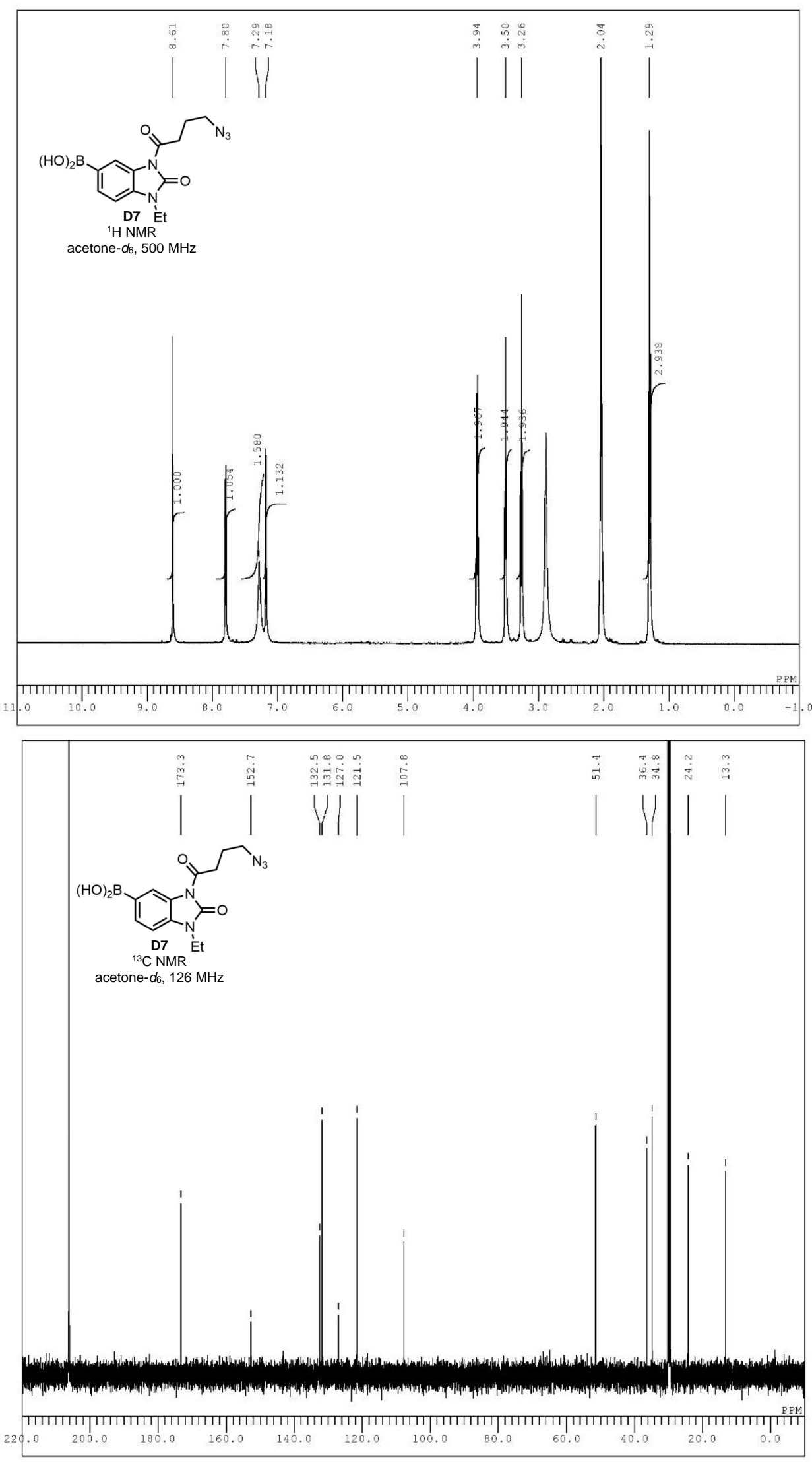

SI-195 


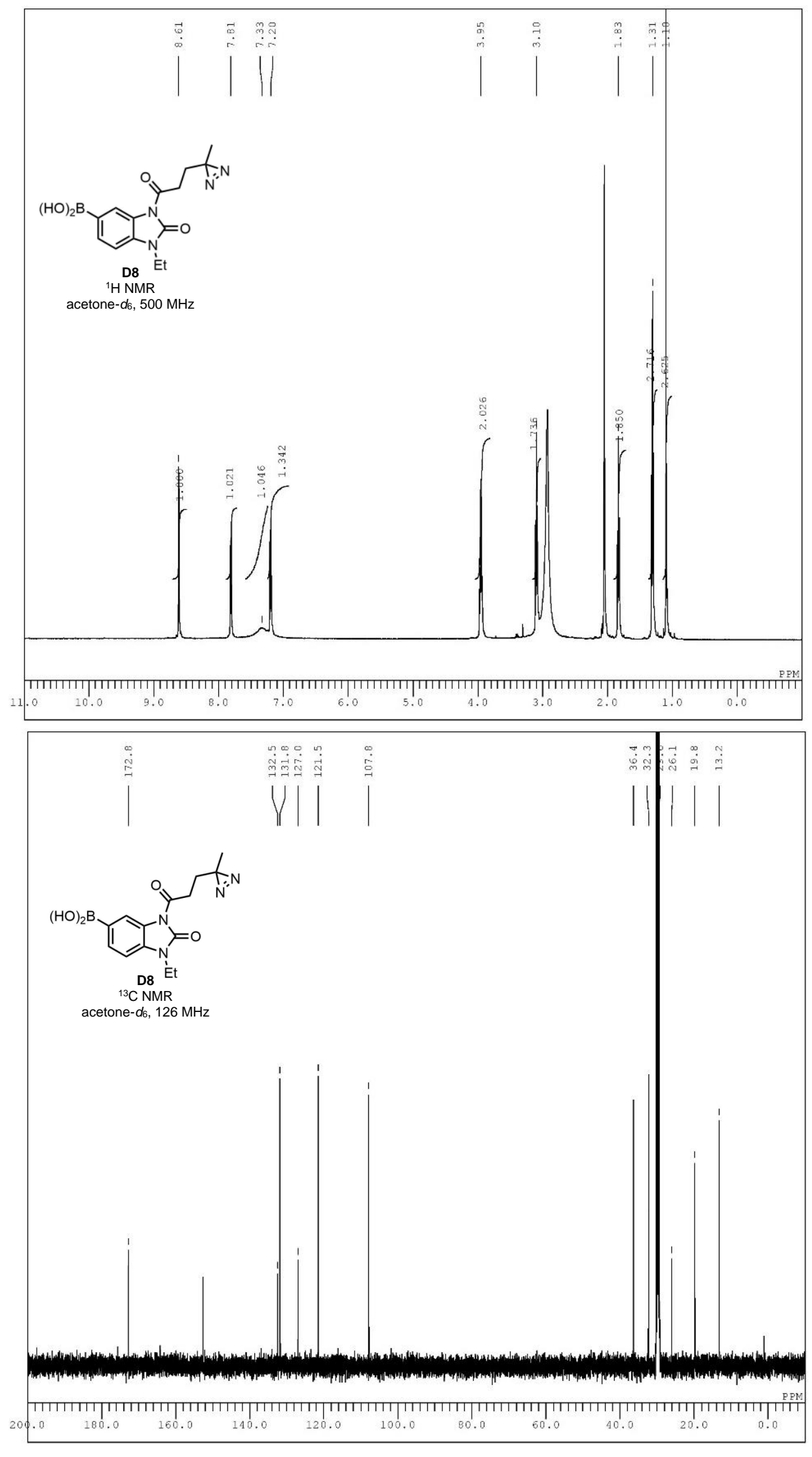

SI-196 

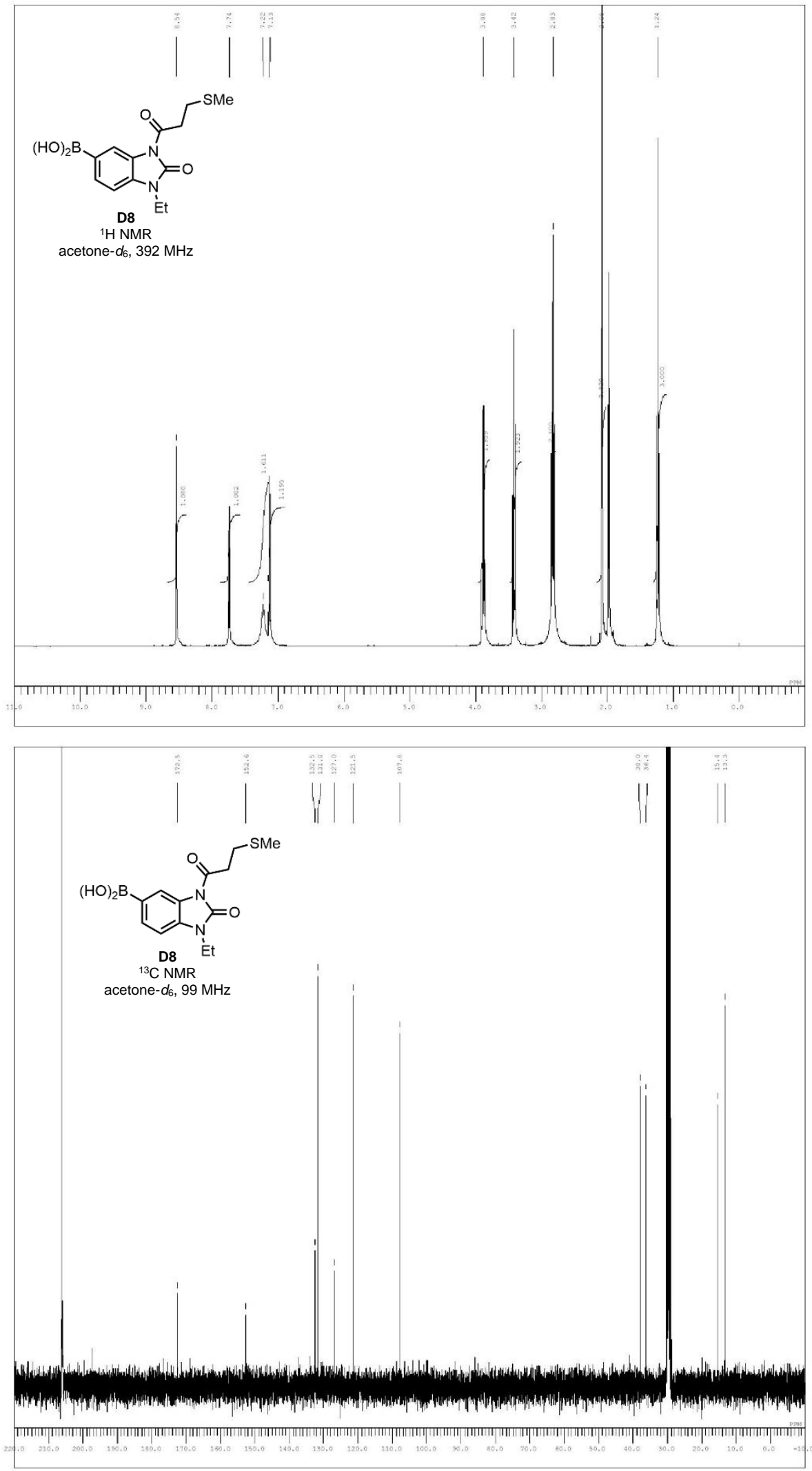

SI-197 

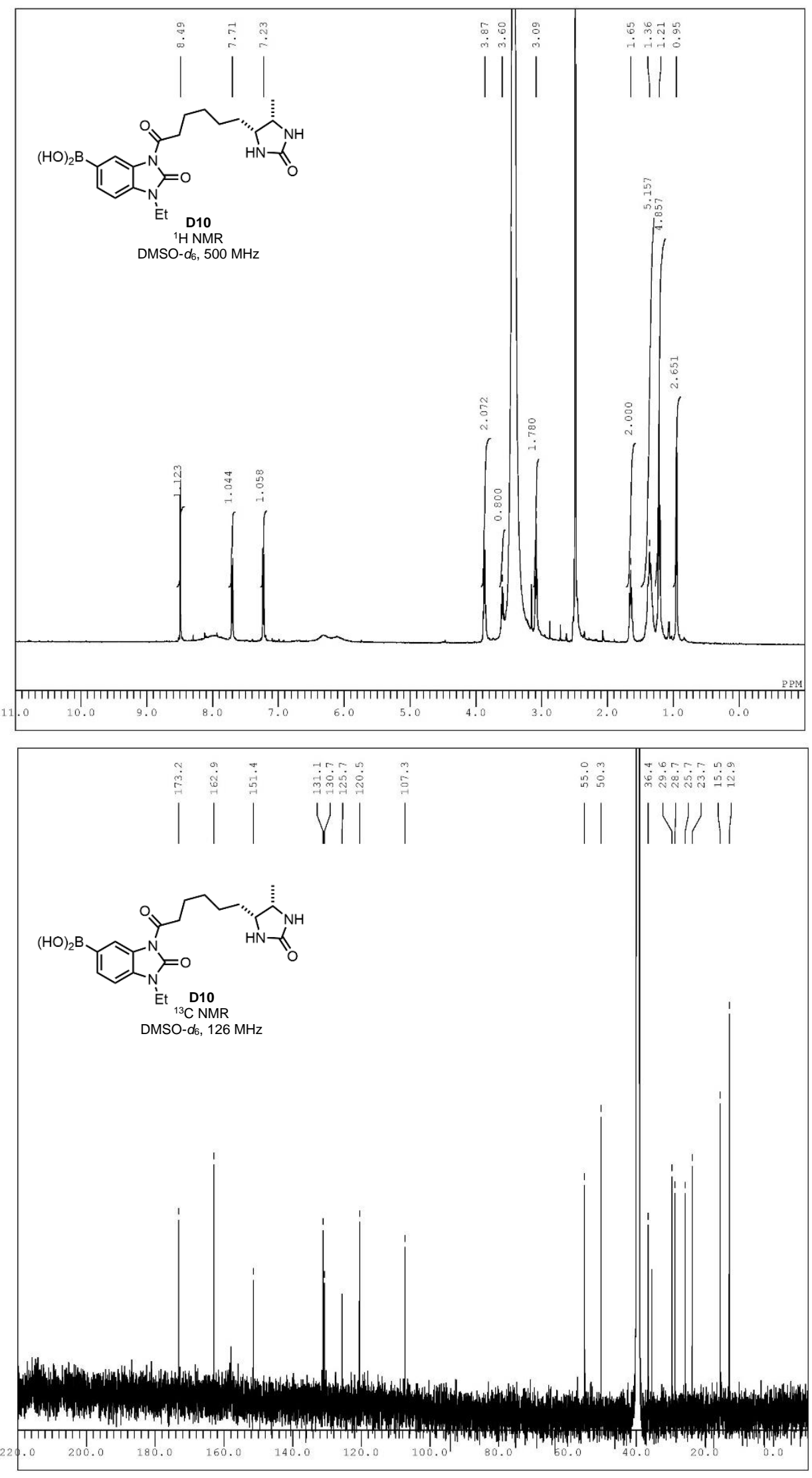

SI-198 

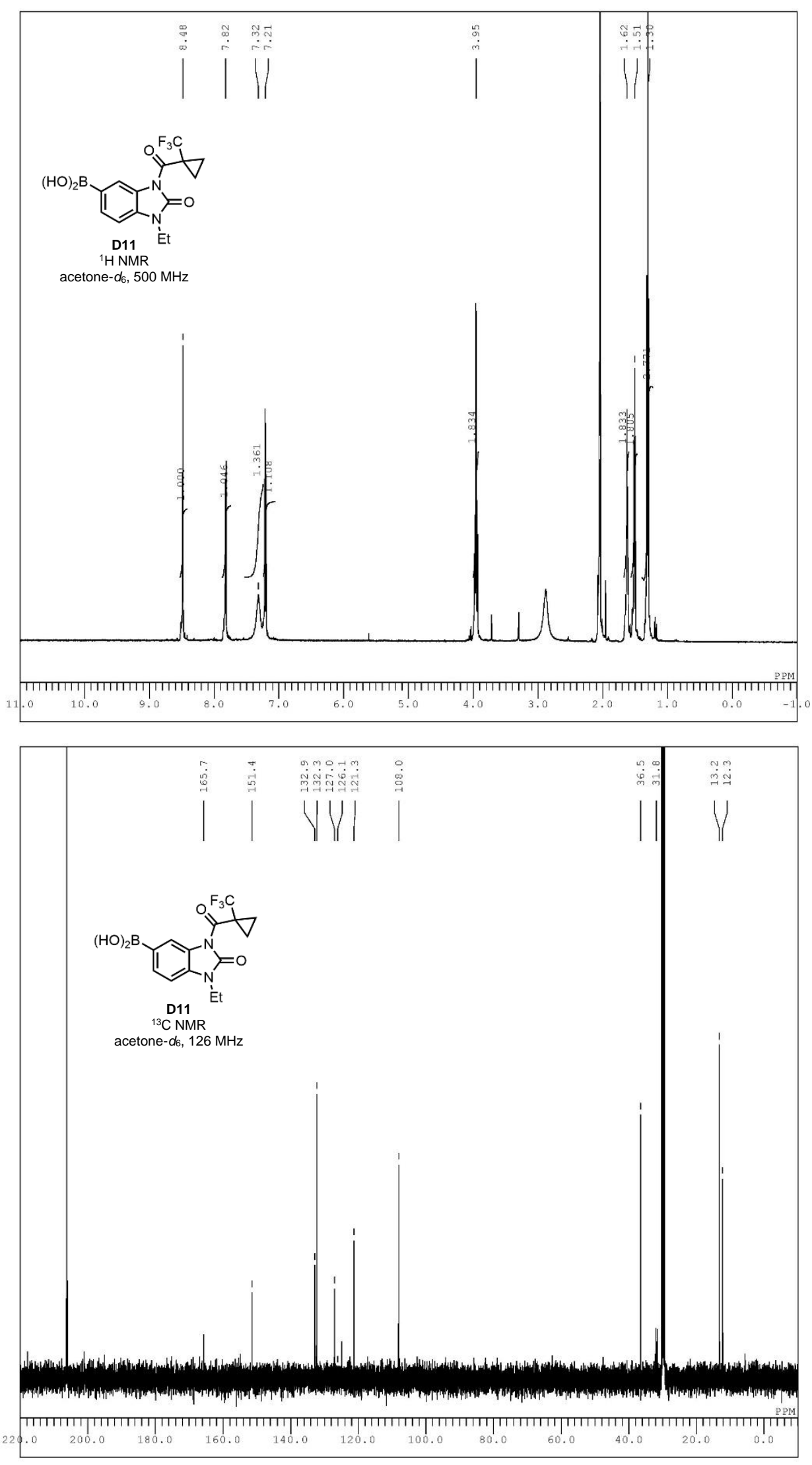

SI-199 

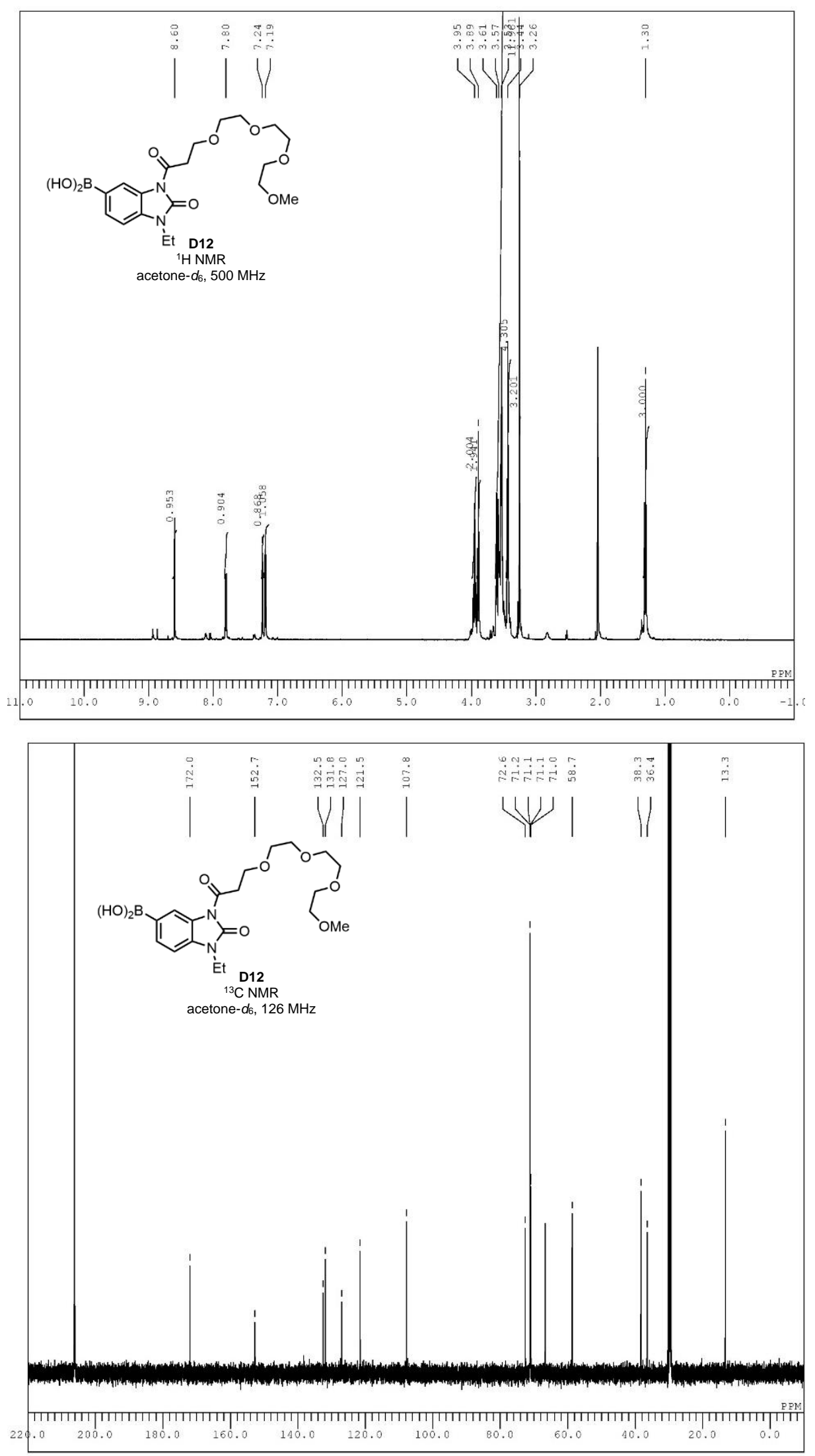

SI-200 

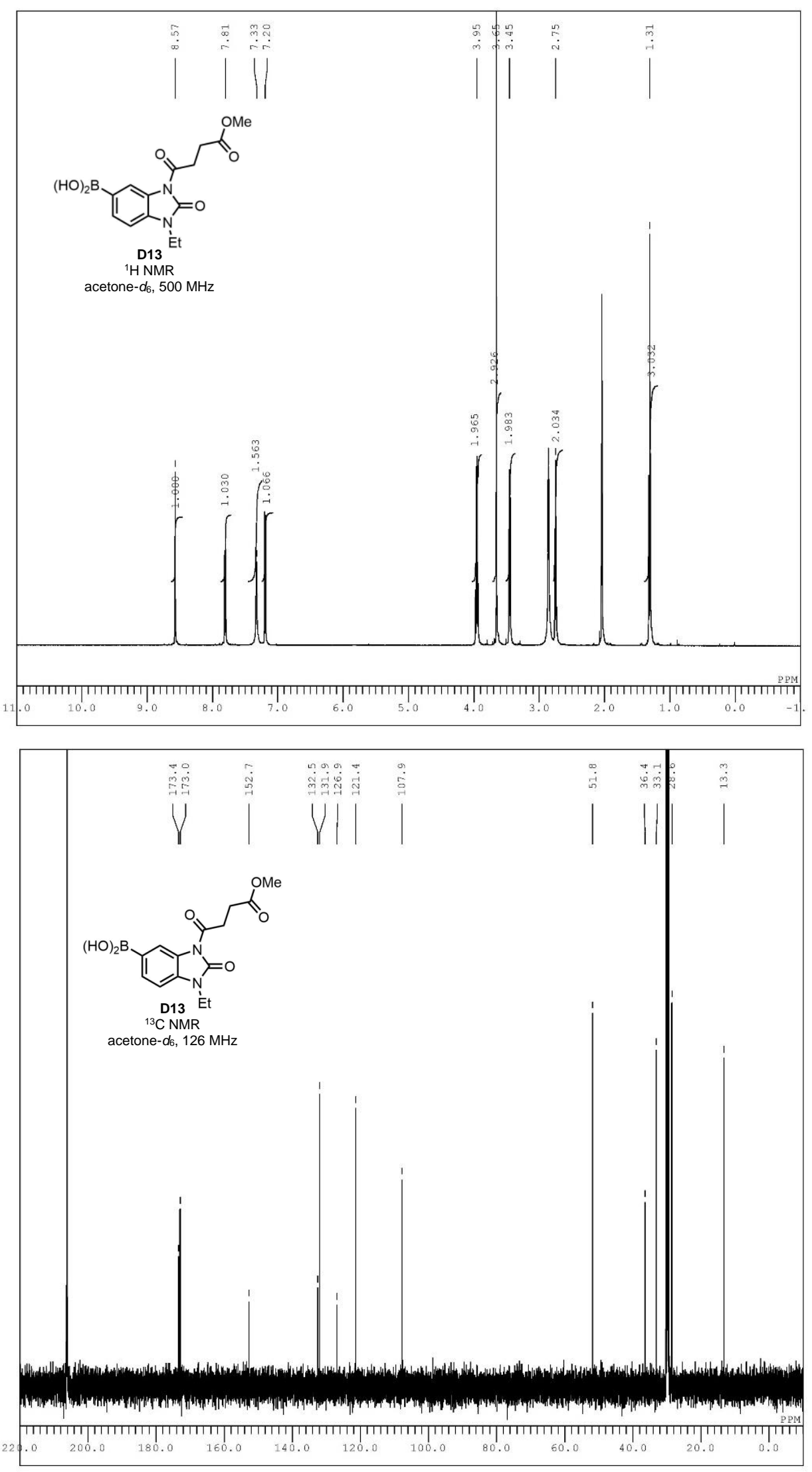

SI-201 

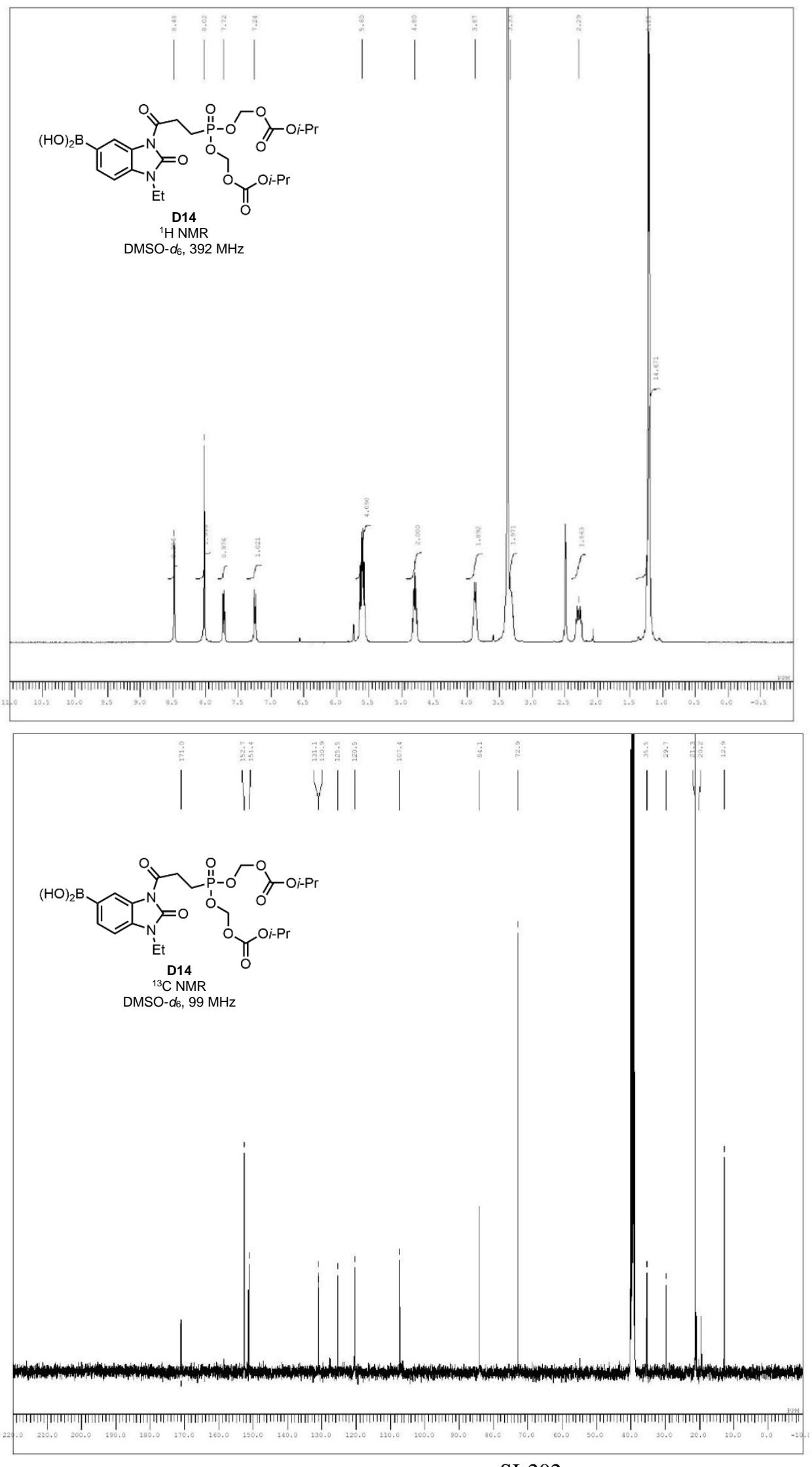

SI-202 

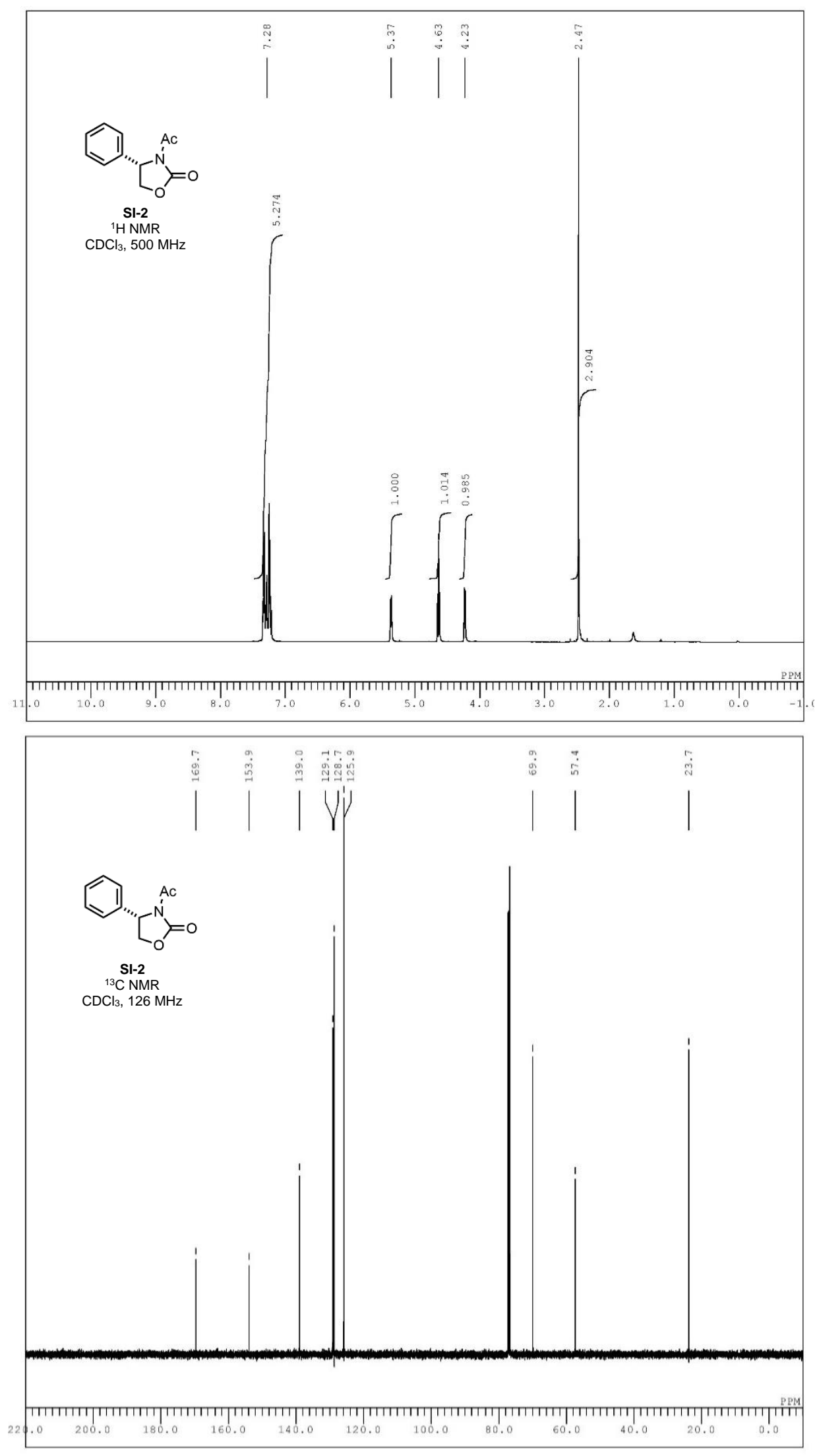

SI-203 

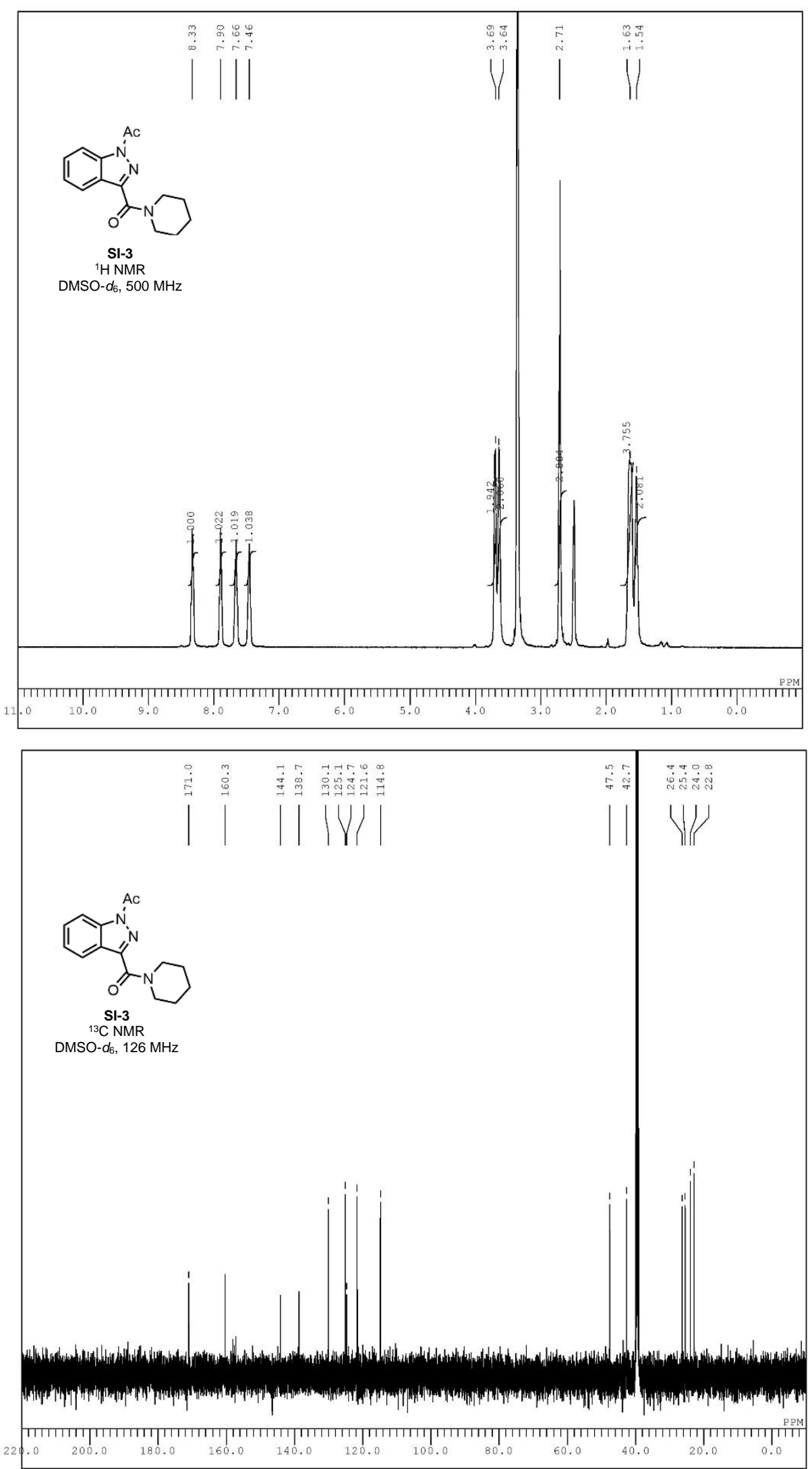

SI-204 

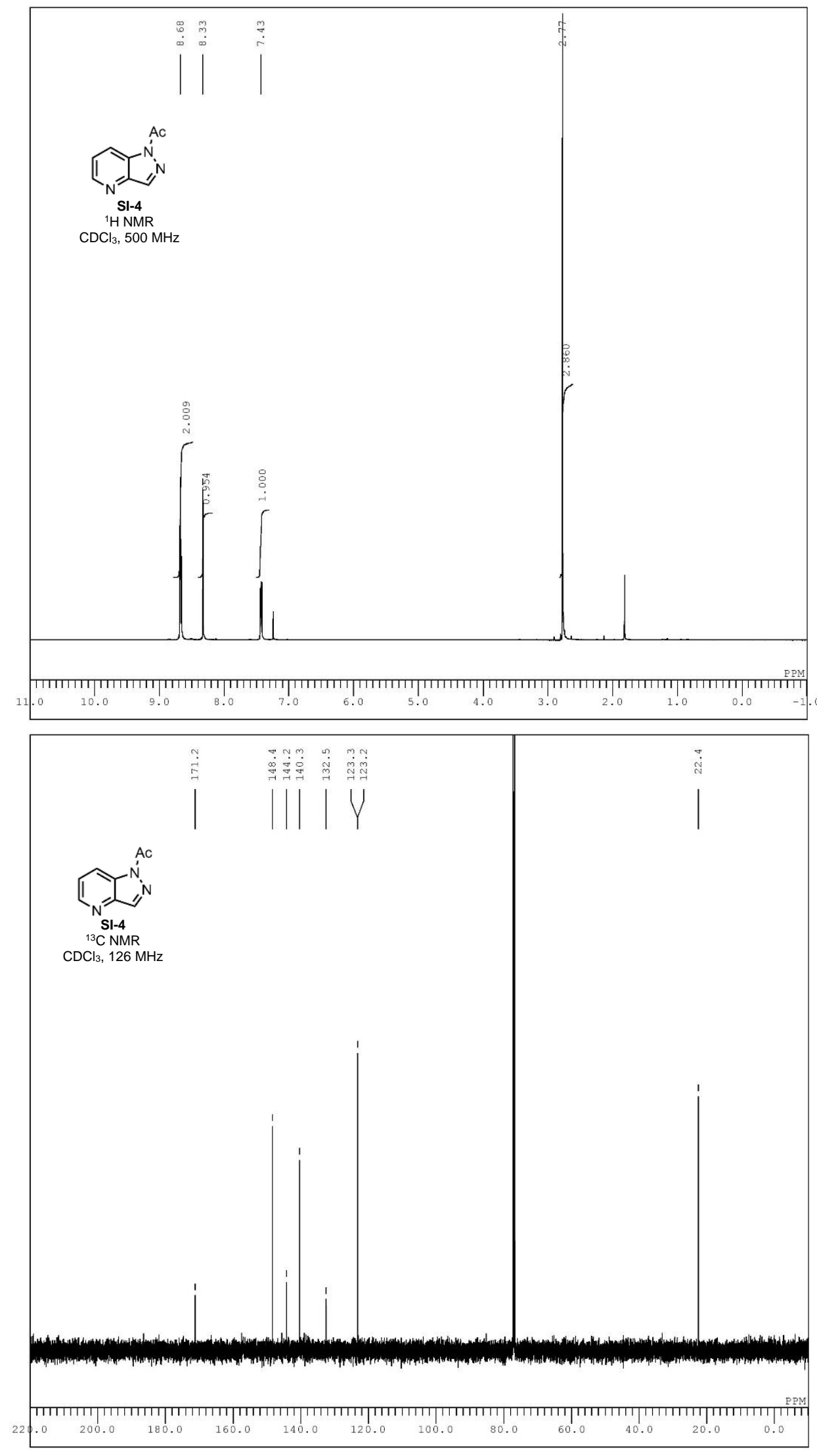

SI-205 

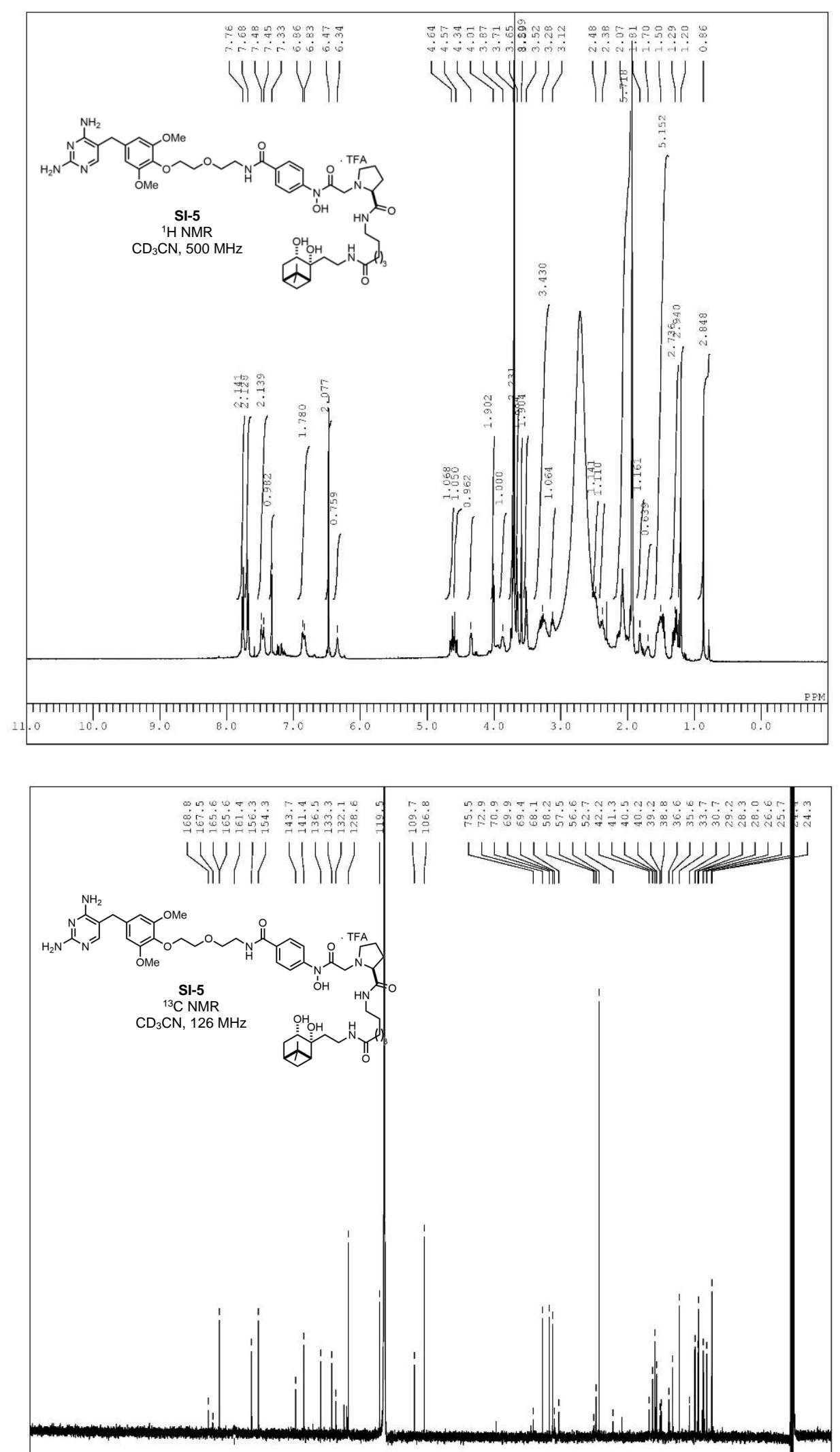

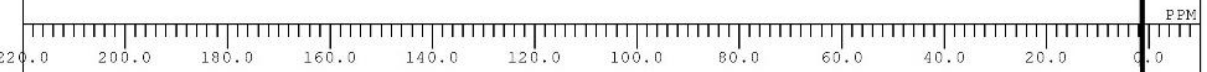



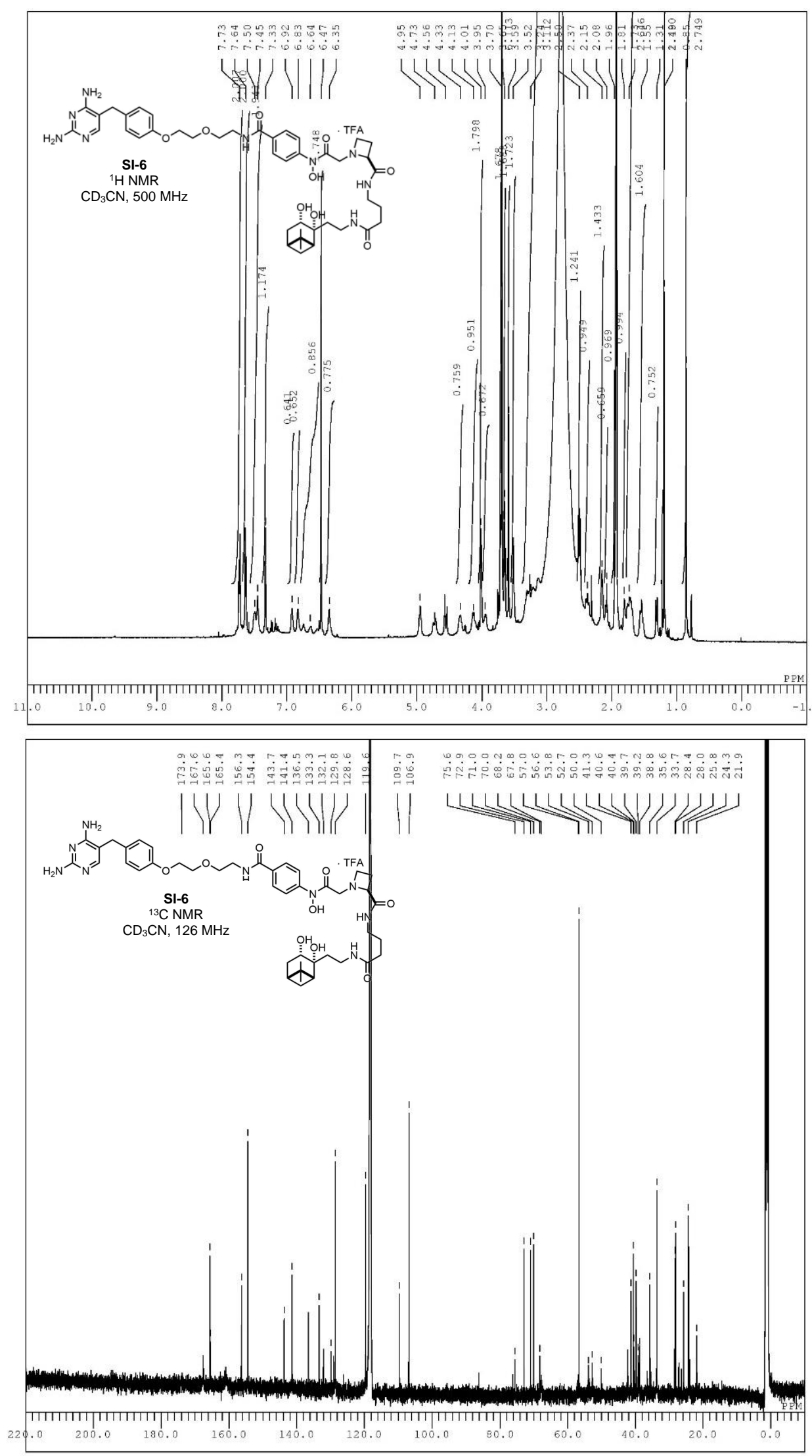

SI-207 


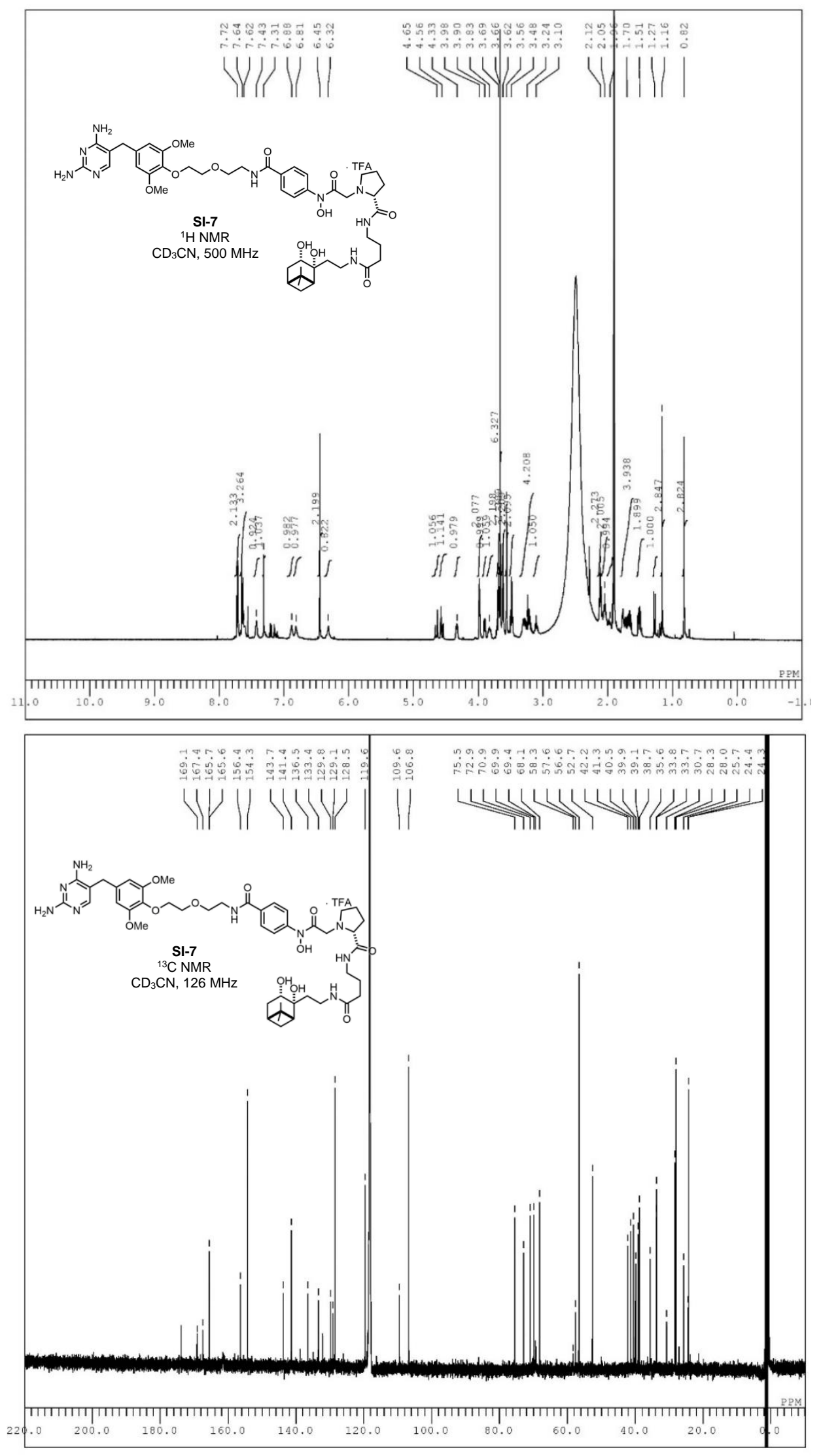

SI-208 

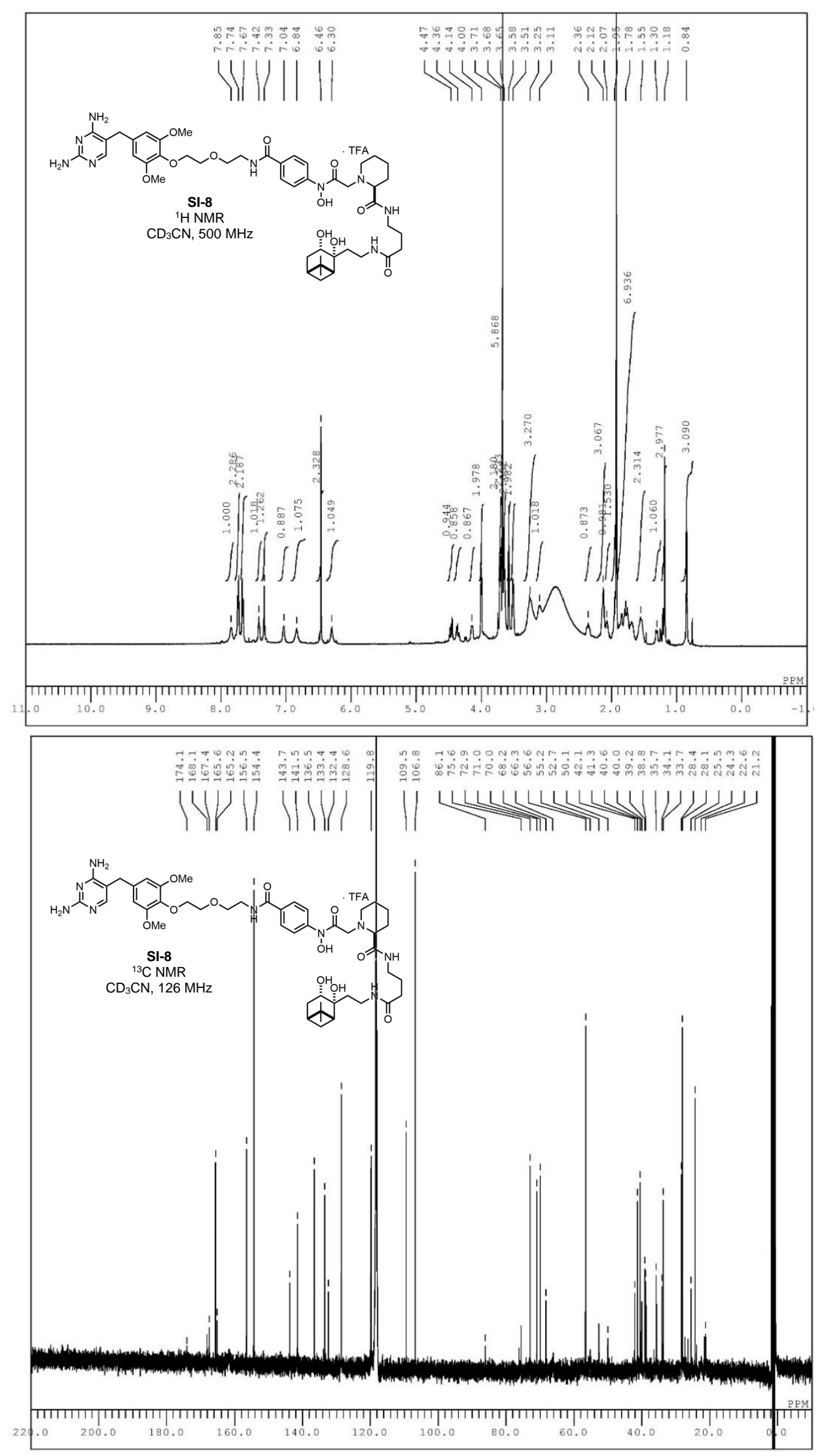

SI-209 

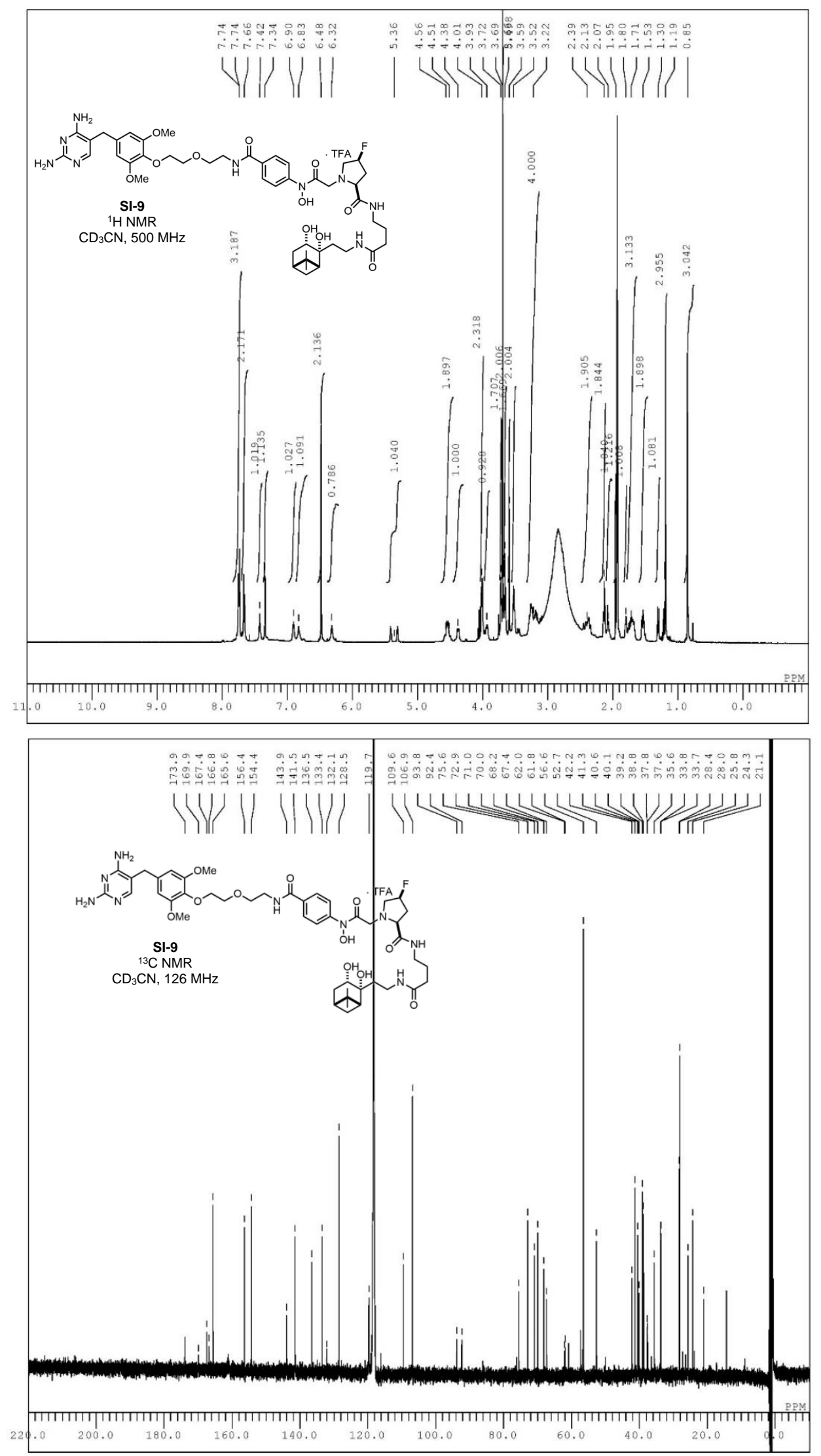

SI-210 

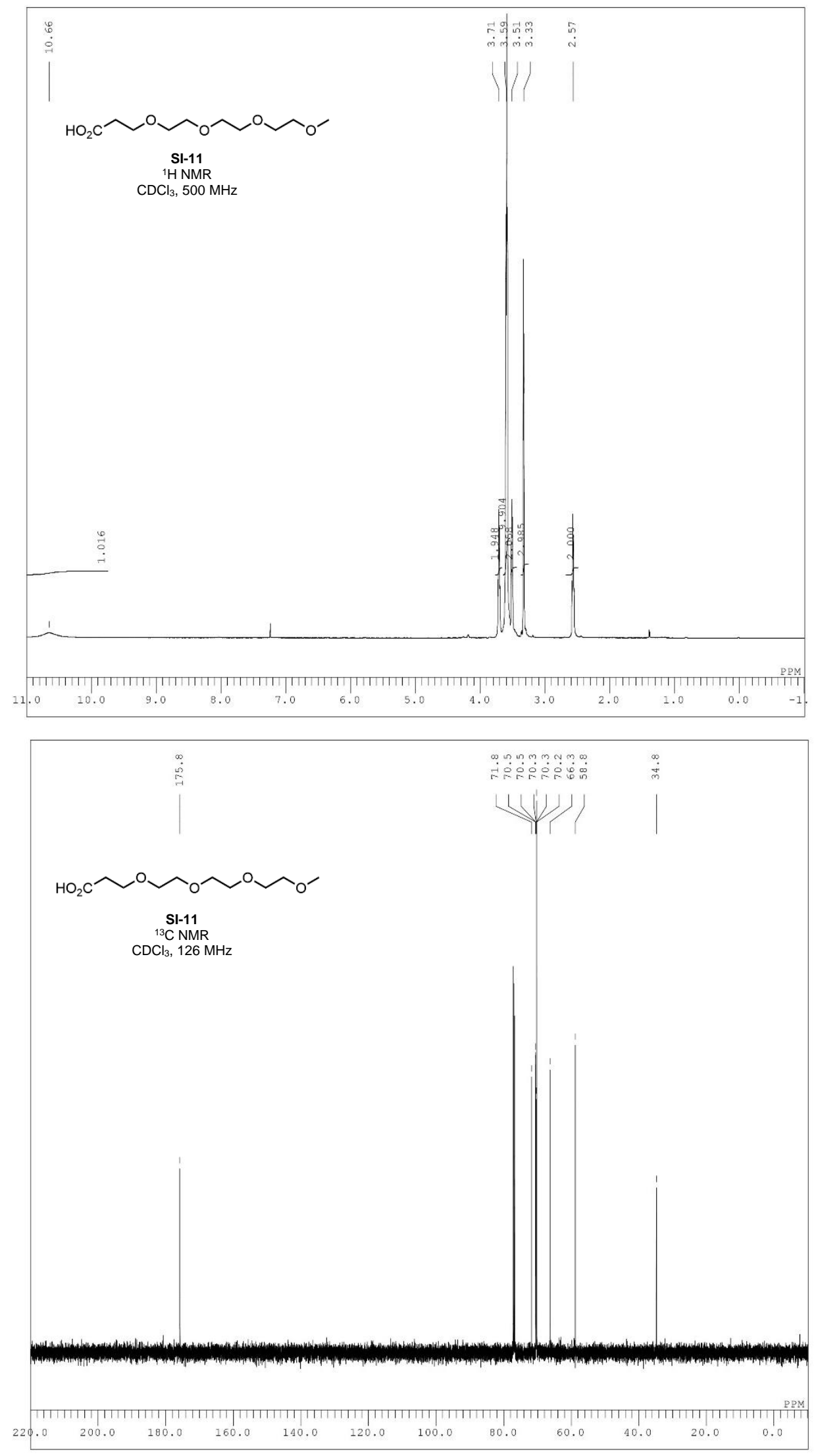

SI-211 

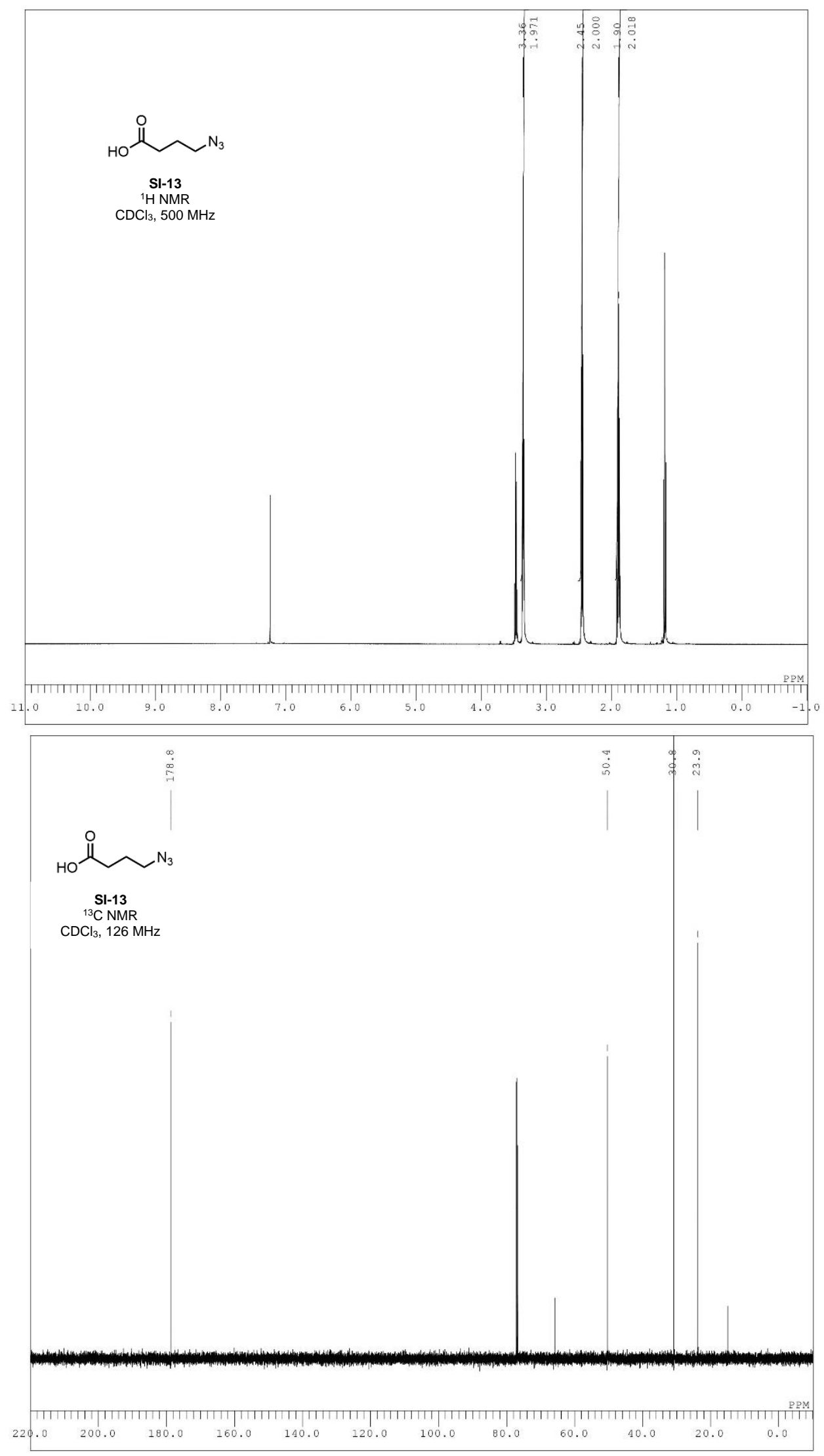

SI-212 

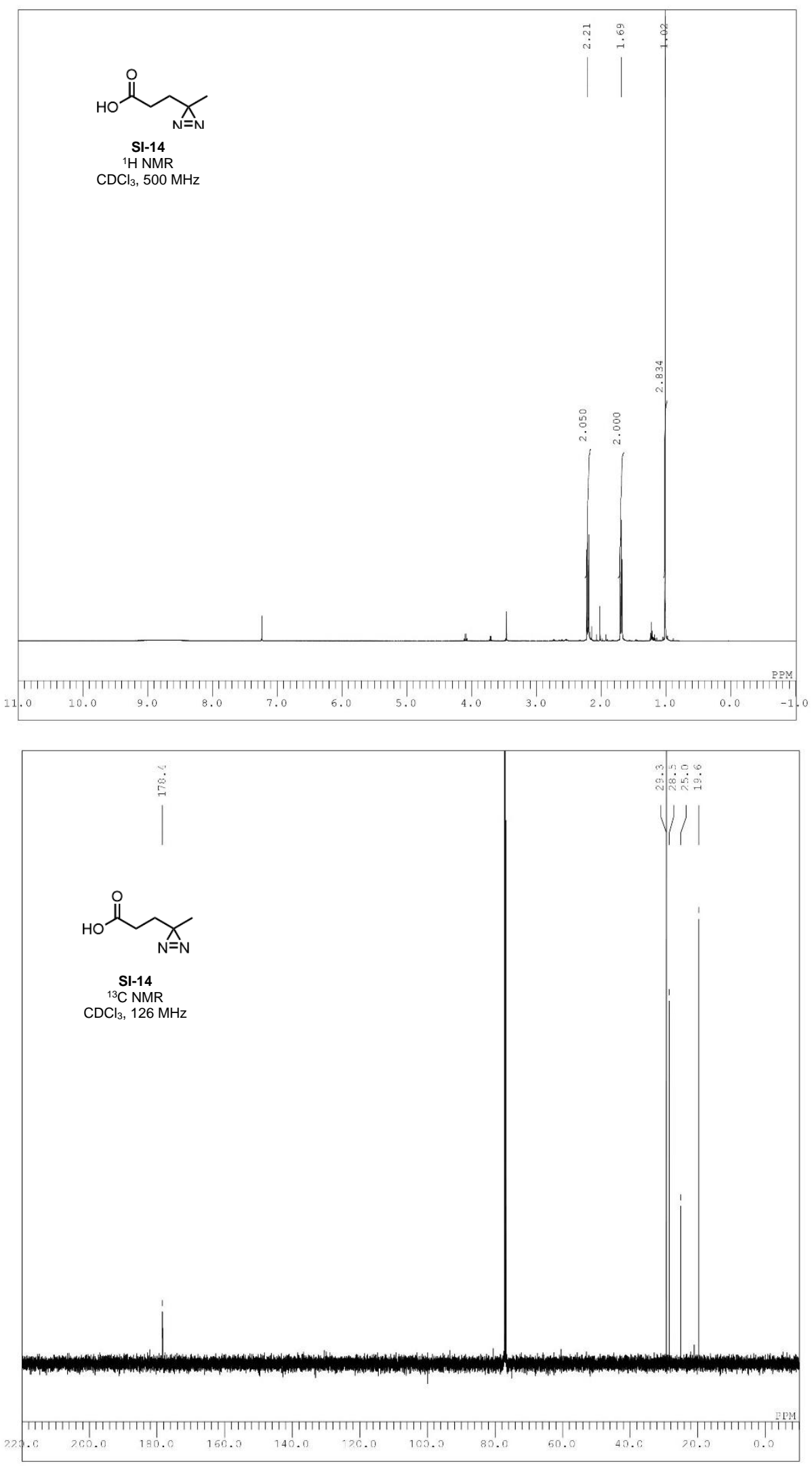

SI-213 


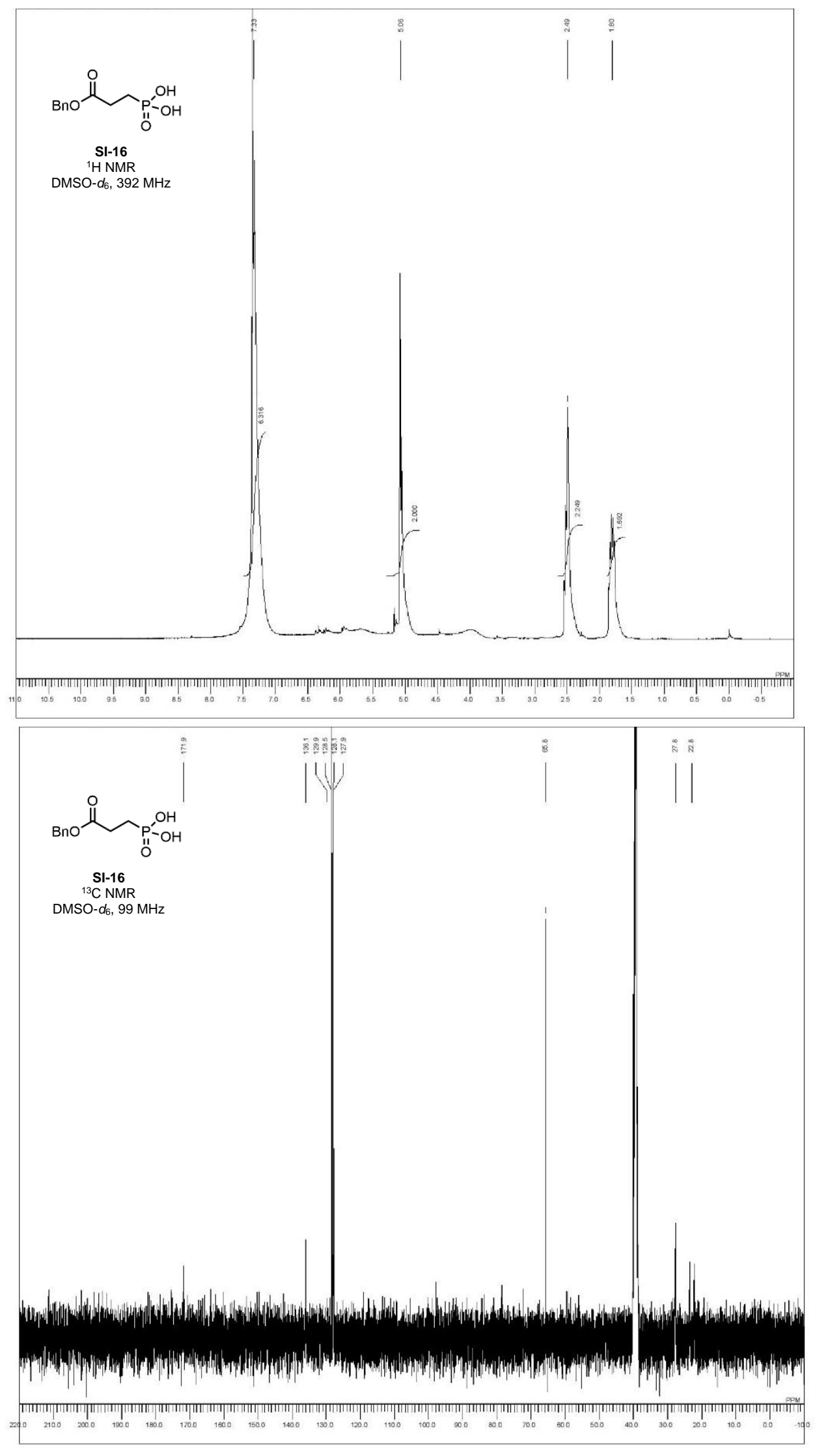

SI-214 


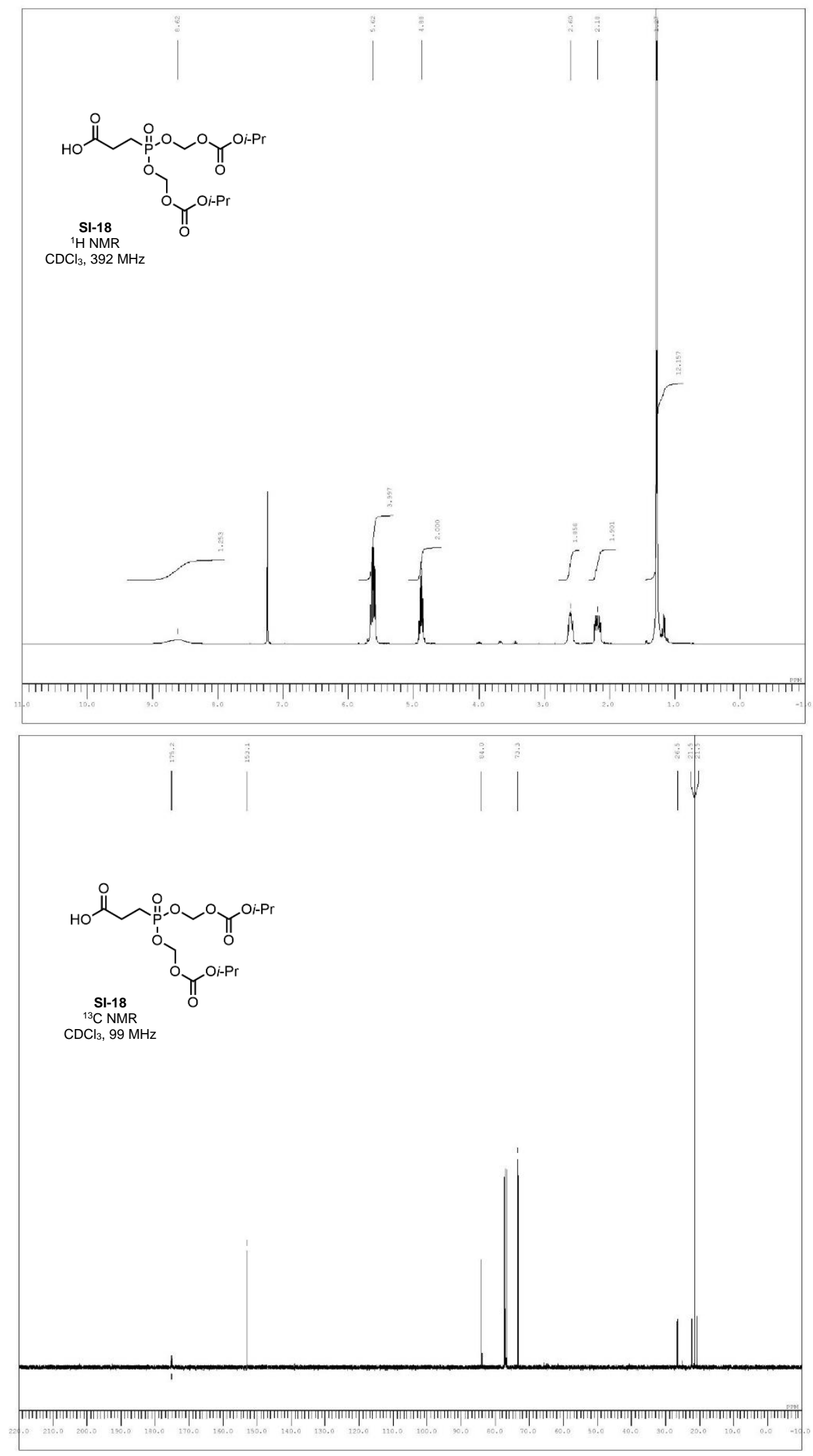

SI-215 

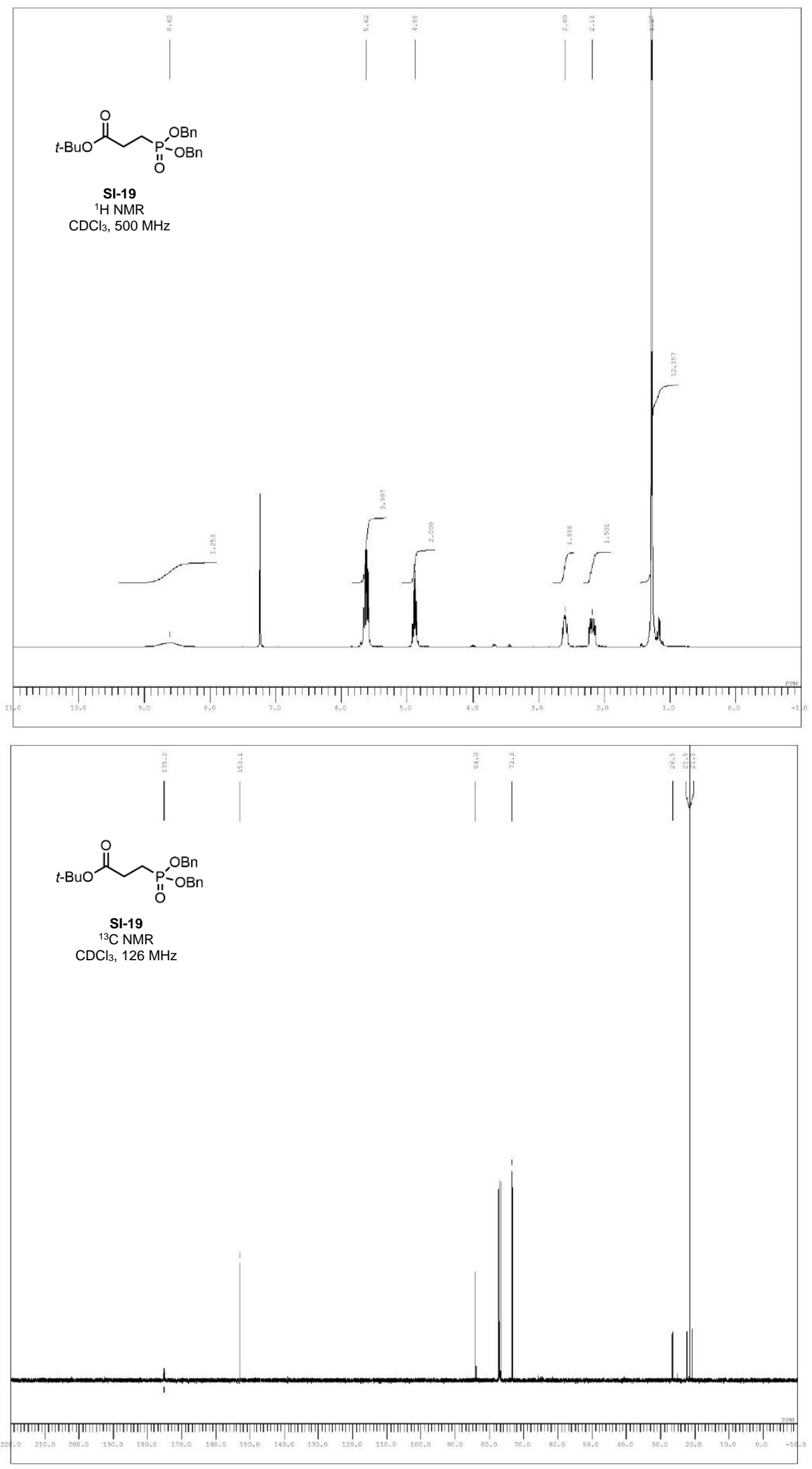

SI-216 


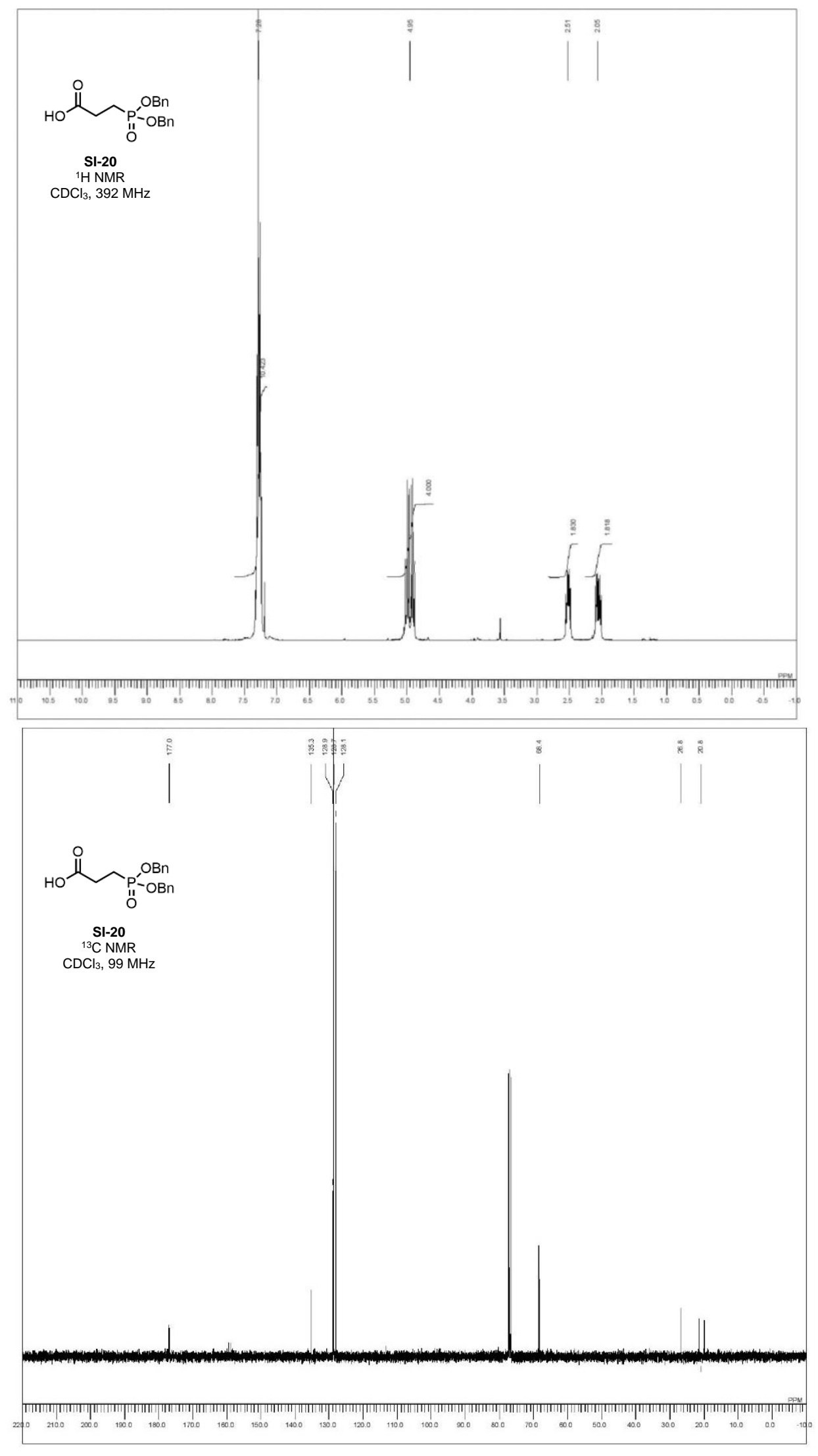

SI-217 


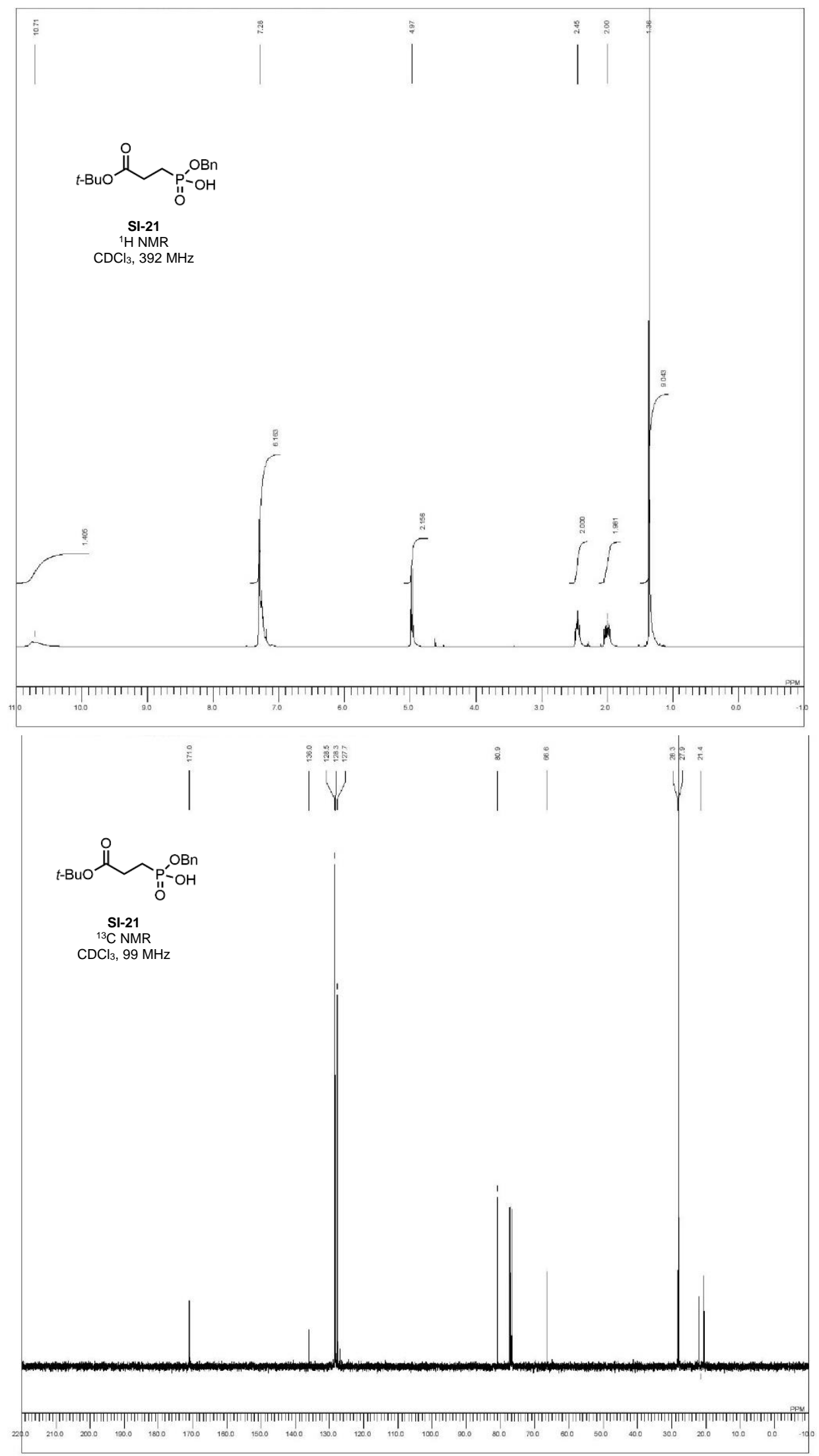

SI-218 

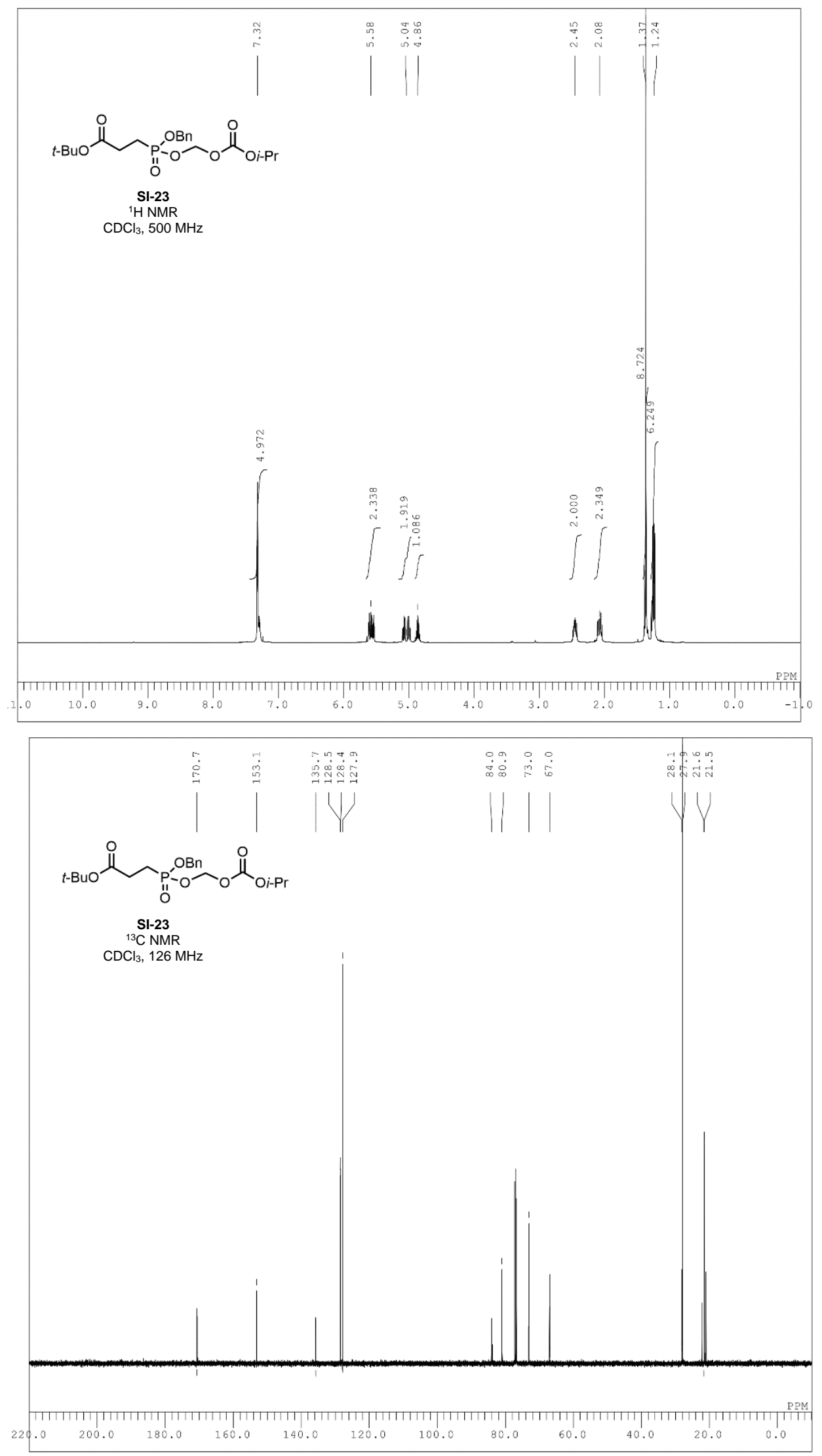

SI-219 

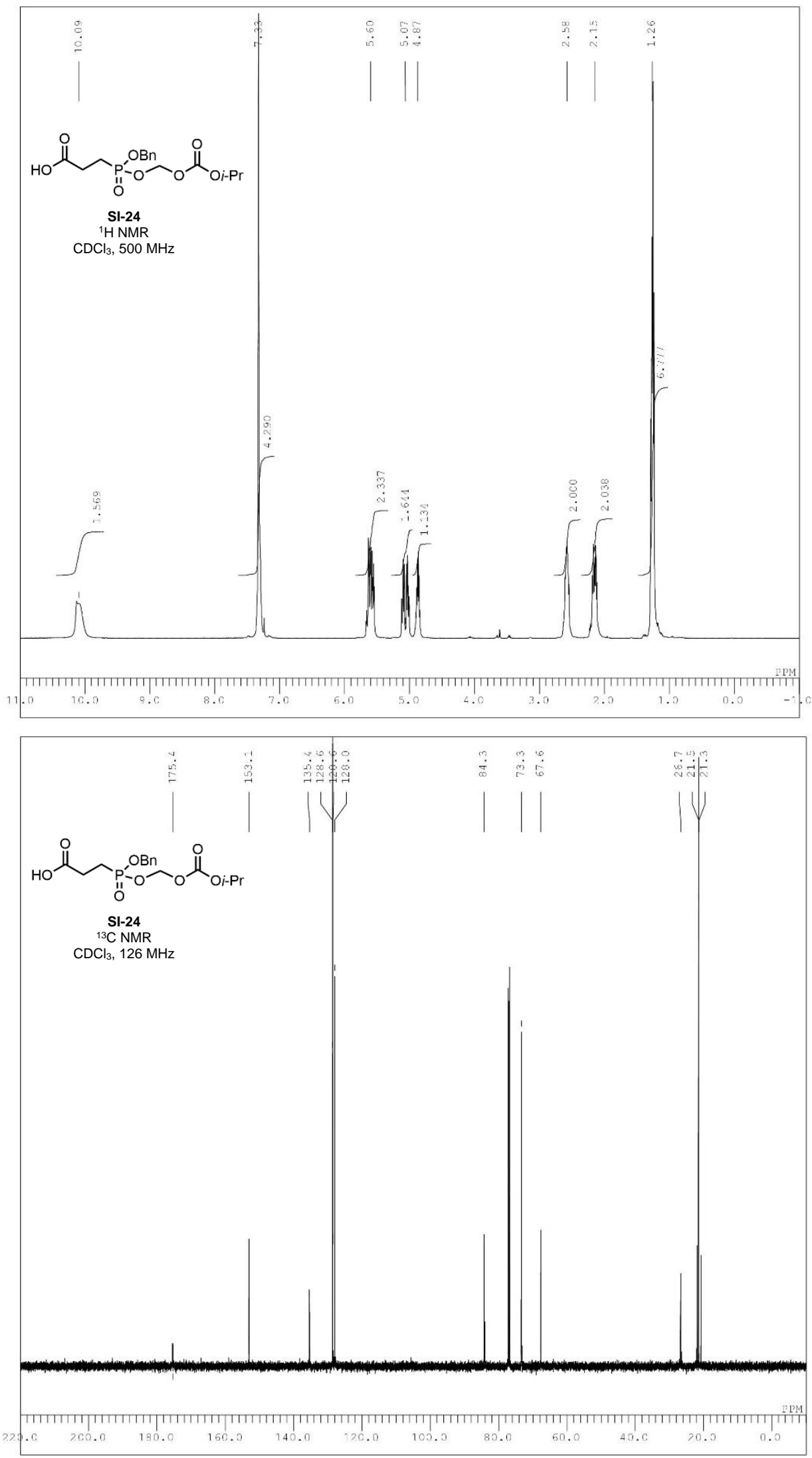

SI-220 

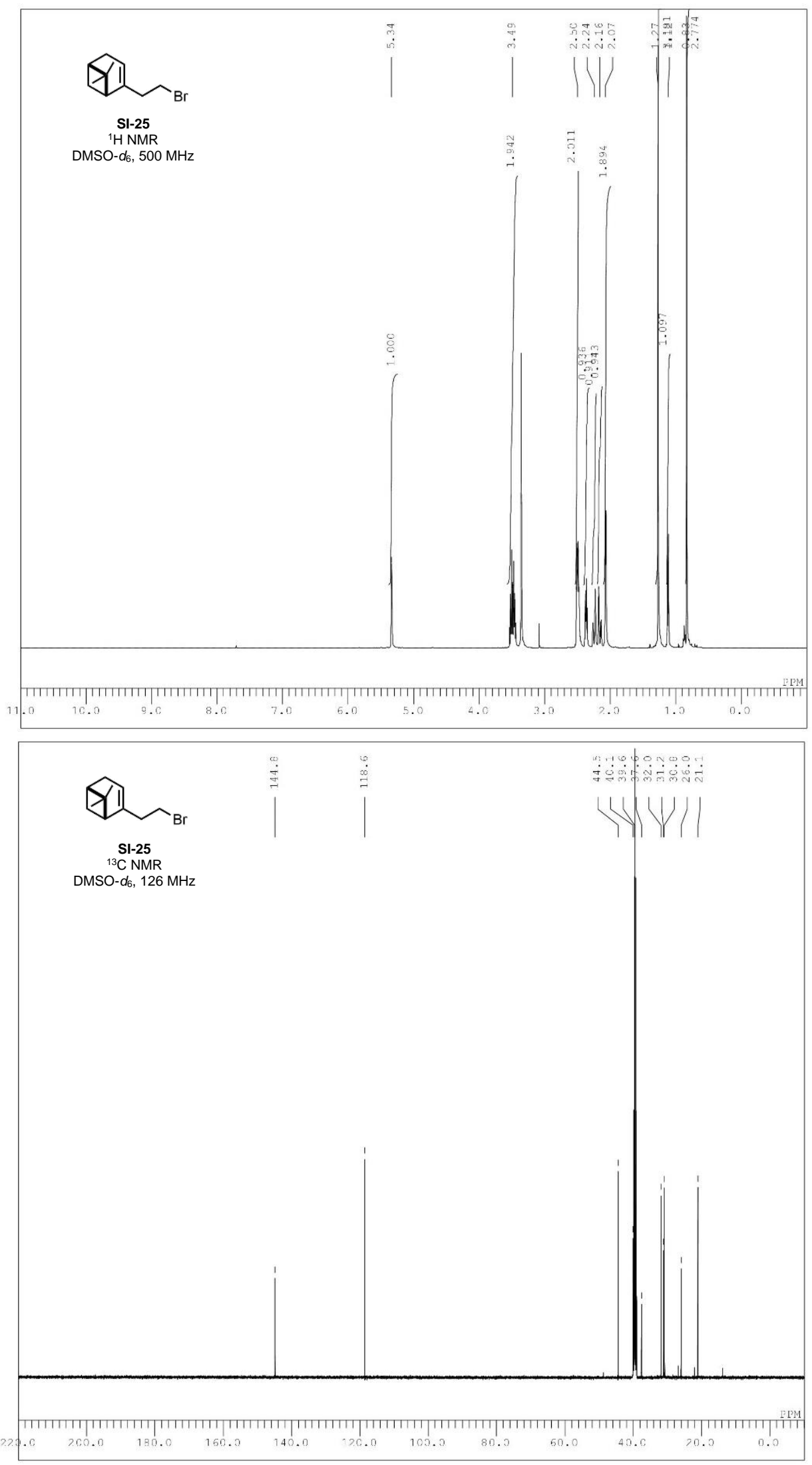

SI-221 

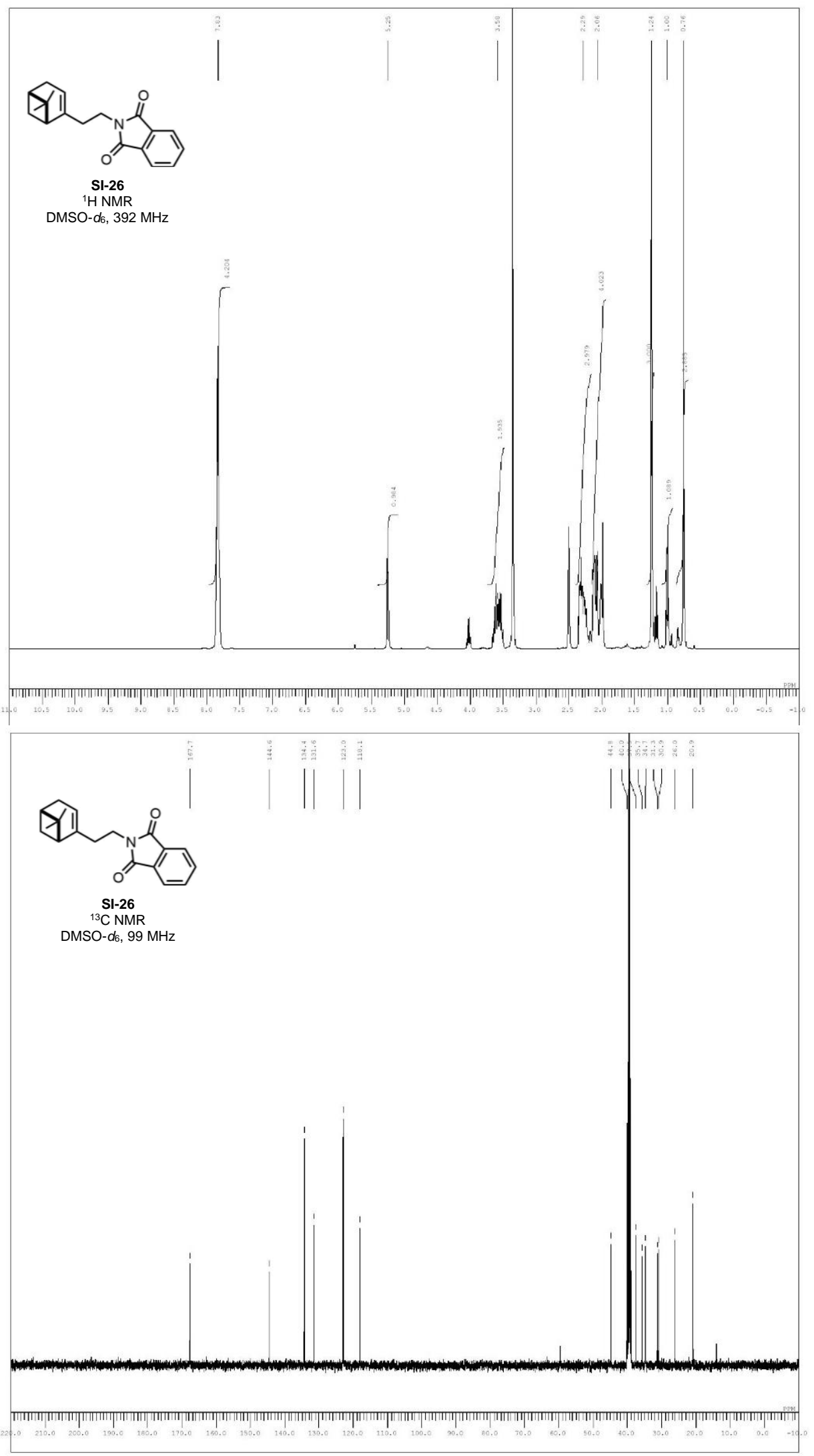

SI-222 

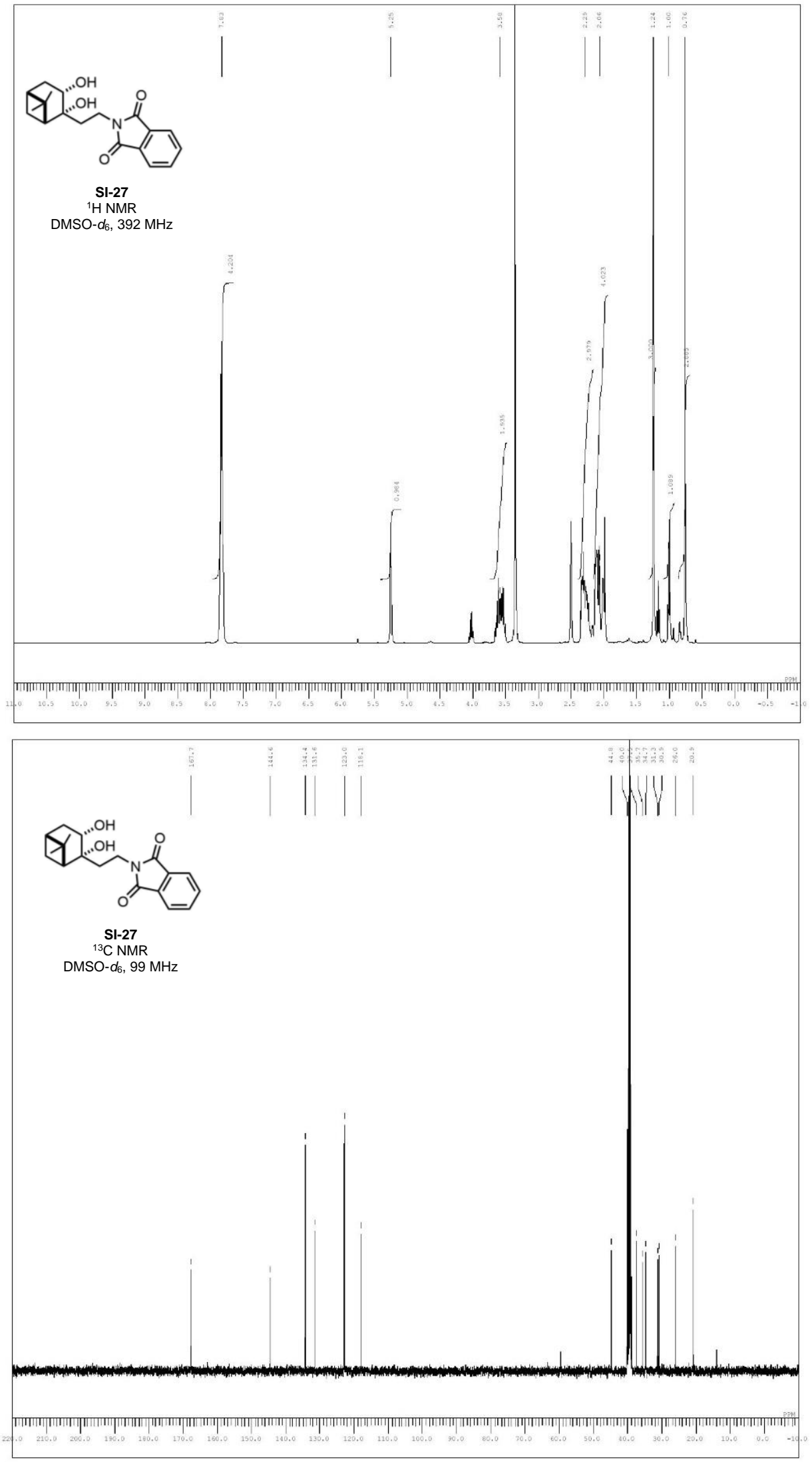

SI-223 


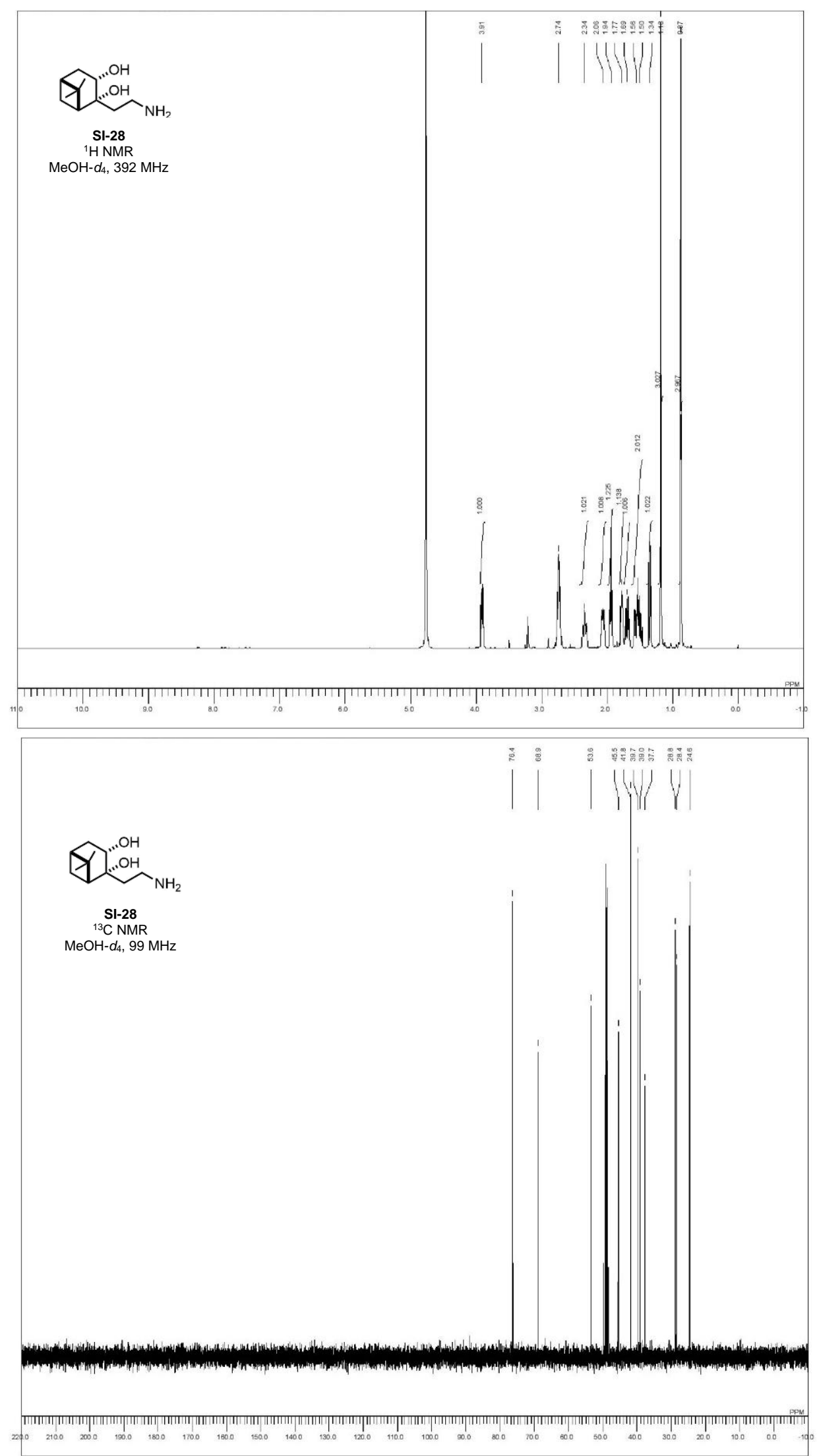

SI-224 


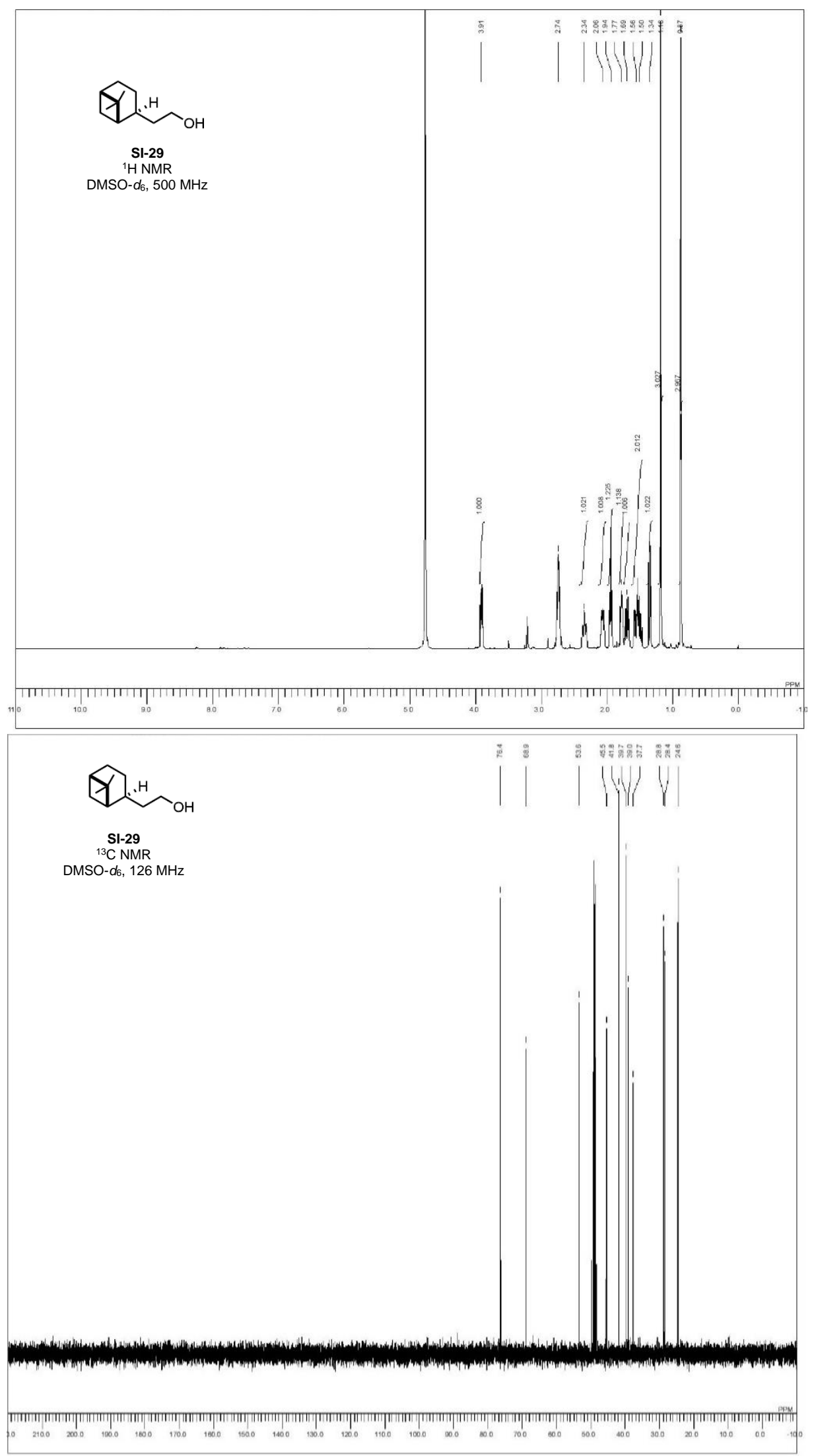

SI-225 

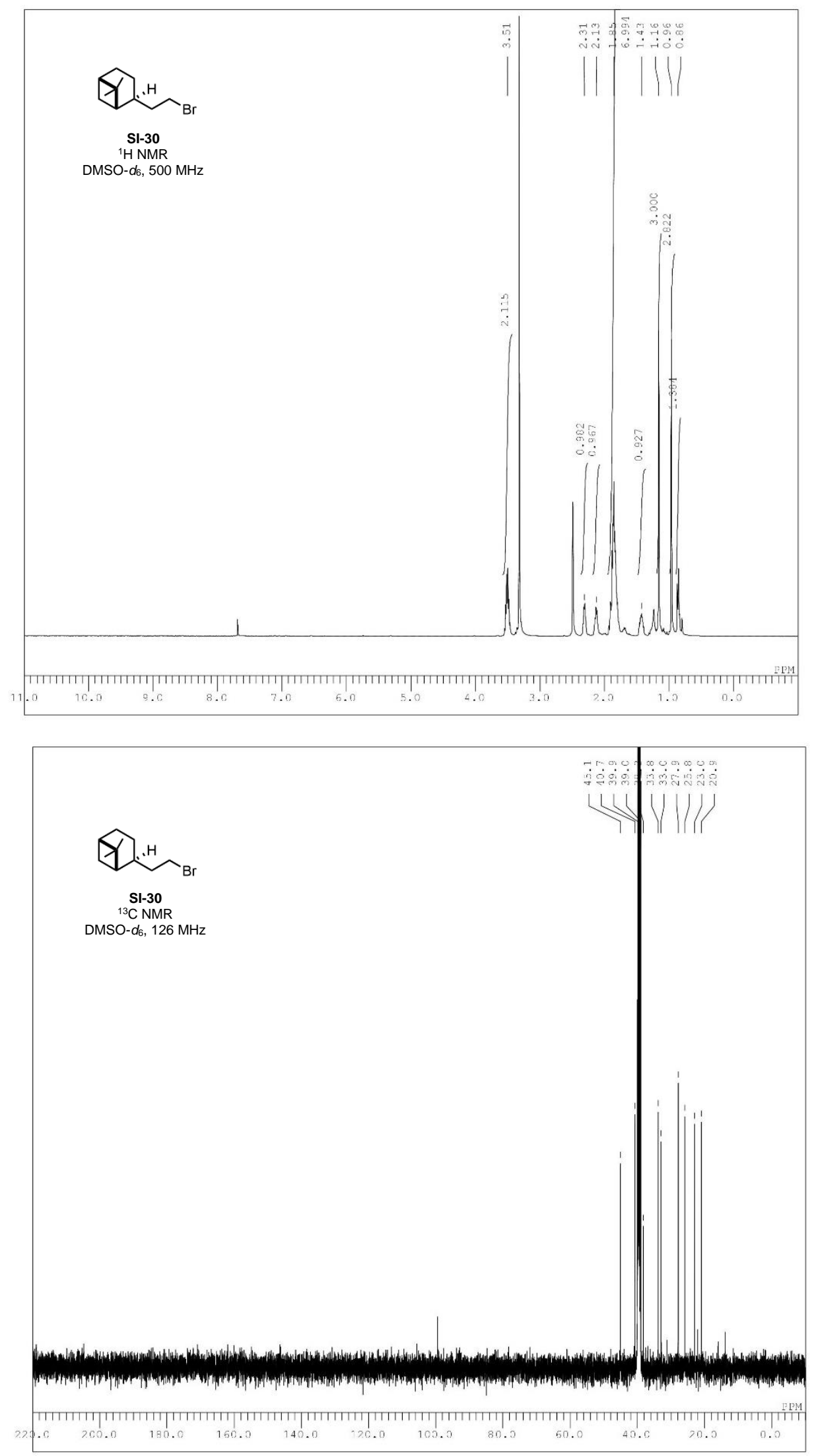

SI-226 

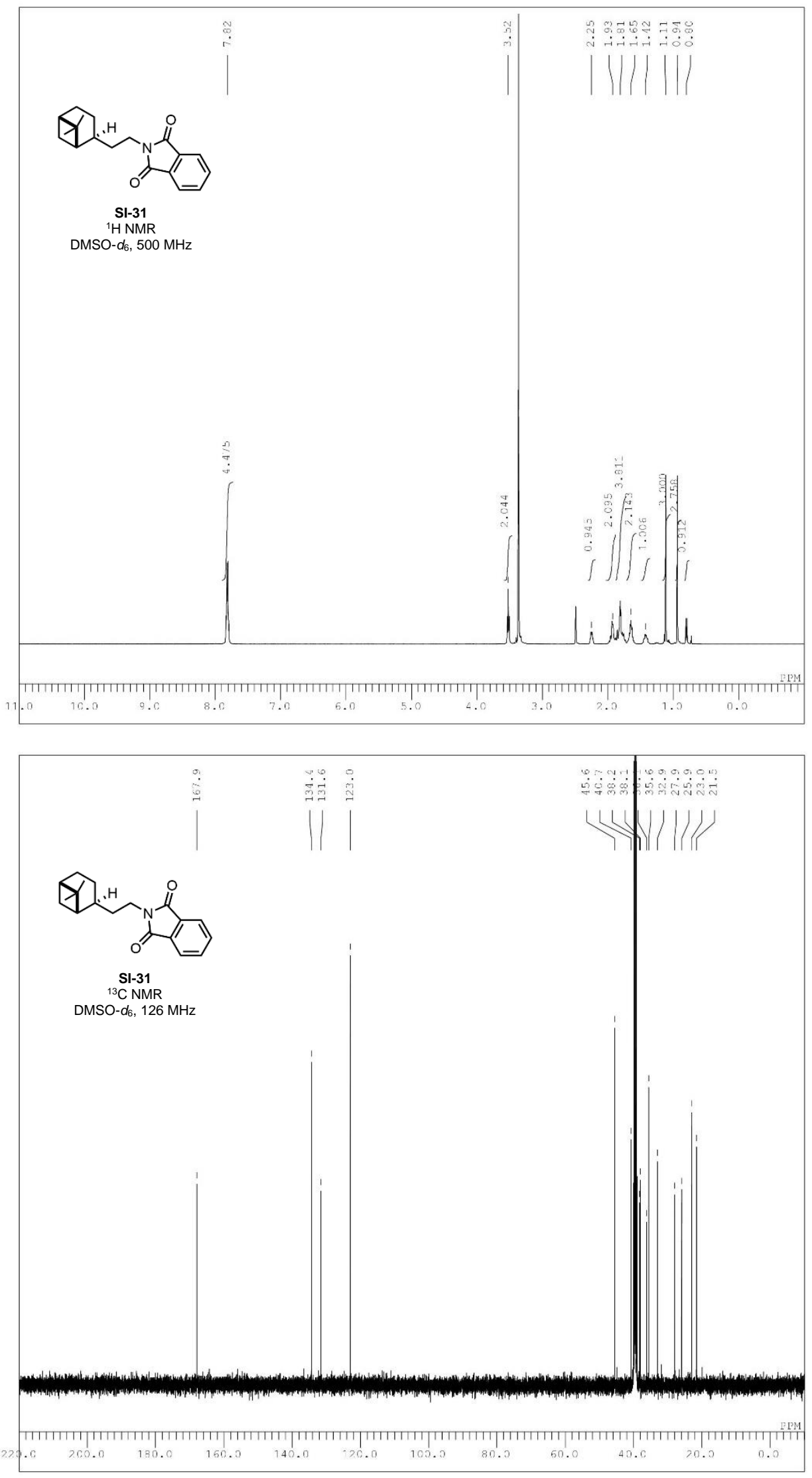

SI-227 

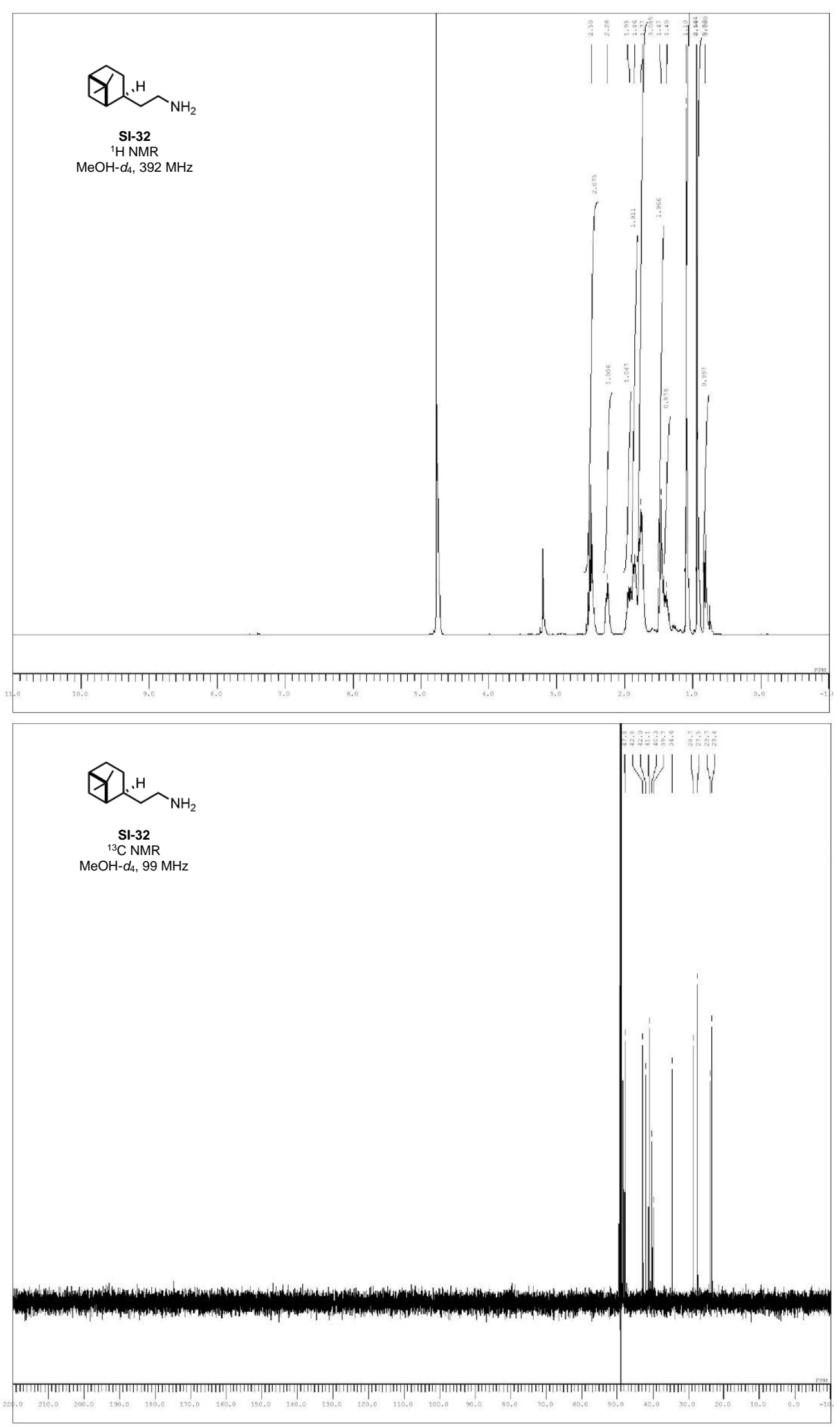

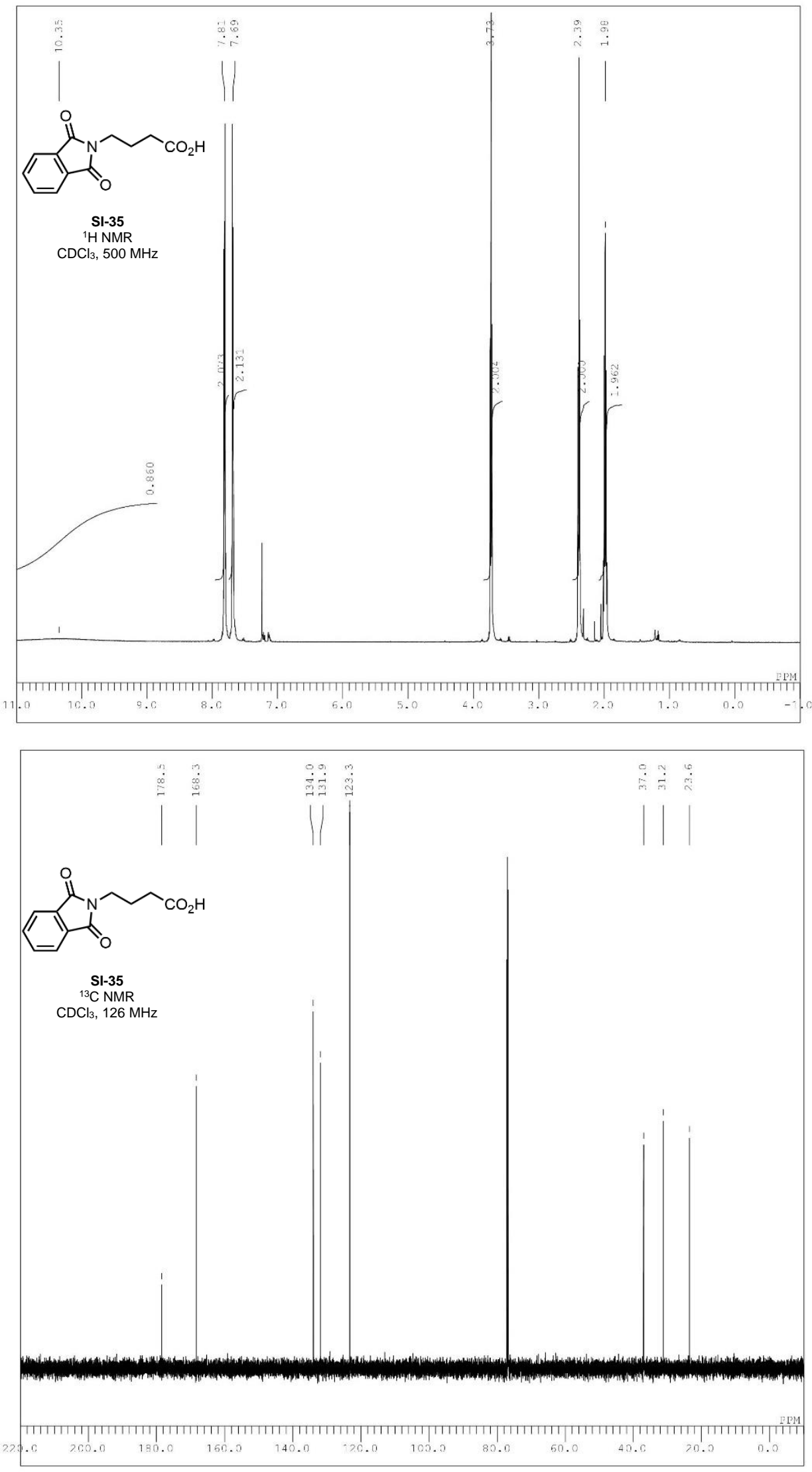

SI-229 

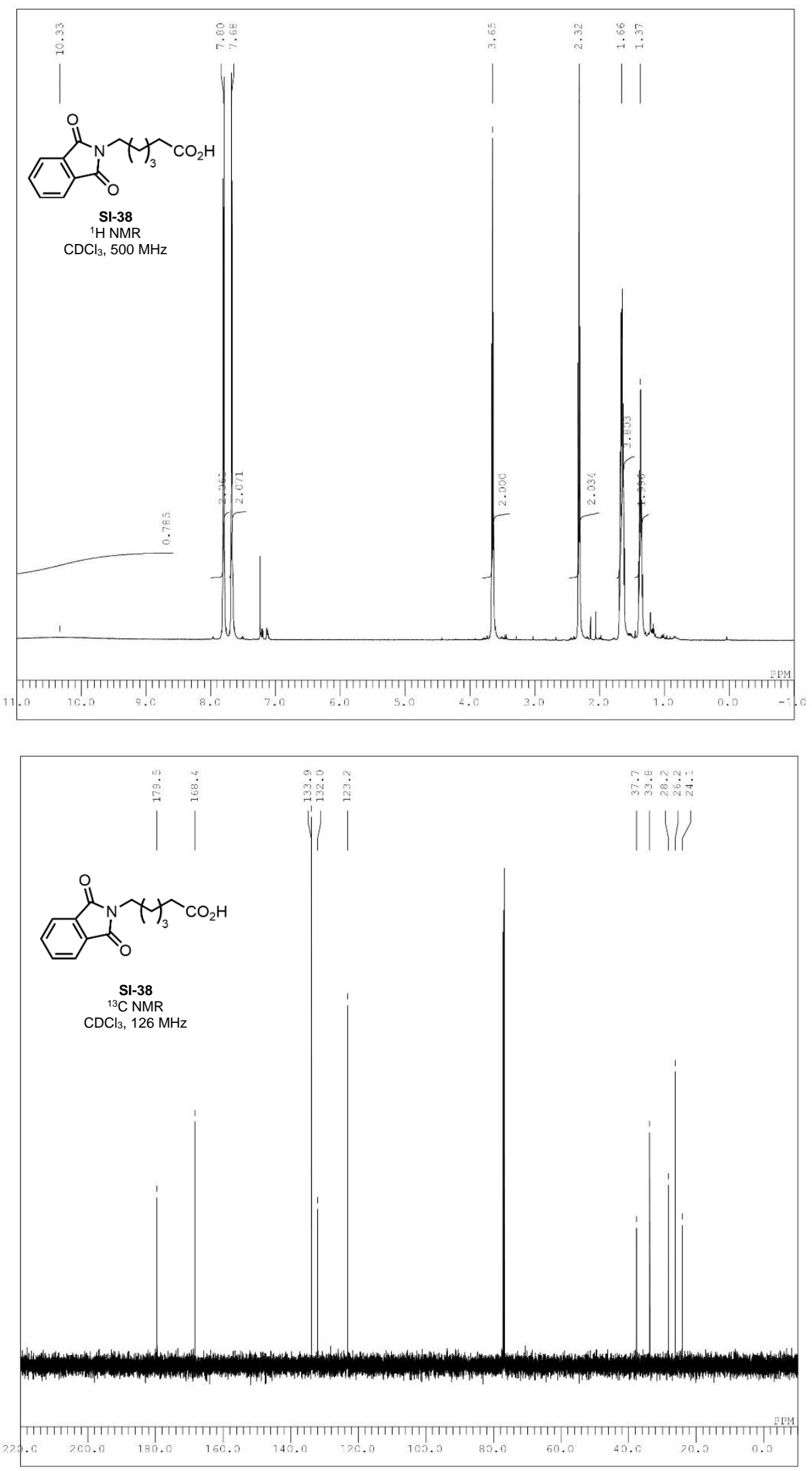

SI-230 

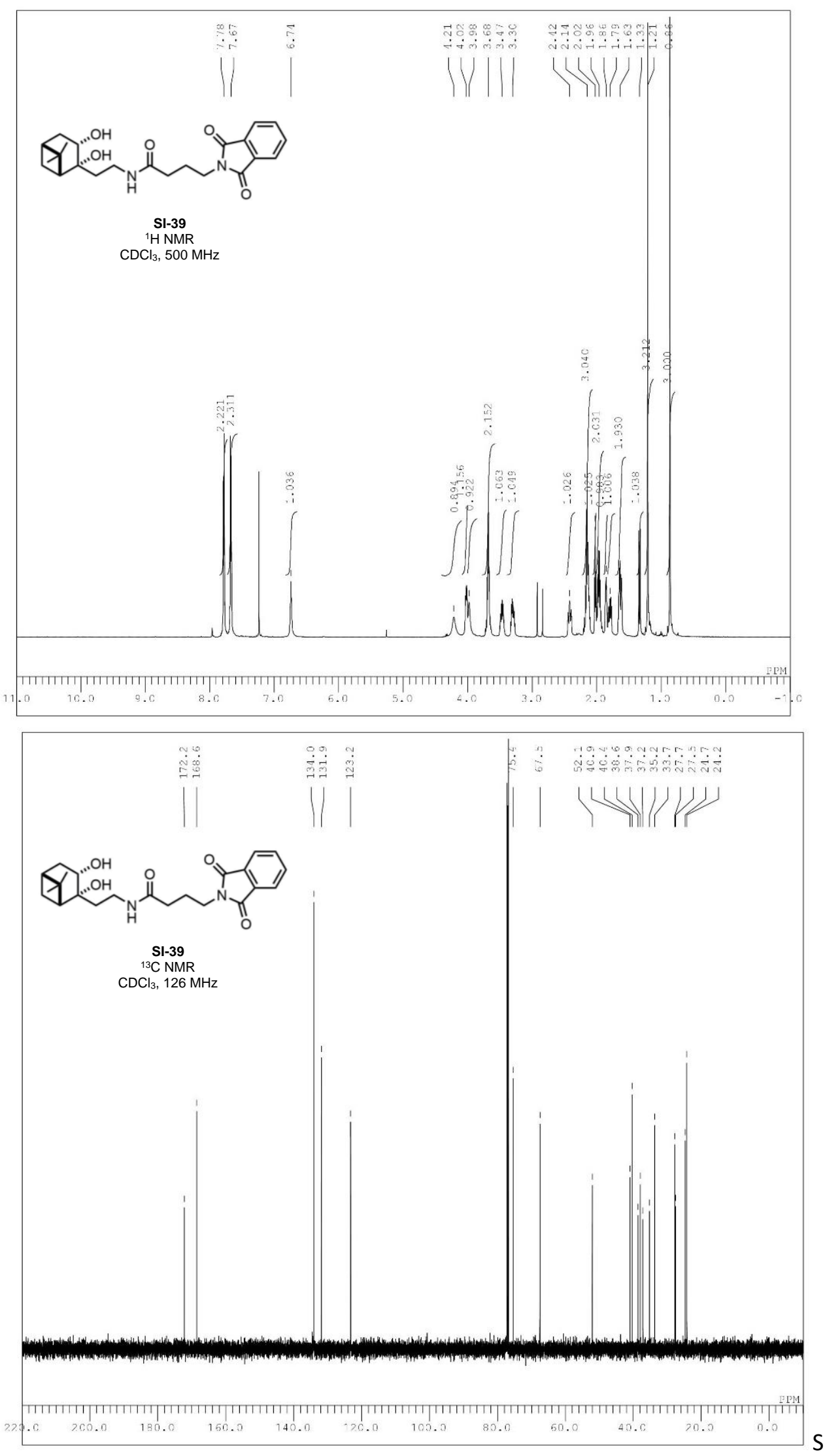

SI-231 

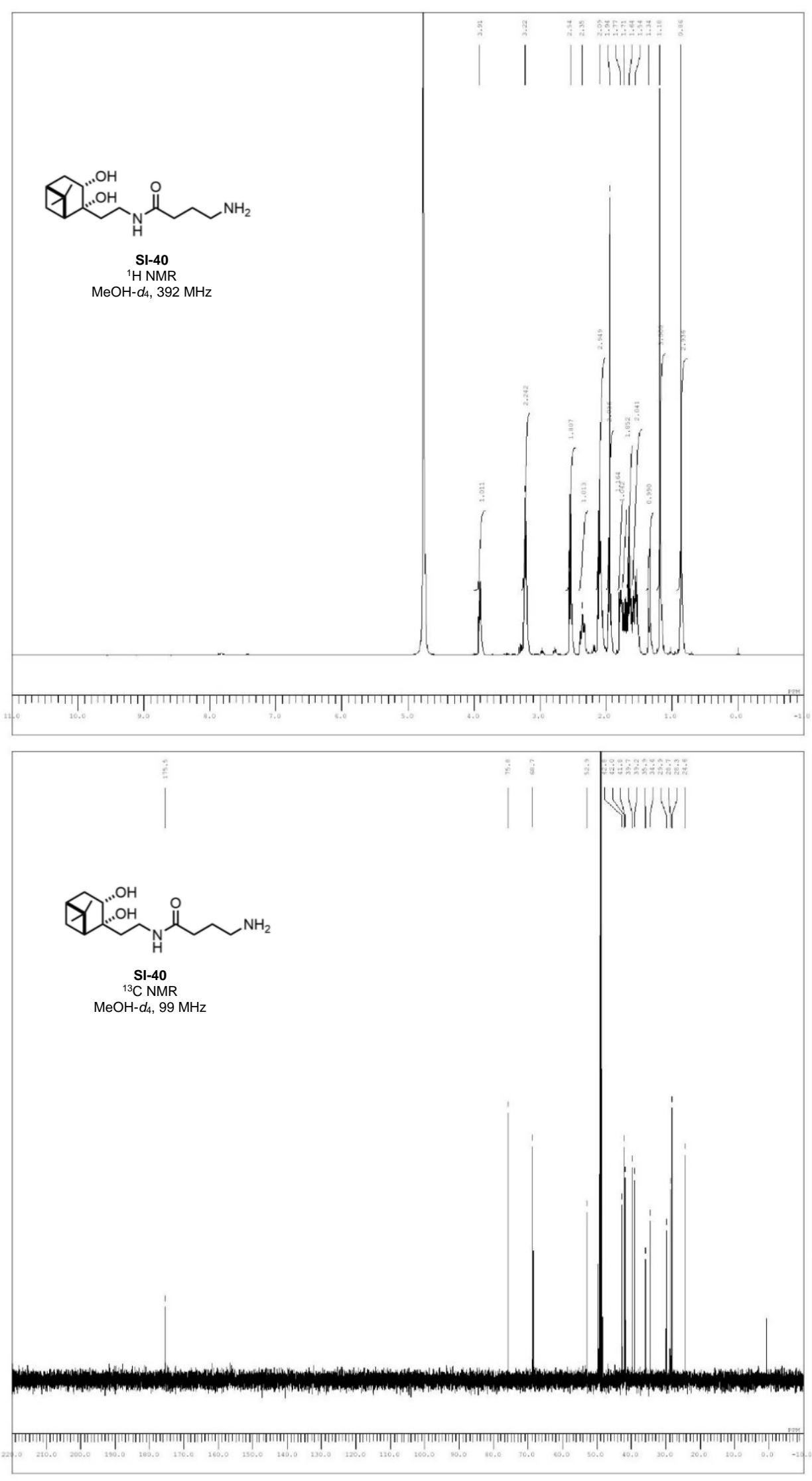

SI-232 

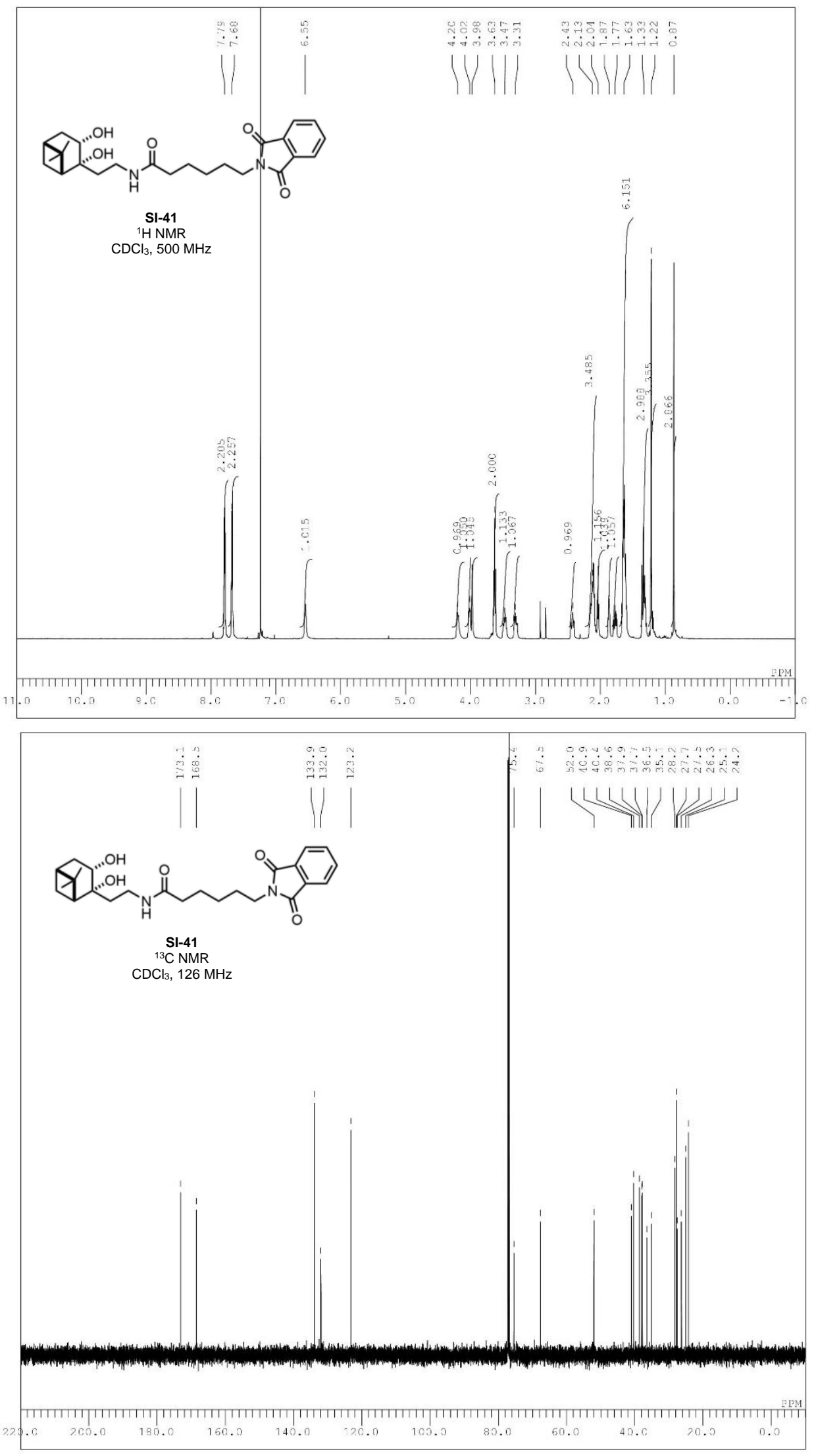

SI-233 

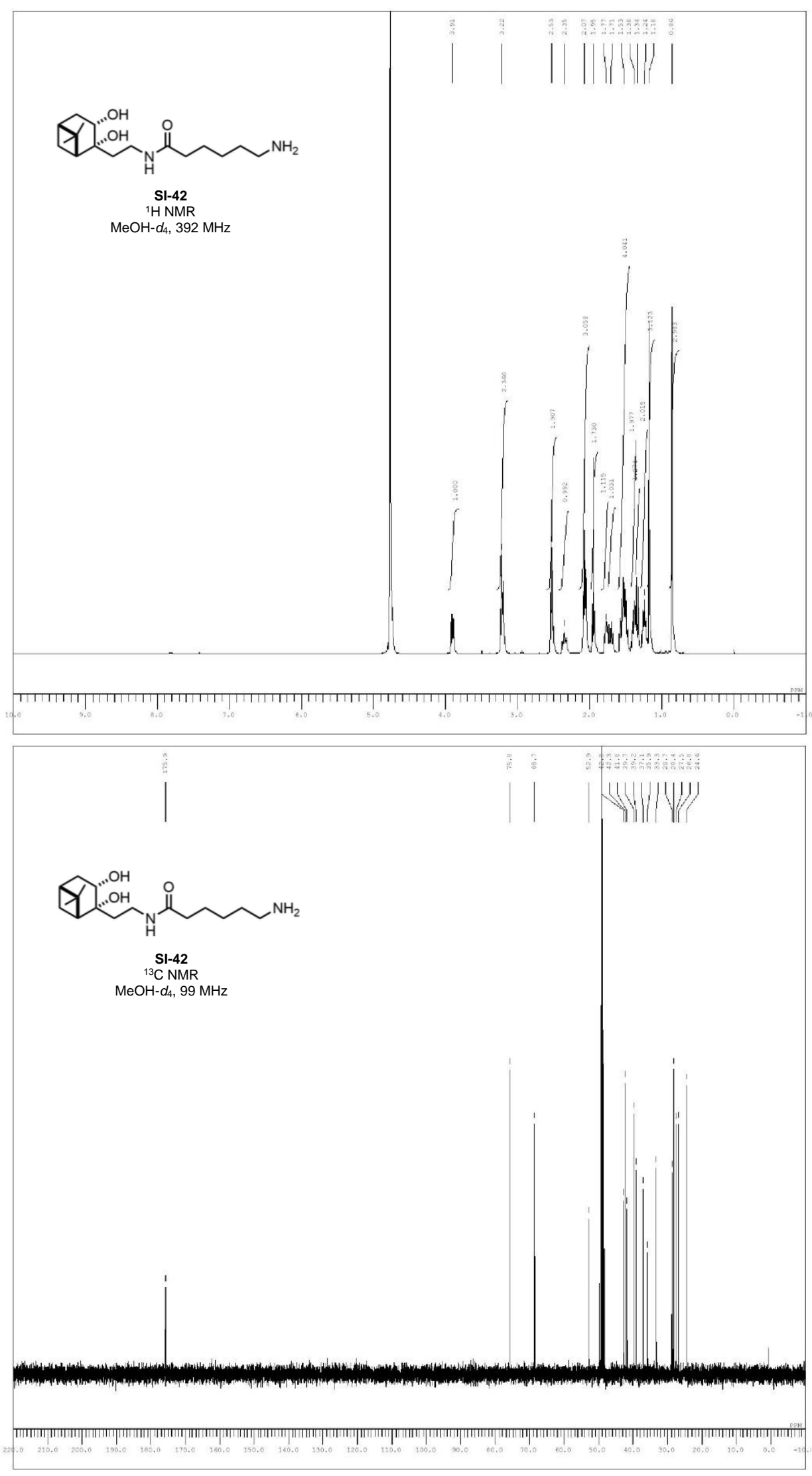

SI-234 

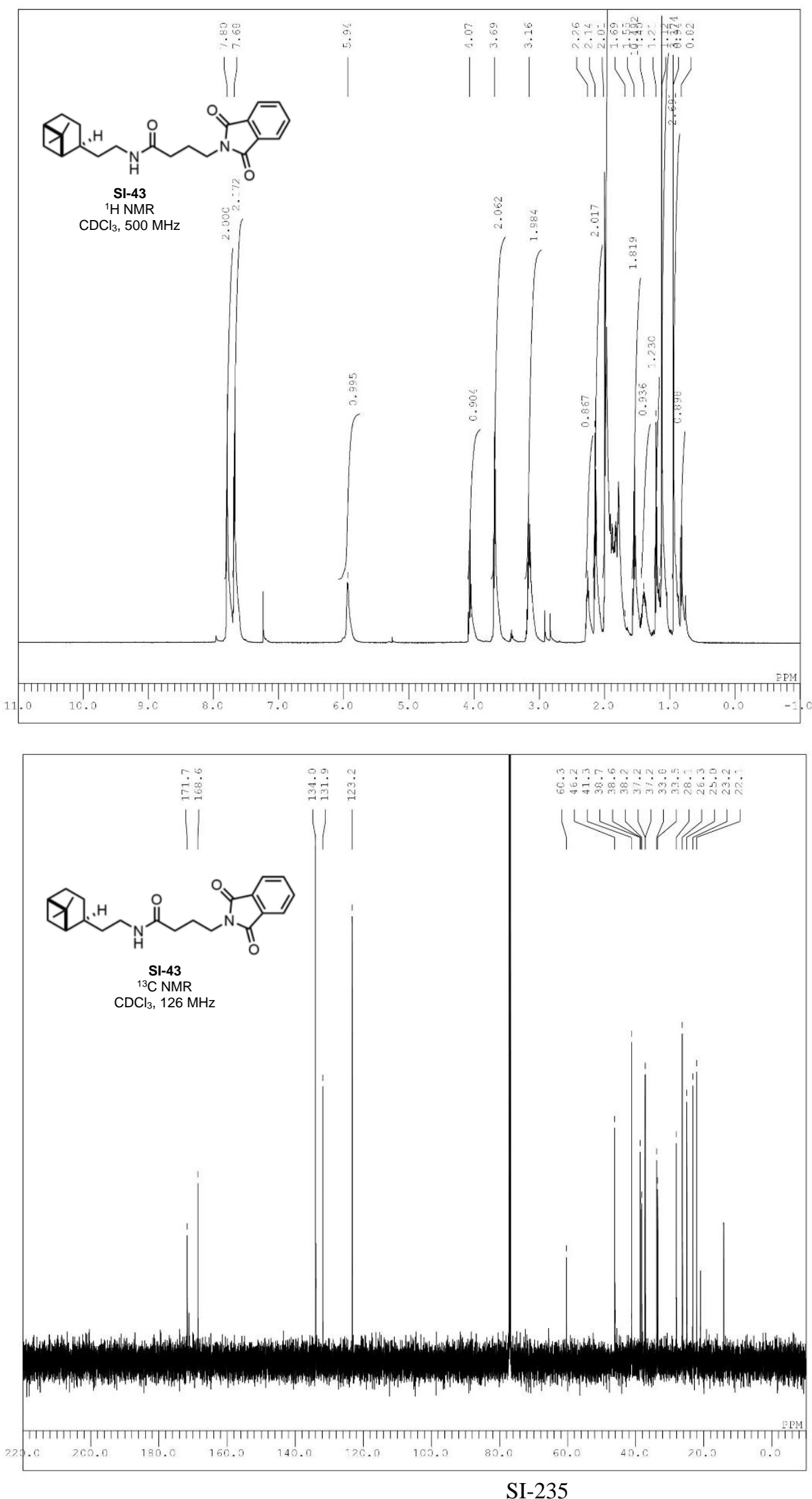

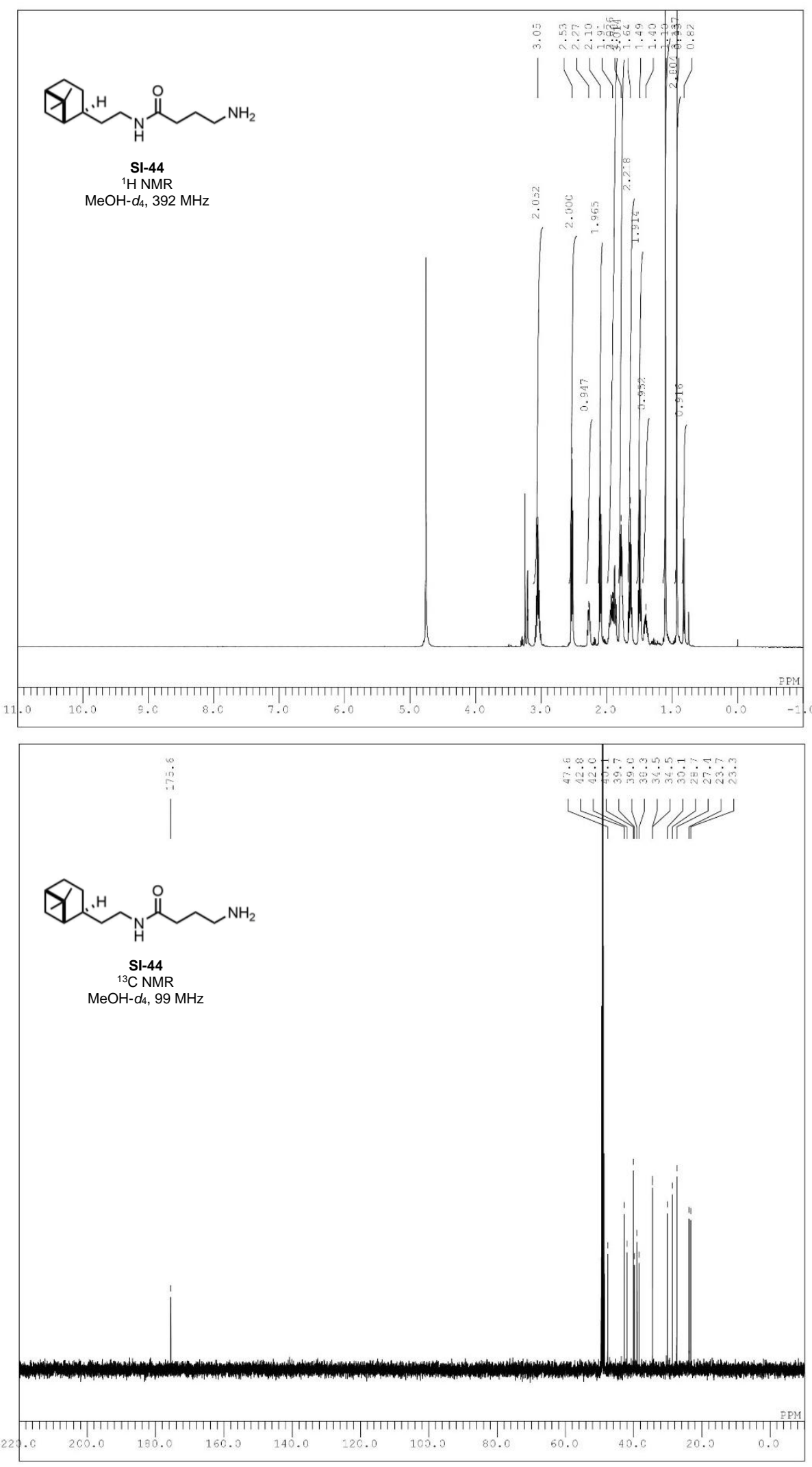

SI-236 


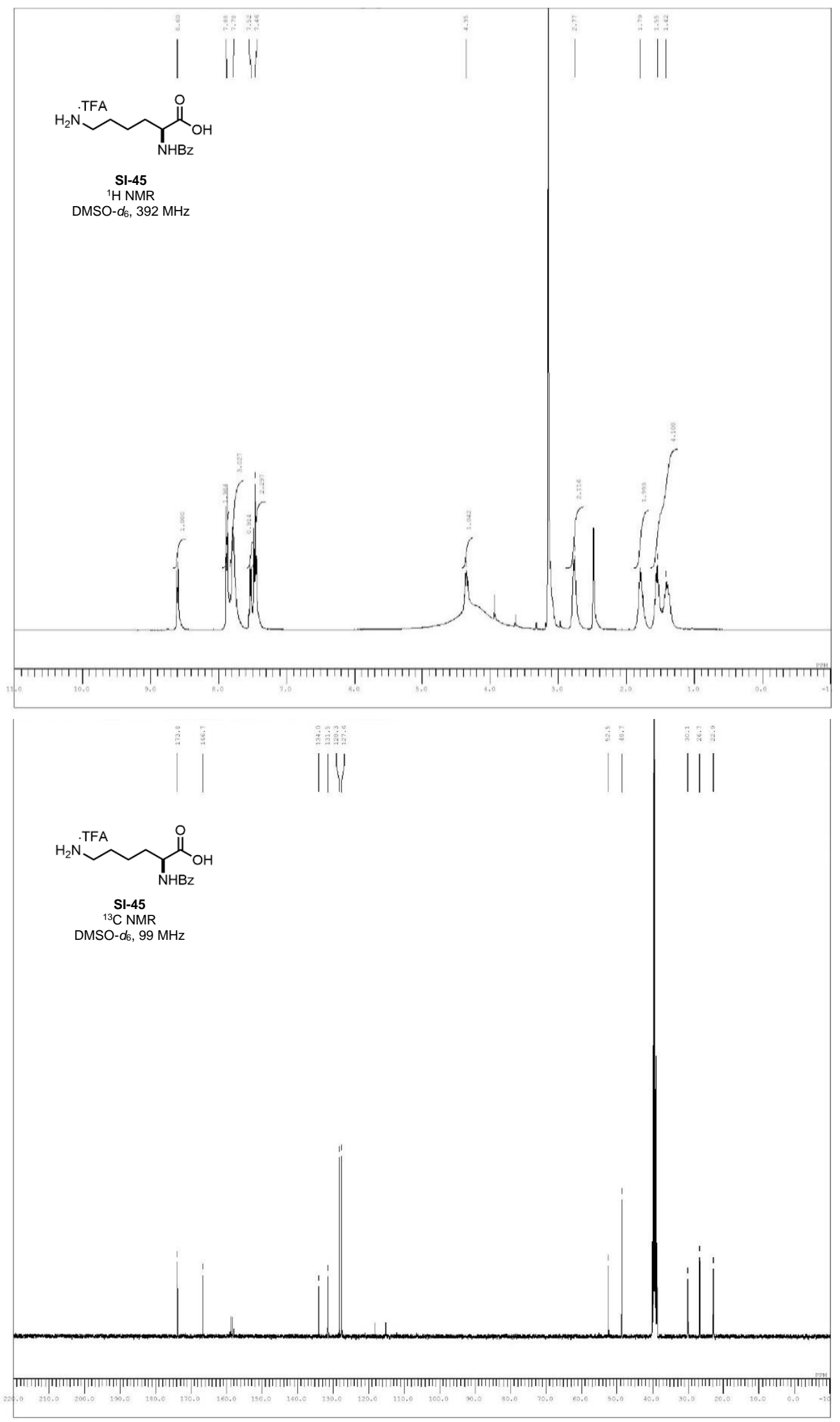

SI-237 


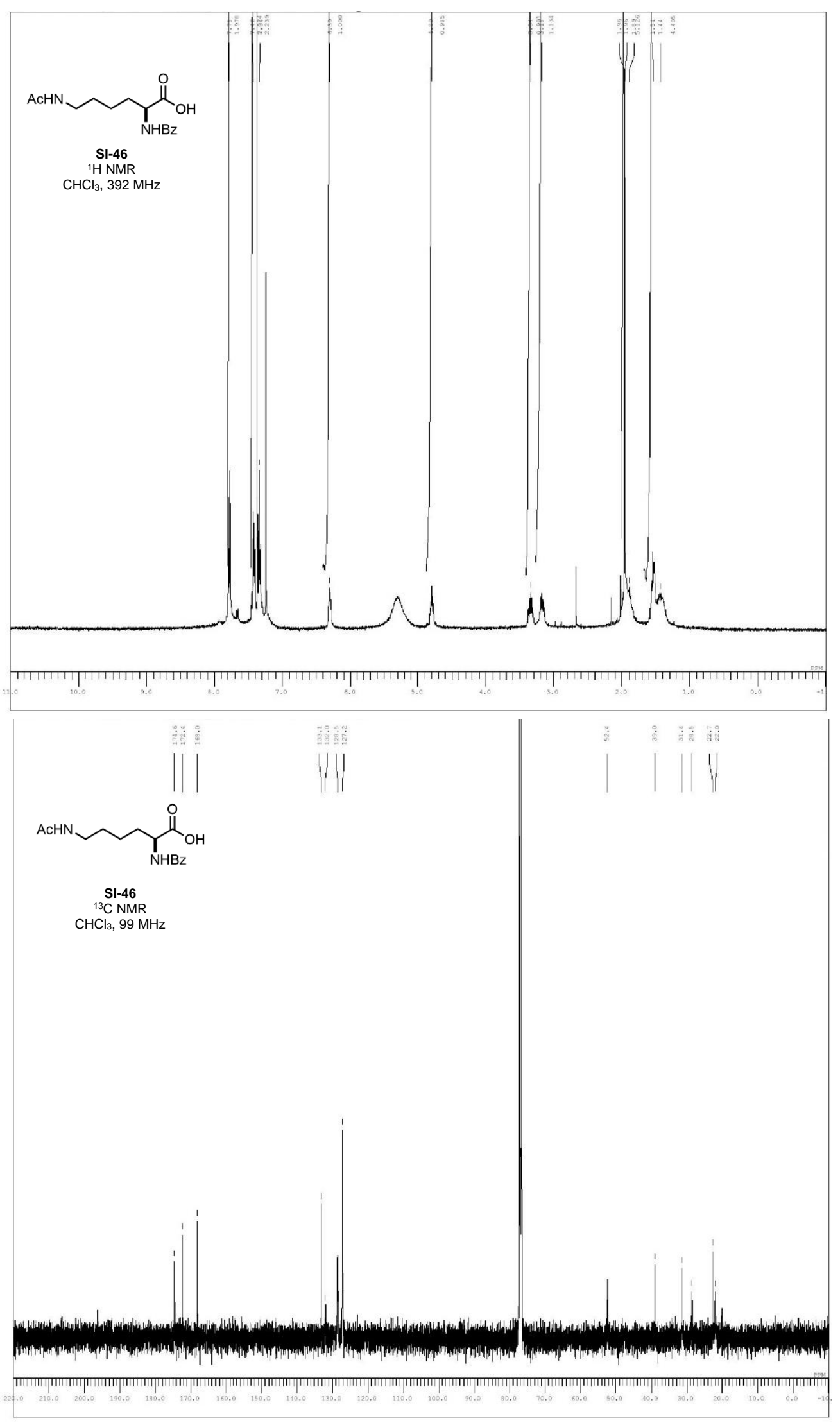

SI-238 

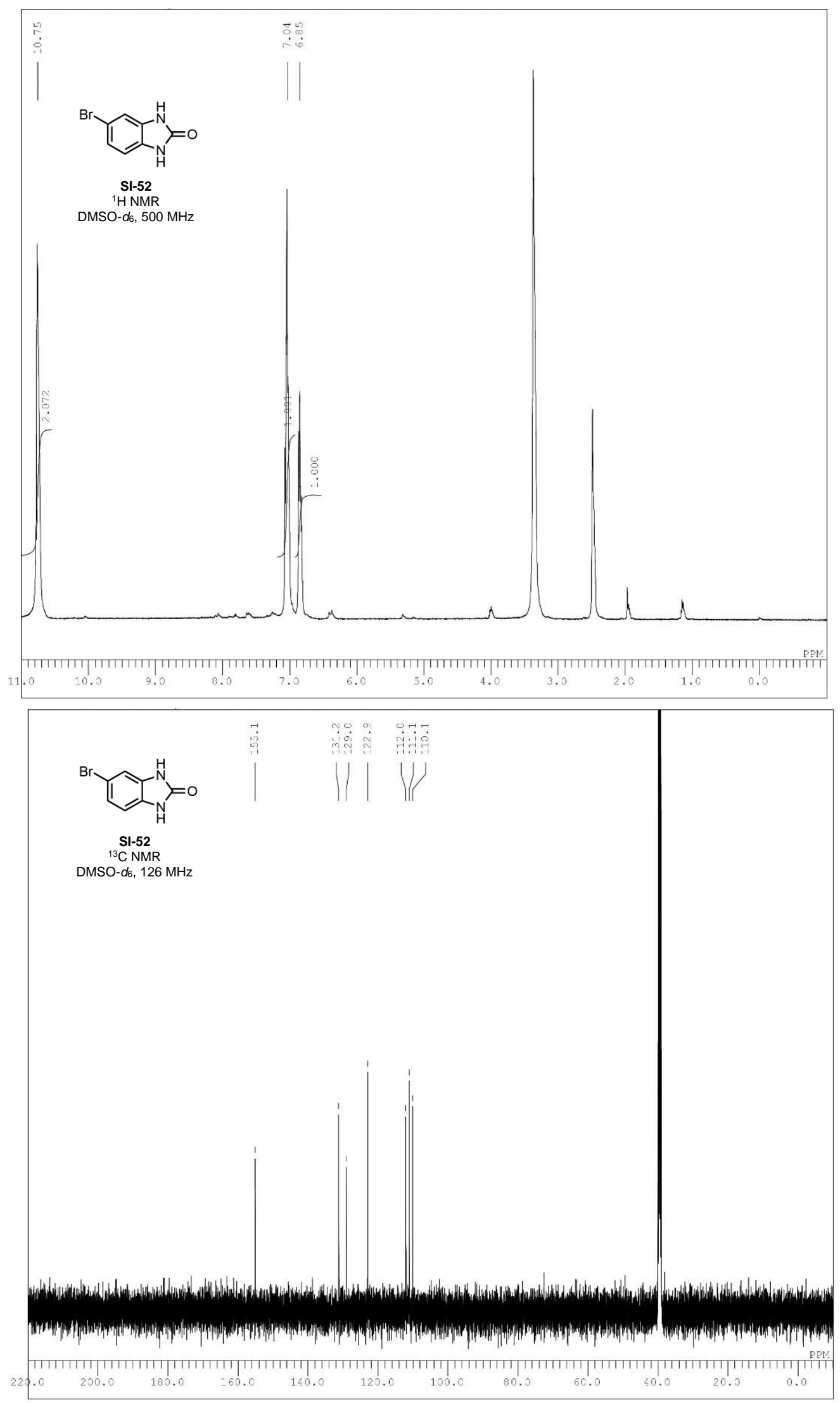

SI-239 

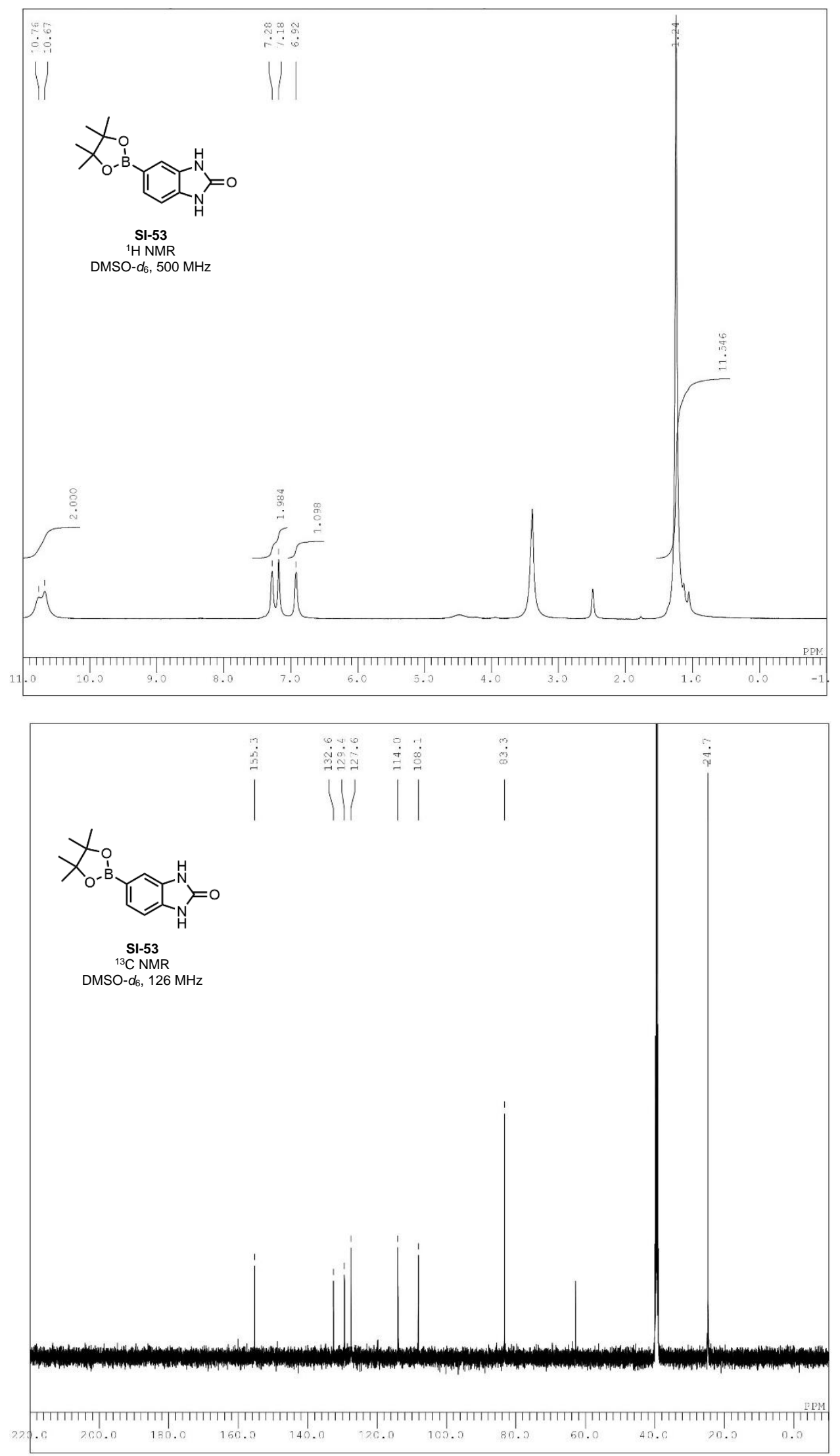

SI-240 


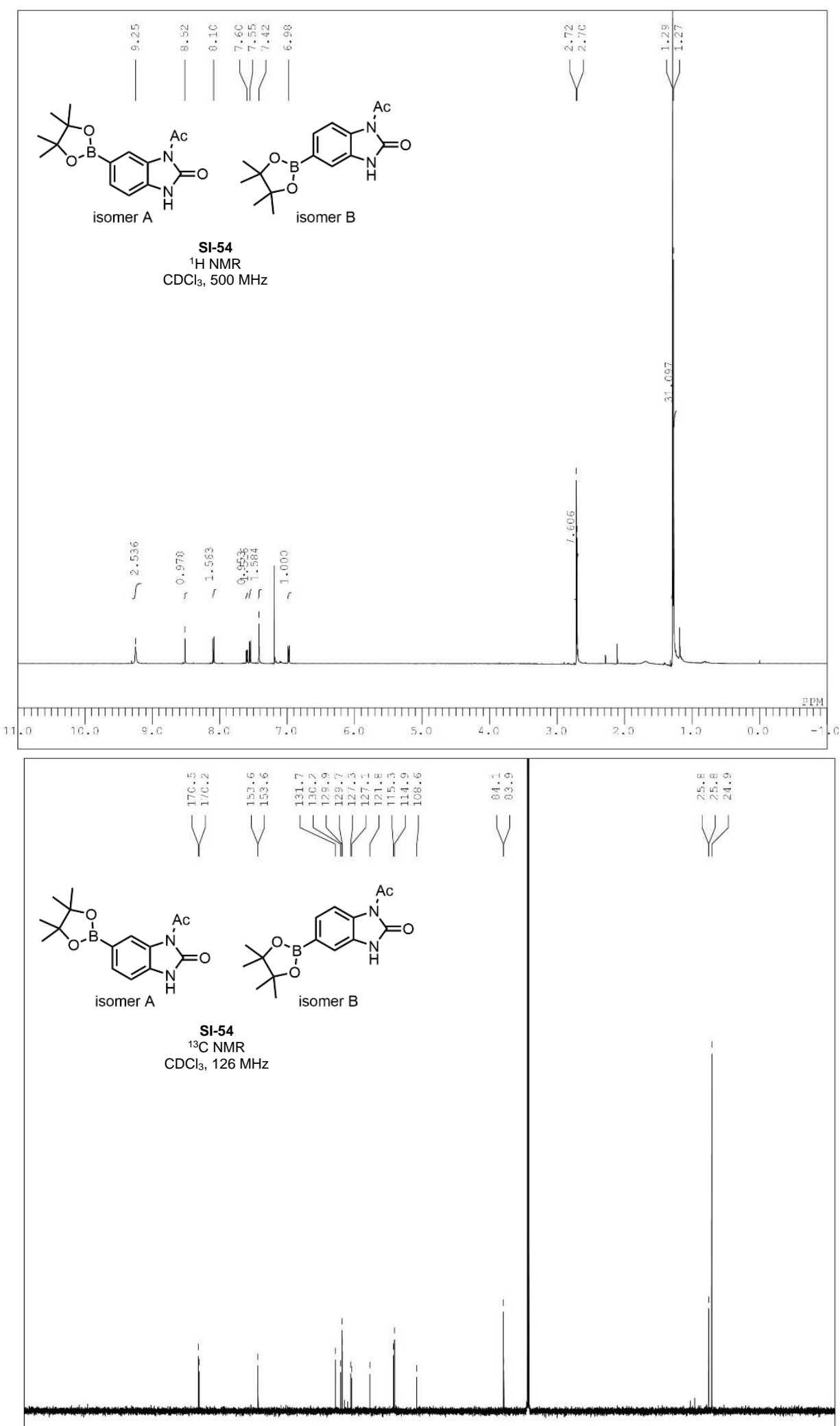

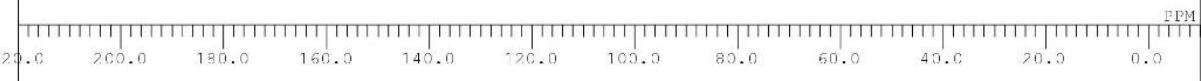



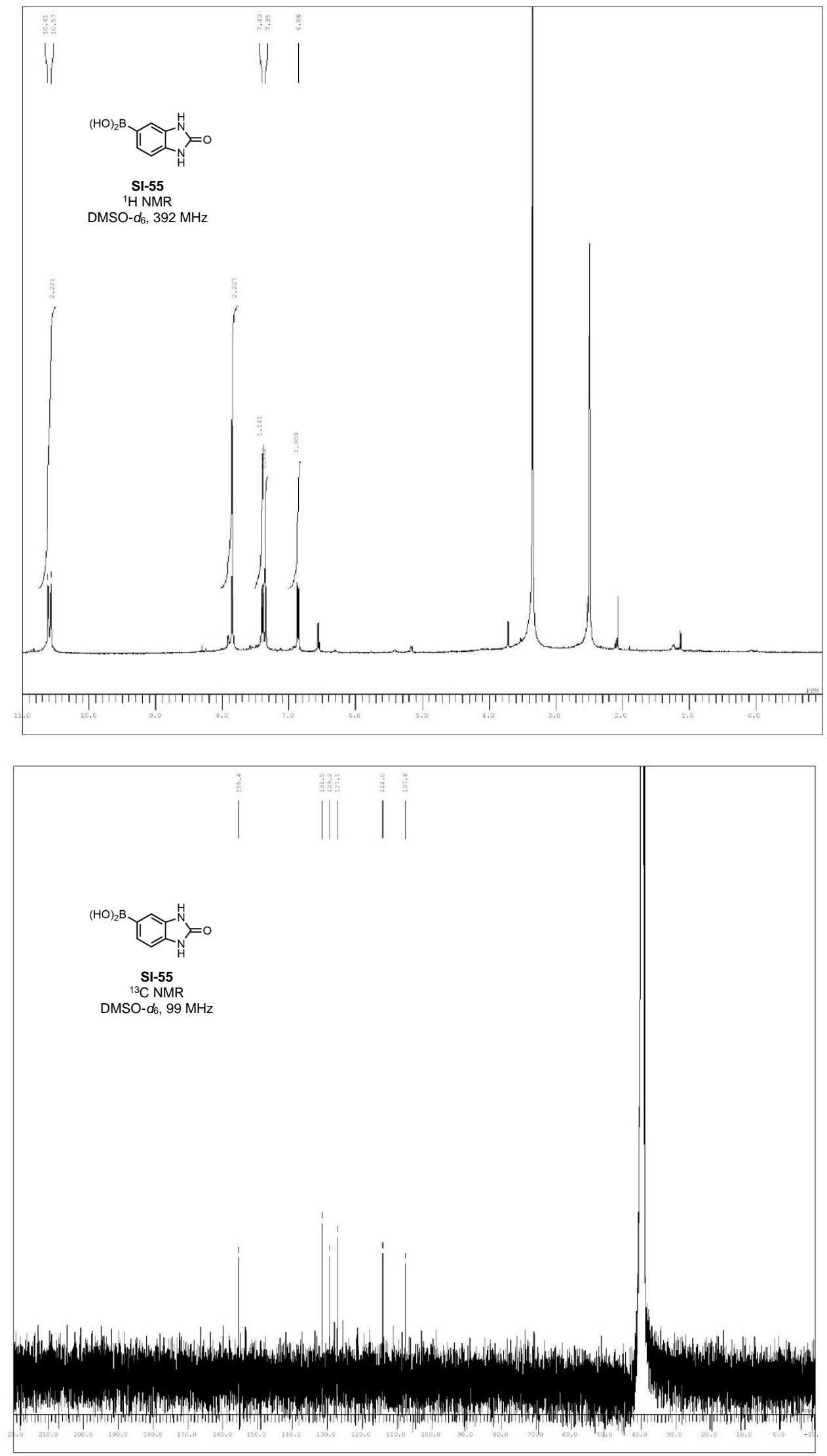

SI-242 

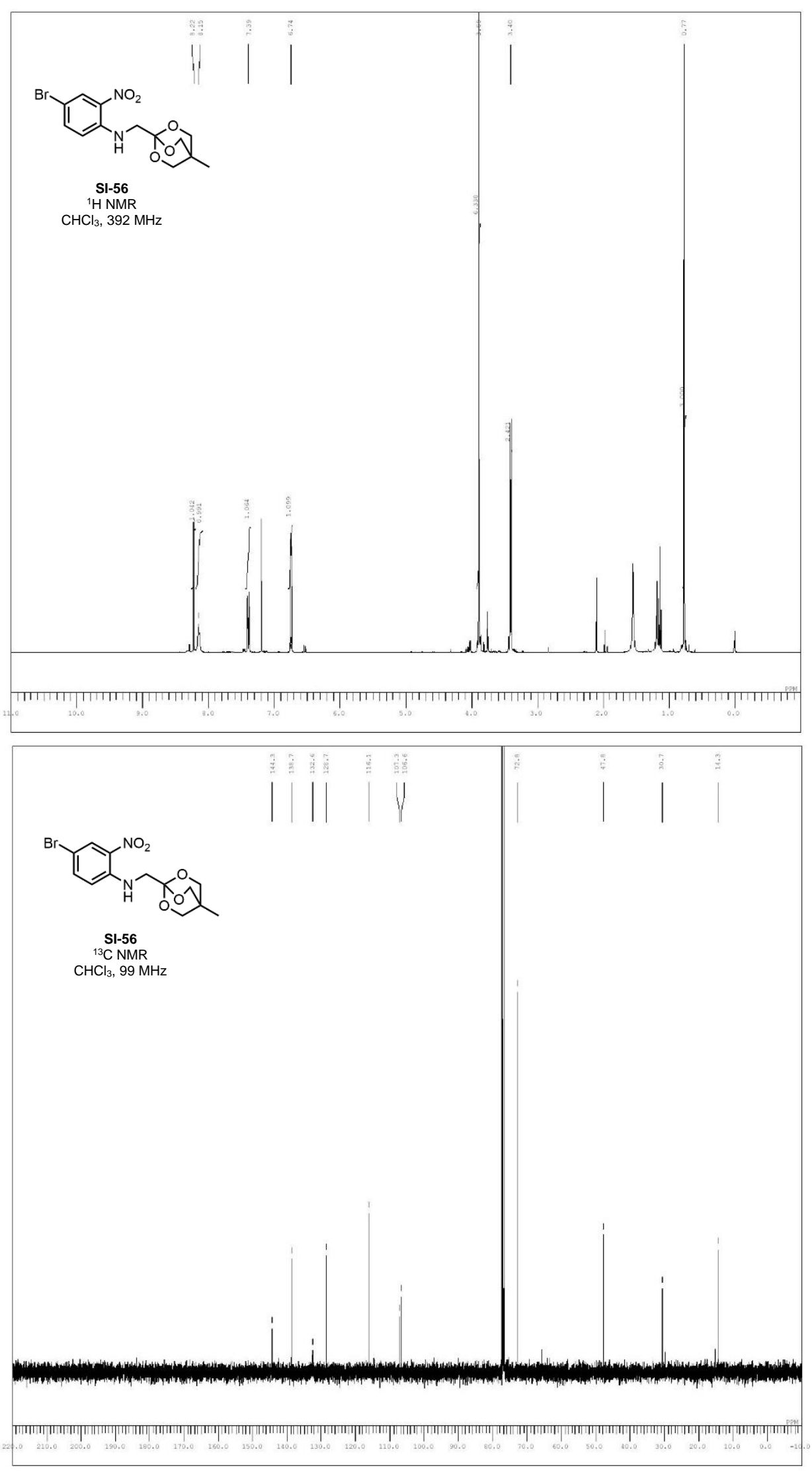

SI-243 


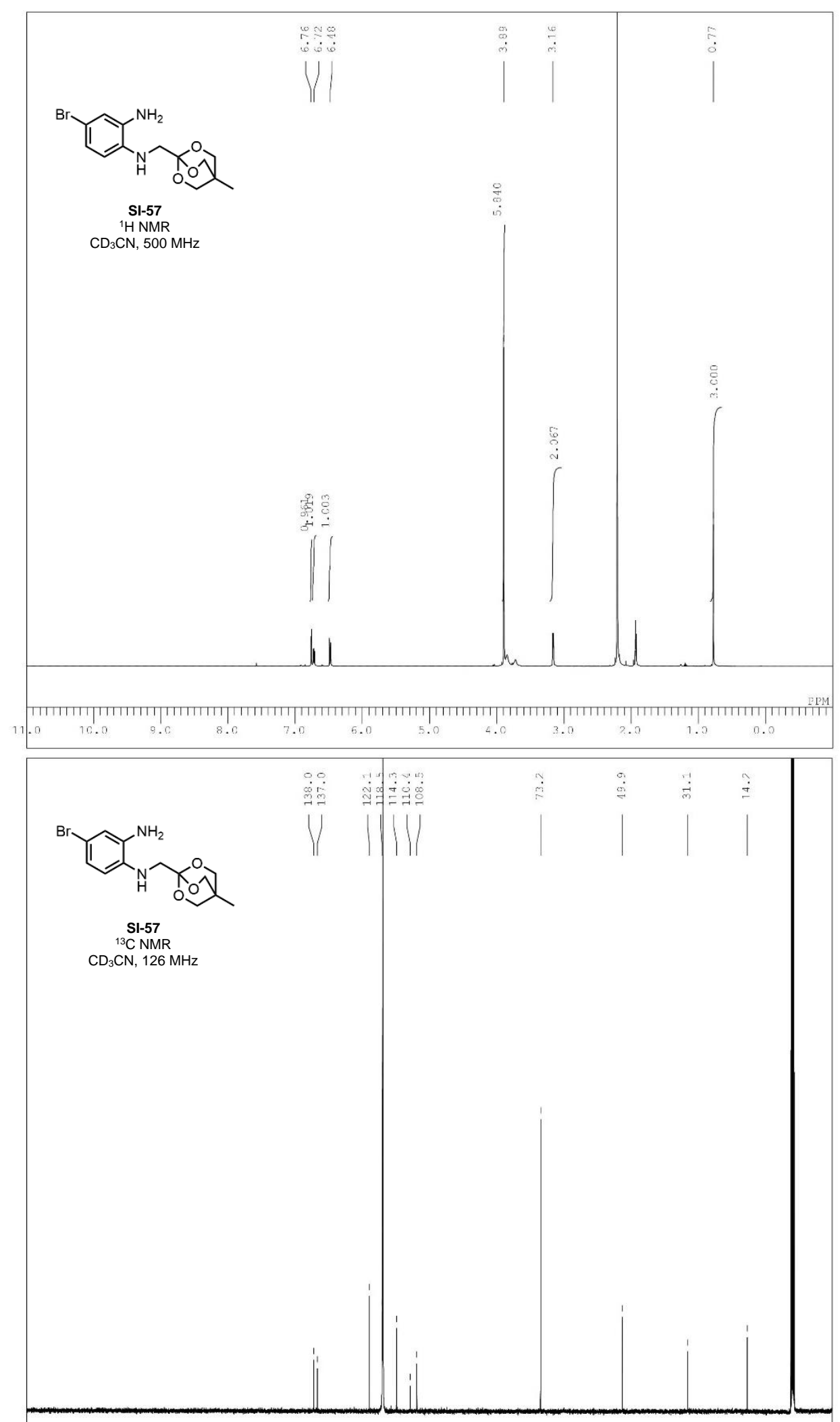

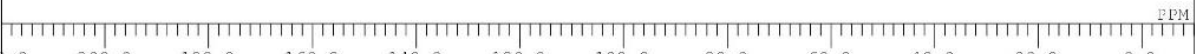

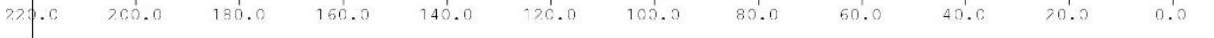

SI-244 

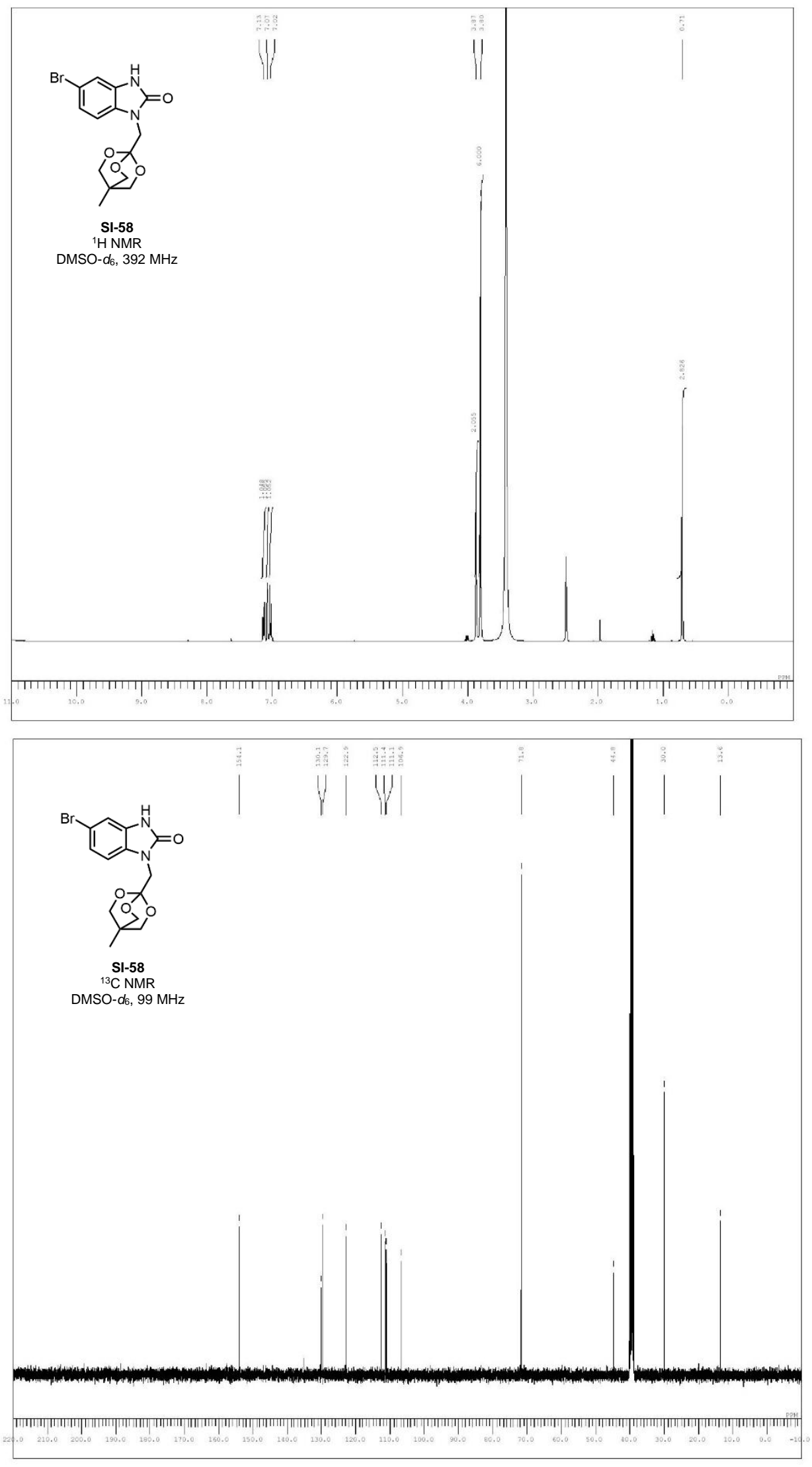

SI-245 

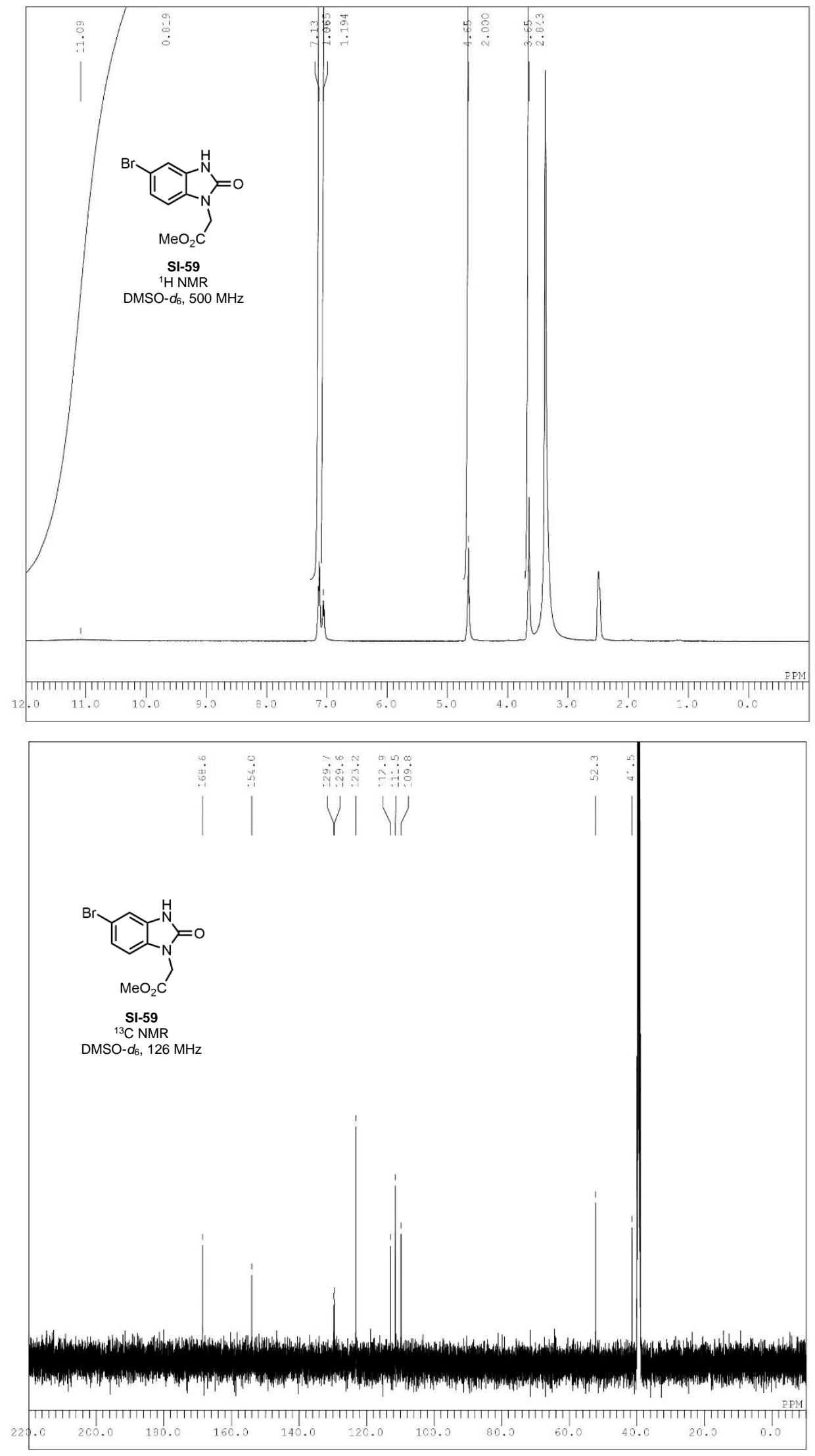

SI-246 

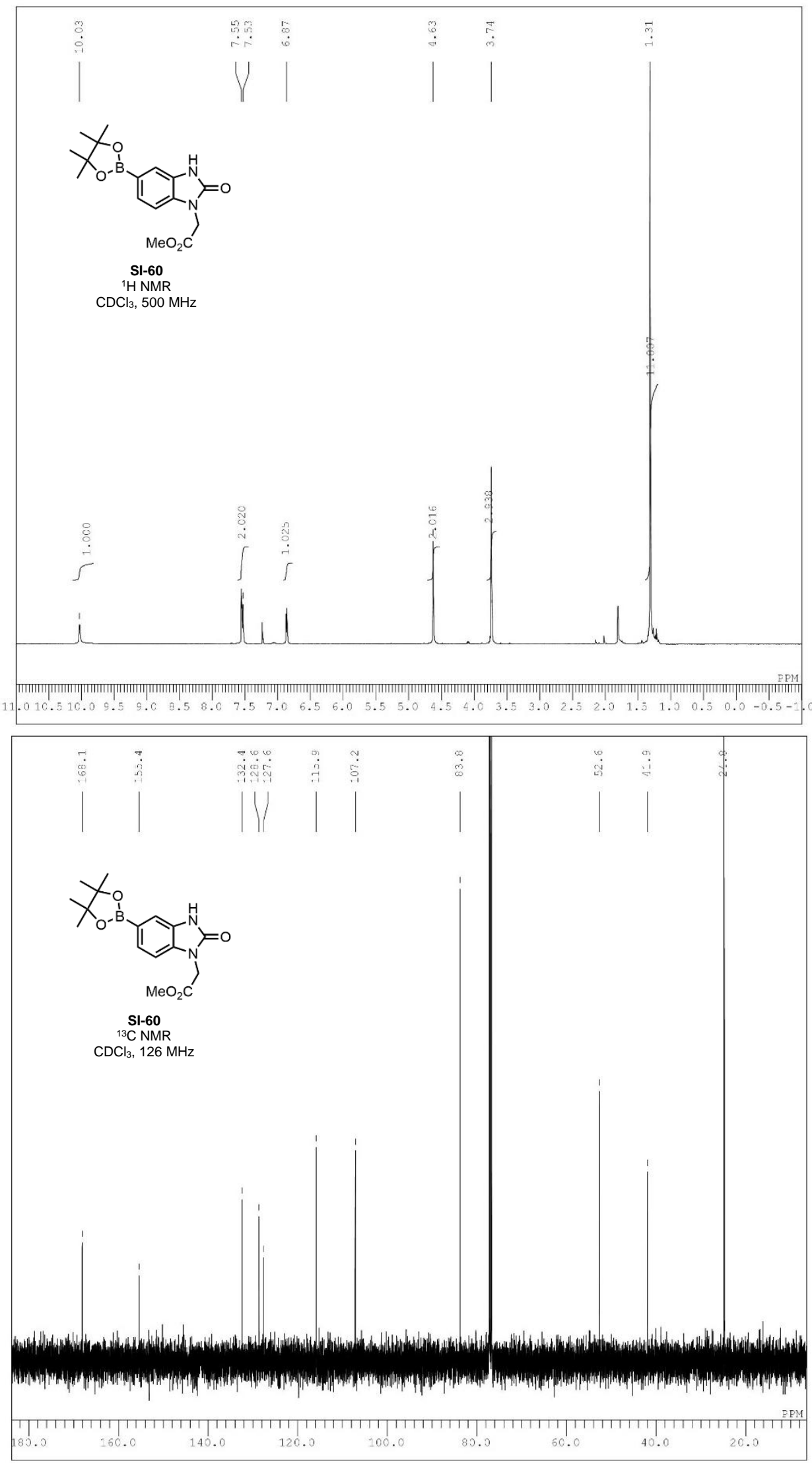

SI-247 

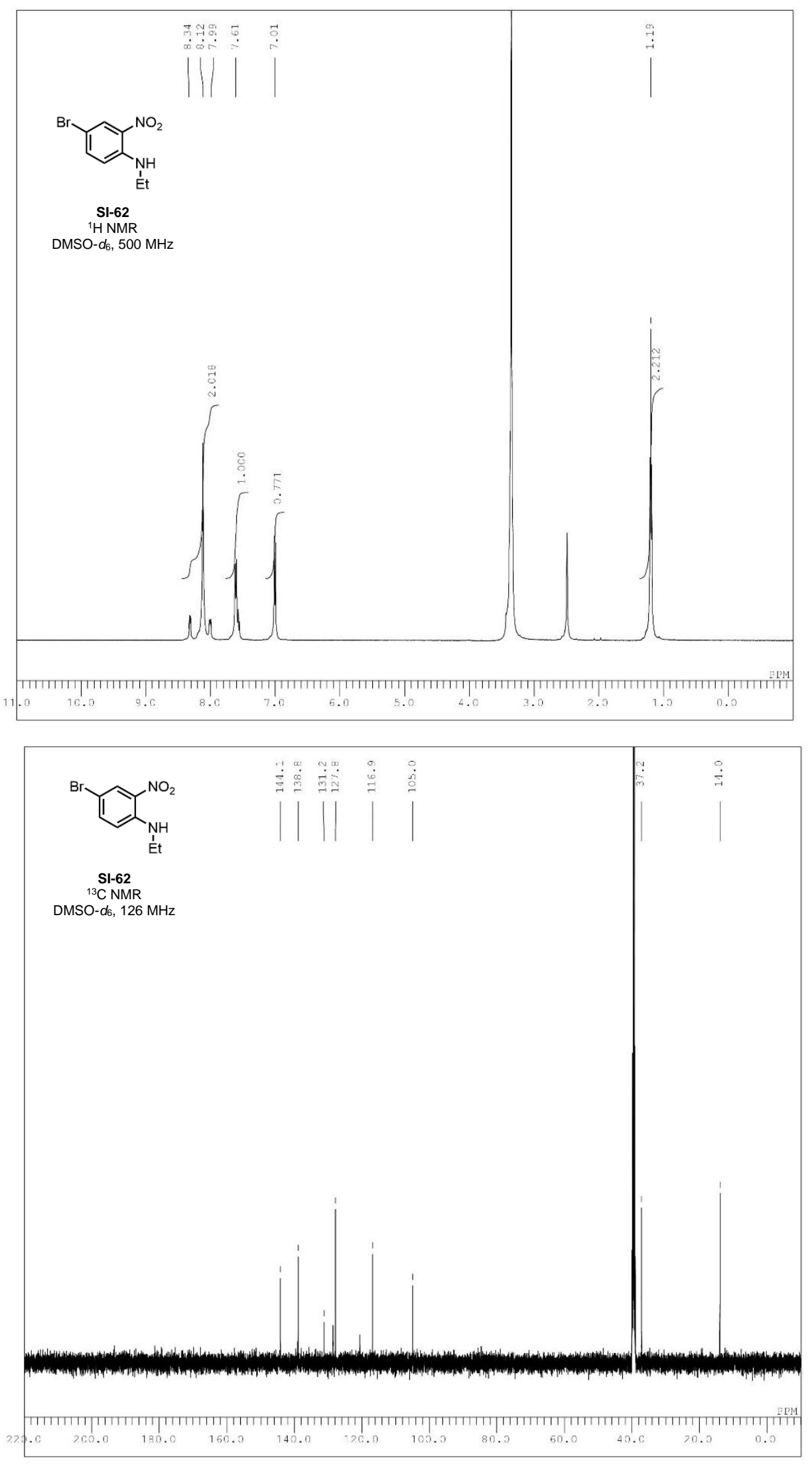

SI-248 


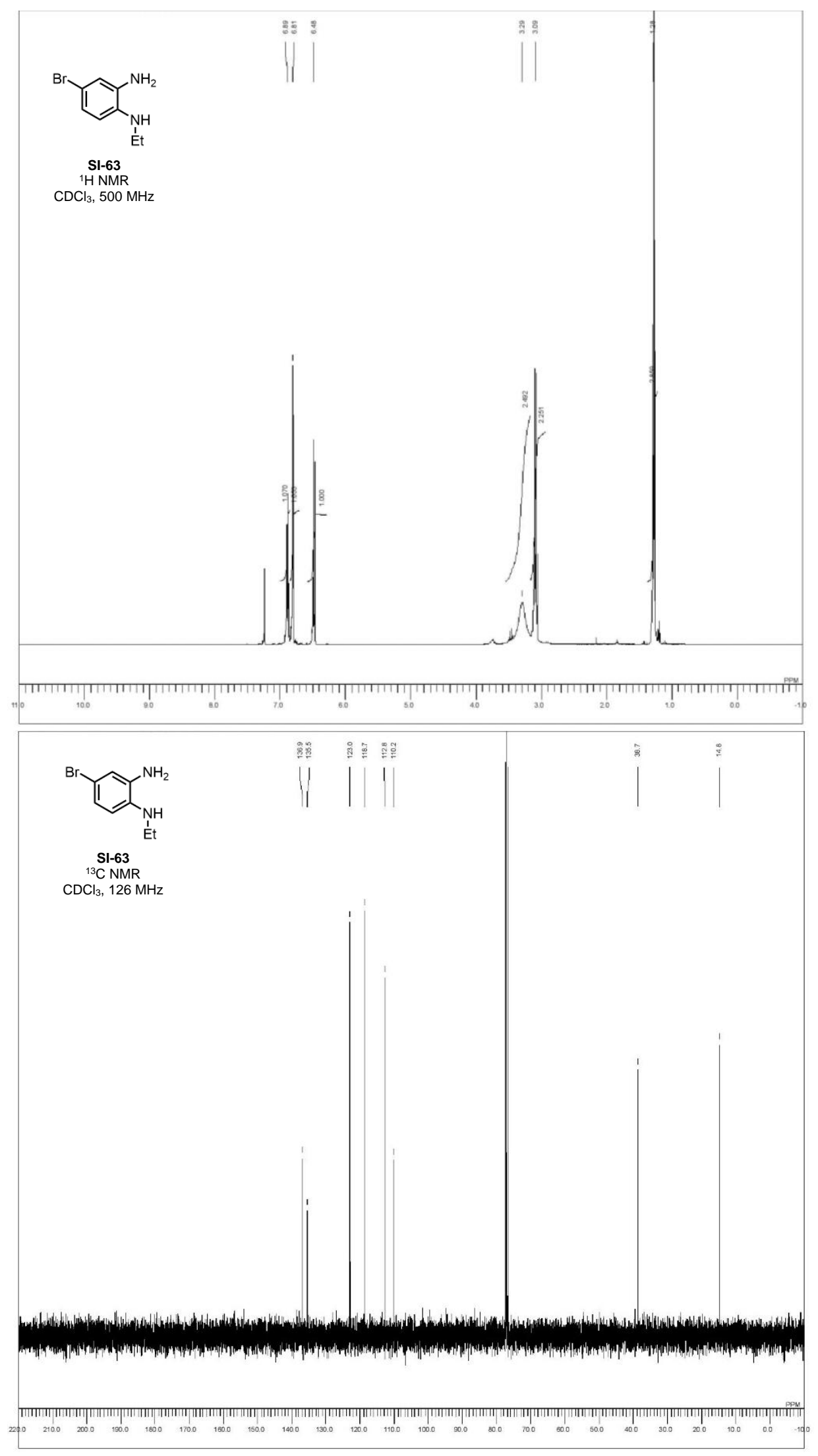

SI-249 

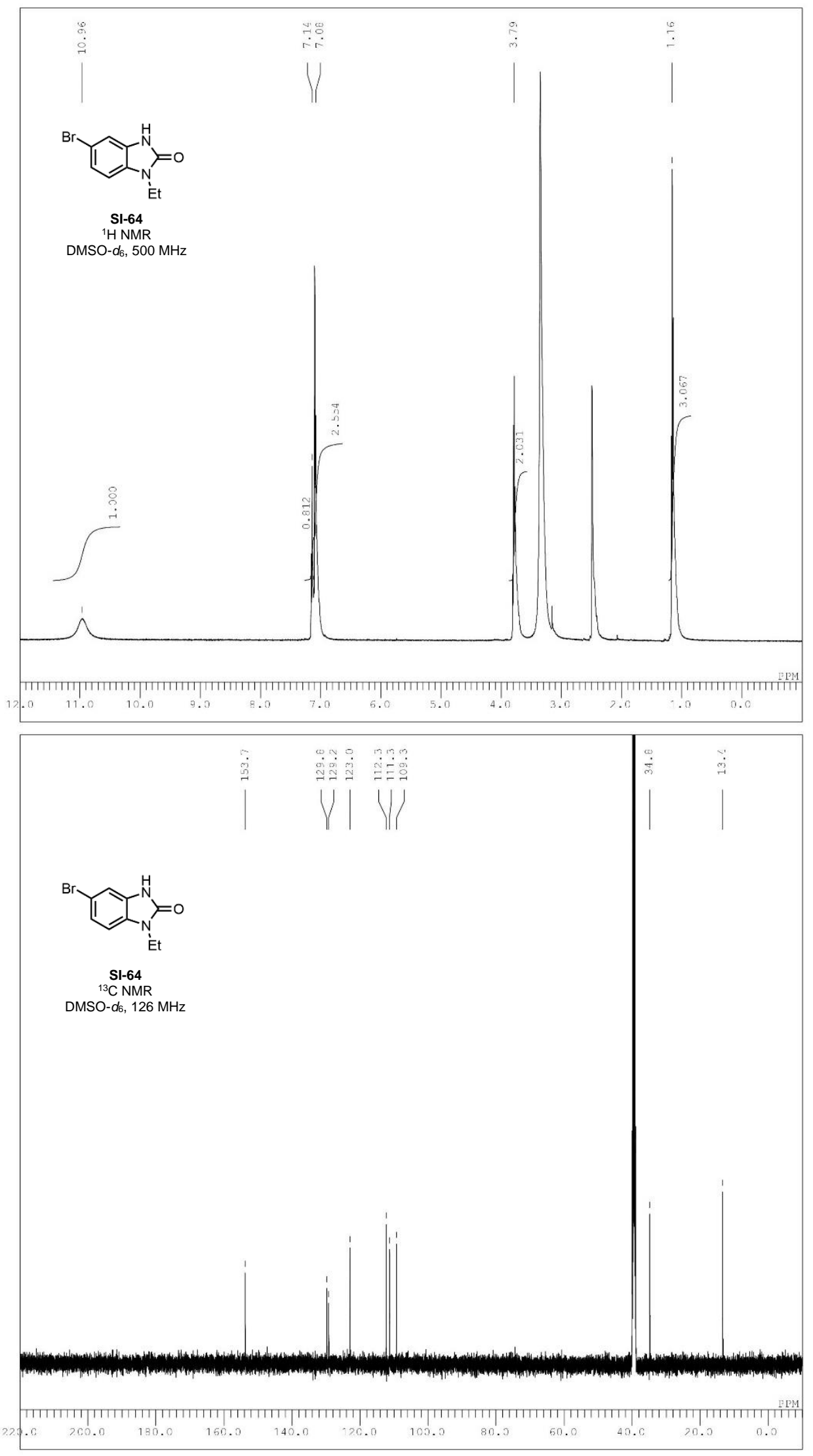

SI-250 

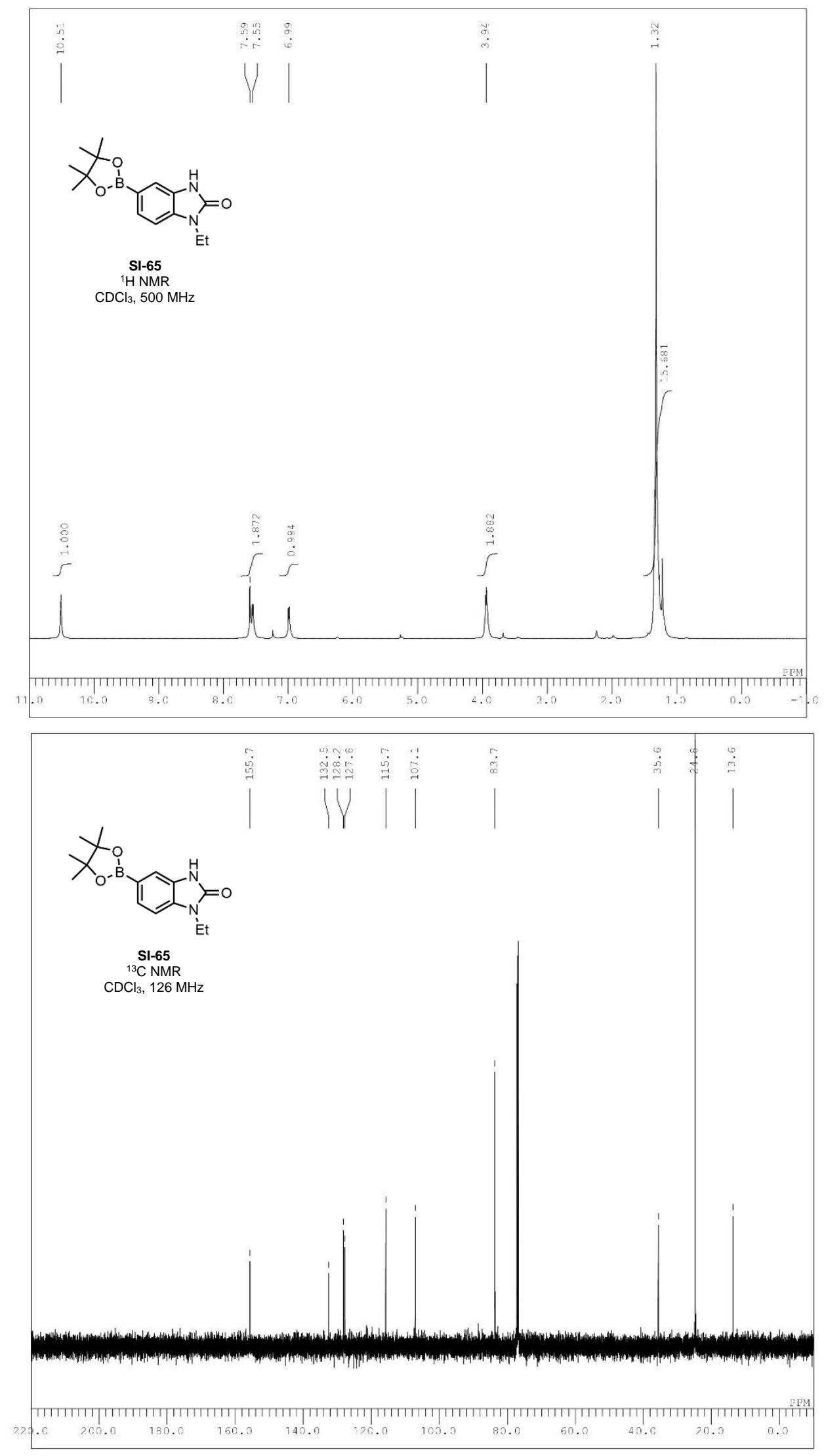

SI-251 

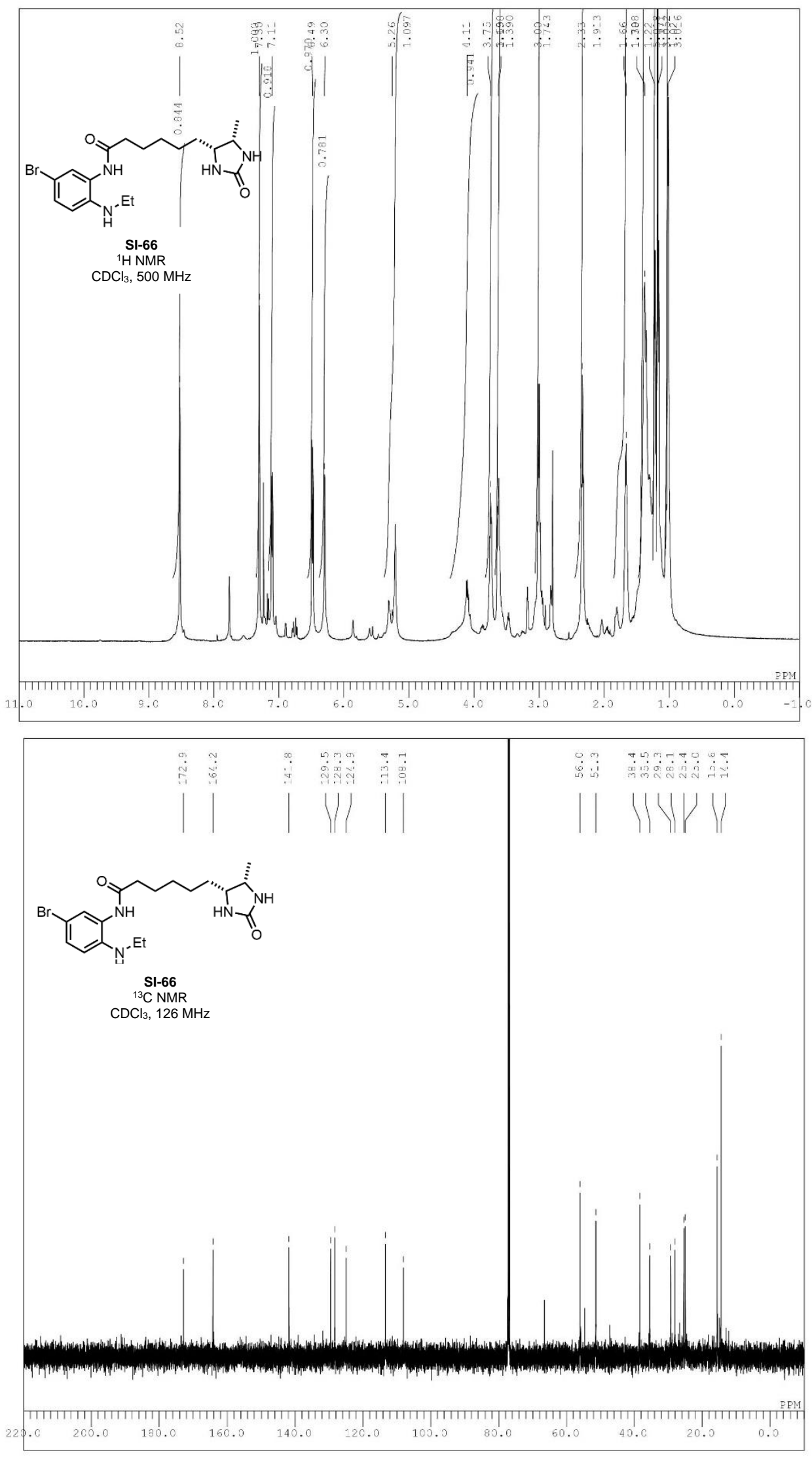

SI-252 

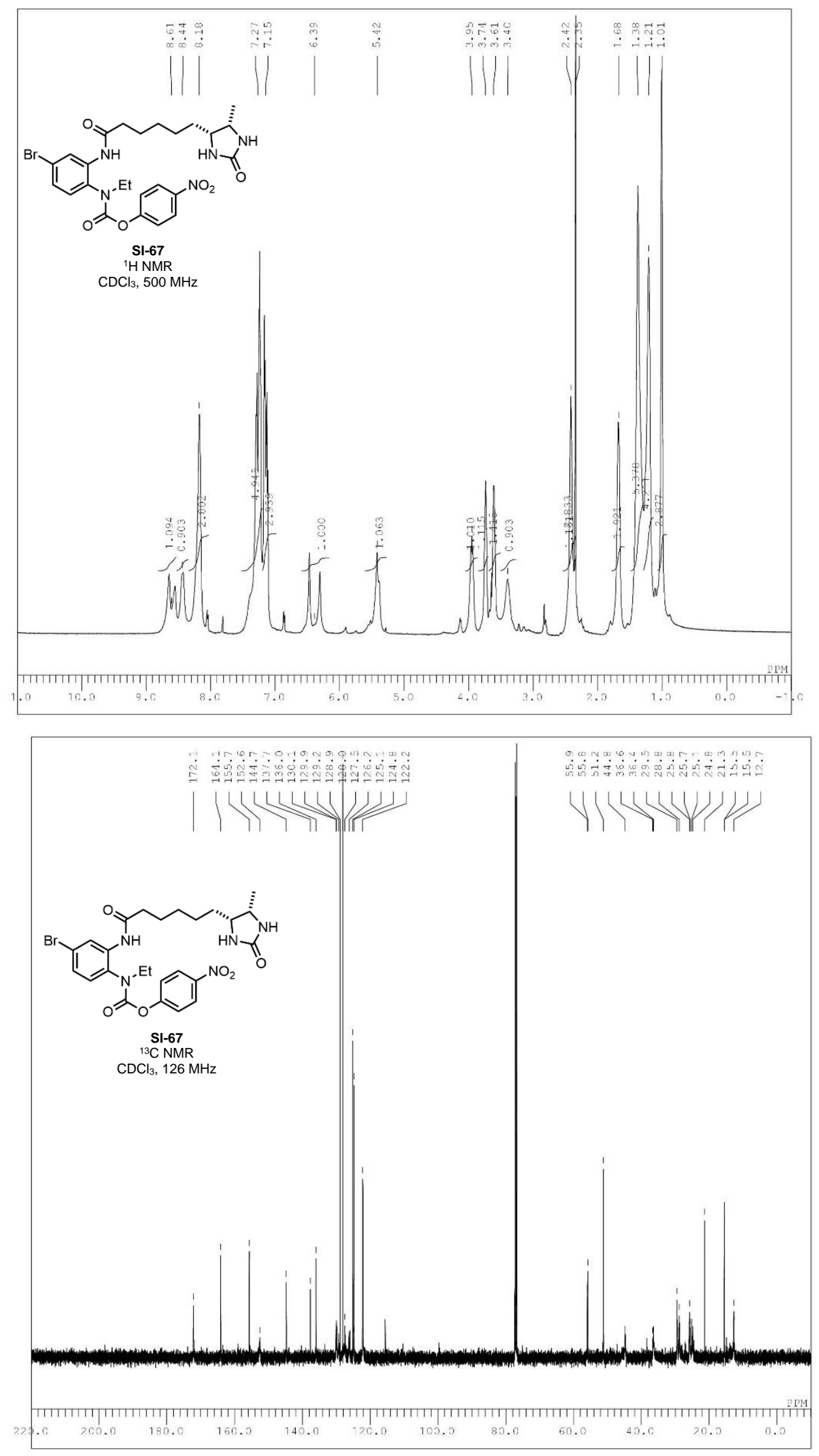

SI-253 

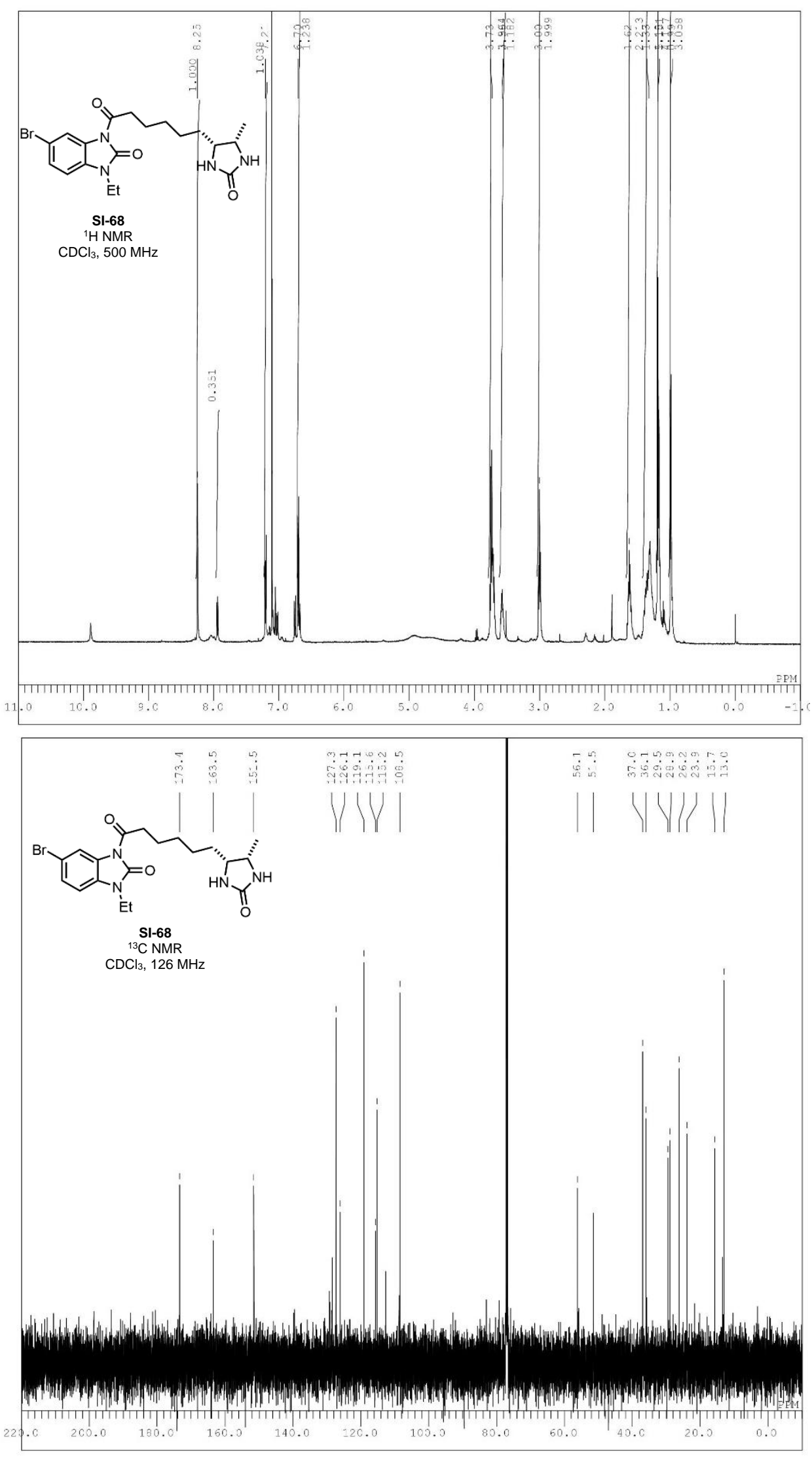

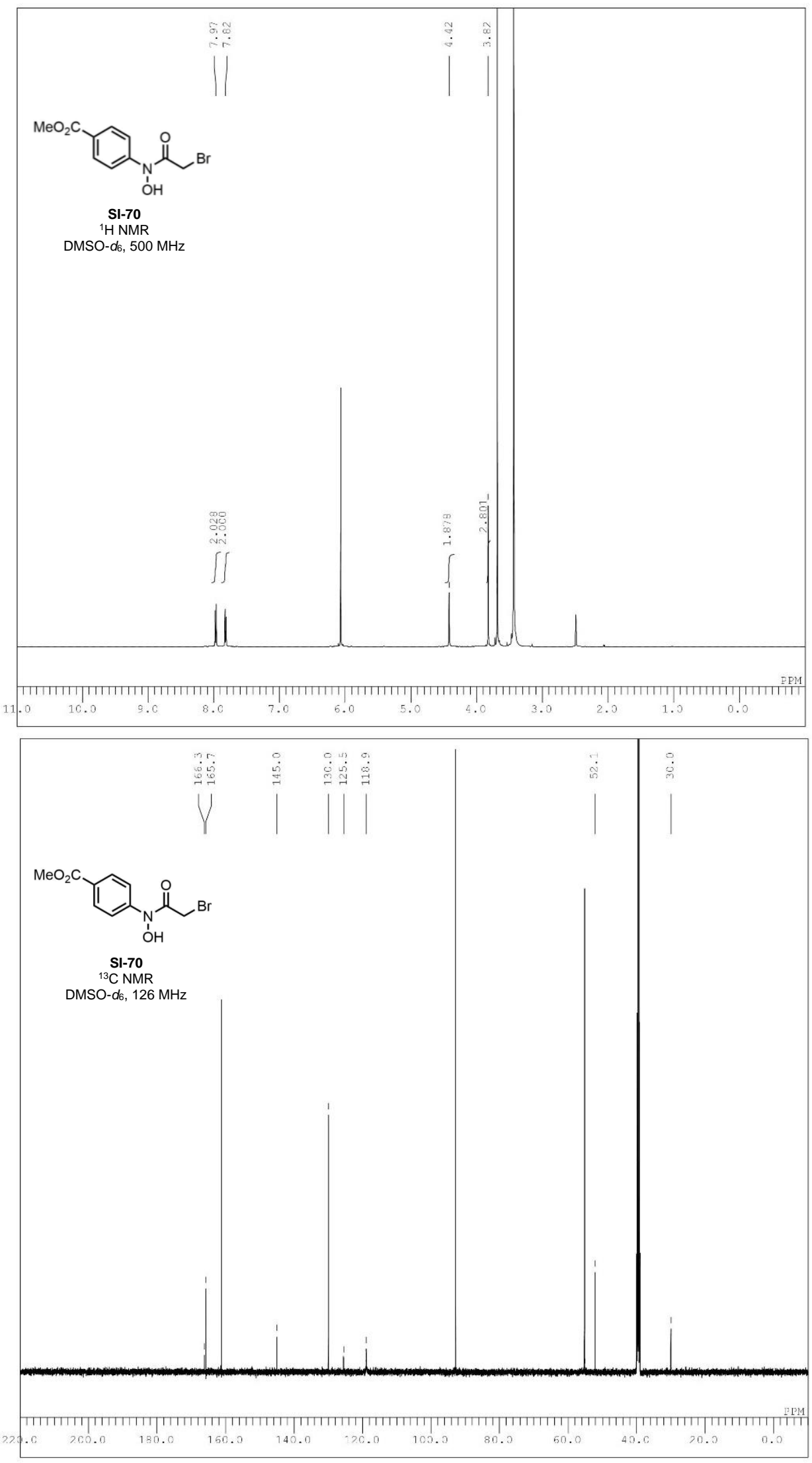

SI-255 


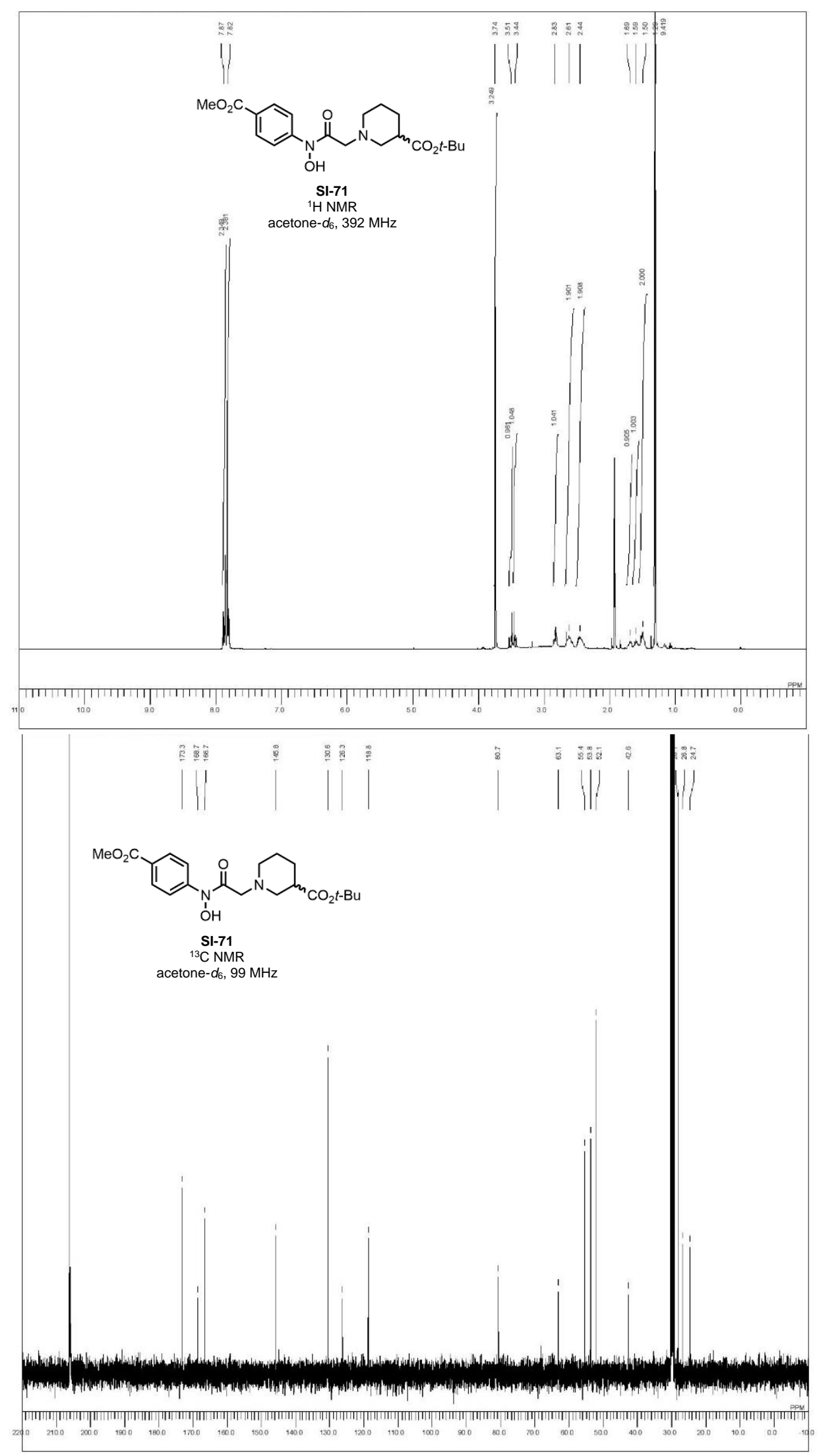

SI-256 

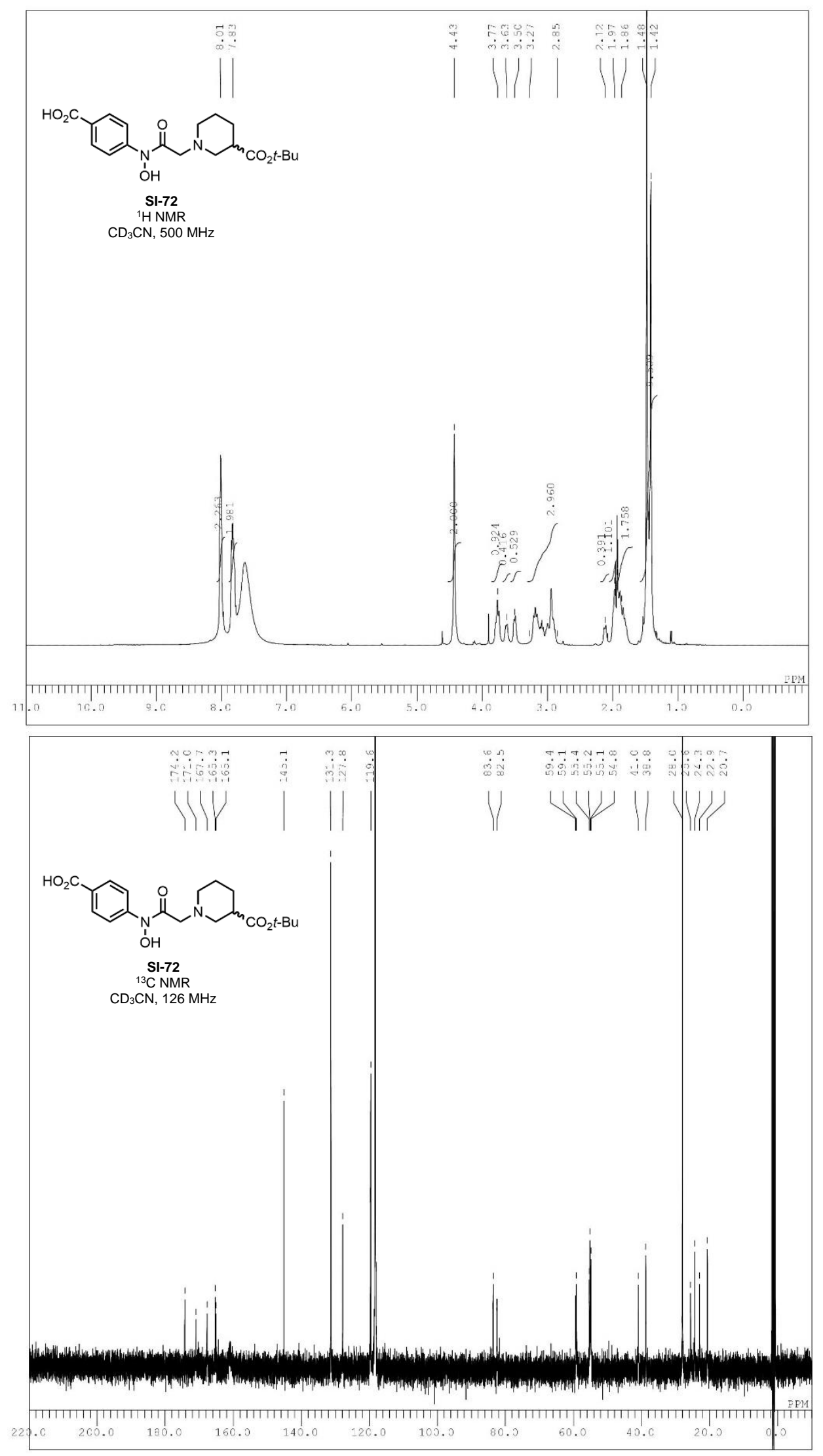

SI-257 

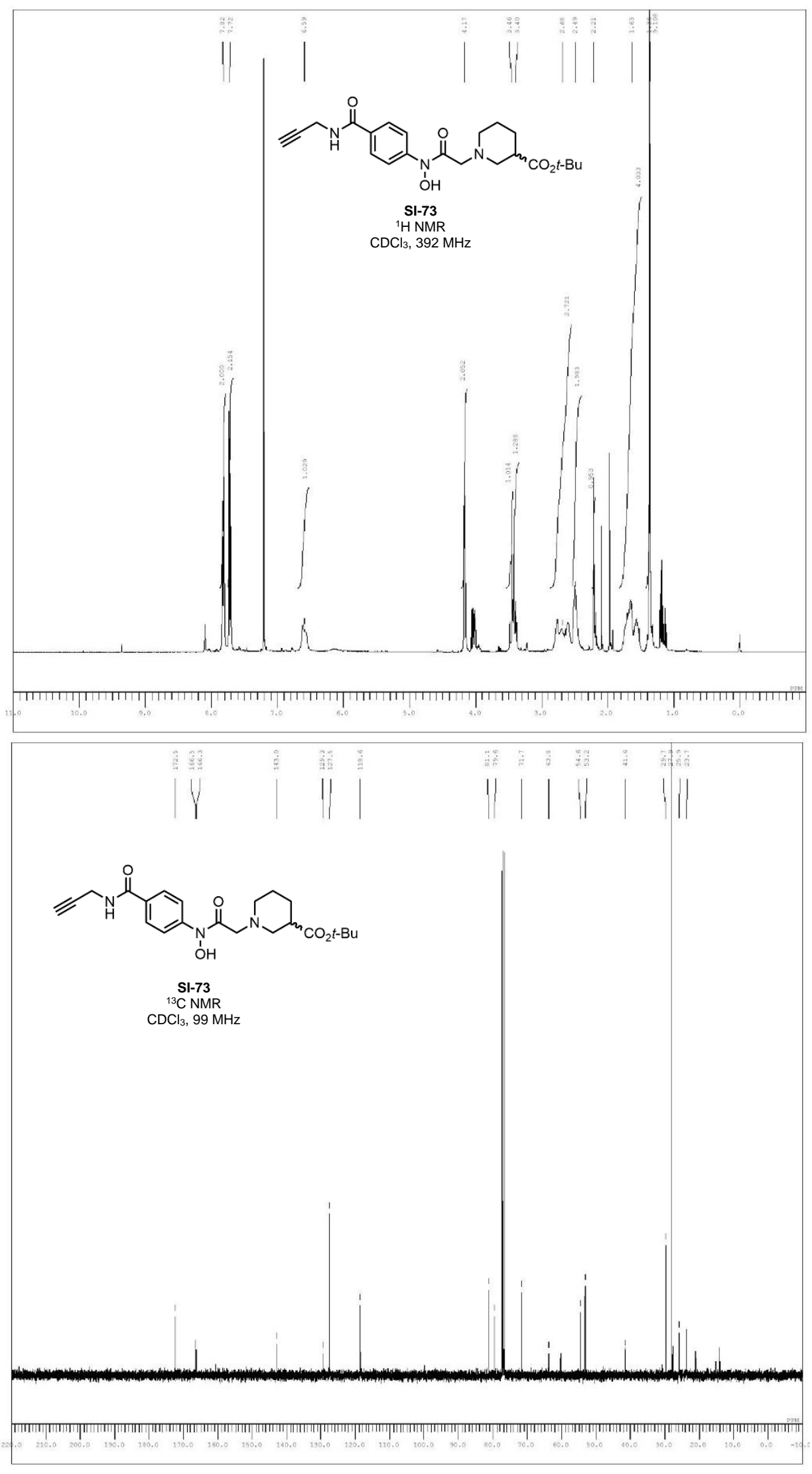

SI-258 

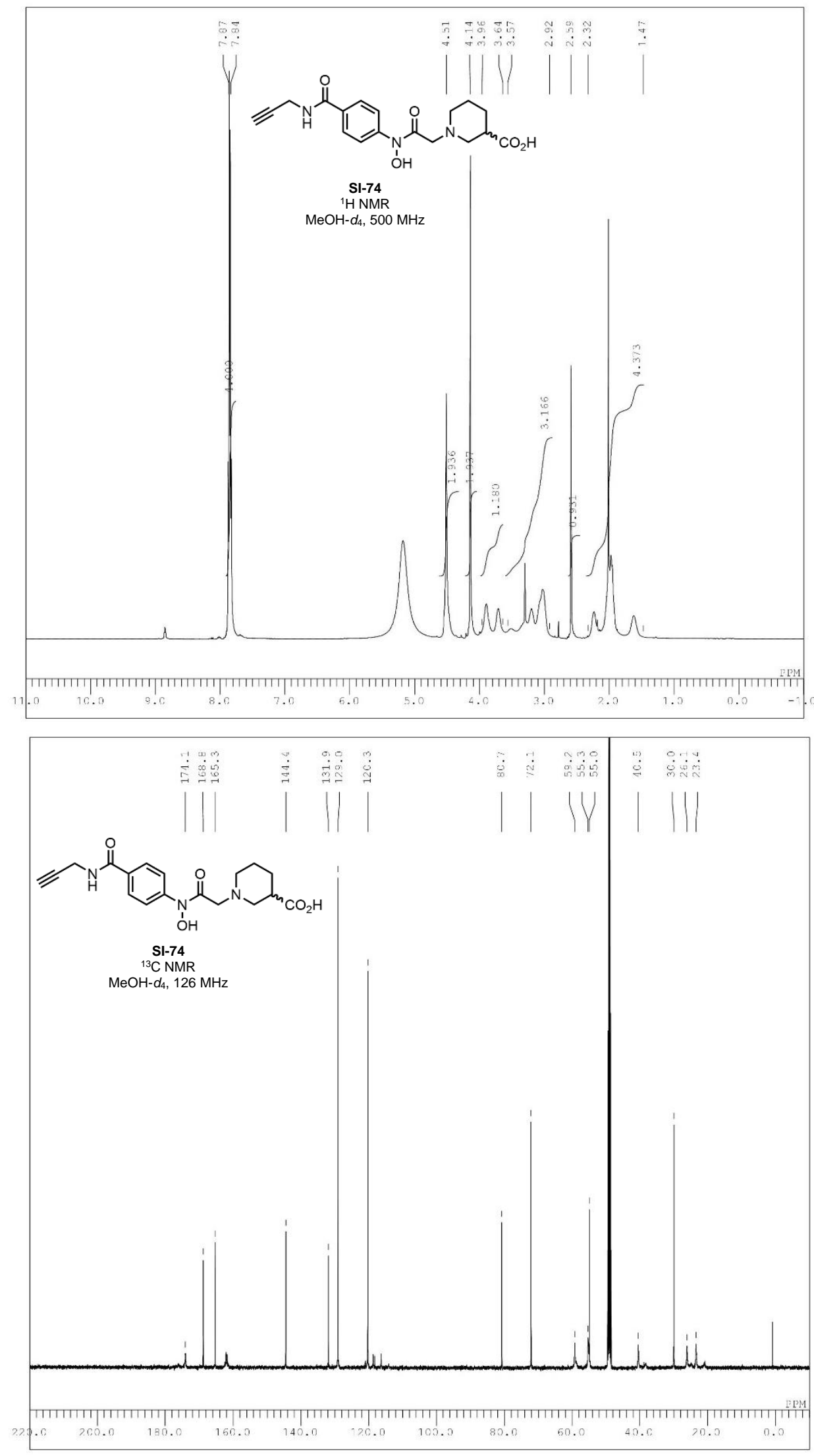

SI-259 

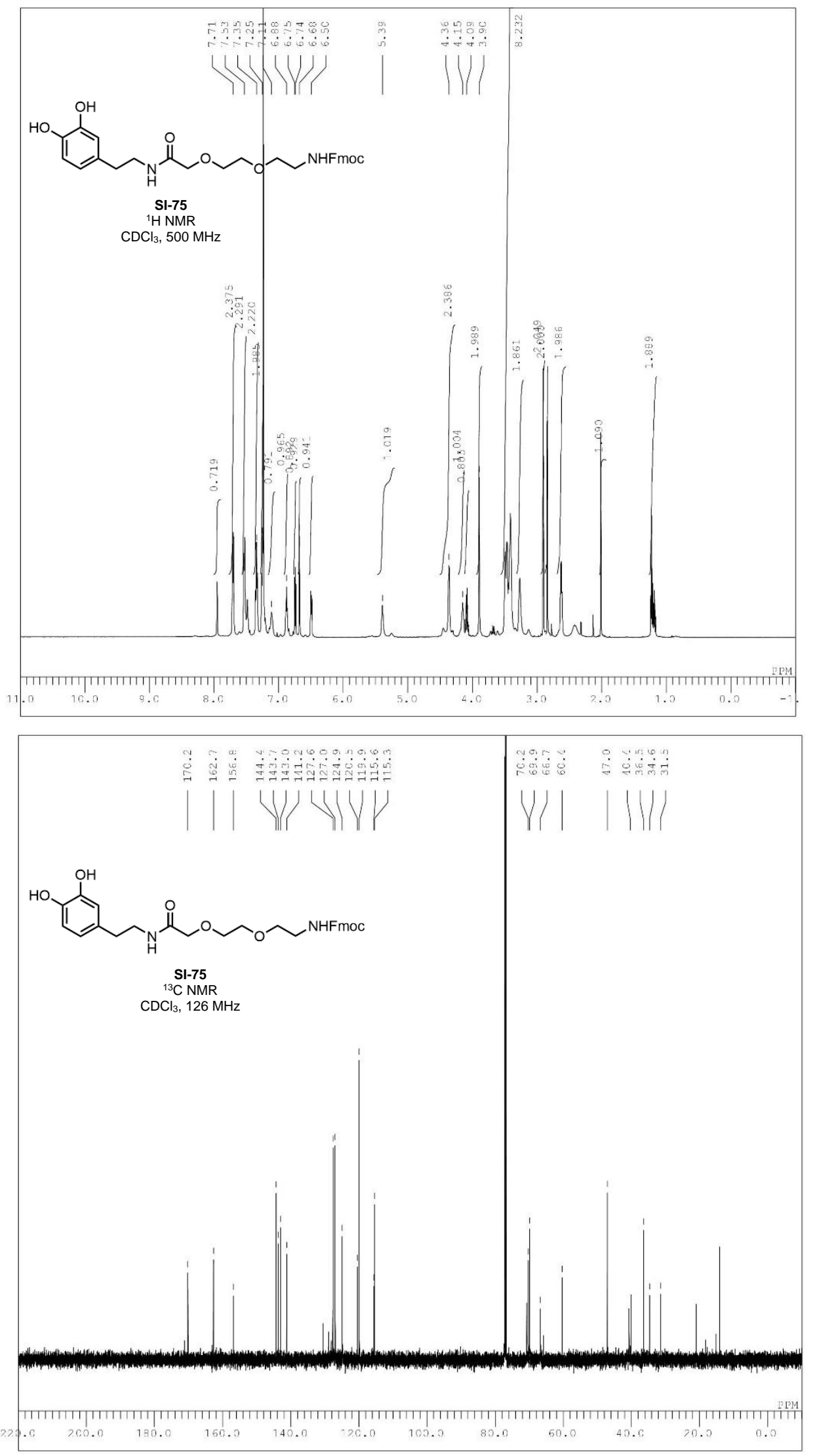

SI-260 

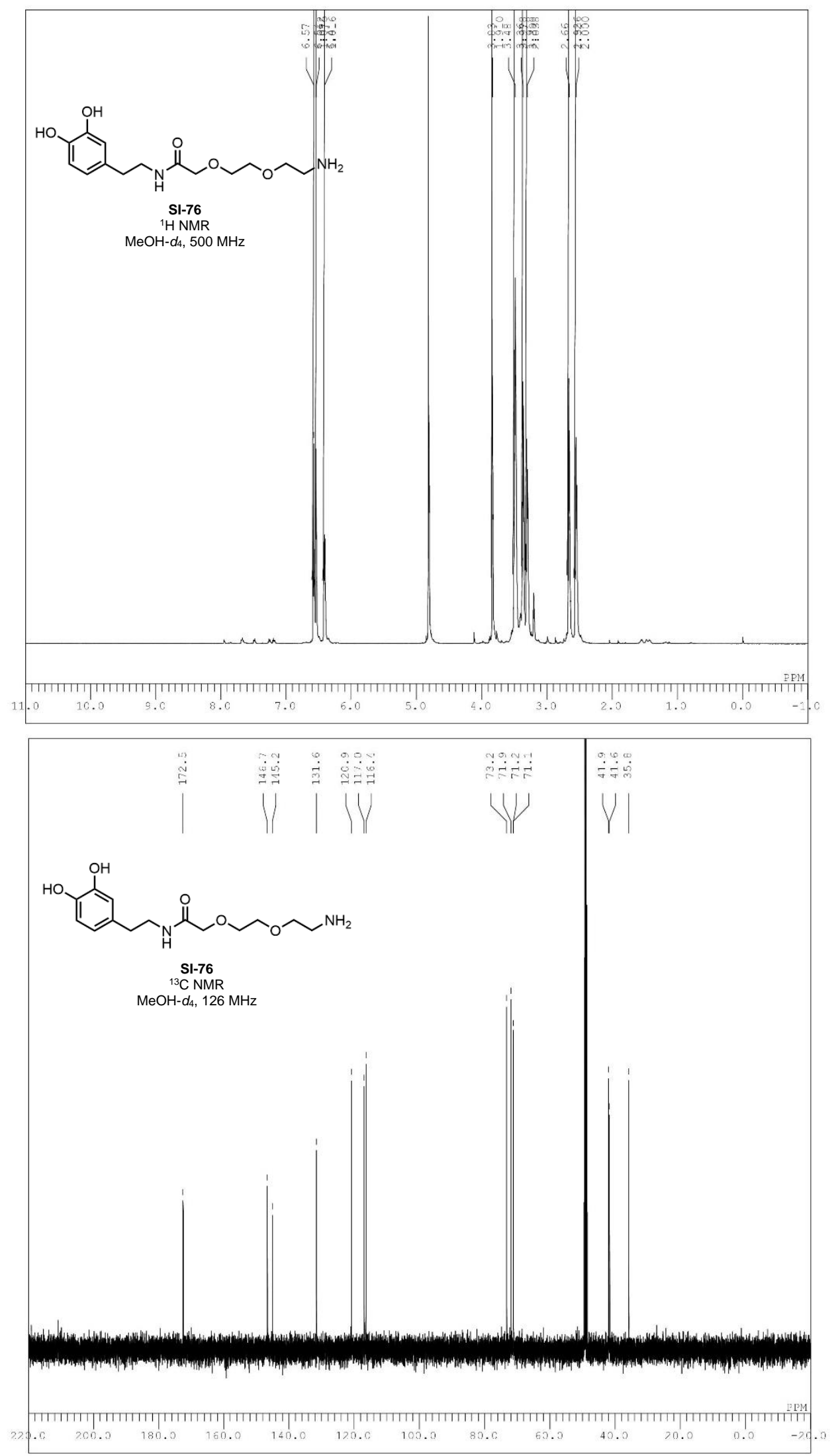

SI-261 

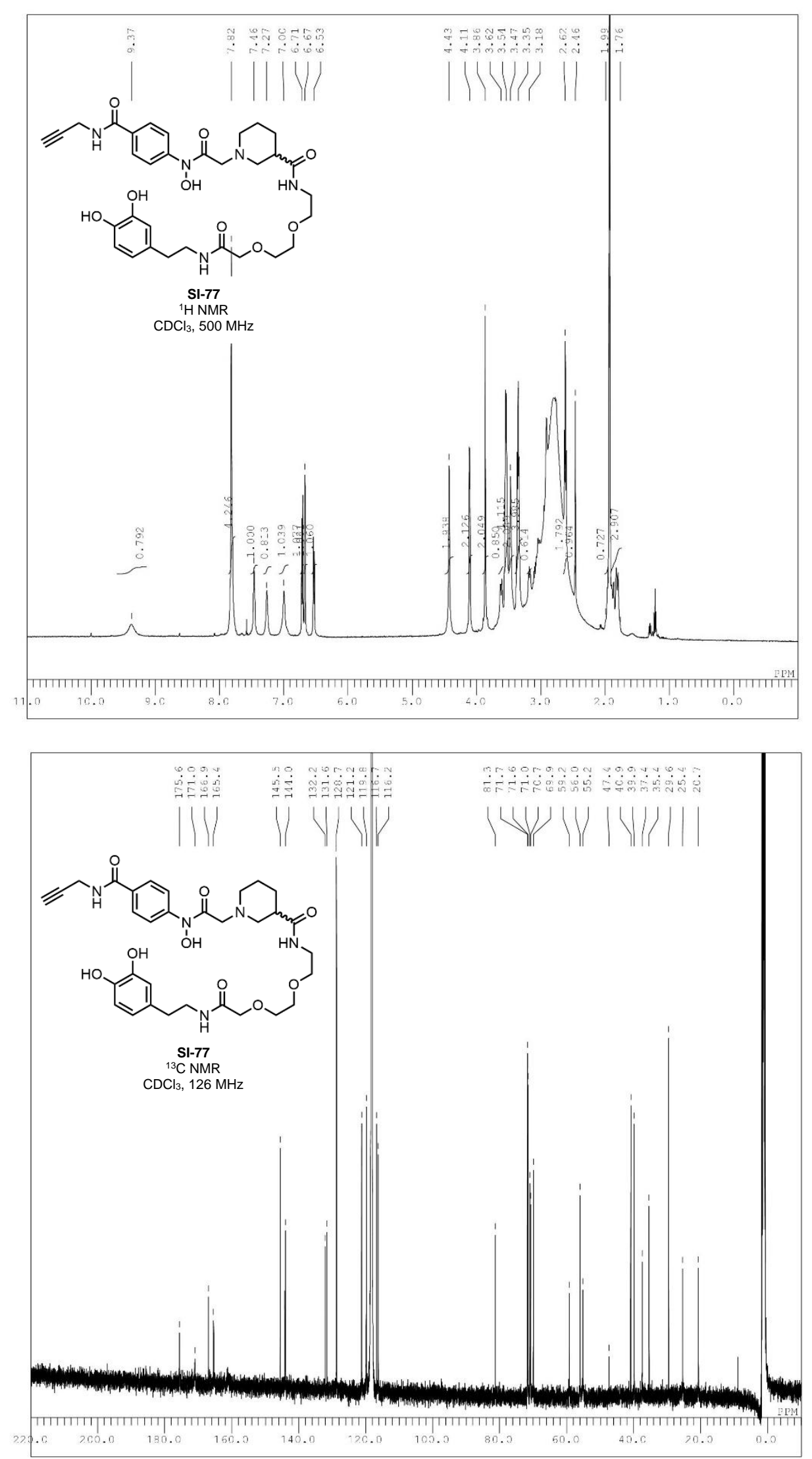

SI-262 

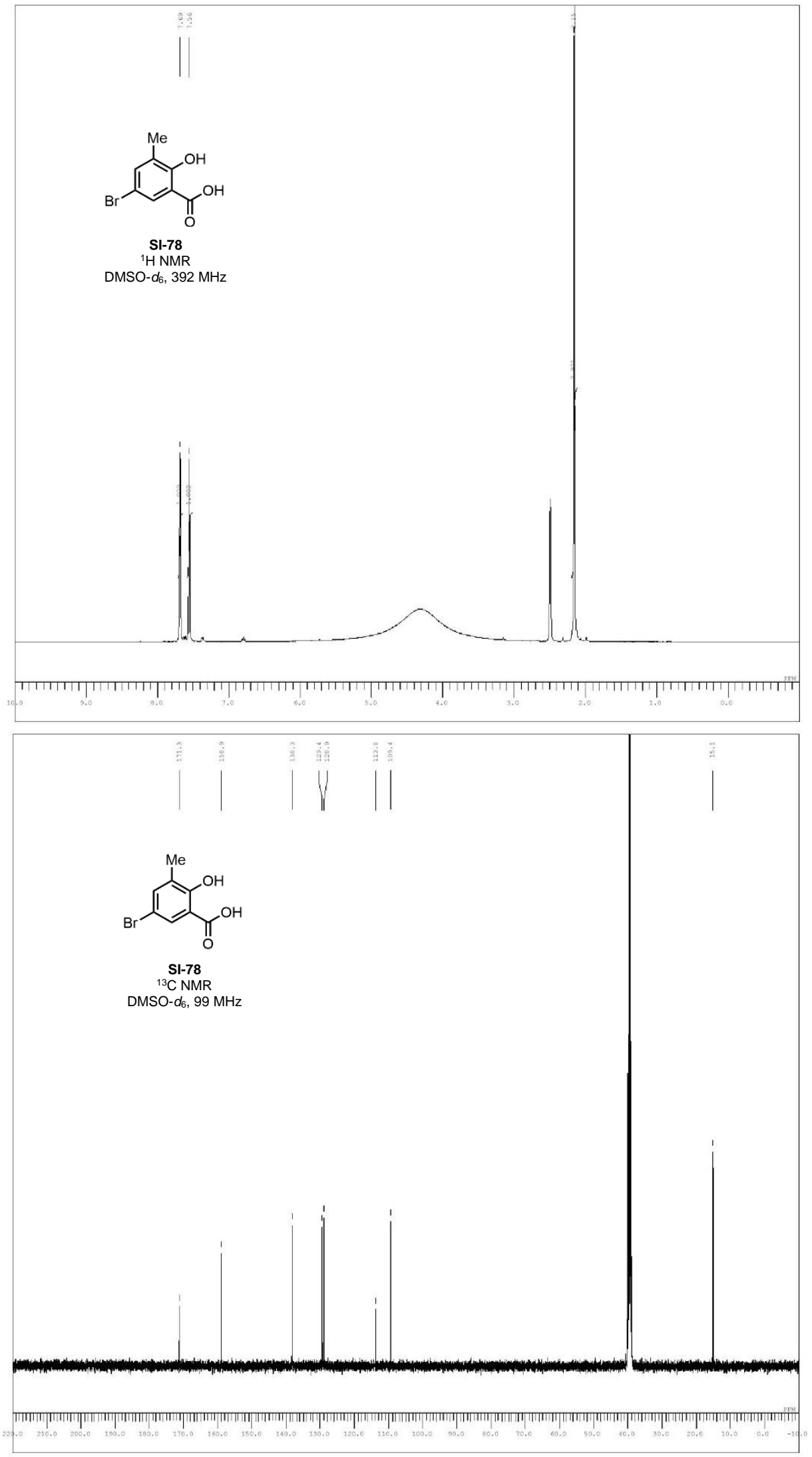

SI-263 

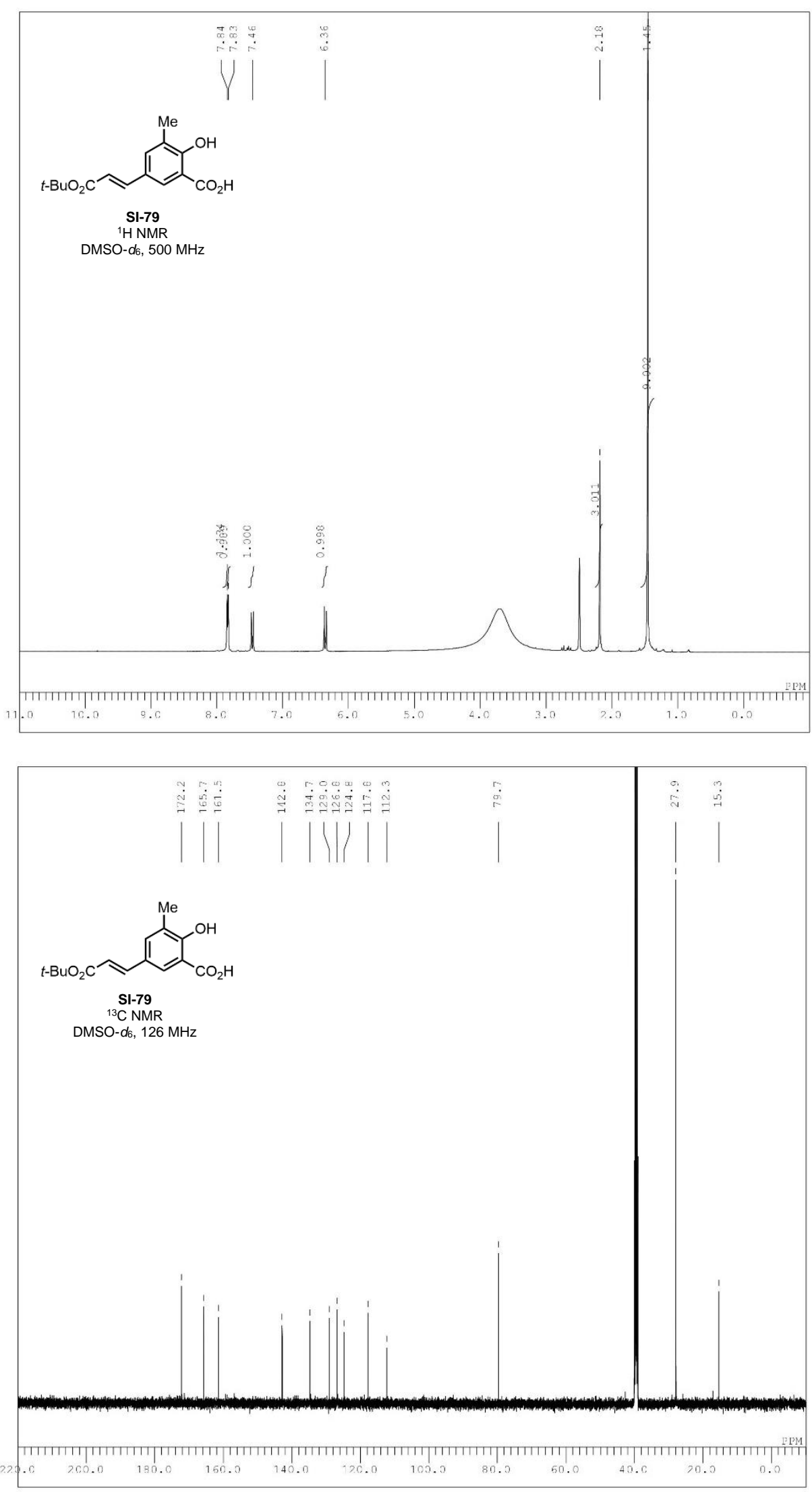

SI-264 

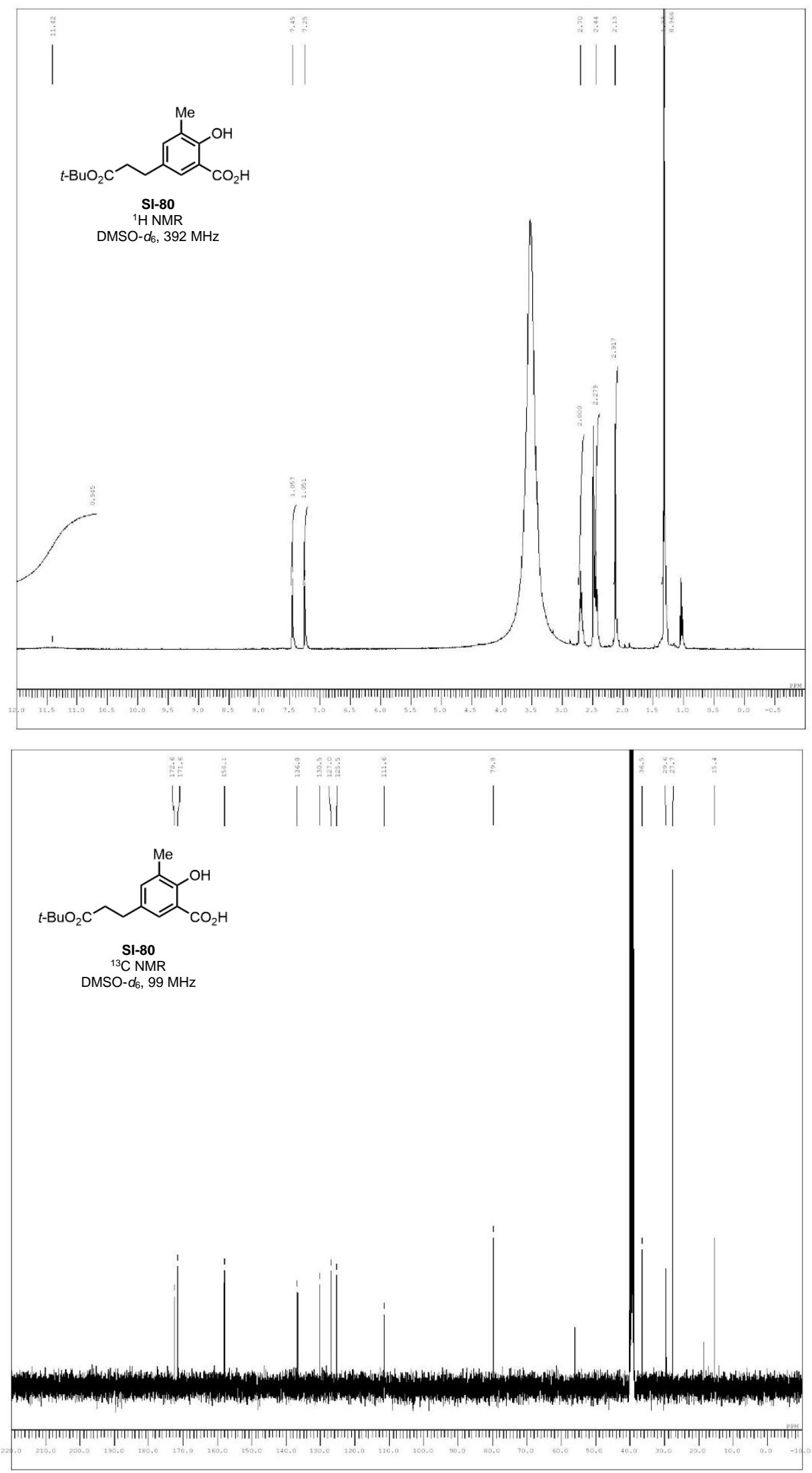

SI-265 

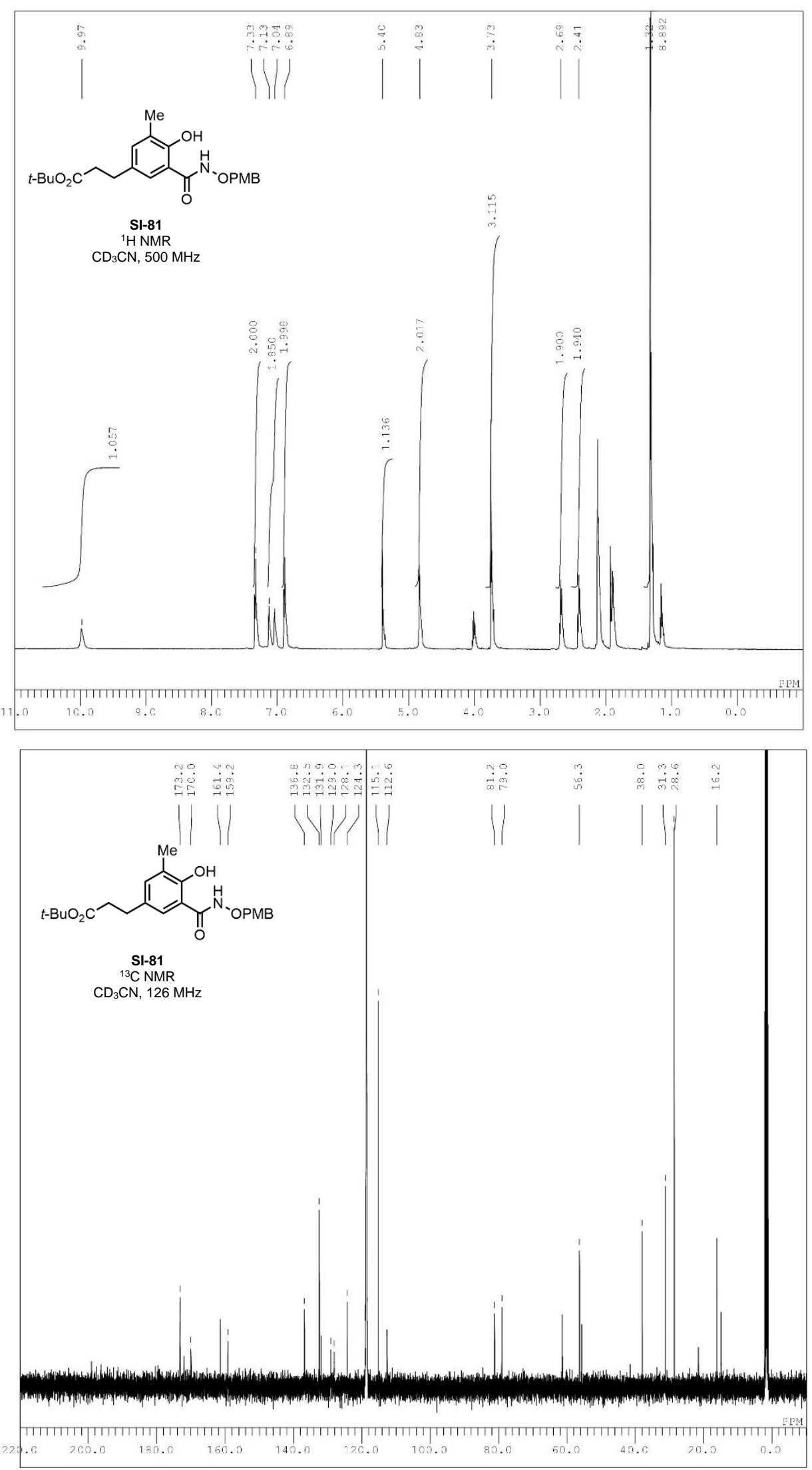

SI-266 

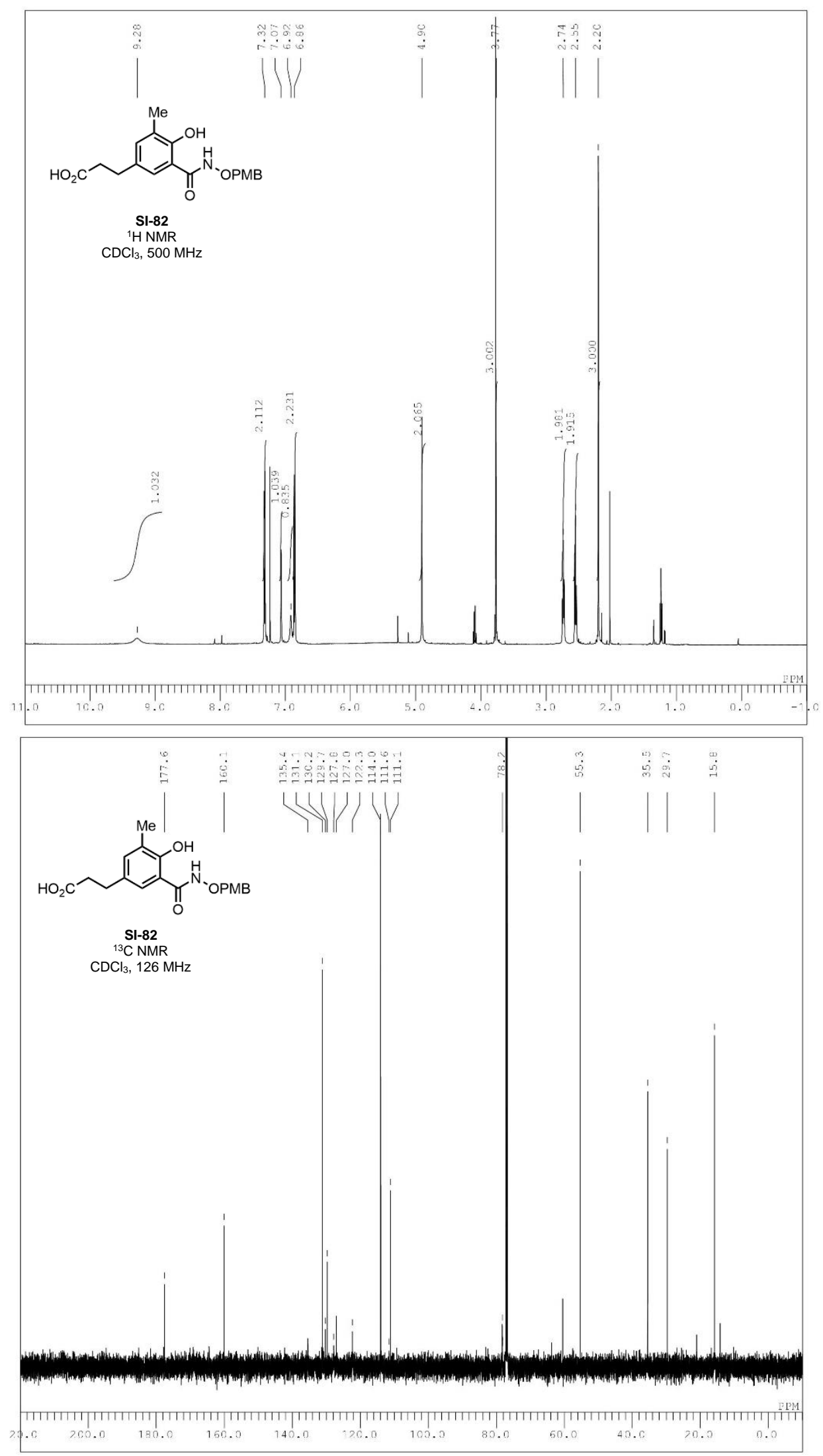

SI-267 

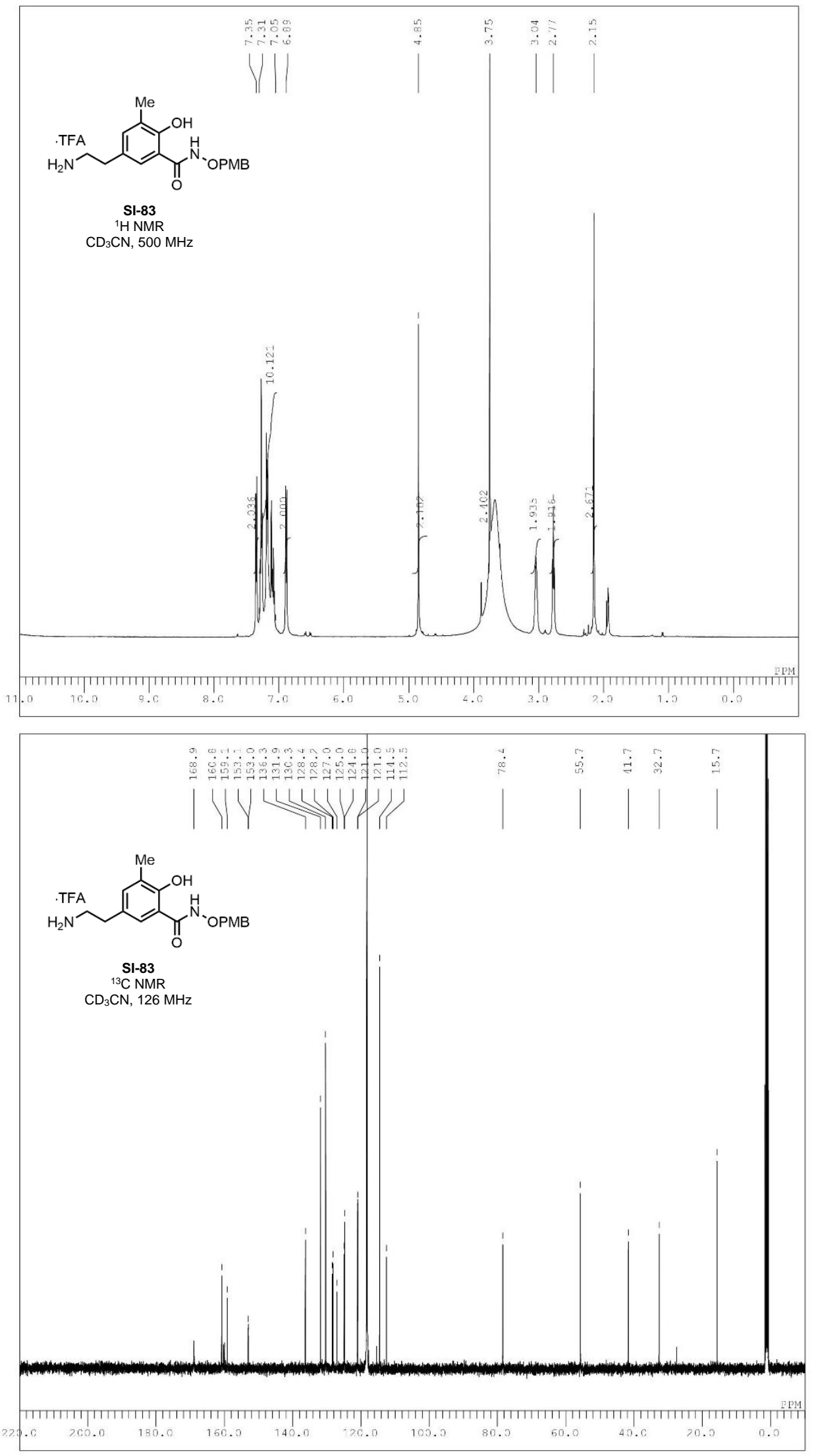

SI-268 

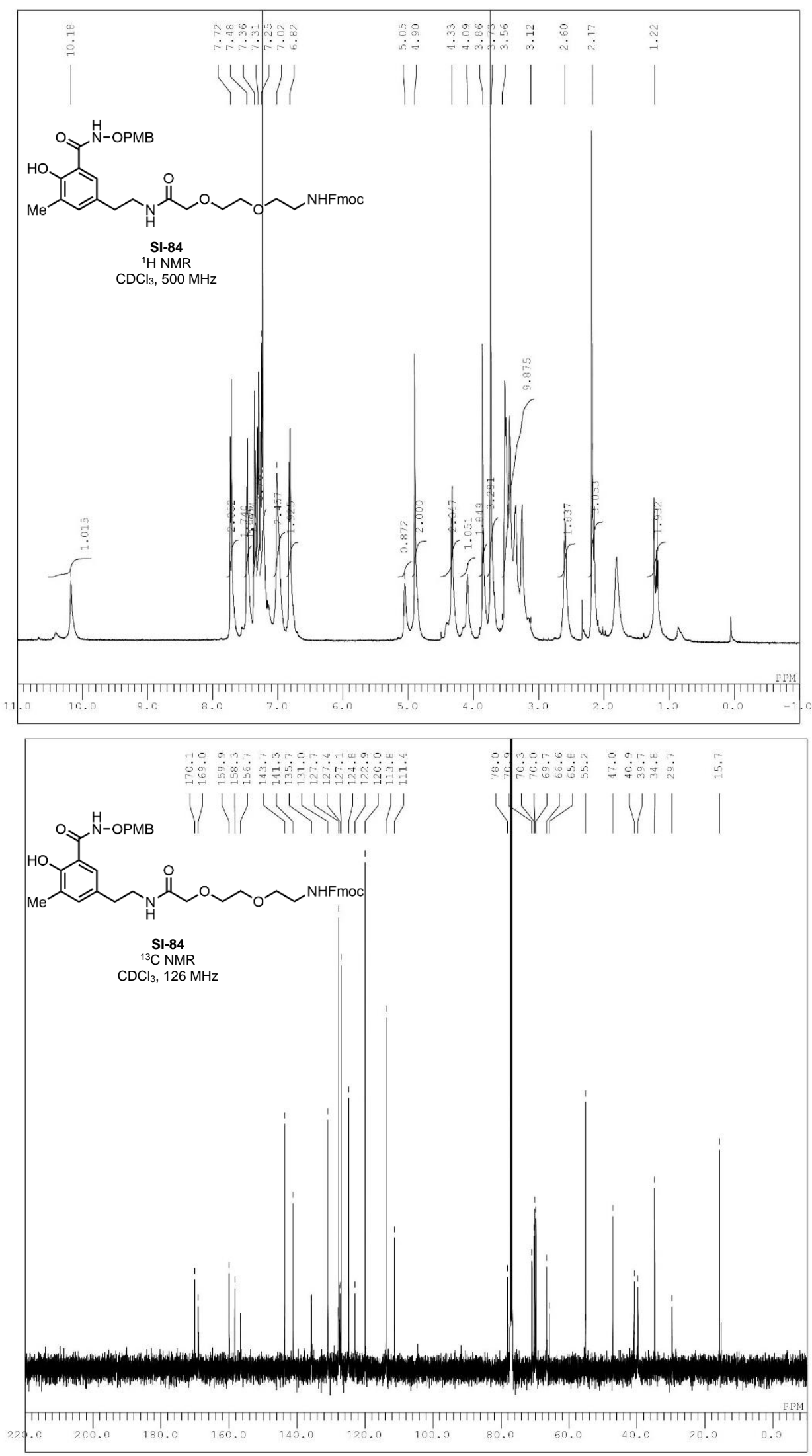

SI-269 

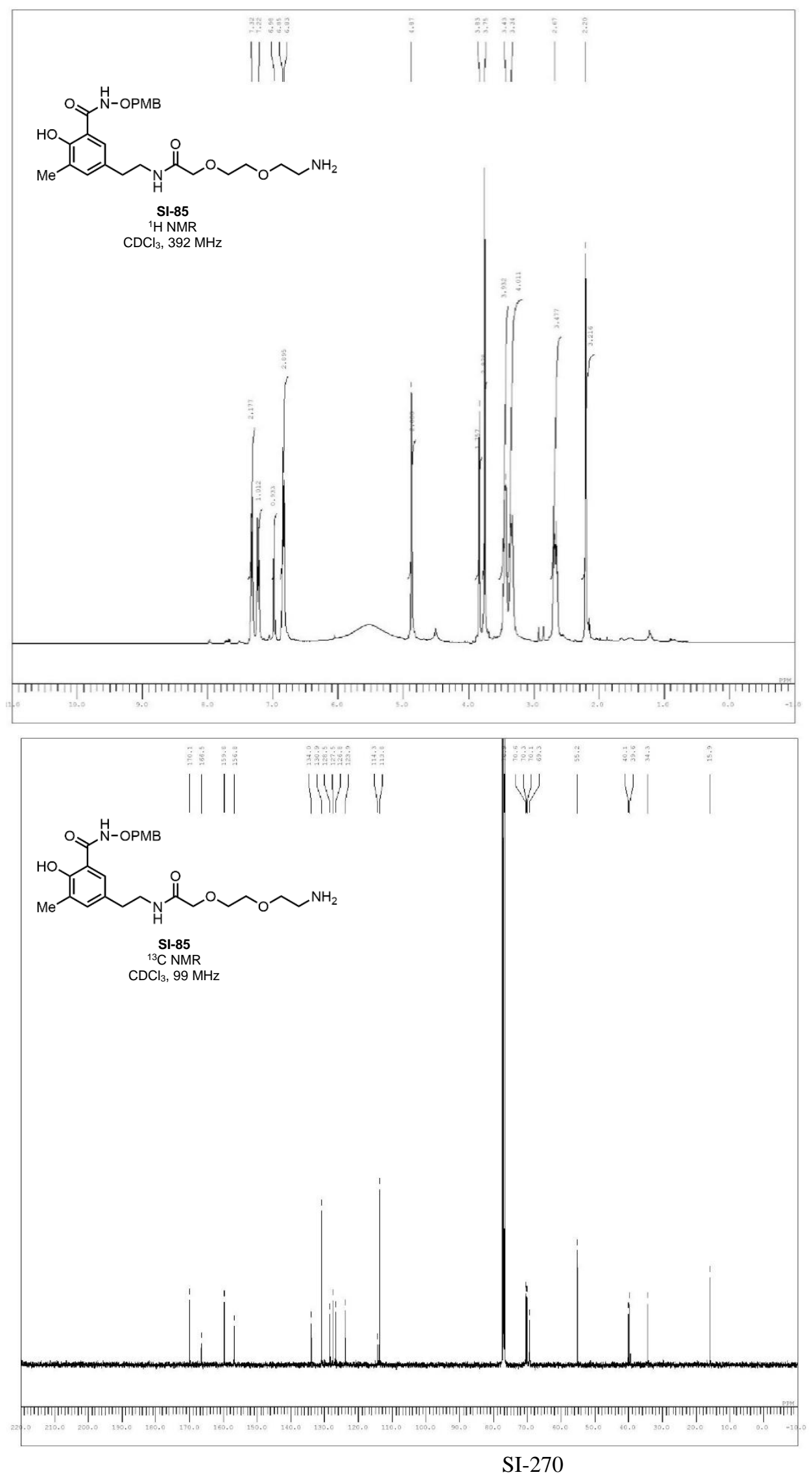

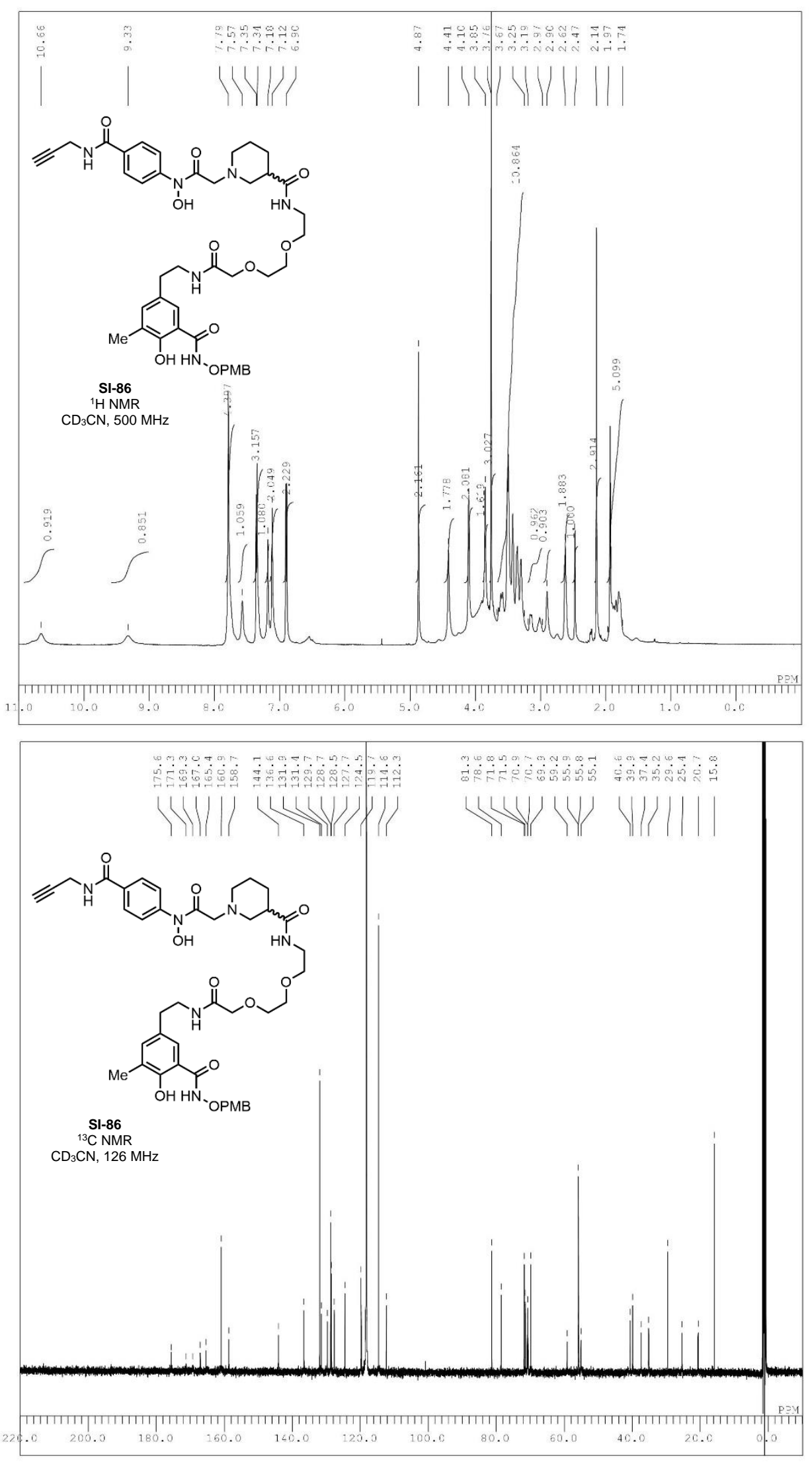

SI-271 

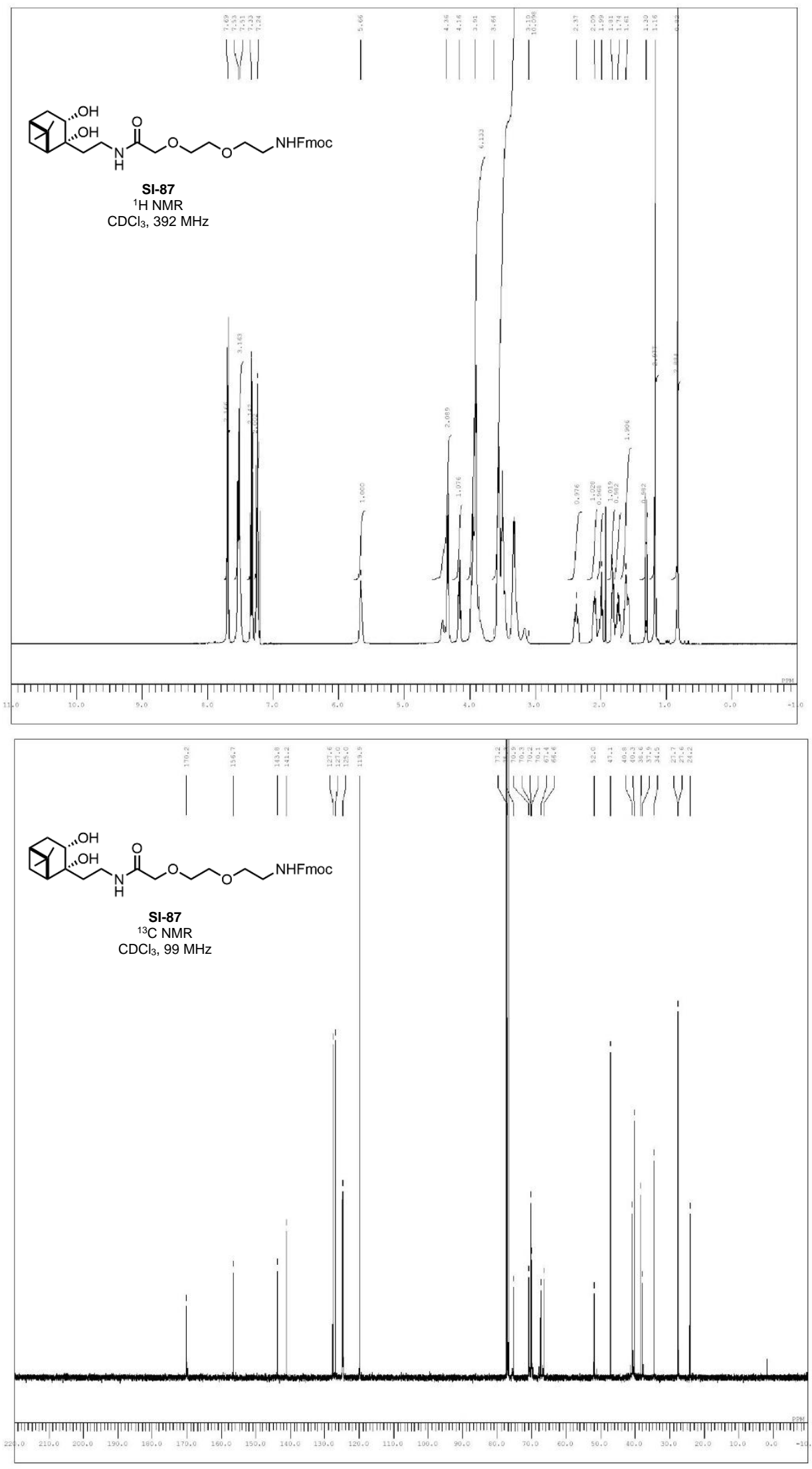

SI-272 

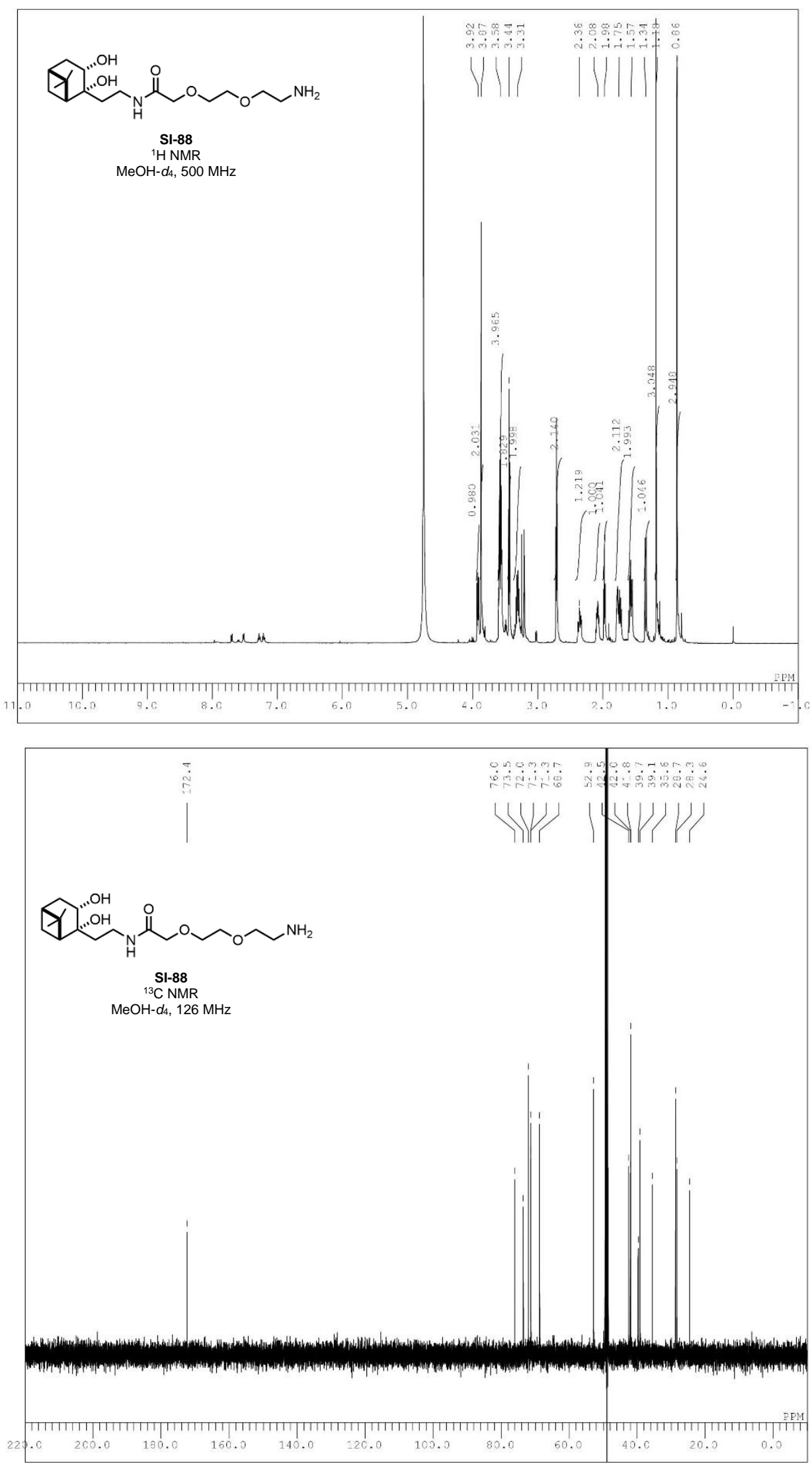

SI-273 

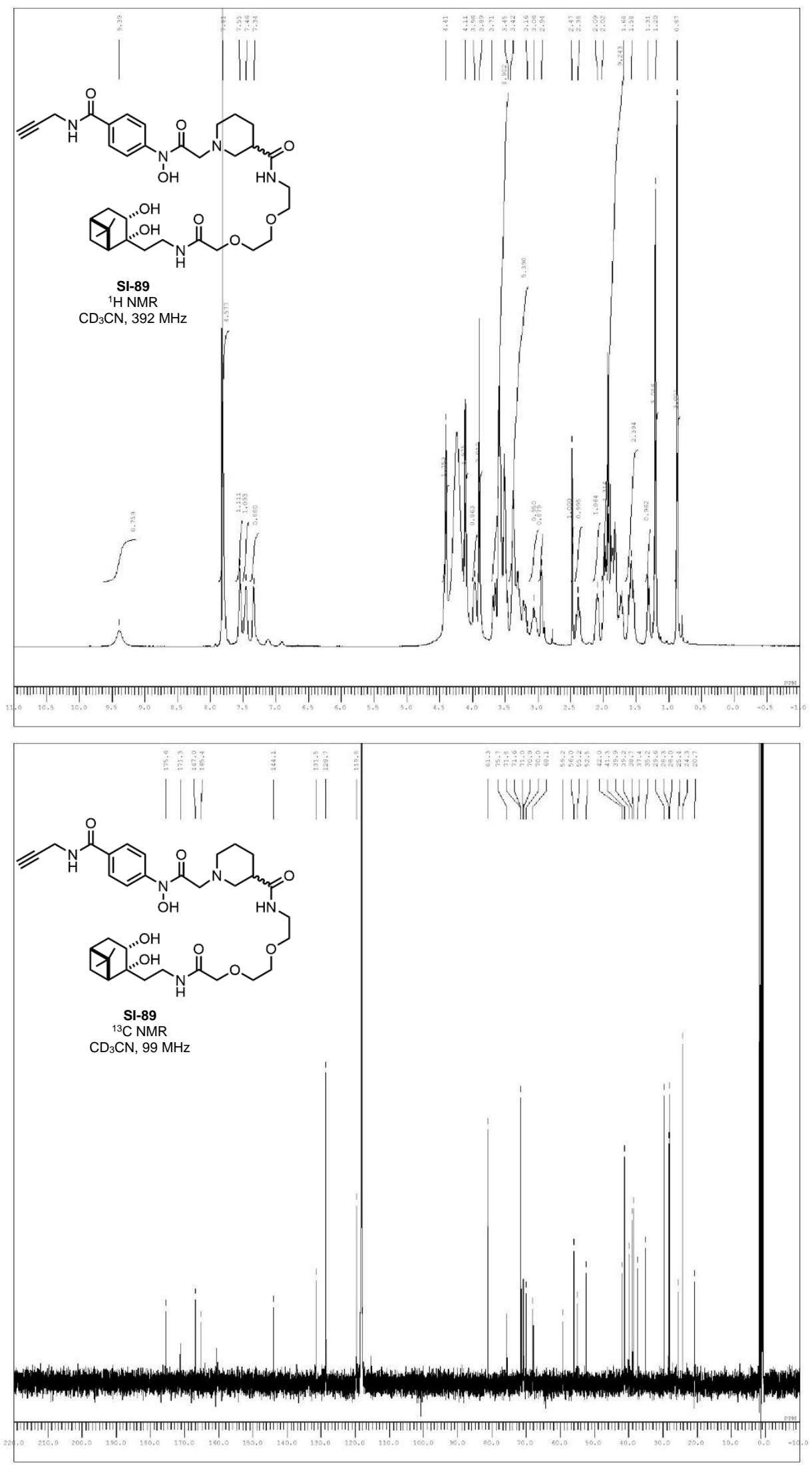

SI-274 

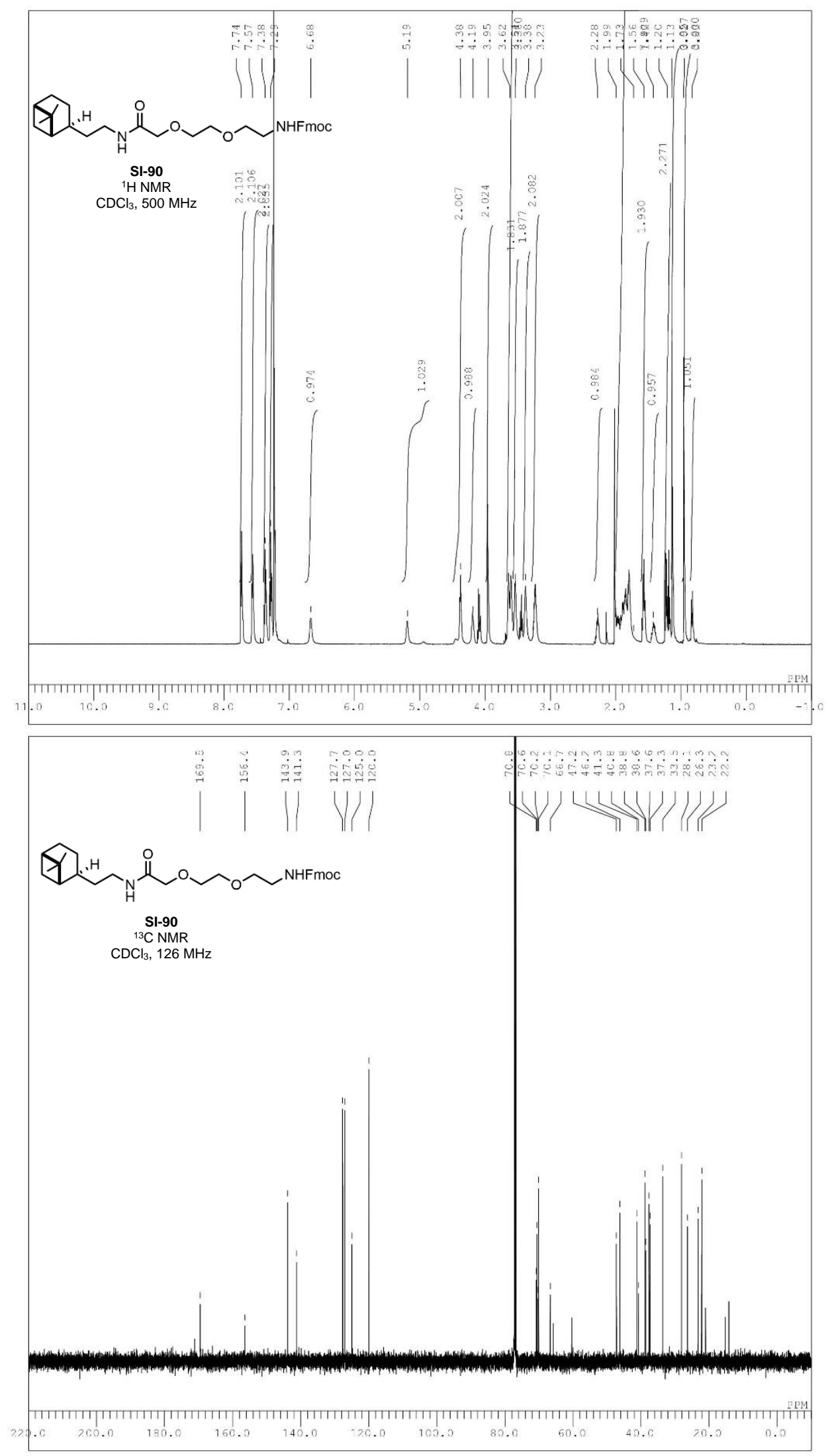

SI-275 

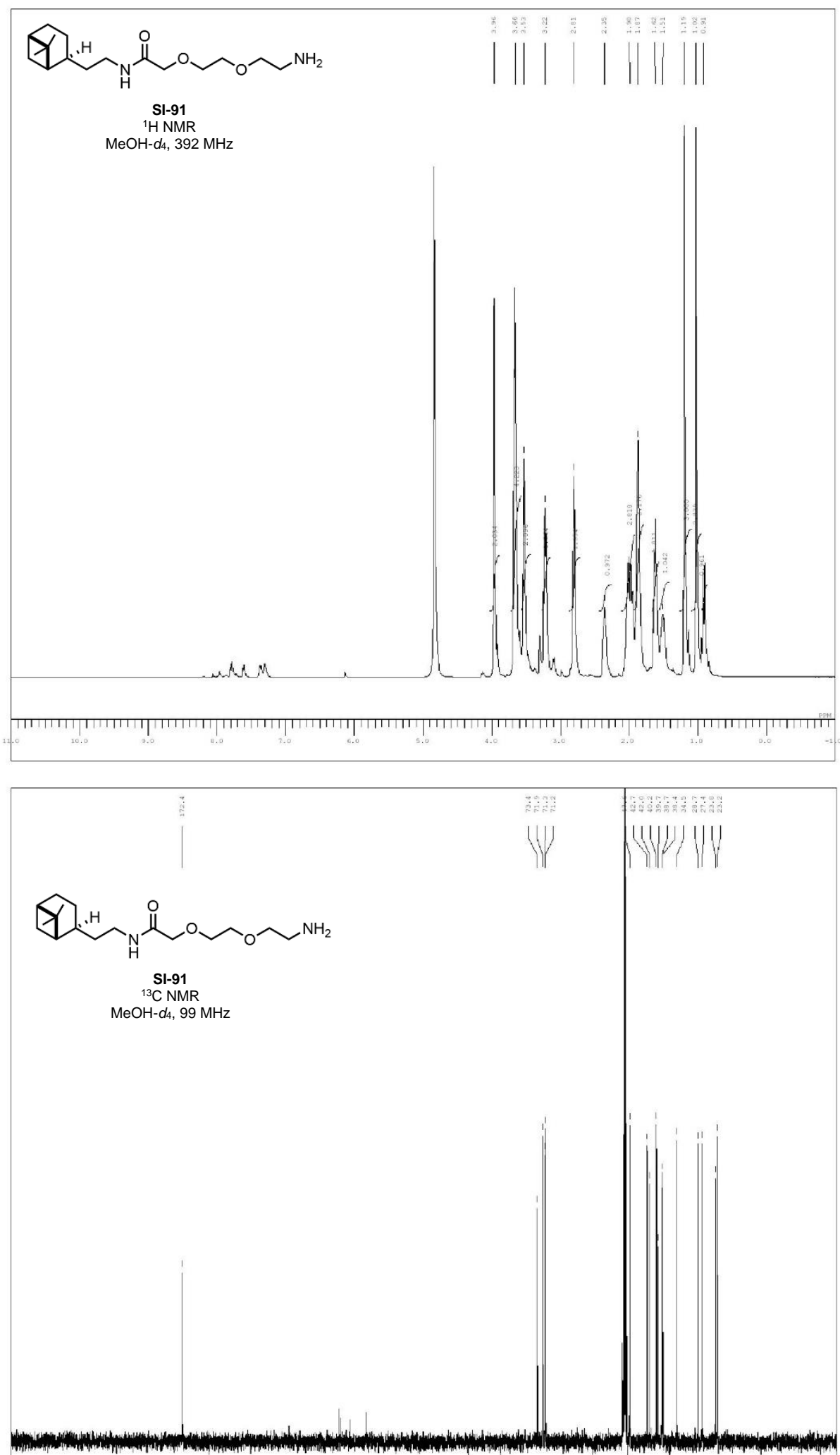

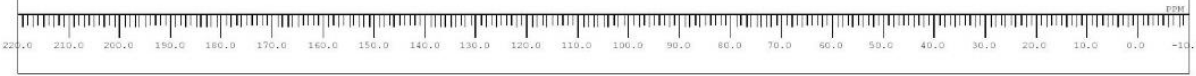



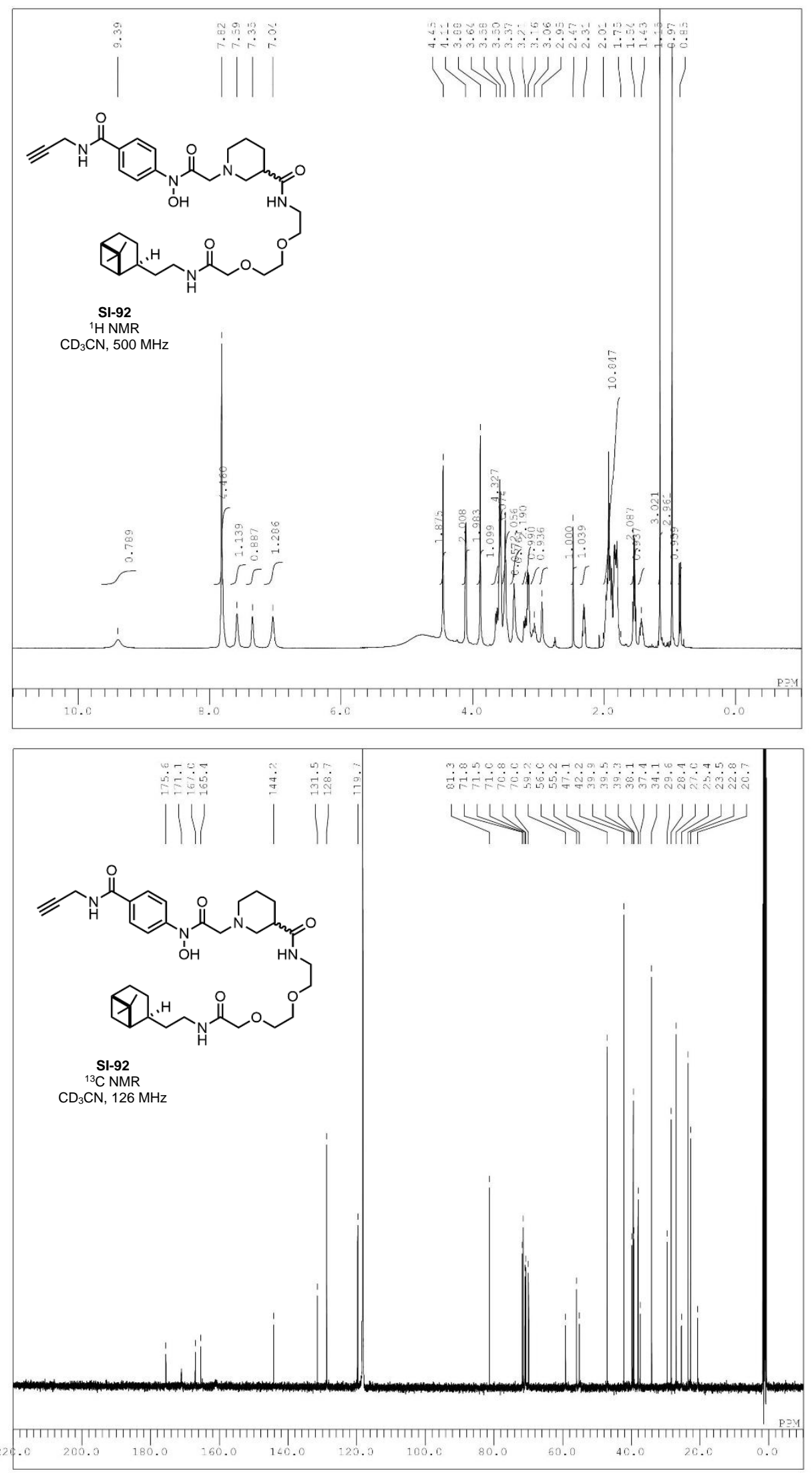

SI-277 

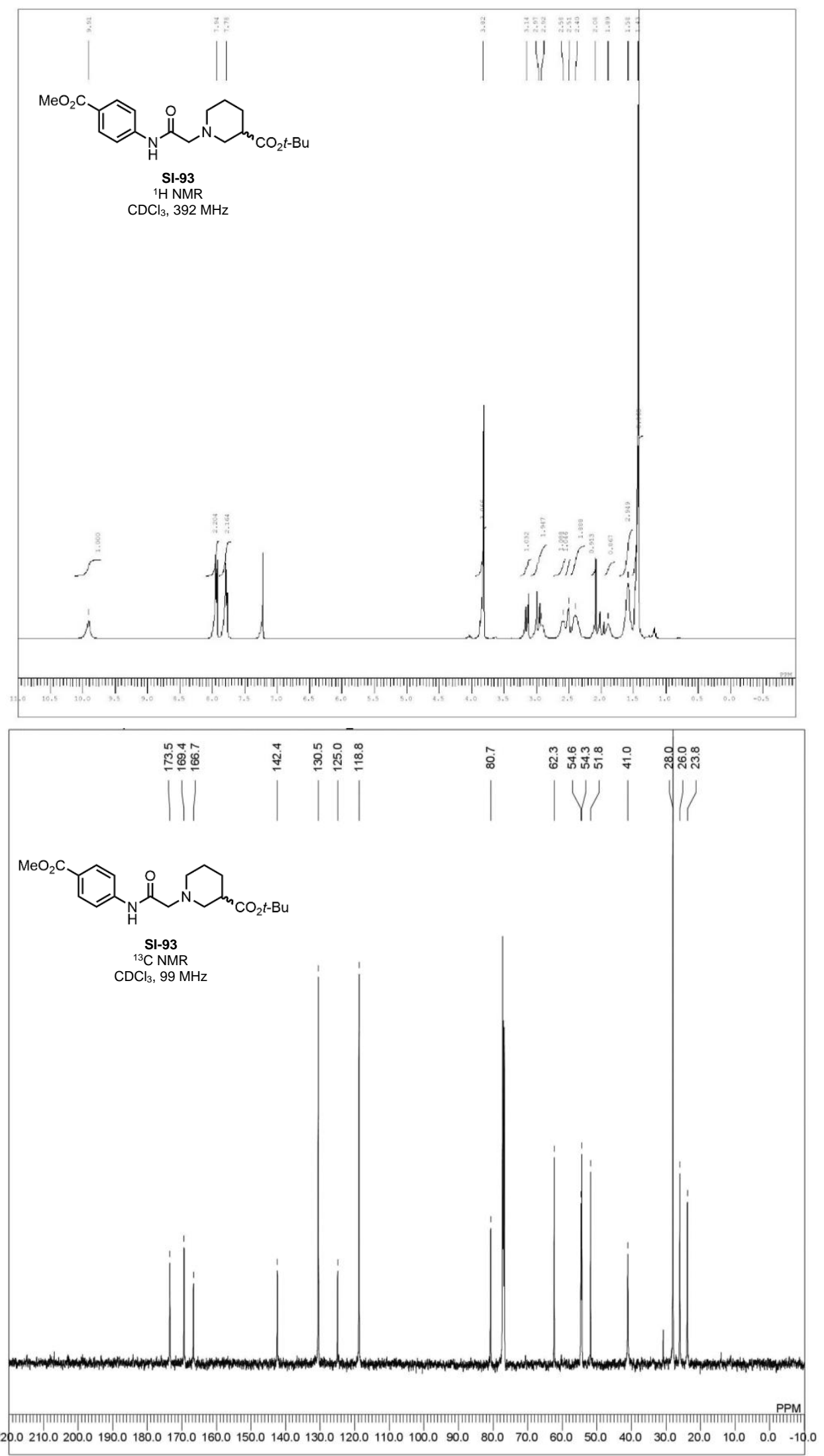

SI-278 

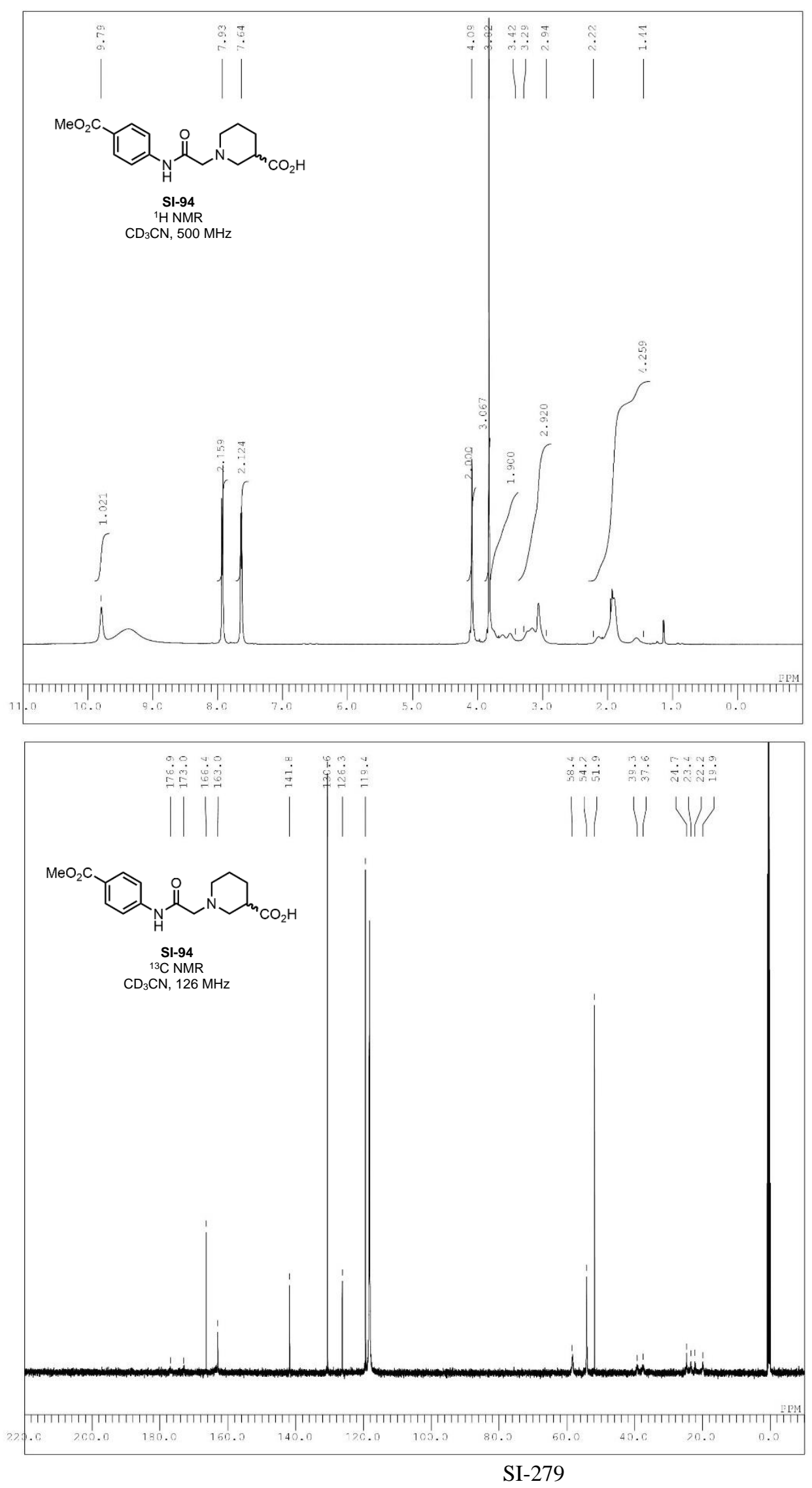


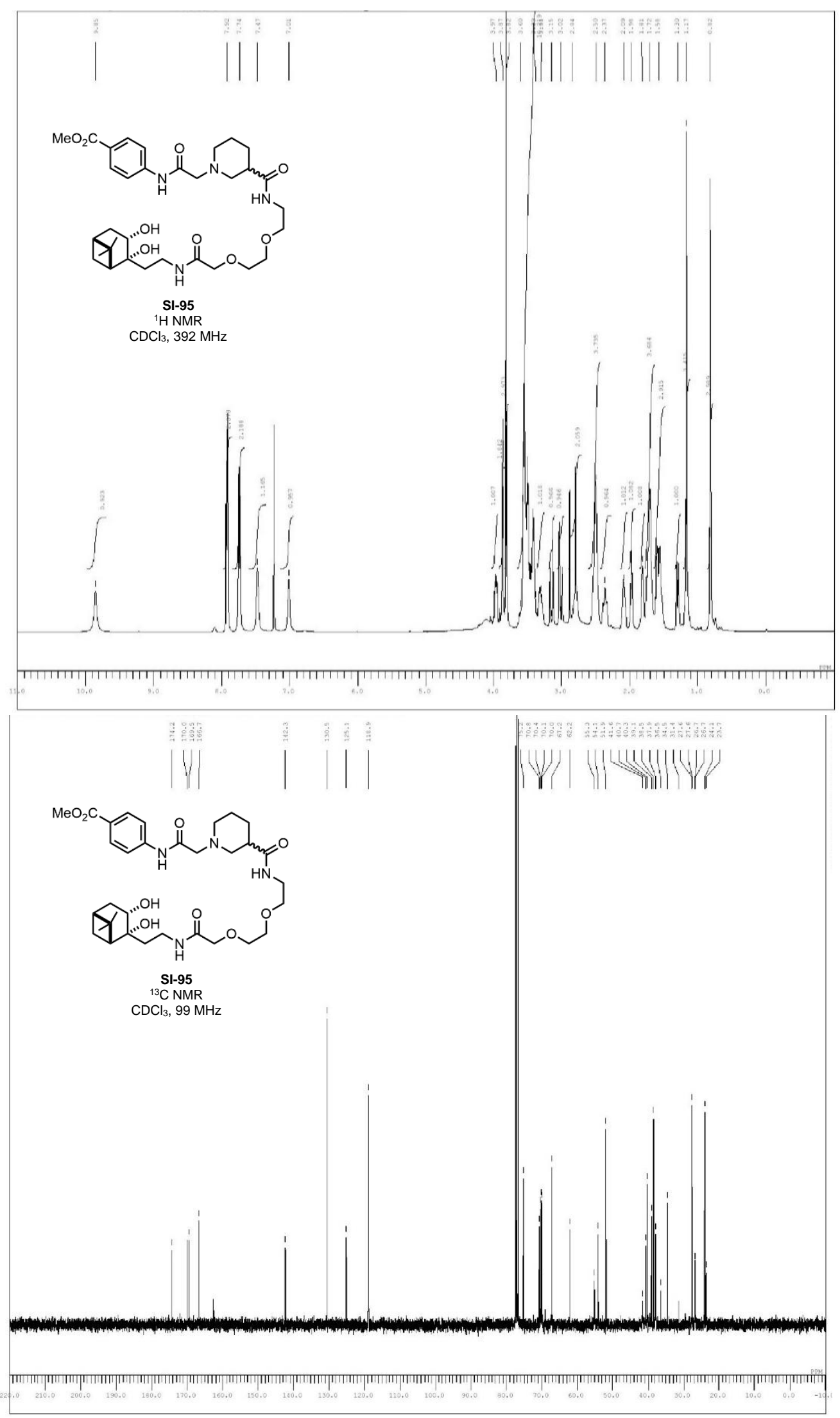

SI-280 


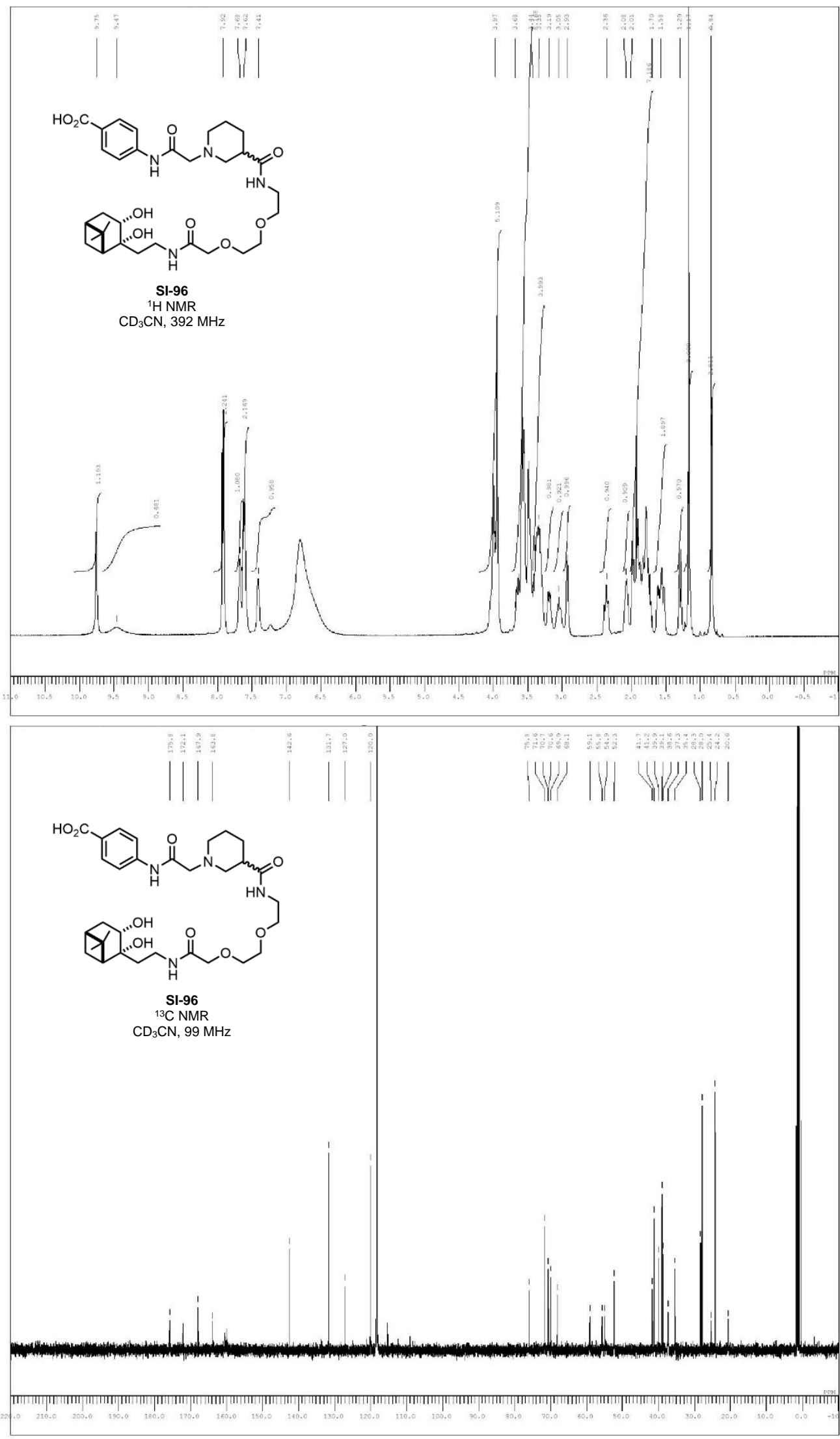

SI-281 

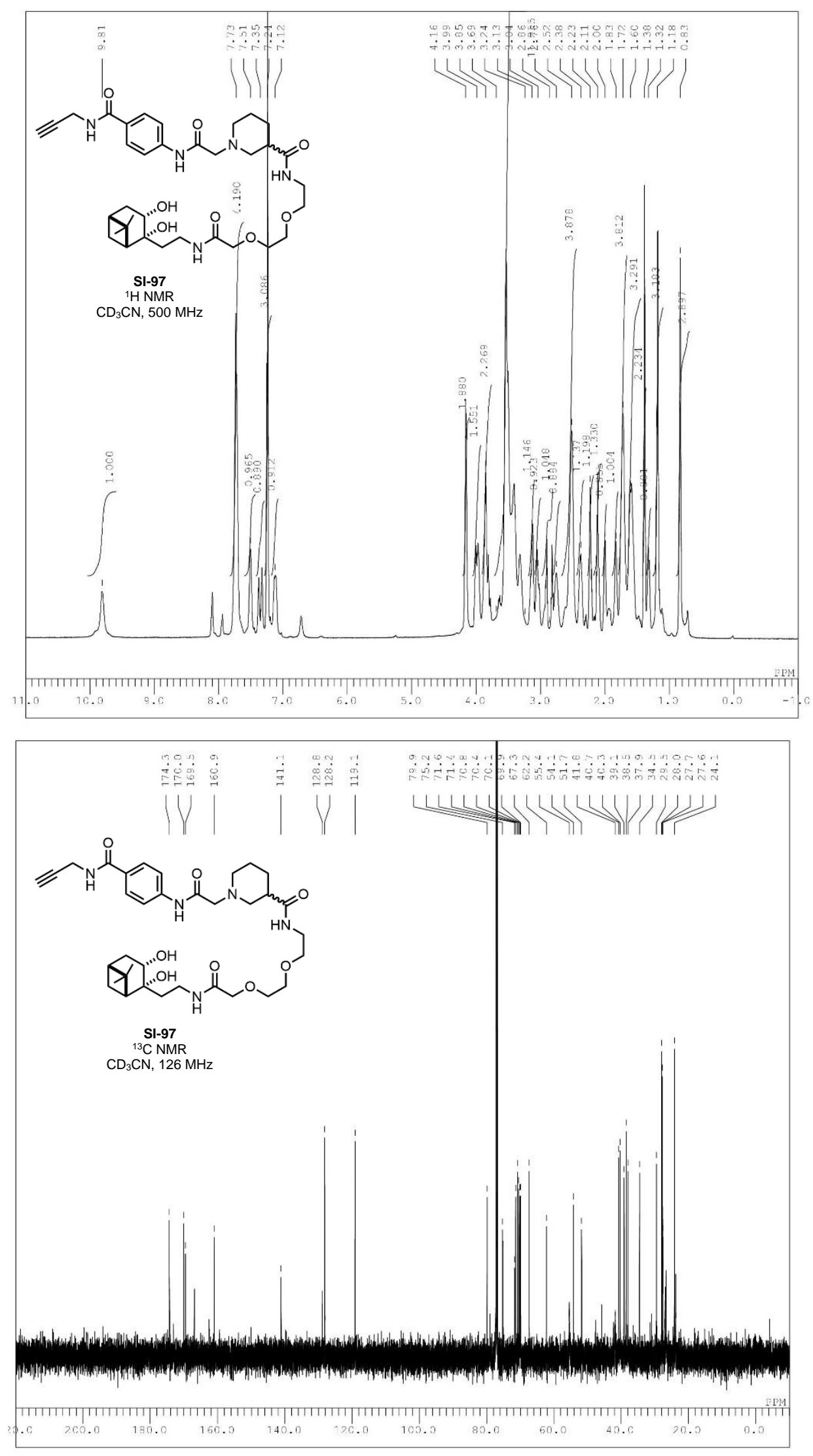

SI-282 

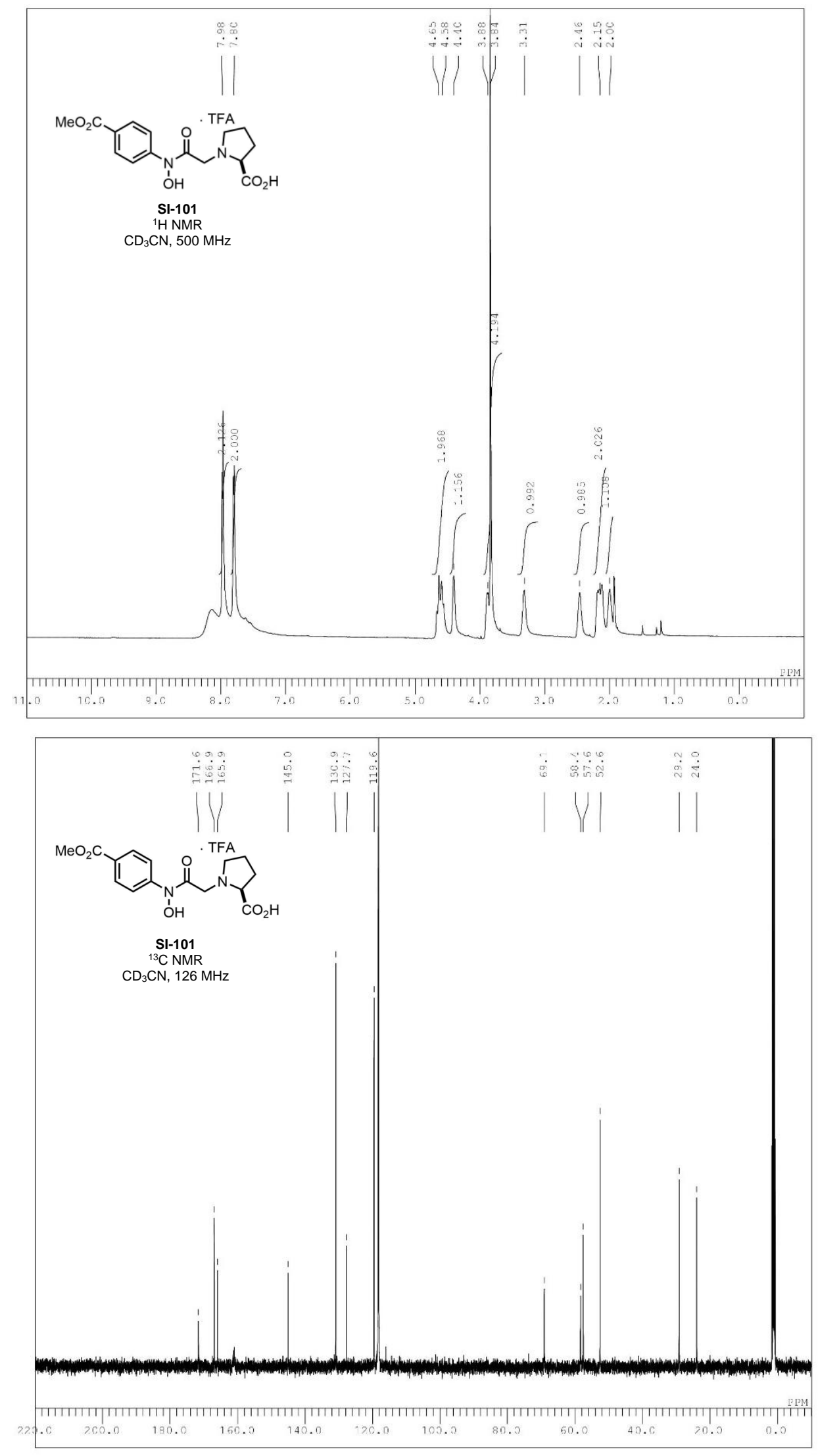

SI-283 

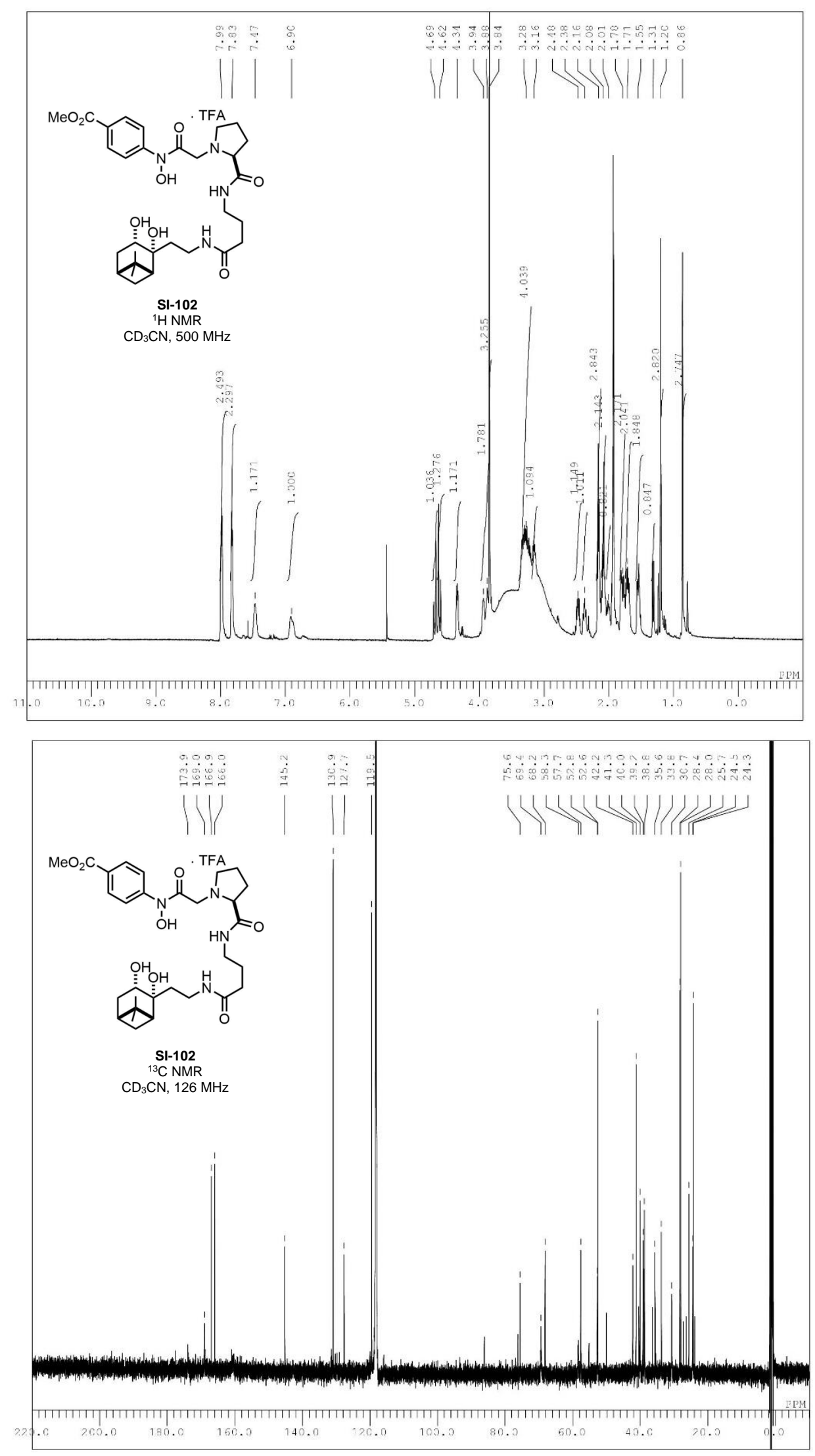

SI-284 

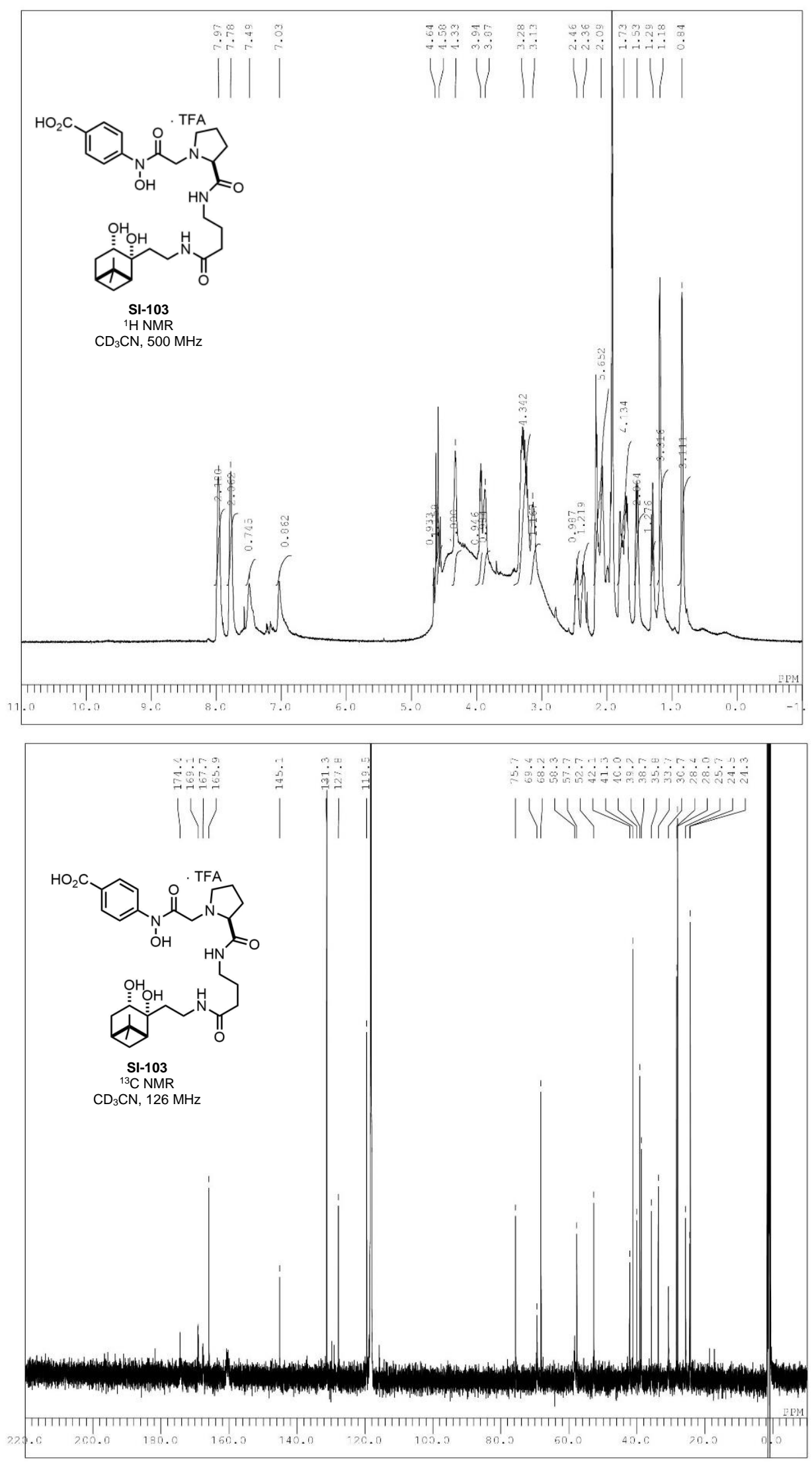

SI-285 

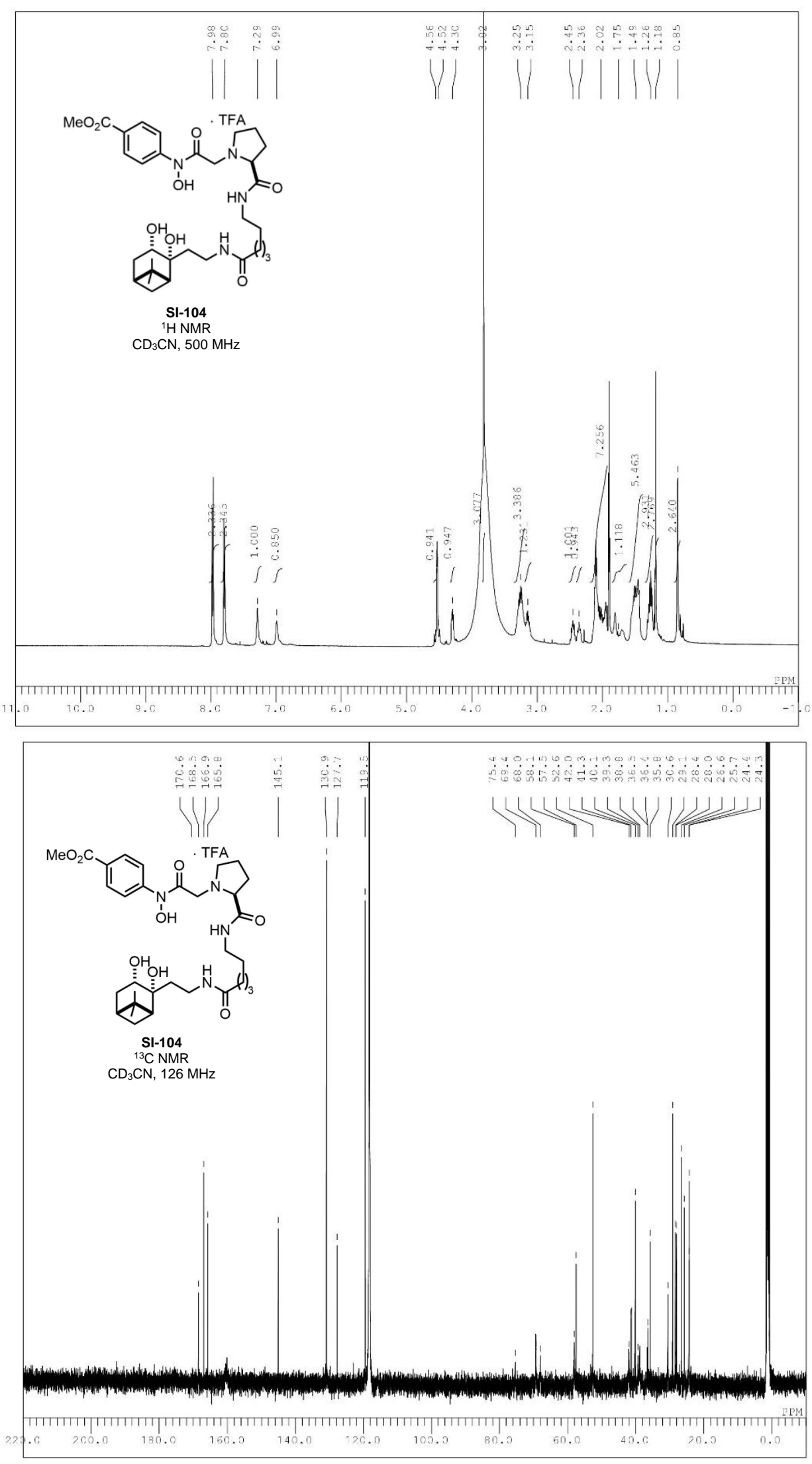

SI-286 

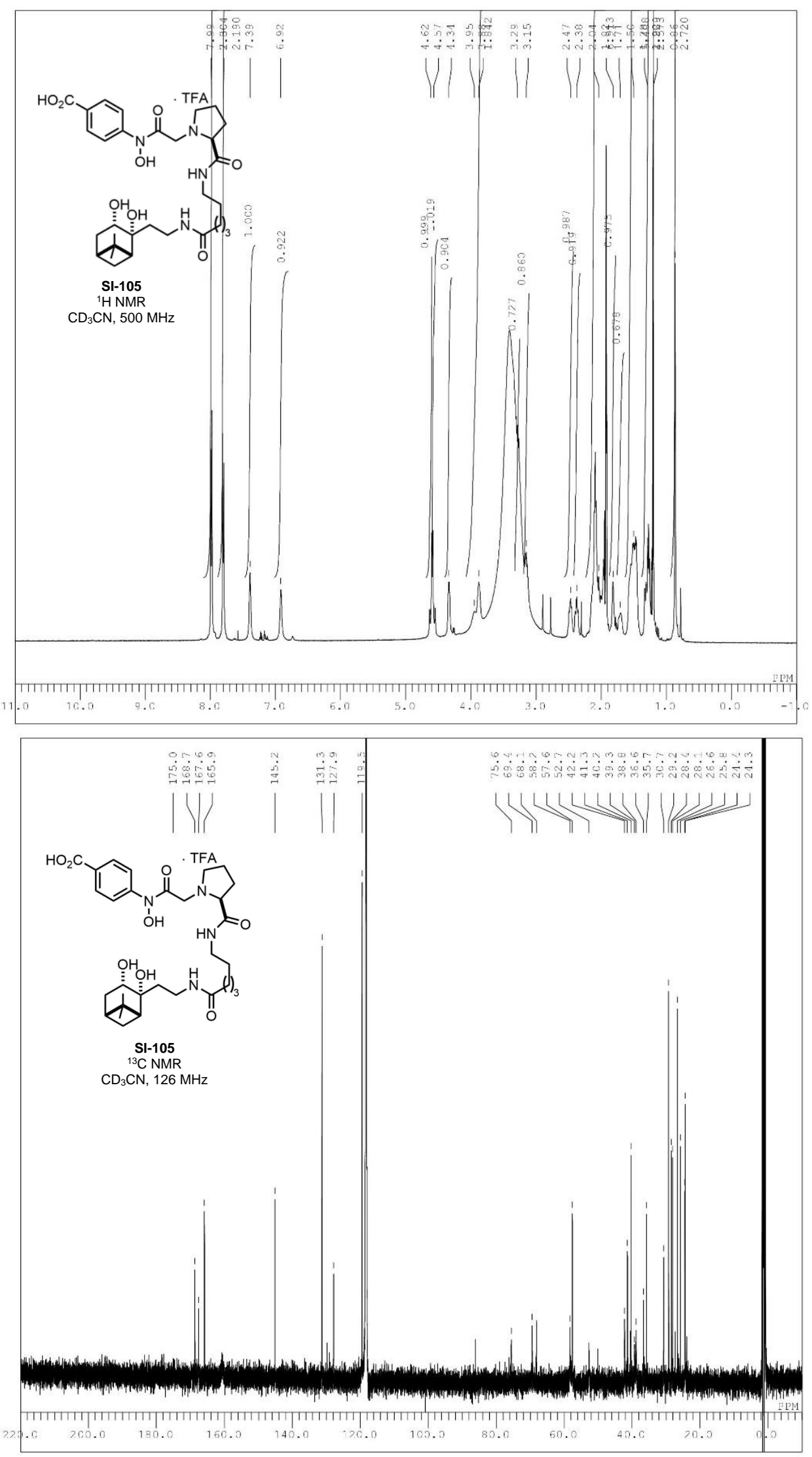

SI-287 


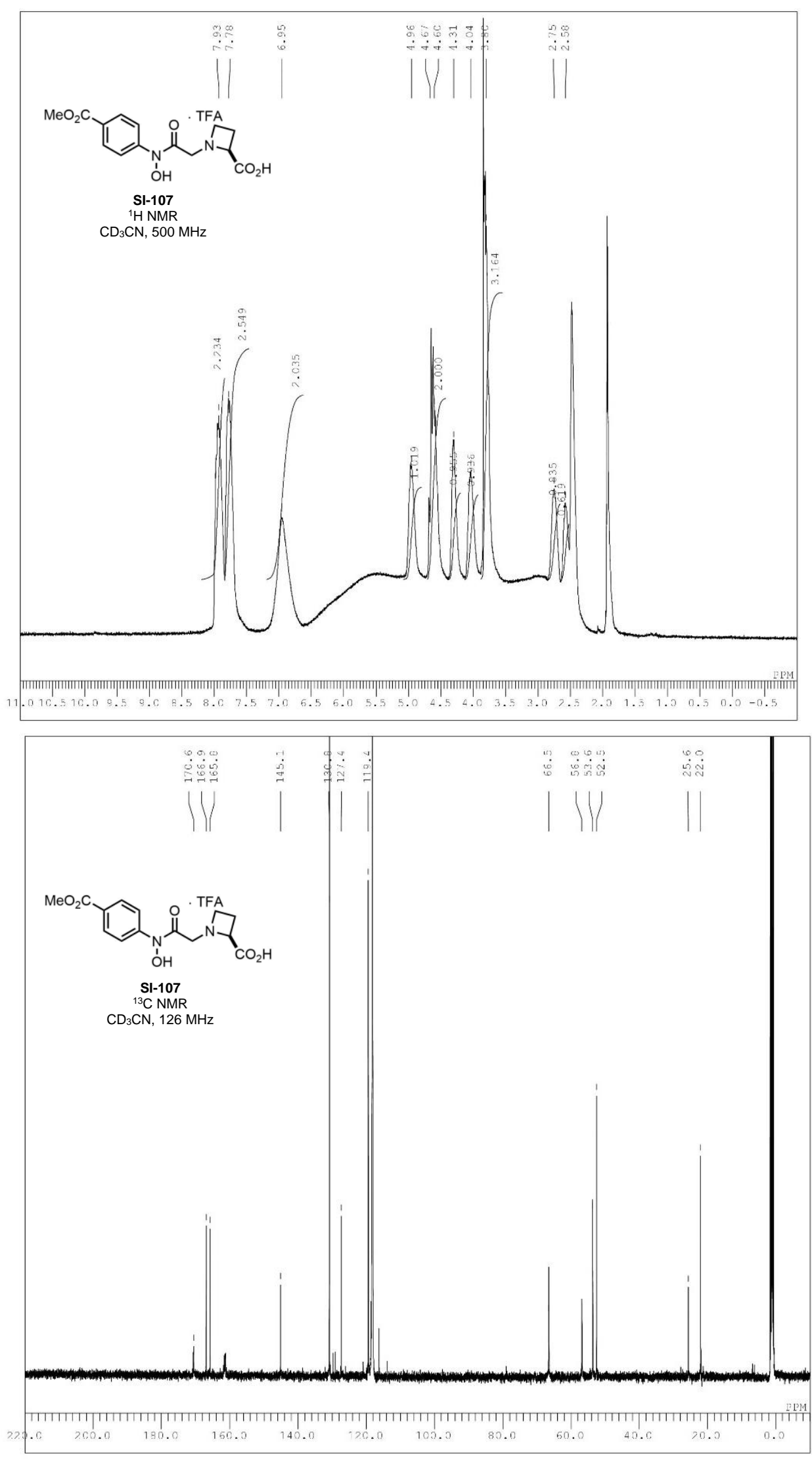

SI-288 

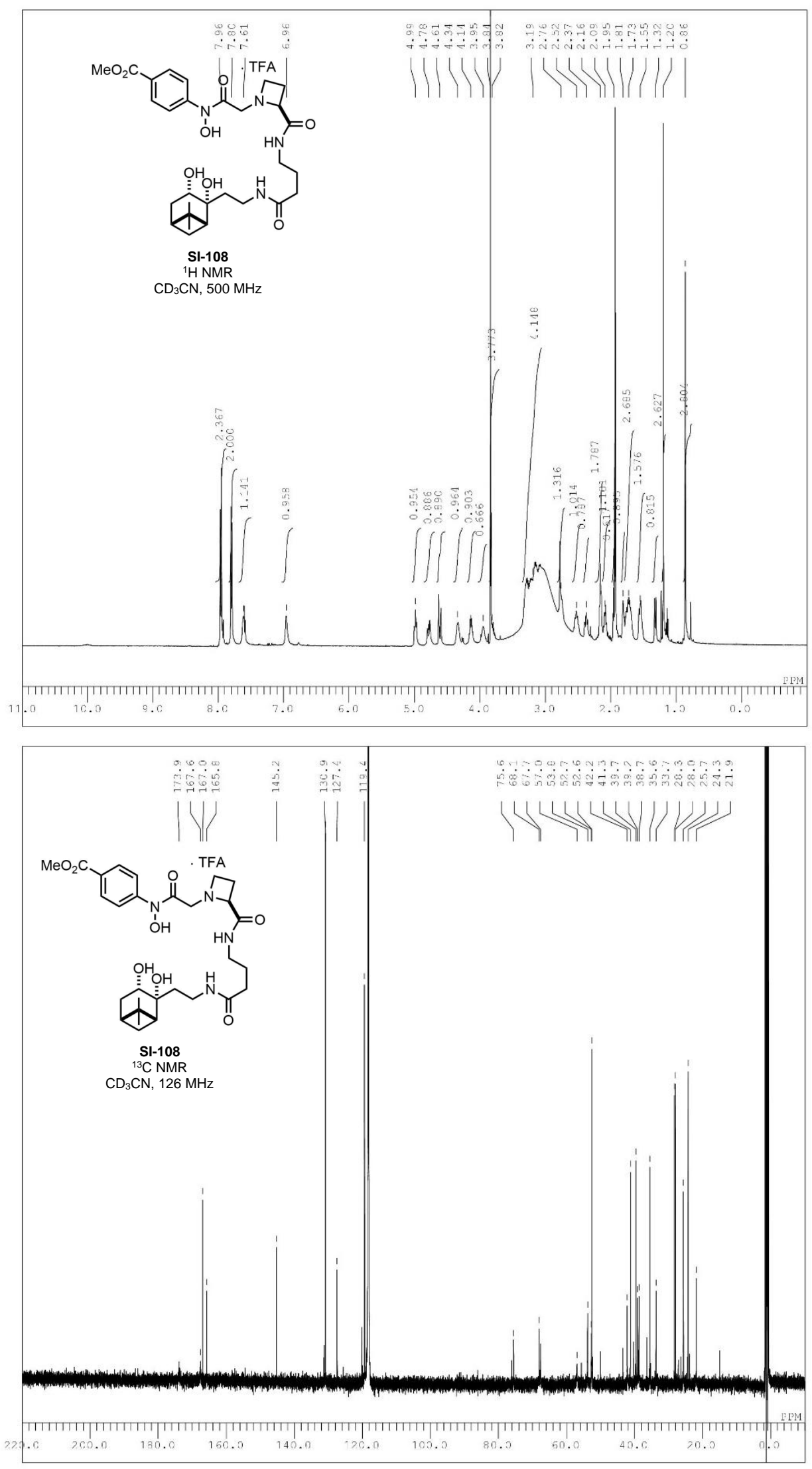

SI-289 

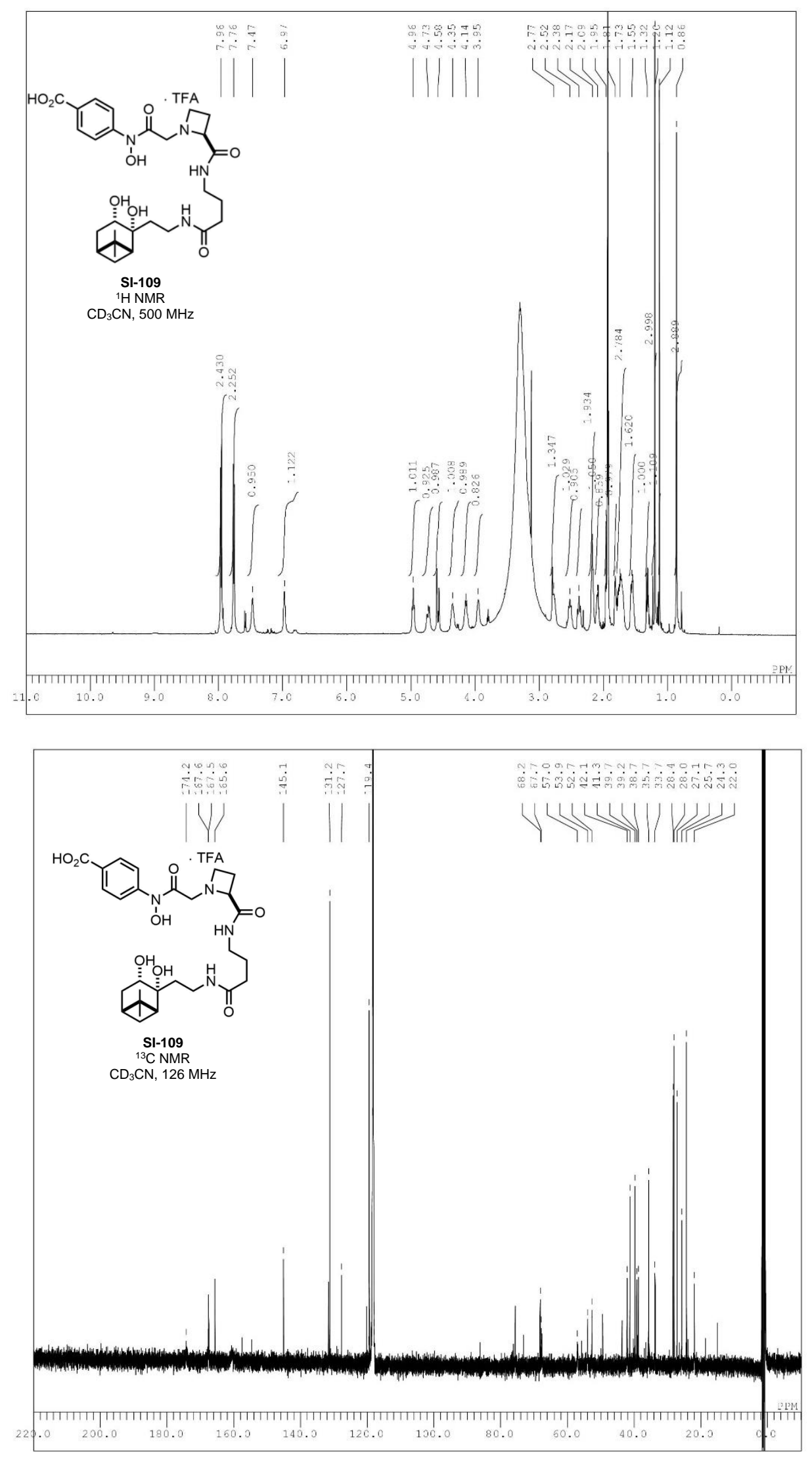

SI-290 

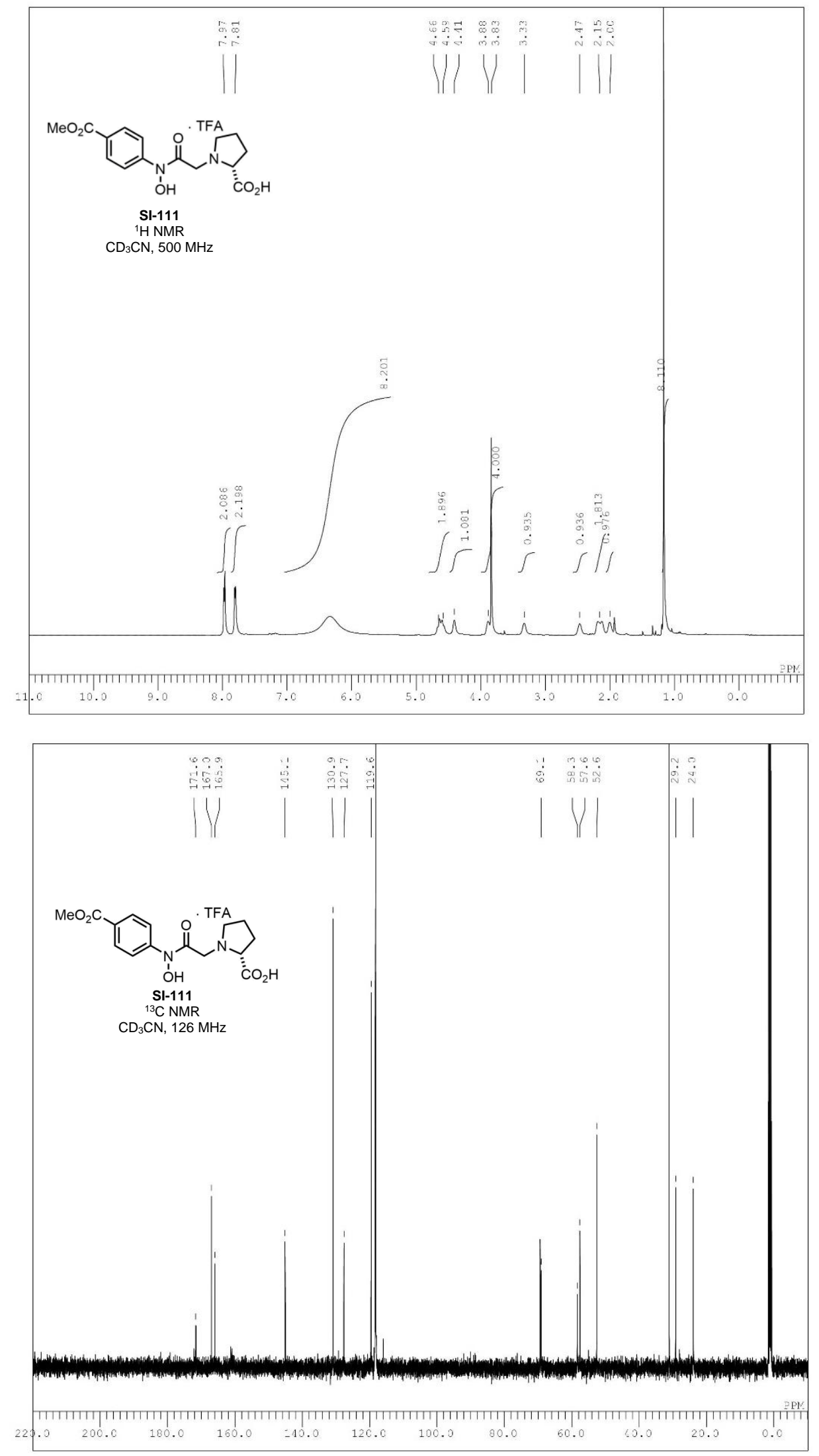

SI-291 


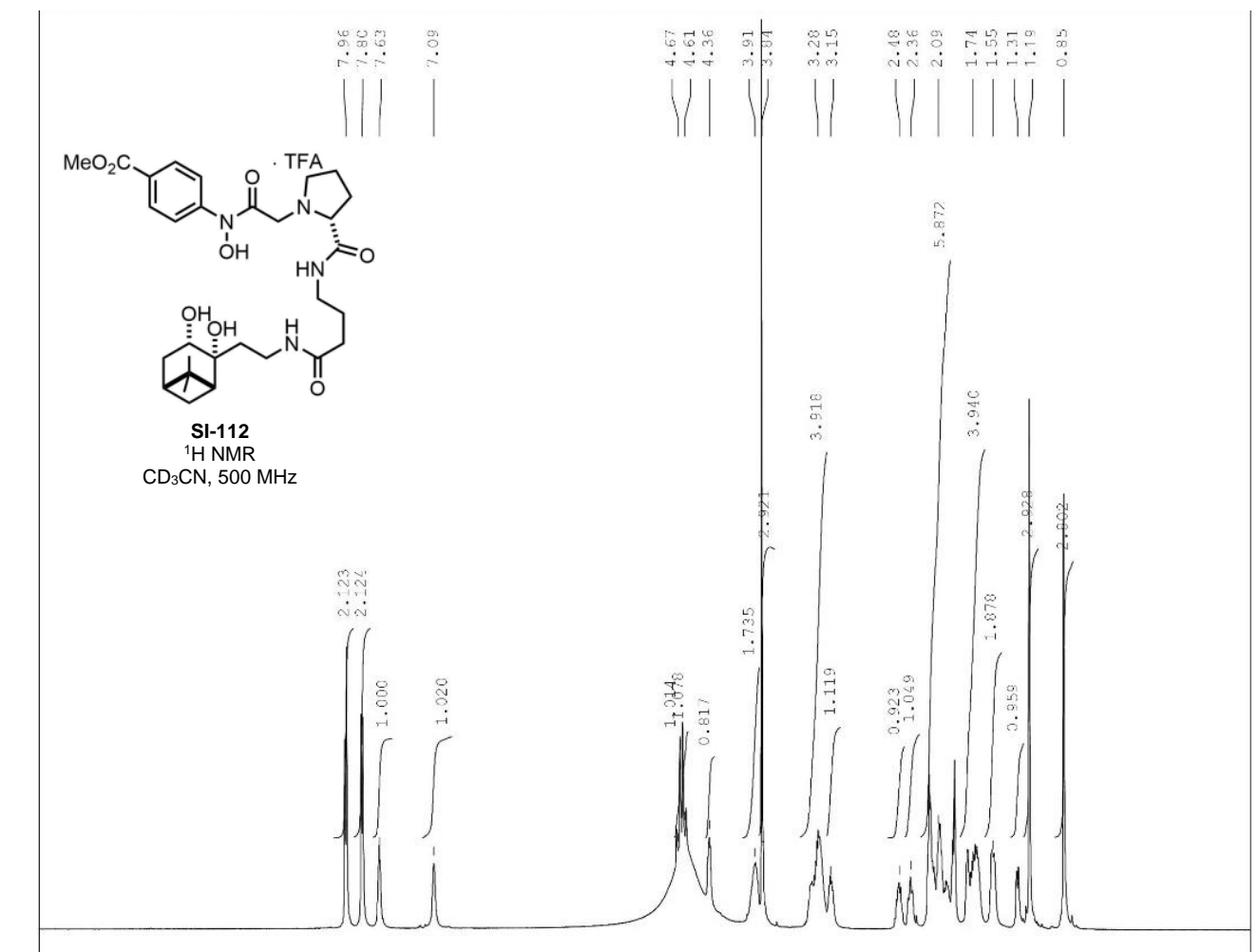

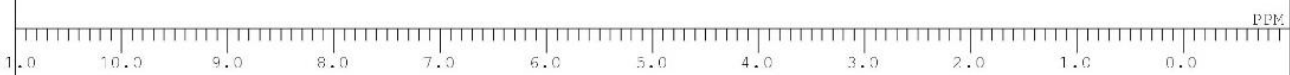

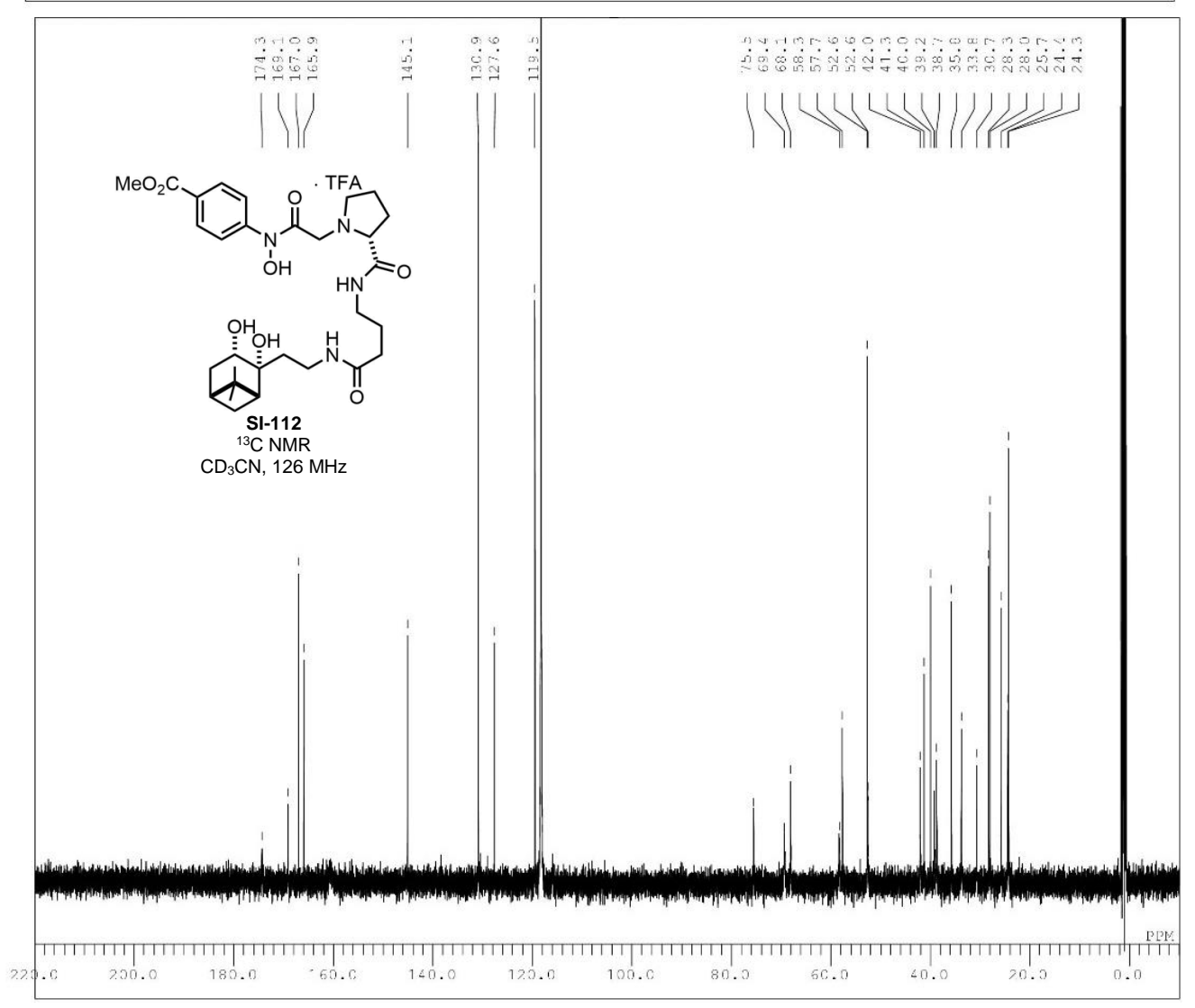

SI-292 

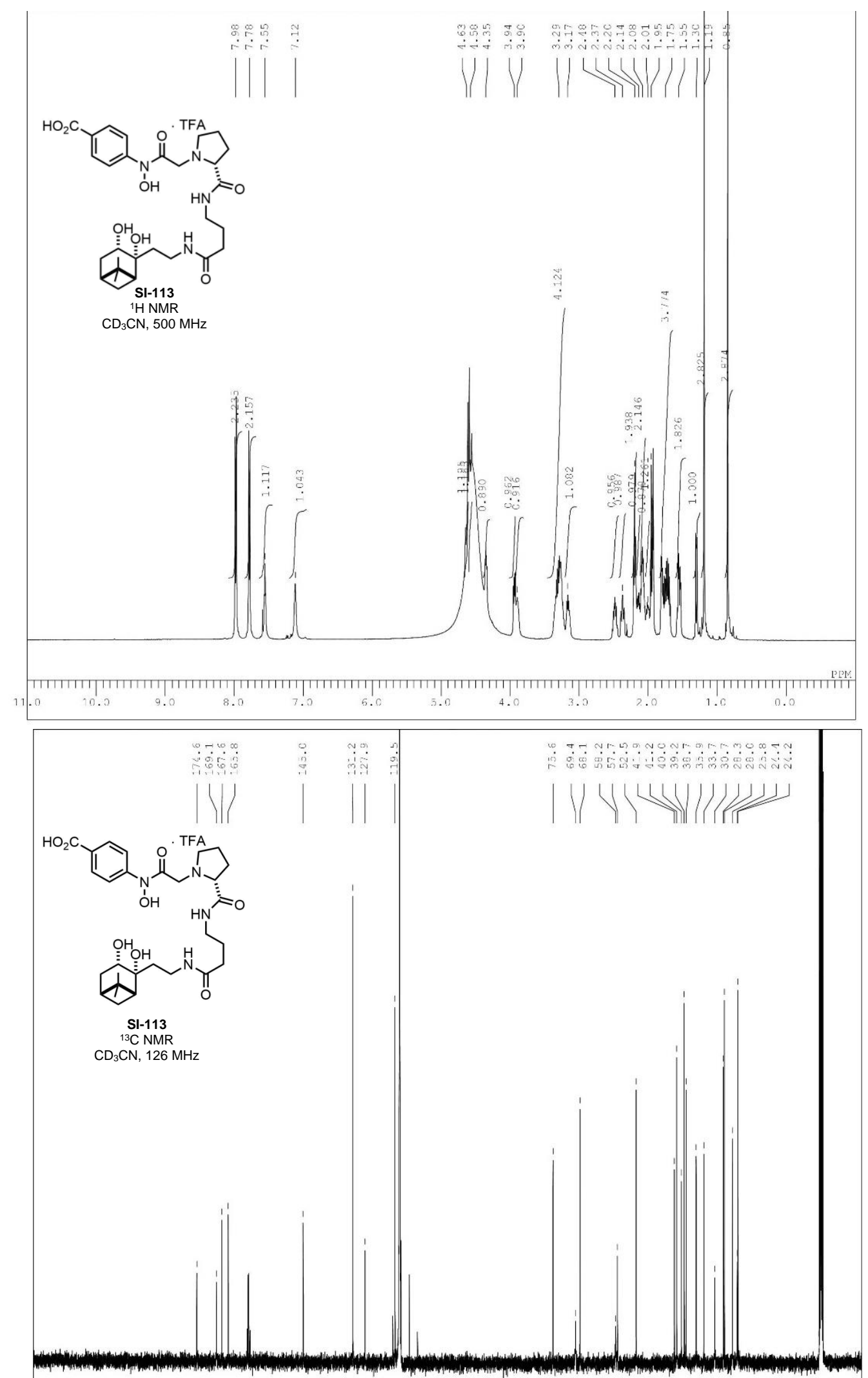

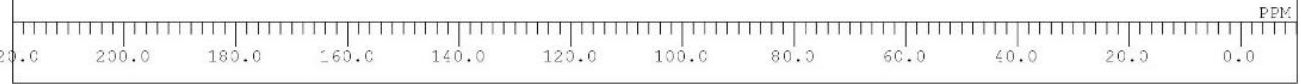




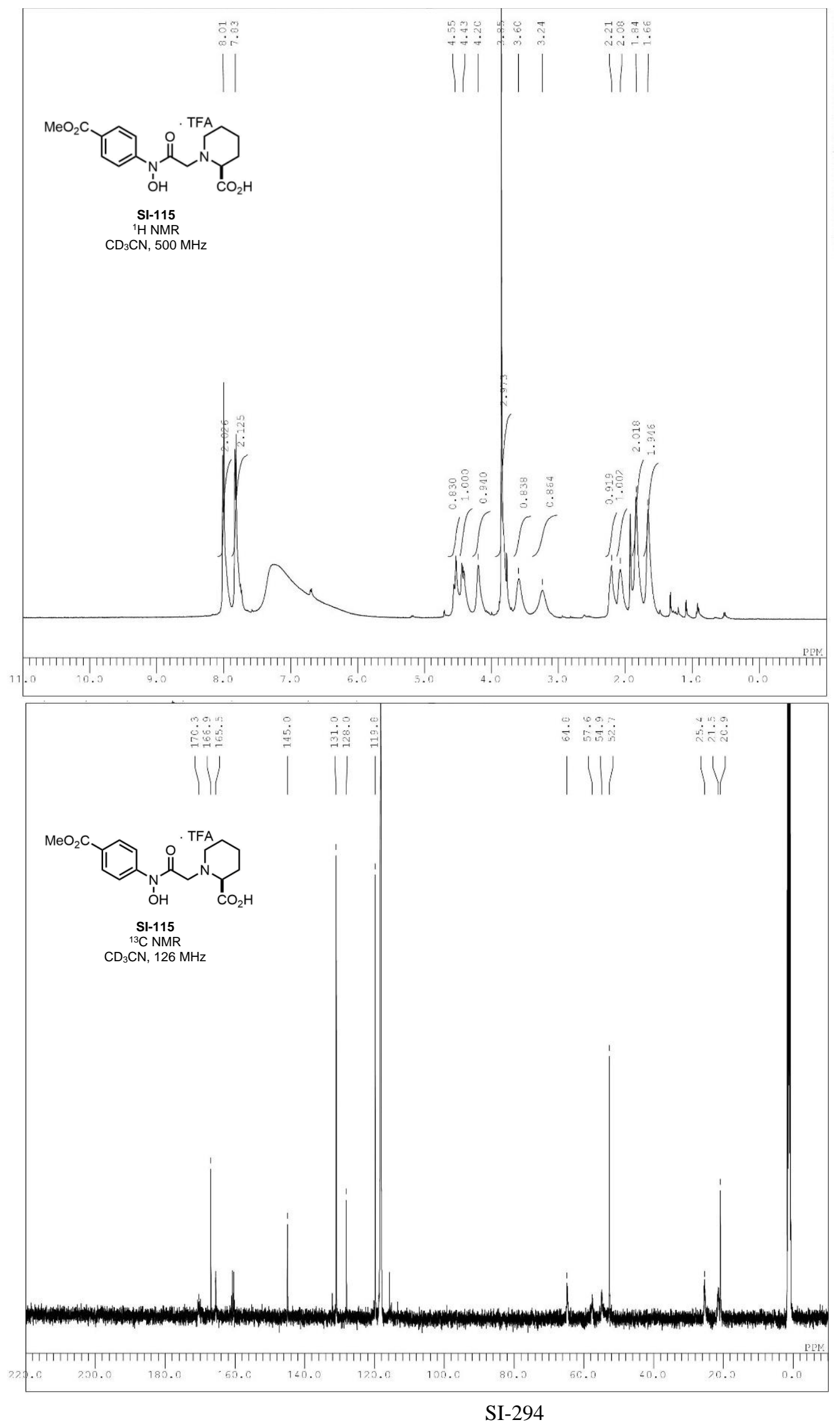




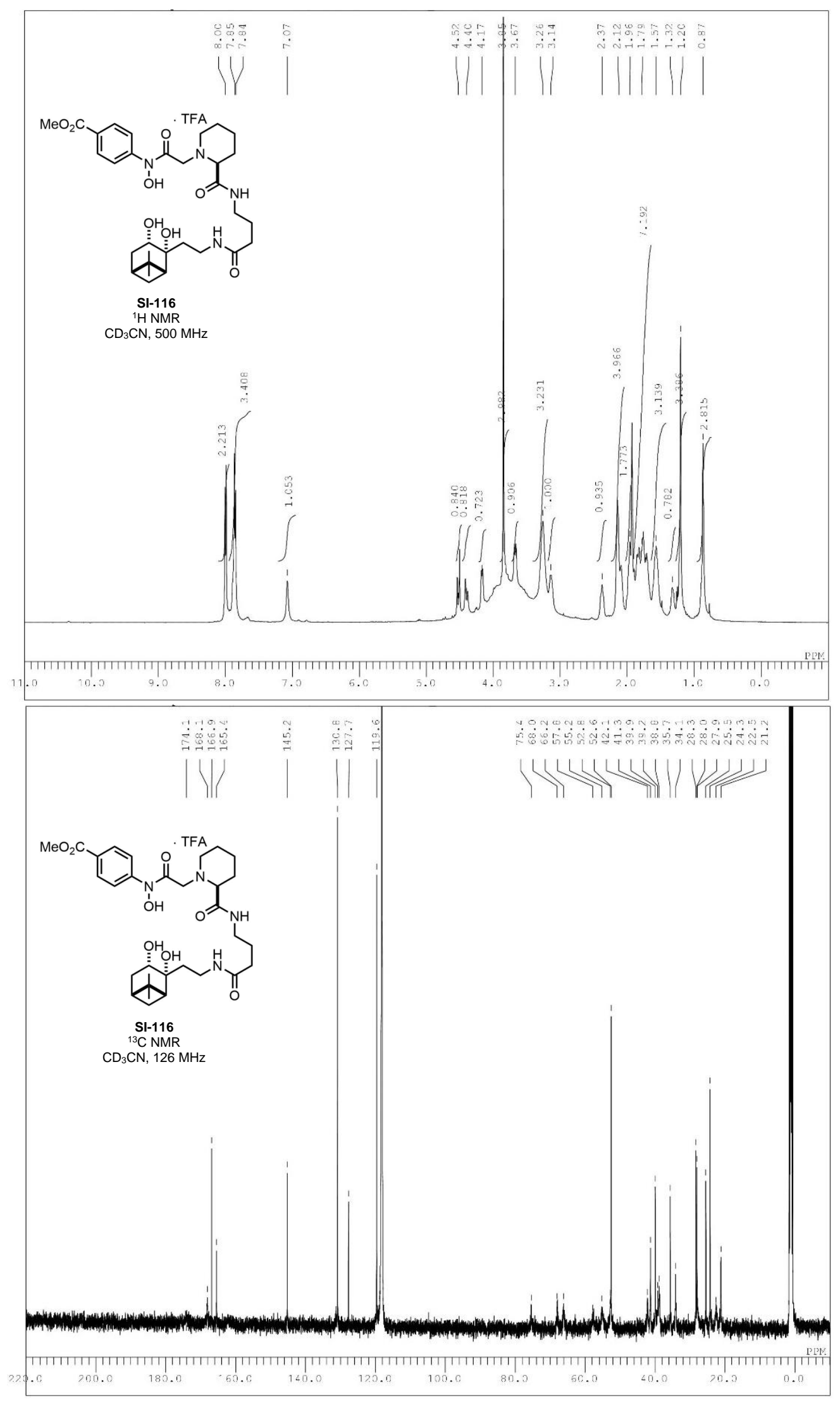

SI-295 


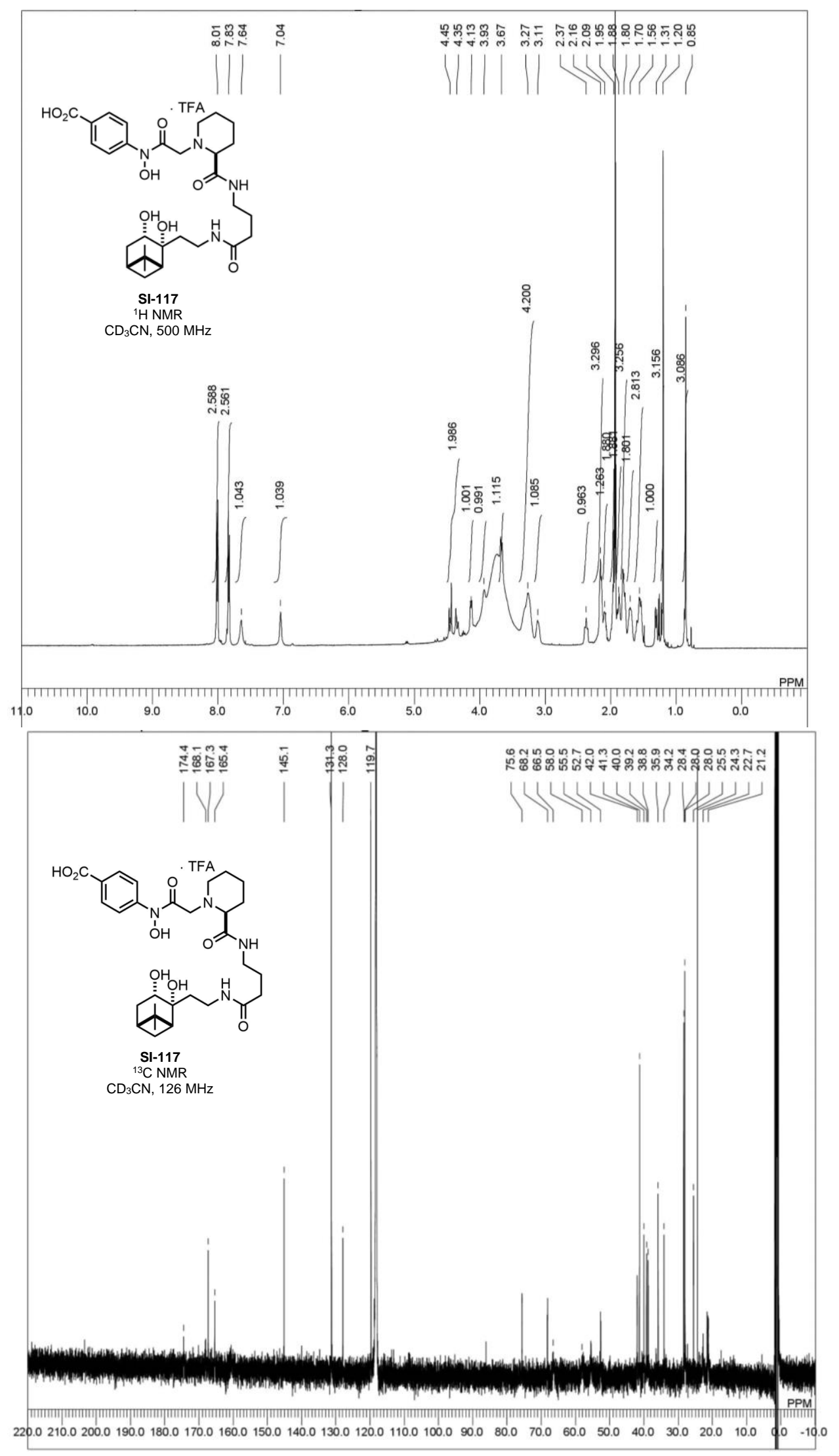

SI-296 

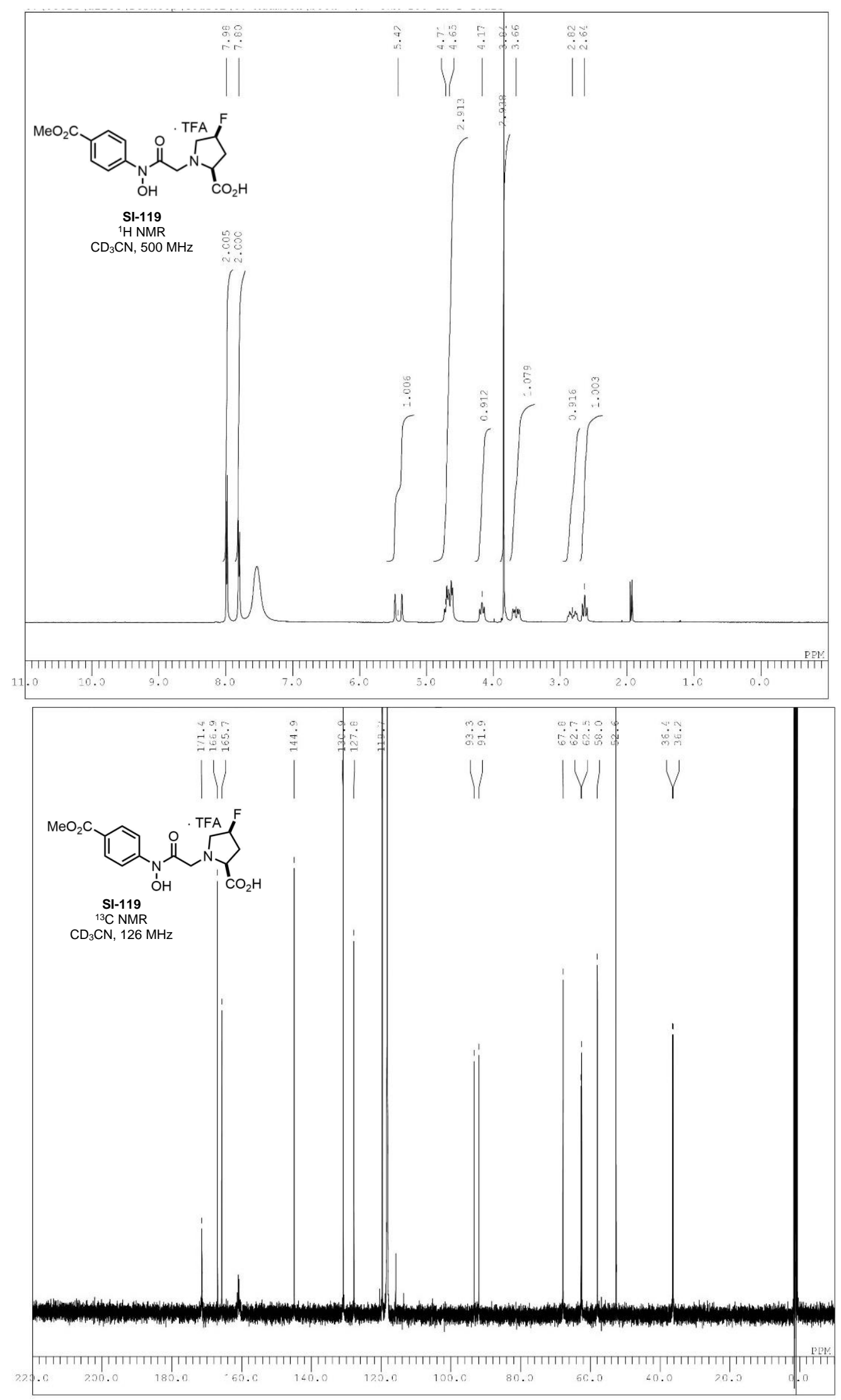

SI-297 


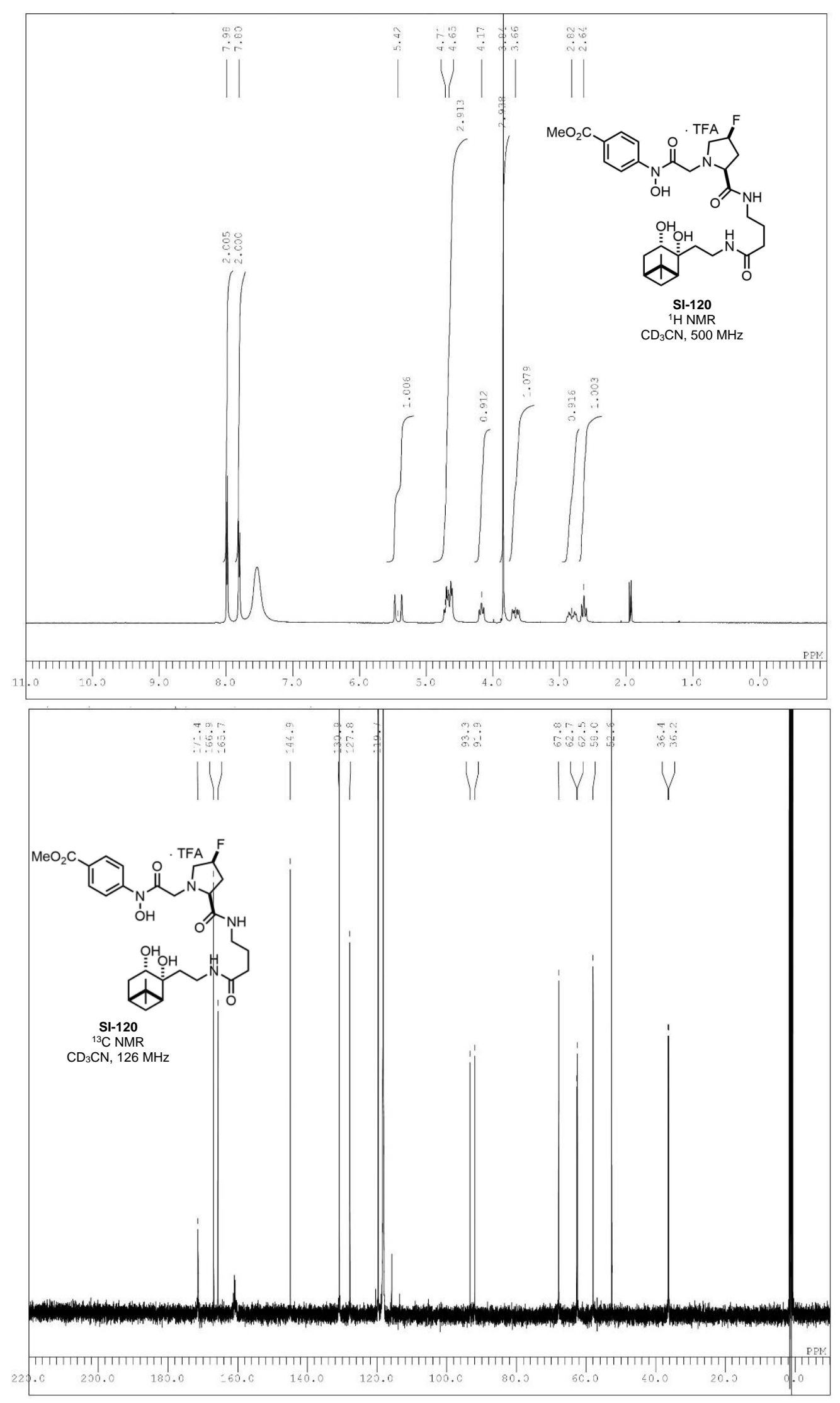

SI-298 

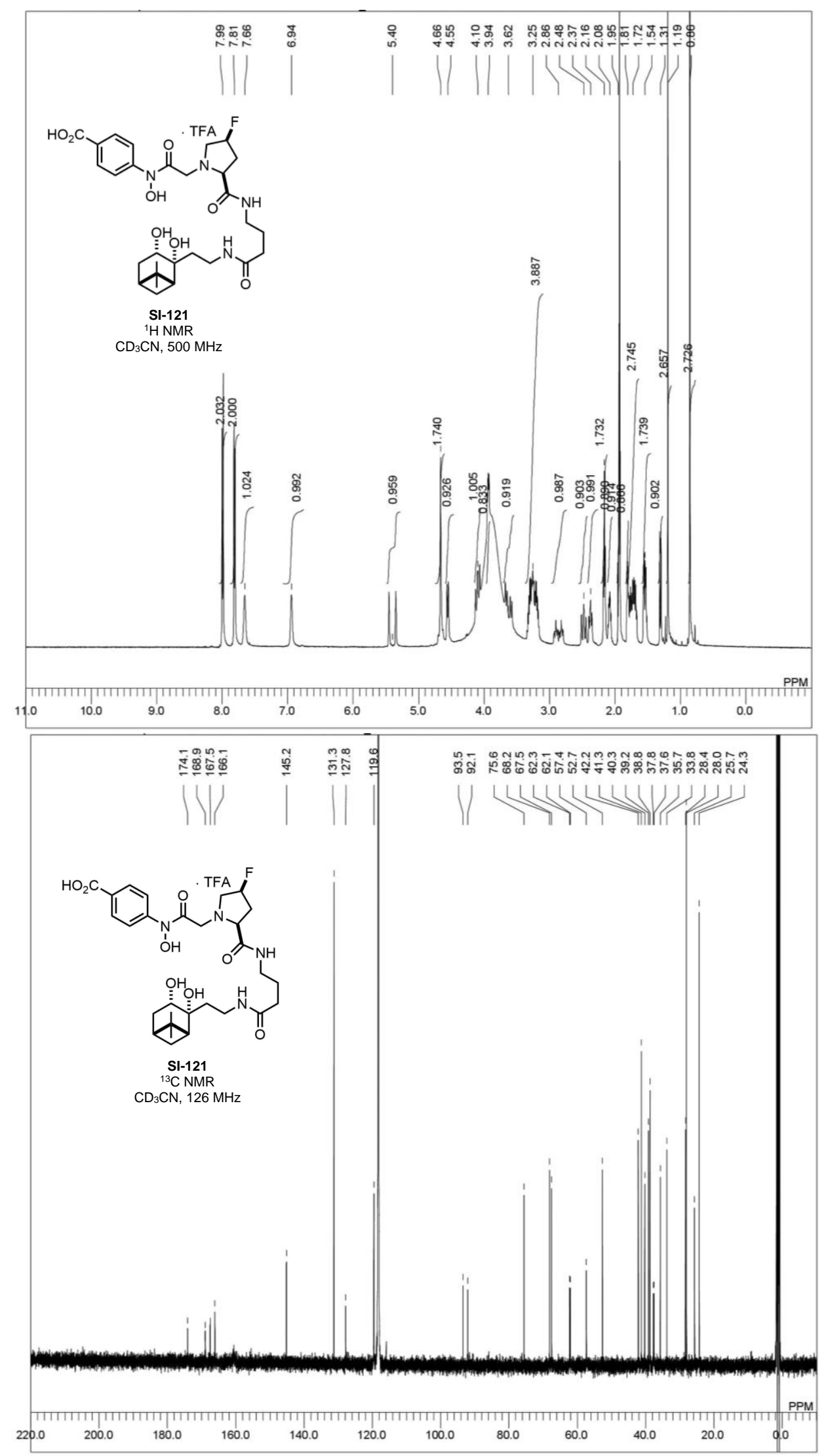

SI-299 


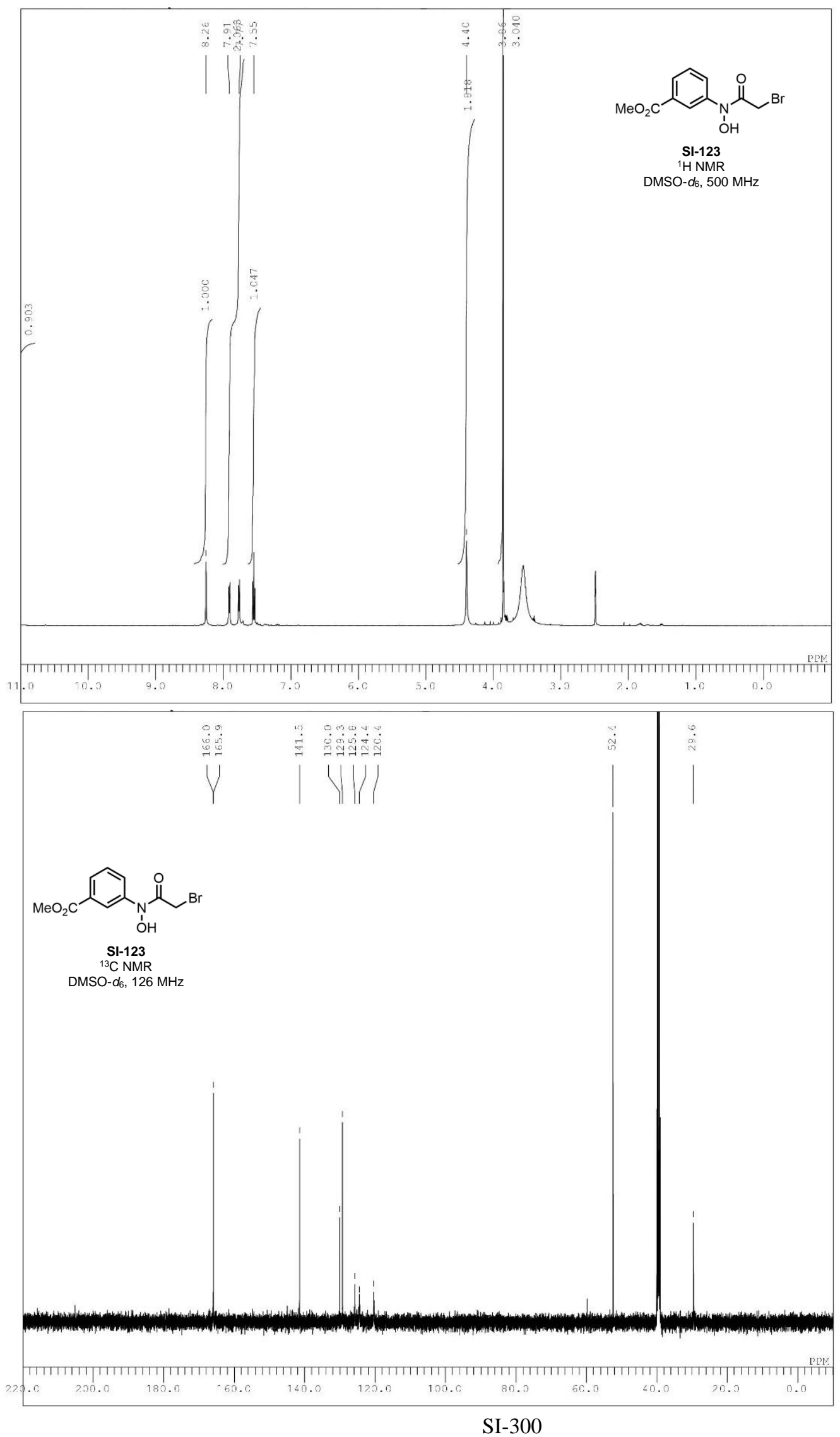



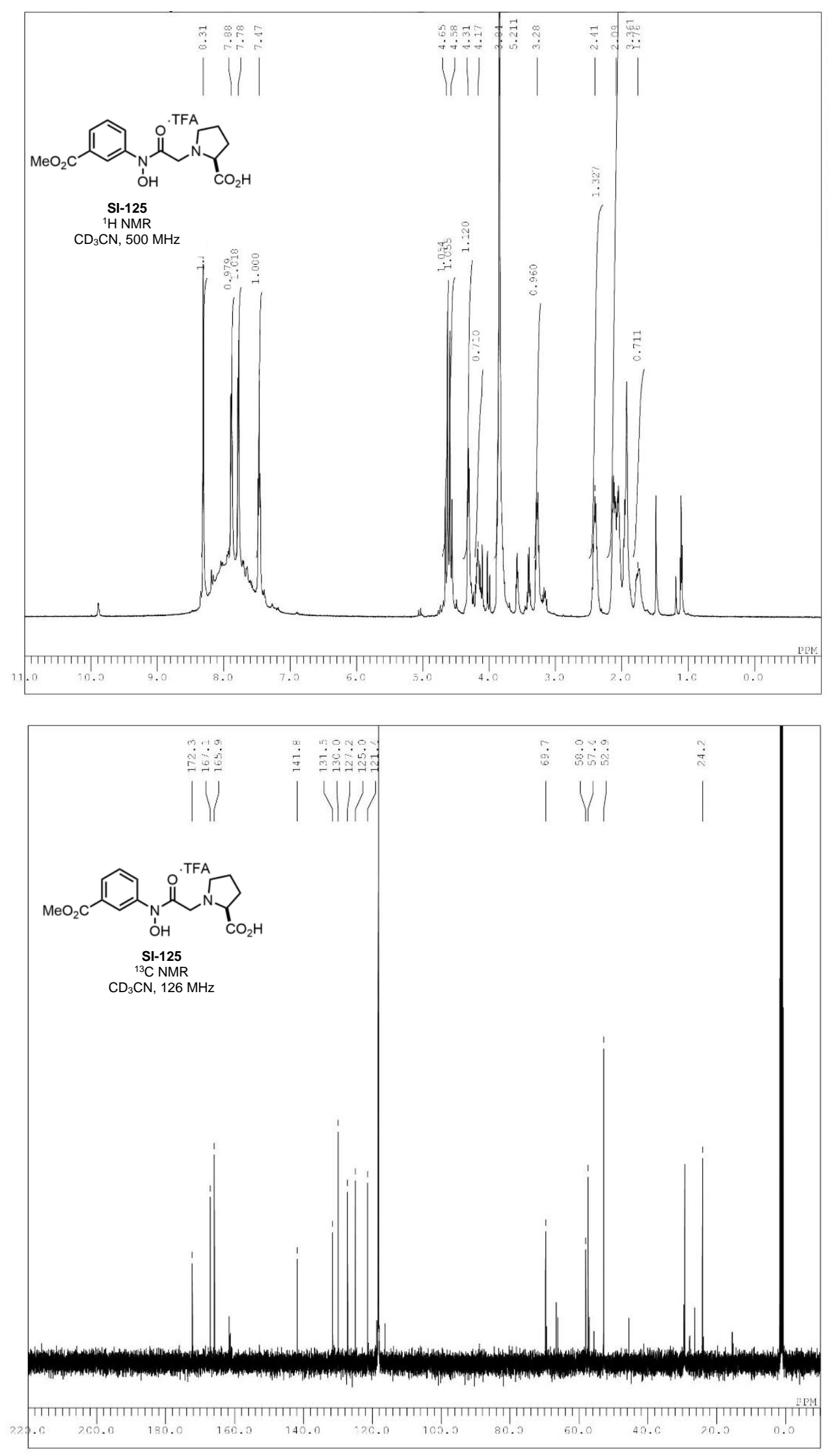

SI-301 


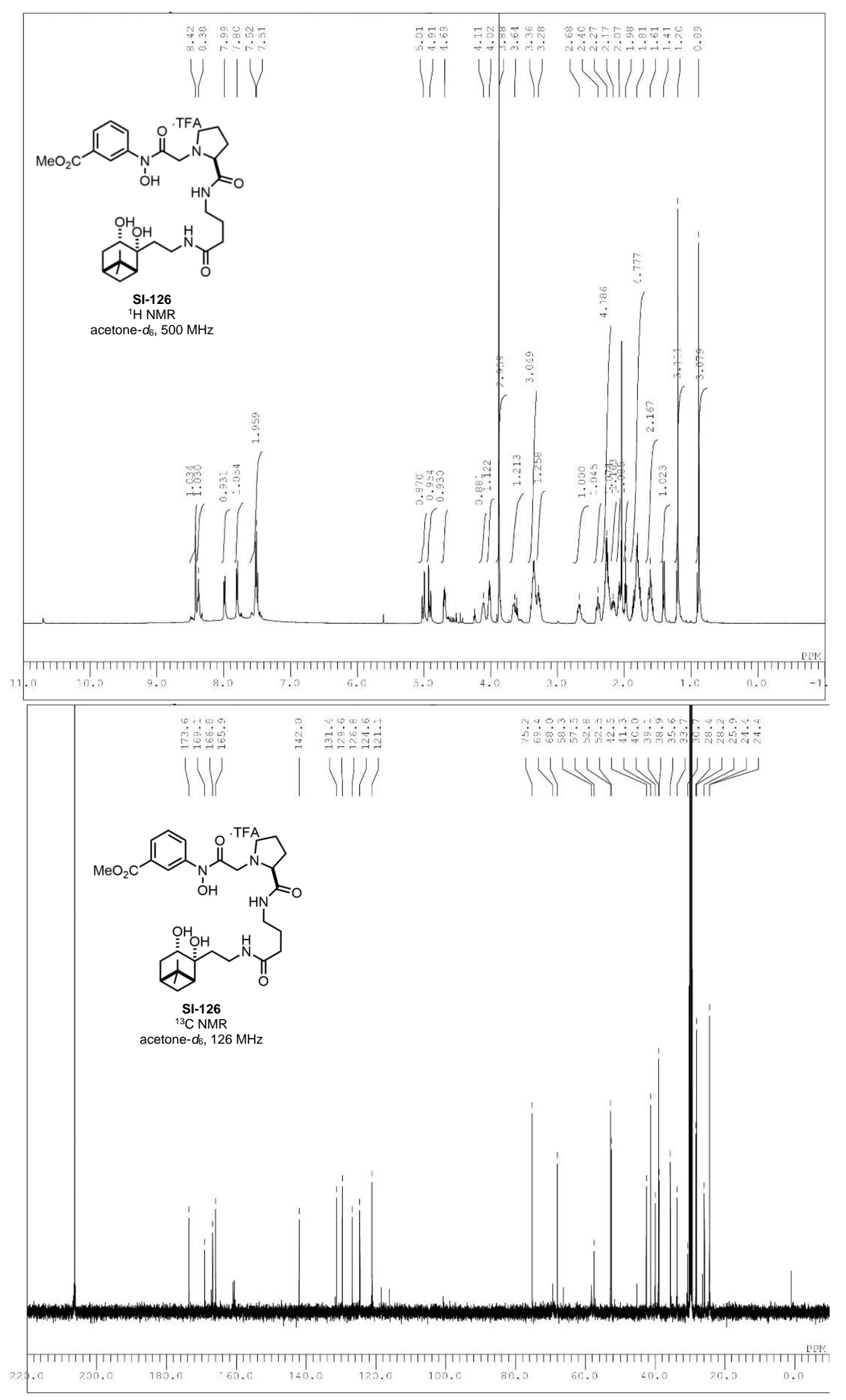

SI-302 

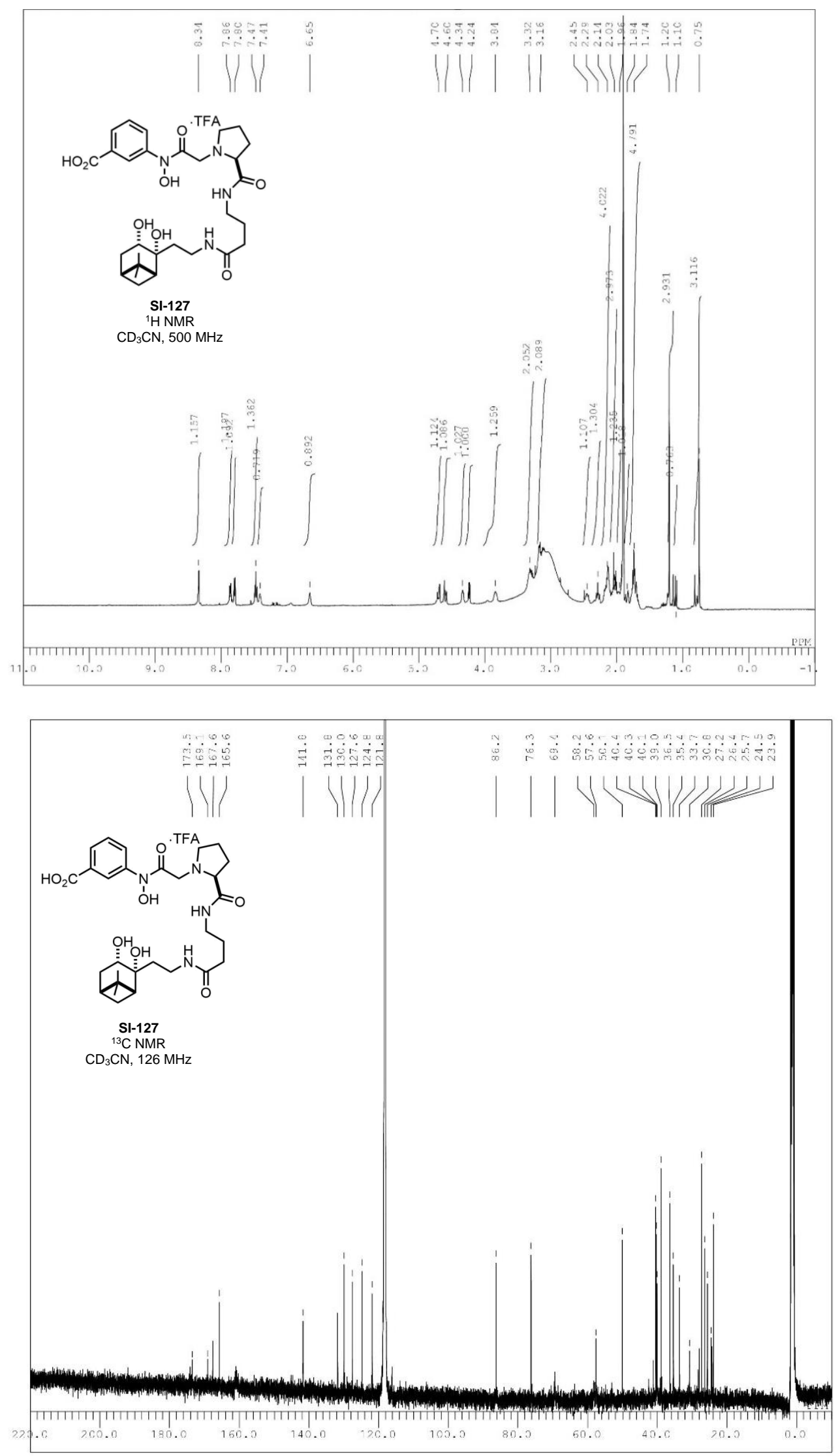

SI-303 